\title{
The external dimension of the EU's migration policy : different legal positions of third-country nationals in the EU. : a comparative perspective
}

Citation for published version (APA):

Eisele, K. (2013). The external dimension of the EU's migration policy : different legal positions of thirdcountry nationals in the EU. : a comparative perspective. [Doctoral Thesis, Maastricht University]. Wolf Legal Publishers. https://doi.org/10.26481/dis.20130516ke

Document status and date:

Published: 01/01/2013

DOI:

10.26481/dis.20130516ke

Document Version:

Publisher's PDF, also known as Version of record

Please check the document version of this publication:

- A submitted manuscript is the version of the article upon submission and before peer-review. There can be important differences between the submitted version and the official published version of record.

People interested in the research are advised to contact the author for the final version of the publication, or visit the DOI to the publisher's website.

- The final author version and the galley proof are versions of the publication after peer review.

- The final published version features the final layout of the paper including the volume, issue and page numbers.

Link to publication

\footnotetext{
General rights rights.

- You may freely distribute the URL identifying the publication in the public portal. please follow below link for the End User Agreement:

www.umlib.nl/taverne-license

Take down policy

If you believe that this document breaches copyright please contact us at:

repository@maastrichtuniversity.nl

providing details and we will investigate your claim.
}

Copyright and moral rights for the publications made accessible in the public portal are retained by the authors and/or other copyright owners and it is a condition of accessing publications that users recognise and abide by the legal requirements associated with these

- Users may download and print one copy of any publication from the public portal for the purpose of private study or research.

- You may not further distribute the material or use it for any profit-making activity or commercial gain

If the publication is distributed under the terms of Article $25 \mathrm{fa}$ of the Dutch Copyright Act, indicated by the "Taverne" license above, 
The External Dimension of the EU's Migration Policy

Different Legal Positions of Third-Country Nationals in the EU.

A Comparative Perspective 
The External Dimension of the EU's Migration Policy

Different Legal Positions of Third-Country Nationals in the EU.

\section{A Comparative Perspective}

Katharina Eisele

Layout by Marina Jodogne

Cover Design by Julian Eisele

olf Legal Publishers (WLP)

Postbus 313

5060 AH Oisterwijk

info@wolfpublishers.nl

www.wolfpublishers.com

Alle rechten voorbehouden. Behoudens de door de Auteurswet 1912 gestelde uitzonderingen, mag niets uit deze uitgave worden verveelvoudigd (waaronder begrepen het opslaan in een geautomatiseerd gegevensbestand) of openbaar gemaakt, op welke wijze dan ook, zonder voorafgaande schriftelijke toestemming van de uitgever. De bij toepassing van artikel 16B en 17 Auteurswet 1912 wettelijk verschuldigde vergoedingen wegens fotokopiëren, dienen te worden voldaan aan de Stichting Reprorecht. Voor het overnemen van een gedeelte van deze uitgave in bloemlezingen, readers en andere compilatiewerken op grond van artikel 16 Auteurswet 1912 dient men zich tevoren tot de uitgever te wenden. Hoewel aan de totstandkoming van deze uitgave de uiterste zorg is besteed, aanvaarden de auteur(s), redacteur(en) en uitgever geen aansprakelijkheid voor eventuele fouten of onvolkomenheden.

(C) 2013 K. Eisele 
The External Dimension of the EU's Migration Policy

Different Legal Positions of Third-Country Nationals in the EU. A Comparative Perspective

\section{DISSERTATION}

to obtain the degree of Doctor

at the Maastricht University,

on the authority of the Rector Magnificus,

Prof. Dr. L.L.G. Soete

in accordance with the decision of the Board of Deans,

to be defended in public

on Thursday, 16 May 2013, at 12.00 hours

by

Katharina Blanca Eisele 
Supervisor

Prof. Dr. H.E.G.S. Schneider

Co-Supervisor

Dr. A. Wiesbrock (University of Oslo)

Assessment Committee

Prof. Dr. B. De Witte (Chair)

Prof. Dr. J. Bast (Radboud University Nijmegen)

Dr. A.P. van der Mei 
Für meinen Vater

Hans Eisele (1949-2003) 



\section{Acknowledgements}

It was a hot and humid summer day when I first set foot on American soil. I remember a tall black man with a baseball cap waiting for me at Washington Dulles International Airport. He smiled warmly, welcomed me, and I stepped into his car. I would experience, for the first time, what it meant to live in a foreign country.

I was sixteen and the man was my host father, Wes Thomas.

Now - thirteen years later - I look back and realise that the high school year I spent in Maryland was more than just a great experience. My stay in the U.S. shaped my life in many ways. Living abroad allows us to learn about other cultures and traditions and makes us aware of the way of life in different parts of the world. Living in a foreign country also enables us to alter our perspective and critically reflect upon our individual identity and mindset. Host countries also benefit from immigrants, who bring with them their customs, knowledge, reflections, languages and food, thereby culturally enriching their host nations.

There is great potential to learn from one another if we overcome prejudice, ignorance and hatred and approach our neighbours with respect and mutual understanding, especially in difficult economic times. The Federal President of Germany, Joachim Gauck, has repeatedly called for a Willkommenskultur, a welcoming culture in which immigrants and those in need are received warmly and with an open heart. During a speech he delivered on 15th January 2013 at the German Federal Office for Migration and Refugees, Joachim Gauck called for increased awareness as to the enriching qualities immigrants bring to their host nations, provided that the citizens are open to them. ${ }^{1}$ The President has pinpointed an issue that is at stake not only in Germany, but in the European Union as a whole, currently standing at 27 Member States.

Writing this doctoral dissertation during the last number of years has allowed me to delve into fundamental questions in relation to European migration law and policy. It was an intellectual adventure and a stimulating challenge, and I am deeply grateful for this enlightening experience that enabled me to grow both personally and professionally. I thoroughly enjoyed the open, international and inspiring atmosphere in Maastricht, where I was presented with the great opportunity to travel to conferences around the globe, presenting and discussing my research. Amazing people have crossed my path during those years and some of them have played a particularly important role. I would like to specifically acknowledge them here.

First and foremost, I would like to express my greatest gratitude to my supervisor Hildegard Schneider, who showed great confidence and enduring faith in my work and in me personally, and has guided me with great patience and cordiality to finalise this dissertation. I have particularly appreciated her firm enthusiasm and her unique

See newspaper article "Bundespräsident Gauck fordert offene Tore und Herzen für Zuwanderer", 15 January 2013, Die Welt, available at: <http://www.welt.de/ewsticker/pa_nt/regiolinegeo/bayern/article112780523/Bundespraesident-Gauckfordert-offene-Tore-und-Herzen-fuer-Zuwanderer.html>, last accessed on 17 January 2013. 
talent to motivate and inspire people around her. I deeply admire her for juggling the demanding tasks associated with her role as the Dean of the Faculty of Law since 2011, and her continued work as a Professor, providing kind and helpful supervision to her doctoral candidates. Likewise, I wish to thank René de Groot who - despite not being my "official" supervisor - has been a source of inspiration and a discussion partner. It was the Masters course on European Migration and Citizenship, which they taught together, that first triggered my keen interest in the research of migration issues.

I owe particular thanks to Anja Wiesbrock who has been a co-supervisor of a different calibre. Anja first introduced me to the world of conferences in 2009 when we met in Melbourne to present our first co-authored paper. It is with great pleasure that I reminisce about our intense discussions and cheerful talks, as well as the many writing and travel adventures that followed in İstanbul, Boston and Oslo. Thank you for your strong support and your detailed feedback on earlier drafts of my dissertation - you should know that I have not forgotten about our plans to climb Mount Ararat and master the Appalachian trail together one day!

A very special thanks goes to the members of my reading committee, Bruno de Witte, Jürgen Bast and Anne Pieter van der Mei for their invaluable and constructive comments on my dissertation. I extend my sincere thanks to Anne Pieter for his profound advice on my research and his encouraging words.

I would like to express my appreciation to my colleagues at the Law Faculty of Maastricht University, a lot of whom I was privileged to work with. With smiles that illuminate the Law Faculty, cordial thanks go to Elise Muir, Maartje de Visser, Gary Low, Mirjam de Mol, Licette Poll, Nishara Mendis, Renata Vargas Amaral, Lisa Waddington, Phyllis Livaha, Mark Provera, Jasper Krommendijk, Serban Vacarelu, Jing Liu, Kevine Kindji, Tamara Lewis, Thomas Biermeyer, Gustavo Arosemena, Sarah Schoenmaekers, Kaiser Chaudhary, Viorelia Gasca, Nicola Gundt, Sascha Hardt, Marcel Schaper, Tiiu Albin, Fernando de Man, Arkadiy Kudryavtsev, and my lovely former office mate Florin Coman-Kund, for their continued support. I have truly enjoyed being part of the International and European Law Department and I felt honoured to be able to represent my fellow $\mathrm{PhD}$ colleagues as a $\mathrm{PhD}$ representative in the Science Committee. It was a fantastic experience to be able to organise a charity gala in May 2011, together with my dear colleagues Jennifer Sellin, Kathrin Hamenstädt, Eveline Ramaekers and Dyebo Shabalala, with the kind approval of the former Dean, Aalt Willem Heringa, and the financial support of the Graduate School of Law.

Moreover, I wish to express my gratitude to Melissa Siegel, who manages and coordinates the IS-Academie on Migration and Development with great commitment and enthusiasm, as well as to my fellow PhD colleagues, Özge Bilgili, Sonja Fransen, Katie Kuschminder, Silja Weyel, and Natasja Reslow who are also involved. I am thankful that I got to know you, Natasja, as a great colleague and a fabulous friend. It is with a big smile that I think back to our conference trip to Madrid in September 2010.

My sincere thanks go to Sergio Carrera for his encouragement and his precious comments on my dissertation. I would like to thank Kees Groenendijk who kindly 
took the time to discuss my research with me and gave me useful feedback. Likewise, I want to thank Lami Bertan Tokuzlu who made my research stay at Bilgi University in İstanbul, in the summer of 2010, possible. It was a real pleasure to get know to you, Zvezda Vankova - thanks for sharing your ideas and thoughts during your visits to Maastricht.

I am very grateful to Carol Ní Ghiollarnáth, who proofread my manuscript at a phenomenal pace and to Marina Jodogne, who did an excellent job with the typesetting. My thanks go to Zdravka Zulj who helped me cordially with the research. I wish to express my deep gratitude to my wonderful friend, Daphne Kolader, who assisted me with the Dutch summary - bartelijk dank! Many thanks to my interview partners for taking the time to share their experiences, expertise and inside views with me. My dissertation has benefited enormously from the continuous help and support of the friendly librarians at the Max Planck Institute for Comparative Public Law and International Law in Heidelberg, which boasts an impressive, up-to-date collection of academic works.

On a more personal note, I would like to express my deepest thanks to a number of close friends who have supported me during the last number of years: Maastricht is the place where I got to know some special people. I was very happy to share a house with Ilona Boute-van de Meent and Brechtje Huiskes, my dear Dutch friends, who explained their culture and language to me. Thank you so much, Susanne Räder, for happy chats and deep conversations. I am equally indebted to my basketball team the Kimbria ladies - who integrated me into Mestreech and also taught me about their language. I feel honoured to have been part of Kimbria and the various teams, as a player and as a team captain, coached successively by Jack Hecker, Mirza Cicak, Jorge Michielsen and Darko Djordjevic. Playing basketball at De Geusselt with you and winning the championship in the spring of 2012 was an incredible experience and the perfect activity to counterbalance the long hours spent sitting at a desk in front of a computer screen. In spirit, dames, I will always be in Maastricht.

I would like to thank my special friend and partner in crime Franziska Weber who I met ten years ago when we started our Bachelor studies together. With great joy I recall our travel adventures, both appreciating the academic world but knowing that there is more to life than writing PhDs.

My time in Maastricht would not have been the same without the regular visits to my friends in Brussels Milena Mihaylova, Anna Réthy, Tanja Ehnert and Stefanie Erdmann. I have spent a few truly awesome weekends with these girls, and blissful memories remind me of cooking, eating, talking, laughing, dancing, sweating, strolling around Brussels and brunching on Banitza or Lángos. Thank you, dear Anna, for providing me with valuable interview contacts for this dissertation. I am especially thankful to you, Milena, my soul mate and amazing friend, whose open heart, lovely personality and delightful sense of humour I cherish deeply. I was privileged to meet some great friends in Brussels in summer of 2012 in the Service Juridique stagiaire group when I was busy finishing up my dissertation. Your support was much appreciated, spending time with you was savage craic! Many thanks go to my dear running buddies Anne Fitzpatrick, Joana Schmid Moura and Alessandro Di Mario for keeping me rolling. I would also like to thank my basketball friend Jana Janotová for her cheerfulness during that time period. 
In my hometown of Heidelberg I got to know some very special people whom I would like to thank for their genuine friendship and uplifting thoughts, including Simone Grunert-Baier, Stefanie Schenk, Nadine Schulz, Birgit Eder and my dear old friend Caroline Breunig who I appreciate having known for almost thirty years. Thank you, Clara Speth, for your energy and our athletic endeavours. I owe particular thanks to Carolin Heindel, my wonderful friend, connected by words that encouraged me to become a writer - Universum, liebe Caro!

For the last twelve years I have received Christmas cards from Huntingtown, Maryland addressed to "a dear daughter and her family." I would like to thank the Thomas Family for having offered me their hospitality and their warm home making my high school year in the U.S. an invaluable experience.

Finally, my heartfelt thanks go to my family who have supported me throughout this journey with the greatest confidence and with their unconditional love. I am privileged to have my two awesome brothers, Julian and Philipp Eisele, whose creative minds always knew how to cheer me up with their laughter and their joie de vivre and, of course, their sensational music. I am deeply indebted to my mother and Philipp Sr. My mother was never tired of encouraging me with words and deeds. Drafting this dissertation would not have been possible without her strong support.

Katharina Eisele

Brussels, 31 January 2013 
Table of Contents - Summary

Part I: Introduction ............................................................................................... 1-11

Part II: EU External Relations and Migration Policy - The Historical

Development of the External Dimension

Part III: The Human Rights of Migrants: Legal Bases and Sources for EU

Migration Law and Policy...

Part IV: The Basis for Differential Treatment among Third-Country Nationals: EU Association Agreements and Cooperation Frameworks

Part V: The Legal Position of Third-Country Nationals: Entry,

Employment and Residence Rights.

Part VI: The Legal Position of Third-Country Nationas: Social Security

Rights.

Part VII: The Legal Position of Third-Country Nationals: Other Economic and Social Rights

Part VIII: Conclusions 363-381

Part IX: Schematic Overview of the Legal Position of Third-Country Nationals $383-407$

Part X: Samenvatting. $409-416$

Part XI: Zusammenfassung.... 417-426

Part XII: Bibliography $427-450$

Part XIII: EU Official Documents, Table of Cases, and List of Interviewees $451-477$ 



\section{Table of Contents}

Acknowledgements vii

List of Abbreviations xxi

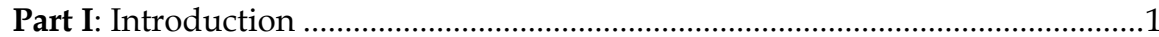

$1 \quad$ Immigration and Immigration Policy in the EU ...................................

$1.1 \quad$ EU Citizen and Third-Country Nationals.................................................

1.2 Distinctions among Third-Country Nationals: Questions at Stake.........3

1.3 Migration and External Relations: Association Agreements and the Court of Justice .......................................................................................4

1.4 External Dimensions of EU Migration Policy .........................................

1.5 EU Law Specifying Rights for Third-Country Nationals .........................7

1.6 Third-Country Nationals as an Integrated Part of the EU Population ..7

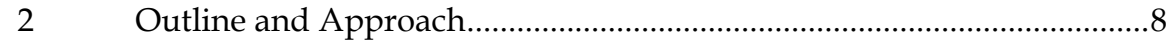

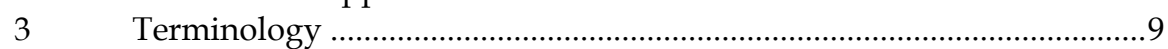

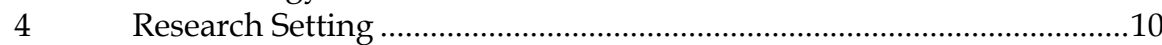

Part II: EU External Relations and Migration Policy - The Historical Development of the External Dimension...............................................................13

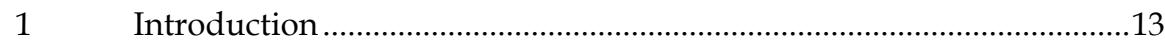

21958 - 1992: The Genesis of the EEC and the Single European Act .....14

$2.1 \quad$ The Treaty of Rome (1958) …...............................................................14

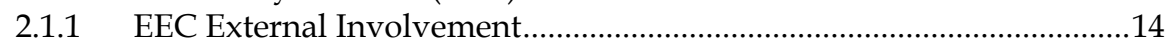

2.1.1.1 EEC External Competences ....................................................................17

2.1.1.2 Express and Implied Powers ....................................................................18

2.1.1.3 Exclusive and Shared Powers.....................................................................20

2.1.1.4 The Development of Mixed Agreements.................................................23

2.1.1.5 Community Agreements in the EEC Legal Order ...................................25

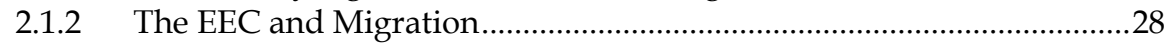

2.1.2.1 The Emerging Migration Regime for Community Workers ..................28

2.1.2.2 The Status of Third-Country Nationals under the EEC Treaty..............31

2.1.2.3 The 1974 Action Programme for Migrant Workers ....................................34

2.1.2.4 Consultation on Migration Unwanted: Decision 85/381/EEC ..............36

2.1.2.5 The Incorporation of Migration in Association Agreements .................38

2.1.3 The 1973, 1981 and 1986 Enlargements ..................................................40

2.2 The Single European Act (1987) ...........................................................41

2.2.1 New External Competences and Clarifying Case Law ..........................41

2.2.2 An Area Without Internal Frontiers? .......................................................43

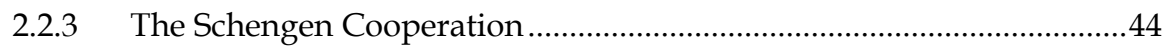

2.2.4 Migration in the EU's External Affairs: The Root Causes Approach...44

3 1993-1998: The Treaty of Maastricht and the Road to Amsterdam .......46

3.1 The EU External Relations Regime: The CFSP ..........................................47

3.2 New External Competences: The Case of Development Cooperation 50 
3.3 External Relations in the Community Framework .............................. 52

3.4 Community Visa Policy and Cooperation in Migration Matters ......... 54

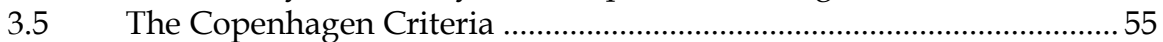

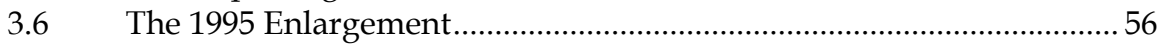

3.7 The 1998 Austrian Presidency and the High-Level Working Group .. 56

4 1999-2008: The Treaties of Amsterdam and Nice and the Tampere

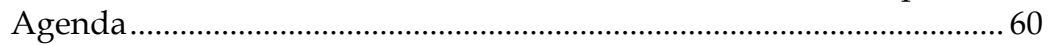

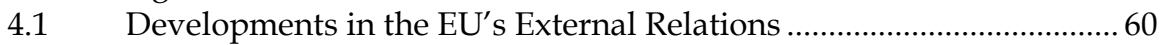

4.1.1 The Enhanced CFSP and the High Representative ................................6 60

4.1.2 Rapprochement in the EU's External Relations - A Digest ...................6 63

4.2 Migration in the Spotlight: Title IV of the Treaty of Amsterdam......... 64

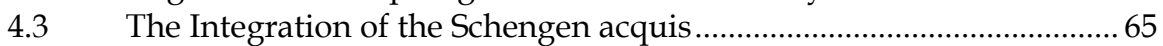

4.4 The Tampere Milestones: The Comprehensive Approach to

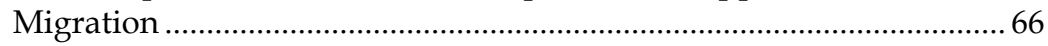

4.5 Da Feira and the Security-Centred Approach ......................................6 67

4.6 Thessaloniki and the Hague Programme: A More Balanced Approach? ..............................................................................................69 69

4.7 EU Secondary Legislation in the Field of Legal Migration ....................69

4.7.1 Council Directive 2003/86/EC on Family Reunification ....................... 70

4.7.2 Council Directive 2003/109/EC on the Status of Long-Term

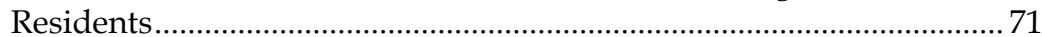

4.7.3 Council Directive 2004/114/EC on the Admission for the Purposes of Studies and Training.......................................................................... 72

4.7.4 Council Directive 2005/71/EC on the Admission for the Purpose of Scientific Research ................................................................................ 73

4.7.5 Council Directive 2009/50/EC on the Admission for the Purposes of Highly Qualified Employment (EU Blue Card) ................................ 73

4.7.6 Directive 2011/98/EU on a Single Permit and on a Common Set of Rights for Third-Country Workers...................................................... 74

4.8 The EU's Global Approach to Migration............................................... 74

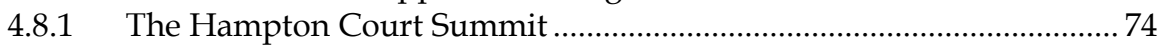

4.8.2 Implementing the Global Approach: Mobility Partnerships as an Umbrella ......................................................................................... 76

4.8.3 Economic Legal Migration and Mobility........................................... 77

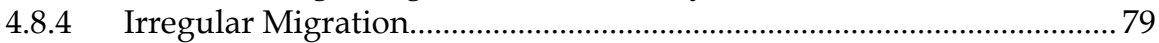

4.8.5 Migration and Development............................................................... 82

4.8.6 The Global Approach and Mobility Partnerships Reviewed................. 85

4.9 The European Pact on Immigration and Asylum ................................... 88

4.10 The 2004 and 2007 Enlargements .......................................................... 89

4.11 The Discrimination of EU Citizens based on Transitional

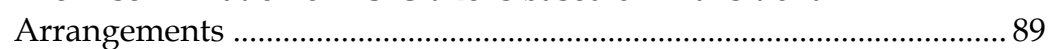

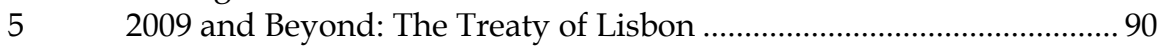

5.1 EU External Relations under the Lisbon Regime ................................... 90

5.1.1 Union Competences .............................................................................. 91

5.1.2 The Conclusion of International Agreements....................................... 94

5.1.3 The CFSP, the High Representative and the EEAS ................................. 95

5.2 Title V TFEU: The Current EU Rules on Migration ................................. 98

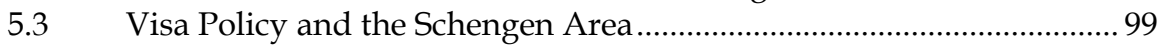


5.3.1 The Stockholm Programme....

5.4 The "Renewed" Global Approach to Migration and Mobility (GAMM)

5.5 The Future 2013 Enlargement .................................................................103

$6 \quad$ Conclusion to Part II ............................................................................. 104

Part III: The Human Rights of Migrants: Legal Bases and Sources for EU Migration Law and Policy

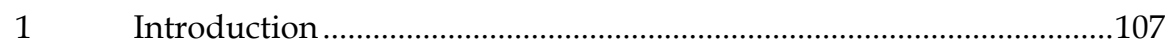

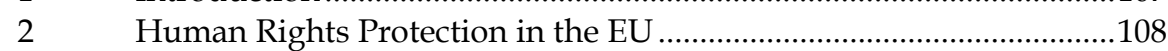

2.1 The Council of Europe and the European Convention on Human Rights (ECHR) .................................................................................. 108

2.1.1 The EU and the ECHR: Questions Relating to Interpretation and Accession..................................................................................................110

2.1.2 The Right to Respect for Family Life (Article 8)......................................113

2.1.3 The Freedom of Thought, Conscience and Religion (Article 9) ..........120

2.1.4 The Prohibition of Discrimination (Article 14 and Protocol No 12)...122

2.2 The EU Charter of Fundamental Rights.............................................126

2.3 The General Principles of EU Law .....................................................128

2.4 Other Council of Europe Standards .....................................................131

2.4.1 The European Convention on Social and Medical Assistance.............131

2.4.2 The European Convention on Establishment.......................................132

2.4.3 The European Social Charter...................................................................134

2.4.4 The European Code of Social Security and the European Convention on Social Security ..................................................................................136

2.4.5 The European Convention on the Legal Status of Migrant Workers.138

3 The Protection of Migrants in the International Arena ........................139

3.1 Human Rights Protection under UN Treaties......................................139

3.2 Migrants' Rights under the ILO Conventions No. 97 and No. 143 ....144

3.3 Migrants' Rights under the UN Migrant Worker Convention ............146

3.4 The Rights of Migrants in the International Migration Discourse .....148

3.4.1 The International Labour Organisation .................................................149

3.4.2 The International Organisation for Migration .....................................150

3.4.3 The Global Commission on International Migration ...........................150

3.4.4 The Global Migration Group ..................................................................151

3.4.5 The High-Level Dialogue on International Migration and Development ......................................................................................152

3.4.6 The Global Forum on Migration and Development..............................152

$4 \quad$ Conclusion to Part III............................................................................ 154

Part IV: The Basis for Differential Treatment among Third-Country Nationals: EU Association Agreements and Cooperation Frameworks. 
2 Differential Treatment and the Prohibition of Nationality

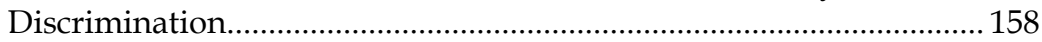

2.1 The Non-Discrimination Principle in Article 18 TFEU ......................... 160

2.2 General Non-Discrimination Clauses in Association Agreements .... 162

2.3 Extending Article 18 TFEU to Third-Country Nationals?................... 163

2.4 Article 21(2) EU Charter, the General Principle of

Non-Discrimination and Article 14 ECHR......................................... 167

2.5 Justifying Differential Treatment among Third-Country Nationals.. 169

2.6 Rethinking Nationality as Decisive Factor for the Legal Position? .... 174

3 The Former Europe Agreements - Leading to Full EU Membership 176

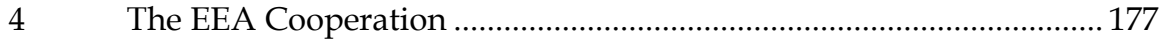

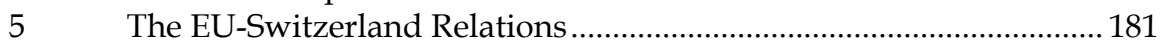

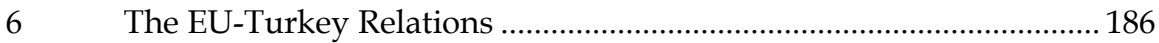

7 The EU and the Western Balkan Countries: Stabilisation and

Association ........................................................................................ 189

$8 \quad$ The EU Relations with San Marino and Andorra ................................ 192

9 The European Neighbourhood Policy Cooperation ............................... 192

9.1 Background and Objectives................................................................. 192

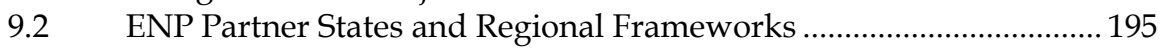

9.3 Implementing the ENP ................................................................... 198

9.4 The EU Relations with the Maghreb States Algeria, Morocco,

Tunisia................................................................................................... 201

9.5 The EU Relations with Egypt, Israel, Jordan and Lebanon.................. 203

9.6 The EU Relations with the Eastern ENP States Armenia,

Azerbaijan, Belarus, Georgia, Moldova and Ukraine......................... 204

9.7 The Mobility Partnerships with Moldova and Georgia ....................... 205

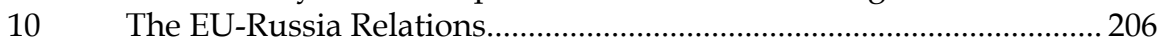

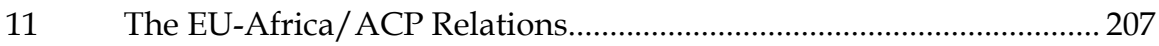

11.1 The 2006 Rabat and Tripoli Conferences ............................................. 208

11.2 The Africa-EU Partnership on MME and the 2008 Paris

Conference............................................................................................... 209

11.3 The 2010 Tripoli Africa-EU Summit and the 2011 Dakar Strategy .... 211

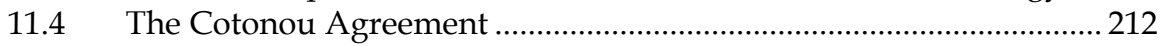

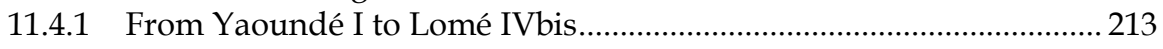

11.4.2 The ACP Conventions and Migration ................................................. 214

11.4.3 Objectives and Principles of the Cotonou Agreement.......................... 216

11.5 The Mobility Partnership with Cape Verde ........................................... 217

12 The EU-Latin and Central America Relations .................................... 218

12.1 The EU-LAC Strategic Partnership and Migration .............................. 218

12.2 The EU-Chile Association Agreement ................................................ 220

12.3 Cooperation Agreement with the Andean Community ...................... 220

12.4 Cooperation Agreement with the Republics of Costa Rica,

El Salvador, Guatemala, Honduras, Nicaragua and Panama............. 221

12.5 EU-Trade Agreement with Colombia and Peru .................................. 222

13 The EU-Asia Relations ............................................................................ 222

14 The EU's Relations with the Gulf Region and the Middle East........... 225

15 Conclusion to Part IV ........................................................................... 226 
Part V: The Legal Position of Third-Country Nationals: Entry,

Employment and Residence Rights.....

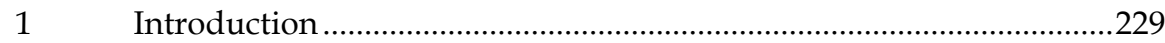

$2 \quad$ Entry Rights and EU Visa Policy.........................................................229

2.1 The Schengen White List: Privileged Third-Country Nationals.........230

$2.2 \quad$ Visa-Free Travel for EEA and Swiss Nationals .....................................2231

2.3 The Schengen Black List: Non-Privileged Third-Country

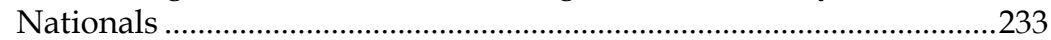

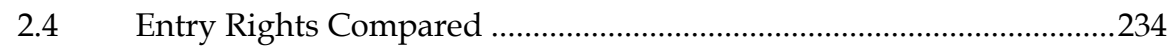

3 Entry Rights for the Purpose of Family Reunification ........................2234

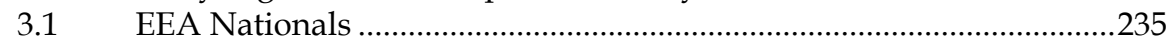

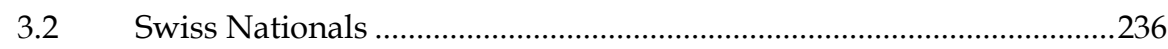

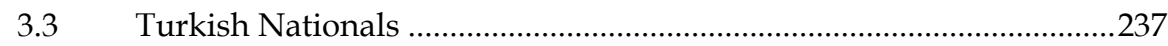

3.4 Other Sources of EU Law Applicable to Third-Country Nationals ...237

3.5 Family Reunification Rights Compared.............................................240

$4 \quad$ Entry Rights for the Purpose of Employment......................................240

4.1 Nationals of the Former Europe Agreement States...............................240

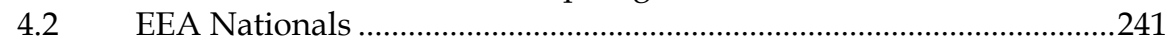

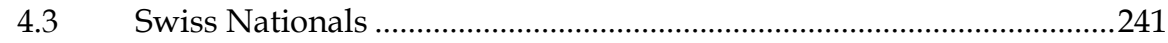

4.4 Other Sources of EU Law Applicable to Third-Country Nationals ...242

4.5 Entry Rights for the Purpose of Employment Compared ....................243

$5 \quad$ Employment and Residence Rights...................................................243

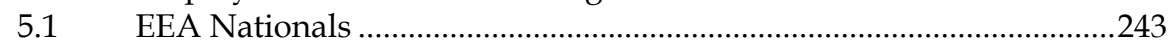

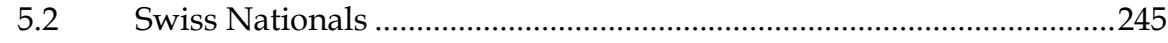

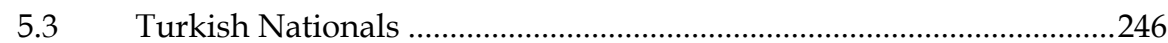

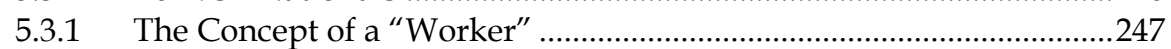

5.3.2 The Condition of Being "Duly Registered as Belonging to the Labour Force" ...................................................................................249

5.3.3 The Prerequisite of "Legal Employment" ............................................249

5.3.4 Periods of Employment under Article 6(1) ...........................................250

5.3.5 The Cessation of the Right of Residence ...............................................252

5.3.6 Residence and Employment Rights of Family Members.....................256

5.4 Nationals of Algeria, Morocco and Tunisia..........................................259

5.5 Other Sources of EU Law Applicable to Third-Country Nationals ...259

5.6 Employment and Residence Rights Compared ..................................261

6 The Right to Equal Treatment in Working Conditions ..........................262

6.1 Nationals of the Former Europe Agreement States.............................262

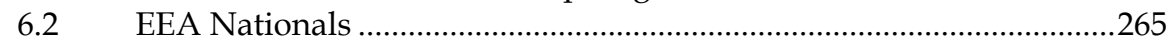

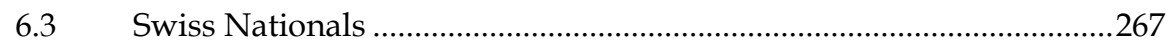

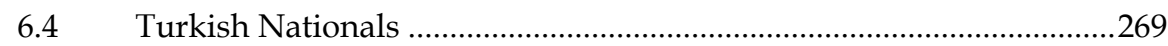

6.5 Nationals of the Western Balkan Countries ...........................................269

6.6 Nationals of San Marino and Andorra.....................................................2.270

6.7 Nationals of the Mediterranean ENP States ........................................220

6.7.1 Nationals of Algeria, Morocco and Tunisia...........................................270

6.7.2 Nationals of Egypt, Israel, Jordan and Lebanon .................................2272

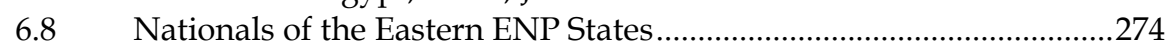

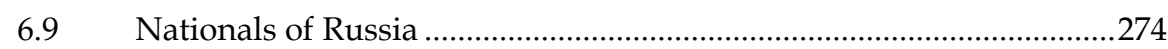




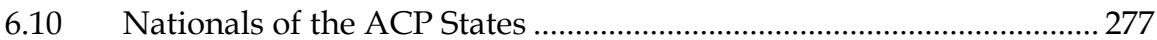

6.11 Nationals of the Central Asian Countries ........................................... 278

6.12 Other Sources of EU Law Applicable to Third-Country Nationals ... 278

6.13 Equal Treatment in Working Conditions Compared ......................... 279

$7 \quad$ The Right to Join Trade Unions and Stand for Elections..................... 282

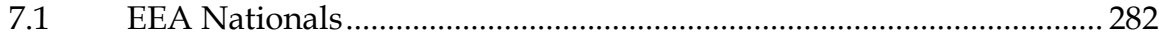

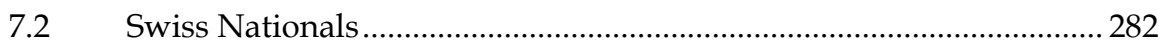

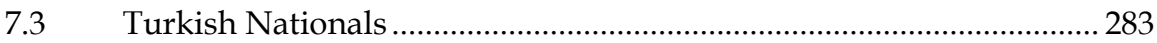

7.4 Other Sources of EU Law Applicable to Third-Country Nationals ... 283

7.5 The Right to Join Trade Unions and Stand for Elections Compared. 284

$8 \quad$ Conclusion to Part V .......................................................................... 284

Part VI: The Legal Position of Third-Country Nationas: Social Security Rights.

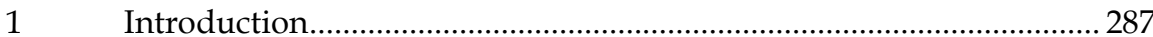

2 Coordination of Social Security and Concomitant Rights.................... 288

2.1 Regulation (EU) No 1231/2010: Extending Social Security

Coordination to Third-Country Nationals .......................................... 288

2.2 Nationals of the Former Europe Agreement States ............................. 291

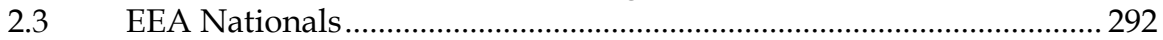

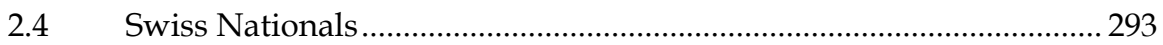

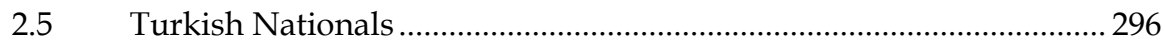

2.6 Nationals of the Western Balkan Countries .......................................... 303

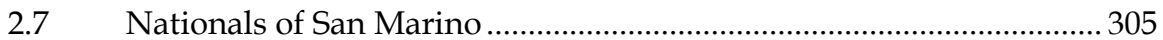

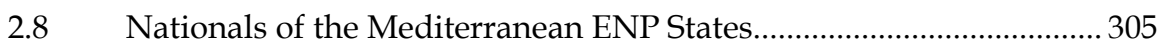

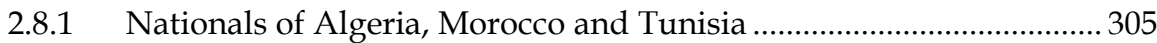

2.8.1.1 The Concept of "Social Security" ............................................................. 308

2.8.1.2 The Concept of a "Worker" in Social Security Matters ........................ 311

2.8.1.3 The Concept of "Family Members" in Social Security Matters .......... 312

2.8.2 Nationals of Egypt, Israel, Jordan and Lebanon..................................... 314

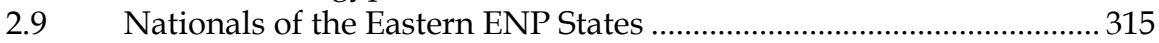

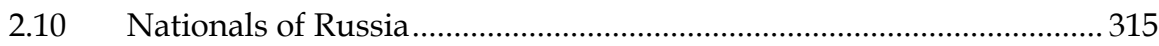

2.11 Other Sources of EU Law Applicable to Third-Country Nationals ... 316

2.12 Social Security Rights Compared …................................................... 318

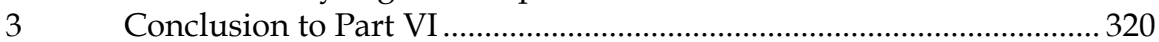

Part VII: The Legal Position of Third-Country Nationals: Other Economic

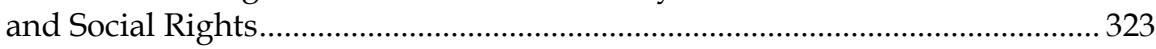

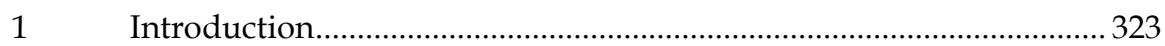

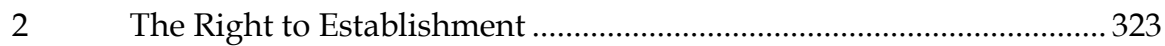

2.1 Nationals of the Former Europe Agreement States ............................. 324

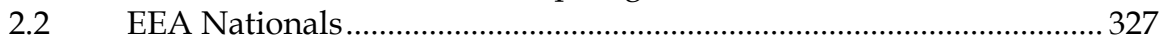

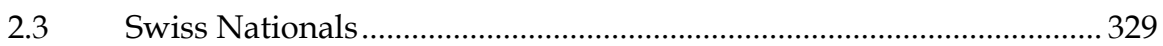

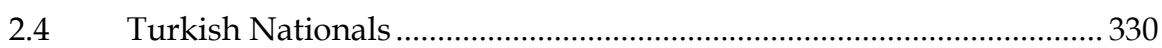


2.5 Nationals of the Western Balkan Countries ...........................................331

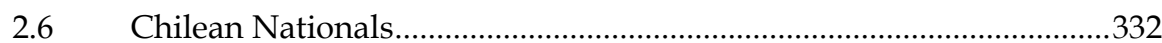

2.7 All Other Third-Country Nationals.........................................................332

2.8 The Right to Establishment Compared .................................................332

3 The Right to Provide Services ................................................................333

3.1 The General Agreement on Trade in Services (GATS) .........................334

3.2 Nationals of the Former Europe Agreement States..............................335

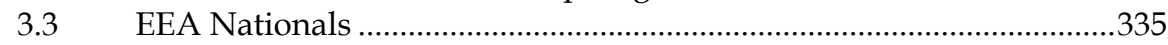

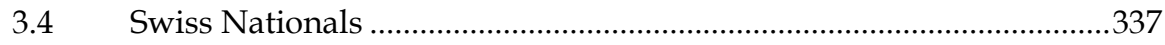

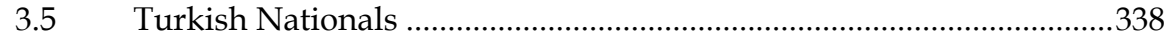

3.6 Nationals of the Western Balkan Countries ...........................................339

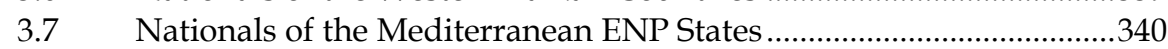

3.7.1 Nationals of Algeria, Morocco and Tunisia..............................................340

3.7.2 Nationals of Egypt, Israel, Jordan and Lebanon ...................................341

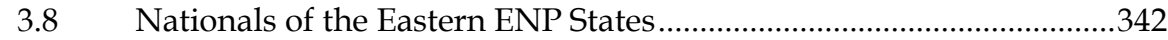

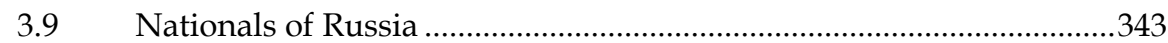

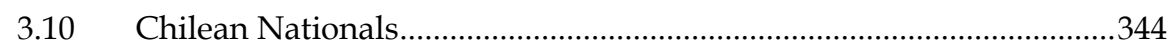

3.11 Nationals of the Central Asian Countries...............................................344

3.12 All Other Third-Country Nationals..........................................................344

3.13 The Right to Provide Services Compared and the Potential of the

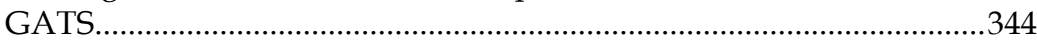

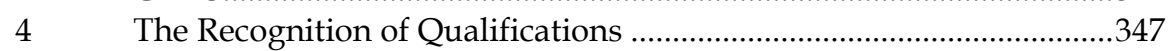

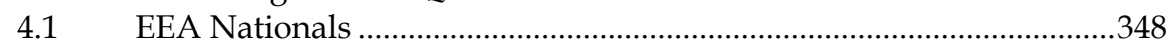

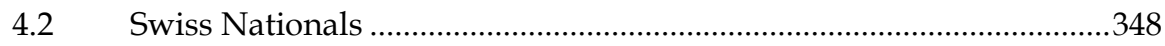

4.3 Other Sources of EU Law Applicable to Third-Country Nationals ...349

4.4 The Recognition of Qualifications Compared ........................................350

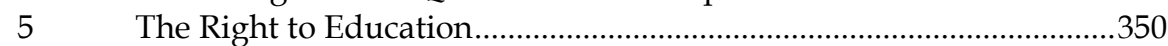

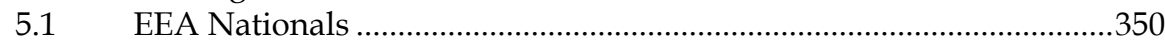

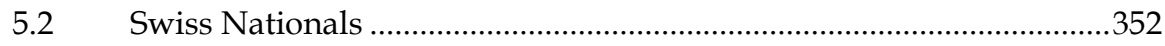

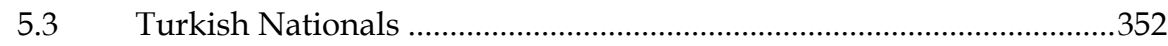

5.4 Other Sources of EU Law Applicable to Third-Country Nationals ...353

5.5 The Right to Education Compared .............................................................354

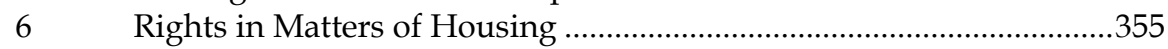

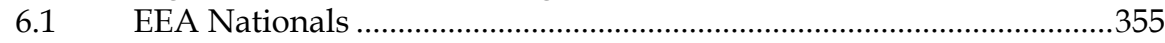

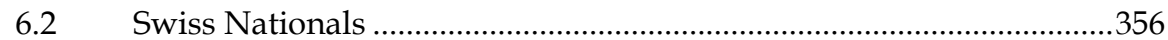

6.3 Other Sources of EU Law Applicable to Third-Country Nationals ....357

6.4 Rights in Matters of Housing Compared................................................358

$7 \quad$ The Right to Social and Tax Advantages ..............................................358

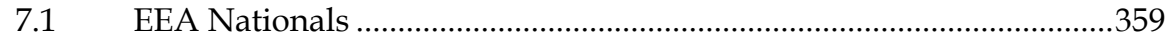

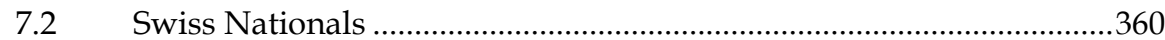

7.3 Other Sources of EU Law Applicable to Third-Country Nationals ...360

7.4 The Right to Social and Tax Advantages Compared ............................361

$8 \quad$ Conclusion to Part VII .............................................................................362 


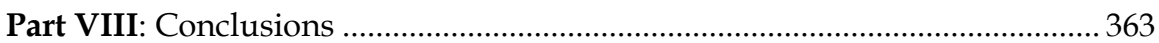

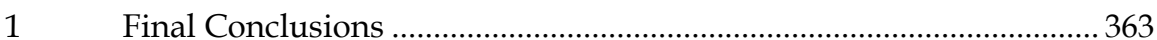

1.1 The Link between Migration Policy and External Relations .............. 363

1.2 The Incorporation of Migration into the EU Legal Framework: The Changing External Dimensions ......................................................... 364

1.3 Difference in Treatment among Third-Country Nationals ................... 367

1.4 The Role of the Court of Justice in Strengthening Migrants' Rights.. 371

1.5 Third-Country Nationals and Equality of Treatment.......................... 373

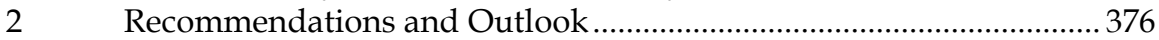

Part IX: Schematic Overview of the Legal Position of Third-Country Nationals

Part X: Samenvatting

Part XI: Zusammenfassung

Part XII: Bibliography

Part XIII: EU Official Documents, Table of Cases, and List of Interviewees.. 451

1 EU Official Documents .

1.1 List of Association, Cooperation, Partnership and Trade

Agreements (referred to in this dissertation)....

1.2 Directives, Regulations, Decisions and Joint Actions .......................... 462

1.3 Decisions of the EU-Turkey Association Council ................................. 465

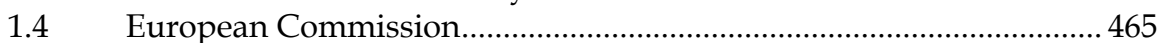

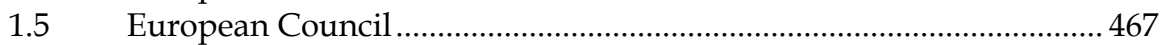

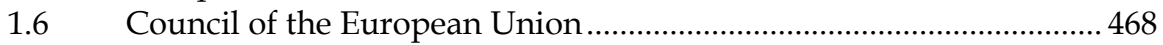

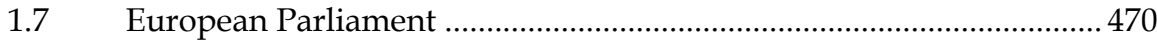

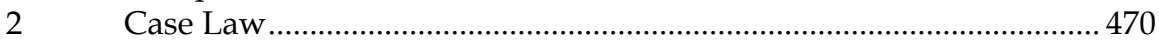

2.1 Cases of the Court of Justice of the European Union........................... 470

2.2 Case C-221/11 Demirkan, reference for a preliminary ruling lodged on 11 May 2011 (2011/C 232/25) Cases of the General

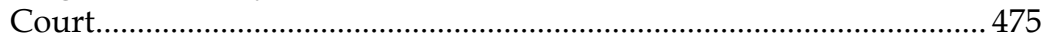

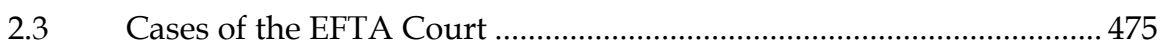

2.4 Cases of the European Court of Human Rights .................................. 475

2.5 Cases of the International Court of Justice........................................... 477

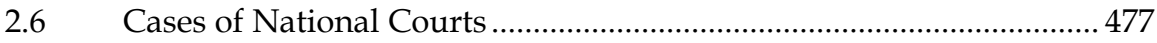

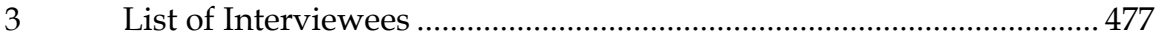

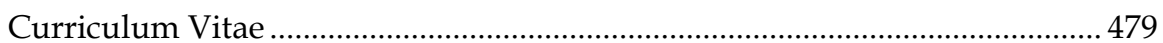




\section{List of Abbreviations}

\begin{tabular}{|c|c|}
\hline ACP States & African, Caribbean and Pacific States \\
\hline AG & Advocate General \\
\hline $\mathrm{AU}$ & African Union \\
\hline BVerwG & $\begin{array}{l}\text { Bundesverwaltungsgericht (Federal Administrative Court } \\
\text { of Germany) }\end{array}$ \\
\hline CAT & Convention against Torture \\
\hline CFSP & Common Foreign and Security Policy \\
\hline CIS & Commonwealth of Independent States \\
\hline COREPER & Committee of Permanent Representatives \\
\hline DG & Directorate-General \\
\hline DG DEVCO & $\begin{array}{l}\text { Directorate-General Development and Cooperation - } \\
\text { EuropeAid }\end{array}$ \\
\hline DG ECHO & $\begin{array}{l}\text { Directorate-General Humanitarian Aid and Civil } \\
\text { Protection }\end{array}$ \\
\hline DG HOME & Directorate-General Home Affairs \\
\hline DG RELEX & (former) Directorate-General for External Relations \\
\hline EC, Community & European Communities \\
\hline ECE & European Convention on Establishment \\
\hline ECHR & European Convention on Human Rights \\
\hline ECJ, Court of Justice & Court of Justice of the European Union \\
\hline ECMW & $\begin{array}{l}\text { European Convention on the Legal Status of Migrant } \\
\text { Workers }\end{array}$ \\
\hline ECOSOC & United Nations Economic and Social Council \\
\hline ECOWAS & Economic Community of West African States \\
\hline ECSC & European Coal and Steel Community \\
\hline ECSMA & European Convention on Social and Medical Assistance \\
\hline ECSS & European Convention on Social Security \\
\hline ECtHR & European Court of Human Rights \\
\hline EEA & European Economic Area \\
\hline EEA Agreement & European Economic Area Agreement \\
\hline EEAS & European External Action Service \\
\hline EEC & European Economic Community \\
\hline EFTA & European Free Trade Association \\
\hline ENP & European Neighbourhood Policy \\
\hline EP & European Parliament \\
\hline EPAs & Economic Partnership Agreements \\
\hline EPC & European Political Cooperation \\
\hline ESC & European Social Charter \\
\hline ESDP & European Security and Defence Policy \\
\hline EU Charter & EU Charter of Fundamental Rights \\
\hline EU, Union & European Union \\
\hline EUROSUR & European External Border Surveillance System \\
\hline FMP Agreement & Free Movement of Persons Treaty with Switzerland \\
\hline FRONTEX & $\begin{array}{l}\text { European Agency for the Management of Operational } \\
\text { Cooperation at the External Borders of the Member } \\
\text { States of the European Union }\end{array}$ \\
\hline FTAs & Free Trade Agreements \\
\hline
\end{tabular}


FYROM

GAMM

GATS

GAT'T

GCC

GFMD

High Representative

ICCPR

ICERD

ICESCR

ICJ

ICMW

ILO

ILOs

IMF

IOM

JAIEX (JHA-RELEX)

LAC

MDGs

MME

OECD

OSCE

PCA

PJCC

SAAs

SEA

TEU, EU Treaty

TFEU

TRIPS

UDHR

UN

UNCTAD

UNESCO

UNHCR

UNICEF

VIS

WHO

WTO
Former Yugoslav Republic of Macedonia

Global Approach to Migration and Mobility

General Agreement on Trade in Services

General Agreement on Tariffs and Trade

Arab States of the Gulf

Global Forum on Migration and Development

High Representative of the Union for Foreign Affairs and Security Policy

International Covenant on Civil and Political Rights

International Convention on the Elimination of All

Forms of Racial Discrimination

International Covenant on Economic, Social and Cultural

Rights

International Court of Justice

UN International Convention on the Protection of the Rights of Migrant Workers and their Families

International Labour Organisation

Immigration Liaison Officers

International Monetary Fund

International Organisation for Migration

Justice and Home Affairs - External Relations Working

Group

Latin American and Caribbean countries

UN Millennium Development Goals

Africa-EU Partnership on Migration, Mobility and Employment

Organisation for Economic Co-operation and

Development

Organisation for Security and Co-operation in Europe

Partnership and Cooperation Agreement

Police and Judicial Cooperation in Criminal Matters

Stabilisation and Association Agreements

Single European Act

Treaty on European Union

Treaty on the Functioning of the European Union

Agreement on Trade-Related Aspects of Intellectual

Property Rights

Universal Declaration of Human Rights

United Nations

United Nations Conference on Trade and Development

United Nations Educational, Scientific and Cultural

Organisation

United Nations High Commissioner for Refugees

United Nations Children's Fund

Visa Information System

World Health Organisation

World Trade Organisation 


\section{Part I : Introduction}

Immigration and emigration processes have shaped the European continent throughout its history. Immigration matters have always been at the very heart of the national sovereignty of states, and a particularly sensitive policy area for governments and societies up to the present day. Territorial supremacy, as recognised under public international law, permits states to exercise discretion in stipulating entry conditions applicable to aliens. Nonetheless, this right is curtailed by international legal obligations to which a state is bound. ${ }^{1}$ Furthermore, supranational legislation has restrained the power of the EU Member States in the fields where competences have been transferred to the European Union (EU, Union).

\subsection{EU Citizen and Third-Country Nationals}

In the evolution of the EU, a basic distinction has been made between those migrants who possess the nationality of an EU Member State and those nationals who possess the nationality of a country located outside of the EU. This distinction has major consequences for the legal position of migrants travelling to and residing in the Union. Importantly, nationals of Member States - EU citizens - may, in principle, freely move, reside, leave and return to a Member State of their choice. ${ }^{2}$ The freedom of movement of persons constitutes one of the four fundamental freedoms of the Union's internal market; it developed from the economic logic of setting up a common market as provided for in the Treaty of Rome, "but also, and perhaps even more" it followed from the specific labour market needs of the founding Member States in 1958.3 After World War II western European countries recorded a substantive lack of workforce. "The great losses of manpower in and through the war, the very considerable stream of emigrants from Europe going overseas, the unexpectedly swift rebuilding of industry in the old industrialised countries - to name only the most important factors - brought into being a favourable climate for the liberalisation in general and for the easing of restrictions on the labour market in particular." 4 Thus, the EU, from its inception, has dealt with immigration matters from an economic point of view. The objective of creating a common market should be achieved by a number of activities including "the abolition, as between Member States, of obstacles to freedom of movement for

1 In this regard, the non-refoulement principle, which has become part of customary international law, stipulates that no person may be expelled or returned for any reason whatsoever to the frontiers of the territories where his life or freedom is in danger as laid down in Art. 33(1) of the 1951 Convention relating to the Status of Refugees. See Directive 2004/38/EC of the European Parliament and the Council of 29 April 2004 on the right of citizens of the Union and their family members to move and reside freely within the territory of the Member States; transitional arrangements are to be taken into account for nationals of some of the newly acceded Member States.

3 See Art. 2 in combination with Art. 8(1) of the Treaty of Rome and K.A. Dahlberg, 'The EEC Commission and the Politics of the Free Movement of Labour', 6 Journal of Common Market Studies (1968), 310, p. 311.

$4 \quad$ K. Lewin, 'The Free Movement of Workers', 2 Common Market Law Review (1964), 300, p. 301. 
persons, services and capital". ${ }^{5}$ The free movement of persons included at the outset workers, the self-employed and service providers, and was hence dependent on the exercise of an economic activity. Only with the introduction of Union citizenship with the Maastricht Treaty of 1992, the prerequisite that EU citizens must be economically active to benefit from the free movement regime dissolved under the jurisdiction of the Court of Justice. ${ }^{6}$

At the time when the European Economic Community (EEC) came into being, third-country nationals were neither in the focus of national nor supranational authorities. The legal situation of non-EU nationals has only little by little edged ever closer to the spotlight in the EU arena, starting with rights granted to third-country nationals on the basis of EU association agreements and to third-country nationals in the capacity of family members of Community workers. ${ }^{7}$ Since then the EU legal framework experienced major changes endowing the Union gradually with more farreaching competences in immigration matters, in particular with the insertion of Title IV of the Treaty of Amsterdam in 1997. Today, the Treaty of Lisbon under Title V TFEU on the area of freedom, security and justice explicitly provides for the EU the task to develop a common immigration policy aimed at ensuring, at all stages, the efficient management of migration flows, fair treatment of third-country nationals residing legally in the Member States, and the prevention of, and enhanced measures to combat irregular immigration and trafficking in human beings. ${ }^{8}$ Therefore, the legal regime under the Treaty of Lisbon incorporated the objectives first announced by the European Council in October of 1999 in Tampere, as ten years later confirmed under the Stockholm Programme in 2009. ${ }^{9}$ The Tampere Conclusions of 1999 were ambitious as the European Council envisaged not only a vigorous integration policy with a view to granting third-country nationals rights and obligations comparable to those of EU citizens and enhancing non-discrimination in economic, social and cultural life, but also set out the goal to approximate the legal status of third-country nationals to that of Member States' nationals. ${ }^{10}$ The EU legislation applicable to third-country nationals is today characterised by a high degree of fragmentation: non-EU nationals who reside or wish to reside in an EU Member State are faced with a great variety of different legal sources that determine their respective legal positions. This may create problems of transparency, clarity and coherency, or even jeopardise legal certainty. One may also wonder whether the

See Art. 3(c) Treaty of Rome.

Case C-85/96 Martinez Sala [1998] ECR I-2691.

See Title III of original Council Regulation (EEC) No 1612/68 of 15 October 1968 on the freedom of movement for workers within the Community on the workers' families, which is now replaced by Art. 10 of Regulation (EU) No 492/2011 of the European Parliament and of the Council of 5 April 2011 on freedom of movement for workers within the Union, as well as Arts. 5, 6, 7, 16, 17 and 23 of Directive 2004/38/EC of the European Parliament and of the Council of 29 April 2004 on the right of citizens of the Union and their family members to move and reside freely within the territory of the Member States.

8 See Art. 79(1) TFEU.

9 Tampere Presidency Conclusions of 15 and 16 October 1999, para. 18; the Stockholm Programme - An Open and Secure Europe Serving and Protecting Citizens, OJ C 115, 4 May 2010, p. 1.

$10 \quad$ Tampere Presidency Conclusions of 15 and 16 October 1999, paras. 18 and 21. 
differing legal positions are compatible with the principle of non-discrimination under the EU legal framework.

\subsection{Distinctions among Third-Country Nationals: Questions at Stake}

Against this background this dissertation aims to answer the following questions: why can third-country nationals with a certain nationality rely on a greater set of rights on the basis of EU law than others, and how do these sets of rights differ? In other words, how does a privileged position of a third-country national differ from a "nonprivileged" one in legal terms? By means of a rights-based approach this research examines the difference in treatment among third-country nationals with a view to provide a comparative analysis of the respective legal positions of non-EU nationals. ${ }^{11}$

To tackle these questions some related issues require further study: first, the research investigates how the two policy fields of migration and external relations relate to one another, and in what ways the EU's external relations have contributed to granting favourable treatment of third-country nationals holding a certain nationality. In this context the role of EU association, cooperation and partnership agreements, which are major tools for shaping the EU's external relations, is explored as well as the reasons for which such agreements have been concluded with third countries in the first place. In addition, it is analysed how, more generally, the EU's external relations have influenced European migration law and policy since the genesis of the Union, and vice versa how migration policy has affected the external relations. This analysis is closely connected with the questions of when and how the "external dimension" of the EU's migration policy came into existence. The questions raised above cannot be answered without concentrating, second, on the following sub-questions: which rights can all third-country nationals rely upon in the EU; how do EU association, cooperation and partnership agreements exactly provide for more favourable treatment - and is this difference in treatment compatible with the principle of nondiscrimination; and how do the legal positions of third-country nationals based on nationality differ in terms of entry, employment, residence, social security, as well as other social and economic rights. By focusing on these questions and issues raised, this research project aims to explain the fragmented approach and disentangle the assorted sources of law that specify rights for third-country nationals.

Finally, on the basis of the findings of this dissertation, it will be assessed whether the aim of establishing a common EU migration policy can be achieved against the backdrop of an ostensible highly selective migration regime existing in the EU today. In the context of this research project the term "common EU migration policy" is understood as a migration policy that applies to all third-country nationals rather than a migration policy that is merely "common" to all EU Member States. One may also question whether it is in fact accurate to speak of one group of third-country nationals, forming the counterpart to EU citizens, considering that the various scopes International, The Hague 2001). 
of rights that third-country nationals enjoy depending on their nationality appear substantial.

\subsection{Migration and External Relations: Association Agreements and the Court of Justice}

Some further introductory remarks which outline how the two policy areas of migration and external relations relate to one another since the EEC's origin are appropriate at this point. The competence to conclude association and trade agreements actually constituted one of the Community's first external powers enabling it to enter into contractual relations with other states for cooperation purposes. Such agreements were first concluded in the 1960s and 1970s with the aim of promoting the economic and political relations between the Community and the third country in question. Within the scope of these early agreements migration has with exceptions - been marginally addressed and has played a subordinate role in the EU's external relations. And yet, at this early stage, migration matters formed part and parcel of Community law and policy. Some agreements offered more than simple trade agreements with regard to workers: such as the association agreements which had the ultimate objective to integrate the associated state into the Community as a fully-fledged Member State. The preparation of incorporating an associated state required the stipulation of more far-reaching commitments, principles and rights. For example, the EEC-Greece association agreement provided for the free movement of workers, in accordance with the Rome Treaty and in line with the rules determined by the EEC-Greece Association Council, after the transitional period of 12 years for the establishment of the customs union. ${ }^{12}$ Moreover, the Ankara Agreement that the Community concluded with Turkey in 1963 constituted the legal basis to adopt subsequently more favourable rules for Turkish workers residing in a Member State. ${ }^{13}$ Importantly, the provisions of association agreements relating to the status or movement of persons are only applicable to the nationals of the respective state parties. What exactly has been the role of the Court of Justice, the EU's highest judicial organ, in this context? How has the Court of Justice interpreted pertinent provisions in association agreements and how has this affected third-country migrants as regards their legal position?

\subsection{External Dimensions of EU Migration Policy}

When people cross borders for the purpose of migrating from one country to another, this process has by nature an international, external component. Notably in the last two decades the "external dimension" of the EU's migration policy has become a catch phrase among policy makers at the national and EU level alike. It was at the beginning of the 1990s that migration gained centre stage within the Community with a focus on the reduction of migratory pressure. The Commission

12 See Arts. 44 and 6 of the Agreement establishing an Association between the European Economic Community and Greece, OJ 26, 18 February 1963, p. 294.

13 Agreement establishing an Association between the European Economic Community and Turkey (Ankara Agreement), OJ L 361, 31 December 1977, p. 1; Additional Protocol and Financial Protocol signed at Brussels on 23 November 1970, annexed to the Agreement establishing the Association between the European Economic Community and Turkey and on measures to be taken for their entry into force, OJ L 293, 29 December 1972, p. 4. 
pointed out that migration had a European dimension which required internal and external policy action. ${ }^{14}$ The conception that a successful immigration policy lays down an internal set of laws for nationals of third countries as well as an external method of approach directed towards countries of origin and transit has gained ground by piecemeal. In this connection, the EU has sought to establish "partnerships" with third countries with a view to enhance dialogue and cooperation on a variety of migration-related issues in the framework of the so-called EU Global Approach to Migration. The EU Heads of State and Government formulated this approach in 2005 as a direct policy response to the lugubrious incidents in Ceuta and Melilla where hundreds of migrants assailed the fences shielding the Spanish enclaves in North Africa. Media images of drowning African migrants in the Mediterranean Sea, who desperately tried to reach the European shores, caused tremendous outrage among civil society; in a short time the notion of a "Fortress Europe" became widely conveyed and it encouraged policy makers to speed up in taking counteractive action. The EU and its Member States were accused of half-hearted attempts to deal with the humanitarian crisis at the gates of a Union that is founded on the values of human dignity, democracy, the rule of law, and the respect for human rights. ${ }^{15}$ P.J. Cardwell observed that the "discussion of migration issues is often strongly linked to the search for security in the internal sphere and this necessitates taking into account factors affecting internal security but outside the physical borders of EU territory", and " $[\mathrm{C}]$ onsequently, and alongside the search for an increased global role for the Union, migration issues are pushed towards the domain of foreign policy." 16

The Global Approach to Migration identified migration matters as a key policy area against the background of the EU's labour market shortages, the Member States' ageing societies, and an alleged increasing influx of irregular migrants. The political leaders of Europe agreed to manage migration effectively by improving cooperation between the Member States on the one hand, and with the countries of origin and the EU neighbouring states on the other. ${ }^{17}$ In October of 2008, the Commission explained the Global Approach defining it as the external dimension of the EU's migration policy based on genuine partnerships with third countries. The Global Approach has been described as comprehensive, balanced, and fully integrated into the EU's other external policies and it has comprised initially of three pillars: legal economic migration, irregular migration, and migration and development. ${ }^{18}$ In the abundant literature on this topic, researchers have questioned the supposedly "balanced" external dimension and the "integrated" Global Approach, pointing to the practice of externalising border control by shifting responsibility to third states. ${ }^{19}$

14 European Commission Communication, SEC(91) 1855, 23 October 1991.

15 See Preamble to the TEU and Art. 2 TEU.

16 P.J. Cardwell, EU External Relations and Systems of Governance: The CFSP, EuroMediterranean Partnership and Migration (Routledge, Abingdon 2009), pp. 140-141.

European Commission Communication, COM(2005) 621, 30 November 2005.

European Commission Communication, COM(2008) 611, 8 October 2008.

See C. Boswell, The "External Dimension" of EU Immigration and Asylum Policy', 79 International Affairs (2003), 619; J.J. Rijpma and M. Cremona, 'The ExtraTerritorialisation of EU Migration Policies and the Rule of Law', EUI Working Papers LAW (2007); A. Baldaccini, 'The External Dimension of the EU's Asylum and Immigration Policies: Old Concerns and New Approaches', in: A. Baldaccini, E. Guild and H. Toner (eds.), Whose Freedom, Security and Justice? EU Immigration and Asylum Law and Policy (Hart Publishing, Oxford 2007), pp. 276-298; P. Devisscher, 'Legal Migration 
It has also been highlighted that "policy coherence and synergies in the context of the external dimension of EU immigration policy should not only be viewed as the full integration (or mainstreaming) of migration (and asylum issues) into the EU's other external policies (e.g. development cooperation, etc.) but should dovetail with the immigration and asylum policy developed under Title V of Part Three of the TFEU" indicating examples "where considerable work still needs to be undertaken to ensure coherence and synergies between the (admittedly still) fledgling external dimension of the EU's immigration policy and its internal dimension."20

The Global Approach was endorsed in the Stockholm Programme setting out the 2010-2014 agenda in justice and home affairs, and was renamed as the "Global Approach to Migration and Mobility" (GAMM) in 2011.21 The Commission contends that the GAMM concentrates on mobility and is "migrant-centred". The GAMM incorporates international protection and asylum as a fourth pillar; and the human rights of migrants are said to be dealt with as a cross-cutting issue. However, as this book demonstrates, an "external dimension" of migration policy in the EU context has existed since the integration of migration rules in association and cooperation agreements - at a time, when the Community did not even dispose of competences in this domain. It must be borne in mind that the conclusion of association agreements is a powerful measure that the EU has at its disposal to shape its external relations under EU law. Association agreements leading to accession have paved the way for the EU as it stands today: a supranational organisation of 27 Member States. Alongside this, the EU has concluded numerous other agreements with the aim to develop and enhance its trade relations, or to build political cooperation and partnerships with countries around the globe. The Treaty of Lisbon has established the European External Action Service (EEAS), a diplomatic service to provide the EU with a more visible representation to the world. The EEAS assists the High Representative of the Union for Foreign Affairs and Security Policy who conducts the Union's common foreign and security policy, as well as the common security and defence policy. ${ }^{22}$ The creation of the EEAS has provoked much debate about its composition, its area of responsibility, and the delimitation of Member States' foreign policies. ${ }^{23}$ The field of migration is explicitly identified as one of the global challenges, which the EEAS aims to tackle.

in the Relationship between the European Union and ACP Countries: The Absence of a True Global Approach Continues', 13 European Journal of Migration and Law (2011), 53. R. Cholewinski, 'The External Dimension of the EU Immigration Policy', in: M. Maes, M.-C. Foblets and Ph. De Bruycker (eds.), External Dimensions of European Migration and Asylum Law and Policy (Bruylant, Bruxelles 2011), pp. 485-500, p. 487.

21 The Stockholm Programme - An Open and Secure Europe Serving and Protecting Citizens, OJ C 115, 4 May 2010, p. 1; European Commission Communication, $\operatorname{COM}(2011)$ 743, 18 November 2011.

$22 \quad$ Arts. 18 and 27(3) TEU.

23 S. Vanhoonacker and N. Reslow, 'The European External Action Service: Living Forwards by Understanding Backwards', 15 European Foreign Affairs Review (2010), 1; S. Duke, 'The Treaty of Lisbon and External Relations', EIPASCOPE (2008), 13. 
Importantly, specific EU legislation applies to third-country nationals irrespective of nationality. The "communitarisation" of migration policies under Title IV of the Treaty of Amsterdam has led to the adoption of EU secondary legislation; the following legislative acts are relevant in the realm of legal migration: the Directive on family reunification, ${ }^{24}$ the Directive on long-term resident status, ${ }^{25}$ as well as the Directives on the admission criteria for students, ${ }^{26}$ researchers ${ }^{27}$ and highly-skilled workers, known as the EU Blue Card Directive. ${ }^{28}$ The amended Commission proposal for a Directive on a single residence and work permit for third-country nationals that has been under discussion for a long time was adopted on 13 December 2011.29 Under the Treaty of Lisbon, Title V TFEU has amended the rules regarding migration and asylum policy. Furthermore, third-country nationals may profit from primary EU law, including the EU Charter of Fundamental Rights (EU Charter) which is, to a large extent, applicable to everyone. The EU Charter has become legally binding with the entry into force of the Treaty of Lisbon on 1 December 2009. Non-EU nationals may also claim protection under international law standards to which Member States or the EU is a party. The European Convention on Human Rights (ECHR) is central in this respect as its scope of application extends to all third-country nationals residing in a contracting state party.

\subsection{Third-Country Nationals as an Integrated Part of the EU Population}

Eurostat data indicates that in 2010, 20.1 million citizens were residing in the Union who are third-country immigrants, which equals $4 \%$ of the total population of almost 501 million inhabitants in the EU. ${ }^{30}$ In 2006 there were, by way of comparison, 18.5 million third-country nationals residing in the EU $(3.8 \%$ of the total population at that time) according to the Third Annual Report on Migration and Integration. ${ }^{31}$ Migration constitutes the main driver of population change in the EU. ${ }^{32}$ In 1997, the scholar S. Peers asked: "who is the European Community for? Is the Community purely for the income-earning nationals of Member States, or is it for all its legal residents, including nationals of third states and persons who are not economically

24 Council Directive 2003/86/EC of 22 September 2003 on the right to family reunification.

25 Council Directive 2003/109/EC of 25 November 2003 concerning the status of thirdcountry nationals who are long-term residents.

26 Council Directive 2004/114/EC of 13 December 2004 on the conditions of admission of third-country nationals for the purposes of studies, pupil exchange, unremunerated training or voluntary service.

27 Council Directive 2005/71/EC of 12 October 2005 on a specific procedure for admitting third-country nationals for the purposes of scientific research. Council Directive 2009/50/EC of 25 May 2009 on the conditions of entry and residence of third-country nationals for the purposes of highly qualified employment. Directive 2011/98/EU of the European Parliament and of the Council of 13 December 2011 on a single application procedure for a single permit for third-country nationals to reside and work in the territory of a Member State and on a common set of rights for third-country workers legally residing in a Member State.

European Commission Communication, COM(2011) 291, 24 May 2011, p. 1.

European Commission Communication, COM(2007) 512, 11 September 2007, p. 3. European Commission Communication, $\operatorname{COM}(2011)$ 291, 24 May 2011, p. 1. 
active?" 33 This question is still today important and relevant in that it relates to the core issue of whether the European Union shall be an inclusive one or not, and presents itself as such to the outside world.

\section{2}

\section{OUTLINE AND APPROACH}

The dissertation is divided into ten parts. Part II sets forth a historical overview of how the fields of the EU's external relations on the one hand, and of EU migration law and policy on the other have developed and influenced each other since the conclusion of the Treaty of Rome in 1957. This part explains in what ways migration issues have gradually been incorporated into the Treaty framework, and how the external competences of the EU have expanded under the interpretation of the Court of Justice and various Treaty amendments.

Part III analyses the human rights instruments, organisations and fora that are of particular relevance for migrants and that have inspired or influenced the formulation of EU migration law and policy. The first section of this Part III focuses on rules and standards that aim to protect human rights in the EU for which especially the ECHR has played a central role. The second section of Part III discusses the protection of migrants' rights under international treaties, and explains the institutional setting that has influenced migration policy on the international level.

Part IV concentrates on the various agreements and cooperation frameworks that the EU has established with third countries, and elaborates on their purpose and structure. Part IV first, however, discusses the application of the principle of nondiscrimination to third-country nationals.

Part V elaborates on entry, residence and employment rights; Part VI deals with rights in the field of social security and Part VII investigates other economic and social rights of third-country nationals. In Parts V to VII the rights of third-country migrants as stipulated in association agreements are used as a basis for a comparative analysis. This comparative analysis also integrates pertinent EU secondary legislation adopted under Title V TFEU on the area of freedom, security and justice.

Following these parts, the conclusion in Part VIII wraps up and evaluates the main findings of the book. On the basis of the conclusions drawn, this last section outlines policy recommendations and provides an outlook on future developments. Part IX comprises a schematic overview of the legal position of third-country nationals that visualises the findings of Parts V to VII in charts.

The methodological approach of this dissertation consists thus of a comparative legal analysis of the relevant international law sources as well as EU legislation, such as EU primary and secondary law, and the case law handed down by the Court of Justice and the European Court of Human Rights (ECtHR). However, reference is also made to some decisions of other international and national courts. The dissertation is 
moreover based on the profound analysis of doctrine, such as AGs' opinions and secondary academic literature. Next to the legal academic literature used, this dissertation also integrates multidisciplinary writings, including of sociological and political nature. The rights-based approach pursued in this book is supplemented by research based on reports and policy documents of the various EU institutions, in particular of the European Commission, and of international organisations and fora to explain the current EU migration and external relations' policy framework. ${ }^{34}$ Finally, semi-structured interviews with a number of actors, including representatives of the EU institutions, the Member States, and civil society, have been held to obtain up-to-date information on relevant developments in the field of migration policy.

This dissertation, however, does not address issues relating to asylum, nationality questions, and irregular migration in greater detail. As regards the subject-matter of integration, the situation is more nuanced. In the EU context, the process of integration of migrants is considered to promote economic development and social cohesion. ${ }^{35}$ The theory goes that the smooth integration of migrants and their families into the host country is considerably facilitated by a secure legal status that provides for equality between their living and working conditions, wages and economic rights and of those enjoyed by EU citizens and their family. Yet, the issue of integration is not explained more in-depth in the framework of this research because other contributions have delved into the topic. ${ }^{36}$ In addition, the derived rights that third-country nationals enjoy in their capacity as family members under Directive 2004/38/EC on the right of citizens of the Union and their family members to move and reside freely within the territory of the Member States are only discussed as rights of family members of EEA citizens; it must be borne in mind that the concept of European citizenship and fundamental status it entails is not applicable to nationals of Iceland, Norway and Liechtenstein. ${ }^{37}$ Finally, this dissertation elaborates exclusively on the agreements that the EU has concluded with third countries. Bilateral agreements in the field of labour or social security between Member States and third countries fall outside the scope of this study.

The EU has used different terms for the agreements it has concluded with third countries, such as "association agreements", "cooperation agreements" and

In E. Guild, Immigration Law in the European Community (Kluwer Law International, The Hague 2001) the scholar first analysed the development of Community law from the perspective of the migrant and his or her rights and possibilities: "The perspective of the migrant must always be informed by what the law permits or prohibits him or her from doing. In the field of immigration, the question is one of the possibilities to move, reside, exercise economic activities and enjoy protection from discrimination and expulsion." (p. 341).

35 See Recital 4 of Council Directive 2003/86/EC of 22 September 2003 on the right to family reunification; European Commission Communication, $\operatorname{COM}(2011)$ 455, 20 July 2011, p. 2.

36 See in particular S. Carrera, In Search of the Perfect Citizen? The Intersection between Integration, Immigration, and Nationality in the EU (Martinus Nijhoff Publishers, Leiden 2009).

37 Directive 2004/38/EC of the European Parliament and of the Council of 29 April 2004 on the right of citizens of the Union and their family members to move and reside freely within the territory of the Member States. 
"partnership agreements". The question arises as to what extent these agreements differ from one another. In Demirel the Court observed that the notion of "association" was not defined in the Treaties; it held that an association agreement created special, privileged links with a non-Member State which had to take part, at least to a certain extent, in the Community system. ${ }^{38}$ While the act of "associating" a country with the EU was usually - but not always (consider the original Yaoundé I Agreement labelled as a "convention d'association", or the EU-Chile Association Agreement) - connected with future EU membership, the terms of "cooperation" and "partnership" have consistently been used for countries unequivocally having no prospect of accession (such as Morocco or Russia). Moreover, the object and purpose of an agreement with a third country was attributed a vital role by the Court of Justice when it came to questions of interpretation. Nevertheless, Article 238 EEC (now Article 217 TFEU) has served as a legal basis for all of the three agreements listed. Association, cooperation, and partnership agreements must, however, be distinguished from pure trade agreements which have been concluded under Article 113 EEC (now Article 207 TFEU). ${ }^{39}$

The notion of "third-country national" is one that is specific to the EU context. Third-country nationals are individuals who do not possess the nationality of an EU Member State. Importantly, only those nationals who do have the nationality of an EU Member State can rely on the concept of European citizenship. Since the Rome Treaty, the EU has developed considerably as a supranational organisation. I have endeavoured to use the terms "Community", "EU" and "Union" as reflected in the pertinent Treaties for each time period.

\section{4}

\section{RESEARCH SETTING}

This dissertation was drafted in the framework of the project "Migration and Development: A World in Motion", which is coordinated by the Maastricht Graduate School of Governance and implemented with the support of the Dutch Ministry of Foreign Affairs (IS Academie). A total of six PhD fellows of Maastricht University have been conducting multidisciplinary research on different aspects of the link between migration and development, including the phenomenon of brain drain, remittances and poverty alleviation, return migration, as well as in the EU setting the new policy instrument of mobility partnerships. My book complements this research by providing a legal perspective on the different positions of third-country nationals arriving at and residing in the EU. ${ }^{40}$ In the discourse on migration and development, the awareness is gaining ground that a secure legal status of migrants, especially migrant workers, is vital for generating contributions to developmental and social progress and to the general welfare in sending and receiving countries: "[T]he migration-protection-development linkages need to be articulated in order to

38 Case C-12/86 Demirel [1987] ECR I-3719, para. 9.

39 See, however, the Court's finding in Ziebell, in which the Court held that the purpose underpinning the EU-Turkey association was solely economic in nature: Case C371/08 Ziebell [2011] Judgment of 8 December 2011, not yet reported, para. 64.

40 The PhD fellows are associated with the Faculty of Arts and Social Sciences of Maastricht University, the Maastricht Graduate School of Governance, and the Faculty of Law of Maastricht University; for more information on the IS Academie project, see website: <http://mgsog.merit.unu.edu/ISacademie/>, last accessed on 18 July 2012. 
strengthen advocacy and action by home countries as well as host countries to uphold the protection of rights that permit migrant workers to obtain their earnings, live and work in decent conditions and safely remit earnings to support families and communities at home." 41 This is in line with the so-called triple-win situation under which the migratory process is envisaged to provide positive outcomes for the home, the host state, as well as the individual migrants. ${ }^{42}$ In 2011, EU policy makers have acknowledged that the human rights of migrants should have a cross-cutting dimension in the EU's GAMM. 43

41 P.A. Taran, 'The Need For a Rights-Based Approach to Migration in the Age of Globalization', in: R. Cholewinski (ed.), Migration and Human Rights (Cambridge University Press, Cambridge 2009), pp. 150-168, pp. 162-163.

42 European Commission Communication, $\operatorname{COM}(2008)$ 611, 8 October 2008, p. 7.

43 European Commission Communication, COM(2011) 291, 24 May 2011, p. 7. 



\section{Part II : EU External Relations and Migration Policy - The Historical Development of the External Dimension}

In its evolutionary history, the EU has experienced an incremental widening and deepening in that it developed from the European Economic Community of six countries into a supranational European Union of 27 Member States. The enlargement processes and the gradual expansion of competences have shaped the EU's existence, and laid the foundation for developing a European dimension of numerous policy domains, including foreign and migration policy. ${ }^{1}$ Part II unfolds the key developments of the EU's external relations on the one hand, and the EU's migration policy on the other from a historical perspective, subdivided into pertinent stages. This detailed breakdown provides the reader with the understanding of how the two policy fields have influenced each other over time in a meaningful way, and how the external dimension of the EU's migration policy has gradually emerged. In addition, Part II explains how the status of non-Member States' nationals has developed in the historical context starting from the EEC framework - this information allows the reader to comprehend the circumstances and motives which have caused the differential treatment of third-country nationals within the EU's external relations' regime.

Today, the EU is a well-established global actor; in addition to being a strong economic power, it is actively engaged in world politics. However, the EU's involvement has predominantly been considered as political and diplomatic in nature rather than coercive due to its shortcoming of military capacity. ${ }^{2}$ Some authors refer to the EU as a soft power considering that it has exerted significant influence in shaping global policies. At the same time, it is emphasised that it has been increasingly difficult for the EU to adopt common positions on politically sensitive and security-related matters. ${ }^{3}$ The EU has set up a wide range of networks and cooperation schemes to establish its contractual relations with third countries and other organisations. The EU's external relations have commonly been described as a complex field owing to the intricate division of competences between the EU and its Member States. Prior to the entry into force of the Treaty of Lisbon, it was stressed that: firstly, a coherent and effective foreign policy at the EU level is hampered by varying decision and law-making processes; secondly, the law that has shaped the EU's external relations is mainly based on case law and comprises procedural and substantive rules; thirdly, delicate and important issues with regard to legality, liability, the influence of external action on internal law, as well as questions concerning the management of external relations have arisen. Within the Commission's setting no less than four Directorates-General have previously dealt with external relations,

1 In fact, it has been pointed out that there is hardly any policy area on the international plane today that does not have an EU dimension, see F. Hoffmeister, The Contribution of EU Practice to International Law', in: M. Cremona (ed.), Developments in EU External Relations Law (Oxford University Press, Oxford 2008), p. 37.

2 P. Craig and G. De Búrca, EU Law: Text, Cases, and Materials (4th edn. Oxford University Press, Oxford 2008), p. 168.

3 S. Hix, The Political System of the European Union (2nd edn. Palgrave Macmillan, Basingstoke 2005), pp. 404-405. 
namely Development, Trade, Enlargement and External Relations. ${ }^{4}$ Thus, the EU's external relations' regime has evolved over time, first under the Community, then under the EU, and today the Treaty of Lisbon regime has endowed the Union with new rules and actors connecting the organisation with its partners in a globalised world.

Just like the EU's external relations, EU migration policy has progressively developed over time. For a long time, migration issues in the European sphere have only been a component of association and cooperation agreements which the EU has concluded with third countries. First, it was Member States' nationals that were in the spotlight of European law-making with a view to facilitating and ensuring the free movement of labour as one of the four fundamental freedoms of the EEC. As time passed, these internal developments relevant for nationals of the Member States triggered policy action with regard to third-country nationals. At the beginning of the 1970s the Council called for an action programme for migrant workers with the objective of achieving equality of treatment for Community and non-Community workers, and their family members in respect of living and working conditions, wages and economic rights. The Commission complied with this request and published such an action programme aiming to launch a "global approach to the problem of migration". ${ }^{5}$ However, only the Treaty of Amsterdam provided the EU with substantive competences in migration and asylum matters with the insertion of Title IV into the EC Treaty in 1999. The EU legislator used the legal bases contained in former Title IV EC to build a comprehensive migration and asylum framework by means of adopting secondary legislation. The Treaty of Lisbon changed the legal regime for EU migration law and policy anew and in a significant way.

\section{$2 \quad 1958$ - 1992: THE GENESIS OF THE EEC AND THE SINGLE EUROPEAN ACT}

\subsection{The Treaty of Rome (1958)}

\subsubsection{EEC External Involvement}

The constituent document of the EEC, the Rome Treaty, was signed on 25 March 1957 and entered into force on 1 January 1958 aimed to establish a common market during a transitional period of twelve years. ${ }^{6}$ The creation of a common market in the EEC framework required the gradual establishment of a customs union based on the prohibition of custom duties between its member states and the implementation of a common custom tariff, which is applicable in the relations with all non-Member States. ${ }^{7}$ Thus, from the outset it was clear that the EEC had to govern its relations with third countries with a view to manage its trade relations with partner states in

$4 \quad$ A. Ott and R. Wessel, 'The EU's External Relations Regime: Multilevel Complexity in an Expanding Union', in: S. Blockmans and A. Lazowski (eds.), The European Union and its Neigbbours (T.M.C. Asser Press, The Hague 2006), p. 24.

5 European Commission, $\operatorname{COM}(74)$ 2250, 14 December 1974, Action Programme in favour of migrant workers and their families (transmitted by the Commission to the Council on 18 December 1974), p. 12.

6 Art. 2 in combination with Art. 8(1) of the Treaty of Rome. See Chapter 1 (Art. 12-29) of the original EEC Treaty. 
the world economy generally, and to set a common external tariff specifically on the basis of the Common Commercial Policy. ${ }^{8}$ The Treaty of Rome also endowed the EEC with the competence to enter into association agreements. Article 238 EEC laid down that the Community may conclude agreements with one or more states or international organisations establishing an association involving reciprocal rights and obligations, common action and special procedures. ${ }^{9}$ This rule and the provisions on the Common Commercial Policy were the first explicit powers in the field of EEC external relations until the adoption of the Single European Act in 1987.

At the beginning of the 1960s the Community had begun to approach certain countries to build its external relations in contractual terms. Greece was the first state with which the EEC concluded an association agreement on the basis of Article 238 EEC; it was signed on 9 July 1961 and entered into force on 1 November 1962.10 The negotiations, lasting approximately one year, culminated in an association that provided for a single customs union between the EEC and Greece, and allowed for the free movement of persons, services and capital. By this means the gradual integration of Greece into the common market was prepared. ${ }^{11}$ On 20 July 1963, the EEC and 18 African countries signed the Yaoundé Convention that came into effect on 1 June 1964. Importantly, the Convention specified commercial benefits and financial support to former colonies but did not include the possibility of future membership. ${ }^{12}$ Consequently, the legal basis of Article 238 EEC was used moreover to provide preferential economic treatment and development assistance; the Community received such an explicit competence as regards development cooperation only with the Maastricht Treaty some 30 years later. The signing of the Ankara Agreement on 12 September 1963 marked the launch of the third major cooperation agreement providing for the Community association with Turkey. The Ankara Agreement came into effect on 1 December 1964 and was later supplemented by the 1970 Additional Protocol. ${ }^{13}$ The wording of Article 238 EEC has been deemed to be rather vague due to the fact that the term "association" was not defined in the Treaty text. The Court made clear in the Demirel case that an association agreement creates privileged links with a non-Member State which must, at least to a certain extent, take part in the Community system. ${ }^{14}$ It is contended that at this point in time the EEC institutions considered that all measures dealing with

8 P. Eeckhout, EU External Relations Law (2nd edn. Oxford University Press, Oxford 2011), p. 12.

$9 \quad$ Art. 217 TFEU under the Treaty of Lisbon.

10 Agreement establishing an Association between the European Economic Community and Greece, OJ 26, 18 February 1963, p. 294.

11 D. Valentine, 'Agreement of Association between Greece and the European Common Market', 10 International and Comparative Law Quarterly (1961), 903, pp. 903-904.

12 Convention d'association entre la Communauté économique européenne et les États africains et malgache associés à cette Communauté, JO 93 du 11 juin 1964, p. 1431 (Yaoundé I).

13 Agreement establishing an Association between the European Economic Community and Turkey (Ankara Agreement), OJ L 361, 31 December 1977, p. 1; Additional Protocol and Financial Protocol signed in Brussels on 23 November 1970, annexed to the Agreement establishing the Association between the European Economic Community and Turkey and on measures to be taken for their entry into force, OJ L 293, 29 December 1972, p. 4.

14 Case C-12/86 Demirel [1987] ECR I-3719, para. 9. 
issues covered by the Treaty regime could be incorporated into the agreements with Greece and Turkey. ${ }^{15}$ The Community established further economic relations with the Mediterranean countries Israel and Lebanon in 1964 and 1965 respectively, ${ }^{16}$ as well as with Morocco, Tunisia and Spain in the years thereafter. ${ }^{17}$ Next, the EEC concluded an agreement establishing an association with Malta in 1971 setting up a customs union between the two parties. ${ }^{18}$ A similar association agreement with Cyprus entered into force on 1 June 1973 providing for economic, technical, and financial cooperation. ${ }^{19}$ In the 1970 s, free trade agreements (FTAs) were signed with the seven European Free Trade Association (EFTA) states on the liberalisation of trade in goods, and a third revised trade agreement was adopted for Israel. ${ }^{20}$ In a similar fashion, FTAs were used as a tool to establish contractual relationships with a number of South American and Asian countries on trade matters; the FTA with Argentina, for instance, dates back to 1971, while the FTA with India was published in the Official Journal in 1974. ${ }^{21}$ In 1976, the Community formalised and renewed its

15 S. Peers, 'EC Frameworks of International Relations: Cooperation, Partnership and Association', in: A. Dashwood and C. Hillion (eds.), The General Law of the EC External Relations (Sweet \& Maxwell, London 2000), p. 161.

16 Accord commercial entre la Communauté économique européenne et l'état d'Israël, JO 95 du 13 juin 1964, p. 1518 (Israel I); Agreement in the form of an exchange of letters renewing the Agreement on trade and technical cooperation between the European Economic Community and the Member States, of the one part, and the Lebanese Republic, of the other part, OJ L 278, 29 October 1975, p. 22 (Lebanon I); revised agreements were signed at the beginning of the 1970s, see accord entre la Communaute économique européenne et l'état d'Israël, JO L 183 du 1 août 1970, p. 2 (Israel II); the agreement with Lebanon signed on 18 December 1972 (Lebanon II) has never been ratified by the latter state.

17 Accord créant une association entre la Communauté économique européenne et le Royaume du Maroc, JO L 197 du 8 août 1969, p. 3; Accord créant une association entre la Communauté économique européenne et la République tunisienne, JO L 198 du 8 août 1969, p. 3; Agreement between the European Economic Community and Spain, OJ L 182, 16 août 1970, p. 2.

18 Agreement establishing an Association between the European Economic Community and Malta, OJ L 61, 14 March 1971, p. 2.

19 Agreement establishing an Association between the European Economic Community and the Republic of Cyprus, OJ L 133, 21 May 1973, p. 2; see also C. Tsardanidis, 'The EC Cyprus Association Agreement: Ten Years of a Troubled Relationship, 1973-1983', 22 Journal of Common Market Studies (1984), 351.

20 Agreement between the European Economic Community and the Swiss Confederation, OJ L 300, 31 December 1972, p. 189; Agreement between the European Economic Community and the Kingdom of Sweden, OJ L 300, 31 December 1972, p. 97; Agreement between the European Economic Community and the Kingdom of Norway, OJ L 171, 27 June 1973, p. 2; Agreement between the European Economic Community and the Republic of Iceland, OJ L 301, 31 December 1972, p. 2; Agreement between the European Economic Community and the Portuguese Republic, OJ L 301, 31 December 1972, p. 165; Agreement between the European Economic Community and the Republic of Austria, OJ L 300, 31 December 1972, p. 2; Agreement between the European Economic Community and the Republic of Finland, OJ L 328, 28 November 1973, p. 2; Agreement between the European Economic Community and the State of Israel, OJ L 136, 28 May 1975, p. 3 (Israel III). Accord commercial entre la Communauté économique européenne et la République argentine, JO L 249 du 10 novembre 1971, p. 19; Trade Agreement between the European Economic Community and the Eastern Republic of Uruguay, OJ L 333, 4 December 1973, p. 2; Commercial Cooperation Agreement between the European 
foreign affairs with the three Maghreb countries Algeria, Morocco and Tunisia by signing cooperation agreements that became effective in $1978 .^{22}$ The cooperation agreements were adopted with the objective to promote overall cooperation between the contracting parties with a view to contributing to the economic and social development of each Maghreb country.

\subsubsection{EEC External Competences}

When considering the Community's external competences, the issue of international legal personality is crucial as it provides its holder with the capacity to operate internationally. In this respect international organisations are commonly conceived as "subjects of international law." This status confers them the capacity to bear rights and obligations under public international law. However, since no single legal authority exists in the international law regime which has the competence to confer personality, scholars and academics have filled the gap with their analytical writing. ${ }^{23}$ According to I. Brownlie, there are three indicators as to whether an entity is a subject of international law or not: the right to conclude international accords, the right to send and receive legations and the right to assert and receive international claims. ${ }^{24}$ The last point was at stake in the famous Reparation for Injuries case where the ICJ held that the UN was endowed with the inherent capacity to bring an international claim although this was not explicitly provided for in the constituent treaty. On the basis of its functions and rights, the universal organisation had to be deemed to be possessing international legal personality. ${ }^{25}$

Although Article 210 EEC enshrined that the Community shall have legal personality, and Article 211 EEC specified that this shall be the most extensive legal capacity accorded to legal persons under their laws, such as acquiring or disposing of movable and immovable property and being party to legal proceedings, it was the

Economic Community and the Republic of India, OJ L 82, 27 March 1974, p. 2; Trade Agreement between the European Economic Community and the Federal Republic of Brazil, OJ L 102, 11 April 1974, p. 24; Agreement between the European Economic Community and the United Mexican States, OJ L 247, 23 September 1975, p. 11; Agreement on commercial cooperation between the European Economic Community and the Republic of Sri Lanka, OJ L 247, 23 September 1975, p. 2; Commercial Cooperation Agreement between the European Economic Community and the Islamic Republic of Pakistan, OJ L 168, 28 June 1976, p. 1; Commercial Cooperation Agreement between the European Economic Community and the People's Republic of Bangladesh, OJ L 319, 19 November 1976, p. 2.

22 Cooperation Agreement between the European Economic Community and the People's Democratic Republic of Algeria, OJ L 263, 27 September 1978, p. 2; Cooperation Agreement between the European Economic Community and the Kingdom of Morocco, OJ L 264, 27 September 1978, p. 2; Cooperation Agreement between the European Economic Community and the Republic of Tunisia, OJ L 265, 27 September 1978, p. 2.

23 J. Klabbers, An Introduction to International Institutional Law (3rd edn. Cambridge University Press, Cambridge 2005), pp. 43-44.

24 I. Brownlie, Principles of Public International Law (7th edn. Oxford University Press, Oxford 2008) p. 57.

25 Reparation for Injuries Suffered in the Service of the United Nations, Advisory Opinion [1949] ICJ Reports 174. 
Court that determined the scope of such legal personality. In the ERTA ruling, the Court pointed out that Article 210 EEC must be construed as granting international legal personality because "in its external relations the Community enjoys the capacity to establish contractual links with third countries over the whole field of objectives defined in Part One of the Treaty, which Part Six supplements". ${ }^{6}$ This must be read in conjunction with two other seminal cases $V$ an Gend en Loos ${ }^{27}$ and Costa v. ENEL 28 in which the Court ruled that the Community constitutes a new legal order of international law and approved the Community's own personality, its own legal capacity, and the capacity of representation on the international plane. It should be noted, however, that capacity does not equal legal competence as the former only provides the possibility for the Community to take action whereas the latter is based on a concrete conferred power stipulated in a Treaty provision. ${ }^{29}$ Article 4 EEC stated that each Community institution shall act within the limits of powers conferred upon it by the Treaty. In the course of time, the Community competences have expanded due to treaty amendments and the Court's case law.

\subsubsection{Express and Implied Powers}

Seeing that the Community is bound to act within the limits of the powers conferred upon it, a legal base in the EEC Treaty has been a prerequisite for the Community to take action in a certain policy field. The legal base stipulates the scope and the subject-matter on which the Community can pass legislation and it also defines the types of laws, the procedures, and the involvement of the institutions in the lawmaking process.$^{30} \mathrm{~A}$ wrong legal basis can entail problematic implications as the ECJ has specified in Opinion 2/00.31 As has been indicated, the first express external competences included the Common Commercial Policy (Article 110 EEC) and the conclusion of association agreements (Article 238 EEC). Legislative competence of the Community can, however, also be implicit in nature. The Court came to this conclusion in its famous ERTA judgment, in which it developed the doctrine of implied external powers. ${ }^{32}$ The case concerned a Council Decision on an international road transport agreement, which had been challenged by the Commission. The latter argued that the Community was competent to negotiate and conclude such an agreement because Article 74 EEC, which invested the EEC with the power to transpose a common transport policy, was applicable to domestic and external issues. The Court first reasoned that Article 210 EEC enables the Community to conclude international agreements with third countries in its external relations. Then it stated that the substantive provisions, as well as the whole scheme of the Treaty, must be taken into account when determining the Community's authority to enter into international agreements. Such an authority does according to the Court, "not only arise from express conferment by the Treaty but may equally

Case 22/70 Commission v. Council (ERTA) [1971] ECR 263, para. 14.

Case 26/62 Van Gend en Loos [1963] ECR 13.

Case 6/64 Costa v. ENEL [1964] ECR 585.

P. Craig and G. De Búrca, EU Law: Text, Cases, and Materials (4th edn. Oxford University Press, Oxford 2008), p. 171.

D. Chalmers and G. Monti, European Union Law: Text and Materials (Cambridge

University Press, Cambridge 2006), p. 140.

Opinion 2/00 Cartagena Protocol [2001] ECR I-9713.

Case 22/70 Commission v. Council (ERTA) [1971] ECR 263. 
flow from other provisions of the Treaty and from measures adopted, within the framework of those provisions, by the Community institutions". 33 In this case, the Community had already passed a common position on social aspects of road transport. The adoption of internal legislation, pursuant to the Court's argumentation, served as a basis to imply the Community's external competences in this specific field.

The ERTA outcome was confirmed in the Kramer case, which dealt with a convention for the conservation of fisheries in the Atlantic Ocean. ${ }^{34}$ In this instance the ECJ took a step forward by ruling that external Community competence was present even in cases where there was a provision for internal measures, although no legislation had been adopted yet on this basis as the participation of the Community was necessary for the attainment of the specific objective. Thus, the internal competence to adopt measures with the aim to conserve the sea included the competence to establish contractual links with non-member countries. P. Eeckhout correctly points out that the issue of fish conservation, by its very nature, presumes a multilateral dimension by means of treaties and convention, simply to ensure its effectiveness. ${ }^{35}$ A. Dashwood underscores the effet utile approach which was followed by the Court, however, the author draws attention to the differing reasoning in both cases: as opposed to the ERTA decision, in Kramer the Court expressly highlighted the competence on the internal level that by reason of equity and effectiveness implies the treaty-making power. Due to the fact that the EEC's external competence is essential to complement its internal competence, this approach has been labelled the "principle of complementarity". 36

The subsequent Opinion 1/76, delivered by the ECJ one year later, provided for some clarification as it asserted that the existence of an external competence of the Community does not depend on whether the Community has exercised its internal competence in the respective policy domain. ${ }^{37}$ The opinion concerned the competence to enter into an international agreement establishing a European layingup fund for inland waterway vessels. Again, the Court argued that external powers could stem from express attribution by the Treaty but may also flow implicitly from its provisions. This is the case when internal power has already been used for the adoption of measures to attain common policies or when the participation of the Community in the international agreement is necessary for the attainment of one of the EEC's objectives. The exact meaning and scope of the opinion was subject to debate: it was supposed that the EEC's internal powers mirror the external powers. This is what has become known as the "principle of parallelism". ${ }^{8}$ According to M. Cremona, this concept relates not only to the scope of internal and external powers

33 Case 22/70 Commission v. Council (ERTA) [1971] ECR 263, para. 16.

34 Joined Cases 3, 4 and 6/76 Kramer [1976] ECR 1279.

35 P. Eeckhout, EU External Relations Law (2nd edn. Oxford University Press, Oxford 2011), p. 78.

36 A. Dashwood and J. Heliskoski, 'The Classic Authorities Revisited', in: A. Dashwood and C. Hillion (eds.), The General Law of EC External Relations (Sweet \& Maxwell, London 2000), pp. 9-10.

37 Opinion 1/76 European Laying-up Fund for Inland Waterway Vessels [1977] ECR 741.

38 T. Tridimas and P. Eeckhout, 'The External Competence of the Community and the Case-Law of the Court of Justice: Principle versus Pragmatism', 14 Yearbook of European Law (1994), 143, p. 151. 
but extends to the objectives and substance of the policies pursued both on the domestic and international plane as well as the distinct features the Community legal system displays externally. ${ }^{39}$ The parallelism principle has been criticised as the Court has never explicitly stated that the Community's power to legislate internally is coextensive with its power to adopt legislative acts externally. Rather, the Court expounded that the Community's involvement in the international agreement was necessary for the attainment of a Community objective. ${ }^{40}$ The doctrine of implied powers evolved further in later decisions and opinions of the Court, in particular in regard to the notion of exclusive competences of the Community.

\subsubsection{Exclusive and Shared Powers}

Once Community competence has been established, the question arises whether this competence is exclusive to the Community or shared between the Community and its Member States. Exclusive competence entails that the Member States have surrendered their law-making powers in a specific realm and have transferred them entirely to the Community. Exclusive Community competence can originate from a Treaty provision or an Act of Accession, from secondary law adopted by the Community institutions, from an express power in an internal Community act or from internal powers, which can only be effectively exercised at the same time as external powers. ${ }^{41}$ The Common Commercial Policy and the common fisheries policy have been designated as exclusive Community competences by the Court. ${ }^{42}$ The exclusive character of the Community's competence on the conclusion of international agreements in view of the Common Commercial Policy was enunciated in Opinion 1/75.43 The Commission asked the Court, on the basis of Article 228(1) EEC, whether the Community was competent to conclude an "Organisation for Economic Co-operation and Development (OECD) Understanding" on export credits. The Court stressed that the Common Commercial Policy, as stipulated in Article 113 EEC, had to be conceived in the context of the operation of the common market, for the defence of the common interests of the Community. This conception is, according to the Court, incompatible with the freedom of Member States to take concurrent action so as to secure their distinct interests. The Court justified its ruling by pointing to the distortion of competition that would likely arise without uniform export credit terms. Also, the Community's exclusive competence regarding the adoption of autonomous legislative action in relation to the Common Commercial Policy was settled in case law. ${ }^{44}$ In Opinion $1 / 78$ on the conclusion of a commodity agreement, the Court held that Article 113 EEC must be construed broadly. ${ }^{45}$ Moreover, it focused on the financing arrangements and attributed them a significant

39 M. Cremona, 'External Relations and External Competence: The Emergence of an Integrated Policy', in: P. Craig and G. de Búrca (eds.), The Evolution of EU Law (Oxford University Press, Oxford 1999), pp. 137-152.

40 I. MacLeod, I.D. Hendry and S. Hyett, The External Relations of the European Communities (Oxford University Press, Oxford 1996), p. 51.

Ibid., pp. 56-61.

Opinion 1/75 Understanding on a Local Cost Standard [1975] ECR 1355 and Case C804/79 Commission v. UK [1981] ECR 1045.

Opinion 1/75 Understanding on a Local Cost Standard [1975] ECR 1355.

Case 41/76 Donckerwolcke [1976] ECR 1921.

Opinion 1/78 Natural Rubber [1979] ECR 2871. 
role taking the view that Member States could participate in the agreement if they had to bear the costs it entails. This approach was considered to be rather awkward taking into account Opinion 1/75 where the Court had stated the exact opposite, namely that the financing was not deemed relevant as far as the allocation of competence is concerned. The outcome of the judgment, which implies that financing can, by implication, determine the nature of competence, was highly contested. ${ }^{46}$

Until the 1980s, the case law on external relations issues was characterised by the socalled pre-emption doctrine which purported that Member States were precluded from acting if the Community had already made use of its competences on an internal or external basis. ${ }^{47}$ It has been emphasised that the claim of exclusivity in the ERTA case is inextricably connected to the autonomous nature of the Community legal order vis-à-vis the Member States and that the Court interlinked implicit competences and their exclusive character. ${ }^{48}$ In ERTA the Court took the view that "each time the Community, with a view to implementing a common policy envisaged by the treaty, adopts provisions laying down common rules, whatever form these may take, the Member States no longer have the right, acting individually or even collectively, to undertake obligations with third countries which affect those rules". ${ }^{49}$ In Kramer the Court's argumentation differed: the mere existence of implied internal powers of the Community could generate EEC external powers, even though no steps have been taken to transpose the respective policy field..$^{50}$ As a consequence, the Member States maintained their competence to take action in this area given that the action is in accordance with EEC objectives and only up to the point where the Community enacts legislation. The climax was reached in Opinion 1/76 in which the Court found that the Community could be in possession of exclusive external competence, although the internal powers had not been exercised, in the exceptional case where a Treaty objective could only be attained by the prior conclusion of an international agreement. This approach has been restricted by later case law in which the Court held that the implementation of internal rules is required for implied powers to become exclusive in nature. ${ }^{51}$

When the Community and the Member States are entitled take action in the same policy field, the competence is said to be "shared". ${ }^{52}$ Shared external competence has been recognised by the Court and it has become an integral part of Community law.

46 J. Weiler, 'The External Legal Relations of Non-Unitary Actors: Mixity and the Federal Principle', in: D. O'Keeffe and H.G. Schermers (eds.), Mixed Agreements (Kluwer, Dordrecht 1983), p. 72; P. Koutrakos, EU International Relations Law (Hart Publishing, Oxford 2006), p. 17.

47 M. Waelbroeck, 'The Emergent Doctrine of Community Pre-emption - Consent and Re-delegation', in: T. Sandalow and E. Stein (eds.), Courts and Free Markets: Perspectives from the United States and Europe (Clarendon Press, Oxford 1982), pp. 548-580.

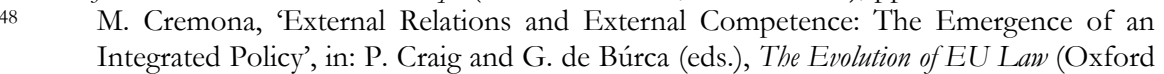
University Press, Oxford 1999), p. 153.

Case 22/70 Commission v. Council (ERTA) [1971] ECR 263, para. 17.

Joined Cases 3, 4 and 6/76 Kramer [1976] ECR 1279.

Opinion 1/94 WTO Agreements [1994] ECR I-5267.

F. Hoffmeister, 'The Contribution of EU Practice to International Law', in: M. Cremona (ed.), Developments in EU External Relations Law (Oxford University Press, Oxford 2008), p. 41. 
However, in practice the concept has triggered heated discussions as third states considered shared powers as an odd legal construct. In their view it was either the Community or the Member States that assume legal responsibility in a given field. ${ }^{53}$ The opinion of AG Jacobs in the EDF case has given rise to the argument that the presence of shared competence is the general rule whereas exclusive EC competence relates to an exemption. ${ }^{54}$ Legal disputes on shared competence have been resolved by the Court, which has adopted a balanced approach to this effect. ${ }^{55}$

Powers can be shared for different reasons. Five specific cases have been pointed out: ${ }^{56}$ firstly, in situations where Treaty provisions confer power on the Community but do not prejudice Member States' competence to negotiate and conclude international agreements. This approach was affirmed by the Court in cases on development cooperation. ${ }^{57}$ Secondly, the existence of non-exclusive Community competence is presumed if the Community is competent to adopt common internal rules but has not yet exercised this power, such as during the transitional period of the common fisheries policy. Thirdly, the Court identified shared competence between the Community and the Member States in cases in which an agreement concerns matters in relation to which the Community as well as the Member States enjoy exclusive competences. Opinion $1 / 78$ exemplifies this way of reasoning: although the Community was found to have exclusive competence for commodity agreements on the basis of Article 113 EEC, the Court ascertained that Member States were to bear the financial burden of the arrangement. This aspect was deemed so fundamental that the Member States' participation in the negotiation process was indispensable. Fourthly, competence is concurrent if external Community competence is deduced from the existence of internal rules which lay down minimum standards. Member States can introduce higher standards in their national legal systems if Member State action does not affect the ambit of Community rules as discussed in Opinion 2/91. Lastly, competence is said to be shared in nature in the special case of intellectual property. Community trade marks exist parallel to the trade marks prevailing in the Member States.

Once it is established that external competence is shared, the duty to closely cooperate resides with both the Community and the Member States in the process of negotiation and conclusion of international agreements as well as in the fulfilment of the commitments entered into. ${ }^{58}$ In this respect the Court held that problems which may arise with regard to implementation, in particular as concerns the coordination necessary to ensure unity of action, cannot be advanced to dismiss the competence which provides for the participation in the respective agreement. ${ }^{59}$ The exercise of

I. MacLeod, I.D. Hendry and S. Hyett, The External Relations of the European Communities (Oxford University Press, Oxford 1996), p. 63.

Case C-316/91 Parliament v. Council [1994] ECR I-625, para. 40.

D. O'Keeffe, 'Exclusive, Concurrent and Shared Competence', in: A. Dashwood and C. Hillion (eds.), The General Law of the EC External Relations (Sweet \& Maxwell, London 2000), p. 193.

I. MacLeod, I.D. Hendry and S. Hyett, The External Relations of the European Communities (Oxford University Press, Oxford 1996), pp. 63-66.

Case C-316/91 Parliament v. Council [1994] ECR I-625 and Case C-181/91 Parliament v. Commission and Council [1993] ECR I-3685.

Opinion 1/94 WTO Agreements [1994] ECRI-5267, paras. 108-109. Ibid., para. 107. 
shared powers leads to mixed agreements which raise cardinal questions relating to legal certainty and the delimitation of powers. ${ }^{60}$

\subsubsection{The Development of Mixed Agreements}

The majority of the agreements that the Community has concluded, in particular association agreements, are mixed in nature and they carry great weight in the Community's external relations. ${ }^{61}$ A mixed agreement is a treaty to which both the Member States and the Community are contracting parties because the respective competences are shared. The concept of mixed agreements is acknowledged by Community law: former Article 102 of the Euratom Treaty made an explicit reference to "agreements or contracts concluded with a third state, an international organisation or a national of a third state to which, in addition to the Community, one or more or more Member States are parties [...]". Also, the concept is confirmed by the Court as it held in a number of cases that the participation of the Member States and the Community is necessary as regards some agreements ${ }^{62}$ and specifically mentioned the term in its Demirel judgment. ${ }^{63}$ This shows that the practice of mixed agreements forms a well-integrated element in the Community legal system. It is interesting to note in this regard that the matter, although subject to extensive legal debate, plays a rather minor role in the ECJ's jurisdiction. ${ }^{64}$

In order to verify the exact division of powers between the Community and the Member States, as well as the nature of the agreement in question, its object must be analysed. This allocation of competencies can develop in the course of time such as was the case with respect to the General Agreement on Tariffs and Trade (GATT) ${ }^{65}$ Efforts have been made to classify mixed agreements with regard to their scope. ${ }^{66}$ However, it has been contended that this theoretical typology oversimplifies the reality which is characterised by an interaction between various Community external powers and a large number of different international conventions and treaties. ${ }^{67}$ Instead, focus should be directed on practice throughout the Community. The Court

60 M. Cremona, 'The Doctrine of Exclusivity and the Position of Mixed Agreements in the External Relations of the European Community', 2 Oxford Journal of Legal Studies (1982), 393.

61 D. MacGoldrick, International Relations Law of the European Union (Longman, London 1997), p. 78.

62 See for example Opinion 1/78 Natural Rubber [1979] ECR 2871, para. 60; Opinion 2/91 ILO Convention No. 170 [1993] ECR I-1061, para. 5; for a detailed analysis of the Court's first decisions on mixed agreements see M. Cremona, 'The Doctrine of Exclusivity and the Position of Mixed Agreements in the External Relations of the European Community', 2 Oxford Journal of Legal Studies (1982), 393, pp. 410-427.

63 Case C-12/86 Demirel [1987] ECR I-3719, para. 8.

64 I. MacLeod, I.D. Hendry and S. Hyett, The External Relations of the European Communities (Oxford University Press, Oxford 1996), pp. 143-144.

65 D. MacGoldrick, International Relations Law of the European Union (Longman, London 1997), pp. 78-79.

66 A. Rosas, 'The European Union and Mixed Agreements', in: A. Dashwood and C. Hillion (eds.), The General Law of EC External Relations (Sweet \& Maxwell, London 2000), pp. 203-207.

67 P. Eeckhout, EU External Relations Law (2nd edn. Oxford University Press, Oxford 2011), pp. 213-214. 
itself, in the Euratom ruling, took the view that it is not necessary to determine the demarcation of competences between the Community and the Member States as it may change over time. ${ }^{68}$ This reflected the general stance which the Court has taken with regard to mixed agreements: if the Community enjoyed no exclusive powers, the Court concentrated on the question as to how participation of the Community and the Member States could best be achieved. ${ }^{69}$ It follows as a logical consequence that "mixity" has required close cooperation between the Member States and the Community when negotiating, concluding and implementing international agreements; the principle of loyal cooperation as regards the first pillar was stipulated in Article 5 EEC.

Concerning the interpretation and enforcement of mixed agreements, the Court has stated that they "have the same legal status in the Community legal order as purely Community agreements in so far as the provisions fall within the scope of Community competence". ${ }^{70}$ M. Cremona concluded that the Member States have, as a consequence, a Community law obligation to transpose a mixed agreement "insofar as its provisions are within the scope of Community competence". It was emphasised that the degree of Community competence and responsibility under a mixed agreement could be difficult to assess. However, the Court's approach, which established the notion of "Community interest" relative to the implementation of a mixed agreement, connected the "scope of Community competence" and the "scope of Community law" according to the author: in the Commission v. Ireland case, Ireland was accused of having violated Community law obligations by not acceding to the Berne Convention. ${ }^{71}$ The Court declared that since the Berne Convention created rights and obligations in the areas covered by Community law, there was a Community interest in ensuring that all contracting parties adhered to that Convention. M. Cremona observed that in casu an overlap of Community legislation with an international agreement was at stake. Yet, she pointed out that a Community interest is also at stake when a Member State breaches a Community law obligation by not transposing a mixed agreement "even though the alleged breach concerned an aspect of the agreement which was not covered by Community legislation". ${ }^{72}$

The international responsibility of the Community and the Member States under mixed agreements raised further questions. A general distinction was made between mixed agreements that expressly specify obligations and those which did not provide for such a commitment. ${ }^{73}$ An example of the first category of mixed agreements is the UN Convention on the Law of the Sea, the ratification of which required a declaration in conformity with Article 2 of Annex IX of the Convention to be made by the Community. Undoubtedly, declarations like these contributed considerably to

68 Ruling 1/78 Euratom [1978] ECR 2151, para. 35

69 P. Craig and G. De Búrca, EU Law: Text, Cases, and Materials (4th edn. Oxford University Press, Oxford 2008), p. 198.

Case C-239/03 Commission v. France [2004] ECR I-9325, para. 25.

Case C-13/00 Commission v. Ireland [2002] ECR I-2943.

M. Cremona, 'External Relations of the EU and the Member States: Competence, Mixed Agreements, International Responsibility, and Effects of International Law', EUI Working Papers LAW (2006), pp. 16-18.

73 C. Tomuschat, 'The International Responsibility of the European Union', in: E. Cannizzaro (ed.), The European Union as an Actor in International Relations (Kluwer Law International, The Hague 2002), p. 185. 
legal certainty. The course of action is less straightforward in respect to the second category of mixed agreements - those lacking a declaration clarifying legal obligations. ${ }^{74}$ In such a case, the Community and the Member States are jointly responsible as concerns the transposition of the agreement. This line of reasoning was in approved by AG Jacobs who reasoned in his opinion in the Parliament $v$. Council case that, unless the provisions of an agreement pointed to the opposite conclusion, the Community and the Member States were jointly liable under a mixed agreement. ${ }^{75} \mathrm{It}$ was clear that the absence of a clarifying provision should not be to the disadvantage of the third party. ${ }^{76} \mathrm{~A}$ third category relates to mixed agreements which contain an interpretive clause. ${ }^{77}$ In such agreements, the Community's and the Member States' areas of competence is not clearly set out. If the competences are not specified, third parties have to verify the Community's participation on the one hand and the Member States' participation on the other by means of Community law. As concerns responsibility, third parties can, in accordance with the principle of legal certainty, file an action against both the Community and the Member States. ${ }^{78}$

\subsubsection{Community Agreements in the EEC Legal Order}

From the outset, the Community institutions or a Member State could obtain the Court's opinion on the compatibility of an agreement with the EEC Treaty before the actual conclusion of the agreement. ${ }^{79}$ The Court was also competent to rule on the interpretation and application of a Community agreement. ${ }^{80}$ According to Article 173 EEC, the Court shall review the legality of acts adopted by the Community institutions. These "institutional acts" include decisions or acts concluding an agreement for the purpose of Community law and the Court has the power to review them on grounds of an alleged wrong legal basis, lack of competence or procedural deficiencies for instance. ${ }^{81}$ The Court's jurisdiction aims at a uniform interpretation in the Community. ${ }^{82}$ This, however, does not mean that the Court construed Treaty articles and similarly formulated agreement provisions in the same way. Rather, the interpretation of international agreements concluded by the Community is based on the ordinary meaning to be given to the terms of the agreement in their context and in the light of their object and purpose as laid down in Article 31(1) of the 1969

\footnotetext{
74 C. Tomuschat, 'Liability for Mixed Agreements', in: D. O'Keeffe and H.G. Schermers (eds.), Mixed Agreements (Kluwer Law and Taxation, Leiden 1983), pp. 127-132. Case C-316/91 Parliament v. Council [1994] ECR I-625, para. 69.

C. Tomuschat, 'The International Responsibility of the European Union', in: E. Cannizzaro (ed.), The European Union as an Actor in International Relations (Kluwer Law International, The Hague 2002), p. 185.

77 See for instance Art. 2(c) of the EEA Agreement.

78 E. Neframi, 'International Responsibility of the European Community and of the Member States under Mixed Agreements', in: E. Cannizzaro (ed.), The European Union as an Actor in International Relations (Kluwer Law International, The Hague 2002), pp. 203-205.

79 Art. 228(1) EEC.

80 Art. 177 EEC.

81 I. MacLeod, I.D. Hendry and S. Hyett, The External Relations of the European Communities (Oxford University Press, Oxford 1996), p. 139.

82 Case C-104/81 Kupferberg [1982] ECR 3641 and Case C-192/89 Sevince [1990] ECR I3461, para. 11.
} 
Vienna Convention of the Law of Treaties.83 The equation of "acts of the institutions" with an agreement and thus the expansion of jurisdiction of the Court under Article 177 EEC to international agreements has been contested. ${ }^{84}$ It can in turn, however, be argued that the ECJ's approach is in accordance with the dynamic structure of the Community's external competences in the sense that a broad reading of the Treaty is indispensable. ${ }^{85}$ In case a Member State failed to fulfil its obligations under an international agreement, the Commission had the competence to bring the matter before the Court, in line with Article 169 EEC.

In Opinion 1/75, the Court made clear that the term "agreement" in Article 228(1) EEC is to be interpreted in an extensive manner meaning "any undertaking entered into by entities subject to international law which has binding force, whatever its formal designation".86 Article 228(1) EEC provided that the Commission negotiated such agreements subject to the powers conferred upon it and that the Council had the competence to conclude them. The agreements concluded had binding force on the institutions of the Community and on Member States. ${ }^{87}$ This rule stipulates the well-known pacta sunt servanda principle in public international law, which implies that every treaty is binding on the parties to it and must be performed by them in good faith. ${ }^{88}$ A clarification on the status of an international agreement concluded by the EEC was given by the Court in its Haegeman decision in $1974 .{ }^{89}$ Accordingly, the provisions of an agreement, which has been duly concluded by the Community, form an integral part of the Community legal order as of the date of its entry into force. It has been indicated that this ruling entails three main consequences: firstly, decisions of entities created by such agreements also form part of Community law; secondly, the agreements in question can give rise to rights and duties which have direct effect in Community law; and thirdly, the Court has a broad jurisdiction in the interpretation and application of the agreements..$^{90}$

The provisions of a Community agreement are capable of having direct effect and individuals can rely on rights derived from agreements before national courts if the conditions of direct effect are met. In public international law the direct effect of a treaty provision depends, as a general rule, on two prerequisites. Not only must the conditions that give rise to direct effect be fulfilled, the respective national law must in the first place allow for provisions to become directly applicable. ${ }^{91}$ In this respect,

I. MacLeod, I.D. Hendry and S. Hyett, The External Relations of the European Communities (Oxford University Press, Oxford 1996), pp. 139-141.

T. Hartley, 'International Agreements and the Community Legal System', 8 European Law Review (1983), 383.

I. Cheyne, 'International Instruments as a Source of Community Law', in: A. Dashwood and C. Hillion (eds.), The General Law of the EC External Relations (Sweet \& Maxwell, London 2000), p. 257.

Opinion 1/75 Understanding on a Local Cost Standard [1975] ECR.

Art. 228(2) EEC.

See Art. 26 of the 1969 Vienna Convention on the Law of Treaties.

Case C-181/73 Haegeman [1974] ECR 449, para. 5.

I. MacLeod, I.D. Hendry and S. Hyett, The External Relations of the European Communities (Oxford University Press, Oxford 1996), p. 135.

I. Brownlie, Principles of Public International Law (7th edn. Oxford University Press, Oxford 2008), p. 48. 
great importance was attached to the intentions of the drafters of the treaty. ${ }^{92}$ In terms of Community law it was the Van Gend en Loos case which introduced the notion of direct effect into the EEC legal system where the Court ruled that direct effect is contingent solely on Community law; the question whether the Member States' domestic legal systems recognised direct effect became irrelevant. This groundbreaking approach provoked harsh criticism on the part of the Member States at the time. ${ }^{93}$ In conformity with the $V$ an Gend en Loos jurisdiction, a treaty article must be clear, unconditional and not subject to further implementation in order to have direct effect. As regards the direct effect of international agreements, other considerations of a political nature play a role. In International Fruit Company, the Court stated that the purpose, the spirit, the general scheme and the terms of the agreement must be considered when determining whether or not international agreements can have direct effect. ${ }^{94}$ This was the first case before the Court dealing with the question whether a GATT article could be directly effective. The Court decided that the GATT, which according to its Preamble was based on the principle of negotiations undertaken on the basis of "reciprocal and mutually advantageous arrangements", was characterised by the great flexibility of its provisions. Also, the facts that consultations played a prominent role and that the contracting parties had wide discretion as regards the settlement of disputes led to the conclusion that the provision in question, Article XI of the GATT, was not capable of conferring rights on citizens. ${ }^{95}$ The question of whether the provision of a free trade agreement between the Community and Portugal could create direct effect was addressed in Polydor. At the time, Portugal was not yet a Member of the EEC. In this instance, the Court adjudicated that the respective provision did not result in direct effect although it was identical to Article 30 EEC. The Court based its reasoning on the argument that the free trade agreement did not have the same purpose as the EEC Treaty in as much the latter sought to create a single market. ${ }^{96}$

In Kupferberg, however, a case decided shortly after, a different article of the same free trade agreement was found to be directly applicable. ${ }^{97}$ The Court held that the provision concerned did fulfil the conditions and that it fell within the object and purpose of the agreement. The outcome in Kupferberg provided some clarification as the importance of the object and purpose of the agreement was emphasised. Consequently, the issue of whether the provision was clear and unconditional was attributed a subordinate role: in the first instance it was significant that the agreement was suitable for direct applicability as a whole. ${ }^{98}$ The criteria related inter alia to the distribution of powers in the EEC's external relations, reciprocity governing the application of free trade agreements, derogatory clauses and the institutional framework established by such agreements to settle differences between the

92 J. Klabbers, 'International Law in Community Law: The Law and Politics of Direct Effect', 21 Yearbook of European Law (2002), 263, p. 272.

93 Case C-26/62 Van Gend en Loos [1963] ECR 13, see submissions of the Belgian and Dutch governments.

Joined Cases 21-24/72 International Fruit Company [1972] ECR 1219, paras. 19-20. Joined Cases 21-24/72 International Fruit Company [1972] ECR 1219, paras. 21-27. Case 270/80 Polydor [1982] ECR 329, para. 18. Case C-104/81 Kupferberg [1982] ECR 3641.

I. Cheyne, 'Haegeman, Demirel and their Progeny', in: A. Dashwood and C. Hillion (eds.), The General Law of the EC External Relations (Sweet \& Maxwell, London 2000), p. 26. 
contracting parties. ${ }^{99}$ The Court rejected the direct effect of provisions dealing with the free movement of workers in the Ankara Agreement establishing an association with Turkey and the 1970 Additional Protocol in Demirel. ${ }^{100}$ However, in casu the Court stressed that an association agreement creates "special, privileged links with a non-member country, which must, at least to a certain extent, take part in the Community system". ${ }^{101}$ Having analysed the nature and purpose of the agreement, the Court drew the conclusions that the agreement defined its objectives but did not lay down the specified rules for how they should be achieved. Therefore, it was judged that the articles were imprecise and not sufficiently unconditional in order to trigger direct effect. However, in Sevince the Court endorsed its jurisdiction to give preliminary rulings on the interpretation of Association Council decisions arguing that they equally form an integral part of the Community legal order as of their entry into force and that Article 238 EC (Article 217 TFEU) serves the purpose of ensuring the uniform application and interpretation of all Community provisions. ${ }^{102}$ In that dispute the

Court confirmed the direct effect of Article 6(1) of Decision No 1/80 because it was clear, precise and unconditional and in line with the purpose and nature of the latter decision that formed part of the Ankara Agreement. ${ }^{103}$ The ruling in Kziber extended this reasoning to the EEC-Morocco Cooperation Agreement. ${ }^{104}$

\subsubsection{The EEC and Migration}

\subsubsection{The Emerging Migration Regime for Community Workers}

The objective to establish a common market should be achieved by a number of Community activities including "the abolition, as between Member States, of obstacles to freedom of movement for persons, services and capital". ${ }^{105}$ The Preamble to the Treaty of Rome furthermore confirmed the social dimension of the EEC in "directing their [the contracting parties] efforts to the essential purpose of constantly improving the living and working conditions of their peoples". Title III EEC specified the rules ensuring such freedom of movement for employed persons (Articles 48 to 51), for self-employed persons (Articles 52 to 58) and for service providers (Articles 59 to 66). Initially, Italy strongly advocated the insertion of the freedom of movement for workers during the negotiations leading to the Treaty of Rome. ${ }^{106}$ It has been pointed out that the provisions on the free movement of labour "resulted not only from the economic logic involved in establishing a common market but, also, and perhaps even more, from the particular constellation of the labour market of the Six in 1958. One of Italy's most pressing economic problems

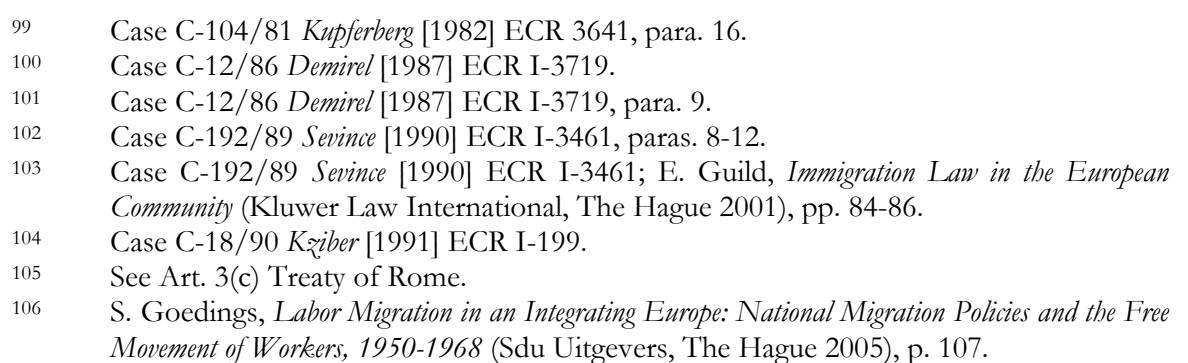


was that of high unemployment, while at the same time Germany had a shortage of all types of labour." 107 The inclusion of the labour provisions, and in particular Articles 48 to 51 , sought to address these interests by setting out extensive rules. For workers, this translated into the right to non-discrimination based on nationality as regards employment, remuneration and other conditions of work and employment, in addition to the rights to accept job offers, to move freely in the Member States for this purpose, to take up employment, live and stay in that Member State subject to limitations justified by grounds of public policy, public security or public health. ${ }^{108}$ In fact, even before the creation of the EEC, the parties to the European Coal and Steel Community (ECSC) agreed to remove any restriction, based on nationality, on the employment of workers in the coal and steel industries. ${ }^{109}$ However, in practice this rule was, due to its narrow scope, of limited relevance only. ${ }^{110}$

The different interests of the Member States' governments led to tensions among the Six when the implementing regulations for Articles 48 to 51 EEC were subject to debate. Italy and the Commission favoured the idea of a "common labour market", which was much discussed in the negotiations leading to the Rome Treaty but was not incorporated in the end. A "common labour market" would involve priority for workers belonging to a national labour market of the Six or for a Member State national. Consequently, a third-country national worker could only be considered for employment after it was proven that no Community worker is available for the specific work. The other Member States expressed their reluctance to such an approach but, after long and tedious negotiations, agreement was eventually reached. ${ }^{111}$ Regulation No 15 came into effect in September 1961 and was the first legislative instrument of supranational character that created a legal framework as regards migration and employment. ${ }^{112} \mathrm{~K}$. Dahlberg identified four key issues that this Regulation sought to address: national and Community priorities, equality of treatment, prolongation of employment and the treatment of the workers' families. It is notable that these issues also became relevant, little by little, regarding thirdcountry nationals. ${ }^{113}$ First, the Regulation authorised Community workers to take up paid employment in another Member State provided that no worker in the national workforce was available to fill the vacancy within three weeks. Article 43 of Regulation No 15 stated that Member States endeavour to give preference to workers from Member States when filling vacancies before having recourse to workers from third countries. This marked the beginning of the principle of Community preference, which lays down that "Member States will consider requests for admission to their territories for the purpose of employment only where vacancies in

107 K.A. Dahlberg, 'The EEC Commission and the Politics of the Free Movement of Labour', 6 Journal of Common Market Studies (1968), 310, p. 311.

108 Art. 48 of the Treaty of Rome.

109 See Art. 69 ECSC Treaty.

110 H. Verschueren, 'De socialzekerheidspositie van niet-EG-onderdanen in het Europese gemeenschapsrecht', in: D. Cuypers, B. Hubeau and M.C. Foblets (eds.), Migratie-en migrantenrecht: recente ontwikkelingen (die Keure, Brugge 2000), pp. 83-84.

111 K. Lewin, 'The Free Movement of Workers', 2 Common Market Law Review (1964), 300, pp. 311-312.

112 Règlement $\mathrm{n}^{\circ} 15$ relatif aux premières mesures pour la réalisation de la libre circulation des travailleurs à l'intérieur de la Communauté.

113 K.A. Dahlberg, 'The EEC Commission and the Politics of the Free Movement of Labour', 6 Journal of Common Market Studies (1968), 310, pp. 312-317. 
a Member State cannot be filled by national and Community manpower or by nonCommunity manpower lawfully resident on a permanent basis in that Member State and already forming part of the Member State's regular labour market". ${ }^{114}$ At this point in time, the priority of Community workers over non-member countries did not materialise. ${ }^{115}$

Second, Articles 8 and 9 of Regulation No 15 dealt with equality of treatment with regard to remuneration and the right to join trade unions. Only later would the Commission manage to negotiate for Community workers not only the right to vote but, also, the right to stand as a candidate for workers' councils - a very controversial issue at that time. Third, Article 6 Regulation No 15 governed the prolongation of employment: after one year of regular employment in another Member, the Community worker had to the right to get his work permit renewed; after three years' regular employment, the Community worker was authorised to change his profession; and after four years' regular employment, the Community worker was free to choose a salaried occupation under the same conditions as national workers. Fourth, the Community worker was permitted to be accompanied in the host Member State by his spouse and minor children irrespective of their nationality, subject to the condition that he had a work permit in that Member State and that he had organised accommodation for them. Housing was scarce in particular in the Netherlands, Germany and France at that time; hence the Member States' governments required Community workers to secure dwellings themselves. ${ }^{116}$ Article 48 of Regulation No 15 enshrined a stand-still provision that prohibited the introduction of new discriminatory rules (or, if introduced after the entry into force of the Treaty it had to be repealed). Regulation No 38/64 superseded Regulation No 15 in 1964, ${ }^{117}$ but the negotiation proved tough: "That there was a hard struggle on almost every Article when both the first and the second Regulations were drawn up can, moreover, be seen from the fact that years were needed to prepare them, before the Council was at last able to approve the texts." 118 It would take another four years to agree on the first comprehensive legal framework for the Community worker which was created with Regulation No 1612/68. ${ }^{119}$

Why is it of relevance to outline the developments aiming at the free movement of Community workers in the Community at that time? What implications did they entail on admission of third-country nationals to the territory of the Member States for employment and Section 2 of Regulation (EU) No 492/2011 of the European Parliament and of the Council of 5 April 2011 on freedom of movement for workers within the Union.

115 K.A. Dahlberg, "The EEC Commission and the Politics of the Free Movement of Labour', 6 Journal of Common Market Studies (1968), 310, p. 313.

116 Ibid., pp. 313-316.

117 Regulation No 38/64/EEC of the Council of 25 March 1964 concerning the free movement of workers within the Community.

118 K. Lewin, 'The Free Movement of Workers', 2 Common Market Law Review (1964), 300, p. 312 .

119 Council Regulation (EEC) No 1612/68 of 15 October 1968 on the freedom of movement for workers within the Community, which is now replaced by Regulation (EU) No 492/2011 of the European Parliament and of the Council of 5 April 2011 on freedom of movement for workers within the Union. 
for third-country nationals? The developments are important for a number of reasons: the discussion on the free movement of Community workers demonstrates the distinct sensitivity with which the Member States conceived economic migration of their own nationals within the Community. From this, it is easy to perceive the Member States' very reserved attitudes towards granting rights to nationals of third countries. Moreover, the priority of Community workers, which turned into a legally binding rule at a later date, significantly affected the status of non-Member State nationals. Finally, not only would the same problems confronted by the Member States with regard to Community workers later be tabled with regard third-country nationals, but similar rules used in relation to Community workers can be traced back in association and cooperation agreements which the EU concluded with third countries. For instance, the residence periods and the stand-still provision applied in Regulation No 15 re-emerges in the EU-Turkey association law, in which both corresponding rules have more than often been asked to be interpreted by the Court of Justice.

\subsubsection{The Status of Third-Country Nationals under the EEC Treaty}

While the freedom to provide services, as set out in Articles 59 to 66 of the Treaty of Rome, is explicitly reserved for nationals of Member States who are established in a State of the Community other than that of the person for whom the services are intended, it was initially uncertain whether Article 48 on the free movement of workers extended to nationals of third countries or not. The adoption of secondary legislation, later Treaty modifications as well as the case law of the Court of Justice made clear that third-country nationals do not fall within the scope of the free movement provisions. ${ }^{120}$ As regards the first point, Article 1 of Regulation 38/64/EEC as well as Article 1 of Regulation (EEC) No 1612/68 mentioned the right of nationals of a Member State to take up an activity of an employed person within the territory of another Member State. ${ }^{121}$ Secondly, the introduction of provisions that specifically cover third-country nationals in the Maastricht and Amsterdam Treaties prove that the free movement of workers, as enshrined in the EEC and EC framework, related to Member States' nationals exclusively. Thirdly, this perception was approved in the cases of Meade and Awoyemi, which were handed down by the Court in 1987 and 1998 respectively. ${ }^{122}$ Finally, there is no doubt that this separation between EU citizens holding the nationality of a Member State and third-country nationals was reinforced by the introduction of EU citizenship with the Maastricht Treaty. ${ }^{123}$

120 G. Papagianni, Institutional and Policy Dynamics of EU Migration Law (Martinus Nijhoff Publishers, Leiden 2006), pp. 4-5.

121 Regulation No 38/64/EEC of the Council of 25 March 1964 concerning the free movement of workers within the Community and Council Regulation (EEC) No 1612/68, which is now replaced by Regulation (EU) No 492/2011 of the European Parliament and of the Council of 5 April 2011 on freedom of movement for workers within the Union.

122 Case C-228/83 Meade [1987] ECR I-2631, para. 7 and Case C-230/97 Awoyemi [1998] ECR I-6781, paras. 29-30.

123 See M. Cremona, 'Citizens of Third Countries: Movement and Employment of Migrant Workers within the European Union', 2 Legal Issues of European Integration (1995), 87, pp. 
However, as crystal clear as this outcome might appear today, it has rightly been argued that from a literal interpretation of Articles 48 and 49 of the Treaty of Rome relating to "workers" it is not evident that this term includes workers holding the nationality of a Member State only. ${ }^{124}$ This view was supported by the wording of Article 69 ECSC, which refers by contrast specifically to "workers who are nationals of a Member State"; thus, so the argument goes, the drafters of the Rome Treaty meant to create a common policy for all workers in the Community regardless of their nationality. ${ }^{125}$ The historical context of the conclusion of the Rome Treaty must also be taken into account: the travaux préparatoires of the Messina Conference of 1955 indicate that the immigration situation was of a different nature than today. Most migrants residing the Community were either French nationals of Algerian origin or Italian nationals. Hence, "there was little concern about the social problems caused by migration to Europe of nationals of non-Member States and more concern with the urgent necessity of finding labour to advance the industrial reconstruction of half the continent." 126

It has been suggested that the drafters of the founding treaties were not interested in the status of nationals of non-member countries as they did not transfer specific competences to the Community in this regard, aside from some exceptions. ${ }^{127}$ Indeed, non-Member State nationals were only indirectly considered within the scope of the Rome Treaty: First, Article 59(2) enabled the Council to extend the benefits of Chapter 3 on services to cover services supplied by nationals of any third country who are established within the Community. Only in 1999 and 2000 did the Commission put forward proposals for the implementation of this Article, ${ }^{128}$ however, both proposals were withdrawn in 2004. ${ }^{129}$ In 1990 the Court clarified in Rush Portuguesa that service providers must be able to move freely with all personnel and that Member States cannot require suppliers of services, established in another Member State, to obtain work permits for their workforce in the Member State

87-88; S. Van den Bogaert, 'Free Movement of Workers and the Nationality Requirements', in: H. Schneider (ed.), Migration, Integration and Citizenship (Forum Maastricht, Maastricht 2005), p. 60.

124 For a more extensive discussion, see S. Goedings, Labor Migration in an Integrating Europe: National Migration Policies and the Free Movement of Workers, 1950-1968 (Sdu Uitgevers, The Hague 2005), pp. 128-135.

125 R. Plender, 'Competence, European Community Law and Nationals of Non-Member States', 39 International and Comparative Law Quarterly (1990), 599, p. 604.

Ibid., pp. 604-605.

127 M. Wathelet, 'The Case Law of the European Court of Justice and Nationals of NonEuropean Community Member States', 20 Fordham International Law Journal (1996), 603, p. 603.

128 European Commission, proposal for a Directive of the European Parliament and the Council on the posting of workers who are third-country nationals for the provision of cross border services and proposal for a Council Directive extending the freedom to provide cross-border services to third-country nationals established within the Community, COM(1999) 3, 27 January 1999/26 February 1999; amended proposal for a Council Directive extending the freedom to provide cross-border services to thirdcountry nationals established within the Community, $\operatorname{COM}(2000) 271,31$ October 2000.

129 See withdrawal of European Commission proposals which are no longer of topical interest, COM(2004) 542, 10 March 2005. 
where the work is to be carried out. ${ }^{130}$ This principle was confirmed for undertakings established in one Member State providing services in another Member State and who lawfully and habitually employ nationals of non-member countries for that purpose. ${ }^{131}$ Yet, the Court declared that Community law did not preclude the Member States from extending their legislation, or collective labour agreements entered into by both sides of industry, to any person who is employed, within their territory, no matter in which country the employer is established. ${ }^{132}$ It is important to notice that, despite these developments, Member States were still able to require entry visas and to carry out border checks for third-country nationals and family members who moved with their employers in order to provide cross-border services. ${ }^{133}$

Second, EU legislation that has implemented the free movement provisions in the Treaty includes certain rights for family members of Member States' nationals irrespective of their nationality. Initially, this held true for Title III of former Regulation No 1612/68 (now Regulation (EU) No 492/2011) on workers' families and Articles 1 to 5 of former Council Directive 73/148/EEC on the abolition of restrictions on movement and residence within the Community for Member States' nationals with regard to establishment and the provision of services. ${ }^{134}$ Regulation (EU) No 492/2011 has authorised non-Member State family members to join the Community worker in the host Member State, to take up employment and for the children to follow general or vocational education. The Court expounded in 1990 that "the aim of Regulation No 1612/68, namely freedom of movement for workers, requires, for such freedom to be guaranteed in compliance with the principles of liberty and dignity, the best possible conditions for the integration of the Community worker's family in the society of the host country". 135 This explanation was interpreted in a twopronged manner: on the one side the attainment of freedom of movement for workers depended on the extension of a number of rights to family members; yet, on the other side, family members only enjoy these rights as derived rights that are granted to persons who have close family relations with a Community worker. ${ }^{136}$

\footnotetext{
130 Case C-113/98 Rush Portuguesa [1990] ECR I-1417.

131 Case C-43/93 Van der Elst [1994] ECR I-3803.

132 Case C-113/98 Rush Portuguesa [1990] ECR I-1417, para. 18.

133 G. Papagianni, Institutional and Policy Dynamics of EU Migration Law (Martinus Nijhoff Publishers, Leiden 2006), pp. 5-6.

134 Council Regulation (EEC) No 1612/68 of 15 October 1968 on the freedom of movement for workers within the Community and Council Directive 73/148/EEC of 21 May 1973 on the abolition of restrictions on movement and residence within the Community for nationals of Member States with regard to establishment and the provision of services; both legal instruments have been repealed in the meantime by Regulation (EU) No 492/2011 of the European Parliament and of the Council of 5 April 2011 on freedom of movement for workers within the Union and Directive 2004/38/EC of the European Parliament and of the Council of 29 April 2004 on the right of citizens of the Union and their family members to move and reside freely within the territory of the Member States.

135 Case C-308/89 Di Leo [1990] ECR I-4185, para. 13.

136 D. Martin and E. Guild, Free Movement of Persons in the European Union (Butterworths, London 1996), p. 126.
} 


\subsubsection{The 1974 Action Programme for Migrant Workers}

In 1974, the Council adopted a resolution concerning a social action programme in which it emphasised the objective of full and better employment in the Community. ${ }^{137}$ With a view to materialising this aim, the Council urged inter alia to set up an action programme for migrant workers (who are nationals of Member States or third countries) and their family members and for the equality of treatment for Community and non-Community workers and their family members in respect of living and working conditions, wages and economic rights. In response to this request, the Commission drew up such an action programme and published it at the end of the same year. ${ }^{138}$ The Commission's action programme for migrant workers aimed at setting up a "global approach to the problem of migration" by addressing the imbalances that cause migration (the root causes approach) and called for social and educational measures to improve the conditions of the migrant worker and their families. ${ }^{139}$ The Commission made clear that "the Community finds itself with a large unassimilated group of foreign workers, who share almost the same obligations of the society in which they live and work but, more often than not, have a less than equal share in its benefits and rights. This situation is, in the long term, intolerable degrading for the migrant and dangerous for the Community." 140 Since third-country migrants do not enjoy the same protection as Community migrants, the action programme must be directed towards the progressive elimination of all forms of discrimination against them in living and working conditions, once, in the case of third-country migrants, they have been legally admitted in the Community. Seeing that the legal situation of third-country workers is often contingent on the Member States' restrictive legislation, and, if existent, bilateral agreements with the countries of origin, the third-country workers are, in general, treated less favourably than Community workers according to the Commission. Against this backdrop, the action programme proposed specific action for third-country migrants, relating to equal treatment in social security, vocational training, housing, education of children, health, information, social services, and enhanced trade union participation rights. Concerning social security, the action programme assessed the elimination of nationality as a condition for eligibility for benefits as well as the possibility to export pensions to the country of origin (invalidity, old age, survivors) accruing from employment in the Member States as vital. This last aspect, the portability of pensions, integrated as a binding rule in the Community cooperation agreements with the Maghreb states Algeria, Morocco and Tunisia, which were signed in 1976.141 For Turkish workers, the portability of pension rights was already ensured in the 1970

137 Council of the European Union, Council Resolution of 21 January 1974 concerning a social action programme.

138 European Commission, $\operatorname{COM}(74)$ 2250, 14 December 1974, Action programme in favour of migrant workers and their families (transmitted by the Commission to the Council on 18 December 1974).

Ibid., p. 12.

Ibid.

Cooperation Agreement between the European Economic Community and the People's Democratic Republic of Algeria, OJ L 263, 27 September 1978, p. 2; Cooperation Agreement between the European Economic Community and the Kingdom of Morocco, OJ L 264, 27 September 1978, p. 2; Cooperation Agreement between the European Economic Community and the Republic of Tunisia, OJ L 265, 27 September 1978, p. 2. 
Additional Protocol to the Ankara Agreement, but the implementing legislation, Decision No 3/80, only entered into force in $1980 .{ }^{142}$ Lastly, the Commission's action programme suggested to coordinate the migration policies of the Member States as, at the time, there were no safeguards to prevent conflicts between national and Community policies in social, developmental and industrial affairs. ${ }^{143}$ The action programme was labelled as the one of the first important tokens that the Community presented for the integration of third-country nationals. ${ }^{144}$

In its resolution of 9 February 1976, the Council did not take over the proactive stance of the Commission. ${ }^{145}$ Despite the determined statements in the Preamble, only one vague commitment referring to encourage the achievement of equality for thirdcountry workers and their family members legally resident in the Member States with regard to living and working conditions, wages and economic rights. It took the Commission almost a decade to issue guidelines for a Community policy on migration that were transmitted to the Council on 7 March $1985 .{ }^{146}$ These guidelines gave an account of Community action in the field of migration and set out the trends of the Member States' migration policies. In view of non-Member States immigrants, the Commission considered it crucial to adapt their legal status "with the aim of consolidating foreign communities which have acquired the characteristics of permanence, by reason of their length of stay and above all through the existence of the second and third generations". ${ }^{147}$ Next, the Commission urged the Member States to ratify the European Convention on the Legal Status of Migrant Workers of the Council of Europe with the aim to safeguard the rights of migrant workers. ${ }^{148}$ In addition, the clarification of the status of migrants contributed to their social and educational advancement in the host society and assisted in putting the foreign population on a stable footing. The guidelines also refer to the reintegration of migrant workers into the economies of their countries of origin; in this context, return policies should be non-mandatory and provide support for those who have decided to return voluntarily. Action relating to the return of migrants should become part of Community policy and be transposed in the framework of Community agreements with third states. The Commission made clear that "an initial step in the gradual extension of Community treatment to workers from other countries will be achieved by the implementation of cooperation and association agreements"; this statement demonstrated the importance the Commission attached

Decision No 3/80 of the EC-Turkey Association Council of 19 September 1980 on the application of the social security schemes of the Member States to Turkish workers and members of their families. European Commission, Action programme in favour of migrant workers and their
families (transmitted by the Commission to the Council on 18 December 1974), pp. 14-22.

144 S. Carrera, In Search of the Perfect Citizen? The Intersection between Integration, Immigration, and Nationality in the EU (Martinus Nijhoff Publishers, Leiden 2009), pp. 22-25.

145 Council of the European Union, Council Resolution of 9 February 1976 on an action programme for migrant workers and members of their families. European Commission, COM(85) 48, 7 March 1985.

Ibid., p. 7.

European Convention on the Legal Status of Migrant Workers of the Council of Europe, 24 November 1977. 
to these agreements in attaining equal treatment of non-Community workers. ${ }^{149}$ The Council took note of the Commission's guidelines on 16 July 1985 and recognised the desirability of a cooperation and consultation procedure between the Member States and the Commission on migration policy, including vis-à-vis third countries. ${ }^{150}$ Also, it expressed its determination to transpose the social security provisions in the association and cooperation agreements and that - in notably very general terms "everyone within the Community should have an equal opportunity of deriving advantages and making a contribution". In the wake of this dialogue between the Commission and the Council - in fact even before the Council had presented its response - the Commission issued the contested decision on the communication and consultation procedure on migration policies in relation to non-member countries. ${ }^{151}$

\subsubsection{Consultation on Migration Unwanted: Decision 85/381/EEC}

The Commission made in 1985 the attempt to use a provision on social policy Article 118 EEC - to adopt Decision 85/381/EEC with a view to setting up a prior communication and consultation procedure on migration policies in relation to nonmember countries. ${ }^{152}$ The Decision asked from the Member States to share and to convey information to the Commission concerning draft measures and draft agreements that deal with the entry, residence and employment of third-country workers and their family members. With this information exchange the Commission aimed to ensure that Member State action is in conformity with Community policy and to examine a possible harmonisation of national legislation on foreigners. Article 118 EEC empowered the Commission to promote close collaboration between the Member States in the social field. Five Member States started proceedings before the Court of Justice against the adoption of this Decision because their governments considered that the legal basis was inadequate and that essential procedural requirements had been infringed. This case illustrates the spirit of the time as the year 1985 marked different events that were of relevance for the migration debate in Europe and subsequent policy action. To begin with, in June 1985 the Commission published a White Paper on completing the internal market setting out the objective to remove physical, technical and fiscal trade barriers. ${ }^{153}$ It triggered negotiations on a new Treaty - the Single European Act signed in 1986 - that included a provision defining the internal market as an area without internal frontiers in which the free movement of goods, persons, services and capital is ensured. Simultaneously, the

149 J. Niessen, 'Association Agreements - Part of the Developing Immigration Policy of the European Union', in: E. Antalovsky and others (eds.), Assoziierungsabkommen der EU mit Drittstaaten (Manz Verlag, Wien 1998), p. 27.

150 Council of the European Union, Council Resolution of 16 July 1985 on guidelines for a Community policy on migration.

151 European Commission, Commission Decision 85/381/EEC of 8 July 1985 setting up a prior communication and consultation procedure on migration policies in relation to non-member countries.

152 European Commission, Commission Decision 85/381/EEC of 8 July 1985 setting up a prior communication and consultation procedure on migration policies in relation to non-member countries.

153 European Commission, COM(1985) 310, 14 June 1985. 
Schengen Agreement for the abolition of internal border controls was signed. ${ }^{154}$ How do these policy developments fit together? E. Guild illuminates that the "two conflicting desires of the Member States had met head on: the creation of an internal market with sufficient strength and cohesion to challenge even in the mightiest of its trading partners and the desire to keep people, at least in do far as they were thirdcountry nationals within the discretionary control of the Member States."155

Thus, the fact that five Member States challenged the Commission's Decision on a communication procedure for migration policies reflected the subliminal competence struggle at the time. AG Mancini, in his elucidating opinion on the case, saw the gist of this conflict in the interpretation of Article 118 EEC as the Member States repudiate that this Treaty rule endows the Commission with the competence in the field of migration policy concerning non-member countries "and, above all, that it does not justify the issue of binding acts". ${ }^{156}$ Before discussing the matters of the case, the AG provided a detailed synopsis of the conditions that shaped the dispute: previous policy documents prove that the Member States were extremely keen to preserve full control as regards migration matters of non-member countries and thus favoured a restrictive interpretation of Article 118. The AG list three reasons as to why the Member States turned to the Court: they did not the Commission's earlier attempts regarding consultations and studies seriously and were simply struck by the Decision; they wanted to retain the control over the admission of third-country workers to their territories due to political and public policy ramifications; the Commission made a mistake in not having stressed the Community's labour market and on the need to enhance employment among Community workers. ${ }^{157}$ The Court declared the Commission's Decision void to the extent to which the Community lacked the competence for its enactment. ${ }^{158}$ It dismissed the Member States' allegations that migration policy in relation to non-member countries is not part of the social field seeing that the employment situation within the Community is liable to be affected by the Member States' policies relating to non-Member States workers (as evidenced by earlier Council Resolutions). The Court rejected the argument that whole area of policy on foreign nationals fell outside the social field inasmuch as it involves questions of public security; likewise it did not accept that the duty of notification was liable to jeopardise the requirements of secrecy and confidentiality. However, the Court made clear that cultural integration goes beyond the field of social policy because it is aimed at immigrant communities in general, without distinction between migrant worker and other foreigners. Moreover, the Commission was empowered under Article 118 EEC to adopt a binding decision vis-à-vis the Member States, yet the Commission lacked the competence to require Member State action to be brought in line with Community policies and action. ${ }^{159}$ In response to

154 For more information on the Schengen Agreement, see E. Whitaker, 'The Schengen Agreement and Its Portent for the Freedom of Personal Movement in Europe', 6 Georgetown Immigration Law Journal (1992), 191.

155 E. Guild, Immigration Law in the European Community (Kluwer Law International, The Hague 2001), p. 234.

156 Opinion of AG Mancini, delivered on 31 March 1987, Joined Cases 281, 283, 284, 285 and 287/85 Germany and Others v. Commission [1987] ECR 3202, para. 3.

157 Ibid., para. 7.

158 Joined Cases 281, 283, 284, 285 and 287/85 Germany and Others v. Commission [1987] ECR 3202.

159 Ibid. 
the Court's judgment the Commission adopted an amended version of the Decision in $1988 .{ }^{160}$

\subsubsection{The Incorporation of Migration in Association Agreements}

Rules that concerned third-country nationals were also inserted into EU association and cooperation agreements concluded with third countries. The question arises as to why these agreements were equipped with such provisions providing for special treatment in the first place. Clearly, the conclusion of association and cooperation agreements is proof of close relations between the EU and the respective third party. In principle, the closer the economic relations the EU maintains with the third country concerned, the more beneficial are the rights granted to the nationals of that country. The examination of association, cooperation and partnership agreements generates a very fragmented picture seeing that they cover labour and migration issues to a varying extent; this also implies that the scope of protection offered to individuals differs significantly. It has been pointed out that provisions governing the situation of natural persons in international agreements, such as equal treatment clauses in working conditions or in social security matters, were used as "bargaining chips" in trade negotiations with third countries. ${ }^{161}$ While this pragmatic reasoning, which implies a simple trade-off in political terms, has certainly been of relevance other reasons for their inclusion were decisive too. EEC trade unions suggested endowing the Community with the competence to conclude conventions with third countries to regulate the free movement of these workers within the Community because they did not fall under the free movement for Community workers. Therefore, "it has been feared that not only would these workers be exploited to a degree not allowed among Community workers, but that as a consequence they would also tend to undercut the Community labour market since they offer a cheaper source of labour: one, pay scales and benefits do not always [...] apply equally to Community and non-Community workers; second, they are temporary workers [...] and as such remain on the low end of whatever pay scales apply."162

The Council addressed the first aspect mentioned - the prevention of exploitation of labour - in the mid-1970s, which has in more detail been discussed above. The Council stated that it was necessary to facilitate the integration of migrant workers and their families into the host country and to encourage equality between their living and working conditions, wages and economic rights and of those enjoyed by Community workers and their family members. ${ }^{163}$ Simultaneously, the Commission emphasised the need to coordinate the Member States' migration policies considering

160 European Commission, Commission Decision 88/384/EEC of 8 June 1988 setting up a prior communication and consultation procedure on migration policies in relation to non-member countries.

161 M. Hedemann-Robinson, 'An Overview of Recent Legal Developments at Community Level in Relation to Third Country Nationals Resident within the European Union, with particular Reference to the Case Law of the European Court of Justice', 38 Common Market Law Review (2001), 525, p. 532.

162 K.A. Dahlberg, 'The EEC Commission and the Politics of the Free Movement of Labour', 6 Journal of Common Market Studies (1968), 310, p. 330.

163 Council of the European Union, Council Resolution of 21 January 1974 concerning a social action programme. 
the vulnerable position of third-country nationals, who did not have any Community protection at the time but who had to rely solely on restrictive national legislation. ${ }^{164}$ Thus, equal treatment provisions were inserted into association agreements with a view to enhance equality and facilitate the integration of third-country migrants in the host society, parallel to the ensuring equality of treatment of Community workers. E. Guild indicated a "cross-fertilisation" as the Commission's social action programme referred to third-country workers in general, whereas the agreements contain specific employment and residence-related provisions for nationals of the parties which entered into the respective agreement. Moreover, the author highlighted that the political circumstances substantively influenced policy-making at the time: facing rising unemployment rates, the governments of North Western European states curtailed the influx of labour immigrants in 1973 and 1974. The restrictive immigration policies were adopted, however, hand in hand with legislation that aimed to better protect migrant workers who formed part of the EU labour market already: the tools for protection were equal treatment provisions incorporated into association and cooperation agreements as regards working conditions and social security for migrant workers. ${ }^{165}$

The second issue referred to in the quote above deserves attention too. While equality of treatment of foreign manpower was progressive, the Member States also considered it as a strategy to prevent wage dumping and a deterioration of employment conditions: equality of treatment placed migrant workers on the same level as domestic workers. It has rightly been pointed out that equal treatment in working conditions does not prevent Member States from expelling a Moroccan worker lawfully employed in the host Member State where the initial reason for the grant of his leave to stay no longer exists by the time his residence permit. ${ }^{166}$ The Court added in El-Yassini that the situation would be different if the national court were to find that the host Member State has granted the Moroccan worker specific rights, in relation to employment, which were more extensive than the rights conferred upon him by that State. ${ }^{167}$ This latter situation was at stake in Gattoussi: the Court held that if a host state has previously granted the migrant worker specific rights relating to employment which are more extensive than the right of residence conferred on him by that state, it cannot then reopen the question on that worker's situation on grounds unrelated to the protection of a legitimate national interest such as public security, public policy or public health, also with regard to the principles of the protection of legitimate expectations and of legal certainty. ${ }^{168}$ The right to equal treatment in employment matters can thus, in an admittedly very restricted way, entail a right of residence in the host country.

Labour provisions in association or cooperation agreements usually provide for postentry rights, that is to say rights that can only be invoked once a third-country

164 European Commission, $\operatorname{COM}(74)$ 2250, 14 December 1974, Action programme in favour of migrant workers and their families (transmitted by the Commission to the Council on 18 December 1974). Hague 2001), pp. 98-99.

Ibid., pp. 99-100.

Case C-416/96 El-Yassini [1999] ECR I-1209.

Case C-97/05 Gattoussi [2006] ECR I-11917, paras. 29-43. 
national legally stays or resides on the territory of a Member State. ${ }^{169}$ Two exceptions to this rule are the European Economic Area Agreement (EEA Agreement) and the Free Movement of Persons Treaty with Switzerland (FMP Agreement), seeing that these agreements also grant entry next to residence and employment rights. One should take note of the fact that, in the hierarchy of norms, international agreements take precedence over EU secondary legislation as confirmed by the Court. ${ }^{170} \mathrm{It}$ follows that even though all third-country nationals can invoke provisions of EU secondary legislation (such as Council Directive 2003/86/EC on family reunification $^{171}$ and Council Directive 2003/109/EC on long-term resident status ${ }^{172}$ ) more favourable rules contained in association agreements prevail. ${ }^{173}$ The view has been advanced that EU association agreements on the one hand and EU immigration law on the other should not be regarded as two separate sources of law, considering that the substantive norms of both bodies of rules are closely intertwined. In fact, both legal frameworks constitute part and parcel of EU law and both sets of rules govern immigration matters at the EU level. However, it should be emphasised that EU legislation in the field of immigration is not applicable to all Member States. As a consequence, for those Member States, the legal regime under the association agreements must be regarded as detached from the secondary EU immigration law. ${ }^{174}$

\subsubsection{The 1973, 1981 and 1986 Enlargements}

The EEC's first enlargement took place on 1 January 1973 when Denmark, Ireland and the UK joined the Community. ${ }^{175}$ All three countries had submitted their application for membership at the beginning of the 1960s but French opposition delayed the accession process considerably. As the UK had a great interest in enhanced economic cooperation, it had already pushed for the creation of the EFTA in 1960 together with six countries including Austria, Denmark, Norway, Portugal, Sweden and Switzerland. ${ }^{176}$ Greece became a fully-fledged EEC Member State on 1 January 1981, six years after it had applied to be affiliated to the Community. ${ }^{177}$ The early EEC enlargements also covered Spain and Portugal that acceded to the Community on 1 January 1986. ${ }^{178}$ Just like Greece, the two Mediterranean countries

169 G. Papagianni, Institutional and Policy Dynamics of EU Migration Law (Martinus Nijhoff Publishers, Leiden 2006), p. 6.

170 Case C-61/94 Commission v. Germany [1996] ECR I-3989, para. 52.

171 Council Directive 2003/86/EC of 22 September 2003 on the right to family reunification.

172 Council Directive 2003/109/EC of 25 November 2003 concerning the status of thirdcountry nationals who are long-term residents.

173 See Art. 3(4)(a) of Council Directive 2003/86/EC and Art. 3(3)(a) of Council Directive 2003/109/EC; Case C-294/06 Payir and Others [2008] ECR I-203, para. 48.

174 S. Peers, 'EU Migration Law and Association Agreements', in: B. Martenczuk and S. Van Thiel (eds.), Justice, Liberty, Security: New Challenges for EU External Relations (VUBPRESS, Brussels 2008), pp. 59-60; most of the directives adopted do not apply to the UK, Ireland and Denmark.

175 Acts of Accession of Denmark, Ireland and the United Kingdom, OJ L 73, 27 March 1972, p. 201.

176 D. Chalmers, European Union Public Law (Cambridge University Press, Cambridge 2010), p. 18.

177 Act of Accession of Greece, OJ L 291, 19 November 1979, p. 191.

178 Acts of Accession of Spain and Portugal, OJ L 302, 15 November 1985, p. 496. 
were scarred by years of economic isolation and dictatorial regimes; their membership procedure was delayed because France feared that its agricultural sector would suffer from the accession of Spain and Portugal.

\subsection{The Single European Act (1987)}

The Single European Act (SEA) of 1986 embodied the first major amendment of the Rome Treaty; it became effective on 1 July 1987.179 The SEA envisaged establishing a single market by the end of 1992 and defined this single market as an area without internal frontiers in which the free movement of goods, persons, services and capital is ensured.

\subsubsection{New External Competences and Clarifying Case Law}

The SEA introduced new external competences related to cooperation in environmental policies and research and technological development. Next, political collaboration was institutionalised in form of the European Political Cooperation (EPC), which essentially aimed to coordinate the foreign ministers' reunions. The EPC was a predecessor to the Common Foreign and Security Policy (CFSP) as adopted under the Maastricht Treaty signed in 1992. Opinion 1/92 brought some clarification as regards the Community's power in competition matters, which is said to be an exclusive competence provided that they fall under Articles 81 to 86 EEC or measures adopted on the basis of these provisions. ${ }^{180}$

Haegeman made clear that the provisions of a Community agreement form an integral part of the Community legal order as of the date of its entry into force; consequently, decisions of entities created by such agreements also form part of Community law. ${ }^{181}$ It must be taken into account that some agreements provide for the establishment of a judicial organ or a committee that helps to transpose the agreement by issuing decisions or supervises the application of the agreement. The decisions of a judicial body which rules on legal disputes between the parties are binding for the Court if it has to adjudicate on the meaning of the agreement as a constituent of Community law. ${ }^{182}$ At the same time, however, the jurisdiction of the highest judicial institution in the Community, the ECJ, may not be undermined. ${ }^{183}$ This reasoning was advanced by the Court in Opinion 1/91 where it ruled that the transfer of jurisdiction upon an EEA judicial organ was contrary to Community law stressing the autonomy of the Community legal system.

A dispute on the division of competences between the Council and the Commission arose during the negotiation phase of an International Labour Organisation (ILO) Convention, which concerned safety in the use of chemicals at work. ${ }^{184}$ The Court stated that the Member States were required to facilitate the achievement of the

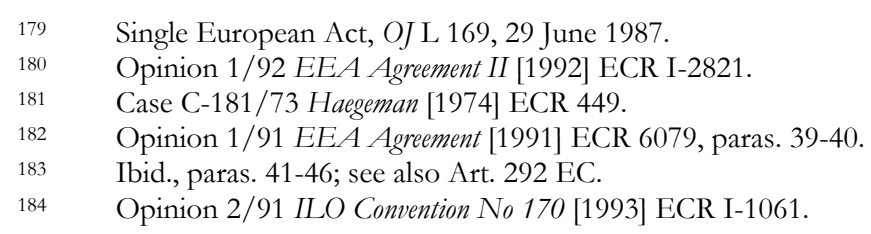


Community's tasks and abstain from any measure which could jeopardise the attainment of the Treaty objectives. Furthermore, it held that the Community had internal legislative competence in the area of social policy on the basis of which it had already adopted a number of Community directives. Although the Convention and the directives were not contradictory to one another, the Court ruled that Member States must refrain from undertaking commitments outside the framework of the Community institutions. As the directives only stipulated minimum standards, which left Member States the freedom to introduce more stringent provisions, the Court concluded that no exclusive competence of the Community could be established in this instance. The reasoning of the Court was interpreted in the sense that where Community legislation deals with the same issues which are the subject matter of an international agreement the Community may either negotiate the competence question beforehand or it may be convinced that the international agreement provides for new provisions, which necessitate the adjustment of Community legislation. ${ }^{185}$ Opinion 1/94, concerning the Community's adoption of the World Trade Organisation (WTO) agreements, exhibits a narrower exegesis of exclusivity: the Commission's claim that both the General Agreement on Trade in Services (GATS) and the Agreement on Trade-Related Aspects of Intellectual Property Rights (TRIPS) would, next to trade in goods, also fall under the Common Commercial Policy was denied as an exclusive external power was generally dependent on the actual exercise of internal powers. ${ }^{186}$ This approach was affirmed in the subsequent Opinion 2/92 regarding the competence of the Community institutions to participate in a decision of the OECD on national treatment. In Opinion 1/94 the Court made some interesting remarks. Notwithstanding the outcome of the judgment which implicated that the competence in WTO matters was shared, the Court listed two grounds for exclusive external Community competence. Firstly, it described the situation where the Community has included in its internal legislative acts provisions relating to the treatment of nationals of non-member countries or expressly conferred on its institutions powers to negotiate with non-member countries. Alternatively and secondly, exclusive external Community competence would arise in the absence of any express provision, where the Community has achieved complete harmonisation of the rules governing access to a self-employed activity. This is so because the common rules thus adopted could be affected within the meaning of the ERT $A$ judgment if the Member States retained freedom to negotiate with nonmember countries. ${ }^{187}$ More restrictively, the Court held in Opinion 2/94 that exclusive Community competence could not simply be supposed because of the risk that bilateral agreements could lead to distortions in the services movement in the internal market. ${ }^{188}$

The open skies cases, in turn, demonstrated the Court's willingness to construe the pre-emption doctrine extensively as it was set out in ERTA. These cases were initiated by the Commission against several Member States which had entered into

185 P. Eeckhout, EU External Relations Law (2nd edn. Oxford University Press, Oxford 2011), p. 86.

186 Opinion 1/94 WTO Agreements [1994] ECR I-5267.

187 Ibid., paras. 95-96.

188 Opinion 2/94 Accession to the ECHR [1996] ECR I-1759; see P. Craig and G. De Búrca, EU Law: Text, Cases, and Materials (4th edn. Oxford University Press, Oxford 2008), p. 179 . 
bilateral aviation agreements with the United States, claiming that the Community was exclusively competent to this effect. ${ }^{189}$ The ECJ reiterated the finding in Opinion $1 / 94$, accepting the Commission's claim in view of its exclusive competence, backed by the ERT $A$ principle: the Community had external exclusive competence as it had exercised its internal competence. In the underlying case, the Council had passed EC legislation in accordance with Article 80(2) EC which the Court considered to be sufficient in order for the ERTA principle to be applicable. The rationale set out in the open skies case was followed by the Court in Opinion 1/03 on the Lugano Convention, which dealt with the jurisdiction, the recognition and enforcement of judgments in civil and commercial matters. ${ }^{190}$

\subsubsection{An Area Without Internal Frontiers?}

The new Treaty, the SEA, described the internal market as an area without internal frontiers in which the free movement of goods, persons, services and capital is ensured. M. Cremona highlighted the contrasting viewpoints: some Member States considered Article 14 EEC, which aimed to establish the internal market until 31 December 1992, to be contingent on the specific free movement rules and thus not creating free movement for all persons with the internal market, whereas the Commission considered the internal market to be logically referring to the free movement of all legally resident third-country nationals for the purpose of engaging in an economic activity. ${ }^{191}$ The author pointed out that the Commission stressed the legal residence of third-country nationals in a Member State and not first entry into the Community; the removal of the internal barriers required by Article 14 EEC entailed thus, in the view of the Commission, the right to free circulation. ${ }^{192}$ Two Declarations appended to the SEA affirmed the Member States' position. The Declaration on Article 13 to 19 SEA preserved the right of Member States to take measures for the purpose of controlling immigration from third countries. The other Declaration was political in nature as it concerned the Member States' intention to cooperate on entry, residence and movement of third-country nationals. It was emphasised that, in practice, "it appears impossible to abolish controls at internal frontiers only for Community nationals" and that - even if the free movement of persons under Article 7(a) EC (former Article 14 EEC) comprises third-country nationals - its meaning differs as it does not entail a right to work or a right to residence in the second Member State. ${ }^{193}$

\footnotetext{
189 See for example Case C-468/98 Commission v. Sweden [2002] ECR I-9575.

190 Opinion 1/03 Lugano Convention [2006] ECR I-1145.

191 M. Cremona, 'Citizens of Third Countries: Movement and Employment of Migrant Workers within the European Union', 2 Legal Issues of European Integration (1995), 87, p. 96; see also European Commission Communication, $\operatorname{COM}(94)$ 23, 23 February 1994, para. 127.

M. Cremona, 'Citizens of Third Countries: Movement and Employment of Migrant Workers within the European Union', 2 Legal Issues of European Integration (1995), 87, p. 96.

193 D. Martin and E. Guild, Free Movement of Persons in the European Union (Butterworths, London 1996), pp. 95-96.
} 


\subsubsection{The Schengen Cooperation}

Already in June of 1985, France, Belgium, Germany, the Netherlands and Luxembourg signed the Schengen Convention, which created a legal framework on the gradual abolition of internal border checks among its parties. ${ }^{194}$ The signature of the Schengen Convention was triggered by a number of developments at the time, including the idea to create a "laboratory for implementing an integrated Europe."195 Furthermore, this intergovernmental initiative was a reaction by the participating states to the protest of truck drivers with a view to making the crossing of frontiers less cumbersome. ${ }^{196}$ While the establishment of an area without internal frontiers stipulating the free movement of persons was institutionalised under SEA, a Community-wide immigration and freedom of movement policy was difficult to attain. ${ }^{197}$ All these factors consequently led to cooperation outside the Community framework. In 1990, the parties adopted the Convention implementing the Schengen Agreement that laid down detailed rules on a number of issues such as the abolition of internal border controls, the reinforcement of external border controls, arrangements on the movement of third-country nationals, the harmonisation of visa policies, the prevention of irregular migration and the establishment of a database, the Schengen Information System. By means of compensatory measures, which include a common visa regime and the shift of border checks to the EU's external borders of the participating parties, the internal border controls could be removed while ensuring a secure system. The UK did not approve the abolition of border controls as set out by the Schengen Convention but it did agree to implement some rules of the Schengen Convention, such as enhanced border control. ${ }^{198}$

\subsubsection{Migration in the EU's External Affairs: The Root Causes Approach}

The Commission stimulated the incremental integration of immigration and asylum matters into the EU's external affairs policy at the beginning of the 1990s; yet, it proceeded in a rather unsystematic manner. A 1991 Commission Communication stressed the incorporation of migration into the Community's external policy in order to counter migration pressure. Emphasis was put on a closer coordination of national and Community development policies so as to better address political, social and cultural facets that have an effect on the labour market and demographic change. In this context, the Commission called for the inclusion of migration in future cooperation agreements with third countries to determine "how, in each of the countries concerned, potential migrant populations can be kept in their areas of

For more information, see D. O’Keeffe, 'The Schengen Convention: A Suitable Model for European Integration?', 11 Yearbook of European Law (1991), 185; V. Hreblay and G. Vandersanden, Les accords de Schengen: origine, fonctionnement, avenir (Bruylant, Brussels 1998).

195 E. Whitaker, 'The Schengen Agreement and Its Portent for the Freedom of Personal Movement in Europe', 6 Georgetown Immigration Law Journal (1992), 191, p. 197.

196 H. Staples, The Legal Status of Third Country Nationals Resident in the European Union (Kluwer Law International, The Hague 1999), p. 111.

197 E. Whitaker, 'The Schengen Agreement and Its Portent for the Freedom of Personal Movement in Europe', 6 Georgetown Immigration Law Journal (1992), 191, p. 197.

198 S. Peers, EU Justice and Home Affairs Law (3rd edn. Oxford University Press, Oxford 2011), p. 140. 
origin". ${ }^{199}$ The intention to stipulate rules on migration in third-country agreements reflects the significance of the matter at the EU level. At that time, the search for work was not anymore the sole incentive to migrate, but family reunification and the request for asylum had emerged as principal causes to relocate. It is pointed out that this document marks the first steps towards an EU policy which aims to connect migration and external relations policies even though only the issue of readmission was considered in detail. ${ }^{200}$

In 1992 the Edinburgh European Council adopted a Declaration which set out principles governing external aspects of migration policies. The drafting of the Declaration was a reaction to the vast number of people fleeing from the conflict in former Yugoslavia and to the awareness that migration flows were likely to continue. The European Council recognised the need to reduce migratory pressure and acknowledged the importance of analysing the causes of migration movements and their remedies: preservation of peace and the termination of armed conflicts; full respect for human rights; the creation of democratic societies and adequate social conditions; and a liberal trade policy to improve the level of economic development in the country of emigration. This approach became generally known as the root causes approach. In this regard, it stated that "coordination of action in the fields of foreign policies, economic cooperation and immigration and asylum policy by the Community and the Member States could also contribute substantially to addressing the question of migratory movements". ${ }^{201}$

The Commission further elaborated on the external dimension of migration policies in 1994, as the Treaty of Maastricht had given a fresh impetus by providing the EU with competences in the field of justice and home affairs. ${ }^{202}$ In its extensive Communication, the Commission drew attention to the need for a comprehensive approach to deal with immigration and asylum policies which should consist of three elements: taking action on migratory pressure; controlling migration flows; and strengthening integration policies for the benefit of legal migrants. Regarding the first concern, special emphasis was placed on addressing the root causes of migration pressure. Migration pressure included economic disparities, demographic pressure, environmental degradation, as well as political conditions prevailing in the country of origin. ${ }^{203}$ An integrated approach, as sketched out at the Edinburgh European Council, could contribute to alleviate factors which trigger migration flows in the first place. In order to tackle economic disparities in developing countries, development cooperation had to be connected to measures that promote international trade and investment, regional economic integration, as well as debt management. The Commission indicated that the interaction of these policy tools was highly complex

199 European Commission Communication, SEC(91) 1855, 23 October 1991, paras. 48-49.

200 S. Peers, 'Irregular Immigration and EU External Relations', in: B. Bogusz and others (eds.), Irregular Migration and Human Rights: Theoretical, European and International Perspectives (Nijhoff, Leiden 2004), p. 205.

See Declaration "on the principles of governing external aspects of migration policy" annexed to the Presidency Conclusions of the Edinburgh European Council of 11 and 12 December 1992, paras. ix and xv.

202 European Commission Communication, $\operatorname{COM}(94)$ 23, 23 February 1994; for the competences in the field of justice and home affairs that were inserted in the Treaty of Maastricht, see Section below.

203 European Commission Communication, $\operatorname{COM}(94)$ 23, 23 February 1994, paras. 47-86. 
and needed effective coordination. Secondly, while the root causes approach was geared towards the reduction of migratory pressure in the long run, it was argued that migration control and management policies were required for short-term purposes. To this effect, admission policies intended to lay down different rules by virtue of family reunification or humanitarian grounds for example. With regard to irregular migration, the Communication stressed the need to identify illegally residing migrants, the collaboration with countries of transit and origin in view of preventive measures, minimum standards for the treatment of irregular migrants, as well as measures concerning their repatriation. Finally, importance was attached to the integration of legal migrants. Successful integration of immigrants into the host societies implied the right economic and socio-cultural conditions, a harmonised legal status and actions against racism and discrimination. The Commission emphasised that the EU is well-equipped for formulating and transposing such a comprehensive strategy and that, until that point in time, no international forum had been able to do likewise. ${ }^{204}$ At the same time, the Council came up with a standard readmission clause to be included in future cooperation and association agreements with third countries. ${ }^{205}$ This standard readmission clause stated that the contracting parties agreed to readmit any of its nationals, illegally present on the territory of either a Member State or the third country in question, upon request by the latter and without further formalities.

The Treaty of Maastricht (Treaty on European Union, TEU, EU Treaty), signed in 1992, marked the next major overhaul of the Treaty text. ${ }^{206}$ Importantly, it created the European Union, established EU citizenship and marked the beginning of developing a single European currency. The Treaty on European Union entered into force on 1 November 1993. According to Article A TEU, the European Union was founded upon the European Communities (constituting the first pillar) and supplemented by the policies and forms of cooperation established by the TEU, including a common foreign and security policy (second pillar) and cooperation in justice and home affairs (third pillar). In accordance with Article C TEU, the EU was served by a single institutional framework, which implied that the same institutions operate under first, second and third pillar of the EU, with a view to ensure the consistency and the continuity of the activities carried out, in order to attain its objectives while respecting and building upon the acquis communautaire. The Treaty of Maastricht did not equip the EU explicitly with international legal personality; it only contained a reference to "identity" in Article B TEU, which referred to to asserting its identity on the international scene as one of the Union's objectives. ${ }^{207}$ Title VI of the Treaty of Maastricht labelled "Provisions on the Cooperation in Justice and

\footnotetext{
204 See Annex IV of $\operatorname{COM}(94)$ 23, 23 February 1994, p. 11.

205 For Community agreements, Council document: 12509/95 of 8 December 1995 and for mixed agreements, Council document: 4272/96 of 22 January 1996.

206 Treaty on European Union, OJ C 191, 29 July 1992.

207 M. Cremona, 'External Relations and External Competence: The Emergence of an Integrated Policy', in: P. Craig and G. de Búrca (eds.), The Evolution of EU Law (Oxford University Press, Oxford 1999), p. 167.
} 
Home Affairs", for the first time, created a legal basis for the Member States to collaborate in migration matters. ${ }^{208}$

The Community concluded ten "Europe Agreements" in the 1990s establishing associations with the Central and Eastern European countries that aimed to transpose common economic, commercial and political objectives and paved the way for future accession at the time. ${ }^{209}$ In 1994, the EEA Agreement entered into force and granted the EFTA States, Norway, Iceland and Liechtenstein, the possibility to take part in the internal market by ensuring the application of EU legislation, including the four freedoms, throughout the EEA zone. ${ }^{210}$ Due to a negative referendum, Switzerland did not join the EEA; however, as an EFTA State, Switzerland established close bilateral relations on political, economic and cultural issues with the EU in 1999. In November of 1995, the Euro-Mediterranean Partnership, also known as the Barcelona Process, was initiated by, at that time, 15 EU Member States and 12 Mediterranean countries. ${ }^{211}$ The Euro-Mediterranean Partnership deals with the domains of economics, politics and security, as well as social and cultural cooperation on a regional and bilateral basis. The economic and political relations between the EU and Russia were governed by the Partnership and Cooperation Agreement (PCA), signed by the parties in 1994 and in force since 1997. In May 2003, a Strategic Partnership between Russia and the EU was set up during the St. Petersburg Summit in four policy areas, so-called "common spaces". The four common spaces refer to economic and environmental issues, external security, freedom, security and justice and research and education, including cultural aspects.

\subsection{The EU External Relations Regime: The CFSP}

The Common Foreign and Security Policy (CFSP) in Title V (Article J TEU) was set up as a policy inherently oriented towards the external world. According to Article J.1 TEU, both the Union and its Member States should define and implement "a common foreign and security policy". This formulation attracted attention: it was pointed out that the Member States remained competent as regards their own foreign policy although they committed themselves to more than just political cooperation in external affairs; there was thus the option to establish a Union common foreign policy or a national individual foreign policy. However, "once the Member States choose to establish 'a' CFSP, this CFSP is to be defined by the Union and by its

208 See Art. K.1 of the TEU.

209 Europe Agreements, OJ L 347, 31 December 1993, p. 2 (Hungary); OJ L 348, 31 December 1993, p. 2 (Poland); OJ L 360, 31 December 1994, p. 2 (Czech Republic); OJ L 359, 31 December 1994, p. 2 (Slovak Republic); OJ L 357, 31 December 1994, p. 2 (Romania); OJ L 358, 31 December 1994, p. 3 (Bulgaria); OJ L 26, 2 February 1998, p. 3 (Republic of Latvia); OJ L 51, 20 February 1998, p. 3 (Republic of Lithuania); OJ L 68, 9 March 1998, p. 3 (Republic of Estonia); OJ L 51, 26 February 1999, p. 3 (Republic of Slovenia).

210 Agreement on the European Economic Area, OJ L 1, 3 January 1994, p. 3.

211 Algeria, Cyprus, Egypt, Israel, Jordan, Lebanon, Malta, Morocco, the Palestinian Authority, Syria, Tunisia and Turkey. 
Member States (Article J.1 TEU) which indicates the mixture of integrationism and intergovernmentalism that permeates the Maastricht CFSP provisions." ${ }^{212}$

The objectives were designated in Article J.1(2) TEU: to safeguard the common values, fundamental interests, independence of the Union, to strengthen the security of the Union and its Member States, to preserve peace and strengthen international security, to promote international cooperation and to develop and consolidate democracy and the rule of law and respect for human rights and fundamental freedoms. These foreign policy objectives are not further specified and their potential coverage is rather broad. As a consequence, the delimitation between the Community's external competences and the powers under the CFSP was sometimes difficult to assess and has resulted in overlaps. ${ }^{213}$ The term "foreign and security policy" were not defined in the TEU, however, Article J.4(1) TEU clarified that the CFSP included all questions relating to the security of the Union, including the eventual framing of a common defence policy, which might in time lead to a common defence. With the latter legal basis, the Treaty of Maastricht first inserted rules for defining a European and defence policy.

The intergovernmental nature of the CFSP was reflected in the decision-making procedure. In order to pass legislation, a unanimous decision of the Council was required in principle. This constituted a major deviation in comparison to the Community method under the first pillar and provided Member States with a strong position. The roles of the EP and the Court were limited. The EP only enjoyed restricted competences under the CFSP pillar: as enshrined in Article J.11 TEU, the Presidency must consult the EP on the main aspects and the basic choices of the CFSP and it must ensure that the EP's views are duly taken into consideration. Also, the EP shall be kept informed and it may ask questions or make recommendations to the Council. The Court's jurisdiction was restricted: first, for conventions concluded in one of the policy areas set out in Article K. 1 under Title VI of the TEU, on cooperation in justice and home affairs, Member States had the possibility to integrate the Court's jurisdiction to interpret their provisions and to rule on any disputes regarding their application; ${ }^{214}$ second, the Court was competent to determine the delimitation of competences between the first and the second pillar; this rule should therefore ensure that measures under the second and third pillar did not encroach upon the Community powers. ${ }^{215}$ In other words, the task to preserve the acquis communautaire was incumbent on the Court. ${ }^{216}$ Arguments have been put forward which substantiate the claim that a Member State could institute proceedings against another Member State before the ICJ, considering that the provisions of Title $\mathrm{V}$ TEU are a matter of legal obligations under international law. ${ }^{217}$ The absence of

212 G. Bono, 'Some Reflections on the CFSP Legal Order', 43 Common Market Law Review (2006), 337, p. 341.

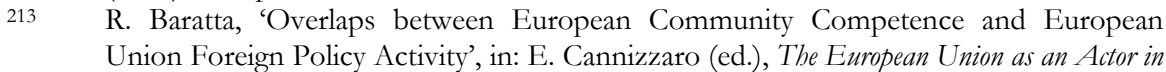
International Relations (Kluwer Law International, The Hague 2002), pp. 51-76. See Arts. K.3(2) and L of the TEU. See Arts. L and M of the TEU.

R.A. Wessel, The European Union's Foreign and Security Policy: A Legal Institutional Perspective (Kluwer Law International, The Hague 1999), p. 224.

217 D. O'Keeffe and others, Legal Issues of the Maastricht Treaty (Wiley Chancery Law, London 1994), p. 222; M. Garbagnati Ketvel, 'The Jurisdiction of the European Court 
case law and the lack of legal certainty with regard to the second pillar have entailed general puzzlement. This holds true for instance for the use of joint actions (for situations where operational action by the Union is deemed to be required, Article 14(1) TEU) and common positions (defining the Union's approach to a particular matter of a geographical or thematic nature, Article 15 TEU), which have been applied interchangeably in the past. This approach has rendered a lucid distinction, in theoretical and practical terms, between both instruments impossible. ${ }^{218}$

The CFSP objectives should be pursued by establishing systematic cooperation between the Member States and by implementing joint actions. ${ }^{219}$ In this regard, it was stipulated that the Member States should inform and consult one another within the Council on any matter of foreign and security policy of general interest and, where necessary, the Council should define a common position. ${ }^{220}$ On the basis of general guidelines from the European Council, the Council should decide on a joint action and lay down the specific scope, the EU's general and specific objectives in carrying out such action. The joint action should be taken by a qualified majority, and in its effect such a joint action would commit Member States to their positions and activities. ${ }^{221}$ In view of the CFSP, the TEU thus introduced a variety of instruments that range from informal collaboration to legally binding acts under international law. 222 A large number of measures on police and military operations have been adopted and they deal with a broad variety of issues, such as the cutback of trade relations with Libya, ${ }^{223}$ an embargo on arms, munitions and military equipment to Sudan, ${ }^{224}$ sanctions against former Yugoslavia ${ }^{225}$ and the objectives and priorities of the EU towards Rwanda ${ }^{226}$ for which action was taken in form of common positions. Also, joint actions have been adopted relating to the convoying of humanitarian aid

of Justice in Respect of the Common Foreign and Security Policy', 55 International and Comparative Law Quarterly (2006), 77.

R.A. Wessel, The European Union's Foreign and Security Policy: A Legal Institutional Perspective (Kluwer Law International, The Hague 1999), pp. 128-130.

219 Art. J.1(3) TEU.

220 Arts. J.2.(1) and (2) TEU.

221 Arts. J.3.(1), (2) and (4) TEU.

222 D. O'Keeffe and others, Legal Issues of the Maastricht Treaty (Wiley Chancery Law, London 1994), p. 222.

223 Council Decision 93/614/CFSP of 22 November 1993 on the Common Position defined on the basis of Art. J.2 of the TEU with regard to the reduction of economic relations with Libya.

224 Council Decision 94/165/CFSP of 15 March 1994 on the Common Position defined on the basis of Art. J.2 of the TEU concerning the imposition of an embargo on arms, munitions and military equipment on Sudan.

225 See Council Decision 94/672/CFSP of 10 October 1994 on the Common Position defined on the basis of Art. J.2 of the TEU and concerning the reduction of economic and financial relations with those parts of the territory of the Republic of BosniaHerzegovina under the control of the Bosnian Serb forces; Council Decision 95/11/CFSP of 23 January 1995 concerning the Common Position, defined on the basis of Art. J.2 of the TEU, and regarding the extension of the suspension of certain restrictions on trade with the Federal Republic of Yugoslavia (Serbia and Montenegro). Council Decision 94/697/CFSP of 24 October 1994 concerning the Common Position adopted by the Council on the basis of Art. J.2 of the TEU on the objectives and priorities of the European Union vis-à-vis Rwanda. 
to Bosnia-Herzegovina, ${ }^{227}$ the support for transition towards a democratic and multiracial South Africa, ${ }^{228}$ the support for the Middle East peace process ${ }^{229}$ and the preparation for the 1995 Conference on the Non-Proliferation of Nuclear Weapons Treaty, ${ }^{230}$ to name just a few.

\subsection{New External Competences: The Case of Development Cooperation}

The Treaty of Maastricht inserted new rules that granted the Community competences in the areas of monetary policy, industrial policy, education and vocational training, culture, energy, public health, social policy, consumer protection, European transport networks, visa policy, telecommunications, as well as development cooperation, including humanitarian assistance and technical cooperation.

Accordingly, a legal basis in the field of development cooperation was only created in 1993. Article 130u of the Maastricht Treaty stipulated that the Community's policies on development cooperation should be complementary to the ones of the Member States fostering: the economic and social development of developing countries; the gradual integration of developing countries into the world economy; the campaign against poverty in developing countries; the human rights' protection, the rule of law and democratic principles. However, as has been pointed out before, policies with development objectives were already introduced at the beginning of the 1960s based on other Treaty provisions; the first Yaoundé Convention was implemented under Article 238 EEC. The newly inserted Article 130y EEC allowed the Community and the Member States, within their respective spheres of competence, to cooperate with third countries and with international organisations and to conclude agreements in this respect to be negotiated and concluded in accordance with Article 228 EEC.

The Community's generalised system of preferences, which was established to integrate developing countries into the global economy by granting them reductions or exemptions of custom duties, was correctly based on Articles 110 et seq. EEC as confirmed by the Court. ${ }^{231}$ In Opinion 1/78, the Court held that the Community was competent to conclude trade agreements that were characterised by developmental aims. The commodity agreements in question, which regulated trade agreements drawn up under the United Nations Conference on Trade and Development (UNCTAD) scheme, thus also fell within the scope of Article 113 EEC. Yet, the

\footnotetext{
227 Council Decision 93/729/CFSP of 20 December 1993 supplementing the joint action on support for the convoying of humanitarian aid in Bosnia-Herzegovina.

228 Council Decision 93/678/CFSP of 6 December 1993 on a joint action adopted by the Council on the basis of Art. J.3 of the TEU concerning support for the transition towards a democratic and multi-racial South Africa.

229 Council Decision 94/276/CFSP of 19 April 1994 on a joint action adopted by the Council on the basis of Art. J.3 of the TEU in support of the Middle East peace process.

230 Council Decision 94/509/CFSP of 25 July 1994 concerning the joint action adopted by the Council on the basis of Art. J.3 of the TEU regarding the preparation for the 1995 Conference of the States parties to the Treaty on the Non-Proliferation of Nuclear Weapons.

231 Case 45/86 Commission v. Council [1987] ECR 2871.
} 
Court emphasised that the Community's competence to negotiate and conclude such an agreement, which set up buffer-stock systems, depended on which actor is bearing the financial burden: if the Community provided resources from its own budget, its power would be exclusive in nature. If the funding fell upon the Member States, their participation in the agreement would be necessary. ${ }^{232}$ The Court further defined the scope of development cooperation in a number of cases.

The two judgments Parliament v. Council and Commission (known as the Bangladesh case) of $1993^{233}$ and Parliament v. Council (known as the Lomé IV or EDF case) of $1994^{234}$ provided for clarifications concerning the allocation of development assistance, and more importantly, they had far-reaching consequences for the Community's institutional setup. In the Bangladesh case, the Parliament challenged the Member States' decision to allot a significant amount of emergency development aid to Bangladesh after it had experienced a severe cyclone causing tremendous damages. The decision at issue was "a decision of the Member States meeting in the Council". The Parliament claimed that its prerogatives were infringed as it had not been consulted in a matter, which had financial implications. The central question was whether the contested decision constituted an act having legal effects and could be subject to judicial review. ${ }^{235}$ In a first step, the Court made clear that acts which are adopted by the representatives of the Member States acting, not on behalf of the Council but, on behalf of their governments and thus collectively exercising the powers of the Member States, are not subject to judicial review by the Court. The Court then pointed out that the act in question was not in reality a decision of the Council, taking into account its content and all the circumstances under which it was adopted. Finally, the Court put forward a number of arguments as to why the decision was not a Council act stressing inter alia that the Community's competence was not exclusive with regard to humanitarian aid, and that consequently the Member States were not precluded from exercising their competence in that regard collectively in the Council or outside it. ${ }^{236}$ Two interesting remarks were made by P. Eeckhout who highlighted the fact that neither the Court nor the AG actually named the legal base for a humanitarian aid strategy in the Treaty and that they would have faced difficulties if they had tried to do so. The author also queried that the "Court had no problems with allowing the Member States collectively to finance emergency aid, taking decisions when meeting in the Council but, not as Council, and entrusting coordination to the Commission, and yet acting outside the framework of the Treaty and of the budget". ${ }^{237}$

The lack of judicial review of intergovernmental acts that are taken by Member States in areas where competences are shared was, to a certain degree, addressed in the Lomé

\footnotetext{
232 Opinion 1/78 Natural Rubber [1979] ECR 2871, paras. 52-60.

233 Joined Cases C-181/91 and C-248/91 Parliament v. Commission and Council [1993] ECR I3685.

234 Case C-316/91 Parliament v. Council [1994] ECR I-625.

235 A. Ward, 'Community Development Aid and the Evolution of the Inter-institutional Law of the European Union', in: A. Dashwood and C. Hillion (eds.), The General Law of the EC External Relations (Sweet \& Maxwell, London 2000), p. 44.

236 Joined Cases C-181/91 and C-248/91 Parliament v. Commission and Council [1993] ECR I3685, paras. 12-25.

237 P. Eeckhout, EU External Relations Law (2nd edn. Oxford University Press, Oxford 2011), p. 129.
} 
IV case. The point at issue concerned the procedure by which the European Development Fund was established as it implements the financial provisions of the Lomé Conventions but does not form part of the Community budget. Again, the Parliament brought an action claiming that it should have been involved as regards the budgetary implications in this instance. Confirming the opinion of the AG Jacobs, the Court ruled that the Community's competence in the sphere of development cooperation was not exclusive. It held that the Member States were accordingly entitled to enter into commitments themselves, vis-à-vis non-Member States, either collectively or individually, or even jointly with the Community. Moreover, the Court took the view that the Community and the Member States on the one hand, and the ACP states on the other, had entered into the Convention. The obligation to grant "the Community's financial assistance" as stipulated in the Convention and the Financial Protocol fell on the Community and on its Member States, considered together. Thus, the competence to transpose the Community's financial assistance was shared between the Community and its Member States and that it is for them to choose the source and methods of financing. In the end, the Court dismissed the case stating that the expenditure necessary for the Community's financial assistance does not constitute a Community expenditure, which must be entered in the Community budget. ${ }^{238}$ The afore-mentioned cases extended the discretion on the funding in view of development aid for both the Community and its Member States.

The later inserted Article 181a EC set out rules dealing with economic, financial and technical cooperation with third countries. It was contended that it was added, among other things, in response to the case Portugal v. Council39 in which the Court, for the first time, clarified the scope of the Community's development cooperation policy. The case concerned Portugal's claim against the conclusion of the EC-India Cooperation Agreement as the Community was not invested with the required competence. Not only was the participation of all Member States necessary to conclude the agreement, but the Community had also overstepped the boundaries regarding some substantive matters which referred to a human rights clause and other specific areas of action. The contested human rights clause provided for the suspension or termination of the cooperation agreement, if the clause was not complied with. The Court rejected the assertions of the Portuguese government, stating that the Community was entitled to conduct its own development policy and was also authorised to include the respective provisions in the agreement. ${ }^{240}$

\subsection{External Relations in the Community Framework}

The relationship between the Community's external relations law and international law further developed and crystallised under the Treaty of Maastricht after the Court had ruled in the two landmark cases at the beginning of the 1960s that the EEC Treaty had created a new and autonomous legal system of international law, for the

238 Case C-316/91 Parliament v. Council [1994] ECR I-625, paras. 24-42.

239 Case C-268/94 Portugal v. Council [1996] ECR I-6177.

240 For a detailed analysis of the case, see S. Peers, 'Fragmentation or Evasion in the Community's Development Policy? The Impact of Portugal v. Council, in: A. Dashwood and C. Hillion (eds.), The General Law of the EC External Relations (Sweet \& Maxwell, London 2000), pp. 100-114. 
benefit of Member States, limited their sovereign rights. ${ }^{241}$ In Commission v. Germany the Court delivered a ruling elucidating the hierarchy of norms: it held that international agreements concluded by the Community prevail over provisions of secondary Community legislation and that this primacy meant that such provisions must, as far as possible, be interpreted in a manner that is consistent with those agreements. ${ }^{242}$ The Court recognised the effect of customary international law in Opel Austria in which it ruled that the principle of good faith forms part of the general principle of legitimate expectations under EU law. ${ }^{243}$ In another case the Court acknowledged the direct effect of a provision in the 1983 cooperation agreement with Yugoslavia: Racke concerned the legality of an EC Regulation that suspended the afore-mentioned agreement unilaterally. ${ }^{244}$

The direct effect of an international agreement was also subject to debate in Council $v$. Portugal in which Portugal claimed that a Council Decision was in breach of WTO law and violated some GATT articles. While the Court recognised that the WTO rules strengthened the system of safeguards and the mechanism for resolving disputes, it held that they were still based on negotiations between the parties. This was exemplified by the structure of the dispute settlement procedure. The Court continued that if the judicial organs were required to refrain from applying domestic rules which are inconsistent with the WTO agreements, this would deprive the legislative or executive organs of the contracting parties of the possibility to enter into negotiated arrangements even on a temporary basis; as a consequence, the WTO agreements did not determine the appropriate legal means of ensuring that they are applied in good faith in the legal order of the contracting parties. Also, the deviating interpretation of the parties' courts in view of the direct applicability of the WTO agreements leads to a lack of reciprocity. These factors induced the Court to deny the direct applicability of the WTO rules. ${ }^{245}$ Generally speaking, the Court has adopted a favourable attitude regarding the direct effect of agreements as its case law has demonstrated. ${ }^{246}$ The receptiveness to international agreements can be substantiated by the fact that international agreements concluded by the Community are binding on its institutions and the Member States (Article 228(7) Treaty of Maastricht), by the principle that EC agreements form an integral part of the Community legal order set out in Haegeman and by the EU's own provenance. ${ }^{247}$ On the contrary, the decisions dealing with the WTO and GATT provisions certainly constitute an exception to the rule. The direct effect of provisions in association or cooperation agreements, or in decisions taken by Association Councils established under such agreements, was affirmed in Sevince and this reasoning was extended to the EEC-Morocco

\footnotetext{
241 Case C-26/62 Van Gend en Loos [1963] ECR 13; Case C-6/64 Costa v. ENEL [1964] ECR 585.

242 Case C-61/94 Commission v. Germany [1996] ECR I-3989, para. 52.

243 Case T-115/94 Opel Austria [1997] ECR II-39; P. Eeckhout, EU External Relations Lam (2nd edn. Oxford University Press, Oxford 2011), p. 387.

244 Case C-162/96 Racke [1998] ECR I-3655.

245 Case C-149/96 Portugal v. Council [1999] ECR I-8395, paras. 36-47.

246 See F.G. Jacobs, 'Direct effect and interpretation of international agreements in the recent case law of the European Court of Justice', in: A. Dashwood and M. Maresceau (eds.), Law and Practice of EU External Relations: Salient Features of a Changing Landscape (Cambridge University Press, Cambridge 2008), pp. 13-33.

247 P. Eeckhout, EU External Relations Law (2nd edn. Oxford University Press, Oxford 2011), p. 374.
} 
Cooperation Agreement by Kziber. 248 The contested judgment of Taflan-Met concerned the entry into force and the (non-)implementation of a decision of the EC-Turkey Association Council; Taflan-Met was, however, reviewed in the latter case of Sürül.249

While the Court held in Polydor that a mere similarity in wording of the EEC Treaty and of an international agreement between the Community and a non-member country was not sufficient to give the wording in the international agreement the same meaning as it has in the EEC Treaty (unless there were express provisions to that effect laid down by the agreement itself). The Court stated more precisely in Metalsa that the extension of an interpretation of a similar or identical wording of a provision in an agreement depends on the aim pursued by each provision in its own particular context and that a comparison between the objectives and context of the agreement and those of the Treaty is of considerable importance in this regard. 250 Contrary to this interpretation approach, F.G. Jacobs indicated to the analogy the Court drew as regards the concept of social security under the cooperation agreements concluded with Morocco and Algeria. ${ }^{251}$

\subsection{Community Visa Policy and Cooperation in Migration Matters}

The Treaty of Maastricht endowed the Community with competences in the field of visa policy. Article $100 \mathrm{c}(1)$ and (3) EC specified that "the Council [...] shall determine the third countries whose nationals must be in possession of a visa when crossing the external borders of the Member States" and "the Council [...] shall adopt measures relating to a uniform format for visas". Until 1 January 1996, the first competence was subject to unanimous approval of the Council and subsequently qualified majority voting, whereas the second competence was to be exercised by qualified majority voting from the entry into force of the EC Treaty. The EP's lawmaking power was restricted to consultation under Article 100c EC. In 1995, the Community adopted a regulation setting out such a visa list, ${ }^{252}$ as well as a regulation on a uniform visa format. ${ }^{253}$

Case C-192/89 Sevince [1990] ECR I-3461; Case C-18/90 Kriber [1991] ECR I-199. Case C-277/94 Taflan-Met [1996] ECR I-4085; Case C-262/96 Sürül [1999] ECR I2685.

Case 270/80 Polydor [1982] ECR 329, paras. 15-19; Case C-312/91 Metalsa [1993] ECR 3751, para. 11.

F.G. Jacobs, 'Direct effect and interpretation of international agreements in the recent case law of the European Court of Justice', in: A. Dashwood and M. Maresceau (eds.), Law and Practice of EU External Relations: Salient Features of a Changing Landscape (Cambridge University Press, Cambridge 2008), pp. 23-24; Case C-18/90 Kįber [1991] ECR I-199; Case C-416/96 El Yassini [1999] ECR I-1209.

Council Regulation (EC) No 2317/95 of 25 September 1995 determining the third countries whose nationals must be in possession of visas when crossing the external borders of the Member States (annulled in 1997, and replaced by Council Regulation (EC) No 574/1999 of 12 March 1999 determining the Non-EU Member Countries whose nationals must be in possession of visas when crossing the external borders of the Member States); see also P. De Bruycker, 'Vers un statut des ressortissants des pays-tiers dans le traité d'Amsterdam: libre circulation ou discrimination?', in: E. 
Title VI of the Treaty of Maastricht labelled "Provisions on the Cooperation in Justice and Home Affairs" provided a legal basis for the Member State to cooperate in the field of migration, as well as in criminal and judicial affairs under the third pillar. $^{254}$ The cooperation in the fields covered - all linked to internal security and the fight against crime - was intergovernmental in nature, meaning that the Member States had to consult and to inform one another in the Council with the aim to coordinate their action. In view of migration, Article K.1 TEU set out the following areas of common interest: asylum policy; rules governing the crossing by persons of the external borders of the Member States and the exercise of controls thereon; and immigration policy and policy regarding nationals of third countries. The later point, immigration policy, referred to (a) conditions of entry and movement by nationals of third countries on the territory of Member States; (b) conditions of residence by nationals of third countries on the territory of Member States, including family reunion and access to employment; and (c) combating unauthorised immigration, residence and work by nationals of third countries on the territory of Member States.

Although the Maastricht Treaty institutionalised action under the third pillar, the lawmaking process was rather slow-paced because most instruments required a unanimous vote in the Council for approval. ${ }^{255}$ The modest output under the third was also due to the sensitive subject-matters, disputes as regards financing and the fact that the Member States preferred to take non-legally binding measures. ${ }^{256}$ The Court was practically left out and had almost no say concerning the interpretation or application of the justice and home affairs provisions. Only with the Treaty of Amsterdam, a real change took place in the sense that immigration and asylum matters were shifted from the intergovernmental third pillar to the "communitarised" first pillar.

\subsection{The Copenhagen Criteria}

The European Council gathered in December of 1993 in Copenhagen where it defined the criteria states must comply with if they envisage EU membership. ${ }^{257}$ The Maastricht Treaty stipulated, in its Article 49, that "any European country which respects the principles set out in Article 6(1) may apply to become a member of the Union"; Article 6(1) TEU enshrined that the Union is founded on the principles of liberty, democracy, respect for human rights and fundamental freedoms and the rule of law, principles which are common to the Member States. The admission criteria,

Bribosia and others (eds.), Union européenne et nationalités: le principe de non-discrimination et ses limites (Bruylant, Bruxelles 1999), pp. 230-231.

Council Regulation (EC) No 1683/95 of 29 May 1995 laying down a uniform format for visas; for more information, see S. Peers, EU Justice and Home Affairs Law (3rd edn. Oxford University Press, Oxford 2011), pp. 249-258.

254 Art. K.1 of the Treaty of Maastricht.

255 H. Schneider, 'Towards a European Migration Policy: From Maastricht to Amsterdam, from Tampere to The Hague', in: H. Schneider (ed.), Migration, Integration and Citizenship (Forum Maastricht, Maastricht 2005), p. 23.

256 H. Staples, The Legal Status of Third Country Nationals Resident in the European Union (Kluwer Law International, The Hague 1999), p. 120.

$257 \quad$ Copenhagen Presidency Conclusions of 21 and 22 June 1993. 
also known as Copenhagen criteria, are cumulative and require candidate countries to dispose of:

- stable state institutions that guarantee the observance of the rule of law, democratic principles, human rights and the protection of minorities;

- a functioning market economy that permits the respective state to participate in a competitive market inside the Union;

- the ability to assume obligations relating to political, economic and monetary aims of EU membership;

- the ability to implement EU law and procedures into the national legal regime.

This last prerequisite was elucidated by the European Council in 1995 at the Madrid summit where it found that states must adjust their administrative structures to create conditions for the gradual and harmonious integration into the EU. ${ }^{258}$

\subsection{The 1995 Enlargement}

With the fourth enlargement process, Austria, Sweden and Finland joined the EU on 1 January 1995.259 Three years prior to these accessions, the EEA Agreement had been signed by the then seven EFTA States (Austria, Denmark, Norway, Portugal, Sweden, Switzerland and the UK), the Community and its Member States; the EEA Agreement entered into force on 1 January 1994. ${ }^{260}$ The establishment of the EEA required the EFTA States to adopt EU legislation in the areas of the internal market, social policy, consumer protection, environment and research and development policy. Next to Austria, Sweden and Finland, Norway had also submitted its application for EU membership but the Norwegian people rejected the country's EU accession in a referendum.

\subsection{The 1998 Austrian Presidency and the High-Level Working Group}

The external elements of immigration and asylum matters gained momentum with the Austrian Presidency in the second half of 1998. Along with Germany, Austria had been one of the major countries that was confronted with a large influx of Bosnian refugees who had fled from the civil war at that time. ${ }^{261}$ Against this background, an undisclosed "Austrian Strategy Paper on immigration and asylum" leaked and was withdrawn after it had triggered severe reactions among civil society but also among Member States. ${ }^{262}$ The Strategy Paper gauged past initiatives to counter irregular migration and asylum as inefficient and presented a new strategy which focused in essence on the reduction of migration pressure. First, a common approach was reemphasized by linking migration-related decisions within EU institutions, in view of

258 Madrid Presidency Conclusions of 15 and 16 December 1995, III under point A. Enlargement.

Act of Accession of Austria, Sweden and Finland, OJ C 241 of 29 August 1994.

Agreement on the European Economic Area, OJ L 1, 3 January 1994, p. 3.

I. Boccardi, Europe and Refugees: Towards an EU Asylum Policy (Kluwer Law International, The Hague 2002), pp. 155-156.

262 Council of the European Union, Strategy Paper on Immigration and Asylum to the K4 Committee, Austrian Presidency 1998, 9809/98, July 1998. 
foreign policy, economic relations with third countries and justice and home affairs. Moreover, the Strategy Paper promoted the creation of so-called concentric circles which should supersede "fortress Europe". The system provides that all states are classified into different circles and collaborate in the reduction of migratory movements to Europe in return for which they are granted economic support. ${ }^{263}$ It was further suggested to make development assistance and economic collaboration contingent upon visa arrangements, the conclusion of readmission agreements and the limitation of push factors. The effectiveness of this practice was challenged as development is a complex, multi-faceted and long-term process which cannot simply be stimulated by short-term tools inflicted by developed countries on migrant sending states. Therefore, it was argued that foreign policy objectives should serve as a basis when linking external relations and migration policies. ${ }^{264}$ In view of asylum, the Strategy Paper declared the 1951 Geneva Convention as obsolete because it no longer corresponded to the prevailing category of refugees who had fled on account of ethnic conflicts. The general tone adopted throughout the Strategy Paper leaves no doubt about Austria's highly restrictive position as regards immigration matters. Notwithstanding its withdrawal, some of the elements can be traced back in the succeeding program, the Vienna Action Plan on establishing an area of freedom, security and justice. ${ }^{265}$ The Action Plan sets out a timeframe of priorities and measures with respect to the transfer of competences under the Treaty of Amsterdam. ${ }^{266}$ In the field of immigration and asylum, the combat of irregular migration, in combination with enhanced border control, was considered as a top priority. It was also pointed out that the integration of Title IV EC would enforce the EU's role as a global actor, as it could cooperate in the area of justice and home affairs with third countries and international organisations to the extent authorised by the Court's case law on external powers. The Vienna Action Plan was officially endorsed at the subsequent Vienna summit on 11 and 12 December 1998.

In the meantime, the Dutch government had recommended a task force dealing with asylum and migration matters. ${ }^{267}$ The need to set up "a common, integrated and cross-pillar ${ }^{268}$ approach targeted at the situation of the most important countries of

263 A. Baldaccini, 'The External Dimension of the EU's Asylum and Immigration Policies: Old Concerns and New Approaches', in: A. Baldaccini, E. Guild and H. Toner (eds.), Whose Freedom, Security and Justice? EU Immigration and Asylum Law and Policy (Hart Publishing, Oxford 2007), pp. 278-279.

264 J. Niessen, 'International Migration on the EU Foreign Policy Agenda', 1 European Journal of Migration and Law (1999), 483, pp. 486-487.

265 I. Boccardi, Europe and Refugees: Towards an EU Asylum Policy (Kluwer Law International, The Hague 2002), p. 160.

266 Action Plan of the Council and the Commission on how best to implement the provisions of the Treaty of Amsterdam on an area of freedom, security and justice, Text adopted by the Justice and Home Affairs Council of 3 December 1998, 1999/C $10 / 01$.

267 See Note from the Dutch government: Asylum and Migration Task Force (Nota van de Nederlandse Delegatie: Task Force Asiel en Migratie) of 6 November 1998, document number 1963721 501-02.

268 Interestingly, the original Dutch version used the expression "pijleroverstijgend", which "gives more the impression of the group being a bridge between, or even above the pillars" as pointed out by Joanne van Selm in J. van Selm, 'Immigration and Asylum or Foreign Policy: The EU's Approach to Migrants and Their Countries of 
origin of asylum seekers and migrants" was already stressed in the EU Action Plan concerning the influx of migrants from Iraq and the neighbouring region. ${ }^{269}$ There was general consensus among Member States to better control the arrival of irregular migrants and people who wrongfully invoked the asylum procedure. The task force, which became known later as High Level Working Group on Asylum and Migration, was assigned to draft cross-pillar action plans for the most important countries of origin and the transit of asylum seekers and migrants. These action plans had multiple objectives such as establishing dialogue with the countries of origin, assessing the human rights situation, organising humanitarian aid for displaced persons, concluding readmission agreements, as well as considering the incorporation and enforcement of provisions on readmission and return in association agreements. Moreover, the reports should provide data analyses in view of asylum and migration flows on the one hand and associated problems on the other. ${ }^{270}$ Interestingly, the initiative to set up this Working Group stemmed originally from the Dutch Ministry of Foreign Affairs and most of its members worked for the foreign ministries of the Member States. ${ }^{271}$

The General Affairs Council recognised the significance of the issues raised and established the Working Group in December 1998. ${ }^{272}$ The Working Group drew up country reports on Albania and Afghanistan and their neighbouring regions, as well as on Iraq, Morocco, Somalia and Sri Lanka. The final report was published in September 1999 in which the Working Group underlined the "practical contribution [of the action plans] by suggesting concrete measures". The cooperation of the Member States, the Community and other organisations laid the foundation to carry out a thorough evaluation of the respective countries and to draw up joint analyses of the root causes of migration. In essence, the report highlighted the need for a longterm, comprehensive approach that takes socio-economic and political features into account and is responsive to changes. The Working Group suggested cooperation measures with the selected countries in three categories, namely foreign policy, development and economic assistance and migration and asylum. Close coordination among all actors involved was deemed indispensible for the effective implementation of the action plans. ${ }^{273}$

Origin', in: S. Lavenex and E. Uçarer (eds.), Migration and the Externalities of European Integration (Lexington Books, Lanham 2002), pp. 143-160. plan adopted by the Council on 26 January 1998, document number 5573/98 - C40124/98. 270 See Note from the Dutch government: Asylum and Migration Task Force (Nota van
de Nederlandse Delegatie: Task Force Asiel en Migratie) of 6 November 1998, document number 1963721 501-02.

271 J. Niessen, 'International Migration on the EU Foreign Policy Agenda', 1 European Journal of Migration and Law (1999), 483, pp. 478-492.

272 See Press Release of General Affairs Council of 6 December 1998, document number $13677 / 98$.

273 See Final Report of the High Level Working Group on Asylum and Migration of 29 September 1999, document number 11450/99 JAI 79 AG 27. 
The creation of the Working Group was generally welcomed, although its action plans have been considered as not providing new insights. ${ }^{274} \mathrm{~J}$. van Selm questions the selection of the countries, taking into account that the authorities of some states did not have diplomatic relations with EU Member States. As a direct consequence, the exchange of information was extremely hampered. The author moreover criticises that the Working Group had not established contacts with the six countries concerned when writing the reports; only at a later point in time had the Working Group commenced communications with certain third countries as described in an Introductory Note ${ }^{275}$ that was submitted to COREPER by the Council's Secretariat. This indeed raises questions with regard to the "appropriateness of the six countries or regions selected from the point of view of successful foreign policy action linked to asylum and migration issues". ${ }^{276}$ The reactions of the countries concerned varied: while the Sri Lankan authorities were eager to work with the EU, the Moroccan government disapproved of the action plan and wished to renegotiate its content. ${ }^{277}$ Another point of criticism related to the proposed preventive measures which were meant to address the root causes of migration. These measures were mostly frustrated as the concrete suggestions referred to instruments that would keep immigrants in the country of origin for example by means of readmission agreements. Cooperation between officials working on the CFSP and Commission officials working on development aid and external relations proved to be difficult. The latter felt precluded from the drafting process and expressed their worries that the Working Group would not act tactfully enough in view of third-country relations; this concern turned out to be justified in the case of Morocco. In the course of time, however, cooperation with the Commission was enhanced. ${ }^{278}$

Today, the High Level Working Group on Asylum and Migration still mainly consists of diplomats of the Member States, although, for instance, staff of the Swedish interior ministry is also involved. The Working Group meets biannually four to five times with Commission officials of DG HOME, DG RELEX and DG DEVCO. Yet, it remains to be seen how the restructuring of DG RELEX, which merges into the European External Action Service, affects the interaction. Coordination and cooperation within this setting has proven difficult at times seeing that the Member States and the different DGs have diverging remits and pursue different policy priorities. The Working Group reports on a regular basis to the General Affairs Council and works closely together with the JAIEX (JHA-RELEX) Working Group that was established as an ad-hoc support group under the French presidency in 2008 with the aim to improve the information flow and to make justice and home affairs and external relations more coherent. In meetings of the High Level Working Group

\footnotetext{
274 J. Niessen, 'International Migration on the EU Foreign Policy Agenda', 1 European Journal of Migration and Law (1999), 483, p. 492.

275 Council of the European Union, Introductory Note: Adoption of the Action Plan for Albania and the Region and the Implementation of the Action Plans for Afghanistan and the Region, Iraq, Somalia and Sri Lanka, Brussels 2000, document number $8939 / 00$.

276 J. van Selm, 'Immigration and Asylum or Foreign Policy: The EU's Approach to Migrants and Their Countries of Origin', in: S. Lavenex and E. Uçarer (eds.), Migration and the Externalities of European Integration (Lexington Books, Lanham 2002), p. 153.

$277 \quad$ Ibid. pp. 153-154.

278 C. Boswell, 'The 'External Dimension' of EU Immigration and Asylum Policy', 79 International Affairs (2003), 619, pp. 631-632.
} 
on Asylum and Migration the 2005 Global Approach to Migration plays a central role. ${ }^{279}$ AGENDA

The Treaty of Amsterdam created the area of freedom, security and justice, in which the free movement of persons was envisaged to be assured in conjunction with measures relating to external border controls, asylum, immigration and the prevention and combating of crime. ${ }^{280}$ The Treaty of Amsterdam, signed on 2 October 1997 and effective from 1 May 1999, constituted a landmark in the development of European migration policy since the Community was transferred substantial competences in the fields of immigration, visa and asylum matters (as well as judicial cooperation in civil matter) under Title IV EC from the third pillar concerning justice and home affairs. The remainder of the third pillar was entitled "Police and Judicial Cooperation in Criminal Matters" (PJCC) under the Amsterdam regime. Moreover, on the basis of a Protocol, the Schengen acquis - the set of rules adopted under the Schengen Convention - was incorporated into the EU framework. The CFSP was made more visible in that the Treaty of Amsterdam established the post of the High Representative for common foreign and security policy to represent the EU's foreign policy interests on the world stage. The Treaty of Nice entailed changes in view of decision-making procedures under Title IV EC, introducing qualified-majority voting and co-decision for most issues relating to asylum with the adoption by the Council of legal measures defining common rules and basic principles on asylum matters. 281 Furthermore, qualified-majority voting and codecision was stipulated in a Protocol to the Nice Treaty for measures on administrative cooperation, the visa list and visa formats as of 1 May 2004.

\subsection{Developments in the EU's External Relations}

\subsubsection{The Enhanced CFSP and the High Representative}

The amendments introduced by the Treaties of Amsterdam (1999) and Nice (2003) have improved and consolidated the CFSP as installed by the Maastricht regime. Most importantly, Article 6 TEU stipulated that the EU is founded on the rule of law, extending the latter principle to the CFSP pillar with one major loophole: the Court's jurisdiction was still excluded for CFSP measures except for the special case where a CFSP instrument encroached upon Community competence (Article 46 TEU). ${ }^{282}$ Another addition related to the requirement of consistent EU action, in particular in EU external activities as a whole, involving external relations, security,

279 Interview with the Secretary of the High Level Working Group of Migration and Asylum, General Secretariat of the EU Council, held on 16 February 2011. Treaty of Amsterdam, OJ C 340, 10 November 1997; see Art. 2 of the TEU as amended by the Treaty of Amsterdam.

281 Treaty of Nice, OJ C 80, 10 March 2001, p. 1.

282 G. Bono, 'Some Reflections on the CFSP Legal Order', 43 Common Market Law Revien (2006), 337, pp. 347-348. 
economic and development policies. ${ }^{283}$ The Council was given a supervisory function regarding CFSP measures under Articles 3 and 11(2) TEU but again a procedure for their actual enforcement was missing in conjunction with the Court's handicapped jurisdiction under Title V TEU. ${ }^{284}$ The Treaty of Amsterdam strengthened the Union's role as regards the setup of the CFSP. According to Article 11 TEU, it was solely the EU that defined and implemented a common foreign and security policy in lieu of the EU and the Member States jointly, as previously ascertained in the Maastricht Treaty. Next, the CFSP was equipped with a "face"; the Secretary-General of the Council should exercise the function of the High Representative for common foreign and security policy and assist the Presidency in representing the Union externally. In particular, the High Representative was given the mandate to contribute to the formulation, the preparation and implementation of policy decisions and through conducting political dialogue with third parties. ${ }^{285}$ The revision of the CFSP furthermore established a new legal instrument, so-called common strategies decided by the European Council and implemented by the EU in areas where the Member States had important interests in common. ${ }^{286}$ Common strategies were to be adopted by joint actions, common positions, or decisions by qualified majority voting in the Council, adding thus a supranational element to CFSP decision-making (Article 23(2) TEU). The EU was first endowed with the power to conclude international agreements in conformity with Article 24 TEU; this raised the question of whether the EU possessed international legal personality, and it was affirmed as being "implicit" in accordance with the ICJ's advisory opinion in the Reparation for Injuries dispute. ${ }^{287}$ This finding is confirmed by the addition of a paragraph 6 to Article 24 TEU with the Treaty of Nice that qualified the agreements as being binding on the EU institutions.

The EP only enjoyed restrained competences under the CFSP pillar: as enshrined in Article 21 TEU, the Presidency must consult the EP on the main aspects and the basic choices of the CFSP and it must ensure that the Parliament's views are duly taken into consideration. Also, the EP shall be kept informed and it may ask questions or make recommendations to the Council. In fact the EP has exercised limited influence because it has a say on the budgetary matters (Article 28 TEU) and the reports drawn by the EP concerning particular policy issues that have been frequently taken into account by the Council. 288 The real protagonists of the CFSP were, according to E. Decaux, the Presidency of the Council, which is responsible for the Union's representation in CFSP matters and its implementation (Articles 18(1) and (2) TEU), the High Representative of the CFSP and the Commission, which is to be fully associated with the CFSP representation and implementation, as well as

\footnotetext{
283 Art. 3 TEU.

284 R.A. Wessel, The European Union's Foreign and Security Policy: A Legal Institutional Perspective (Kluwer Law International, The Hague 1999), pp. 209-211.

285 Arts. 18 and 26 TEU.

286 Art. 13(2) TEU.

287 Reparation for Injuries Suffered in the Service of the United Nations, Advisory Opinion [1949] ICJ Reports 174; G. Bono, 'Some Reflections on the CFSP Legal Order', 43 Common Market Law Review (2006), 337, pp. 354-357.

288 E. Denza, The Intergovernmental Pillars of the European Union (Oxford University Press, Oxford 2002), pp. 188-190, 337.
} 
general work carried out in the CFSP field (Articles 18(4) and 27 TEU). ${ }^{289}$ The author has depicted this structure as follows:

“Sans pouvoir entrer dans les détails techniques, l'action extérieure de l'Union europénne ne ressemble même pas à un aigle bicéphale, mais plutôt à un monstre à plusieurs têtes, ce qui n'est pas a priori un facteur d'efficacité, avec d'un côté un Secrétaire général s'exprimant sous le contrôle de la présidence du Conseil pour ce qui concerne la PESC proprement dite, dans le prolongement de la coopération intergouvernementale [...] et de l'autre un Commissaire aux relations extérieures, luimême placé sous la direction du président de la Commission [...] pour tout ce qui concerne la projection internationale de l'action communautaire."

At the time there were, in total, four Directorates-General dealing with external relations and numerous others displayed an external dimension. Beyond doubt, this construct required coordination and diplomatic talent and two strong personalities in these positions so as to give the EU a coherent and dynamic image on the international scene. ${ }^{290}$ This aim is backed by the following operating principles: the Council and the Commission are responsible for ensuring the consistency of the EU's policies (Article 3(2) TEU); the Member States are obliged to respect the principle of loyal cooperation; the Council shall ensure the unity, consistency and effectiveness of the Union's action (Article 13(3) TEU). The principle of loyal cooperation under the Community framework was first stipulated in Article 5 EEC, arguably, however, its application also extended to the second and third pillar. With regard to the third pillar, the matter has been confirmed by the ECJ in Pupino, ${ }^{291}$ as regards the second pillar, Article 11(2) TEU lays down the Member States' general duty to support the Union's external and security policy actively and unreservedly in a spirit of loyalty and mutual solidarity. It has been underscored that this duty of close cooperation results from the "requirement of unity in the international representation of the Community" 292 and that it constitutes "one of the fundamental principles of the external relations of the Communities". ${ }^{293}$

The proposal for an enhanced integration on security issues was submitted by the UK government and became an Anglo-French initiative to deepen defence cooperation within the Union in 1998, also referred to as the "St Malo process". During the following European Council summits the proposal was repeatedly amended and became known as the European Security and Defence Policy (ESDP). Moreover, the so-called Petersburg tasks were included which consist of humanitarian and rescue tasks, peacekeeping tasks and tasks of combat forces in crisis management, including peacemaking as laid down in Article 17(2) TEU. The ESDP has thus three dimensions: the military crisis management, civilian crisis management and conflict prevention. ${ }^{294}$ The evolution of the ESDP has been

289 E. Decaux, 'Le Processus de Décision de la PESC: Vers une Politique Etrangère Européenne? ', in: E. Cannizzaro (ed.), The European Union as an Actor in International Relations (Kluwer Law International, The Hague 2002), pp. 23-24.

Ibid., p. 24.

Case C-105/03 Pupino [2005] ECR I-5285, para. 42.

Opinion 2/91 ILO Convention No 170 [1993] ECR I-1061, para. 36.

I. MacLeod, I.D. Hendry and S. Hyett, The External Relations of the European Communities (Oxford University Press, Oxford 1996), p. 145. 
explained as the result of a historical process at a time when the EU was faced with major conflicts in the Western Balkan countries but also due to the Member States' willingness, the Union's persistency, the necessity to adapt to unforeseeable developments in the international arena in which the U.S. is a major actor. ${ }^{295}$

\subsubsection{Rapprochement in the EU's External Relations - A Digest}

At the end of the 1990s and the turn of the millennium, the EU continued to build its external relations, including laying the foundation for accession negotiations with some countries. Following the 1996 regional approach with states of Former Yugoslavia, in 2000 the EU initiated the Stabilisation and Association Process aiming at ensuring continuous stability and security in South-East Europe, as well as an approximation of the countries in this region to the European integration process. In this context, Stabilisation and Association Agreements (SAAs) were negotiated with countries in the Western Balkan region with the objective to establish a free trade area, to import EU standards and to stipulate democratic principles and the rule of law. To date, the EU has concluded six such agreements with the Western Balkan countries out of which four have entered into force. ${ }^{296}$

Between 1991 and 1996, ten association agreements with Central and Eastern European states, the so-called Europe Agreements, were signed to provide a legal framework to establish market economies and gradually to integrate the Eastern neighbours into the EU for future accession purposes. ${ }^{297}$ During the Helsinki summit in 1999 the European Council granted candidate status to thirteen states, including Cyprus, Hungary, Poland, Estonia, the Czech Republic, Slovenia, Romania, Slovakia,

295 A. Deighton, 'The European Security and Defence Policy', 40 Journal of Common Market Studies (2002), 719.

296 Stabilisation and Association Agreement between the European Communities and their Member States, of the one part, and the Republic of Albania, of the other part, OJ L 107, 28 April 2009, p. 166; Stabilisation and Association Agreement between the European Communities and their Member States, of the one part, and the Republic of Croatia, of the other part, OJ L 26, 28 January 2005, p. 3; Stabilisation and Association Agreement between the European Communities and their Member States, of the one part, and the former Yugoslav Republic of Macedonia, of the other part, OJ L 84, 20 March 2004, p. 13; Stabilisation and Association Agreement between the European Communities and their Member States of the one part, and the Republic of Montenegro, of the other part, OJ L 108, 29 April 2010, p. 3; Stabilisation and Association Agreement between the European Communities and their Member States, of the one part, and the Republic of Serbia of the other part, signed on 29 April 2008; Stabilisation and Association Agreement between the European Communities and their Member States, of the one part, and Bosnia and Herzegovina, of the other part, signed on 16 June 2008; as of 22 October 2011, the SAAs with Albania, Croatia, Macedonia and Montenegro have entered into force; the ratifications of the SAAs with Serbia and Bosnia and Herzegovina are pending.

297 Europe Agreements OJ L 347, 31 December 1993, p. 2 (Hungary); OJ L 348, 31 December 1993, p. 2 (Poland); OJ L 360, 31 December 1994, p. 2 (Czech Republic); OJ L 359, 31 December 1994, p. 2 (Slovak Republic); OJ L 357, 31 December 1994, p. 2 (Romania); OJ L 358, 31 December 1994, p. 3 (Bulgaria); OJ L 26, 2 February 1998, p. 3 (Republic of Latvia); OJ L 51, 20 February 1998, p. 3 (Republic of Lithuania); OJ L 68, 9 March 1998, p. 3 (Republic of Estonia); OJ L 51, 26 February 1999, p. 3 (Republic of Slovenia). 
Latvia, Lithuania, Bulgaria, Malta and Turkey. ${ }^{298}$ The membership negotiations with Turkey have proven difficult at times; in February of 2008 a revised Turkey Accession Partnership was adopted.

The 1972 Free Trade Agreement regulating the Community's economic relations with Switzerland was superseded by two packages of seven bilateral agreements signed in 1999 and in 2004 respectively. ${ }^{299}$ A negative referendum prevented Switzerland from joining the EEA in 1992 and the new set of agreements constituted a new impetus in the EC-Switzerland relations. The first package of bilateral agreements contained the Agreement on the Free Movement of Persons that came into force in June of 2002.300

In 2003, the EU developed a vision on a wider Europe addressed to Eastern and Southern neighbours, which developed in 2004 into the European Neighbourhood Policy (ENP). The ENP was set up as an integrated approach envisaging an area of peace, stability and prosperity, a "ring of friends" with the EU neighbouring countries to promote peaceful and cooperative external relations. 301 The ENP expressly comprises countries that do not have the prospect of EU membership; with so-called Action Plans the EU intended to enhance cooperation concerning political, economic and social aims, as well as collaboration on transport, energy, environment, research and justice and home affairs.

The EU-ACP relations, which were first governed by the Yaoundé I and Yaoundé II Agreements until 1975, were replaced by the Lomé I to IVbis Conventions covering the time period until the entry into force of the Cotonou Agreement in April 2003. The ACP partnership is characterised today by three complementary pillars consisting of development cooperation, economic and trade cooperation and a political dimension.

\subsection{Migration in the Spotlight: Title IV of the Treaty of Amsterdam}

The insertion of Title IV of the Treaty of Amsterdam on visas, immigration and other policies related to the free movement of persons conferred upon the Community competencies to adopt measures as regards inter alia the abolition of internal border controls; the crossing of external borders including short-term visas; asylum; immigration policy, including conditions of entry and residence, family reunion, irregular migration and measures defining the rights and conditions under which legally-residing third-country nationals may reside in other Member States. ${ }^{302}$ As explained in further detail below, the legal bases permitted the Community to pass

Helsinki Presidency Conclusions of 10 and 11 December 1999, paras. 3-13.

See website of the Swiss Federal Department of Foreign Affairs on bilateral agreements Switzerland -EU and EFTA: < http://www.europa.admin.ch/themen/00500/index.html?lang $=$ en $>$, last accessed on 7 November 2011.

Agreement between the European Community and its Member States, of the one part, and the Swiss Confederation, of the other, on the free movement of persons, OJ L 114, 30 April 2002, p. 6.

European Commission Communications, $\operatorname{COM}(2003)$ 104, 11 March 2003; $\operatorname{COM}(2004)$ 373, 12 May 2004. Arts. 61-63 EC. 
a considerable amount of secondary legislation in the fields covered. As a result, the Community has created a comprehensive set of European migration and asylum law. The law-making procedures under Title IV were subject to special rules. Until May of 2004, the Commission shared the right to propose legislation with the Member States and almost all measures under Title IV EC required the Council's unanimous approval with the exception of matters relating to the visa list and format and emergency measures. The EP's participation in the law-making process during this timeframe was limited to consultation. After the lapse of the five-year transition period, the co-decision procedure and qualified majority voting in the Council applied to rules on a uniform visa and conditions and procedures for issuing visas by Member States; on the basis of a decision, the Council extended the co-decision procedure and qualified majority voting in the Council to all measures under Title IV, except for those concerning regular migration and family law and visa lists and formats in line with Article 67(2) EC. ${ }^{303}$ The jurisdiction of the Court was severely restricted under Title IV seeing that preliminary rulings could only be sought if there were no national legal remedies available. ${ }^{304}$ The geographical application of Title IV EC was curtailed from the outset because Denmark, Ireland and the UK negotiated special rules on their position in separate Protocols. While Denmark completely optedout of Title IV, Ireland and the UK decided on a rule which allowed them "to opt-in" on each measure if they communicated their interest of participation to the Council. ${ }^{305}$

\subsection{The Integration of the Schengen acquis}

The Treaty of Amsterdam integrated the Schengen acquis that provides for free movement of persons within an area without internal border controls into the framework of the EU, reconciling the Schengen cooperation and collaboration in justice and home affairs that had led to overlapping rules. ${ }^{306}$ The 1990 implementing Convention had binding force on the Benelux states, France, Germany, Spain and Portugal from 1993 but was only effectively applied from March 1995. Accession treaties were soon signed with Italy, Greece, Austria, Sweden, Denmark and Finland. The Schengen acquis applied to 13 Member States when the Treaty of Amsterdam entered into force on 1 May 1999.307 The Schengen acquis comprised the 1985 Schengen Agreement, the 1990 implementing Convention, the accession protocols and agreements to the 1985 Agreement and the 1990 implementing Convention and the measures adopted by the Executive Committee. ${ }^{308}$

303 Council Decision of 22 December 2004 providing for certain areas covered by Title IV of Part Three of the Treaty establishing the European Community to be governed by the procedure laid down in Art. 251 of that Treaty, OJ L 396, 31 December 2004, p. 45; S. Peers, 'Transforming Decision-Making on EC Immigration and Asylum Law', 30 European Law Review (2005), 283.

304 Art. 68(1) EC.

305 See Protocols 4 and 5 to the TEU on the position of the UK and Ireland, and Denmark, respectively.

306 Protocol 2 to the TEU integrating the Schengen acquis into the framework of the European Union.

307 S. Peers, EU Justice and Home Affairs Law (3rd edn. Oxford University Press, Oxford 2011), pp. 36-37.

308 See Annex of Protocol 2 to the TEU integrating the Schengen acquis into the framework of the European Union. 


\subsection{The Tampere Milestones: The Comprehensive Approach to Migration}

Building a common immigration and asylum policy within the scope of the Treaty of Amsterdam should form an integral part of the area of freedom, security and justice. The European Council held a special meeting on the creation of this area on 15 and 16 October 1999 under the Finnish Presidency in Tampere. At this summit, the European Council set out the political priorities and guidelines in justice and home affairs matters which related, in essence, to four policy domains: a common EU migration and asylum policy; a genuine European area of justice; a unionwide fight against crime; and stronger external action. ${ }^{309}$

With regard to migration issues, the Tampere Presidency Conclusions emphasised the need to develop a common EU migration and asylum policy comprising a number of elements. Firstly, the European Council considered partnerships with countries of origin to be a key element for a successful comprehensive approach to migration which addresses human rights, political aspects and development matters in countries and regions of origin and transit. ${ }^{310}$ Secondly, the establishment of a common European asylum system based on the full and inclusive application of the Geneva Conventions and in cooperation with the United Nations High Commissioner for Refugees (UNHCR) was stressed. The right to seek asylum and the principle of nonrefoulement, which prohibits the deportation of a person facing persecution, were the guiding principles in this respect. ${ }^{311}$ Thirdly, the need to ensure fair treatment of third-country nationals who reside legally on the territory of a Member State was highlighted. This could best be achieved by an integration policy geared towards granting third-country nationals rights and obligations comparable to those of EU citizens. ${ }^{312}$ Lastly, the European Council underlined a more efficient management of migration flows in developing a common EU migration and asylum policy. This point referred to initiating information campaigns on the legal migration opportunities, a common visa policy on the basis of the incorporation of the Schengen acquis into the Union and the prevention of human trafficking. The Presidency Conclusions also accentuated the importance of fighting irregular migration and stimulating closer cooperation as regards border control. In this connection, voluntary return and the conclusion of readmission agreements with countries of origin were considered to be crucial. ${ }^{313}$

Another point discussed at Tampere related to stronger external action. The European Council emphasised that all competences and instruments of the Union must be utilised to create the area of freedom, security and justice. The European Council called for the drawing up of specific recommendations on policy objectives and priorities of the Union's external action in the field of justice and home affairs prior to the European Council meeting in June 2000.314 The Council, in cooperation with the Commission, complied with this request and issued a report on 6 June

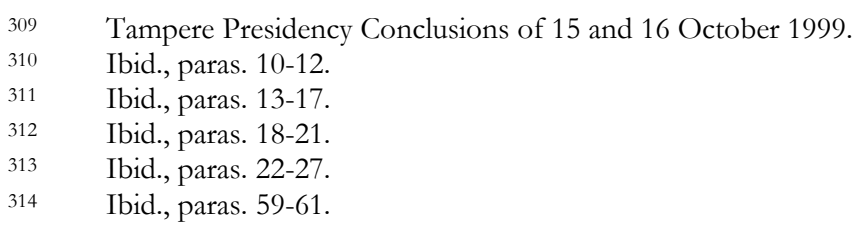


2000. ${ }^{315}$ The report reiterated the full integration of justice and home affairs matters into the EU's external policies so as to enable the Union to pursue an integrated, cross-pillar and comprehensive approach. In this context, it was pointed out that creating an external justice and home affairs dimension was not an aim in itself; rather, it sought to contribute to setting up the area of freedom, security and justice. The report stipulated that the existence of internal measures was a precondition to justify external action. Both issues raised underpin the functional nature of the external dimension of the comprehensive approach to migration. ${ }^{316}$ As concerns the priority areas for cooperation, the report explicitly mentioned the external dimension of migration policy. Under this heading, the document identified partnerships with countries of origin, a cross-pillar approach, readmission agreements and effective border control as essential elements.

\subsection{Da Feira and the Security-Centred Approach}

The European Council endorsed the building of an area of freedom, security and justice, as promulgated at the Tampere summit in Santa Maria da Feira in June 2000 and it welcomed the report drawn up by the Council and the Commission dealing with the justice and home affairs' priorities in the EU's external relations. ${ }^{317}$ The Feira Presidency Conclusions included a request to append a chapter on the implementation of the external dimension in the report for December 2001. The European Council condemned the series of terrorist acts and affirmed their commitment to combat terrorism across Europe. In this regard, emphasis was put on the possibilities laid down in the treaties to promote cooperation and solidarity. ${ }^{318}$ The terrorist attacks, which struck Spain in 2000, marked the beginning of an era where security concerns have increasingly influenced other policies, particularly migration policy. The attacks of 11 September 2001 in the U.S. reinforced this trend on a large scale.

In November 2001, the Commission published a Communication "on a common policy on illegal migration", which confirmed the top priority and the high sensitivity of the subject matter. ${ }^{319}$ The 26-page document laid down guidelines, targets and requirements, as well as an action plan on how to tackle irregular migration in Europe. The Commission proposed six fields in which action to prevent and combat irregular migration could be taken. These included visa policy, information exchange, border management, police cooperation, aliens and criminal law and return and readmission policy. At the Laeken European Council in December 2001, the European leaders stressed some achievement in the area of asylum but, at the same time, pointed out that further progress regarding migration and refugee protection

315 Council of the European Union, "A" Item Note from COREPER to the General Affairs Council/ European Council, document number: 7653/00 LIMITE JAI 35 on "European Union priorities and policy objectives for external relations in the field of justice and home affairs" of 6 June 2000; see also previous draft, document number 7512/00 LIMITE JAI 33 of 24 May 2000.

316 S. Sterkx, The Comprehensive Approach Off Balance: Externalisation of EU Asylum and Migration Policy (Universiteit Antwerpen, Antwerp 2004), p. 9.

317 Santa Maria da Feira Presidency Conclusions of 19 and 20 June 2000, para. 51.

$318 \quad$ Ibid., paras. 51-52.

319 European Commission Communication, COM(2001) 672, 15 November 2001. 
was necessary. The integration of migration policy in the Union's foreign policy was repeated in the context of concluding readmission agreements. Furthermore, the combat of xenophobia and racism, as well as the introduction of common standards on procedures on asylum, reception and family reunification, were highlighted. A better control of the Union's external border would, in addition, provide support in fighting illegal migration networks, terrorism and human trafficking. 320

The European Council meeting of summer 2002 took place under the Spanish Presidency in Seville. The Presidency Conclusions dedicated almost six pages to the area of migration and asylum and encouraged the speedy implementation of the Tampere agenda. The priorities of the Seville summit concerned the following four aspects: measures to combat irregular migration; the management of external borders; the incorporation of migration policy into the EU's external relations; and the speeding up of current legal instruments. It is interesting to indicate the reasons as to why migration policy should be integrated into the EU's external relations in the European Council's view: the chief aim was to fight irregular migration "with the use of all appropriate instruments in the context of the European Union's external relations" by inter alia tackling the root causes of migration flows. ${ }^{321}$ In this regard, the European leaders suggested readmission and migration management clauses in future agreements with the Community or the EU - an idea that the Commission had already put forward in 1991. The seriousness of the underlying issue was further substantiated by an assessment mechanism, with which the European Council tried to threaten third countries: insufficient cooperation in combating irregular migration could impede closer collaboration with the EU and could even lead to the adoption of CFSP measures. ${ }^{322}$ As a follow-up to the Seville summit, the Commission presented a Communication on the correlation of migration and development in December 2002 as a component of the comprehensive approach towards migration. ${ }^{323}$ The language used reveals how migration was viewed: as a problem that needs to be tackled. This was not altered by the fact that the Commission later pointed out that migration could also entail positive ramifications and produced challenges and opportunities. ${ }^{324}$ The first part of the document provided for an analysis of international migration and its implications. The second part was devoted to the effectiveness of financial resources at the Community's disposal to repatriate immigrants and rejected asylum seekers, to manage the EU's external borders and to support projects in third countries. The Commission further set out four key principles determining the integration of migration into the Community's external relations: overall coherence of external action, the root causes approach as a longterm priority and a strategic framework aiming at the conclusion of readmission agreements. ${ }^{325}$

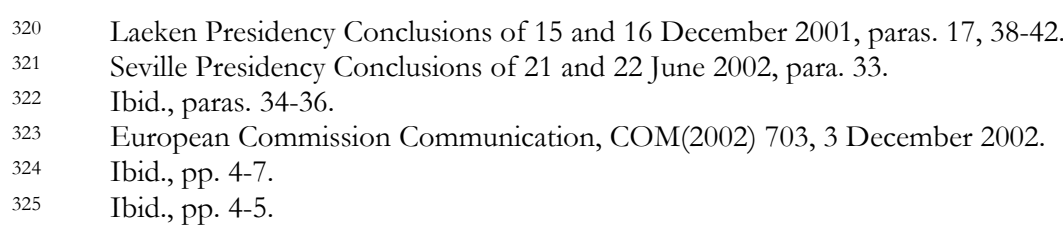


The Thessaloniki European Council took place in June 2003. The fight against terrorism played a prominent role in Annex I to the Presidency Conclusions but migration issues were extensively addressed too. In fact, it was again the fight against irregular migration that ranked on top of the agenda, this time in relation to visas, external borders, the return of illegally residing migrants, partnership with third countries, funding and "burden-sharing". The areas of asylum and measures for the integration of third-country nationals who reside legally in the EU were covered subordinately. After the five-year time frame set out at Tampere had lapsed, the Council adopted a new multi-annual agenda in December 2004, known as the Hague Programme.326 On the one hand, this new agenda welcomed the progress in building an area of freedom, security and justice, while at the same time emphasising its further strengthening. The section entitled "external dimension of asylum and migration" comprised partnerships with third countries, partnerships with countries and regions of origin and transit, as well as return and readmission policy. EU policy should be geared towards supporting third countries in managing migration flows, enhancing border control and document security, promoting refugee protection, fostering legal migration opportunities and preventing irregular migration. The European Council proposed EU Regional Protection Programmes for capacity building in cooperation with the UNHCR. Moreover, the European Council stressed effective removal and repatriation for undocumented migrants residing on EU territory. The security dimension of the Hague Programme is eye-catching: the terrorist acts of 11 September 2001 in the U.S. and also in March 2004 in Madrid, required better coordination and coherence in the area of security according to the European Council.327 With regard to external relations, the European Council considered it important to draw up a strategy that covers all aspects of the Union policy on freedom, security and justice in 2005.

\subsection{EU Secondary Legislation in the Field of Legal Migration}

On the basis of the competences that the Community had received with the Treaty of Amsterdam, in the subsequent years, it passed a considerable amount of legislative instruments in the field of immigration and asylum in line with the Tampere Conclusions of developing an integration policy based on fair treatment that grants third-country nationals rights and obligations comparable to those of EU citizens. The measures relating to immigration and the legal status of third-country nationals have reinforced the protection of the latter coming to and residing in the EU, and they have partly facilitated the movement to another Member State after having resided lawfully for a certain period in the "first" Member State. ${ }^{328}$ As opposed to the criterion of nationality, which is decisive for the application of association and cooperation agreements, the EU secondary legislation passed under Title IV EC set

326 Council of the European Union: "The Hague Programme: strengthening freedom, security and justice in the European Union", document number 16054/04 JAI 559 of 13 December 2004.

327 Ibid., p. 3.

328 For a comprehensive analysis of the various directives, and their implementation in five EU Member States, see A. Wiesbrock, Legal Migration to the European Union (Martinus Nijhoff Publishers, Leiden 2010). 
out other criteria triggering their application, such as the length of legal residence, professional qualification and family status. Next to the directives listed below, the Commission proposed two further directives in July of 2010: one directive relates to the admission of third-country seasonal workers, the other one concerns the admission of third-country intra-corporate transferees. ${ }^{329}$

It is important to note that Directive 2004/38/EC on the right of EU citizens to move and reside freely within the territory of the Member States, which was adopted in April of 2004, is of relevance to EEA nationals to whom its field of application is extended. ${ }^{330}$ Directive 2004/38/EC integrated existing Community legislation and codified the Court's case law by providing for a comprehensive set of rights for all EU citizens, including their family members, allowing for the free movement and residence in the EU. The Directive simplified the administrative procedures and set out the possibility to acquire the right of permanent residence. ${ }^{331}$

All directives relating to third-country nationals apply without prejudice to more favourable provisions of bilateral and multilateral agreements between the EU or the EU and its Member States on the one hand and third countries, on the other. Therefore, the rights that third-country nationals can acquire on the basis of these directives complement the status they might enjoy by virtue of association or cooperation agreements. It is crucial to keep in mind that the EU secondary legislation was unilaterally enacted by the EU legislator, in accordance with the pertinent procedural rules. In other words, third countries were not involved in the decision-making process and, therefore, the directives constitute internal legislation although they have implications for third-country nationals who plan to come to the EU or who are already residing there. This section provides only an overview considering that the protection set out by the various directives are discussed in detail under the respective rights in Parts V, VI and VII.

\subsubsection{Council Directive 2003/86/EC on Family Reunification}

Council Directive 2003/86/EC on the right to family reunification was adopted in September 2003 with the objective to protect the family and the respect for family life of third-country nationals, as recognised under Article 8 ECHR. ${ }^{332}$ The right to

European Commission, proposal for a directive of the European Parliament and of the Council on the conditions of entry and residence of third-country nationals for the purposes of seasonal employment, $\operatorname{COM}(2010)$ 379, 13 July 2010; European Commission, proposal for a directive of the European Parliament and of the Council on conditions of entry and residence of third-country nationals in the framework of an intra-corporate transfer, $\operatorname{COM}(2010)$ 378, 13 July 2010; at the time of writing the Directive on seasonal employment awaits the first European Parliament reading, while the Directive on intra-corporate transferees has been endorsed by the EP on 26 January 2012 (20 February 2012). Directive 2004/38/EC of the European Parliament and of the Council of 29 April 2004 on the right of citizens of the Union and their family members to move and reside freely within the territory of the Member States.

331 S. Carrera, 'What Does Free Movement Mean in Theory and Practice in an Enlarged EU? ', 11 European Law Journal (2005), 699, pp. 712-713.

332 Council Directive 2003/86/EC of 22 September 2003 on the right to family reunification. 
family reunification is granted to third-country nationals who are lawfully residing in the territory of a Member State. The instrument specifies that family reunification should apply in particular to members of the nuclear family, that is to say the spouse and the minor children but that Member States are free to extend family reunification to other close family members. In Parliament $v$. Council, the Court of Justice emphasised that the Member States are under the obligation to apply the Directive in a way that is in conformity with the protection of fundamental rights, such as the respect for family life and the best interests of the child; it added that the right to family reunification is a fundamental right that is protected under EU and international law. ${ }^{333}$ In November 2011, the Commission issued a Green Paper providing for a consultation on Council Directive 2003/86/EC to collect opinions on how to have more effective rules on family reunification at the EU level and to provide factual information and data on the application of the Directive. ${ }^{334}$

\subsubsection{Council Directive 2003/109/EC on the Status of Long-Term Residents}

Council Directive 2003/109/EC concerning the status of third-country nationals who are long-term residents, enacted in November 2003, provides third-country nationals who have lawfully and continuously resided in the territory of a Member State for a period of five years with the possibility to obtain long-term resident status. ${ }^{335}$ This status equips third-country nationals with a more secure legal position in the host Member State, considering that long-term residents enjoy equal treatment with nationals of the Member State concerned in specified areas and enhanced protection against expulsion. Next, long-term residents can acquire the right to reside in the territory of another Member State if certain conditions are met. To sum up, Council Directive 2003/109/EC facilitates the integration of third-country nationals by strengthening economic and social cohesion for third-country migrants, and it ties in with the foundation of the internal market and the free movement rules by setting forth a legal regime that allows long-term residents to move more easily to a "second" Member State. 336 The Commission published a report on the application of Council Directive 2003/109/EC in September 2011, in which it labelled the legal instrument as "a major milestone in the development of EU immigration policy, which concerns more than half a million third-country nationals in the 24 Member States to whom the Directive applies." 337 The Commission had started infringement proceedings against 20 Member States, either because of not having implemented Council Directive 2003/109/EC in time, or for not having properly informed the Commission as regards the transposition of the Directive into national law. After the Court of Justice delivered judgments against Portugal, Spain and Luxembourg, the other Member States communicated their implementing measures to the Commission

333 Case C-540/06 Parliament v. Council [2006] ECR I-7569; see also Opinion of AG Kokott, delivered on 8 September 2005, on the case.

334 European Commission Communication, COM(2011) 735, 15 November 2011.

335 Council Directive 2003/109/EC of 25 November 2003 concerning the status of thirdcountry nationals who are long-term residents.

336 For a detailed commentary on the genesis and content of the Directive, see S. BoelaertSuominen, Non-EU Nationals and the Council Directive 2003/109/EC on the Status of Third-Country Nationals who are Long-Term Residents: Five Paces Forward and Possibly Three Paces Back', 42 Common Market Law Review (2005), 1011. European Commission Communication, COM(2011) 585, 28 September 2011. 
and the infringement proceedings were suspended. ${ }^{338}$ The Commission reported implementation shortcomings concerning almost all provisions of the Directive and regretted the weak impact of the Directive since its adoption. Against this backdrop, the Commission stressed the need for correct transposition measures, enhanced information campaigns to raise the awareness among third-country nationals on longterm resident status and it suggested possible amendments so that Council Directive 2003/109/EC can fully deploy its effectiveness. ${ }^{339}$

\subsubsection{Council Directive 2004/114/EC on the Admission for the Purposes of Studies and Training}

The EU institutions adopted Council Directive 2004/114/EC on the conditions of admission of third-country nationals for the purposes of studies, pupil exchange, unremunerated training or voluntary service in December 2004.340 In line with the EU's objective to promote Europe in the field of education and vocational training as a whole as "world centre of excellence" and to facilitate the mobility of third-country nationals for the purpose of study, this Directive has established a legal regime that governs the admission conditions and procedures for students, pupils, unremunerated trainees and volunteers. It is explicitly stated that migration, for the purposes set out in this Directive, which is, by definition, temporary and does not depend on the labour-market situation in the host country, constitutes a form of mutual enrichment for the migrants concerned, their country of origin and the host Member State and helps to promote better familiarity among cultures. ${ }^{341}$ Council Directive 2004/114/EC provides for third-country students to follow part of the studies already commenced in another Member State, or complement them with a related course of study in another Member State. Also, Member States are obliged to grant such third-country students the possibility to carry out an economic activity subject to the labour market situation. ${ }^{342}$ The Commission evaluated the application of Council Directive 2004/114/EC in a report it published in September 2011.343 The Commission's infringement proceedings against Member States were closed after the Member States concerned submitted the required information. The Commission indicated that the Directive supports the aim to attract third-country students to the EU and assessed it as valuable in a setting in which Member States increasingly underscore the internationalisation of national education systems. However, it is also pointed out that the potential of Council Directive 2004/114/EC is not fully exploited when considering its partly poor implementation into the Member States' national legislation. In the light of these developments, the Commission offered its

\footnotetext{
338 Cases C-5/07 Commission v. Portugal [2007] ECR I-120; C-59/07 Commission v. Spain [2007] ECR I-161; C-34/07 Commission v. Luxembourg [2007] ECR I-175.

339 European Commission Communication, $\operatorname{COM}(2011)$ 585, 28 September 2011; for a detailed analysis on Council Directive 2003/109/EC see D. Acosta Arcarazo, The LongTerm Residence Status as a Subsidiary Form of EU Citizenship: An Analysis of Directive 2003/109 (Martinus Nijhoff Publishers, Leiden 2011).

340 Council Directive 2004/114/EC of 14 December 2004 on the conditions of admission of non-EU nationals for the purposes of studies, pupil exchange, unremunerated training or voluntary service.

341 See Recital 7 of the Preamble to Council Directive 2004/114/EC.

342 See Arts. 8 and 17 of Council Directive 2004/114/EC.

343 European Commission Communication, COM(2011) 587, 28 September 2011.
} 
support to address the shortcomings and assist in making information available to third-country nationals to stimulate brain circulation. ${ }^{344}$ Finally, the Commission considered amendments even though the focus should be on an effective implementation in the first instance. ${ }^{345}$

4.7.4 Council Directive 2005/71/EC on the Admission for the Purpose of Scientific Research

In October 2005, the EU legislator adopted Council Directive 2005/71/EC on a specific procedure for admitting third-country nationals for the purposes of scientific research. ${ }^{346}$ This framework has the objective of promoting the European research area in concert with the 2000 Lisbon Strategy that envisaged the EU becoming the most competitive and dynamic knowledge-based economy in the world by 2010 . The facilitated mobility of researchers is reflected in an admission system for thirdcountry researchers for the purpose of carrying out a research project for more than three months under hosting agreements with approved research organisations. Admitted third-country researchers are permitted to teach in the host Member State, they enjoy equal treatment in certain economic and social areas and they may move to another Member State with a view to carry out part of the research there. ${ }^{347}$

\subsubsection{Council Directive 2009/50/EC on the Admission for the Purposes of Highly Qualified Employment (EU Blue Card)}

Council Directive 2009/50/EC on the conditions of entry and residence of thirdcountry nationals for the purposes of highly qualified employment, the so-called EU Blue Card Directive, was adopted in May 2009.348 The EU Blue Card Directive provides for an admission scheme for attracting highly-skilled third-country migrants, by which the EU aims to create growth and jobs and to address the labour market need prevailing in the Member States. Council Directive 2009/50/EC sets out the entry and residence conditions for EU Blue Card holders and their family members and additionally specifies the conditions under which the EU Blue Card holder may move to a "second" Member State. In Article 6 of Council Directive 2009/50/EC, the Member States expressly preserve their right to determine the volume of admission of third-country nationals entering their respective territory for the purpose of highly qualified employment. The rights enjoyed by EU Blue Card holders are defined in Articles 12 to 17 of the Directive; they concern inter alia labour market access and equality of treatment.

\footnotetext{
344 The concept of brain circulation refers a form of migration in which migrants return to their own country on a regular or occasional basis, sharing the benefits of the skills and resources they have acquired while living and working abroad, see Global Commission on International Migration, Migration in a Interconnected World: New Directions for Action (SRO-Kundig, Switzerland 2005), available at: <http://iom.int/jahia/Jahia/gcim/>, last accessed on 20 February 2012, p. 31.

345 European Commission Communication, COM(2011) 587, 28 September 2011.

346 Council Directive 2005/71/EC of 12 October 2005 on a specific procedure for admitting third-country nationals for the purposes of scientific research.

347 See Arts. 11 to 13 of Council Directive 2005/71/EC.

348 Council Directive 2009/50/EC of 25 May 2009 on the conditions of entry and residence of third-country nationals for the purposes of highly qualified employment.
} 
4.7.6 Directive 2011/98/EU on a Single Permit and on a Common Set of Rights for Third-Country Workers

In 2007, the Commission proposed a framework for a single permit for third-country nationals wishing to reside and work in the EU and the legal instrument was adopted in December of $2011 .{ }^{349}$ This Directive aims to facilitate the admission procedures of third-country nationals to reside and work in the EU by introducing a single permit that combines work and residence authorisations. In its explanatory memorandum the Commission pointed out that there was a "rights gap" in relation to third-country workers as opposed to own nationals: "[G]ranting employment-related rights to them (e.g. working conditions including pay, access to vocational training and core social security benefit) comparable to own nationals recognizes that third-country workers contribute to the European economy through their work and tax payments. It can also help reduce unfair competition emanating from this rights gap, thus serving as a safeguard for EU citizens by protecting them from cheap labour and migrants from exploitation. In addition granting a common set of rights in Community law would create a level playing field within the EU for all third-country nationals legally working, irrespective of the Member State in which they stay." 350

Holders of such a single permit are entitled to enter and reside in the Member State that issued the single permit; the legislative instrument also lays down rules on the basis of which specified third-country workers enjoy equal treatment with nationals of that Member State where they reside as regards a set of rights. This right to equal treatment is without prejudice to the right of the Member State to withdraw or to refuse to renew the residence permit issued under this Directive, the residence permit issued for purposes other than work, or any other authorisation to work in a Member State. ${ }^{351}$ Importantly, Article 3 of Directive 2011/98/EU on a single permit defines its scope of application; a number of categories of third-country nationals are excluded, such as self-employed workers.

\subsubsection{The Hampton Court Summit}

The tragic events in September 2005 on the Spanish enclaves of Ceuta and Melilla in North Africa, where hundreds of African migrants tried to climb fences with the aim to reach the European shores, first triggered enormous media attention and subsequently policy action at the EU level. During an informal summit at Hampton Court in October 2005, the EU Heads of State and Government agreed on a

349 Directive 2011/98/EU of the European Parliament and of the Council of 13 December 2011 on a single application procedure for a single permit for thirdcountry nationals to reside and work in the territory of a Member State and on a common set of rights for third-country workers legally residing in a Member State. European Commission, proposal for a Council Directive on a single permit for thirdcountry nationals to reside and work in the territory of a Member State and on a common set of rights for third-country workers legally residing in a Member State, $\operatorname{COM}(2007) 638,30$ October 2007, p. 3. See Arts. 11 and 12(1) and (3) of Directive 2011/98/EU. 
comprehensive approach to tackle migration matters and the implications which it entailed. The Council further dwelled on migration and its external dimension in the Council Conclusions of November 2005, in which it stressed the balanced and comprehensive nature of such an approach: it should promote the benefits of migration for the third country, the EU and the individual migrant, while guaranteeing coordinated action with regard to irregular migration, human trafficking and people smuggling. The Council indicated that migration can form a seminal element of development policy if both fields of action are configured in a coherent way. Existing third-country agreements could serve as a basis for cooperation and dialogue in view of migration issues including the enhanced management of migration flows within the Barcelona Process. ${ }^{352}$ In response to the position of the Council, the Commission put forward priority actions arguing that a coherent and overall European approach to migration was indeed indispensable for the EU's credibility on the international plane. ${ }^{353}$ The Commission reiterated its intention to concentrate on all aspects of migration and to address migration projects within the frameworks in place in the areas of development, external relations, employment and freedom, security and justice. The focus was first put on the Mediterranean region and on African countries, although migration was explicitly recognised as a global phenomenon. The Commission targeted action with a view to improving cooperation between Member States on the one hand and strengthening the dialogue and collaboration with the countries of origin and the neighbouring states, which often have a dual role as countries of origin and transit, on the other. ${ }^{354}$ The approach pursued became known as the "Global Approach to Migration", which the European Council officially adopted during the Council meeting on 15 and 16 December 2005. 355

In 2006, the Commission presented a first evaluation of the projects established and gave recommendations on how to make the Global Approach truly comprehensive. ${ }^{356}$ As a first step, conferences in Rabat and Tripoli dealing with migration and development deepened the dialogue with African states. The Commission underscored that partnerships with third countries on legal migration, irregular migration, refugee protection and integration needed to be enhanced. Furthermore, it was highlighted that the funding concerning migration-related projects was to be intensified. In 2007, the Global Approach to Migration was extended to the Eastern and South-Eastern regions, which border the EU Member States' external boundaries. ${ }^{357}$ The principal countries concerned included Turkey, the Western Balkan countries (Albania, Bosnia and Herzegovina, Croatia and the Former Yugoslav Republic of Macedonia (FYROM), Montenegro and Serbia, including Kosovo), the ENP partner states in Eastern Europe (Ukraine, Moldova and Belarus) and the Southern Caucasus (Armenia, Azerbaijan and Georgia) as well as the Russian Federation. The following countries were also taken into consideration: the Middle Eastern ENP partner states (Syria, Jordan and Lebanon), Iran and Iraq, Central Asian

352 Council of the European Union: "Council Conclusions on Migration and External Relations", document number: 14769/05 of 21 November 2005, pp. 4-7.

353 European Commission Communication, $\operatorname{COM}(2005)$ 621, 30 November 2005.

354 Ibid., pp. 2-9.

355 Brussels Presidency Conclusions of 15 and 16 December 2005.

356 European Commission Communication, COM(2006) 735, 30 November 2006

357 European Commission Communication, COM(2007) 247, 16 May 2007. 
countries (Kazakhstan, Kyrgyzstan, Tajikistan, Turkmenistan and Uzbekistan) and Asian sending states including China, India, Pakistan, Afghanistan, Bangladesh, Sri Lanka, Vietnam, the Philippines and Indonesia. The Commission made this selection on the basis of the "migratory route" concept, which involved the close cooperation with third countries along the main migratory routes. The significance of cooperating with these regions was clear from the outset: approximately one third of the thirdcountry nationals residing in the EU have come originally from the Eastern neighbouring countries and the Russian Federation. The Commission argued that the 2004 and 2007 EU enlargement processes raised the new Member States' attractiveness as destination countries for Eastern neighbouring states. ${ }^{358}$ For each state or region, the Commission outlined the existing cooperation framework, which generally comprised the area of migration and gave recommendations for medium- or long-term action. This cooperation could take different forms, such as an association agreement in the case of Turkey, or a partnership agreement in the case of Russia. The extension of the Global Approach to the East was launched under the German presidency in 2007 with a view to establishing geographical balance. The focus on the Eastern migratory routes was continued by the Czech Presidency in 2009 and the Hungarian Presidency in 2011; for the latter Presidency, cooperation with former Commonwealth of Independent States (CIS) countries relating to border control was high on the agenda. ${ }^{359}$ The Global Approach was renewed and renamed in 2011, and is today known as GAMM. ${ }^{360}$

\subsubsection{Implementing the Global Approach: Mobility Partnerships as an Umbrella}

The important role of the Global Approach in shaping the external dimension of the EU migration and asylum policy crystallised in the subsequent time period. While the Global Approach comprised political dialogue and cooperation with third-countries as regards the full range of migration issues, particular emphasis was put on the "fight against illegal migration". The Commission pointed out that tackling irregular migration required joint and coordinated action with countries of origin and transit for the management of the EU's external borders, return and readmission, as well as a mechanism to combat networks which are engaged in human trafficking. ${ }^{361}$ In response to the Council's request to further develop the Global Approach to Migration the Commission issued a Communication in October $2008 .^{362}$ In this document, the Commission defined the Global Approach as the external dimension of the EU's migration policy based on genuine partnership with third countries, balanced in nature and fully incorporated into the EU's other external policies. ${ }^{363}$ In addition, it was contended that the Global Approach constituted a shift in perception in the sense that the externally-oriented European migration policy, which previously only aimed at curtailing migratory movements, was no longer dominated by security

$358 \quad$ Ibid., p. 4.

359 Interview with an official of the Permanent Representation of Hungary to the EU in charge of the Global Approach to Migration under the Hungarian Presidency in the first half of 2011, held on 16 February 2011.

360 See Section 5.5 below on the Global Approach to Migration and Mobility (GAMM).

361 European Commission Communication, COM(2007) 780, 5 December 2007.

362 Council of the European Union: "Adoption of the Council Conclusions on enhancing the Global Approach to Migration”, document number: 9604/08 of 20 May 2008. European Commission Communication, COM(2008) 611, 8 October 2008, p. 2. 
concerns. Instead, the Global Approach represented a more balanced approach, taking into account all pertinent elements of migration such as converting migration into a beneficial impetus for development. The Global Approach has three thematic dimensions - legal economic migration and mobility, irregular migration and migration and development. In this context, mobility partnerships providing a framework to effectively manage migration flows have been established. Mobility Partnerships are political, non-binding declarations between some EU Member States and a third country setting out measures to prevent and fight irregular migration on the one hand, while offering enhanced legal immigration opportunities on the other hand. Moreover, they envisage integrating action and cooperation in the field of migration and development. Mobility partnerships have been concluded with Cape Verde and Moldova, in May 2008 and with Georgia in November 2009. Negotiations on the conclusion of further mobility partnerships with Senegal, Ghana and Armenia are ongoing. ${ }^{364}$ The Commission identified mobility partnerships as the "most innovative and sophisticated tool to date of the Global Approach to Migration" and they were said to contribute substantially to its transposition with regard to all three dimensions. ${ }^{365}$ The subsequent sections discuss the three dimensions of the EU's Global Approach to Migration, followed by a critical evaluation.

\subsubsection{Economic Legal Migration and Mobility}

It is a well-known fact that the EU will significantly be affected by the demographic change which will entail the decrease of the working-age population in the EU by 48 million people between now and 2050 and an increase in the proportion of elderly people (two persons of working-age for every citizen aged 65 and above, instead of four). Undoubtedly, these trends will have substantial implications for the labour markets in the Member States and for future economic growth that is projected to decline. ${ }^{366}$ Against this backdrop, EU action in the field of legal economic migration gained in importance in shaping a common EU migration policy to address labour market demands. ${ }^{367}$ However, the issue of labour immigration had always been a particularly sensitive policy field for the Member States, and agreement seemed at times extremely difficult to reach. This sensitivity is reflected in the policy-making with the rejection of the 2001 Commission proposal on the conditions of entry and residence of third-country nationals for employment purposes and the subsequent sectoral approach pursued as suggested by the Policy Plan on legal migration. ${ }^{368}$ The researchers' Directive for admission of third-country nationals for the purpose of scientific research and the EU Blue Card Directive for the purpose of highly qualified

364 For an assessment on the mobility partnerships concluded, see N. Reslow, 'The Role of Third Countries in EU Migration Policy: The Mobility Partnerships', 14 European Journal of Migration and Law (2012), 393.

365 European Commission Staff Working Document, SEC(2009) 1240, 18 September 2009, p. 4.

366 European Commission Communication, COM(2006) 571, 12 October 2006, pp. 4-5.

367 S. Carrera and M. Formisano, 'An EU Approach to Labour Migration: What is the Added Value and the Way Ahead?', 232 Centre for European Policy Studies Working Document (2005), p. 7.

368 European Commission, proposal for a Council Directive on the conditions of entry and residence of third-country nationals for the purpose of paid employment and selfemployed economic activities, $\operatorname{COM}(2001)$ 386, 11 July 2001; European Commission Communication, Policy Plan on legal migration, COM(2005) 669, 21 December 2005. 
employment were adopted in 2005 and 2009, respectively. ${ }^{369}$ While these internal developments introduced admission rules for certain categories of third-country migrants, the EU made additional external efforts envisaging partnerships with third countries so as to respond to the EU labour market needs in view of all sectors and skill levels with full respect for the principle of Community preference. The Commission, in this regard, stressed the promotion of third countries' capacities to manage economic migration and the close cooperation with partner countries in order to enhance legal migration opportunities. ${ }^{370}$ Specific suggestions as to how to attain these goals included carrying out targeted campaigns for potential migrants, providing detailed information on legal access to the EU, on the risk of opting for irregular entry and on their rights and obligations in the country of destination. Socalled migration portals should lay down the relevant rules and procedures for legal migration to the EU Member States. The dissemination of information concerning admission conditions was stated to be the key task of migration information and management centres. In 2008, such a centre was established in Bamako, Mali, with funding stemming principally from the $9^{\text {th }}$ European Development Fund. The Centre provides assistance and guidance on legal immigration, implements and coordinates Mali's migration policy and, in addition, serves as a contact point for returning migrants. ${ }^{371}$ Another proposition related to improved job and skills matching mechanisms to facilitate and accelerate the matching of jobseekers to vacancies. Twinning between employment agencies and key institutions in the Member States and third countries are germane in this context. Next, it was considered crucial to boost the EU's economic growth in line with the 2000 Lisbon Strategy by enhancing the mobility for short stays and business purposes within the framework of a common visa policy. The latter was improved by the Visa Information System (VIS) which provides a scheme for the Schengen Member States to exchange information on short-term and transit visas. ${ }^{372}$ The VIS Regulation sets out the collection of biometric data at consular posts and entails a gradual roll-out to all third countries that are bound by visa requirements. ${ }^{373}$ The Community Code on Visas, which stipulates the procedures and conditions for issuing short-stay and airport transit visas, entered into force in April 2010 and replaced the Common Consular Instructions and some other Schengen-related decisions and regulations. ${ }^{374}$ To date, nine EU visa facilitation agreements and one visa waiver agreement for short-stays

Ancil Directive 2005/71/EC of 12 October 2005 on a specific procedure for admitting third-country nationals for the purpose of scientific research; Council Directive 2009/50/EC of 25 May 2009 on the conditions of entry and residence of third-country nationals for the purposes of highly qualified employment. European Commission Communication, COM(2008) 359, 17 June 2008, pp. 6-10. See website of the Mali Migration Information and Management Centre: $<$ www.cigem.org>, last accessed on 11 October 2011.

Regulation (EC) No 767/2008 of the European Parliament and of the Council of 9 July 2008 concerning the Visa Information System (VIS) and the exchange of data between Member States on short-stay visas.

European Commission Communication, $\operatorname{COM}(2008)$ 611, 8 October 2008, p. 4; Council of the European Union, Press Release, 2696th Council Meeting, Justice and Home Affairs, Brussels, 1-2 December 2005, p. 33.

Regulation (EC) No 810/2009 of the European Parliament and of the Council of 13 July 2008 establishing a Community Code on Visas. 
have been concluded with third countries. ${ }^{375}$ Visa facilitation agreements are a first step in establishing a visa-free travel scheme by facilitating people-to-people contacts. Furthermore, the concept of circular migration can stimulate legal economic migration. The Commission defined circular migration as "a form of migration that is managed in a way allowing some degree of legal mobility back and forth between two countries". ${ }^{376}$ It was pointed out that this form of movement could support the matching of cross-border labour supply and demand and could contribute to the development of sending countries, if circularity was ensured. Next, the exchange of best practices between Member States, third countries, migrants and diaspora organisations on circular migration schemes, brain circulation including dual posts, and the integration of migrants could serve as a basis for the best policy options at the EU level in the view of the Commission.

\subsubsection{Irregular Migration}

From the outset of the gradual integration of migration into the EU's external relations, the fight against irregular migration has been high on the agenda. The 1991 Communication suggested the approximation of the Member States' legislation as regards combating unauthorised migration and the associated issue of undeclared work, as well as agreements for the repatriation of immigrants in an irregular situation. ${ }^{377}$ These latter agreements are known as readmission agreements and they aim to guarantee the swift return of migrants who reside on the territory of an EU Member State without legal permission. Readmission agreements have become the major tool in combating and deterring irregular migration; to date the EU has concluded thirteen readmission agreements with third countries, in particular with neighbouring countries in the East. ${ }^{378}$ Already in 1995, the Council suggested the insertion of standard readmission clauses into future cooperation and association agreements with third countries. ${ }^{379}$ As a result, a lot of agreements concluded by the EU now contain readmission clauses; however, it has proven difficult to make use of them, and the mere existence of a readmission clause does not necessarily lead to the conclusion of a readmission agreement. The EU favours the additional conclusion of readmission agreements - and has thus targeted a double-track approach - because

375 As of 11 October 2011, EU visa facilitation agreements have been concluded with the Republic of Moldova, Georgia, Bosnia and Herzegovina, the former Yugoslav Republic of Macedonia, the Republic of Albania, the Republic of Montenegro, the Republic of Serbia, and the Russian Federation, and Ukraine; short-stay visa waiver agreements have been concluded with the Republic of Seychelles, Mauritius, the Bahamas, Barbados, Antigua and Barbuda; two more such agreements have been signed with Brazil, and Saint Kitts and Nevis.

376 European Commission Communication, $\operatorname{COM}(2007)$ 248, 16 May 2007, p. 8.

377 European Commission Communication, SEC(91) 1855, 23 October 1991, paras. 53-54.

378 As of 11 October 2011, EU readmission agreements have been concluded with the Republic of Moldova, Bosnia and Herzegovina, the former Yugoslav Republic of Macedonia, the Republic of Albania, the Republic of Montenegro, the Republic of Serbia, and the Russian Federation, Ukraine, the Democratic Socialist Republic of Sri Lanka, the Macao Special Administrative Region of the People's Republic of China, and the Government of the Hong Kong Special Administrative Region of the People's Republic of China, the Islamic Republic of Pakistan, and Georgia.

379 For Community agreements, Council document: 12509/95 of 8 December 1995 and for mixed agreements, Council document: 4272/96 of 22 January 1996. 
such agreements specify the distinct details of the whole readmission process and the obligations incumbent on each contracting party. A mandate for the Commission to conclude a readmission agreement with Belarus is being negotiated. ${ }^{380} \mathrm{~A}$ readmission agreement with Turkey is also under discussion but the negotiations are dragging. The Turkish government envisages visa-free travel against the backdrop of the Soysal judgment and has thus opposed a visa facilitation agreement offered by the EU.381

The Commission delved into the phenomenon of unauthorised migration in a Communication published in November 2001 in which it outlined principles and targets and specified required action. ${ }^{382}$ It stated that the prevention of and the fight against irregular movement of persons to the EU constituted a cornerstone of a comprehensive European migration and asylum policy. To this end, it emphasised the need to carry out analyses and research concerning the patterns of unauthorised residence, organised crime geared towards human trafficking and the irregular movements from the countries of origin via the transit countries to the countries of destination. Severe sanctions for serious crimes, such as people smuggling, were, in the Commission's view, indispensable to send clear signals to potential criminals, just as the effective enforcement of the existing rules. Action plans in different fields, including visa policy, readmission and return and border management, were proposed. The Commission's approach reflected the Zeitgeist as the events of 11 September 2001 fanned fear among citizens and policy makers, who used the occasion to adopt dubious anti-terror legislation and prioritised the security dimension of migration parallel to the Council's position taken in da Feira. One year later, a Commission Communication followed on a Community return policy on irregular residents which demonstrated the determination with which the Community pursued the goal to reduce irregular migration. ${ }^{383}$ As has been described above, the subsequent European Council summits focused upon measures on irregular migration. In response, the Hague Programme put a special emphasis on this subjectmatter and put illegal employment, return and readmission and border security on the agenda. ${ }^{384}$ The management of the EU's external borders was said to be closely linked to the fight against irregular migration. In 2004, the border control agency FRONTEX was established which is in charge of the coordination of operational cooperation between the Member States in view of border security. FRONTEX also provides training for border guards, assistance to Member States in need of technical and operational support at the EU's external borders and it cooperates with the law enforcement agencies in third countries. ${ }^{385}$ Another tool to combat irregular

Interview with an official of the Permanent Representation of the Netherlands to the EU, held on 21 February 2011.

381 Council of the European Union, Council Conclusions on EU-Turkey Readmission Agreement and Related Issues, 3071st Justice and Home Affairs Council meeting, 24 and 25 February 2011; Case C-228/06 Soysal [2009] ECR I-1031; see Part VII, Section 3.5 on the right to provide services for Turkish nationals.

382 European Commission Communication, COM(2001) 672, 15 November 2001.

383 European Commission Communication, COM(2002) 564, 14 October 2002.

384 Council of the European Union: "The Hague Programme: strengthening freedom, security and justice in the European Union", document number 16054/04 JAI 559 of 13 December 2004.

385 Council Regulation (EC) No 2007/2004 of 26 October 2004 establishing a European Agency for the Management of Operational Cooperation at the External Borders of the Member States of the European Union. 
migration is the immigration liaison officers' network. The underlying idea of the network is the deployment of Member States' representatives - the Immigration Liaison Officers (ILOs) - to a third country where the officer is in contact with the local authorities in order to gather and exchange information on the flows and routes of unauthorised migrants, the smuggling of migrants, the falsification of identity documents and return options. ${ }^{386}$

In 2006, the Commission issued another detailed policy document on priorities in the fight against irregular migration, such as cooperation with third countries and the conclusion of readmission agreements. ${ }^{387}$ EU readmission agreements are bilateral agreements between the Community and a third country, which lay down reciprocal obligations and administrative and operational procedures to facilitate the return and transit of persons who do not, or no longer, fulfil the conditions for entry into, presence in or residence in the requesting state. ${ }^{388}$ The readmission of own nationals is a widely acknowledged rule under customary international law, however, EU readmission agreements, under certain circumstances, also cover other third-country nationals and stateless persons. In this respect, the agreements create new obligations for the contracting parties. Readmission agreements are technical in the sense that they do not define the illegality of a person's stay in an EU Member State, but they only come into play once the unauthorised status of a person has been established. As readmission agreements are concluded in the interest of the EU and its Member States only, incentives have been offered to the third countries in question after negotiations were difficult in some instances. In the case of Algeria, the stagnancy faced was attributed to technical problems where, in fact, political dissensions posed the main challenge in reaching a consensus. ${ }^{389}$ In particular visa waiver and facilitation agreements serve as such incentives ${ }^{390}$ but also the conclusion of mobility partnerships has been offered in some cases. After the conclusion of the readmission agreement with Russia that was coupled with the conclusion of a visa facilitation agreement, this "package deal" was standardised. ${ }^{391}$ As regards return, it is important to indicate the adoption of Council Directive 2008/115/EC, which lays down common standards and procedures in Member States for returning irregularly staying third-country nationals. ${ }^{392}$ This Directive, which has been called "the directive of shame" has been heavily criticised by various organisations. ${ }^{393}$ Next, the EU

386 Council Regulation (EC) No 377/2004 of 19 February 2004 on the creation of an immigration liaison officers' network.

387 European Commission Communication, COM(2006) 402, 19 July 2006.

388 European Commission Communication, $\operatorname{COM}(2002)$ 564, 14 October 2002, p. 26.

389 Interview with the Secretary of the High Level Working Group of Migration and Asylum, General Secretariat of the EU Council, held on 16 February 2011.

390 M. Schieffer, 'Readmission and Repatriation of Illegal Residents', in: B. Martenczuk and S. Van Thiel (eds.), Justice, Liberty, Security: New Challenges for EU External Relations (VUBPRESS, Brussels 2008), pp. 96-108.

391 Interview with an official of the Permanent Representation of the Netherlands to the EU, held on 21 February 2011.

392 Council Directive 2008/115/EC of 16 December 2008 on common standards and procedures in the Member States for returning illegally staying third-country nationals.

393 See press releases "Amnesty International EU office Reaction to the Return Directive Vote" of 18 June 2008; "UNHCR Position on the Proposal for a Directive on Common Standards and Procedures in Member States for Returning Illegally Staying Third-Country Nationals" of 16 June 2008. 
institutions adopted the employer sanctions' Directive on 18 June 2009, which set out the measures and sanctions against employers of unauthorised staying third-country nationals. ${ }^{394}$ The Commission also suggested cooperation to establish a European External Border Surveillance System (EUROSUR) within the framework of the ENP and collaboration with the main countries of origin and transit among other things under the Cotonou Agreement. ${ }^{395}$

\subsubsection{Migration and Development}

In 1991, the Commission declared that "emigration is a reflection of the difficulties encountered by [...] countries. In this connection, it is important to limit the brain drain; to do so will require the strengthening of scientific cooperation activities, thereby contributing to the development of resources in the countries of origin." 396 These considerations demonstrate the Commission's awareness of a strong link between migration flows and the economic development of sending countries. At the 2002 Seville European Council, the British and Spanish Prime Ministers Tony Blair and José Maria Aznar proposed to make development assistance conditional on effective cooperation to impede undocumented migrants from entering the EU; this suggestion was strongly opposed by inter alia DG DEVCO because development aid should not constitute a trade-off tool for enhanced border control in third countries. ${ }^{397}$ The European Commission elaborated in-depth on the correlation between migration and development in the Communication of December 2002, in which it outlined the various interrelations and presented measures to reinforce the cohesion between both policy domains at the EU level. ${ }^{398}$ In 2005, the Commission built on its previous publication and clarified its ambitions: in order to ascertain policy coherence for development, the best practices of Member States, non-state actors and other countries should be taken into consideration. Emphasis was put on improving the transfer of remittances, promoting diaspora networks, coping with the negative consequences of brain drain and fostering circular migration. ${ }^{399}$ The idea that migration entailed positive ramifications for the home and host state, as well as the individual migrants - the so-called triple-win situation - was also a much discussed matter in the international context. In parallel to the global developments, the Commission encouraged action to formulate an EU policy by launching a comprehensive dialogue on globalisation and regional cooperation with developing countries. ${ }^{400}$ The Commission stressed the incorporation of migration policies into

Council Directive 2009/52/EC of 18 June 2009 providing for minimum standards on sanctions and measures against employers of illegally staying third-country nationals. European Commission Communication, $\operatorname{COM}(2008)$ 611, 8 October 2008, p. 6. European Commission Communication, SEC(91) 1855, 23 October 1991, para. 11; the Oxford English Dictionary defines brain drain as the emigration of highly trained or qualified people, regarded as detrimental to a country's economy or society. Interview with a Commission official, DG DEVCO, European Commission, held on 21 February 2011.

European Commission Communication, COM(2002) 703, 3 December 2002. European Commission Communication, COM(2005) 390, 1 September 2005. European Commission Communication, COM(2005) 621, 30 November 2005, p. 4. 
other policies, including those on health, education, human capital, social and economic development, with a view to economic reform and job creation. ${ }^{401}$

The EU confirmed its political intentions to address the challenges which come along with migration, by having regard to the UN Millennium Development Goals (MDGs) and the European Consensus on Development. ${ }^{402}$ In order to promote dialogue with countries of origin and transit, conferences were organised such as the Euro-African Ministerial Conference on Migration and Development held in Rabat in July 2006. ${ }^{403}$ Commitments were further elucidated in the Tripoli Joint Africa-EU Declaration on Migration and Development of November 2006.404 Mobility Partnerships and circular migration hold a prominent role in the EU discourse "in making migration work for development". While mobility partnerships are said to provide the overall framework for action to stipulate the priorities and specific needs of the contracting parties, circular migration was praised to have positive effects on the country of origin, minimise the risk of brain drain, promote skill transfers and meet the demands of the EU Member States' labour markets. The Commission, in this respect, stressed two modes in particular: the first one related to circular migration of third-country nationals who are settled in the EU and who engage in an activity in their country of origin, while retaining their main residence in a Member State. This category covers among other things professionals and business people who wish to start an activity in their native country. The second category relates to circular migration of persons residing in a third country who come temporarily to the EU for work, study and training purposes and who leave again for their country of origin as soon as their residence permit has expired; these transitional migrants should easily re-establish their main residence and activity in the country of origin. ${ }^{405}$ In order to attain its objective, the actual circularity of the migration process was attached vital importance; such circularity could be fostered by prospects of future possibilities to travel to the EU and by making reintegration of returning migrants in their country of origin as smooth as possible. It was rejected to link circular migration to Mode 4 of GATS on the temporary movement of natural persons considering the economic objective underlying the GATS system. ${ }^{406}$ Moreover, the effective return of the migrant in question was underscored, and the Commission underlined that the implementation of circular migration schemes should be monitored. ${ }^{407}$ In addition, the Commission initiated other measures to promote the linkages between migration

\footnotetext{
401 European Commission Communication, $\operatorname{COM}(2008)$ 611, 8 October 2008, p. 7.

402 Joint Statement by the Council and the representatives of the governments of the Member States meeting within the Council, the European Parliament and the Commission on the European Union Development Policy: 'The European Consensus' (2006/C 46/01), published in the OJ on 24 February 2006. Euro-African Partnership for Migration and Development - 2006 Rabat Declaration, available at: <http://www.maec.gov.ma/migration/Doc/RABAT\%20DECLARATION_EN.pdf $>$, last accessed on 11 October 2011. 2006 Tripoli Joint Declaration on Migration and Development, available at: <http://www.euromed-migration.eu/e1152/e1537/e2138/e2279/e1258/e1286/ENtripolideclarationreadmatwg3s32022042009nuremberg_eng.pdf $>$, last accessed on 11 October 2011.

405 European Commission Communication, COM(2007) 248, 16 May 2007, pp. 8-9.

406 Interview with a Commission official, DG DEVCO, European Commission, held on 21 February 2011. 
and development. Migration missions were established to improve the cooperation and foster the dialogue on migration matters with third countries. These missions allow for the relevant stakeholders (Member States, Commission, authorities of the third country) to discuss concrete issues. The negotiations with Cameroon in February 2011, for instance, related to close bilateral relations between Germany and Cameroon as the large majority of Cameroonians in Germany have legal residence and are often highly skilled; topics, such as voluntary return and reintegration, were subject to discussion. The Member States offered support in view of checking biometrical passports that the Cameroonian authorities introduced but for which they lacked the proper reading machines. ${ }^{408}$ Migration profiles drafted by the Commission and the relevant country should provide specific information on the labour market situation of a country, the unemployment rate, migration flows, labour demand and supply, as well as skill shortages. They should also give an overview of the political and legal frameworks in place. ${ }^{409}$ Migration support teams consist of experts from EU Member States who provide technical and financial assistance to a third country to enhance capacity building and to address the root causes of migration flows. Another initiative pursued relates to cooperation platforms on migration and development; they are communication channels, which bring together migration and development actors in a country or a region, to manage migration more effectively. Such a platform was established in Ethiopia in 2007.410 The 2007 EU Africa-Strategy "partnership on migration, mobility and employment" provides a framework of collaboration with African countries, while existing cooperation mechanisms and mobility partnerships are used in relation to Eastern Europe, Africa and Asia. Furthermore, the Commission promoted action to strengthen policy coherence for development in relation to the migration-development-nexus, to foster support activities by migrant and diaspora organisations and to reduce the transfer costs of remittances. ${ }^{411}$ In the course of reorganisation, DG DEVELOPMENT merged with DG AIDCO, the EuropeAid cooperation office, into DG DEVCO, where eleven people work on migration issues. According to a Commission official of DG DEVCO, the three dimensions of the Global Approach to Migration should be complemented by a fourth dimension that deals with migrants' rights. ${ }^{412}$ This materialised in November 2011, although differently than anticipated, when the Commission published a Communication on the new Global Approach to Migration - the GAMM - that integrates the human rights of migrants as a cross-cutting issue. ${ }^{413}$ charge of the Global Approach to Migration under the Hungarian Presidency in the first half of 2011, held on 16 February 2011. European Commission Communications, $\operatorname{COM}(2007)$ 247, 16 May 2007, p. 19; $\operatorname{COM}(2006) 735,30$ November 2006, p. 6.

410 See website of DG HOME, European Commission, available at: $<$ http://ec.europa.eu/home-affairs/policies/immigration/immigration_relations_en.htm>, last accessed on 11 October 2011.

411 European Commission Communication, $\operatorname{COM}(2008)$ 611, 8 December 2008, pp. 7-8.

412 Interview with a Commission official, DG DEVCO, European Commission, held on 21 February 2011

413 European Commission Communication, COM(2011) 743, 18 November 2011. 


\subsubsection{The Global Approach and Mobility Partnerships Reviewed}

The Global Approach to Migration has been defined as the external dimension of the EU's migration policy based on genuine partnership with third countries, balanced in nature and fully incorporated into the EU's other external policies. ${ }^{414}$ However, an examination of the Global Approach reveals certain "imbalances" as regards its structure, content and implementation. There is evidence that the EU prioritises the fight against irregular migration in comparison to policy and law-making under the other two dimensions of the Global Approach. This might not come as a surprise taking into account that that it was DG HOME that initiated the Global Approach to Migration. "Cooperation" and "genuine partnership" with countries of origin and transit seems to translate into to a give-and-take approach, a trade-off, where enhanced legal migration opportunities are offered in return for stricter border control and a more rigorous fight in view of undocumented migrants. This standpoint has been confirmed by both representatives of the Member States' authorities and academics. ${ }^{415}$ While it was emphasised that "the coherent and consequent application of all dimensions" is said to be of vital importance for a comprehensive approach to migration, leading to the assurance of the interests of the $\mathrm{EU}$ and of the third countries, it must not be forgotten that it was the EU that launched the Global Approach, and that it is the EU that has dominated the negotiations with third countries. ${ }^{416}$ Clearly, the economic downturn has triggered a more restrictive attitude towards immigration on the side of the Member States as higher unemployment rates have led to the protection of the labour market. ${ }^{417}$ Already with the building of the area of freedom, security and justice, introduced by the Treaty of Amsterdam, by far the most legislative proposals were made in the field of irregular migration, including border control, visa and return policy and agreement among Member States in this policy field was reached noticeably faster than in other areas. This trend is not only attested by the number of the documents adopted by the Justice and Home Affairs Council, but the incremental coupling of EU visa facilitation and readmission agreements as a "package" from 2002 onwards has confirmed the eagerness with which the EU and its Member States try to combat undocumented migration. ${ }^{418}$ The Global Approach continues with this disequilibrium and the selective form of cooperation is telling: mobility partnerships, the "most innovative and sophisticated tool of the Global Approach" according to the Commission, are mere political declarations and not legally binding; their nature

414 European Commission Communication, COM(2008) 611, 8 October 2008, p. 2.

415 This view was explicitly confirmed by staff of the Permanent Representations of the Netherlands, Germany and Hungary to the EU, interviewed on 24 January 2011, 2 February 2011 and 21 February 2011; E. Collett, 'The 'Global Approach to Migration': Rhetoric or Reality?', European Policy Centre (2007); P. Devisscher, 'Legal Migration in the Relationship between the European Union and ACP Countries: The Absence of a True Global Approach Continues', 13 European Journal of Migration and Law (2011), 53.

416 A. Weinar, 'EU Cooperation Challenges in External Migration Policy', Research Report European University Institute and Migration Policy Institute (2011), p. 15.

417 Interviews with officials of the Permanent Representation of Hungary to the EU under the Hungarian Presidency in the first half of 2011, held on 5 February 2011 and 16 February 2011.

418 F. Trauner and I. Kruse, 'EC Visa Facilitation and Readmission Agreements: A New Standard EU Foreign Policy Tool?', 10 European Journal of Migration and Law (2008), 411, pp. 414-415. 
provides Member States with the flexibility to make commitments to secure foreign affairs interests and aims at action on a bilateral level with specific countries, for which they cannot be held accountable from a legal point of view as the jurisdiction of the Court of Justice is excluded. While the Commission is involved in the initiation and the negotiations of the mobility partnerships, the EP has no say in the drafting and designing of the latter instruments. ${ }^{419}$ The eligibility criteria of potential candidates for mobility partnerships are rather vague and leave wide scope for discretion; they relate to geographical balance between Eastern Europe and Africa, the importance of migration flows from or through the country to the EU, the readiness to cooperate on readmission and the fight against irregular migration, the interest of EU Member States to cooperate with the country in question and its interest to enter into such a partnership. ${ }^{420}$ It has been pointed out that mobility partnerships are driven by the labour market demands prevailing in the EU Member States; as a result, they are highly selective in respect to the type of workers who are able to benefit from enhanced mobility. Non-EU nationals "are therefore not treated as workers and holders of human rights but rather as financial units (or numbers) at the service of the economic and labour market needs of the states." ${ }^{421}$

Next, one has to bear in mind that it is the Commission and the respective Member State holding the Presidency in the Council which determine the focus of the Global Approach and impel its implementation on the basis of joint efforts. In this regard, it is no secret that the priorities of the Presidencies differ: while Spain encouraged cooperation with its South American partners, Hungary was particularly interested in applying the Global Approach to its Eastern neighbouring countries. It is rather easy to challenge the supposedly global character of the Global Approach, first addressed to African countries and subsequently extended to Eastern and Central European states. The Secretary of the High Level Working Group of Migration and Asylum ascribes the discrepancy that the Global Approach exhibits to the EU's varying competences concerning the three dimensions of the Global Approach. The control and containment of unauthorised migrants is indeed a subject-matter on which the Member States easily agree. This is reflected in the Treaty of Lisbon that endowed the EU with the explicit power to conclude readmission agreements with third countries under Article 79(3) TFEU and for which the Commission holds the negotiating mandate. Contrarily, the area of legal migration is still a very sensitive issue for the Member States, in which they have preserved their right to determine the volumes of admission of third-country nationals for the purposes of labour (Article 79(5) TFEU). This legal setting limits the room for manoeuvre in shaping the Global Approach. ${ }^{422}$ On the other hand, border control, readmission and return have now become part of a broader migration agenda and are tabled in the EU's external

419 See N. Reslow, 'Deciding on EU External Migration Policy: The Member States and the Mobility Partnerships', Journal of European Integration (2011), 1; the author drafts a dissertation on mobility partnerships at the Faculty of Arts and Social Sciences of Maastricht University.

420 European Commission Staff Working Document, SEC(2009) 1240, 18 September 2009 , p. 3.

421 S. Carrera and R. Hernández i Sagrera, 'The Externalisation of the EU's Labour Immigration - Towards Mobility or Insecurity Partnerships?', Centre for European Policy Studies Working Document (2009), p. 34.

422 Interview with the Secretary of the High Level Working Group of Migration and Asylum, General Secretariat of the EU Council, held on 16 February 2011. 
relations as the cooperation of third countries has been acknowledged as being indispensable for "successful" policies. As regards migration and development, the Global Approach does not have much to offer in terms of legally binding commitments; it is rather a grey area of initiatives and programmes, such as the migration missions and the "pick and choose" toolbox of mobility partnerships. The much-discussed concept of circular migration has, at the moment, more of a theoretical nature as its implementation requires the grant of exit and entry visas, which lies at the discretion of the Member States. The enhanced engagement of diaspora communities, as well as the easier and cheaper transfer of remittances, were said to be policy goals which neither entail tangible results nor legally enforceable obligations on behalf of the Member States. ${ }^{423}$ The proposal to integrate migrants' rights as an autonomous pillar under the Global Approach is a step in the right direction, as a rights-based approach to human mobility puts migrants back at the centre of the migration process. The migration-development-nexus has been criticised as shifting the main development responsibility from the country of origin to migrant communities abroad which are expected to selflessly step up as "development agents". ${ }^{24}$ This thinking that attributes immigrant communities a key role in "making migration work for development", without guaranteeing their protection is unrealistic and ignorant. A sound legal status that protects, empowers and enables migrants to contribute in various ways to the development of their home country is an indispensable element of a successful migration and development agenda. ${ }^{425}$

The question arises as to what added value the Global Approach actually implicates and in which respects it is more than policy rhetoric. It has been pointed out that the Global Approach must be understood as a strategic and policy-oriented concept that sets out a global vision. More importantly, it brings together the state parties concerned and provides third countries with ownership; for example, from the start Moldova expressed its interest in enhancing return migration and did not favour legal migration opportunities so much; still, a common visa office was opened in Chisinau in April of 2007.426 Thus, the Global Approach is said to be an umbrella term aiming at providing a comprehensive framework for policy action. ${ }^{427}$ The EU's keen interest in stipulating readmission obligations is evidenced by its efforts to conclude readmission agreements with major source countries, although transit countries also show interest in the latter agreements - a fact which is generally not known to the public. Next, readmission is endeavoured within the scope of association and

423 Interview with the Secretary of the High Level Working Group of Migration and Asylum, General Secretariat of the EU Council, held on 16 February 2011.

424 As pointed out by V. Chetail, 'Paradigm and Paradox of the Migration-Development Nexus: The New Border for North-South Dialogue', 52 German Yearbook of International Law (2008), 183, p. 213. 425 K. Eisele, 'Reinforcing Migrants' Rights? The EU's Migration and Development Policy
under Review', 5 Global Justice Network Journal: Special Issue on Global Justice and Migration (2012), 31, p. 44.

426 Interview with a Commission official, DG HOME, European Commission, held on 21 February 2011.

427 The German and Dutch translations emphasise the comprehensiveness of the Global Approach ("Gesamtansatz"; "algehele aanpak") as pointed out by an official of the Permanent Representation of the Netherlands to the EU, interviewed on 21 February 2011. 
cooperation agreements, in which the readmission clause is since 1999 a permanent feature. As a general rule, visa facilitation is offered as an incentive in the home affairs negotiations of such agreements seeing that each department of the Commission bargains its own chapter with the third country in question and tradeoffs between the various chapters is not desired.428 Despite contrary affirmations, migration control and containment has top priority from the side of the EU. In recent times, border control measures appear to be favoured over the root causes approach, which involves a long-term process that is difficult or even to be measured. By contrast, the investment in border control provides clearer results in a specified time frame. Such investment has been increased considerably: the draft budget of FRONTEX, the European border agency, amounted to about $€ 6$ million in 2005 , while the 2009 draft budget added up to $€ 83$ million.

\subsection{The European Pact on Immigration and Asylum}

The European Pact on Immigration and Asylum, which was proposed by the French Presidency in July 2008 and adopted by the European Council two months later, centres on five integral commitments. These include measures to manage legal migration subject to the needs of the Member States and to promote integration and with regard to irregular migration to ensure return. Furthermore, a common European asylum system is envisaged, as well as instruments guaranteeing effective border control. Finally, the Pact provides for the setup of cooperation mechanisms with third countries to enhance synergies between migration and development. ${ }^{429}$ The priorities correspond to the foundations of a common immigration policy set out in a Commission Communication of December 2007.430 The Pact has triggered major outcries among various stakeholders. Academics have pointed out that the document is strongly influenced by conservative French immigration rules, that it promoted the idea of "selective immigration" and that it confirmed the position of Member States instead of cultivating a coherent European immigration and asylum policy. ${ }^{431}$ Another shortcoming was identified despite its revision by some Member States. Notwithstanding the differentiation between migrant groups, the Pact speaks of third-country nationals as if they were a uniform and homogenous group disregarding possible positive effects, such as cultural enrichment and diversity in the receiving country, which come along with migration. ${ }^{432}$ The Commission put forward a tracking method in June 2009 with a view to monitor the transposition of commitments as laid down in the Pact. This tracking method includes an annual report of the Commission on the main action taken and significant developments planned on the basis of the Pact and from 2011, also on the basis of the Stockholm

Interview with a Commission official, DG HOME, European Commission, held on 21 February 2011.

429 Council of the European Union, "European Pact on Immigration and Asylum", document number 13440/08 of 24 September 2008.

430 European Commission Communication, COM(2007) 780, 5 December 2007.

431 S. Carrera and others, 'The French Presidency's European Pact on Immigration and Asylum: Intergovernmentalism vs. Europeanisation? Security vs. Rights?', CEPS Policy Brief No 170 (2008), pp. 4-7.

432 E. Collett, 'The EU Immigration Pact - from Hague to Stockholm, via Paris', EPC Policy Brief (2008), p. 3. 
Programme. The Commission generated the information processed in the annual report itself, or Member States transmitted the required data. ${ }^{433}$

\subsection{The 2004 and 2007 Enlargements}

The biggest enlargement in EU history took place on 1 May 2004 when ten countries, including Hungary, Poland, Estonia, the Czech Republic, Slovenia, Slovakia, Latvia, Lithuania, as well as Malta and Cyprus, acceded to the Union expanding the EU-15 to an EU-25. The inclusion of new Member States located in Central and Eastern Europe was prepared on the basis of the Europe Agreements. Malta's relations with the Community date back to the 1971 EEC-Malta Association Agreement, while Cyprus concluded such a Community agreement two years later in 1973.434 Bulgaria and Romania became fully-fledged EU Member States on 1 January 2007; their previous EU relations were governed by 1994 Europe Agreements.

\subsection{The Discrimination of EU Citizens based on Transitional Arrangements}

Under specific transitional arrangements, nationals of most of the Member States that joined the EU in 2004 and 2007, respectively, have been confronted with more restrictive movement rules than under the previous Europe Agreements. ${ }^{435}$ This paradox, which puts certain EU citizens in a worse position than they enjoyed before the EU accession, is based on a stand-still obligation contained in the country annex in the accession treaties that arguably only relates to national market access restrictions not to Community law, including the Europe Agreements. ${ }^{436}$ For eight out of the ten countries having acceded in 2004, the Act of Accession contained provisions on permanent safeguard measures. ${ }^{437}$ These provisions provide a system to adopt protective measures if serious and persistent difficulties arise for the economy of a Member State. Almost all EU-15 Member States made use of the possibility to establish labour market restrictions, with the exception of the UK, Ireland and Sweden. The transitional periods have affected workers and service providers and severely restricted their rights to move and reside in the EU made up of the "old" Member States. The transitional movement regime is divided into three

433 European Commission Communication, COM(2009) 266, 10 June 2009.

434 Agreement establishing an Association between the European Economic Community and Malta, OJ L 61, 14 March 1971, p. 2; Agreement establishing an Association between the European Economic Community and the Republic of Cyprus, OJ L 133, 21 May 1973, p. 2.

435 Transitional rules were applied, until 1 May 2011, to nationals of the eight Central and Eastern European Member States that acceded to the EUin 2004; transitional arrangements are still in place for nationals of Bulgaria and Romania.

436 A. Ott, 'Grundfreiheiten', in: F. Merli and S. Huster (eds.), Die Verträge zur EUOsterweiterung - Kommentar mit systematischen Erläuterungen (Berliner Wissenschaftsverlag, Berlin 2008), paras. 65-67; K. Inglis, 'Treading the Tightrope between Flexibility and Legal Certainty', in: D. Hanf and R. Muñoz (eds.), La libre circulation des personnes - États des lieux et perspectives (Cahiers du Collège d'Europe, Bruxelles 2007), pp. 108-110.

Arts. 37-39 of the Act Concerning the Conditions of Accession of the Czech Republic, the Republic of Estonia, the Republic of Cyprus, the Republic of Latvia, the Republic of Lithuania, the Republic of Hungary, the Republic of Malta, the Republic of Poland, the Republic of Slovenia and the Slovak Republic and the Adjustments to the Treaties on which the European Union is founded, OJ L 236, 23 September 2003, p. 33. 
phases $(2+3+2$ years) and may possibly last up to seven years in total depending on the labour market situation of the respective Member State. S. Carrera highlighted that this detrimental treatment is not only inconsistent with the principle of equality, creating "second-class" EU citizens but also contrary to the spirit of the Court's case law on free movement of persons (which is not applicable to the transitional arrangements), stipulating that all EU nationals are subject to the same treatment in law, as well as conflicting with the case law on equal treatment within the scope of the Europe Agreements. 438

\section{AND BEYOND: THE TREATY OF LisBON}

The Treaty of Lisbon, signed on 13 December 2007 and entered into force on 1 December 2009, comprises the amended TEU and the Treaty on the Functioning of the European Union (TFEU) and formally abolished the pillar structure.439 The Treaty of Lisbon brought along important changes, both for the EU external relations' regime and the legal framework for EU migration policy. The new treaty regime created a substantive set of rules for the EU to shape its external relations with third countries, including the establishment of the EEAS, which supports the High Representative of the Union for Foreign Affairs and Security Policy as a diplomatic corps in engaging in the EU's foreign policy. Moreover, newly inserted Title V TFEU put an end to the derogatory character of Title IV of the Treaty of Amsterdam. Importantly, with the entry into force of the Treaty of Lisbon, the EU Charter of Fundamental Rights also became legally binding for the institutions, bodies, offices and agencies of the Union with due regard for the principle of subsidiarity and to the Member States only when they are implementing Union law. 440 The Charter was solemnly proclaimed and signed on 7 December 2000 with the aim to reinforce the fundamental rights' protection in the EU. The Treaty of Lisbon created moreover a legal basis for the EU's accession to the ECHR. ${ }^{441}$

\subsection{EU External Relations under the Lisbon Regime}

The Treaty of Lisbon provided institutional and substantive modifications in view of the EU's external relations regime and took over most of the amendments elaborated in the Constitutional Treaty. These changes are said to be potentially far-reaching, providing the Union with a "more coherent" role as an international actor. ${ }^{442}$ Under

S. Carrera, 'What Does Free Movement Mean in Theory and Practice in an Enlarged EU?', 11 European Law Journal (2005), 699, pp. 706-709.

Treaty on European Union (consolidated version), OJ C 83, 30 March 2010, p. 13; Treaty on the Functioning of the European Union (consolidated version), OJ C 83, 30 March 2010, p. 47; see Art. 1 TEU.

Charter of Fundamental Rights of the European Union, OJ C 83, 30 March 2010, p. 389; see Art. 6(1) TEU and Art. 51(1) of the EU Charter.

New Art. 6(2) TEU; on the interaction between the Court's rulings and the Strasbouro case law, see J.L. Murray, 'Fundamental Rights in the European Community Legal Order', 32 Fordham International Law Journal (2008), 531, pp. 537 et seq.

S. Duke, 'The Treaty of Lisbon and External Relations', EIPASCOPE (2008), 13, For an overview see also J. Wouters, D. Coppens and B. De Meester, 'The European Union's External Relations after the Treaty of Lisbon', in: S. Griller and J. Ziller (eds.), 
the Treaty of Lisbon, the Union has legal personality as laid down in Article 47 TEU, which has to be interpreted as international legal capacity in line with the ERTA decision. ${ }^{443} \mathrm{~A}$ further institutional amendment concerns the creation of the position of the High Representative of the Union for Foreign Affairs and Security Policy, which is supported by the newly established EEAS. The aims of the EU external relations are defined in Article 3(5) TEU: "In its relations with the wider world, the Union shall uphold and promote its values and interests and contribute to the protection of its citizens. It shall contribute to peace, security, the sustainable development of the Earth, solidarity and mutual respect among peoples, free and fair trade, eradication of poverty and the protection of human rights, in particular the rights of the child, as well as to the strict observance and the development of international law, including respect for the principles of the United Nations Charter."

It is further stipulated in Article 21(1) TEU that "the Union's action on the international scene shall be guided by the principles which have inspired its own creation, development and enlargement and which it seeks to advance in the wider world: democracy, the rule of law, the universality and indivisibility of human rights and fundamental freedoms, respect for human dignity, the principles of equality and solidarity and respect for the principles of the United Nations Charter and international law. The Union shall seek to develop relations and build partnerships with third countries and international, regional or global organisations which share the principles referred to in the first subparagraph. It shall promote multilateral solutions to common problems, in particular in the framework of the United Nations."

The Union shall ensure consistency between the different areas of its external relations and between these and its other policies. ${ }^{444}$ Title V TEU sets out the general provision the external action of the Union as well as specific provisions on the CFSP, while Part V of the TFEU specifies the Union's external actions. These cover a chapter on development cooperation, a chapter on economic, financial and technical cooperation with third countries and a chapter on humanitarian aid. Articles 216 to 219 TFEU are concerned with the conclusion of international agreements. Article 8 TEU identifies a special relationship with neighbouring countries. The rules on association of the overseas countries and territories are provided in Article 198 TFEU and general association is determined in Article 217 TFEU and the subsequent provisions.

\subsubsection{Union Competences}

Article 2 TFEU expressly distinguishes the different types of competences, which are specified in the following provisions. When the Treaties confer exclusive competence on the Union, only the Union may legislate and adopt legally binding acts. When the

The Treaty of Lisbon: EU Constitutionalism without a Constitutional Treaty? (Springer Verlag, Wien 2008), pp. 143-189. 
Treaties confer shared competences on the Union, the latter and the Member States act jointly; the Member States shall exercise their competence to the extent that the Union has not exercised its competence. ${ }^{445}$ The Union has the competence to define and implement a common foreign and security policy. ${ }^{446}$

According to Article 3 TFEU, the Union holds exclusive powers with regard to the customs union; the establishing of the competition rules necessary for the functioning of the internal market; monetary policy for the Member States whose currency is the euro; the conservation of marine biological resources under the common fisheries policy; and the Common Commercial Policy (Article 3(1) TFEU). Also, the Union is exclusively competent to conclude an international agreement when its conclusion is provided for in a legislative act of the Union or is necessary to enable the Union to exercise its internal competence, or in so far as its conclusion may affect common rules or alter their scope as stipulated in Article 3(2) TFEU. The "a priori exclusivity" in the first paragraph has to be distinguished from the preemption principle, which is usually applicable in respect to shared powers but is now included in the second paragraph of Article 3 TFEU. As a result, M. Cremona argued that the two different concepts of "a priori exclusivity" and "pre-emption exclusivity", respectively, are mixed up and, moreover, it "conflates the two separate questions of the existence of implied external competence and the exclusivity of that competence". ${ }^{447}$ In addition to this, Article 3(2) TFEU does not refer to Article 216(1) TFEU, which enshrines the general treaty-making powers of the Union, even though a link seems clearly present. Instead, the similarly-worded provisions lay down that the Union's implied treaty-making power is exclusive in nature; implied shared competence would thus disappear - a stance that runs counter to the mainstream of ECJ case law. ${ }^{448}$

P. Eeckhout described the wording and interrelationship of the two provisions as "somewhat puzzling". ${ }^{49}$ In his view Article 3(2) TFEU deals with exclusive competence, while Article 216(1) TFEU "addresses, one assumes, both shared and exclusive competence." The author specifies that for Union competence to be exclusive there must be (a) a legislative act setting out the conclusion of an agreement and not just a legally binding act; and (b) the agreement at hand must be necessary to enable the Union to exercise its internal competence and not just a Union objective. Next, it is sufficient for exclusive competence to be present for an agreement if its conclusion may affect common rules or alter their scope. P. Eeckhout underscored that one should not pay to much attention to the formulation of the provisions, however, considering they were taken over from the Constitutional Treaty, the drafters of which aims at codifying established principles of the Court's case law. 450 The phrasing of Article 216(1) TFEU was also criticised as the potential competence

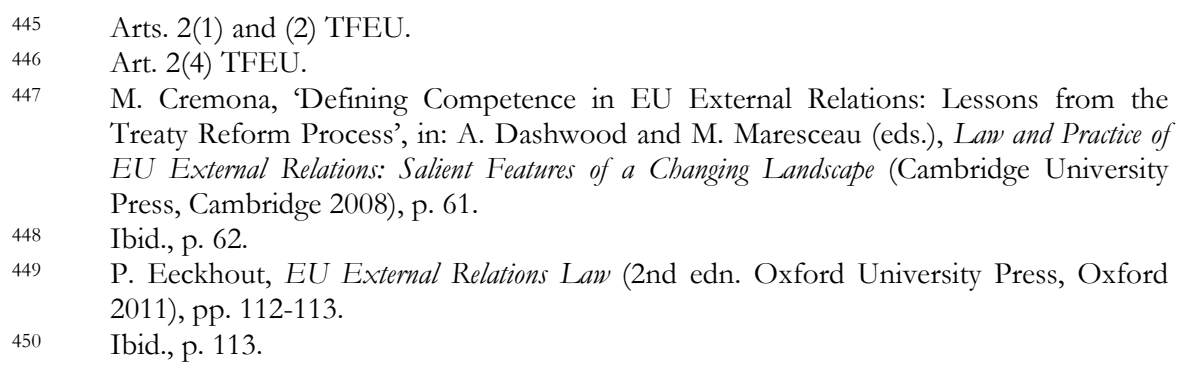


to conclude international agreements does not cover the whole field of objectives defined in Part One of the (then) EEC Treaty, in conformity with the ERTA judgment. ${ }^{451}$ Another remark by P.J. Kuijper related to the fact that the Treaty of Lisbon does not prevent the parallel conclusion of treaties regarding the same subject-matters by the Union on the one hand and the Member States on the other. This could, in particular, seriously undercut efforts at the EU level in the area of justice and home affairs, for instance, if Member States conclude readmission agreements at the national level with third countries. ${ }^{452}$

The principal areas in which competences are shared between the Union and the Member States are listed in Article 4(2) TFEU. Article 6 TFEU lays down that the Union has the power to carry out actions to support, coordinate or supplement the actions of the Member States at the European level, including the protection and improvement of human health, industry, culture, tourism, education, vocational training, youth and sport, civil protection and administrative cooperation.

The difficulties which related to the determination of the correct legal base within the scope of the EC Treaty on the one side and between the pillars on the other side, were not solved by the Treaty of Lisbon. The appropriate legal basis has however "constitutional significance", as held by the Court in Opinion 2/00.453 The boundaries of the Community competences and the EU competences were previously regulated by old Article 47 TEU that aimed to protect the acquis communantaire. The Court ruled in a number of judgments on the interrelationship between the first and third pillar. ${ }^{454}$ With its ruling in Small Arms and Light Weapons (ECOWAS) the Court first provided clarification on the division of competences between the first and the second pillar. ${ }^{455}$ The case concerned a joint action adopted by the Council on combating the accumulation and spread of small arms and light weapons under the CFSP. ${ }^{456}$ Consequently, the Council transposed this joint action by virtue of a decision setting out the EU's financial contribution to the Economic Community of West African States (ECOWAS) to support the latter's efforts to implement a UN moratorium on small arms and light weapons. The Commission was of the view that the legal measure should have been taken under the first pillar, namely Article 179 EC concerning development cooperation and brought an action for annulment; the Court agreed that old Article 47 TEU had been violated. P. Eeckhout stressed three principles which the case manifested: first, old Article 47 TEU protected all Community competences, exclusive and shared and such specific Community competences prevail over CFSP powers; second, the demarcation of the competences

451 P.J. Kuijper, Of 'Mixity' and 'Double-hatting': EU External Relations Law Explained (Vossiuspers UvA, Amsterdam 2008), p. 16.

452 Ibid., pp. 15-16; see also Declaration 36 to the Treaty of Lisbon.

453 Opinion 2/00 Cartagena Protocol [2001] ECR I-9713, para. 5.

454 See Case C-170/96 Commission v. Council (Airport Transit Visas) [1998] ECR I-2763; Case C-176/03 Commission v. Council (Environmental Criminal Law) [2005] ECRI-7879; Case C440/05 Commission v. Council (Ship-Source Pollution) [2007] ECR I-9097; R. van Ooik, 'Cross-Pillar Litigation before the ECJ: Demarcation of Community and Union Competences', 4 European Constitutional Law Review (2008), 399, pp. 400-402.

455 Case C-91/05 Small Arms and Light Weapons (ECOW AS) [2008] ECR I-3651.

456 Joint Action 2002/589/CFSP of 12 July 2002 with a view to a European Union contribution to the destruction of ammunition for small arms and light weapons in Albania. 
at hand had to be determined on the basis of the main purpose or element of the respective instrument; and third, the Court denied recourse to a dual legal basis in that case, as opposed to other external competences. ${ }^{457}$

The distinction between CFSP competence and Community external competence was maintained in the Lisbon framework as the decision-making is still particular and the Court's jurisdiction largely limited; yet still notable amendments were made. New Article 40 TEU sets the dividing line stating that neither the CFSP nor the external Union policies shall affect each other. In this respect, new Article 40 TEU amended the old version of Article 47 TEU in that it safeguards CFSP from external Union policy and vice versa. It has been argued that this provision focuses more on the procedures than the separation of competences. ${ }^{458}$ However, the CFSP is still not defined more clearly in the Treaty of Lisbon. Moreover, it is questionable whether the interdependency, introduced by current Article 40 TEU, provides for a more balanced approach than under the Court's principle of delimitation established in ECOWAS that concentrated on the main purpose of a measure. The overall objectives of EU external action, as well as the broad CFSP objectives identified in Article 21(2)(c) TEU, do not render making a demarcation easier. As regards the content, in two provisions, the Treaty of Lisbon provides the same rule stating that "the adoption of legislative acts shall be excluded." 459 This rule was deemed to be bewildering; it was suggested that it has been inserted to clarify that the limited judicial review is not contrary to the democratic principles upon which the Union is built. ${ }^{460}$

\subsubsection{The Conclusion of International Agreements}

The EU's treaty-making powers are broad, as confirmed under the Treaty of Lisbon; already in 1975 the Court found that the term "agreement" in Article 218 TFEU (former Article $300 \mathrm{EC}$ ) is to be interpreted in an extensive manner meaning "any undertaking entered into by entities subject to international law which has binding force, whatever its formal designation". 461 Article 218 TFEU defines the general decision-making procedure for the conclusion of an international agreement. In line with Article 218 TFEU, the Council authorises the opening of negotiations, adopts negotiating directives and authorises the conclusion of an international agreement upon the recommendations of the Commission or the High Representative for Foreign Affairs and Security Policy where the envisaged agreement relates to the CFSP. The Council nominates the Union negotiator to which it may address

\footnotetext{
457 P. Eeckhout, EU External Relations Law (2nd edn. Oxford University Press, Oxford 2011), pp. 179-180.

458 M. Cremona, 'Defining Competence in EU External Relations: Lessons from the Treaty Reform Process', in: A. Dashwood and M. Maresceau (eds.), Law and Practice of EU External Relations: Salient Features of a Changing Landscape (Cambridge University Press, Cambridge 2008), pp. 38-46.

459 Arts. 24(1) and 31(1) TEU.

460 P. Eeckhout, EU External Relations Law (2nd edn. Oxford University Press, Oxford 2011), pp. 182-184.

461 Opinion 1/75 Understanding on a Local Cost Standard [1975] ECR 1355; see also K. Lenaerts and E. De Smijter, 'The European Community's Treaty-Making Competence', 16 Yearbook of European Law (1996), 1.
} 
directives. On a proposal by the negotiator, the Council adopts a decision on the signature of the agreement in question and adopts a second decision on the conclusion of the agreement. Except where agreements relate exclusively to the common foreign and security policy, the Council shall adopt the decision concluding the agreement

- after obtaining the consent of the EP as regards:

- association agreements;

- agreement on the EU accession to the ECHR;

- agreements establishing a specific institutional framework by organising cooperation procedures;

- agreements with important budgetary implications for the EU;

- agreements covering fields to which either the ordinary legislative procedure applies or the special legislative procedure where consent by the European Parliament is required.

- after consulting the EP in other cases. ${ }^{462}$

In principle, the Council acts by a qualified majority throughout the procedure, however it acts unanimously for association agreements, agreements under Article 212 TFEU, the agreement on the EU accession to the ECHR, as well as agreements that cover a field for which unanimity is required for the adoption of a Union act. ${ }^{463}$ The Council, moreover, has the competence to suspend the application of an agreement as laid down in Article 218(9) TFEU. A special procedure to obtain the Court's opinion on the compatibility of an envisaged agreement with the Treaty is set out in Article 218(11) TFEU; such a request can be submitted by an EU institution, or a Member State. The EP is to be fully and immediately informed about all stages of the procedure.

\subsubsection{The CFSP, the High Representative and the EEAS}

The Treaty of Lisbon clarified the Union's legal personality and confirmed the pursuit of unity and consistency in the Union's external action. ${ }^{464}$ The post of the High Representative of the Union for Foreign Affairs and Security Policy and the establishment of the EEAS provided the Union with a new institutional structure in this regard. Nonetheless, the Treaty of Lisbon preserved the intergovernmental features giving the Council broad leeway in decision-making and restricting the scope of action for the Commission, the EP and the Court. Article 2(4) states that the Union is competent, in accordance with the TEU, to define and implement a common foreign security policy; thus, "the EU's CFSP competence is neither exclusive nor shared, but rather in an undefined category of its own." Hence, it was assumed that the CFSP was expressly not categorised as shared so as to prevent a pre-emptive effect. ${ }^{465}$ In line with Article 24(1) TEU, the Union's competence in

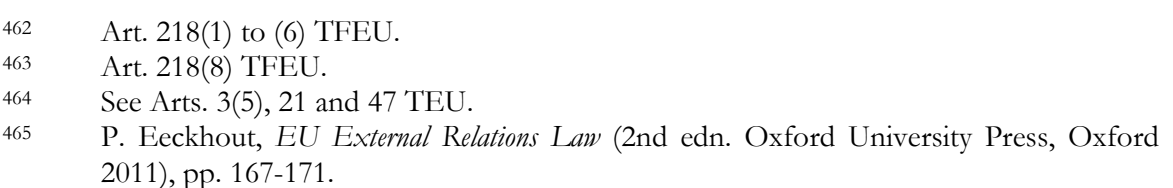


matters of common foreign and security policy shall cover all areas of foreign policy and all questions relating to the Union's security, including the progressive framing of a common defence policy that might lead to a common defence. The Member States are under the obligation to support the Union's external and security policy actively and unreservedly in a spirit of loyalty and mutual solidarity and to comply with the Union's action in this area. ${ }^{466}$ In addition to that, decisions taken by the Council on the basis of Article 28(1) TEU commit the Member States in their positions and activities and consultation with the Council and the European Council shall take place on any matter of foreign and security policy of general interest in order to determine a common approach. ${ }^{467}$

The specification that the Union's common foreign and security policy covers all areas of foreign policy and all questions relating to the Union's security reflects considerable room for manoeuvre in foreign policy issues which are not further defined in the Treaties. In comparison, the security and defence policy is framed in detail under Section 2 of the Chapter on the CFSP in the TEU; the security and defence policy shall provide the Union with an operational capacity, drawing on civilian and military assets which may be used on missions outside the Union for peace-keeping, conflict prevention and strengthening of international security consistent with the UN Charter. ${ }^{468}$ It was pointed out that the Lisbon framework changed the former CFSP objectives in old Article 11(1) TEU by setting out the Union's overall external action aims in Article 21(1) TFEU.469

The CFSP instruments are laid down in Article 25 TEU comprising general guidelines, decisions and systematic cooperation between the Member States. It is the European Council that defines the general guidelines, identifies the Union's strategic interests and determines the objectives of the common foreign and security policy. 470 This task refined former common strategies (abolished with the Treaty of Lisbon) considering that these decisions on the Union's strategic interests and objectives extend the entire width of EU external action, including CFSP. ${ }^{471}$ Although the former CFSP instruments of joint actions and common positions are now replaced by decisions under the Treaty of Lisbon, the differentiation is still upheld in that a decision can still define both positions and actions. ${ }^{472}$ Article 28(1) TEU determines that the Council shall adopt the necessary decisions when "the international situation requires operational action by the Union"; Article 29 specifies the Council's competence to adopt decisions defining the Union's approach to a particular matter of a geographical or thematic nature. The legal nature and effects of decisions providing either for actions or positions remains unclear. ${ }^{473}$ Decisions are, as a general rule, taken by the European Council and the Council acting unanimously except where provided for otherwise. Such an exception relates inter alia to a decision

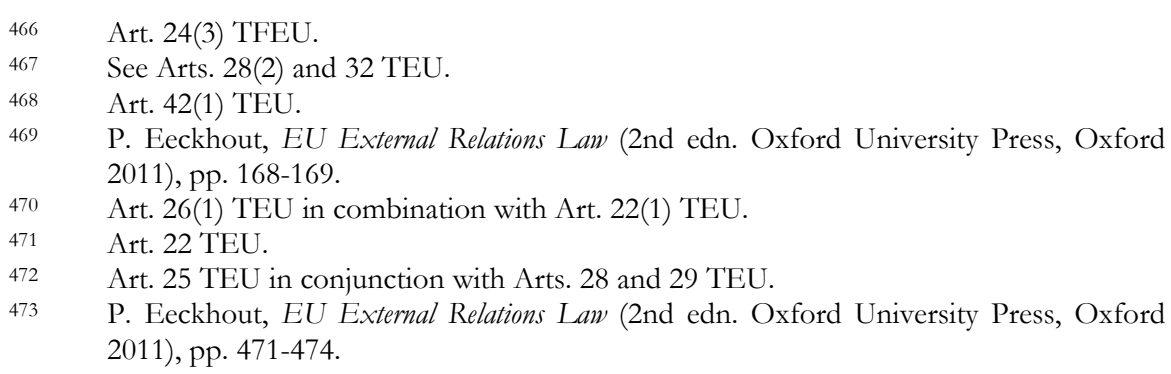


defining a Union action or position on the basis of a decision of the European Council concerning the Union's strategic interests and objective as set out in Article 22(1) TEU.474

The Treaty of Lisbon created the office of the High Representative of the Union for Foreign Affairs and Security Policy who also holds the vice-presidency of the Commission with a view to ensuring coherent and efficient action in the EU's external relations. The position of the High Representative of the Union is equipped with more far-reaching competences than its predecessor under the Treaty of Amsterdam. The High Representative conducts the Union's common foreign and security policy, as well as the common security and defence policy, assisted by a foreign service, the EEAS. 475 Subsequently, the High Representative has to reconcile on the one hand the interests of the Council, which seem to take priority according to Article 18(4) TEU, with the concerns of the Commission on the other. In addition to that, the High Representative has to collaborate with the President of the European Council (Article 15(6) TEU) and cooperate with the President of the Commission for practical reasons. It remains to be seen how this "super-Minister of Strategic and Foreign Relations" can master these demanding tasks. ${ }^{476}$ The role of the High Representative has been called "double-hatted" in the sense that she or he will hold the combined position of the former High Representative and the former Commissioner for External Relations. ${ }^{477}$ The High Representative makes proposals for the development of the CFSP and the common security and defence policy and carries them out as mandated by the Council. ${ }^{478}$ The tasks of proposing and implementing EU external action is supplemented by a supervisory function: the High Representative shall ensure the implementation of the decisions adopted by the European Council and the Council. ${ }^{479}$ The High Representative, together with the Commission, ensures compliance with the principles of loyalty and mutual solidarity which the Member States have to observe and is in charge of supervising special representatives. ${ }^{480}$ The High Representative represents the Union in matters relating to the CFSP, conducts political dialogue with third parties on the Union's behalf and has the challenging responsibility, if not the mammoth task, to ensure the consistency of the Union's external action. ${ }^{481}$

The EEAS shall assist the High Representative as the diplomatic service of the Union. The EEAS shall cooperate with the diplomatic services of the Member States and comprise officials from relevant departments of the General Secretariat of the Council and of the Commission as well as staff seconded from national diplomatic

\footnotetext{
$474 \quad$ Art. 31(1) TEU.

475 Arts. 18 and 27(3) TEU.

476 P.J. Kuijper, Of 'Mixity' and 'Double-hatting': EU External Relations Law Explained (Vossiuspers UvA, Amsterdam 2008), pp. 14-15.

477 C. Kaddous, 'Role and Position of the High Representative of the Union for Foreign Affairs and Security Policy under the Treaty of Lisbon', in: S. Griller and J. Ziller (eds.), The Treaty of Lisbon: EU Constitutionalism without a Constitutional Treaty? (Springer Verlag, Wien 2008), p. 209.

478 Arts. 18(2), 24(1) and 26(3) TEU.

479 Art. 27(1) TEU.

480 Arts. 24(3) and 33 TEU.

481 Art. 18(4) TEU.
} 
services of the Member States. ${ }^{482}$ The Council called the EEAS into being by adopting a decision in July of $2010 .{ }^{483}$ In accordance with this decision, the EEAS supports the High Representative in relation to

- matters concerning the CFSP and common security and defence policy;

- his/her capacity as President of the Foreign Affairs Council;

- his/her capacity as Vice-President of the Commission.

The EEAS also assists the President of the European Council, the President of the Commission and the Commission in the exercise of their respective functions in the area of external relations. ${ }^{484}$ The Commission delegations in third countries are gradually transformed into EU delegations under the authority of the High Representative; 485 "it is, however, not clear yet whether they will report to the High Representative through the EEAS." 486 The financing of the EEAS was subject to discussion, considering the composition of the EEAS, and it has been pointed out that "the budgetary question will be one of the most difficult since it poses in a rather stark manner the extent to which the EU Member States wish to be involved in the EEAS and the extent to which it should be susceptible to leverage from the European Parliament." 487 In 2010, the budget lines from the Commission and the Council Secretariat were transferred to the EEAS.488 On 1 January 2011 staff from the Council and the Commission were officially relocated to the EEAS. ${ }^{489}$

\subsection{Title V TFEU: The Current EU Rules on Migration}

The Treaty of Lisbon entailed major changes in the field of justice and home affairs, including migration policy, on the basis of a new Title $\mathrm{V}$ TFEU on the area of freedom, security and justice that incorporated the former third pillar. Title V TFEU sets out general provisions, as well as rules on border checks, asylum, immigration, judicial cooperation in civil and criminal matters, and police cooperation. Title $\mathrm{V}$ TFEU confers the Commission with the exclusive right of legislative initiative. Qualified majority voting is the common voting method in the Council and the codecision making procedure, now labelled as "ordinary legislative procedure", applies in most areas of justice and home affairs. The Court of Justice has received full

Art. 27(3) TEU.

Council Decision 2010/427 of 26 July 2010 establishing the organisation and functioning of the European External Action Service. Art. 2 of Council Decision 2010/427 of 26 July 2010.

On the EU delegations, see Art. 5 of Council Decision 2010/427 of 26 July 2010.

S. Vanhoonacker and N. Reslow, 'The European External Action Service: Living Forwards by Understanding Backwards', 15 European Foreign Affairs Review (2010), 1, pp. 12-13.

S. Duke, 'Providing for European-Level Diplomacy after Lisbon: The Case of the European External Action Service', 4 The Hague Journal of Diplomacy (2009), 211, pp. 229-230.

Europa, press release "EEAS Decision - main elements", MEMO/10/311, of 8 July 2010.

Europa, press release "A new step in the setting-up of the EEAS: Transfer of staff on 1 January 2011”, IP/10/1769, 21 December 2010. 
jurisdiction as regards almost all justice and home affairs issues with exceptions concerning police and criminal law. ${ }^{490}$

Articles 77 to 80 TFEU concern policies on border checks, asylum and immigration; the Union shall develop a common immigration policy. Article 77 TFEU lays down that the Union shall establish an internal/external border control policy by adopting a number of measures such as a common visa policy, external border checks and the conditions under which third-country nationals shall have the freedom to travel within the Union for a short period. The provisions on a common asylum policy are to be found in Article 78 TFEU. Article 79 TFEU forms the new legal basis for adopting measures on legal and irregular migration and on combating human trafficking. The new rule now expressly mentions the objectives of ensuring fair treatment of legally residing third-country nationals, the efficient management of migration flows and the prevention of human trafficking. An explicit competence to conclude readmission agreements with the countries of origin is stipulated in Article 79(3) TFEU. ${ }^{491}$ The EP and the Council may support Member States' action to promote the integration of legally residing third-country nationals, without the harmonisation of the laws and regulations of the Member States. ${ }^{492}$ In Article 79(5) TFEU, the Member States preserved the right to determine the volumes of admission of labour migrants.

\subsection{Visa Policy and the Schengen Area}

The visa-related rules under the Lisbon regime - as described above - have been amended as the EU now has the competence to adopt a common visa policy and other short-stay residence permits. ${ }^{493} \mathrm{Next}$, the EU has the power to stipulate conditions under which third-country nationals shall have the freedom to travel within the Union for a short period - this specification provides the EU with a greater scope of discretion. From 5 April 2010 persons with a long-stay visa also enjoy the freedom to travel within the Schengen area. ${ }^{494}$ Today, the Schengen area consists of 26 states, including 22 EU Member States (except for Ireland and the UK, which to do not take part in the Schengen acquis; as well as Bulgaria, Cyprus and Romania, to which the Schengen acquis has not yet fully been extended), the EEA states Iceland, Norway, Liechtenstein and Switzerland. 495

490 S. Peers, EU Justice and Home Affairs Law (3rd edn. Oxford University Press, Oxford 2011), p. 45.

491 See G. De Baere, 'The Framework of EU External Competences for Developing the External Dimension of the EU Asylum and Migration Policy', 50 Leuven Centre for Global Governance Studies Working Paper (2010), pp. 39-40.

492 Art 79(4) TFEU.

$493 \quad$ Art. $77(2)$ (a) TFEU.

494 Regulation (EU) No 265/2010 of the European Parliament and of the Council of 25 March 2010 amending the Covention Implementing the Schengen Agreement and Regulation (EC) No 562/2006 as regards movement of persons with a long-stay visa.

As of 24 December 2011; see Council of the European Union, "Schengen enlargement: Liechtenstein to become 26th member state" of 13 December 2011, document number: 18446/11; Council Decision of 9 June 2011 on the application of the provisions of the Schengen acquis relating to the Schengen Information System in the Principality of Liechtenstein; Council of the European Union, "Protocol between 


\subsubsection{The Stockholm Programme}

Adopted by the European Council on 11 December 2009, the Stockholm Programme determines the Member States' priorities in the area of freedom, security and justice for the subsequent five years to be implemented under the Treaty of Lisbon. 496 The Commission Communication of June 2009, which intended to put the citizen in the focus of justice and home affairs as the issues covered concerns the daily life of individuals, served as a basis for the drafting of the Stockholm Programme. ${ }^{497}$ Interestingly, the final version of the 2010-2014 justice and home affairs agenda was subject to major amendments in order to lay down the specific interests of the Member States. One such amendment related to the deletion of the immigration code. This code, as stipulated in the draft Stockholm Programme of 16 October 2009, provided for the consolidation of all immigration legislation based on an evaluation of the existing acquis communautaire and possible modifications. ${ }^{498}$

The political priorities of the Stockholm Programme, which are said to centre on Union citizens and other persons for whom the Union has a responsibility, are: promoting citizenship and fundamental rights; a Europe of law and justice; a Europe that protects; access to Europe in a globalised world; a Europe of responsibility, solidarity and partnership in migration and asylum matters; the role of Europe in a globalised world - the external dimension. Thus, in relation to EU migration and asylum policy, the new multiannual strategy purports the idea of "a Europe of responsibility, solidarity and partnership in migration and asylum matters" upon which "a dynamic and comprehensive migration policy" shall be based. The European Council confirms the commitments of the 2008 European Pact on Immigration and Asylum and underscores their implementation. Moreover, the Global Approach to Migration is attributed a major role as it promotes the integration of migration policies into the EU's external relations. According to the European Council, the three dimensions of the Global Approach need to be balanced with a special emphasis on cooperation with countries in Africa and Eastern and South-Eastern Europe. The continued and expanded use of mobility partnerships as the main instrument of the Global Approach is called for. Next to the three dimensions of legal economic migration, migration and development and the fight against irregular migration, the European Council demands proactive policies

the European Union, the European Community, the Swiss Confederation and the Principality of Liechtenstein on the accession of the Principality of Liechtenstein to the Agreement between the European Union, the European Community and the Swiss Confederation on the Swiss Confederation's association with the implementation, application and development of the Schengen acquis" of 13 February 2008, document number: $16462 / 06$.

496 The Stockholm Programme - An Open and Secure Europe Serving and Protecting Citizens, OJ C 115, 4 May 2010, p. 1; see also Council of the European Union, "European Council 10/11 December 2009 Conclusions", document number: EUCO 6/09 of 11 December 2009.

497 European Commission Communication, COM(2009) 262, 10 June 2009.

498 Council of the European Union, "Multiannual Programme for an Area of Freedom, Security and Justice serving the Citizen (The Stockholm Programme)", document number: 14449/09 of 16 October 2009; for a detailed discussion on the immigration code, see S. Peers, 'An EU Immigration Code: Towards a Common Immigration Policy', 14 European Journal of Migration and Law (2012), pp. 33-61. 
for migrants and their rights, successful integration policies and special attention for unaccompanied minors. In general, the European Council stresses the need for a coherent approach between the EU migration policy and other related relevant policies, in particular the migration-development link. The Heads of State and Government reiterate the importance of the external dimension of the Union's justice and home affairs agenda and the objective to build a common EU immigration policy.

The European Parliament commented on the Stockholm Programme in a resolution of 25 November $2009 .{ }^{499}$ In this document, the European Parliament welcomed the adoption of the Treaty of Lisbon as it provides for an improved legislative framework for the area of freedom, security and justice such as the introduction of the ordinary legislative procedure or the extension of the ECJ's jurisdiction. In view of the European delegates, the Programme should specifically address the problems of migration by means of a solidary approach and guarantee a balance in securing the protection of individual rights and security concerns. With regard to migration, the European Parliament takes the stance that the root causes of migration must be tackled and urges the Union to act coherently and to fully respect fundamental rights and the ECHR. The Global Approach to Migration should be designed to improve migration flows and to prevent humanitarian tragedies.500 In light of the accomplishments and the shortcomings of the Hague Programme, scholars formulated recommendations for the subsequent five-year policy agenda before the adoption of the Stockholm Programme. ${ }^{501}$ While the Stockholm Programme does provide for the suggested evaluation mechanism in the area of freedom, security and justice, one searches in vain for the proposed use of monitoring instruments in place to guarantee fundamental rights and the rule of law; merely, the Programme emphasises the respect for fundamental freedoms and the rule of law. In April of 2011, the Commission put forward an action plan on the implementation of the Stockholm Programme. This action plan considers a genuine immigration and asylum policy based on solidarity and responsibility to be fundamental. It is specified that "robust defence of migrants' fundamental rights out of respect for our values of human dignity and solidarity will enable them to contribute fully to the European economy and society. Immigration has a valuable source to play in addressing the Union's demographic challenge and in securing the EU's strong economic performance over the longer term." 502 The Commission emphasised that "the EU must strive for a uniform level of rights and obligations for legal immigrants comparable with that of European citizens." 503 The action plan includes a catalogue of different actions in the annex assigning the party responsible for transposition, as well as a timetable. The various actions concern, in particular, reports on enacted legislation, evaluations on programmes and initiatives and Commission communications on future projects and the promotion of dialogues and meetings.

499 European Parliament, "Multi-annual Programme 2010-2014 regarding the area of freedom, security and justice (Stockholm Programme)", document number: P7_TAPROV(2009)0090.

$500 \quad$ Ibid., paras. 43-48.

501 E. Guild, S. Carrera and A. Atger, 'Challenges and Prospects for the EU's Area of Freedom, Security and Justice: Recommendations to the European Commission for the Stockholm Programme', CEPS Working Document No 313 (2009).

502 European Commission Communication, $\operatorname{COM}(2010)$ 171, 20 April 2010, p. 7.

503 Ibid. 
In November of 2011, the Commission published a document on a renewed and revised Global Approach to Migration: the GAMM. ${ }^{504}$ In the wake of the Arab Spring and related developments in the Southern Mediterranean region, the Commission communicated the need to further strengthen the EU's external migration policy on the basis of a comprehensive and balanced migration policy. Back in May 2011, the Commission had suggested that dialogue for migration, mobility and security should address the challenges of the historic events that have occurred in the Southern Mediterranean since December of 2010; the "migration crisis" required, in the eyes of the Commission, a comprehensive policy response based on increased solidarity. 505 This dialogue is said to be in line with the EU's Global Approach to Migration and proposes short, medium and long-term measures to deal with migratory movements from the Southern Mediterranean. The Commission put emphasis on the expeditious allocation of humanitarian assistance, the active engagement of FRONTEX to deal with irregular and mixed migration flows, Regional Protection Programmes and resettlement schemes, mobility partnerships and a vigorous fight against the root causes of migration in the long term. 506

The GAMM is said to be designed to meet these objectives by being more strategic and efficient and by better aligning the internal and external dimensions of the relevant policies. The Commission considered that mobility of third-country nationals across the EU's external borders is of particular importance applying to a wide range of people, which is reflected by the renaming of the Global Approach. The GAMM should be firmly embedded in the EU's external foreign policy, it should be driven by migration and mobility dialogues and it should be implemented by the Commission, the EEAS and the Member States. ${ }^{507}$ The GAMM ties in with the three existing pillars - legal economic migration, irregular migration and migration and development - adding a fourth pillar: international protection to render the external dimension of the EU's asylum policy more visible. The GAMM should concentrate on the needs, aspirations and problem of individuals and should thus be migrantcentred. The Commission highlighted that the human rights of migrants are a crosscutting theme that concerns all four pillars. As regards the geographic coverage, the GAMM envisages being truly global covering all interested and relevant partners; it has a strong emphasis on regional dialogue processes but also complements bilateral initiatives. The mobility partnerships play a crucial role in implementing the GAMM. For those partners who are willing but not yet able to cooperate with the EU by virtue of a mobility partnership, the Commission suggested the Common Agenda for Migration and Mobility - a framework for advanced cooperation - that could be upgraded to a mobility partnership at a later stage.

\footnotetext{
$504 \quad$ European Commission Communication, COM(2011) 743, 18 November 2011.

505 European Commission Communication, $\operatorname{COM}(2011)$ 292, 24 May 2011, p. 2; European Commission Communication, COM(2011) 248, 4 May 2011.

506 European Commission Communication, COM(2011) 292, 24 May 2011; on the EU's reaction to the migration influx from the Mediterranean, see also European Commission Communication, COM(2011) 248, 4 May 2011. 
In view of the four pillars the GAMM sets out priorities and makes recommendations. Under the first pillar the GAMM underscores the different directives in the field of legal migration, as well as possible amendments of the researchers' and students' directives; the full application of the Visa Code; cooperation between higher education and training institutions; employment and labour matching; and migration and mobility resource centres. As far as the second pillar is concerned, the GAMM emphasises an integrated border management, support for partners to prevent and reduce trafficking, smuggling and irregular migration; the use of FRONTEX and of the ILOs; enhanced document security; the implementation of the return and employer sanctions directives; and better protection for victims of human trafficking. The third pillar concentrates on the Regional Protection Programmes; support provided by the European Asylum Support Office for non-EU countries; enhanced resettlement; and stronger efforts to help solve protracted refugee situations. Under the fourth pillar, the GAMM focuses on diaspora engagement; private-public partnerships; the transfer of remittances; and the use of the World Health Organisation (WHO) Code of practice on the recruitment of health personnel..$^{508}$

The Commission presents the GAMM as a new stimulus in shaping the EU's Global Approach to Migration. Whether its focus on mobility materialises in concrete action to promote the mobility of third-country nationals is questionable. It is to be welcomed that the GAMM incorporated the dimension on international protection and puts the individual migrant at the centre of attention. The fact that the human rights of migrants are now explicitly acknowledged as a cross-cutting theme demonstrates a willingness on the side of the EU to accept that the protection of fundamental rights concerns migrants in source, transit and destination countries alike. The European Council endorsed the GAMM with its four pillars as overarching framework of the EU external migration policy in April of 2012.509 The European Council acknowledged that the GAMM should be applied globally but stressed at the same time the need for further geographical priorisation taking into account migratory routes and countries of origin and transit of strategic interest of the EU.

\subsection{The Future 2013 Enlargement}

Croatia's accession to the EU is scheduled for 1 July 2013 as membership negotiations were closed in all chapters on 30 June 2011.510 Croatia will be the first state to join the EU under the Stabilisation and Association Process instituted for the Western Balkan countries; this demonstrates the successful enlargement policy the EU has pursued in the region. Croatia was the second state after the FYROM to sign a Stabilisation and Association Agreement in 2001. The exact accession date depends on the ratification of the accession documents by all Member States and Croatia. Once Croatia accedes to the EU, Croatian nationals will be faced with transitional

\footnotetext{
508 Ibid., pp. 12-20.

509 Council of the European Union, "Council Conclusions on the Global Approach to Migration and Mobility", document number: 9417/12 of 3 May 2012.

510 Documents concerning the accession of the Republic of Croatia to the European Union, OJ L 112, 24 April 2012, p. 1.
} 
movement rules introduced by the Member States under the accession treaty, just like nationals of Member States that joined the Union in 2004 and 2007.511

Part II has provided a detailed, historical overview of the relevant developments that have formed the EU as it stands today, composed of soon-to-be 28 Member States after experiencing the (by then) seventh enlargement process. Enlargement is a powerful, if not the most important, foreign policy instrument that the EU has to offer to states which meet the membership requirements. The EU underwent the biggest accession process in 2004 when eight Central and Eastern European states, as well as Cyprus and Malta were welcomed by the EU-15 and absorbed by the Union. The EU has built its external relations on the basis of association, cooperation and partnership agreements with third countries that deal with a broad variety of subjectmatters. ${ }^{512}$ In the course of time, the Union has also grown in terms of powers that the Member States have either completely handed over to the EU, or have shared with the supranational entity. The express powers included in the EEC Treaty related to the Common Commercial Policy and the conclusion of association agreements; however, in a large volume of case law and opinions, the Court extended and refined the EU's competences, substantively and in view of their nature. In conjunction with various treaty modifications, today the EU disposes of a wide range of external competences, be they exclusive or shared. In an attempt to codify case law, the Treaty of Lisbon provides a list of the exclusive and shared EU competences but the meaning and scope of the relevant provisions are still subject to academic debates. ${ }^{513}$ The EU's appearance and role as an international actor has been enhanced by the amendments set out in the Treaty of Lisbon, in particular by the introduction of the High Representative of the Union for Foreign Affairs and the EEAS.

Part II has moreover revealed the manner in which migration policy has assumed a European dimension step-by-step and has by now become a solid EU policy area despite the sensitivity that Member States have always associated with immigration. In this regard, it is telling that third-country nationals were not at all considered in the original EEC legal framework but were only integrated into the Treaty regime in a piecemeal fashion, starting with designated rights as family members of Member States' nationals and nationality-bound rights as included in association agreements. The Treaty of Amsterdam brought a major overhaul with its Title IV EC, transforming the intergovernmental cooperation in migration issues stipulated in the Maastricht Treaty into tangible Community competences, even if Title IV was subject to derogatory procedural rules. The EU legislation adopted within the scope of Title IV EC contributes significantly to constructing a common and comprehensive European migration policy in that it consolidates the legal position of third-country nationals coming to and lawfully residing in the EU. This added value is irrespective of the partial deficient implementation of the enacted directives in the Member

511 See Annex V (on transitional measures) of the Documents concerning the accession of the Republic of Croatia to the European Union, OJ L 112, 24 April 2012, p. 67.

512 See Part IV of this study.

513 See Arts. 3 and 4 TFEU. 
States' national legal systems. ${ }^{514}$ On that score, the Commission launched infringement proceedings against 20 Member States in 2007 for wrongfully or belatedly implementing Council Directive 2003/109/EC on the long-term resident status of third-country nationals, with three judgments delivered by the Court in the meantime. 515 The Treaty of Lisbon has brought further improvements, such as the removal of the Court's "strait jacket" under Title IV EC: from 1 December 2009 national courts of all instances may ask the Court in Luxembourg for preliminary rulings under Title V TFEU as regards most justice and home affairs issues. The selective measure of concluding association agreements with particular non-member countries has, at an early stage, liaised migration matters with the EU's external relations. There has thus been an emerging interaction of migration policy and the EU's external relations that dates back to the 1960s and 1970s and the Court has defined the strict limits which these association agreements set with regard to national policy and law-making.

514 See Chapter 5 of A. Wiesbrock, Legal Migration to the European Union (Martinus Nijhoff Publishers, Leiden 2010).

515 Council Directive 2003/109/EC of 25 November 2003 concerning the status of thirdcountry nationals who are long-term residents; on the application of this Directive, see European Commission, COM(2011) 585, 28 September 2011; Cases C-5/07 Commission v. Portugal [2007] ECR I-120; C-59/07 Commission v. Spain [2007] ECR I-161; C-34/07 Commission v. Luxembourg [2007] ECR I-175. 



\section{Part III : The Human Rights of Migrants: Legal Bases and Sources for EU Migration Law and Policy}

From the perspective of states, migrant workers are often considered as economic actors, however they are first and foremost human beings who are covered by humans rights' instruments. In the second half of the $20^{\text {th }}$ century, the state community drafted a number of such multilateral agreements for the protection of mankind inter alia as a reaction to the atrocities committed during World War II. Part III analyses the human rights that migrants enjoy in the sphere of European and international law. Moreover, Part III elucidates the institutions and initiatives that have substantially contributed to raising awareness of the migration phenomenon among the community of states and, more specifically, in strengthening the human rights of migrants. This synopsis, which acquaints the reader with the relevant human rights legislation that is applicable to all third-country nationals irrespective of nationality, provides the basis for the latter to develop the understanding how the legal status of a third-country national in a privileged position differs from the status of somebody who does not qualify for privileged treatment in legal terms. Furthermore, it will become clear that a number of human rights instruments have strongly influenced EU law and, more specifically, law-making in the field of EU migration policy. The structure of Part III follows an own pattern: the instruments and organisations are explored in a self-contained way (rather than being classified by the various rights they set forth, which is the approach adopted in Parts V to VII) taking into account that not all legal documents are ratified by the EU and/or all Member States and no distinction is made on the basis of nationality.

Chapter 2 of Part III first outlines the applicable framework for human rights protection in the EU. In this context, the Council of Europe has adopted a pioneering role in drafting and enacting norms and standards for the protection of human rights, including those of migrant communities, among which the ECHR has a prominent role. In the course of time the ECHR has become part of EU law, and the Treaty of Lisbon provides for the EU's accession to the ECHR. Next, the EU Charter of Fundamental Rights, which is strongly influenced by the ECHR, as well as the general principles of the EU, are important legal sources for the protection of human rights under EU law. Chapter 2 also illuminates instruments drafted under the auspices of the Council of Europe that partly inspired Community legislation, such as the European Convention on Establishment (ECE). The Commission recognised the importance of the human rights of migrants and their cross-cutting dimension in EU migration policy in the EU's GAMM in November of $2011 .^{1}$

Chapter 3 of Part III expounds the international dimension of the protection of migrants. To this end, Chapter 3 first provides a synopsis of relevant international human rights standards applicable to all human beings, including migrants. It has been underlined that "this body of international human rights law has opened a new chapter in international affairs in that it does not concern the traditional function of international law, that of regulating relations between sovereign states, but rather 
seeks to regulate the relationship between the state and individuals within its territory and jurisdiction." 2 In the second place, Chapter 3 specifically addresses treaty regimes composed for the protection of migrants, notably the UN Migrant Worker Convention (ICMW). Third, Chapter 3 discusses which fora and organisations pushed migration issues on the agenda of governments and advocated a sound protection of the human rights of migrants. The attribution of a set of rights to aliens who settle in a host state can substantially facilitate their economic, social, cultural and political integration in the host society. The more far-reaching the catalogue of rights, the more likely is the successful integration process in the country of residence.

\section{Human Rights Protection in the EU}

The protection of human rights, which by implication includes those of third-country migrants, has over time incrementally developed within the EU legal order from the late 1960s onwards. While the original EEC Treaties made no reference whatsoever to safeguarding human rights, the EU - as it stands today - has transformed into a supranational organisation that "is founded on the values of respect for human dignity, freedom, democracy, equality, the rule of law and respect for human rights [...]."3 As regards the issue of whether the EU could be regarded as a human rights organisation, A. von Bogdandy considered that "human rights, though important, should not be understood as the raison d'etre of the Union." 4 S. Peers indicated three principal sources of human rights protection in the EU legal framework: the ECHR, the EU Charter and the general principles of EU law. ${ }^{5}$

\subsection{The Council of Europe and the European Convention on Human Rights (ECHR)}

The Council of Europe was founded in 1949 as an international organisation with the aim to promote human rights, democracy, the rule of law, as well as cultural identity in Europe. The Council of Europe advocated its mission by composing norms and standards and opened them for signature to its members, and it became a major regional institution committed to fighting human rights violations. The most pivotal instrument is the ECHR. ${ }^{6}$ The ECHR was signed on 4 November 1950 with the objective to protect human rights and fundamental freedoms and entered into force on 3 September 1953; today 47 states are parties to the Convention, including all 27 EU Member States. ${ }^{7}$ The ECHR's scope of application includes all persons within the

2 S. Grant, 'International Migration and Human Rights', Global Commission on International Migration (2005), p. 16.

Art. 6(1) TEU.

A. Von Bogdandy, 'The European Union as a Human Rights Organization? Human Rights and the Core of the European Union', 37 Common Market Law Review (2000), 1307, p. 1338.

5 S. Peers, EU Justice and Home Affairs Law (3rd edn. Oxford University Press, Oxford 2011), p. 96.

European Convention for the Protection of Human Rights and Fundamental Freedoms, 4 November 1950, CETS No 5.

As of 21 October 2011; see website of the Council of Europe: <http:/ / conventions.coe.int/Treaty/Commun/ChercheSig.asp?NT=005\&CM=8\&DF $=21 / 10 / 2011 \& C L=E N G>$, last accessed on 21 October 2011. 
jurisdiction of the contracting parties; the ECHR thus covers citizens and non-citizens alike. ${ }^{8}$ Notwithstanding the impression that the ECHR conveys of being an inclusive and all-embracing agreement, closer scrutiny has proven that only a limited set of basic rights is indeed guaranteed to everyone under the convention. As a result, "[]n reality is must be admitted that the classical approach of distinguishing between aliens and nationals continues to exist [...] after all, it is not difficult to draft provisions, which are noble, objective and non-discriminatory in purpose and yet whose practical effect is at times quite marginal." The non-derogable rights relate inter alia to the right to life (Article $2 \mathrm{ECHR}$ ), as well as the prohibition of torture, slavery and servitude (Articles 3 and 4(1) ECHR). ${ }^{10}$ Some provisions explicitly concern nonnationals; for instance, state parties may derogate from the right to liberty in cases where the lawful arrest or detention shall either prevent unauthorised entry into the country, or shall ensure the capture of a person against whom action is being taken with a view to deportation or extradition. ${ }^{11}$ Moreover, Article 1 of Protocol No 7 determines procedural safeguards relating to the expulsion of legally staying aliens, and Article 4 of Protocol No 4 prohibits the collective expulsion of aliens. Article 16 ECHR expressly permits the contracting parties to impose restrictions on the political activity of aliens; nothing in Articles 10, 11 and 14 ECHR shall be interpreted otherwise in this respect.

The adherence of the contracting parties to the ECHR is monitored by the European Court of Human Rights (ECtHR) situated in Strasbourg. The ECtHR has left the state parties initially wide discretionary powers in view of controlling and regulating immigration. It was only when the Strasbourg Court handed down the precedent in Abdulazir, Cabales and Balkandali v. The United Kingdom in 1985 that it became clear that the right to respect for family life also applies to national immigration legislation. ${ }^{12}$ Incrementally, the ECtHR has developed clearer guidelines on how the right to family life interacts with immigration policy on the basis of its case law; parallel constructive principles have been generated on the part of the Court of Justice as it has started to interpret free movement rights with reference to Article 8 ECHR. ${ }^{13} \mathrm{~A}$. Wiesbrock argued that the most important rights of the ECHR concerning the treatment of foreigners are Article 8 on the right to family life, Article 9 on the freedom of thought, conscience and religion and Article 14 on the principle of nondiscrimination. ${ }^{14}$ Concerning the scope of equal treatment under the ECHR, A.

\footnotetext{
8 See Art. 1 ECHR; on the notion of “jurisdiction" under Art. 1 ECHR, see M. Gondek, "Extraterritorial Application of The European Convention on Human Rights: Territorial Focus in the Age of Globalization?', 52 Netherlands International Law Review (2005), 3.

9 A. Drzemczewski, 'The Position of Aliens in Relation to the European Convention of Human Rights: A General Survey', in: Council of Europe (ed.), Human Rights of Aliens in Europe (Martinus Nijhoff Publishers, Dordrecht 1985), pp. 351-399.

10 See Art. 15 ECHR on derogation in time of emergency.

11 Art. 5(1)(f) ECHR.

12 Abdulariv, Cabales and Balkandali v. The United Kingdom (Application Nos. 9214/80, 9473/81; 9474/81) Judgment of 28 May 1985, 7 EHRR 471.

13 N. Rogers, 'Immigration and the European Convention on Human Rights: Are New Principles Emerging?', European Human Rights Law Review (2003), 53, p. 54.

14 A. Wiesbrock, Legal Migration to the European Union (Martinus Nijhoff Publishers, Leiden 2010), pp. 209-210; as rights of potential relevance for migrants the author indicates: the freedom to move within a state (Art. 2(1) of Protocol No 4); the freedom to leave a
} 
Wiesbrock referred to the case of Belgian Linguistic in which it was emphasised that the rights set out in the ECHR must be guaranteed without discrimination and that "the principle of equality of treatment is violated if the distinction has no objective and reasonable justification." 15 The European Commission on Human Rights, which was replaced by the ECtHR in 1998, further stated that " $[\mathrm{t}]$ he existence of such a justification must be assessed in relation to the aim and effects of the measure under consideration, regard being had to the principles which normally prevail in democratic societies. A difference of treatment in the exercise of a right laid down in the Convention must not only pursue a legitimate aim: Article 14 ECHR is likewise violated when it is clearly established that there is no reasonable relationship of proportionality between the means employed and the aim sought to be realised."16 Before delving into the application of Articles 8, 9 and 14 ECHR, which are in particular of relevance for aliens, the interrelationship between the ECHR in the EU legal order is outlined.

\subsubsection{The EU and the ECHR: Questions Relating to Interpretation and Accession}

Despite the fact that the EU is not a party (yet) to the ECHR, the Court of Justice in Luxembourg has repeatedly referred to this human rights treaty in the past, stating that the ECHR has special significance as regards fundamental rights protection in the Community framework. ${ }^{17}$ In 1974, the Court of Justice first held in Nold that fundamental rights form an integral part of the general principles of law and that "international treaties for the protection of human rights on which the Member States have collaborated or of which they are signatories can supply guidelines [for the protection of fundamental rights, next to constitutional traditions common to the Member States]." 18 In this regard it was pointed out that "in the absence of any catalogue of actual rights, the ECHR was, in practice, the only realistic point of reference. The occasional references made by the Court to inspiration from national constitutions were, in reality, perfunctory rather than scientific and were in any event incomplete." 19 The judgment in Nold must be considered against the backdrop of the Rome Treaty that did not intrinsically protect fundamental rights, apart from the four

state (Art. 2(2) of Protocol No 4); the prohibition of expulsion of nationals (Art. 3(1) of Protocol No 4); the right to enter the territory of one's own state (Art. 3(2) of Protocol No 4); the procedural rights for lawful residents as regards expulsion (Art. 1 of Protocol No 7).

15 A. Wiesbrock, Legal Migration to the European Union (Martinus Nijhoff Publishers, Leiden 2010), p. 210; Belgian Linguistic Case (No. 2) (Application Nos. 1474/62; 1677/62; 1691/62; 1769/63; 1994/63; 2126/64) Judgment of 23 July 1968, 1 EHRR 252.

16 Belgian Linguistic Case (No. 2) (Application Nos. 1474/62; 1677/62; 1691/62; 1769/63; 1994/63; 2126/64) Judgment of 23 July 1968, 1 EHRR 252.

17 Case C-299/95 Kremrow [1997] ECR I-2629, para. 14.

18 Case 4/73 Nold [1974] ECR 491, para. 13; later confirmed in Case 44/79 Hauer [1979] ECR 3727, para. 15; see also Joint Declaration by the European Parliament, the Council and the Commission "Concerning the Protection of Fundamental Rights and the European Convention for the Protection of Human Rights and Fundamental Freedoms, OJ C 103, 27 April 1977, p. 1.

19 N. Fennelly, 'Pillar Talk: Fundamental Rights Protection in the European Union', Judicial Studies Institute Journal (2008), 95, p. 100. 
freedoms and the prohibition of discrimination. ${ }^{20}$ Yet, the Court's "rushing ahead" in protecting fundamental rights was endorsed by the Member States in successive treaty amendments: a first reference to human rights was integrated into the SEA of 1986; the Preamble to the Maastricht Treaty confirms the respect for human rights, and Article F TEU first specifically referred to the respect of fundamental rights as guaranteed by the ECHR; ${ }^{21}$ the Treaty of Lisbon has created a legal basis for the EU to accede to the ECHR to provide a sound fundamental rights protection in the EU framework, together with the legally binding EU Charter. ${ }^{22}$

As far as the EU's accession to the ECHR is concerned, a draft accession agreement has been negotiated that lays down certain adaptations within the Convention system, considering the EU is not a state but a supranational organisation embedded with its own specific legal framework. The draft accession agreement has the objective "to preserve the equal rights of all individuals under the Convention, the rights of applicants in the Convention procedures, and the equality of all High Contracting Parties." As regards the control mechanism under the ECHR, it has been pointed out that it should be preserved as far as possible and applied to the EU in the same way as to other contracting parties, by making only those adaptations that are strictly necessary. ${ }^{23}$ Some delegations expressed objections as regards this draft agreement at the COREPER meeting of 6 October 2011; such objections related to the scope of the EU's accession to the ECHR, the non-affectation of the Member States' competences resulting from the accession, the extent of application of the corespondent mechanism and the exercise of voting rights of the EU and its Member States in the Committee of Ministers when supervising the execution of judgments against the EU by the ECtHR. The Working Party on fundamental rights, citizens' rights and free movement of persons, which is in charge of the accession proceedings, has continued to iron out the Member States' concerns with a view to attain a common position. ${ }^{24}$

The legal scenario of the EU becoming a party to the ECHR is not new. The Court was asked to deliver an opinion on the Community's accession to the ECHR in the $1990 \mathrm{~s}^{25}$ In the absence of any express or implied powers of the Community institutions to enact rules on human rights or to conclude international conventions in this field at that time, the Court considered Article $235 \mathrm{EC}$ as a potential legal basis for an accession. Article $235 \mathrm{EC}$ is designed to fill the gap where no specific provisions of the Treaty confer, upon the Community institutions, express or implied

20 J.L. Murray, 'Fundamental Rights in the European Community Legal Order', 32 Fordham International Law Journal (2008), 531, p. 534.

21 Art. F TEU under the Treaty of Maastricht was, however, not enforceable by the Court of Justice, see Art. L TEU.

22 See Art. 6(2) TEU as amended by the Treaty of Lisbon; Protocol No 8 to the Treaty of Lisbon; Art. 17 of Protocol No 14 to the ECHR.

23 Steering Committee for Human Rights, Report to the Committee of Ministers on the elaboration of legal instruments for the accession of the European Union to the European Convention on Human Rights of 14 October 2011, document number: $\mathrm{CDDH}(2011) 009$.

24 Council of the European Union, "Accession of the Union to the European Convention for the Protection of Human Rights and Fundamental Freedoms - State of Play", of 6 December 2011, document number: 18117/11.

25 Opinion 2/94 Accession ECHR [1996] ECR I-1759. 
powers to act should such powers appear nonetheless necessary for the operation of the common market. The provision enables the Community to carry out its functions with a view to attaining one of its objectives laid down in the Treaties. In this respect the Court emphasised that the fundamental rights protection is important in the Community framework and that respect for fundamental rights is a condition of the lawfulness of Community acts. However, the Court also made clear, at the same time, that accession to the ECHR would entail a complete distinct institutional system, as well as the integration of the Convention into the Community legal order; such a substantial modification would be of constitutional significance and would therefore go beyond the scope of Article 235 EC. This being said, the Court concluded that as Community law stands, the Community has no competence to accede to the ECHR. ${ }^{26}$

The Treaty of Lisbon has, in addition, turned over a new leaf in view of human rights protection in the EU as the EU Charter of Fundamental Rights has obtained binding legal authority and is now enforceable as an integral part of EU law before the Court. ${ }^{27}$ The EU Charter binds the Union institutions, bodies, offices and agencies with due regard for the principle of subsidiarity, as well as the Member States when they are implementing Union law. ${ }^{28}$ Article 51(2) furthermore states that the Charter does not extend the field of application of European Union law beyond the powers of the Union, and it does not establish any new power or task for the Union, or modify powers and tasks as defined in the Treaties. In Dereci and Others the Court of Justice stressed that, accordingly, it is called upon to interpret, in the light of the Charter, the law of the European Union within the limits of the powers conferred on it. ${ }^{29}$ This case concerned the refusal of the Austrian authorities to grant residence permits to third-country national family members of Union citizens. With regard to the right to respect for private and family life, the Court of Justice left the discretion to the national judges by adjudicating that "if the referring court considers, in the light of the circumstances of the disputes in the main proceedings, that the situation of the applicants in the main proceedings is covered by European Union law, it must examine whether the refusal of their right of residence undermines the right to respect for private and family life provided for in Article 7 of the Charter. On the other hand, if it takes the view that the situation is not covered by European Union law, it must undertake the examination in the light of Article 8(1) of the ECHR. All the Member States are, after all, parties to the ECHR which enshrines the right to respect for private and family life in Article 8." 30

Most certainly the Charter will strengthen the promotion of human rights in the EU's external relations and in this regard continue and expand the "trend" of human rights protection set out in Article 177 of the Treaty on development cooperation for other

26 Opinion 2/94 Accession ECHR [1996] ECR I-1759, paras. 25-36; for an academic discussion on the accession of the EU to the ECHR under the Maastricht regime, see J.M. Sera, 'The Case For Accession of the European Union to the European Convention For the Protection of Human Rights', 14 Boston University International Law Journal (1996), 151.

27 Art. 6(1) TEU.

28 Art. 51(1) of the EU Charter.

29 Case C-265/11 Dereci and Others [2011] Judgment of 15 November 2011, not yet reported, para. 71 .

$30 \quad$ Ibid., paras. $72-73$. 
policy fields too; legal disputes such as the one in Portugal v. Council in which the Portuguese government challenged the Community's competence to refer to the respect for human rights and democratic principles in Article 1 of the EC-India Cooperation Agreement as the basis for the cooperation of the contracting parties would indeed be obsolete in the light of the EU Charter. ${ }^{31}$ The EU Charter is said to codify existing EU obligations to respect fundamental rights and has been denominated as a "syncretic document" considering that various sources of law, including the ECHR and the case law of the Court of Justice, inspired and greatly influenced the drafting of this binding set of rights. The EU Charter does not offer any new EU competences but contains a number of innovations, such as the prohibition of human cloning. ${ }^{32}$

\subsubsection{The Right to Respect for Family Life (Article 8)}

Article 8 ECHR enshrines that everyone has the right to respect for his private and family life, his home and his correspondence; paragraph 2 of the provision specifies that there shall be no interference by a public authority with the exercise of this right, except such as is in accordance with the law and is necessary in a democratic society in the interests of national security, public safety or the economic well-being of the country, for the prevention of disorder or crime, for the protection of health or morals, or for the protection of the rights and freedoms of others. As a consequence, interferences with rights set out in Article 8 ECHR must be in accordance with the law; the aim of the limitation must be legitimate; and the limitation must be necessary in a democratic society. Finally, the ECtHR will ascertain whether the interference is proportionate in securing the legitimate aim. The rule stipulates a positive obligation in that a state must not only abstain from interfering with the rights covered and prevent interferences by other individuals, but it must actively ensure that respect for the rights under Article 8 ECHR is protected. ${ }^{33}$ This was confirmed by the Court when it recalled that, "although the essential object of Article $8 \mathrm{ECHR}$ is to protect the individual against arbitrary interference by the public authorities, there may in addition be positive obligations inherent in an effective respect for family life. However, especially as far as those positive obligations are concerned, the notion of respect is not clear-cut: having regard to the diversity of the practices followed and the situations obtaining in the Contracting States, the notion's requirements will vary

31 As pointed out by A.J. Menéndez, 'Chartering Europe: Legal Status and Policy Implications of the Charter of Fundamental Rights of the European Union', 40 Journal of Common Market Studies (2002), 471, pp. 485-486; Case C-268/94 Portugal v. Council [1996] ECR I-6177.

32 J.L. Murray, 'Fundamental Rights in the European Community Legal Order', 32 Fordham International Law Journal (2008), 531, p. 540; G. De Búrca, 'The Drafting of the EU Charter of Fundamental Rights', 26 European Law Review (2001), 126, p. 130; Art. 51(2) of the EU Charter.

33 C. Ovey and R.A.W. White, The European Convention on Human Rights (4th edn. Oxford University Press, Oxford 2006), p. 222; p. 243. 
considerably from case to case." 34 Article 8 ECHR has been identified as "one of the most open-ended provisions of the Convention." 35

As pointed out above, the ECtHR has begun, over time, to adjudicate on immigration matters in the framework of the Convention; among these rulings mainly two types of situations have crystallised: the first relates to the expulsion of integrated migrants, including second generation immigrants and long-term residents, on grounds of public order following a criminal conviction; the second situation concerns the expulsion or the refusal of admission of third-country nationals with close family members in the territory of a state on economic interest grounds, or for the maintenance of immigration policy. ${ }^{36}$

In respect to the first category, it is clear that states have an interest in expelling immigrants who have come to the attention of national authorities because they have been convicted for criminal offences. In such cases, the ECtHR has balanced the extent, timing and seriousness of the criminal offence committed with the implications that an expulsion from that state would entail for the individual's family life. In this regard the ECtHR attached importance to the ties of the person concerned with the country of origin, including the number of family members living there and language skills. ${ }^{37}$ For an expulsion decision to be quashed, the individual in question must thus have established family life in the host country; moreover, the state's interference with such family life may not be justified under Article 8(2) ECHR. Effective family in the sense of Article 8 ECHR life between members of a family requires, in essence, that the persons concerned have been living together and have a close relationship to one another. ${ }^{38}$ Scholars and judges have disapproved of inconsistent Article 8 case law, labelling the contradictory case-by-case approach of the ECtHR as a "judicial lottery". 39

34 Abdulariz, Cabales and Balkandali v. The United Kingdom (Application Nos. 9214/80; 9473/81; 9474/81) Judgment of 28 May 1985, 7 EHRR 471, para. 67.

35 C. Ovey and R.A.W. White, The European Convention on Human Rights (4th edn. Oxford University Press, Oxford 2006), p. 241; see also D. Feldman, 'The Developing Scope of Article 8 of the European Convention on Human Rights', 3 European Human Rights Law Review (1997), 265.

36 N. Rogers, 'Immigration and the European Convention on Human Rights: Are New Principles Emerging?', European Human Rights Law Review (2003), 53, pp. 54-55; cases that specifically concern the national security of a state are Lin v. Russia (Application No. 42086/05) Judgment of 6 December 2007; Bashir and Others v. Bulgaria (Application No. 65028/01) Judgment of 14 June 2007.

37 S. Peers, EU Justice and Home Affairs Law (3rd edn. Oxford University Press, Oxford 2011), p. 400.

38 C. Ovey and R.A.W. White, The European Convention on Human Rights (4th edn. Oxford University Press, Oxford 2006), p. 241; on the re-conceptualisation of the notion of family life see D. Thym, 'Respect for Private and Family Life Under Article 8 ECHR in Immigration Cases: A Human Right to Regularize Illegal Stay?', 57 International and Comparative Law Quarterly (2008), 87.

39 M.B. Dembour, 'Human Rights Law and National Sovereignty in Collusion: The Plight of Quasi-Nationals in Strasbourg', 21 Netherlands Quarterly of Human Rights (2003), 63, p. 66; see dissenting opinion of Judge Martens in Boughanemi v. France (Application No. 22070/93) Judgment of 24 April 1996, 22 EHRR 228 who called the case law "a source of embarrassment for the Court." 
In Moustaquim v. Belgium the ECtHR found a violation of Article 8 ECHR because the deportation from Belgium of a Moroccan national who was inter alia charged with aggravated theft would wrongfully endanger his right to family life with his parents and siblings. ${ }^{40}$ In a similar vein, the Algerian applicant in Beldjoudi v. France could successfully invoke the right to family life although he had been convicted for a series of crimes, including assault, battery and criminal damage, adding up to an imprisonment charge of 10 years; the applicant at hand was born in France, had married a French national and did not have any connection to Algeria, apart from that of nationality. ${ }^{41}$ In Nasri $v$. France, the ECtHR held that the special circumstances of the case involving a deaf and illiterate Algerian national who had resided in France for most of his life and was convicted of gang rape, justified the suspension of the expulsion order against the latter as deportation would not be in accordance with the principle of proportionality. ${ }^{42}$ By contrast, in Boughanemi v. France the Court ruled that expelling a Tunisian national who was sentenced to three and a half years' imprisonment for living on the earnings of prostitution, burglary and assault, but yet had continuously lived in France for 20 years from the age of eight, did not amount to a violation of Article 8 ECHR. ${ }^{43}$ Likewise, in Boujlifa v. France, the ECtHR rejected the application of a Moroccan citizen who had claimed that his deportation would breach Article 8 ECHR. ${ }^{44}$ The individual concerned was accused of armed robbery and had lived most of his life in France where most of his family also resided. While the latter two cases cited may suggest otherwise, ${ }^{45}$ the degree of the individual's integration in the state of residence as part of a family has served as an indicator: the stronger the family ties, the more difficult it will be for states to deport non-nationals from their territories; as a result, this approach favours second generation immigrants as well as long-term residents. ${ }^{46}$

The ECtHR clarified the rather confusing case law by establishing guiding principles for expulsion decisions in Boultif v. Switzerland in which it held that it will consider:

- the nature and seriousness of the offence committed by the applicant;

\footnotetext{
40 Moustaquim v. Belgium (Application No. 12313/86) Judgment of 18 February 1991, 13 EHRR 802

41 Beldjoudi v. France (Application No. 12083/86) Judgment of 26 March 1992, 14 EHRR 801; for an analysis of this case with regard to social integration, see R. O'Connell and R.R. Marin, 'The European Convention and the Relative Rights of Resident Aliens', 5 European Law Journal (1999), 4, pp. 11-14.

42 Nasri v. France (Application No. 19465/92) Judgment of 13 July 1995, 21 EHRR 458.

43 Boughanemi v. France (Application No. 22070/93) Judgment of 24 April 1996, 22 EHRR 228; see also Mutlag v. Germany (Application No. 40601/05) Judgment of 25 March 2010.

44 Boujlifa v. France (Application No. 25404/94) Judgment of 21 October 1994, 30 EHRR 419.

45 See critical remarks in the dissenting opinion of Judge Baka in Boughanemi v. France, as well as of Judges Baka and Van Dijk in their joint dissenting opinion in Boujlifa v. France, para. 17; Judge Martens establishes a connection between an expulsion and the disruption of all social ties of the individual concerned, which amounts in his view to a breach of the right to respect for private life, see his concurring opinion in Beldjoudi v. France.

46 See R. Cholewinski, 'Strasbourg's "Hidden Agenda"?: The Protection of SecondGeneration Migrants from Expulsion under Article 8 of the European Convention on Human Rights', 12 Netherlands Quarterly of Human Rights (1994), 287.
} 
- the duration of the applicant's stay in the country from which he is going to be expelled;

- the time which has elapsed since the commission of the offence and the applicant's conduct during that period;

the nationalities of the various persons concerned;

the applicant's family situation, such as the length of the marriage;

- other factors revealing whether the couple lead a real and genuine family life;

- whether the spouse knew about the offence at the time he or she entered into a family relationship;

and whether there are children in the marriage and, if so, their age;

- the seriousness of the difficulties which the spouse would be likely to encounter in the applicant's country of origin, although the mere fact that a person might face certain difficulties in accompanying her or his spouse cannot in itself preclude expulsion. ${ }^{47}$

These principles were affirmed in Amrollabi v. Denmark and refined in Üner v. The Netherlands, in which the ECtHR stated that in addition:

- the best interests and well-being of the children, in particular the seriousness of the difficulties which any children of the applicant are likely to encounter in the country to which the applicant is to be expelled;

- the solidity of social, cultural and family ties with the host country and with the country of destination must be taken into account. ${ }^{48}$

With regard to the second category that relates to the expulsion or the refusal of admission of third-country nationals with close family members on economic interest grounds, or for the maintenance of immigration policy, a number of cases have equally triggered raised eyebrows. In a series of cases, the Court underscored that - as a general rule - the right to family life does not imply the right to enjoy family life in a particular country; Article 8 ECHR rather protects "effective" family life, which cannot be established elsewhere. In the East African Asians case, the Commission first dealt with the question as to whether the refusal of national authorities of admitting the applicants' husbands from Uganda infringed Article 8 ECHR because such a refusal would constitute an interference with the applicants' family lives that prevent family reunion in the UK.49 In Abdulariv, Cabales and Balkandali v. The United Kingdom, the ECtHR ruled that Article 8 ECHR cannot be interpreted as imposing a general obligation upon state parties to respect the choice by married couples of the country of their matrimonial residence and to accept the non-national spouses for settlement in that country. ${ }^{50}$ The legal dispute dealt with three female applicants who had legal

47 Boultif v. Switzerland (Application No. 54273/00) Judgment of 2 August 2001, 33 EHRR 50, para. 48.

48 Amrollabi v. Denmark (Application No. 56811/00) Judgment of 11 July 2002, 22 EHRR 585; Üner v. The Netherlands (Application No. 46410/99) Judgment of 18 October 2006, paras. 57-58. 4423/70; 4434/70; 4443/70; 4476-8/70; 4486/70; 4501/70; 4526-30/70) Commission Decision of 14 December 1973, 3 EHRR 76, para. 232.

50 Abdulariv, Cabales and Balkandali v. The United Kingdom (Application Nos. 9214/80; 9473/81; 9474/81) Judgment of 28 May 1985, 7 EHRR 471, para. 68. 
and permanent residence in the UK and who challenged the refusal of the British authorities to be joined by their husbands holding the nationalities of their home countries; the Court, however, found no violation of Article 8 ECHR alone.

The decision in Marckx $v$. Belgium established that by guaranteeing the right to respect for family life, Article 8 ECHR presupposes the existence of a family. The ECtHR affirmed that the notion of family must be construed broadly: "family life" in the sense of Article 8 ECHR applies to "legitimate" and "illegitimate" families and covers a single woman and her child. ${ }^{51}$ In Berrehab v. The Netherlands the Court clarified that family, within the scope of Article 8 ECHR, includes a child born in wedlock and it is ipso jure part of that relationship; hence, from the moment of the child's birth and by the very fact of it, there exists a bond amounting to family life between him and his parents, even if the parents are not then living together. ${ }^{52}$ Moreover, the concept of family life, in the case of a married couple, normally comprises cohabitation but extends to a relationship that arises from a lawful and genuine marriage, even if a family life in a joint home has not yet been fully established. ${ }^{53}$ Family life is thus regarded as a process with normal stages of development, at the centre of which is the family relationship of a natural parent and child, or that of a couple in the form of marriage and potentially persisting after their breakup. ${ }^{54}$

Marriage can have implications for the legal status of immigrants in the country of residence and so can divorce. In Berrehab v. The Netherlands a Moroccan national got divorced from his Dutch spouse and successfully enforced a right of residence in the Netherlands, where his daughter resided, on the basis of Article 8 ECHR. ${ }^{55}$ The ECtHR underpinned its judgment by indicating to the distance between the Netherlands and Morocco and the financial problems entailed in Mr Berrehab's enforced return to his home country. In this respect, it has been pointed out that divorce can generate a positive outcome for the individuals concerned in that "the non-national parents of children who were divorced or separated from a settled parent with custody of the children were likely to encounter the 'obstacles' to enjoying a family life with the children given that the custodial parent would be unlikely to follow the non-national parent to the receiving country." 56

The much contested family reunification case of Gül v. Switzerland concerned a Turkish family father whose asylum application was rejected but who was accorded a temporary residence permit on humanitarian grounds by the Swiss authorities for

\footnotetext{
51 Marckx v. Belgium (Application No. 6833/74) Judgment of 13 June 1979, 2 EHRR 330, para. 31.

52 Berrehab v. The Netherlands (Application No. 10730/84) Judgment of 21 June 1988, 11 EHRR 322, para. 21.

53 Abdulariv, Cabales and Balkandali v. The United Kingdom (Application Nos. 9214/80; 9473/81; 9474/81) Judgment of 28 May 1985, 7 EHRR 471, para. 62.

54 H. Storey, 'The Right to Family Life and Immigration Case Law at Strasbourg', 39 International and Comparative Law Quarterly (1990), 328, pp. 334-335.

55 Berrehab v. The Netherlands (Application No. 10730/84) Judgment of 21 June 1988, 11 EHRR 322.

56 N. Rogers, 'Immigration and the European Convention on Human Rights: Are New Principles Emerging?', European Human Rights Law Review (2003), 53, p. 58.
} 
himself, his wife and his daughter. ${ }^{57}$ The family had to struggle with medical issues: due to an illness, Mr Gül received a partial-invalidity pension and his wife suffered from serious burns and epilepsy. The father's request for family reunification in Switzerland with his two sons who resided in Turkey, was turned down. The older son did not qualify for a residence permit for the purpose of family reunion because he had reached the age of majority; with regard to the younger son, Ersin, the Strasbourg Court acknowledged family links and accepted the existence of family life but ruled that " $[1] \mathrm{n}$ view of the length of time Mr and Mrs Gül have lived in Switzerland, it would admittedly not be easy for them to return to Turkey, but there are, strictly speaking, no obstacles preventing them from developing family life in Turkey. That possibility is all the more real because Ersin has always lived there and has therefore grown up in the cultural and linguistic environment of his country." 58 The Court explained its decision by emphasising that the applicant, Mr Gül, was only permitted to stay in Switzerland temporarily on humanitarian grounds; that he would continue to receive his ordinary invalidity pension and half of the supplementary benefit in Turkey; that the focus of his son Ersin's family life was in the Turkish Republic; that he had made various visits to his country of origin from which he returned safe and sound; and that his wife's medical condition had improved.59 This decision caused a stir considering the particular circumstances and the hardship which the Gül family was confronted with. C. Forder stressed that the Court had failed to address whether the daughter, who was born on Swiss territory, could actually accompany her parents to Turkey; this factor was in the author's view highly relevant for the "only way" test that related to the question posed by the Court as "to what extent it is true that Ersin's move to Switzerland would be the only way for Mr Gül to develop family life with his son." 60 The ECtHR endorsed its reasoning of Gül v. Switzerland in the decision of Abmut v. The Netherlands, in which a Moroccan father was denied the right to be joined by his son in the Dutch state; the judgment was delivered by five votes to four. ${ }^{61}$

The ECtHR recognised the difficulty of its restrictive approach in J.M. v. The Netherlands in which it suggested that it may be unreasonable to give a parent who has achieved settled status in a country and wants to be reunited with his or her children, who are left behind, the choice of leaving the country of residence, or to remain

57 Gül v. Switzerland (Application No. 23218/94) Judgment of 19 February 1996, 22 EHRR 93; on the applicability of Art. 8 ECHR regarding refugees and other persons in need of protection, see H. Lambert, 'The European Court of Human Rights and the Right of Refugees and Other Persons in Need of Protection to Family Reunion', 11 International Journal of Refugee Law (1999), 427.

58 Gül v. Switzerland (Application No. 23218/94) Judgment of 19 February 1996, 22 EHRR 93, para. 42.

$59 \quad$ Ibid., paras. 30 and 41.

60 Ibid., para. 39; C. Forder, 'Family Rights and Immigration Law: A European Perspective', in: H. Schneider (ed.), Migration, Integration and Citizenship (Forum Maastricht, Maastricht 2005), p. 84.

61 Ahmut v. The Netherlands (Application No. 21702/93) Judgment of 28 November 1996, 24 EHRR 62; see dissenting opinion of Judge Martens in Ahmut v. The Netherlands, as well as C. Warbrick, 'The Structure of Article 8', European Human Rights Law Review (1998), 32, p. 42. 
separated from the offspring. ${ }^{22}$ The Court adapted its rationale in the case of Sen $v$. The Netherlands that dealt with the complaint of parents who faced the refusal of the Dutch authorities to admit their eight-year-old daughter to the Netherlands: it concluded that the latter state had violated a positive obligation under Article 8 ECHR by not granting entry to the Sen child. ${ }^{63}$ The Court underlined that this case could not be analysed solely from the perspective of immigration matters and referred to the principle set out in Abdulariv, Cabales and Balkandali v. The United Kingdom (Article 8 ECHR does not provide spouses with the right to choose the country of residence), which applied to cases of family formation but not to cases of family reunification. ${ }^{64}$ To strike a fair balance with regard to the competing interests, account must be taken of:

- the age of the children;

- their situation in the country of origin;

- $\quad$ and the degree to which they actually depend on their parents. ${ }^{65}$

Sen $v$. The Netherlands is a landmark court decision in matters of family reunion in that it departed from the "only way" test by switching to an approach of "the most suitable manner" to consolidate a joint family life. ${ }^{66}$

The validity of a deportation decision was at stake in 2006 in Rodrigues da Silva and Hoogkamer v. The Netherlands in which a Brazilian mother gave birth to a Dutch child and claimed a right to abode; the mother had no legal authorisation to reside in the Netherlands but could rely on the right to family life secured by Article 8 ECHR to regularise her stay there. The child was born from a relationship with a Dutch national who was granted parental authority. However, the parents had, since then, split up and lived apart. It follows that Article 8 ECHR can be invoked by irregular migrants for the purpose of obtaining a right of residence if their protection of family life (including the child's best interests) outweighs a state's interest in the economic well-being of the country. ${ }^{67} \mathrm{D}$. Thym highlighted that the Court in this dispute aimed to establish principles for cases of family reunion similar to the criteria it had developed in Boultif v. Switzerland for the expulsion of aliens. ${ }^{68}$ These general principles comprise the important consideration whether family life was created at a

J.M. v. The Netherlands (Application No. 38047/97) Decision of 9 January 2001, application declared inadmissible.

63 Sen v. The Netherlands (Application No. 31465/96) Judgment of 21 December 2001, 36 EHRR 81.

64 Sen v. The Netherlands (Application No. 31465/96) Judgment of 21 December 2001, 36 EHRR 81, para. 37; C. Forder, 'Family Rights and Immigration Law: A European Perspective', in: H. Schneider (ed.), Migration, Integration and Citizenship (Forum Maastricht, Maastricht 2005), p. 86.

65 Sen $v$. The Netherlands (Application No. 31465/96) Judgment of 21 December 2001, 36 EHRR 81, para. 39.

66 Ibid., para. 40 referring to "le moyen le plus adéquat pour développer une vie familiale".

67 Rodrigues da Silva and Hoogkamer v. The Netherlands (Application No. 50435/99) Judgment of 31 January 2006, 44 EHRR 729, para. 44; see also Nunezv. Norway (Application No. $55597 / 09)$ Judgment of 28 June 2011.

68 D. Thym, 'Respect for Private and Family Life Under Article 8 ECHR in Immigration Cases: A Human Right to Regularize Illegal Stay?', 57 International and Comparative Law Quarterly (2008), 87. 
time when the persons involved were aware that the immigration status of one of them was such that the persistence of that family life within the host state would be precarious from the outset; the Court has previously held that where this is the case it is likely only to be in the most exceptional circumstances that the removal of the non-national family member will constitute a violation of Article 8 ECHR. ${ }^{69}$ According to D. Thym "these parameters do not appear as a generous extension of the human rights status of illegal immigrants. The innovation rather lies in the prior assumption that illegal entry and residence status are only one, albeit important, element in the proportionality test and require balancing with other factors arguing in favour of the illegal immigrants. This provides immigration lawyers, respective interest groups and national courts with an important new legal tool to redesign national immigration law from a human rights perspective, since the weighing of interests under the proportionality tests is inherently not a strict dogmatic undertaking and opens the law for considerations of equity." ${ }^{\prime 70}$ Whenever deportation or extradition takes place, states have to observe Article 3 ECHR, which prohibits torture and degrading treatment. ${ }^{71}$ The Court of Justice in Luxembourg has not flinched from increasingly referring to Article 8 ECHR and relevant case law since it handed down the ruling in Carpenter. ${ }^{72}$

\subsubsection{The Freedom of Thought, Conscience and Religion (Article 9)}

Article 9 ECHR stipulates that everyone has the right to freedom of thought, conscience and religion; this right includes the freedom to change his religion or belief and freedom, either alone or in community with others and in public or private, to manifest his religion or belief, in worship, teaching, practice and observance. The freedom to manifest one's religion or beliefs is subject only to such limitations as are prescribed by law and are necessary in a democratic society, in the interests of public safety, for the protection of public order, health or morals, or for the protection of the rights and freedoms of others. According to P.W. Edge Article 9 ECHR comprises three significant and distinct elements: the absolute right to freedom of thought, conscience and religion and to change his religion or belief of 31 January 2006, 44 EHRR 729, para. 39; see also case of Arvelo Aponte v. The Netherlands (Application No. 28770/05) Judgment of 3 November 2011, para. 59. D. Thym, 'Respect for Private and Family Life Under Article 8 ECHR in Immigration Cases: A Human Right to Regularize Illegal Stay?', 57 International and Comparative Law Quarterly (2008), 87.

71 Soering v. United Kingdom (Application No. 14038/88) Judgment of 7 July 1989, 11 EHRR 439; see C. Van den Wyngaert, 'Applying the European Convention on Human Rights to Extradition: Opening Pandora's Box?', 39 International and Comparative Law Quarterly (1990), 757; Y. Arai-Takahashi, "Uneven, But in the Direction of Enhanced Effectiveness - A Critical Analysis of Anticipatory Ill-Treatment" under Article 3 ECHR', 20 Netherlands Quarterly of Human Rights (2002), 5.

72 Case C-60/00 Carpenter [2002] ECR I-6279; see also Case C-413/99 Baumbast [2002] ECR I-07091; Case C-109/01 Akrich [2004] ECR I-9607; Case C-127/08 Metock and Others [2008] ECR I-6241; as well as Part V, Section 3.3 on Entry Rights for the Purpose of Family Reunification. 
(Article 9(1)); the right to manifest such a belief (Article 9(1)); and qualifications of this latter right permitting states to restrict the manifestation of belief (Article 9(2)). ${ }^{73}$

It is maintained that litigation within the limits of Article 9 ECHR has focused on the issue of whether Muslim women may wear veils as an expression of their religious belief. ${ }^{74}$ The Commission first ruled in the decision of Karaduman $v$. Turkey that a Turkish university could validly deny the issue of a university degree certificate because the individual in question had, contrary to the regulations, submitted a photograph on which she was wearing a headscarf. The Court argued that the applicant had deliberately chosen to pursue higher education studies at a secular university and that the refusal of such an institution to deliver a degree certificate because of failure to comply with the university regulation did not constitute an inference with the freedom of religion or conscience. ${ }^{75}$ The importance of the principle of lä̈cité was backed in subsequent cases.

In Dablab v. Switzerland, Swiss legislation banning religious symbols in classrooms, which included prohibiting school teachers from wearing headscarves, was judged as not violating Article 9 ECHR. The ECtHR moreover stressed that "it cannot be denied outright that the wearing of a headscarf might have some kind of proselytising effect, seeing that it appears to be imposed on women by a precept which is laid down in the Koran and which [...] is hard to square with the principle of gender equality. It therefore appears difficult to reconcile the wearing of an Islamic headscarf with the message of tolerance, respect for others and, above all, equality and nondiscrimination that all teachers in a democratic society must convey to their pupils. ${ }^{\prime 76}$

The Court's reference to gender equality has been assessed as superficial considering that the judicial organ in Strasbourg did not elaborate on what it actually means to wear a headscarf. ${ }^{77}$ The ECtHR endorsed the finding in Dablab v. Switzerland in the case of Leyla Sabin $v$. Turkey by ruling that the ban on headscarves in Turkey was compatible with Article 9 ECHR. ${ }^{78}$ The University of İstanbul excluded a medical student wearing a veil from participating in exams and attending lectures, against which the individual initiated legal proceedings. After having outlined the different approaches as regards the headscarf question in a number of countries across Europe, the Court concluded that the ban interfered with the applicant's right to

73 P.W. Edge, 'The European Court of Human Rights and Religious Rights', 47 International and Comparative Law Quarterly (1998), 680, p. 680.

74 A. Wiesbrock, Legal Migration to the European Union (Martinus Nijhoff Publishers, Leiden 2010), p. 225; for an analysis of the 'headscarf-discussion' and relevant court decisions in Germany, see S. Berghahn, 'Deutschlands konfrontativer Umgang mit dem Kopftuch der Lehrerin', in: S. Berghahn and P. Rostock (eds.), Der Stoff aus dem Konflikte sind - Debatten um das Kopftuch in Deutschland, Österreich und der Schweiz (Transcript Verlag, Bielefeld 2009), pp. 33-72.

75 Karaduman $v$. Turkey (Application No. 16278/90) Decision of 3 May 1993, application declared inadmissible.

76 Dablab v. Switzerland (Application No. 42393/98) 15 February 2001, application declared inadmissible.

77 D. Lyon and D. Spini, 'Unveiling the Headscarf Debate', 12 Feminist Legal Studies (2004), 333, p. 338.

78 Leyla Şabin v. Turkey (Application No. 44774/98) Judgment of 10 November 2005, 41 EHRR 8 (the case was referred to the Grand Chamber). 
manifest her belief. ${ }^{79}$ However, the Court approved that the state's interference was justified since there was a legal basis for the interference in Turkish law; next, the impugned interference primarily pursued the legitimate aims of protecting the rights and freedoms of others and of protecting public order; and the interference was necessary in a democratic society and was proportionate. The Court emphasised that the freedom of thought, conscience and religion is one of the foundations of a "democratic society" within the meaning of the ECHR. In addition, the Court stressed the state's role as the neutral and impartial organiser of the exercise of various religions, faiths and beliefs and that this role was conducive to public order, religious harmony and tolerance in a democratic society. The interference in this case, the ECtHR continued, was in particular based on the two principles of secularism and equality; the principle of secularism "is undoubtedly one of the fundamental principles of the Turkish State which are in harmony with the rule of law and respect for human rights, may be considered necessary to protect the democratic system in Turkey." 80 The fact that the case was transferred to the Grand Chamber of the ECtHR demonstrates its importance. In its reasoning, the Grand Chamber essentially followed the Chamber's decision of 29 June 2004.

The final judgement was subject to criticism; complaints relate to an inadequate application of the margin of appreciation doctrine; a narrow interpretation of the freedom of religion; the imposition of "fundamentalist secularism"; and adverse implications on Muslim women's right to education. ${ }^{81}$ In Dogru v. France, it was ruled that the French authorities could lawfully ban a girl of the Islamic faith from a physical education class since she refused to take off her veil in that context. ${ }^{82}$ In general terms, the ECtHR has thus repeatedly highlighted the paramount importance of the principles of laïcité and pluralism in a democratic society which entail a wide margin of appreciation for states to interfere with Article 9 ECHR and, as a consequence, to curtail the display of religious symbols and the freedom of women wearing headscarves because of their religious conviction. ${ }^{83}$

\subsubsection{The Prohibition of Discrimination (Article 14 and Protocol No 12)}

The non-discrimination provision in Article 14 ECHR provides that "the enjoyment of the rights and freedoms set forth in this Convention shall be secured without discrimination on any ground such as sex, race, colour, language, religion, political or other opinion, national or social origin, association with a national minority, property, birth or other status. Article 14 ECHR is not a free standing provision in that it

\footnotetext{
$79 \quad$ Ibid., paras. 55-65; 75-78.

80 Ibid., paras. 84-123; for a discussion see C. Decker, 'Case Note on Leyla Şahin v. Turkey', 6 European Human Rights Law Review (2004), 672; T. Lindholm, 'The Strasbourg Court Dealing with Turkey and the Human Right to Freedom of Religion and Belief: A Critical Assessment in the Light of Recent Case Law (Leyla Sabin v. Turkey, 29 June 2004)', Strasbourg Consortium ( Strasbourg 2005).

81 A. Vakulenko, "Islamic Headscarves" and the European Convention On Human Rights: An Intersectional Perspective', 16 Social \& Legal Studies (2007), 183, p. 190.

82 Dogru v. France (Application No. 27058/05) Judgment of 4 March 2009; see also Köse and Others v. Turkey (Application No. 26625/02) Decision of 24 January 2006, application declared inadmissible. 
cannot be invoked alone but applies only in combination with other rights protected under the Convention; however, it does not presuppose the breach of such rights. ${ }^{84}$ Article 14 ECHR is supplemented by Protocol No 12 which has created a general and independent right of non-discrimination to remedy the shortcomings of the protection under Article $14 \mathrm{ECHR}$, taking into account that the principles of equality and non-discrimination are fundamental elements of international human rights law. Protocol No 12 covers the same (non-exhaustive) grounds as listed in Article 14 ECHR in respect of the enjoyment of any right set forth by law. The expression "any right set forth by law" relates to any legal right recognised in domestic or international law and to the acts or omissions of public authorities. ${ }^{85}$ As a result, Protocol No 12 provides greater protection than Article 14 ECHR which aims to ensure equal treatment within the ambit of rights contained in the Convention only.

The notion of discrimination has consistently been interpreted in the case law of the Court namely that a difference of treatment is discriminatory if it has no objective and reasonable justification, that is if it does not pursue a legitimate aim or if there is not a reasonable relationship of proportionality between the means employed and the aim sought to be realised. ${ }^{86}$ The Belgian Linguistic case specified that "the competent national authorities are frequently confronted with situations and problems which, on account of differences inherent therein, call for different legal solutions", as cited by the Court in its opinion on draft Protocol No $12 .{ }^{87}$ The Court added that this approach is further reflected in the margin of appreciation accorded to the national authorities in assessing whether and to what extent differences in otherwise similar situations justify a difference of treatment in law, in line with the subsidiary character of the Convention system. ${ }^{88}$ Protocol No 12 entered into force on 1 April 2005 but the number of ratifications is rather low. ${ }^{89}$

In order to test whether or not differential treatment or practice is justified under Article 14 ECHR, the Court examines the following questions according to C. Ovey and R.A.W. White:

- Does the discrimination at hand fall within the scope of a protected right?

- Is there a violation of the substantive provision?

- Is there different treatment?

- Does the treatment pursue a legitimate aim?

- Are the means employed proportionate to the legitimate aim?

Van Raalte v. The Netherlands (Application No. 20060/92) Judgment of 2 February 1997, 24 EHRR 503, para. 33.

G. Moon, 'The Draft Discrimination Protocol to the European Convention on Human Rights: A Progress Report', European Human Rights Law Review (2000), 49, pp. 51-52. Explanatory Report to Protocol No 12 to the Convention for the Protection of Human Rights and Fundamental Freedoms, para. 18

87 Opinion of the ECtHR on draft Protocol 12 to the European Convention on Human Rights (adopted at the plenary administrative session of the Court on 6 December 1999) of 5 January 2000, document number: 8608, para. 5; Belgian Linguistic Case (No. 2) (Application Nos. 1474/62; 1677/62; 1691/62; 1769/63; 1994/63; 2126/64) Judgment of 23 July 1968, 1 EHRR 252, para. 34.

88 Rasmussen v. Denmark. (Application No. 8777/79) Judgment of 28 November 1984, 7 EHRR 371, para. 40.

$89 \quad$ As of 13 November 2011, 17 state parties have ratified Protocol No 12. 
- Does the differential treatment go beyond a state's margin of appreciation? ${ }^{90}$

The ECtHR has adopted an extensive reading in determining whether the facts of a case relate to rights that are protected under the ECHR and made clear that the scope of the ECHR extends beyond the actual letter of the rights guaranteed. ${ }^{11}$ With regard to the appraisal as to whether there is a violation of a substantive provision, the Court explained in Chassagnou and Others v. France that "[W] here a substantive Article of the Convention has been invoked both on its own and together with Article 14 and a separate breach has been found of the substantive Article, it is not generally necessary for the Court to consider the case under Article 14 also, though the position is otherwise if a clear inequality of treatment in the enjoyment of the right in question is a fundamental aspect of the case." 92

In the East African Asians case, the Commission found a violation of Article 14 in conjunction with Article 8 ECHR because of sex discrimination. A UK law stipulated that the wife of a Commonwealth citizen was entitled to admission for settlement, whereas no corresponding rule existed for husbands of Commonwealth citizens. The UK government stated in those cases that the separation of husband and wife occurred voluntarily and that Article 8 guaranteed a right for a family to reside together at the place where the husband lawfully resided and not the wife. ${ }^{93}$

Discrimination on grounds of sex in relation to immigration issues was also at stake in Abdulariz, Cabales and Balkandali v. The United Kingdom in which the applicants complained that it was easier for a man settled in the United Kingdom than for a woman so settled to obtain permission for his or her non-national spouse to enter or remain in the country for settlement. ${ }^{94}$ This time the British authorities argued that the difference of treatment had the aim of limiting "primary immigration", and was justified by the need to protect the domestic labour market at a time of high unemployment. Moreover, the government pointed to the margin of appreciation enjoyed by state parties in this area and laid particular stress on what they described as a statistical fact: men were more likely to seek work than women, with the result that male immigrants would have a greater impact than female immigrants on the said market. ${ }^{95}$ The Court accepted that the UK had an interest in protecting its domestic labour market but held that the differential treatment was not justified; the British state was furthermore bound by the major goal in the member States of the

90 C. Ovey and R.A.W. White, The European Convention on Human Rights (4th edn. Oxford University Press, Oxford 2006), pp. 419-429.

91 EU Agency for Fundamental Rights, European Court of Human Rights and Council of Europe, Handbook on European Non-Discrimination Law (Vienna/Strasbourg 2011), pp. 61-63.

92 Chassagnou and Others v. France (Application Nos. 25088/94; 28331/95; 28443/95) Judgment of 29 April 1999, 29 EHRR 615, para. 89.

93 East African Asians v. The United Kingdom (Application Nos. 4403-19/70; 4422/70; 4423/70; 4434/70; 4443/70; 4476-8/70; 4486/70; 4501/70; 4526-30/70) Commission Decision of 14 December 1973, 3 EHRR 76, para. 232.

94 Abdulariz, Cabales and Balkandali v. The United Kingdom (Application Nos. 9214/80; 9473/81; 9474/81) Judgment of 28 May 1985, 7 EHRR 471.

95 Ibid., para. 75 . 
Council of Europe to advance the equality of the sexes. Therefore there was a violation of Article 14 together with Article 8 ECHR. ${ }^{96}$

Immigration control, by its very nature, can be considered discriminatory, the crucial question being whether the difference in treatment is justifiable. A. Wiesbrock placed strong reliance on the development of the case law on the Convention that became more nuanced, not to say changed in view of immigration and nationality aspects in the course of time. ${ }^{97}$ The Commission took the position in Agee v. The United Kingdom that the status of an alien would, in itself, provide reasonable and objective justification for his being subject to different treatment in the field of immigration law to than persons with UK nationality. ${ }^{98}$ Equally, the Court dismissed the complaint of a Moroccan national in C. v. Belgium who alleged to be a victim of discrimination on the grounds of nationality and race. The applicant was deported by the Belgian authorities because he had been convicted of criminal damage, unlawful possession of drugs and conspiracy, although he had been a long-term resident. The Moroccan applicant maintained that, in breach of Article 14 of the Convention, taken in conjunction with Article 8, his deportation amounted to less favourable treatment than was accorded to criminals who, as EU citizens, were protected against such a measure in Belgium. The Court followed the Belgian government's view by ruling that such preferential treatment was based on an objective and reasonable justification, given that the EU Member States formed a special legal order, which has, in addition, established its own citizenship. ${ }^{99}$

However, only one month later, the ECtHR indicated in Gaygusuz v. Austria that although states enjoy a certain margin of appreciation in assessing whether and to what extent differences in otherwise similar situations justify a different treatment, very weighty reasons would have to be put forward before the Court for it to rule that a difference of treatment, based exclusively on the ground of nationality, would be compatible with the Convention. ${ }^{100}$ The applicant had started proceedings against Austria because he was denied an unemployment benefit on the basis of his nationality. The Court deemed the refusal of payment by the Austrian state as a breach of Article 14 ECHR taken in conjunction with Article 1 of Protocol No 1. This approach has been confirmed in later cases dealing with social security benefits. ${ }^{101}$ Yet, scholars have opined that Article 14 ECHR in conjunction with Protocol No 12 has not suggested "the development of a generic equality law under

\footnotetext{
$96 \quad$ Ibid., paras. $78-83$.

97 A. Wiesbrock, Legal Migration to the European Union (Martinus Nijhoff Publishers, Leiden 2010), p. 227-229.

98 Agee v. The United Kingdom (Application No. 7729/76) Commission Decision of 17 December 1976, para. 30, application declared inadmissible.

99 C. v. Belgium (Application No. 21794/93) Judgment of 7 August 1996, paras. 37-38.

100 Gaygusuz v. Austria (Application No. 17371/90) Judgment of 16 September 1996, 23 EHRR 364, para. 42.

101 See Kona Poirrez v. France (Application No. 40892/98) Judgment of 30 December 2003, 40 EHRR 34; Okpisz v. Germany (Application No. 59140/00) Judgment of 25 February 2006, 42 EHRR 32.
} 
the Convention" in the near future considering the lack of signatures and ratifications. ${ }^{102}$

\subsection{The EU Charter of Fundamental Rights}

Under the Treaty of Lisbon, the Union recognises the rights, freedoms and principles set out in the EU Charter of Fundamental Rights (EU Charter) which adds considerably to the fundamental rights' protection in the EU. ${ }^{103}$ The EU Charter acknowledges that the Union is founded on the indivisible, universal values of human dignity, freedom, equality and solidarity and that it is based on the principles of democracy and the rule of law. ${ }^{104}$ The Preamble to the Charter moreover sets forth its principle aim: "[T] his Charter reaffirms [...] the rights as they result, in particular, from the constitutional traditions and international obligations common to the Member States, the European Convention for the Protection of Human Rights and Fundamental Freedoms, the Social Charters adopted by the Union and by the Council of Europe and the case law of the Court of Justice of the European Union and of the European Court of Human Rights." 105 Two aspects are of importance here: first, the Charter reaffirms existing rights resulting from traditions and obligations and consequently it does not create any new rights; second, the legal sources of the Charter are listed, that is to say, the national constitutions of the Member States, the ECHR, the case law of the Court of Justice and the ECtHR.

The legal effect that the EU Charter unfolds is laid down in Article 6(1) TEU that speaks of the Charter as having "the same legal value as the Treaties" but, even before the entry into force of the Lisbon regime, the Court and the Court of First Instance (now the General Court) referred to the Charter for interpretative purposes. ${ }^{106}$ In many instances the Court of Justice has made references to the Charter after it became legally binding in December of 2009. ${ }^{107}$ Nine years earlier, on 7 December 2000, the Commission, the Council and the EP had solemnly proclaimed the EU Charter in Nice. The EU Charter is subdivided into seven Titles, including Title I on dignity (Articles 1 to 5); Title II on freedoms (Articles 6 to 19); Title III on equality (Articles 20 to 26); Title IV on solidarity (Articles 27 to 38); Title $\mathrm{V}$ on citizens' rights (Articles 39 to 46); Title VI on justice (Articles 47 to 50); and Title VII on general provisions governing the interpretation and application of the Charter (Articles 51 to 54). The EU Charter is conducive to the protection of migrants as its scope of application relates to - except for Title V and some other provisions that are reserved for Union citizens - everyone covering third-country

102 C. Ovey and R.A.W. White, The European Convention on Human Rights (4th edn. Oxford University Press, Oxford 2006), p. 431.

103 Charter of Fundamental Rights of the European Union, OJ C 83, 30 March 2010, p. 389.

104 See Recital 2 of the Preamble to the EU Charter.

105 See Recital 5 of the Preamble to the EU Charter; Case C-540/03 EP v. Council [2006] I5769 , para. 38.

106 See Case C-540/03 EP v. Council [2006] I-5769, para. 58; Case C-438/05 Viking [2007] ECR I-10779, paras. 43-44; Case T-77/01 Territorio Histórico de Álava [2002] ECR II-81, para. 35; Case T-54/99 max.mobil Telecommunikation [2002] ECR II-313, para. 48.

107 See for instance Case C-555/07 Kücükedeveci [2010] ECR I-00365, para. 22; Case C578/08 Chakroun [2010] ECR I-01839, para. 44; Case C-571/07 Blanco Pérez [2010] ECR I-04629, para. 65. 
nationals and Union citizens alike. The specific provisions that are of importance for migrants are discussed in Parts V to VII.

Article 51(1) of the Charter provides that the provisions of the document are addressed to the institutions, bodies, offices and agencies of the Union with due regard for the principle of subsidiarity and to the Member States only when they are implementing Union law. Article 51(2) of the Charter stipulates that the Charter does not extend the field of application of EU law beyond the powers of the Union, and it does not establish any new power or task for the Union, or modify powers and tasks as defined in the Treaties. The Court of Justice emphasised, in this respect, that it is called upon to interpret, in the light of the Charter, the law of the EU within the limits of the powers conferred on it..$^{108}$

Article 52 of the EU Charter specifies the scope and interpretation of the rights and principles. It is determined that:

- any limitation on the exercise of the rights and freedoms recognised by this Charter must be provided for by law and respect the essence of those rights and freedoms. Subject to the principle of proportionality, limitations may be made only if they are necessary and genuinely meet objectives of general interest recognised by the Union or the need to protect the rights and freedoms of others (Article 52(1) EU Charter);

- rights recognised by this Charter for which provision is made in the Treaties shall be exercised under the conditions and within the limits defined by those Treaties (Article 52(2) EU Charter).

As regards the interpretation of the EU Charter, it is laid down that:

- in so far as this Charter contains rights which correspond to rights guaranteed by the ECHR, the meaning and scope of those rights shall be the same as those laid down by the said Convention. This provision shall not prevent Union law providing more extensive protection (Article 52(3) EU Charter);

- in so far as this Charter recognises fundamental rights as they result from the constitutional traditions common to the Member States, those rights shall be interpreted in harmony with those traditions (Article 52(4) EU Charter).

Article 53 of the Charter makes clear that the existent level of protection with respect to human rights and fundamental freedoms as guaranteed by other relevant legal sources, in their respective fields of application, shall be upheld in the sense that nothing in the Charter shall be interpreted as restricting or adversely affecting such rights and freedoms. These sources comprise EU law, international law, international agreements to which the Union or all the Member States are party, including the ECHR and the Member States' constitutions. The Court of Justice dealt with the correlation of the EU Charter and the ECHR in Dereci and Others in which it instructed the national court to decide whether the situation was covered by EU law,

108

Case C-400/10 PPU McB [2010] ECR I-08965, para. 51; see also Joined Cases C483/09 and C-1/10 Gueye and Salmerón Sánchez [2011] Judgment of 15 September 2011, not yet reported, para. 69 . 
which would entail the application of the Charter, or whether the situation was fell outside the scope of EU law, which would imply the application of the ECHR. ${ }^{109}$

The British and the Polish governments' position as regards the EU Charter are laid down in Protocol No 30 to the Treaty of Lisbon. ${ }^{110}$ Article 1(1) of Protocol No 30 states that the Charter does not extend the ability of the Court of Justice, or any court of Poland or of the UK, to find that the laws, regulations or administrative provisions, practices or actions of Poland or of the UK are inconsistent with the fundamental rights, freedoms and principles that it reaffirms. Article 1(2) of Protocol No 30 further specifies that, for the avoidance of doubt, nothing in Title IV of the Charter creates justiciable rights applicable to Poland or the UK, except in so far as Poland or the UK has provided for such rights in its national law. Finally, Article 2 of Protocol No 30 clarifies that, to the extent that a provision of the Charter refers to national laws and practices, it shall only apply to Poland or the UK to the extent that the rights or principles that it contains are recognised in the law or practices of Poland or of the UK. The question arises as to what added value these provisions have, seeing that the TEU and the EU Charter already stipulate that the provisions of the Charter shall not extend, in any way, the competences of the Union as defined in the Treaties. ${ }^{111}$ A. Dashwood commented that the purpose of the two provisions is interpretative only: "to state unequivocally, and with the force of primary law, what ought to be obvious from a reading of the Charter in the light of the horizontal provisions and of the official Explanations." 112

\subsection{The General Principles of EU Law}

In 1965, the Court of Justice rejected in Sgarlata and Others the applicants' argument that a restrictive reading of Article 173 EEC would deprive individuals of all protection by the courts, both under Community law and under national law, which would be contrary to the fundamental principles governing all the Member States. ${ }^{113}$ In that case, the applicants claimed that a calculation fixing reference prices for citrus fruits was of direct and individual concern to them within the scope of Article 173 EEC. In contrast to this decision, the Court made a "u-turn" in 1969 in view of applying fundamental principles acknowledged in the national legal systems of the Member States in the ruling of Stauder, dealing with the question of whether making the sale of butter, at a reduced price, to beneficiaries under welfare schemes, dependent on revealing the beneficiaries' names is compatible with the general principles of Community law. ${ }^{114}$ The Court concluded that the provision at issue contained nothing capable of prejudicing the fundamental human rights enshrined in

109 Case C-265/11 Dereci and Others [2011] Judgment of 15 November 2011, not yet reported, paras. 72-73; the case concerned the right of residence of third-country family members of Union citizens.

110 Protocol to the Treaty of Lisbon No 30 to the application of the Charter of Fundamental Rights to the European Union to Poland and to the United Kingdom.

111 See Art. 6(1) TEU and Art. 51(2) of the EU Charter.

112 A. Dashwood, 'The Paper Tiger that is No Threat to Britain's Fundamental Rights', Parliamentary Brief, 10 March 2008, available at: <http://www.thepolitician.org/articles/the-paper-tiger-646.html>, last accessed on 21 November 2011.

113 Case 40/64 Sgarlata and Others [1965] ECR 215.

114 Case 29/69 Stauder [1969] ECR 419. 
the general principles of Community law and protected by the Court. ${ }^{115}$ The Court availed itself of the opportunity to refine its stance on general principles of Community law in subsequent legal disputes referred to it. In the landmark case of Internationale Handelsgesellschaft, the Luxembourg Court held that "respect for fundamental rights form an integral part of the general principles of Community law protected by the Court of Justice" and that "the protection of such rights, whilst inspired by the constitutional traditions common to the Member States, must be ensured within the framework of the structure and objectives of the Community."'116

In Nold the Court confirmed its view that fundamental rights form an integral part of the general principles of Community law; moreover, it stated that, in safeguarding these rights, it is bound to draw inspiration from the Member States' constitutional traditions and from international human rights treaties to which the Member States are signatories. ${ }^{117}$ The general principles of Community law comprise thus two distinct elements, that is to say, the constitutional traditions as existent in the Member States' national legal systems and international human rights conventions according to the Court. In the past, far more references were made, however, to international treaties than to national constitutional traditions. This imbalance was regarded as "obvious" considering the difficulty faced by the Court to ascertain a tradition in the form of a common right in case that a certain right is not reflected in every single Member State constitution. In addition, it has been observed that "the fear of compromising the doctrinal supremacy of EU law by appearing to defer to a particular national constitutional provision has animated the ECJ's case law ever since Costa v. ENEL." 118

In respect to international human rights treaties, the Court has granted the ECHR a special status as a source of the general principles of Community law. ${ }^{119}$ This is also mirrored within the ambit of the Treaty of Lisbon. Article 6(3) TEU determines that fundamental rights, as guaranteed by the ECHR and as they result from the constitutional traditions common to the Member States, constitute general principles of the Union's law. The Court has alluded to other international human rights standards to a lesser extent; these include the International Covenant on Civil and Political Rights (ICCPR), ${ }^{120}$ the European Social Charter, ${ }^{121}$ the International

\footnotetext{
115 Ibid., para. 7.

116 Case 11/70 Internationale Handelsgesellschaft [1970] ECR 1125, para. 4.

117 Case 4/73 Nold [1974] ECR 491, para. 13; the Court has affirmed this approach in Case 44/79 Hauer [1979] ECR 3727, para. 15.

118 P. Craig and G. De Búrca, EU Law: Text, Cases, and Materials (4th edn. Oxford University Press, Oxford 2008), p. 386; Case 6/64 Costa v. ENEL [1964] ECR 585.

119 Case 36/75 Rutili [1975] ECR 1219, para. 32; Case 222/84 Jobnston [1986] ECR 1651, para. 18; many other cases followed that contained a reference to the ECHR, see Part III, Section 2.1 on the ECHR. Case C-374/87 Orkem [1989] ECR 3283, para. 31; Case C-249/96 Grant [1998] ECR I621, para. 44.

121 Case 199/77 Defrenne [1978] ECR 1365, para. 28; see also Opinion of AG Stix-Hackl in Case C-459/99 MRAX [2002] ECR I-6591, para. 26.
} 
Convention on the Rights of the Child, ${ }^{122}$ the 1951 UN Convention relating to the Status of Refugees, ${ }^{123}$ but also the principle of ius cogens. ${ }^{124}$

The legal bases of some general principles of EU law can be found directly in the Treaties, such as the principle of subsidiarity and the principle of proportionality stipulated in Article 5 TEU. The principle of subsidiarity requires the Union to act in areas which do not fall within its exclusive competence only if and in so far as the objectives of the proposed action cannot be sufficiently achieved by the Member States, either at the central level or at the regional and local level, but can rather, by reason of the scale or effects of the proposed action, be better achieved at the Union level. ${ }^{125}$ Under the principle of proportionality, the content and form of Union action shall not exceed what is necessary to achieve the objectives of the Treaties. ${ }^{126}$ The principle of sincere cooperation laid down in Article 4(3) TEU has led the Court to create the principles of direct effect and supremacy of Community law. ${ }^{127}$

The principle of non-discrimination on grounds of nationality today is enshrined in Article 18 TFEU and Article 21(2) of the EU Charter. The latter rule stipulates that discrimination on grounds of nationality shall be prohibited "within the scope of application of the Treaties and without prejudice to any of their specific provisions": discrimination on the basis of nationality, as a result, is only permitted if in conformity with EU law. ${ }^{128}$ The Treaty of Amsterdam inserted Article 19 TFEU that has allowed the EU to adopt legislation in order to combat discrimination based on sex, racial and ethnic origin, religion or belief, disability, age or sexual orientation. Based on Article 19 TFEU, two directives were enacted, Council Directive 2000/43/EC on equal treatment in relation to race and Council Directive $2000 / 78 / E C$ on equal treatment in employment and occupation. ${ }^{129}$ In the famous case of Mangold, the Court held that the principle of non-discrimination on grounds of age must be regarded as a general free-standing principle of Community law, and it assigned the national court the task of guaranteeing the full effectiveness of this principle by setting aside any provision of national law which might conflict with Community law, even where the period prescribed for transposition of that Directive

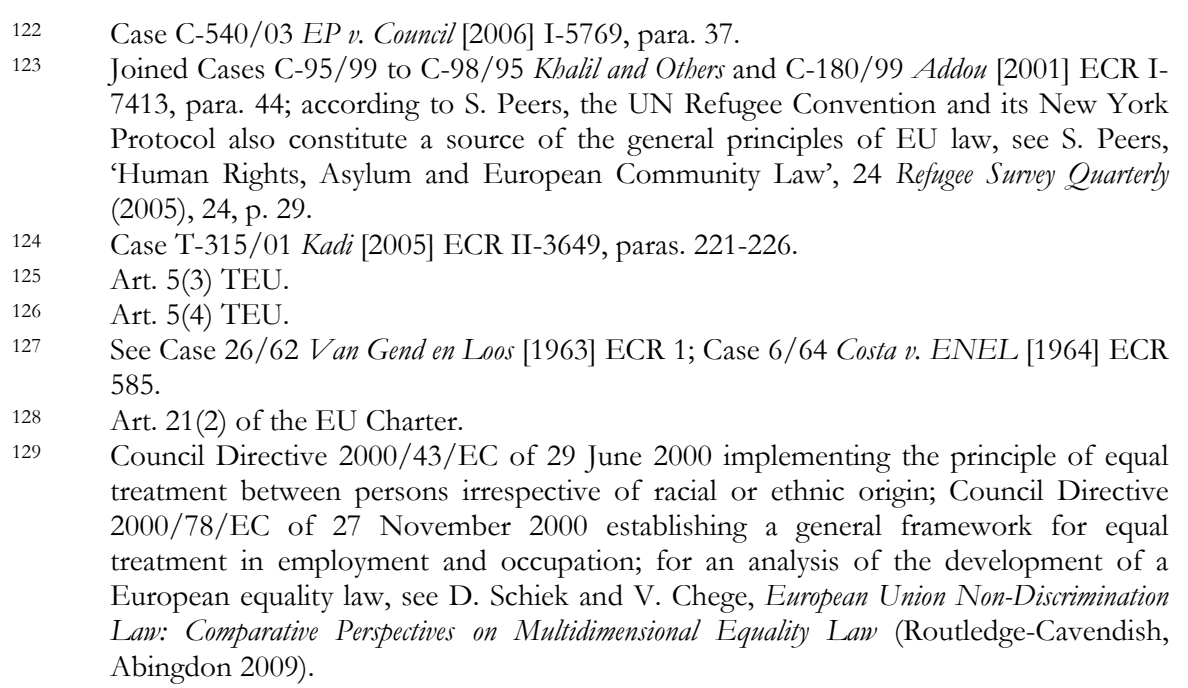


has not yet expired. ${ }^{130}$ The applicant had challenged the compatibility of German legislation, which lowered the minimum age of fixed-term employment contracts from 58 to 52 years without justification to create a more flexible employment scheme, with the equal treatment framework Directive. ${ }^{131}$ The scope of the principle of non-discrimination on grounds of age was confirmed and clarified in Kücükedeveci. ${ }^{132}$ Next, the EU Charter now provides for a general right to non-discrimination in Article 21(1) according to which "any discrimination based on any ground such as sex, race, colour, ethnic or social origin, genetic features, language, religion or belief, political or any other opinion, membership of a national minority, property, birth, disability, age or sexual orientation shall be prohibited."

Another general principle of EU law is the principle of legal certainty which demands that EU legislation must be clear and predictable. ${ }^{133}$ Central to the principle of legal certainty is the principle of legitimate expectations that sets strict limitations on the retroactive application of EU law: it has been pointed out that " $[\mathrm{L}]$ egal certainty requires the rules which apply at a given time to be clear and precise for the benefit of the individual, [whereas] [P]rotection of legitimate expectations [...] requires public authorities to exercise their powers over a period of time in such as a way as to ensure that situations and relationships lawfully created under Community law are not affected in a manner which could not have been foreseen by a diligent person."'134

\subsection{Other Council of Europe Standards}

\subsubsection{The European Convention on Social and Medical Assistance}

The European Convention on Social and Medical Assistance (ECSMA) was signed in 1953 and entered into force in $1954 .{ }^{135}$ Under this treaty, the state parties undertake to ensure that nationals of the other parties who are lawfully present in any part of its territory and who are without sufficient resources shall be entitled, in the same way as its own nationals and on the same conditions, to social and medical assistance. ${ }^{136}$ Importantly for migrants, Article 6(a) ECSMA enshrines that the party in whose

130 Case C-144/04 Mangold [2005] ECR I-9981, paras. 75 and 78; see case notes: E. Muir, 'Enhancing the Effects of Community Law on National Employment Policies: The Mangold Case', European Law Review (2006), 879; D. Schiek, 'The ECJ Decision in Mangold: A Further Twist on Effects of Directives and Constitutional Relevance of Community Equality Legislation', 35 Industrial Law Journal (2006), 329.

131 Council Directive 2000/78/EC of 27 November 2000 establishing a general framework for equal treatment in employment and occupation.

Case C-555/07 Kücükdeveci [2010] ECR I-00365; see M. de Mol, 'Kücükdeveci: Mangold Revisited - Horizontal Direct Effect of a General Principle of EU Law', 6 European Constitutional Law Review (2010), 293.

133 Joined Cases 212-217/80 Salumi [1981] ECR 2735, para. 10.

134 T. Tridimas, The General Principles of EU Law (2nd edn. Oxford University Press, Oxford 2006), p. 262 referring to Case C-63/93 Duff and Others [1996] ECR I-569; see also J. Raitio, 'The General Principle of Legal Certainty as a General Principle of EU Law', in: U. Bernitz, J. Nergelius and C. Cardner (eds.), General Principles of EC Law in a Process of Development (Kluwer Law International, Alphen aan den Rijn 2008), pp. 47-73. European Convention on Social and Medical Assistance CETS No.: 014 of 11 December 1953.

136 Art. 1 ECSMA. 
territory a national of another party is lawfully resident shall not repatriate that national on the sole ground that he is in need of assistance; the legal instrument secures thus that repatriation only takes place when it is really necessary and does not violate any humanitarian considerations. ${ }^{137}$ The ECSMA counts 18 ratifying parties. ${ }^{138}$

\subsubsection{The European Convention on Establishment}

The European Convention on Establishment (ECE) was concluded in 1955 and became effective in 1965 when five state parties ratified the legal instrument; to date, however, the ECE has not attracted much ratification. ${ }^{139}$ The Preamble to the ECE and the explanatory report illuminate that common rules ensuring fair and uniform treatment accorded to nationals of each contracting party in the territory of the others further the achievement of greater unity between the Council of Europe members. ${ }^{140}$ Equality of treatment between the nationals of one party and those of another forms the key principle of the ECE; hence, the ECE's ratione personae is limited to nationals of Council of Europe states that have ratified the latter Convention. ${ }^{141}$

The ECE consists of eleven chapters that inter alia set out rules regarding entry, residence and expulsion (Chapter I); the exercise of private rights (Chapter II); judicial and administrative guarantees (Chapter III); gainful occupations (Chapter IV); individual rights (Chapter V); taxation, expropriation and nationalisation (Chapter VI); the establishment of a standing committee (Chapter VII); and the settlement of disputes (Chapter X). Article 1 ECE specifies that each contracting party shall (merely) facilitate the entry into its territory by nationals of the other parties for the purpose of temporary visits and shall permit them to travel freely within its territory except when this would be contrary to ordre public, national security, public health or morality. ${ }^{142}$ Moreover, each state party shall facilitate the prolonged or permanent residence in its territory of nationals of the other parties. ${ }^{143}$ Article 3 ECE secures equal treatment in respect of the possession and exercise of private rights, whether personal rights or rights relating to property of nationals of one contracting state in the territory of another contracting state. Nationals of state parties enjoy full legal and judicial protection of their persons and property and of their rights and interests, in

137 J. Nickless, European Code of Social Security: A Short Guide (Council of Europe Publishing, Strasbourg 2003), p. 28.

138 As of 16 November 2011.

139 European Convention on Establishment CETS No.: 019 of 13 December 1955; as of 14 November 2011, 12 states are contracting parties to the ECE.

140 Explanatory Report of the European Convention on Establishment CETS No.: 019 of 13 December 1955

141 R. Cholewinski, Migrant Workers in International Human Rights Law: Their Protection in Countries of Employment (Clarendon Press, Oxford 1997), p. 213.

142 The Protocol to the ECE makes clear that the grounds for the exclusion of nationals of one party from the territory of another, including ordre public, national security, public health or morality, as well as the circumstances which constitute a threat to national security or an offence against ordre public or morality shall be judged by national criteria. Importantly, the concept of "ordre public" is to be understood in the wide sense generally accepted in continental countries (Section I and III of the Protocol to the ECE). 
the territory of another party and they shall have access to the competent judicial authorities and legal assistance in the same manner as the nationals. ${ }^{144}$ Contracting parties shall authorise nationals of the other Parties to engage in its territory in any gainful occupation (employed and self-employed) on an equal footing with its own nationals, unless the said Contracting Party has cogent economic or social reasons for withholding the authorisation in accordance with Article 10 ECE. Nationals of any contracting party, lawfully residing in the territory of any other Party, shall be authorised to engage in any gainful occupation on an equal footing with nationals of the latter party, in conformity with Article 12 ECE, provided they comply with one of the following conditions:

- they have been lawfully engaged in a gainful occupation in that territory for an uninterrupted period of five years;

- they have lawfully resided in that territory for an uninterrupted period of ten years;

- they have been admitted for permanent residence.

A standing committee that comprises of representatives of the state parties to the ECE makes proposals for the Convention's practical implementation and arranges for the publication of a periodical report containing all information regarding the laws and regulations of the parties in respect of matters provided for in the ECE. ${ }^{145}$ Any disputes which may arise between the Contracting Parties concerning the interpretation or the application of this Convention are to be submitted to the ICJ by special agreement or by application by one of the parties to the dispute, unless the parties agree on a different method of peaceful settlement. ${ }^{146}$ The ECE does not provide a right for petition for individuals in cases of alleged violations of rights contained in the ECE. ${ }^{147}$ R. Plender also attached significance to the fact that the ECE has influenced the rules on the freedom of movement of persons within the EEC framework at that time. He pointed out that especially the regime centering on the limitations on grounds of public policy, public security and public health in the EEC Treaty, as well as the rule present in Council Directive 64/221 that lays down that the right of expulsion may only be exercised in individual cases seemed to be inspired by the formulation of the ECE. ${ }^{148}$ Thus, even though the movement rules under the ECE fall short of the elaborated free movement regime in the EU, the former have had an important impact on the development of the latter. ${ }^{149}$

\footnotetext{
144 Art. 7 ECE.

145 Art. 24 ECE.

146 Art. 31 ECE.

147 R. Plender, International Migration Law (Kluwer Academic Publishers, Dordrecht 1988), pp. 236-237.

148 Ibid., p. 238; Council Directive 64/221/EEC of 25 February 1964 on the coordination of special measures concerning the movement and residence of foreign nationals which are justified on grounds of public policy, public security or public health.

149 As emphasised by R. Cholewinski, Migrant Workers in International Human Rights Law: Their Protection in Countries of Employment (Clarendon Press, Oxford 1997), p. 214.
} 


\subsubsection{The European Social Charter}

The European Social Charter (ESC) was drafted in 1961 under the auspices of the Council of Europe as a counterpart to the International Covenant on Economic, Social and Cultural Rights (ICESCR) of the UN framework to guarantee social and economic human rights in Europe and it entered into force in $1965 .{ }^{150}$ Against the backdrop of the ILO's active participation in the drafting of the ESC, it is not surprising that the ILO's standards are reflected in the document. ${ }^{151}$ Despite "extensive jurisprudence" on the ESC, the latter treaty has led "a twilight existence" as "various factors have conspired to prevent the Charter realising its full potential [most of which] result from a lack of political will." 152 In 1996, the ESC was revised (effective since 1 July 1999) with a view to address the deficiencies; the substantive review aimed at improving the effectiveness of the Charter in general and the supervisory machinery in particular. ${ }^{153}$ The Amending Protocol provides also for oral hearings and the inclusion of observers of employers' and trade union organisations in the Governmental Committee; furthermore, under the Amending Protocol it is the Committee of Independent Experts only that is competent to interpret the Charter and decide on questions of compliance. In order to become effective, all contracting states have to ratify the Amending Protocol. ${ }^{154}$ The Protocol to the ESC Providing for a System of Collective Complaints entered into force in $1998 .{ }^{155}$ Importantly, the revised ESC introduced a general prohibition of discrimination in its Article E laying down that "[T] he enjoyment of the rights set forth in this Charter shall be secured without discrimination on any ground such as race, colour, sex, language, religion, political or other opinion, national extraction or social origin, health, association with a national minority, birth or other status." The revised ESC today has 31 ratifications. ${ }^{156}$

On the basis of Part I of the ESC, the parties accept to create conditions in which the rights and principles included in Part II may be effectively realised. Part II of the ESC sets out a broad array of rights to be enjoyed by nationals of the contracting parties, many of which are also applicable to migrant workers, in relation to employment

150 European Social Charter CETS No.: 035 of 18 October 1961/CETS No.: 163 of 3 May 1995 (revised); D. Harris, 'A Fresh Impetus for the European Social Charter', 41 International and Comparative Law Quarterly (1992), 659.

151 ILO, 'The European Social Charter and International Labour Standards', 84 International Labour Review (1961), 354.

152 D. Harris, 'A Fresh Impetus for the European Social Charter', 41 International and Comparative Law Quarterly (1992), 659, p. 659.

153 Decision of the Committee on the European Social Charter, 449th meeting (November-December 1990); see Explanatory Report of the European Social Charter CETS No.: 163 of 3 May 1995 (revised), para. 2.

154 See Protocol Amending the European Social Charter; for its entry into force, all contracting states have to ratify the Amending Protocol in accordance with its Art. 8; D. Harris, 'A Fresh Impetus for the European Social Charter', 41 International and Comparative Law Quarterly (1992), 659, pp. 662-672; the absence of a tripartist structure within the ambit of the ESC was pointed out by B. Hepple, 'European Social Charter', 17 Industrial Law Journal (1988), 124, p. 125.

155 See Additional Protocol to the European Social Charter Providing for a System of Collective Complaints.

156 As of 15 November 2011. 
conditions, education, health, social security, social and medical assistance, social and legal protection, non-discrimination and housing. Generally speaking, the ESC's scope of application extends to foreigners only in so far as they are nationals of other parties lawfully resident or working regularly within the territory of another party. ${ }^{157}$ Articles 18 and 19 ESC specifically address the protection and assistance of migrant workers and their family members. The Secretariat of the ESC declared that "[T]he purpose of Articles 18 and 19 is to require of Parties certain minimum safeguards for migrant workers and their families."158 Article 18 ESC stipulates the right to engage in any gainful occupation in the territory of another party; Article 19 ESC sets out the right to protection and assistance of migrant workers and their family members.

Under the ESC, migrants enjoy a number of rights according to the ESC's Secretariat. ${ }^{159}$ State parties shall ensure:

- the right to engage in any gainful occupation in the territory of any other Party for workers, self-employed persons and job seekers (Articles 1 and 18(4) ESC); moreover, states agreed to apply existing regulations in a spirit of liberality, to simplify existing formalities and to reduce or abolish chancery dues and other charges payable by foreign workers or their employers and to liberalise, individually or collectively, regulations governing the employment of foreign workers (Articles 18(1), (2) and (3) ESC); loss of employment must not lead to the cancellation of the residence permit but states are required to extend the validity of the residence permit to provide sufficient time for a new job to be found;

- adequate and free services providing reliable information on the necessary formalities and living and working conditions for migrant workers, as well as the protection against misleading propaganda relating to emigration and immigration (Article 19(1) ESC);

- the facilitation of the departure, journey and reception of migrant workers and their families, such as the issuance of travel documents and the provision of appropriate services for health, medical attention and good hygienic conditions during the journey (Article 19(2) ESC);

See Paragraph 1 of the Appendix to the European Social Charter (revised) on its scope in terms of persons protected that reads "[W]ithout prejudice to Article 12, paragraph 4, and Article 13, paragraph 4, the persons covered by Articles 1 to 17 and 20 to 31 include foreigners only in so far as they are nationals of other Parties lanfully resident or working regularly within the territory of the Party concerned, subject to the understanding that these articles are to be interpreted in the light of the provisions of Articles 18 and 19. This interpretation would not prejudice the extension of similar facilities to other persons by any of the Parties."

158 See "Migrants' Rights in the European Social Charter", information document prepared by the Secretariat of the ESC of 22 June 2006 (not binding on the European Committee of Social Rights), available at: <http://www.coe.int/t/dghl/monitoring/socialcharter/Theme $\% 20$ factsheets/FactsheetMigrants2008_en.pdf $>$, last accessed on 15 November 2011.

159 As indicated by the Secretariat of the ESC in "Migrants' Rights in the European Social Charter", information document of 22 June 2006, pp. 5-13, available at: <http://www.coe.int/t/dghl/monitoring/socialcharter/Theme\%20factsheets/Factshe etMigrants2008_en.pdf $>$, last accessed on 15 November 2011. 
- the promotion of cooperation between social services, public and private, in emigration and immigration countries (Article 19(3) ESC);

- equal treatment for migrant workers lawfully within their territories in respect of remuneration and other employment and working conditions, membership of trade unions and enjoyment of the benefits of collective bargaining and accommodation (Article 19(4) ESC);

- equal treatment for migrant workers lawfully within their territories regarding employment taxes, dues or contributions payable in respect of employed persons (Article 19(5) ESC);

- equal treatment for migrant workers lawfully within their territories in respect of legal proceedings relating to matters referred to in Article 19 (Article 19(7) ESC);

- the facilitation of the family reunion of a foreign worker permitted to establish himself in the territory (Article 19(6) ESC); the term "family of a foreign worker" is understood to mean at least the worker's spouse and unmarried children, as long as the latter are considered to be minors by the receiving state and are dependent on the migrant worker (see Appendix to the ESC on Article 19(6) ESC);

- the protection of workers lawfully residing within their territories against expulsion unless they endanger national security or offend against public interest or morality (Article 19(8) ESC);

- the transfer of the earnings and savings of migrant workers within legal limits (Article 19(9) ESC);

- the protection and assistance provided for in Article 19 for self-employed migrants insofar as such measures apply (Article 19(10) ESC);

- language teaching to migrant workers and their families of the national language of the receiving state and the teaching of the migrant worker's mother tongue to the children of the migrant worker, as far as practicable (Articles 19(11) and (12) ESC).

\subsubsection{The European Code of Social Security and the European Convention on Social} Security

Both legal instruments, the European Code of Social Security and ECSS, envisage facilitating social progress among the Council of Europe members. The European Code of Social Security, together with an annexed Protocol, has been open for signature since 1964 and came into force four years later, in 1968.160 The Code sets out minimum standards for national social security systems which are higher than those embodied in ILO Convention No 102 concerning Minimum Standards of Social Security. ${ }^{161}$ The Code has been described as a "menu" from which states can pick and choose the rules they wish to adhere to. ${ }^{162}$ The detailed provisions of the Code concern a broad range of benefits, itemised in Parts II to X, covering inter alia medical care, as well as sickness, unemployment and old-age benefits. Each part

160 European Code of Social Security CETS No.: 048 of 16 April 1964 and the Protocol to the European Code of Social Security; as of 16 November 2011, the European Code of Social Security has 21 ratifications.

161 ILO Convention No. 102 concerning Minimum Standards of Social Security of 28 June 1952.

162 J. Nickless, European Code of Social Security: A Short Guide (Council of Europe Publishing, Strasbourg 2003), p. 11. 
specifies the exact material and personal scope. Part XI defines the rules on the calculation of periodical payments. The 1990 revision of the Code is said to satisfy three basic goals, namely to raise the minimum standards, to prescribe greater flexibility and to promote a gender neutral approach. ${ }^{163}$

While the Code provides for substantive provisions that aim at harmonising the parties' legislation in the field of social security, the ECSS, signed in 1972 and effective since 1977, has the aim to multilaterally coordinate national social security law. ${ }^{164}$ ECSS is permeated by the spirit of the 1953 European Interim Agreements on Social Security, equally modelled by the Council of Europe but is also influenced by EEC Council Regulation No 3 on social security for migrant workers. ${ }^{165}$ The Preamble to the ECSS states that the Contracting Parties to the Code shall endeavour to conclude a special instrument governing questions relating to social security for foreigners and migrants, particularly with regard to equality of treatment with their own nationals and to the maintenance of acquired rights and rights in course of acquisition. Next, the Preamble affirms the principle that the benefits under social security legislation should be maintained despite any change of residence by the protected persons within the territories of the contracting parties.

The ECSS is applicable to persons who are or have been subject to the legislation of one or more of the contracting parties and are nationals of a contracting party, or are refugees or stateless persons resident in the territory of a contracting party, as well as to the members of their families and their survivors. ${ }^{166}$ As far as the material coverage is concerned, the ECSS applies to all legislation governing the following branches of social security: sickness and maternity benefits; invalidity benefits; oldage benefits; survivors' benefits; benefits in respect of occupational injuries and diseases; death grants; unemployment benefits; family benefits, including contributory and non-contributory benefits. ${ }^{167}$ The ECSS is complemented by a Supplementary Agreement for the Application of the ECSS, which lays down rules on the

163 European Code of Social Security CETS No.: 139 of 6 November 1990 (revised), as of 16 November 2011 the revised Code has not entered into force; see J. Nickless, European Code of Social Security: A Short Guide (Council of Europe Publishing, Strasbourg 2003), p. 18.

164 European Convention on Social Security CETS No.: 078 of 14 December 1972; see J. Nickless, European Code of Social Security: A Short Guide (Council of Europe Publishing, Strasbourg 2003), pp. 24-29.

165 European Interim Agreement on Social Security Schemes Relating to Old Age, Invalidity and Survivors CETS No.: 012 of 11 December 1953; European Interim Agreement on Social Security other than Schemes for Old Age, Invalidity and Survivors CETS No.: 013 of 11 December 1953; Council Regulation (EEC) No 3 of 16 December 1958 on social security for migrant workers; see Paragraphs 1 and 4 of the Explanatory Report of the European Convention on Social Security.

166 See Art. 4 ECSS.

167 See Art. 2 ECSS; the entitlement to non-contributory benefits may be made conditional on the beneficiary having resided in the territory of the Contracting Party concerned or, in the case of survivors' benefits, on the deceased having resided there for a certain period in line with Art. 8(2) ECSS. 
procedures, the relationship between the competent authorities and the application of the specific provisions. ${ }^{168}$

The principle of equal treatment is central to the ECSS and is to be found in Article 8(1) ECSS and reads: "[U]nless otherwise specified in this Convention, persons who are resident in the territory of a contracting party and to whom the Convention is applicable shall have the same rights and obligations under the legislation of every contracting party as the nationals of such party." In addition, the ECSS sets out the principle of aggregation of insurance periods and the application of the national legislation of only one contracting party to a migrant. ${ }^{169}$ Only 8 state parties have ratified the ECSS to date. ${ }^{170}$

\subsubsection{The European Convention on the Legal Status of Migrant Workers}

In 1977, the Council of Europe adopted the first multilateral treaty that expressly envisaged the protection of migrants: the European Convention on the Legal Status of Migrant Workers (ECMW), which came into force in 1983.171 The Convention is open for signature for member states of the European Council; to date, 11 states (out of 47 state parties) have ratified the ECMW that envisages the equal treatment of migrant workers regarding all living and working conditions as far as possible with national workers in the receiving state, as well as the social advancement of migrant workers and their family members. ${ }^{172}$

In general terms, the ECMW does not confer rights upon migrants but seeks to provide a horizontal base for interstate agreements; therefore, it has been considered as questionable whether a migrant can directly invoke provisions of the Convention. Only four provisions, in fact, mention the rights of migrants of which three relate to the principle of non-discrimination. ${ }^{173}$ The Explanatory Report to the ECMW explicitly expounds that the Convention forms a framework agreement dealing with the most important aspects of migrant workers' legal status but without attempting to regulate all those aspects in detail. ${ }^{174}$ This raises the question as to whether the ECMW can indeed be considered of added value for the human rights' protection of migrant workers. The overall weak protection, which the ECMW offers to migrant workers, has been attributed to the oil crisis of $1973 .{ }^{175}$ Within the ambit of the ECMW, a migrant worker is a national of a contracting party who has been authorised by another contracting party to reside in its territory in order to take up

Supplementary Agreement for the Application of the European Convention on Social Security CETS No.: 078A of 14 December 1972.

Arts. 10, 14-18 ECSS.

As of 16 November 2011.

European Convention on the Legal Status of Migrant Workers CETS No.: 093 of 24 November 1977.

As of 16 November 2011; see Recitals 2 and 3 of the European Convention on the Legal Status of Migrant Workers.

R. Plender, International Migration Law (Kluwer Academic Publishers, Dordrecht 1988), p. 251.

See Paragraph 8 of the Explanatory Report to the European Convention on the Legal Status of Migrant Workers.

A. Wiesbrock, Legal Migration to the European Union (Martinus Nijhoff Publishers, Leiden 2010), p. 236. 
paid employment. ${ }^{176}$ The ECMW applies, as a consequence, to migrants "in the classic employment situations" who move cross-border to accept a job; however, it is unclear whether Article 1, for example, also covers migrants admitted for the purpose of family reunion who have a work authorisation in the host country. ${ }^{177}$ Article 4 includes the right of exit and right to admission, as well as rules on administrative formalities. Chapter III (Articles 8 to 29) of the ECMW concerns economic and social aspects, such as residence and work permits, family reunification, housing, employment conditions and social security. The Consultative Committee made up of state representatives has the task to implement the ECMW and to examine proposals to amend it. ${ }^{178}$

E. Guild explained the lack of interest of states in ratifying the ECMW by indicating two reasons. First, the author stated that states were invited to sign the ECMW at a point in time when the demand for labour migration had dropped significantly and that most contracting parties were already bound to provide a considerable higher level of protection for migrant workers based on the EEC and later EU legal framework. Second, the author pinpointed the decreasing role that states play with regard to labour immigration; rather, international corporations and private recruitment agencies find out about demand and supply of labour that is subsequently subject to approval by the state authorities. ${ }^{179}$

\section{The Protection of Migrants In the INTERNATIONAL ARENA}

\subsection{Human Rights Protection under UN Treaties}

One of the UN's purposes relates to promoting the universal respect for and the observance of, human rights and fundamental freedoms for all, without distinction as to race, sex, language, or religion, for the achievement of which the state parties and the organisation shall take action. ${ }^{180}$ Human rights are universal, inalienable, egalitarian and indivisible - this starting point raises the question how migrants are covered by human rights that have experienced a continuous internationalisation from the 1950 s onwards according to G.S. Goodwin-Gil. ${ }^{181}$ The Universal Declaration of Human Rights (UDHR) defines human rights as "basic rights and freedoms that all human beings are entitled to, without distinction of any kind, such as race, colour, sex, language, religion, political or other opinion, national or social

\footnotetext{
176 Art. 1 ECMW.

177 E. Guild, 'The European Convention on the Legal Status of the Migrant Workers (1977): An Analysis of its Scope and Benefits' (Council of Europe, Strasbourg 1999), document number: mig $\backslash$ tmg $\backslash$ docs $\backslash 99 \backslash$ cdmg (99) 11e, p. 11.

178 Art. 33 ECMW.

179 E. Guild, 'The European Convention on the Legal Status of the Migrant Workers (1977): An Analysis of its Scope and Benefits' (Council of Europe, Strasbourg 1999), document number: mig $\backslash$ tmg $\backslash$ docs $\backslash 99 \backslash$ cdmg (99) 11e, pp. 23-24.

180 Arts. 55 and 56 of the Charter of the United Nations, 1 UNTS XVI, signed on 26 June 1945.

181 G.S. Goodwin-Gill, 'International Law and Human Rights: Trends Concerning International Migrants and Refugees', 23 International Migration Review (1989), 526, p. 527.
} 
origin, property, birth or other status. ${ }^{182}$ The UN General Assembly adopted the UDHR, which was drafted in the aftermath of World War II as the first international human rights treaty for the benefit of mankind composed of a catalogue of rights, in 1948. ${ }^{183}$ The principle of non-discrimination as set out in Article 2 UDHR is openended, but it does not expressly refer to "nationality" or "citizenship" (just "national origin”). The UDHR's universal wording, it was pointed out, makes the dividing line of permissible and prohibited discrimination against migrants, under the UDHR, difficult to draw. ${ }^{184}$ Nevertheless, Article 13(2) UDHR stipulates the right for nonnationals, such as migrant workers, to leave any country and return to their own. In contrast, Article 21 UDHR on political rights is said to exclude foreigners from their scope of application. ${ }^{185}$ The principle of non-discrimination is central to all important international human rights treaties and an exception to non-discrimination is only permissible if the differential treatment at stake pursues a legitimate aim, can objectively be justified and is proportionate to the aims sought to be achieved. ${ }^{186}$ To that effect it was stressed that international human rights law thus demands, in principle, the equal treatment of citizens and non-citizens, although alienage is not explicitly listed as a prohibited reason for discrimination. ${ }^{187}$

Other human rights instruments are more precise in their application as regards the distinction between citizens and non-citizens. The ICCPR sets out certain rights that cannot be deviated from. ${ }^{188}$ In fact, most rights contained in the ICCPR must be guaranteed, regardless of the nationality of a person, as the Human Rights Committee made clear in its General Comment No. 15 on the position of aliens under the Covenant. ${ }^{189}$ The Committee highlighted especially that Article 2(1) ICCPR requires each State Party to ensure that the rights in the Covenant apply to "all individuals within its territory and subject to its jurisdiction" irrespective of reciprocity, nationality or statelessness. ${ }^{190}$ The non-discrimination principle in the latter provision is non-exhaustive but does not specifically mention nationality as a potential ground

182 Art. 2(1) of the Universal Declaration of Human Rights, UN General Assembly Resolution A/RES/217(III) of 10 December 1948.

183 See M.A. Glendon, 'Knowing the Universal Declaration of Human Rights', 73 Notre Dame Law Review (1997), 1153; J. Morsink, The Universal Declaration of Human Rights: Origins, Drafting, and Intent (University of Pennsylvania Press, Philadelphia 1999). J. Fitzpatrick, 'The Human Rights of Migrants', in: T.A. Aleinikoff and V. Chetail (eds.), Migration and International Legal Norms (T.M.C. Asser Press, The Hague 2003), p. 172.

185 R. Cholewinski, Migrant Workers in International Human Rights Law: Their Protection in Countries of Employment (Clarendon Press, Oxford 1997), pp. 48-49.

186 J. Fitzpatrick, 'The Human Rights of Migrants', in: T.A. Aleinikoff and V. Chetail (eds.), Migration and International Legal Norms (T.M.C. Asser Press, The Hague 2003), pp. 171-172.

187 C. Tiburcio, The Human Rights of Aliens under International and Comparative Law (Martinus Nijhoff Publishers, Leiden 2001), p. 97; D. Weissbrodt, 'The Protection of NonCitizens in International Human Rights Law', in: R. Cholewinski, R. Perruchoud and E. MacDonald (eds.), International Migration Law: Developing Paradigms and Key Challenges (T.M.C. Asser Press., The Hague 2007), p. 223. International Covenant on Civil and Political Rights, UN General Assembly Resolution 2200A (XXI) of 16 December 1966.

189 General Comment No. 15: The position of aliens under the Covenant of 11 April 1986.

$190 \quad$ Ibid., para. 1. 
for discrimination. J. Fitzpatrick classifies the rights set out in the ICCPR in view of migrants into five categories:

- rights that must be guaranteed in equal measure to nationals and migrants, such as the right to life (Article 6 ICCPR); equality before the law and a fair trial (Article 14 ICCPR); the prohibition of any advocacy of national, racial or religious hatred that constitutes incitement to discrimination, hostility or violence (Article 20(2) ICCPR); ${ }^{191}$

- arbitrary state action is prohibited by some provisions, which may allow for a narrow differentiation between nationals and migrants; for instance, immigration detention does not fall under the prohibition on arbitrary arrest and detention, but migrants may not be treated differently in criminal proceedings;

- discriminatory treatment of migrants may be justified on the basis of national security or public order, if the state objective is legitimate and the action undertaken proportionate; this case can relate for example to the freedom of expression (Article 18 ICCPR);

- certain political rights are reserved for nationals, including the right to vote and to be elected (Article 25 ICCPR);

- some rights aim at the protection of all migrants, such as the special rules on expulsion (Article 13 ICCPR), other rules exclusively protect nationals and migrants having a legal status, such as the right to liberty of movement within a state's territory (Article 12(1) ICCPR). ${ }^{192}$

The ICESCR ascertains protection of socio-economic rights for all persons, including the right to work and just and favourable working conditions, the right to an adequate standard of living, the right to health, the right to education and cultural rights. The ICESCR details a non-discrimination clause in Article 2(2) which is, just like its counterpart in the ICCPR, formulated in an open-ended fashion. ${ }^{193}$ However, the scope of the non-discrimination clause is restricted in that developing countries may confine economic rights for non-nationals. ${ }^{194}$ This derogation intends to enable developing countries to exclude non-citizens from certain benefits with a view to straighten the implications that colonialism entailed for them. ${ }^{195}$ On top of that, Article 4 ICESCR permits state parties to limit the rights under the ICESCR for the purpose of promoting the general welfare in a democratic society. The ICESCR also includes a right, recognised by the state parties, of everyone to social security, including social insurance. ${ }^{196} \mathrm{R}$. Cholewinksi advances two grounds as to why the

191 This first category of rights include Arts. 6, 7, 8, 10, 11, 12(2), 14, 15, 16, 18, 19(1),
20(2), 23, 24, 27 ICCPR of which some are non-derogable rights in line with Art. 4
ICCPR; see General Comment No. 15: The position of aliens under the Covenant of
11 April 1986, para. 7.
J. Fitzpatrick, 'The Human Rights of Migrants', in: T.A. Aleinikoff and V. Chetail
(eds.), Migration and International Legal Norms (T.M.C. Asser Press, The Hague 2003), pp.
173-174.
International Covenant on Economic, Social and Cultural Rights, UN General
Assembly resolution 2200A (XXI) of 16 December 1966.
Art. 2(3) ICESCR.
W.A. McKean, Equality and Discrimination under International Law (Clarendon Press,
Oxford 1983), p. 201.
For an interpretation of Art. 9 ICESCR and its relation to EU migration law, see A.
Farahat, 'Is there a Human Right to Equal Social Security? EU Migration Law and the 
ICESCR provides migrants with less protection than the UDHR and the ICCPR: first, the full realisation of norms contained in the ICESCR are to be achieved progressively, which implies that nobody can always expect to fully benefit from the rights of the ICESCR; second, the standards included in the ICESCR "involve state affirmative measures and when resources are scarce, especially in developing countries, it is not surprising that states prefer to favour their own nationals." 197 There is agreement that the principle of non-discrimination, as present in the ICESCR, only partly applies to non-nationals and that migrants are only entitled to the lowest common denominator of rights under the ICESCR regime. ${ }^{198}$ The UDHR, most rules of which are today considered as customary international law, together with the ICCPR and the ICESCR that were both signed in 1966 form the international bill of rights. ${ }^{199}$

The International Convention on the Elimination of All Forms of Racial Discrimination (ICERD) is of special importance to migrant groups that make up minorities in the state of residence. ${ }^{200}$ State parties to the ICERD shall condemn and eliminate racial discrimination, which is defined as "any distinction, exclusion, restriction or preference based on race, colour, descent, or national or ethnic origin which has the purpose or effect of nullifying or impairing the recognition, enjoyment or exercise, on an equal footing, of human rights and fundamental freedoms in the political, economic, social, cultural or any other field of public life." 201 Importantly, Article 1(2) ICERD precludes its application to distinctions, exclusions, restrictions or preferences made by a state party to the ICERD between citizens and noncitizens. This provision was inserted at the insistence of national authorities so as to be able to restrict certain entitlements to foreigners, such as political rights. Still, aliens may claim protection if they fall victim to racial or ethnic discrimination; "the ICERD clearly operates to rights of non-citizens" as the dispute Yilmaz-Dogan v. The Netherlands illustrates. ${ }^{202}$ In accordance with Article 3(1) ICERD, contracting states may not discriminate against any particular nationality.

Requirements of Art. 9 ICESCR', in: M. Maes, M.-C. Foblets and Ph. De Bruycker (eds.), External Dimensions of European Migration and Asylum Law and Policy (Bruylant, Bruxelles 2011), pp. 529-548.

197 R. Cholewinski, Migrant Workers in International Human Rights Law: Their Protection in Countries of Employment (Clarendon Press, Oxford 1997), pp. 56-57; R. Cholewinski refers to R.B. Lillich, The Human Rights of Aliens in Contemporary International Law (Manchester University Press, Manchester 1984), p. 47.

198 R. Cholewinski, Migrant Workers in International Human Rights Law: Their Protection in Countries of Employment (Clarendon Press, Oxford 1997), p. 58; M.C.R. Craven, The International Covenant on Economic, Social, and Cultural Rights: A Perspective on its Development (Clarendon Press, Oxford 1995), pp. 173-174.

199 R. Cholewinski, 'The Human and Labor Rights of Migrants: Visions of Equality', 22 Georgetown Immigration Law Journal (2008), 177, p. 183.

200 International Convention on the Elimination of All Forms of Racial Discrimination, UN General Assembly Resolution 2106(XX) of 21 December 1965. Art. 1(1) ICERD.

202 R. Cholewinski, Migrant Workers in International Human Rights Law: Their Protection in Countries of Employment (Clarendon Press, Oxford 1997), pp. 62-63; Yilmaz-Dogan v. The Netherlands, Communication No. 1/1984, UN Doc. A/43/18, Annex IV, 59-64. 
The 1984 Convention against Torture (CAT) commits parties to prevent and combat torture and other cruel, inhuman or degrading treatment or punishment. ${ }^{203}$ Within the scope of the CAT, "torture" means any act by which severe pain or suffering, whether physical or mental, is intentionally inflicted on a person for such purposes as obtaining from him or a third person information or a confession, punishing him for an act he or a third person has committed or is suspected of having committed, or intimidating or coercing him or a third person, or for any reason based on discrimination of any kind, when such pain or suffering is inflicted by or at the instigation of or with the consent or acquiescence of a public official or other person acting in an official capacity. It does not include pain or suffering arising only from, inherent in or incidental to lawful sanctions. ${ }^{204}$ For migrants, Article 3 CAT is of supreme importance; the provision enshrines that no state party shall expel, return or extradite a person to another State where there are substantial grounds for believing that he would be in danger of being subjected to torture.

It has been pointed out that there is no general codification of rights of aliens. ${ }^{205}$ However, one has to take into account that the UN Migrant Worker Convention, which entered into force in 2003, applies to any person who is to be engaged, is engaged or has been engaged in a remunerated activity in a state of which he or she is not a national; this broad definition of a migrant worker includes those who have an irregular status in the country of employment. ${ }^{206}$ Just as the UN Migrant Worker Convention, the Convention on the Elimination of All Forms of Discrimination Against Women of 1979, as well as the Convention on the Rights of the Child of 1989 envisage to provide protection for specifically vulnerable groups of society. ${ }^{207}$ The 1951 UN Convention relating to the Status of Refugees and the 1966 Protocol protect the rights of refugees and determine the asylum obligations of states which are parties to the Convention. ${ }^{208}$ In line with Article 33(1) of the 1951 Convention, no person may be expelled or returned for any reason whatsoever to the frontiers of the territories where his life or freedom is in danger (principle of non-refoulement). A refugee is defined as "any person who owing to a well-founded fear of being persecuted for reasons of race, religion, nationality, membership of a particular social group or political opinion is outside the country of his nationality and is unable or,

203 Convention against Torture and Other Cruel, Inhuman or Degrading Treatment or Punishment, UN General Assembly Resolution 39/46 of 10 December 1984.

204 Art. 1(1) of the CAT.

205 J. Fitzpatrick, 'The Human Rights of Migrants', in: T.A. Aleinikoff and V. Chetail (eds.), Migration and International Legal Norms (T.M.C. Asser Press, The Hague 2003), p. 170 .

206 Art. 2(1) of the UN Migrant Worker Convention: UN General Assembly Resolution $\mathrm{A} / \mathrm{RES} / 45 / 158$ on International Convention on the Protection of the Rights of all Migrant Workers and Members of Their Families of 18 December 2006, 69th Plenary Meeting.

207 Convention on the Elimination of All Forms of Discrimination Against Women, UN General Assembly Resolution 34/180 of 18 December 1979; Convention on the Rights of the Child, UN General Assembly Resolution 44/25 of 20 November 1989.

208 Final Act of the United Nations Conference of Plenipotentiaries on the Status of Refugees and Stateless Persons, and Convention relating to the Status of Refugees, 2 to 25 July 1951 (A/CONF.2/108/Rev.1); UN General Assembly Resolution 2198 (XXI) of 16 December 1966 on the Protocol relating to the Status of Refugees. 
owing to such a fear is unwilling to avail himself of the protection of that country $[\ldots], .209$

In 1999, the Commission on Human Rights created the post of the UN Special Rapporteur on the Human Rights of Migrants who has the task to examine ways and means to overcome the obstacles to the full and effective protection of the human rights of this vulnerable group, including obstacles and difficulties for the return of migrants who are undocumented or in an irregular situation. ${ }^{210}$ This UN Special Rapporteur, D. Weissbrodt, concluded in 2003 in the Final Report on the Rights of Non-Citizens that "all persons should by virtue of their essential humanity enjoy all human rights unless exceptional distinctions, for example, between citizens and noncitizens, serve a legitimate State objective and are proportional to the achievement of that objective." Next, he indicated a large gap between the rights that international human rights law guarantees to non-citizens and the realities they must face as, in many countries, there are still institutional and endemic problems confronting noncitizens. $^{211}$ Xenophobia and racism, abuse and harassment continue to exacerbate the everyday lives of non-citizens in host countries, despite clear international human rights standards that are either not enforced, or actively disregarded and infringed by discriminating legal rules or policies. ${ }^{212}$

\subsection{Migrants' Rights under the ILO Conventions No. 97 and No. 143}

The ILO Conventions No 97 and No 143 are the most significant treaties providing for the protection of migrant workers and their families which were drafted under the patronage of the ILO. ${ }^{213}$ Both Conventions are supplemented by non-binding recommendations. There is general consensus that the two Conventions have had an added value in raising awareness and sensitivity as regards the protection of migrant workers, however, the actual impact of these international standards is rather modest: 49 states have ratified Convention No 97 and 23 states adhere to Convention No 143.

ILO Convention No 97 concerning Migration for Employment was prepared in the wake of World War II and adopted in 1949. Post-war reconstruction efforts and the large number of refugees and internally-displaced persons in Europe prompted the formulation of immigration and emigration policies, as well as resettlement schemes. The drafting of Convention No 97 responded to the call for migrant labour by

Art. 1A para. 2 of the 1951 Convention relating to the Status of Refugees; see J. Fitzpatrick, 'Revitalizing the 1951 Refugee Convention', 9 Harvard Human Rights Journal (1996), 229.

Commission on Human Rights Resolution 1999/44 on the Human Rights of Migrants of 26 April 1999, 55th session.

D. Weissbrodt, UN Special Rapporteur on the Rights of Migrants, Final Report on the rights of non-citizens, UN Doc. E/CN.4/Sub.2/2003/23 (2003).

D. Weissbrodt, 'The Protection of Non-Citizens in International Human Rights Law', in: R. Cholewinski, R. Perruchoud and E. MacDonald (eds.), International Migration Law: Developing Paradigms and Key Challenges (T.M.C. Asser Press., The Hague 2007), pp. 228232.

ILO Convention No. 97 concerning Migration for Employment of 1 July 1949; ILO Convention No. 143 concerning Migrations in Abusive Conditions and the Promotion of Equality of Opportunity and Treatment of Migrant Workers of 24 June 1975. 
providing a flexible tool covering the migration circle from entry and recruitment (see Annex I) to return. ${ }^{214}$ Article 6 of Convention No 97 enshrines the nondiscrimination for lawfully resident migrant workers compared to national workers in respect of remuneration and employment conditions, membership of trade unions, accommodation, social security, employment taxes and legal proceedings. Undocumented migrants do not fall under the scope of application of the Convention No 97 as clarified in Article 11(1).

ILO Convention No 143, adopted in 1975, supplements Convention No 97 in that is has a broader scope of application than its predecessor. ${ }^{215}$ Convention No 143 was designed at a time of economic downturn caused by the oil crisis at the beginning of the 1970s which led to unemployment and, subsequently, to the closing up of borders for labour migration. 216 The political climate was tense as "clandestine migration, discrimination and xenophobia moved to the forefront of public concern."'217 The 1975 Convention has the focus on the prevention of clandestine migration and associated illicit employment and promotes equality of opportunity and treatment. Referring to Recitals 3 and 4 of the Preamble, R. Cholewinksi remarked that the document recognises the link between a lack of economic opportunity in the countries of origin and the existence of irregular migration movements connected to the search of employment. ${ }^{218}$

Convention No 143 applies to all migrant workers, including irregular migrants. Article 1 states that "each member for which this Convention is in force undertakes to respect the basic human rights of all migrant workers". The integration of migrants that have an unauthorised status in the country of employment is reflected, in addition, in Article 9 of Convention No 143 which specifies equality of treatment for irregular migrant workers with regular migrants in respect of rights arising out of past employment, as regards remuneration, social security and other benefits. However, this concession is restricted insofar as Part II of Convention No 143 on Equality of Opportunity and Treatment sets out rules that are only applicable to migrant workers who have been regularly admitted (Article 11(1)). State parties shall determine the scope of clandestine migration in their territories and take appropriate measures to suppress clandestine movements and to prevent people smuggling and illegal employment; these measures include administrative, civil and penal sanctions. Furthermore, state parties shall ensure systematic contact and mutual information exchange on the subject-matter. ${ }^{219}$ Under Article 10 of Part II of Convention No 143, members undertake to promote and guarantee equality of opportunity and

214 ILO Convention No. 97 concerning Migration for Employment of 1 July 1949; M. Hasenau, 'ILO Standards on Migrant Workers: The Fundamentals of the UN Convention and their Genesis', 25 International Migration Review (1991), 687, p. 693.

215 ILO Convention No. 143 concerning Migrations in Abusive Conditions and the Promotion of Equality of Opportunity and Treatment of Migrant Workers of 24 June 1975; R. Cholewinski, 'The Human and Labor Rights of Migrants: Visions of Equality', 22 Georgetown Immigration Law Journal (2008), 177, p. 189.

216 K. Bade, Migration in European History (Blackwell Publishing, Oxford 2003), p. 228.

217 M. Hasenau, 'ILO Standards on Migrant Workers: The Fundamentals of the UN Convention and their Genesis', 25 International Migration Review (1991), 687, p. 695.

218 R. Cholewinski, Migrant Workers in International Human Rights Law: Their Protection in Countries of Employment (Clarendon Press, Oxford 1997), p. 96. Arts. 2 to 6 ILO Convention No. 143. 
treatment in respect of employment and occupation, of social security, of trade union and cultural rights and of individual and collective freedoms for migrant workers and their families (with a legal status). The rules on family reunification are rather weak; state parties shall facilitate reunification of spouse, dependent children, father and mother. ${ }^{220}$

\subsection{Migrants' Rights under the UN Migrant Worker Convention}

The UN General Assembly approved the UN International Convention on the Protection of the Rights of Migrant Workers and their Families (UN Migrant Worker Convention, ICMW) in December of 1990.221 In accordance with the procedural requirements set out in Article 87(1), the ICMW entered into force on 1 July 2003.222 The ICMW was drafted with the objective to provide a comprehensive legal framework for the protection of migrant workers and their family members. By referring to existing international covenants and migration-related work of various organisations, the scope of global migratory movements and the hardship connected to the migration process, the Preamble indicates the need to strengthen the position of migrant workers and their families on the one hand and to prevent irregular migration while recognising and assuring the protection of fundamental human rights on the other.

R. Cholewinksi pointed out that not all the rationales for the IMCW are stated in the Preamble, e.g. "the ICMW constitutes a delicate balance between the protection of migrants' rights and the principle of state sovereignty." 223 One special characteristic of the ICMW relates to its inclusiveness, seeing that it applies to migrants to have a legal status in the country of residence, as well as migrants who are undocumented; migrants in a regular situation are granted more extensive rights, which are laid down in Part IV of the ICMW. The broad definition of who is considered to be a migrant worker in Article 1 of the ICMW makes this international treaty an ambitious and important contribution in mitigating the precarious conditions that irregular migrants have to face. ${ }^{224}$ With a view to ensuring the application of the Convention to all migrant workers, Article 88 of the ICMW expressly prohibits state parties from excluding any category of migrant workers from its scope of application; this is an innovative element of the ICMW seeing that, by way of comparison, the ILO Convention No 143 and the European Social Charter do allow for such derogations. $^{225}$ Although the state parties may notify reservations to the UN

\footnotetext{
220 Art. 13 ILO Convention No. 143.

221 UN General Assembly Resolution A/RES/45/158 on International Convention on the Protection of the Rights of all Migrant Workers and Members of Their Families of 18 December 2006, 69th Plenary Meeting.

222 Art. 87(1) ICMW stipulates that the Convention enters into force on the first day of the month following a period of three months after the date of the deposit of the twentieth instrument of ratification or accession.

223 R. Cholewinski, Migrant Workers in International Human Rights Law: Their Protection in Countries of Employment (Clarendon Press, Oxford 1997), p. 146.

224 L.S. Bosniak, 'Human Rights, State Sovereignty and the Protection of Undocumented Migrants under the International Migrant Workers Convention', 25 International Migration Review (1991), 737, p. 740.

225 As pointed out by R. Cholewinski, Migrant Workers in International Human Rights Law: Their Protection in Countries of Employment (Clarendon Press, Oxford 1997), p. 148.
} 
Secretary-General, these reservations may not be incompatible with the object and the purpose of the ICMW in accordance with Article 91(2). The ICMW was adopted under the auspices of the UN after disagreements with the ILO which had a keen interest in drafting and shaping the document as a specialised agency, and it was stressed that it was inevitable that the ICMW draws heavily on, and sometimes duplicates, standards set out in the ILO Conventions. ${ }^{226}$

The ICMW is structured in nine parts, including scope and definitions; nondiscrimination with respect to human rights; human rights of all migrant workers and their families; other rights of migrants who are in a regular situation; provisions applicable to particular categories of migrants; the promotion of sound, equitable, humane and lawful conditions in connection with international migration; application of the Convention; general provisions; and final provisions. The ICMW grants a set of rights and liberties to all migrant workers and their families. They relate to the prohibition of discrimination in ensuring the rights set out in the ICMW (Article 7); freedom to leave the country and enter the state of origin (Article 8); the right to life (Article 9); freedom from torture and inhuman ore degrading treatment (Article 10); freedom from slavery or forced labour (Article 11); freedom of thought, conscience and religion (Article 12); freedom of opinion and expression (Article 13); freedom from arbitrary or unlawful interference with privacy, family, correspondence or other communications, or unlawful attacks relating to honour (Article 14); property rights (Article 15); the right to liberty and security of person (Article 16); the right of migrants deprived of their liberty to be treated with humanity and dignity (Article 17); the right to a fair trial (Article 18); the compliance with the nulla poena sine legeprinciple (Article 19); no imprisonment for failure to fulfil a contract (Article 20); no confiscation or destruction of identity documents (Article 21); freedom from collective expulsion (Article 22); the right to have recourse to consular or diplomatic assistance and protection (Article 23); the right to recognition as a person before the law (Article 24); equal treatment in working conditions and remuneration (Article 25); the right to join trade unions (Article 26); equal treatment in social security (Article 27); the right to receive urgent medical care (Article 28); the right of a child to a name, birth registration and nationality (Article 29); and equality of treatment as regards access to public education (Article 30); respect for cultural identity (Article 31); the right to transfer earnings, savings and belongings (Article 32); the right to information about the rights under the ICMW (Article 33).

With the objective to discourage irregular migration as set out in Recital 15 of the Preamble to the ICMW, documented migrants are granted additional rights in Part IV. They concern the right to be informed about admission and employment conditions (Article 37); the right to liberty of movement in the territory of the state of employment (Article 39); the right to form association and trade unions (Article 40); the right to participate in public affairs of the state of origin (Article 41); the right to equal treatment with regard to access to education, vocational guidance and training, housing, social and health services and cultural life (Articles 43 and 45); protection of the family unity (Article 44); freedom to choose a remunerated activity (52); equal treatment in respect to dismissal, unemployment benefits, access to public work schemes intended to combat unemployment (Article 54).

226 R. Bohning, 'The ILO and the New UN Convention on Migrant Workers: The Past and Future', International Migration Review (1991), 698. 
Part V of the ICMW specifies particular categories of migrant workers, such as frontier and seasonal workers, project-tied workers and specified-employment workers (all defined in Article 2). Part VI of the ICMW provides cooperation and consultation mechanisms for state parties so as to promote that the international migration of workers takes place under sound, equitable, humane and lawful conditions. These procedures of the ICMW - the Convention that has been labelled as the most comprehensive human rights instrument with 93 provisions - allow for mutual information exchange and collaboration fighting irregular migration by inter alia introducing employer and trafficker sanctions. In this regard, the ICMW actively promotes the prevention and abolition of all forms of irregular migration and puts away with the "myth" that the Convention would encourage undocumented human mobility. 227

While the finalisation of the ICMW was generally welcomed after negotiations that lasted some 10 years, scholars have also emphasised the downsides of the document. ${ }^{228}$ It has been highlighted that the ICMW confirms and reiterates existing basic human rights in a framing for the specific target group of migrant workers and their families but does not create new rights. ${ }^{229}$ The signature and ratification process has been criticised as rather slow; although, to date, 45 states - for the most part sending and developing countries - have ratified the ICMW. ${ }^{230}$ Moreover, the ICMW has not been high on the agenda of governments and UN institutions, the ICMW because the Convention was considered as "impractical", "too ambitious" and "unrealisable". ${ }^{231}$ R. Cholewinski stressed that the protection that the ICMW offers is incomplete owing to the changing forms of labour migration entailing dynamics that ICMW does not account for, such as the feminisation of migrant labour, temporary labour movements and an increasing number of irregular migrants. ${ }^{232}$

\subsection{The Rights of Migrants in the International Migration Discourse}

Various international organisations and global initiatives have stimulated discussions on transfrontier migratory movements, the manifold manifestations thereof, regulation policies, the role of migrants in source and destination countries and - to an increasing degree in recent years - the importance of protecting migrants' rights. In the run up to the 2006 High-Level Dialogue on Migration and Development, K.

R. Cholewinski, 'The Rights of Migrant Workers', in: R. Cholewinski, R. Perruchoud and E. MacDonald (eds.), International Migration Law: Developing Paradigms and Key Challenges (T.M.C. Asser Press, The Hague 2007), p. 259.

For a reflection of the negotiating process, see J. Lonnroth, 'The International Convention on the Rights of All Migrant Workers and Members of their Families in the Context of International Migration Policies: An Analysis of Ten Years of Negotiation', International Migration Review (1991), 710.

D. Weissbrodt, 'The Protection of Non-Citizens in International Human Rights Law', in: R. Cholewinski, R. Perruchoud and E. MacDonald (eds.), International Migration Law: Developing Paradigms and Key Challenges (T.M.C. Asser Press., The Hague 2007), p. 226. As of 21 September 2011.

P.A. Taran, 'Human Rights of Migrants: Challenges of the New Decade', 38 International Migration (2001), 7, pp. 18-19.

R. Cholewinski, 'The Rights of Migrant Workers', in: R. Cholewinski, R. Perruchoud and E. MacDonald (eds.), International Migration Law: Developing Paradigms and Key Challenges (T.M.C. Asser Press, The Hague 2007), pp. 259-260. 
Annan professed that "for the full benefits of international migration to be realised, the rights of migrants must be respected. States have the obligation to protect the fundamental rights of all persons in their territory and they must take effective action to protect migrants against all forms of human rights violations and abuse. They must also combat all forms of discrimination, xenophobia, ethnocentrism and racism." 233 In a similar vein, in 2006 at the (United Nations Economic and Social Council) ECOSOC High-Level Segment that took place in Geneva, J. Somavia, DirectorGeneral of the International Labour Office, claimed that "gains from migration and protection of migrant rights are indeed inseparable. Migrant workers can make their best contribution to host and source countries when they enjoy decent working conditions and when their fundamental human and labour rights are respected." 234 The statements of these two top officials underline the key role of migrants' rights, also for promoting development processes.

\subsubsection{The International Labour Organisation}

The International Labour Organisation (ILO) is a specialised UN agency established in 1919 to promote decent work conditions, social justice and internationally recognised human and labour rights. The ILO is devoted to formulate international policies to improve living and working conditions, to create and monitor international labour standards and to provide technical cooperation and training. Its structure as an international organisation is unique in that it is characterised by tripartism: agents of national authorities work together with representatives of employers' and workers' organisations. ${ }^{235}$ With the adoption of the Conventions No 97 and No 143, the ILO produced, next to international labour instruments that apply regardless of a worker's nationality or legal status, legislative frameworks specifically applicable to migrant workers. ${ }^{236}$ The recognition and the respect for workers' rights, including migrant workers, constitute one pillar of the ILO's "Decent Work for All" Agenda. The Decent Work Agenda is based on the assumption that decent work is of paramount importance for the well-being of people in that work not only guarantees income but contributes to the social and economic advancement of individuals, their families and communities. Next to rights at work, the Decent Work Agenda focuses on job creation, social protection and social dialogue. ${ }^{237}$

\footnotetext{
233 K. Annan, UN Secretary-General Report on International Migration and Development, UN/GA A/60/871 of 18 May 2006, para. 77.

234 J. Somavia, Statement of the Director-General of the International Labour Office, 2006 ECOSOC High-Level Segment, Geneva, 5 July 2006, available at: <http://www.ilo.org/pubcgi/links_ext.pl?http://www.un.org/docs/ecosoc/meetings /2006/hls2006/documents/DG\%20ILO-RT3.pdf>, last accessed on 29 September 2011.

235 J. Klabbers, An Introduction to International Institutional Law (3rd edn. Cambridge University Press, Cambridge 2005), p. 171.

236 R. Cholewinski, 'The Rights of Migrant Workers', in: R. Cholewinski, R. Perruchoud and E. MacDonald (eds.), International Migration Law: Developing Paradigms and Key Challenges (T.M.C. Asser Press, The Hague 2007), p. 258; W.R. Simpson, 'The ILO and Tripartism: Some Reflections', 117 Monthly Labor Review (1994), 40.

237 See ILO website on "Decent Work": <http://www.ilo.org/global/about-theilo/decent-work-agenda/lang--en/index.htm>, accessed on 4 November 2011.
} 


\subsubsection{The International Organisation for Migration}

The International Organisation for Migration (IOM) is an intergovernmental organisation that was established in 1951 with the objective to promote humane and systematic migration management that is favourable for all actors involved. IOM encourages collaboration in the field of migration and provides assistance and advice for migrants and governments. The IOM's work areas concern migration and development, the facilitation and regulation of migration and forced migration. To date IOM has 146 state parties; a further 13 countries and numerous international organisations and non-governmental organisations hold observer status. ${ }^{238}$ The organisation has a well-established and long-term liaison with the UN. This is manifested by the IOM's observer status that it has had at the UN General Assembly since 1992, the attendant permanent observer mission in New York, as well as a cooperation agreement between the UN and IOM that aims to intensify the secretariats' work relations. ${ }^{239}$ The organisation's structure is decentralised with two administrative centres, eight regional offices, two special liaison offices and more than 250 country offices and sub-offices. IOM carries out research and analysis in its work areas, including migration law and the human rights of persons involved in the migration process, to improve policies and enhance practices. ${ }^{240}$ The 2011 World Migration Report indicated general improvements to the protection of migrants' rights although the global economic crisis hit migrant workers, in particular, hard; their vulnerable situation was aggravated by a lack of labour laws protecting nonnational workers or their non-enforcement. ${ }^{241}$

\subsubsection{The Global Commission on International Migration}

The Global Commission on International Migration was a project called into being by the UN Secretary-General and a number of governments in December of 2003. The independent Commission was composed of 19 internationally experienced commissioners and provided a framework to generate coherent and comprehensive policy responses to the challenges which international migration poses. The Commission's mandate related to raising the awareness of international migration on a world-wide scale, conducting research on migration policies, analysing links between migration and other related policy areas and formulating recommendations for stakeholders. During its two-year existence, the Commission organised conferences and expert meetings and published a considerable number of thematic and regional studies, as well as 56 issues of the Global Migration Perspectives. With the aid of comprehensive consultations in different parts of the world, the

238 See website of the IOM: <http://www.iom.int/jahia/Jahia/lang/en/pid/1>, last accessed on 10 December 2011.

239 See UN General Assembly Resolution A/RES/47/7 on the Observer Status of the International Organization for Migration in the General Assembly of 16 October 1992, 41st Plenary Meeting; Cooperation Agreement between the UN and the IOM, signed on 25 June 1996 in Geneva.

See IOM, The Human Rights of Migrants - IOM Policy and Activity (IOM, Geneva 2009), document number: MC/INF/298 of 12 November 2009. Jahia/lang/en/pid/1>, last accessed on 10 December 2011. 
Commission drafted a major report before the termination of its mandate in October 2005 and presented it to the UN Secretary-General, the UN Member States and other stakeholders. The gist of the report concerned the failure of the international community to address the challenges and opportunities that international migration entails. Firstly, the Commission pointed out that states often lacked the required capacity to create and transpose the right set of migration policies due a shortage of accurate migration information, best practices and resources to supervise programmes. Secondly, the report indicated that the existing policies were frequently incoherent with ministries having different or even competing priorities and that migration was not considered in the decision-making procedures of other policy fields, such as trade and development. Thirdly, the Commission suggested a closer cooperation between states emphasising the cross-border nature of international migration and an improved collaboration among international organisations working on migration was recommended. Next, the report identified the need for a coherent legal and normative framework affecting international migrants and an effective implementation and non-discriminatory application thereof so as to guarantee the human rights and labour standards for all migrant women and men. The Commission attributed a fundamental role to the UN and governments of sending, transit and receiving countries in this respect. ${ }^{242}$

\subsubsection{The Global Migration Group}

As a follow-up to the recommendations of the Global Commission on International Migration, in 2006 the UN Secretary-General established the Global Migration Group. The Global Migration Group is the successor of the Geneva Migration Group and has the goal to enhance inter-agency cooperation as regards international migration issues, especially with regard to promoting an effective response to the impact of population movements. Consisting of $14 \mathrm{UN}$ agencies, the IOM and the World Bank, the Global Migration Group also plays an active part in organising the Global Forum on Migration and Development (GFMD), which was first held in 2007 in Brussels. ${ }^{243}$ The Global Migration Group is chaired by one of the agencies for six months each and convenes regularly. The one-year task schedule for 2011, under the chairmanship of the United Nations Children's Fund (UNICEF) and the United Nations Educational, Scientific and Cultural Organisation (UNESCO), has concentrated on youth, adolescents and migration and climate change and migration. The 2011 work plan, moreover, highlighted the need to mainstream migration into national development planning inter alia by establishing linkages with the 2011 GFMD that centred on migration and development-coherence, capacity and cooperation. Migration and human rights constitutes one of the Global Migration Group's work domains, in which it works closely with the IOM. ${ }^{244}$

\footnotetext{
242 Global Commission on International Migration, Migration in a Interconnected World: New Directions for Action (SRO-Kundig, Switzerland 2005), available at: <http://iom.int/jahia/Jahia/gcim/>, last accessed on 16 December 2011.

243 See Global Migration Group, "Terms of Reference", available at: <http://www.globalmigrationgroup.org/>, last accessed on 17 October 2011.

244 See website of the Global Migration Group: <http://www.globalmigrationgroup. org/en/>, last accessed on 10 December 2011.
} 


\subsubsection{The High-Level Dialogue on International Migration and Development}

The High-Level Dialogue on International Migration and Development was a twoday large-scale conference initiated and conducted by the UN General Assembly on 14 and 15 September 2006, with a view to reinforce the development gains that are directly linked to migration. The UN Secretary-General Kofi Annan, in his address, underscored the urgency of exploring and discussing migration patterns, practices and policies on account of three key issues: first, international migration affected an increasing number of countries and the classification in the countries of origin, transit and destination becomes increasingly blurred. Second, the positive repercussions of migration on development were significant including remittances and the transfer of skills and knowledge. Third, this gainful perspective on migration had also progressively been adopted by governments. ${ }^{245}$

The High-Level Dialogue comprised plenary sessions and round tables, with contributions from representatives of $147 \mathrm{UN}$ Member States and the participation of inter- and non-governmental organisations, entities from the private sector and civil society. All participants expressed a keen interest in analysing the link and synergies between international migration and development and agreed that migration can entail positive implications for both the country of origin and destination, subject to the condition that the right policies are in place. The participants also recognised the significance of tackling the root causes of migration so that people move as a result of deliberation rather than out of necessity, and they noted that migration can contribute in attaining the Millennium Development Goals. There was broad agreement to continue the global dialogue on international migration and development in the form of a voluntary, state-led forum. ${ }^{246} \mathrm{~A}$ second High-Level Dialogue on International Migration and Development is scheduled for 2013.

\subsubsection{The Global Forum on Migration and Development}

First held on 9 to 11 July 2007 in Brussels, the GFMD is an initiative that resulted directly from the 2006 UN High-Level Dialogue because of the UN Member States' strong interest in continuing the debates on "how to make migration work for development". The Global Forum is an informal platform for dialogue led by governments and founded with the objective to share experiences and practices, to discuss policies and to enhance the consultation process among stakeholders related to the migration-development nexus. The actors involved are meant to benefit from concrete and action-oriented output of the Global Forum, such as the setup of partnerships and the formulation of policy recommendations. The Belgian authorities agreed to host and organise the 2007 GFMD which consisted of two sessions: the civil society meeting on the first day and the government summit on the second and third day. Three interrelated topics were dealt with at the Brussels Forum which

The Secretary-General Address to the High-Level Dialogue of the General Assembly on International Migration and Development, New York, 14 September 2006, available at: <http://www.un.org/migration/index.html>, last accessed on 17 October 2011.

UN General Assembly, Summary of the High-Level Dialogue on International Migration and Development, document number: A/61/515 of 13 October 2006. 
corresponded to the priorities put forward by the UN Member States in a preceding consultation, including human capital development and labour mobility, remittances and other diaspora resources, as well as policy and institutional coherence and partnerships. ${ }^{247}$ The Global Forum has been assessed as a new global governance approach to migration as a result of the active participation of civil society actors and the introduction of a global network of focal points, which facilitates and coordinates the dialogue at national and international level. ${ }^{248}$

Since the Brussels GFMD, the event has been conducted annually, each time with one meeting for civil society actors and one for policy makers. In 2008, the second Global Forum took place in Manila with the support of Philippine authorities under the heading "Protecting and Empowering Migrants for Development". Roundtable 1 of this GFMD on migrants' rights reiterated that the development benefits of labour migration depended upon the degree to which are protected and empowered by the origin and destination countries. It was pointed out that the responsibility to protect migrants' rights was shared between the sending and receiving countries in accordance with the different stages of the migration process regarding predeparture; post-departure and work; and return. It was highlighted that the country on the territory of which a certain stage occurred is in the best position to exercise supervision. ${ }^{249}$ The third Global Forum was held in Athens, Greece, in November of 2009 , with a focus on integrating migration policies into development strategies for the benefit of all stakeholders.

The 2011 GFMD was held in Geneva, from 29 November to 2 December 2011, with more than 120 representatives of 100 states and 20 observers. ${ }^{250}$ The civil society days took place under the central topic "Taking Action on Labour Migration, Development and the Protection of Migrant Workers and their Families". Two subsessions were relevant taking into consideration that they concern the legal protection of migrants: one session concerned rights-based policy-making for the benefit of migrant workers and their families, and the other one addressed protection of migrants working or moving in irregular circumstances. ${ }^{251}$ In connection with the appeal to states of previous GFMD's meetings to ratify the ICMW, this time, special emphasis was put first on the ILO's Multilateral Framework on Labour Migration of 2005, which underscores that "[T] he human rights of all migrant workers, regardless of their status, should be promoted and protected" and that "the contribution of

247 See Website of the 2007 Global Forum on Migration and Development, available at: <http://www.gfmd.org/en/gfmd-meetings/brussels-2007.html>, last accessed on 18 October 2011.

248 R. Matsas, 'The Global Forum on Migration and Development: A New Path for Global Governance', The Brussels Journal of International Relations, EGMONT Institute (Brussels 2008), pp. 11-13.

249 ILO Background Paper of Roundtable 1 on Migration, Human Rights and Development (Session 1.1 Protecting the Rights of Migrant Workers - A Shared Responsibility), GFMD, 27-30 October 2008, available at: <http://www.ilo.org/public/english/protection/migrant/download/ilo_paper_gfmd_rt_1.pdf $>$, last accessed on 29 September 2011.

250 See 2011 GFMD website, available at: <http://www.gfmd.org/>, last accessed on 29 September 2011.

2512011 Programme GFMD Civil Society Days, available at: <http://www.gfmdcivilsociety.org/>, last accessed on 29 September 2011. 
labour migration to employment, economic growth, development and the alleviation of poverty should be recognised and maximised for the benefit of both origin and destination countries." 252 Second, the ILO Convention Concerning Decent Work for Domestic Workers adopted in June 2011 was put in the spotlight stressing its potential to provide protection to a large and vulnerable group of migrant domestic workers from exploitation and abuse. ${ }^{253}$

\section{CONCLUSION TO PART III}

Part III has detailed the human rights protection of migrants from a European and an international legal perspective. The international legal framework consists of international declarations and treaties that are open for signature for all states. On the other hand, regional pedants were created setting out human and migrants' rights protection in countries on the European continent. While notably the UN and the ILO as a specialised agency have taken a leading role in drafting, advancing and disseminating international standards, it was the Council of Europe that assumed such a key role for the European conventions. Importantly, some human rights' standards, such as most of the UDHR, have, from the point of view of international lawyers, become customary international law in the course of time. It is remarkable that membership of the Council of Europe and the associated adherence to the ECHR enjoys great popularity among European countries in the broadest sense, whereas other conventions have only a very limited number of ratifying states. The lack of interest in European treaty regimes dealing with social security and protection of migrant workers and their families can be ascribed to the fact that the EU Member States are already bound by a much more advanced set of rights under EU free movement rules.

The ECHR and the case law of the ECtHR have made a significant contribution in strengthening the legal status of migrants in the territory of the contracting parties. As early as in 1985, the ruling in Abdulariz, Cabales and Balkandali v. The United Kingdom laid down that the right to respect for family life applies to the state parties' immigration laws. ${ }^{254}$ The ECtHR, in 2006, held that a national deportation order addressed to a Brazilian mother of a Dutch child, who had no authorisation to live in the Netherlands, violated Article 8 ECHR. ${ }^{255}$ In addition, the ECHR and the jurisprudence of the ECtHR have had a major impact on the human rights protection within the EU legal order. The Court of Justice in Luxembourg was ready to interpret EU law in the light of and with explicit reference to, the case law of the Court in Strasbourg. Once the EU has acceded to the ECHR, there is no doubt that not only

252 ILO Multilateral Framework on Labour Migration: Non-Binding Principles and Guidelines for a Rights-Based Approach to Labour Migration (International Labour Office, Geneva 2006), pp. 15 and 29, available at: <http://www.ilo.org/public/libdoc/ilo/2006/106B09_343_engl.pdf>, last accessed on 11 December 2011.

253 ILO Convention PR No. 15a concerning Decent Work for Domestic Workers of 16 June 2011.

254 Abdulariz, Cabales and Balkandali v. The United Kingdom (Application Nos. 9214/80; 9473/81; 9474/81) Judgment of 28 May 1985, 7 EHRR 471.

255 Rodrigues da Silva and Hoogkamer v. The Netherlands (Application No. 50435/99) Judgment of 31 January 2006, 44 EHRR 729, para. 44; see also Nunez. v. Norway (Application No. $55597 / 09)$ Judgment of 28 June 2011. 
the EU Member States but the EU itself must observe the ECHR as a party. The EU Charter, as inspired by the ECHR, has binding force since 1 December 2009 and, moreover, has equipped the EU with a tool for the protection of fundamental rights and freedoms, of which a major part of the provisions apply to everyone, including EU citizens and third-country nationals. Next to the ECHR, other instruments drafted by the Council of Europe, such as the ECE, have influenced the EU free movement and protection regime; vice versa EEC Council Regulation No 3 on social security for migrant workers had an impact on the formulation of the ECSS.

Part III has, in addition, illustrated the overarching international dimension of the protection of migrants. This international dimension includes international human rights standards as well as treaty regimes that are specifically designed to protect migrants' rights, notably the ICMW. However, the ICMW, just like the ILO conventions and the Council of Europe instruments (with the exception of the ECHR), has not attracted the ratifications of a large number of states. It is telling that the state parties to the ICMW are, for the most part, developing states. Nonetheless, the ICMW's importance should not be underestimated in that the mere existence of the standards it sets forth and the debates which its content and application triggers, raise awareness of the need to protect migrants on a world-wide scale. This last aspect, raising awareness for the concerns of migrant workers and their families, as well as advocating a sound protection of the human rights of migrants, has also been put on the agenda of governments by global discussion fora and organisations. 



\section{Part IV : The Basis for Differential Treatment among Third-Country Nationals: EU Association Agreements and Cooperation Frameworks}

The EU is an emerging central figure on the international plane that maintains strong relations with other countries and organisations. The creation of the EEAS illustrates that the EU is keen to represent its interests visibly and effectively on a world-wide scale. The EU's external relations comprises of a broad network of association, partnership and cooperation mechanisms: to date the EU has concluded some 782 bilateral agreements and 242 multilateral agreements concerning a wide number of cooperation areas, according to Treaties Office Database of the European External Action Service. ${ }^{1}$ The Common Commercial Policy and the competence to conclude association agreements were the first explicit powers with regard to external relations until the application of the European Single Act in 1987. The EU makes use of a variety of different cooperation instruments for the purpose of collaborating with third countries, in a formal setting, to achieve its foreign policy objectives.

With a view to tackling the question as to why certain third-country nationals enjoy a more favourable legal status than others, Part IV breaks down the various association agreements and cooperation frameworks that are of relevance for individuals in that they stipulate rules on the status and/or movement of persons. Part IV examines the reasons for which the EU has concluded such agreements and frameworks with third countries. First, however, Chapter 2 of Part IV investigates how such frameworks, providing for preferential treatment for third-country nationals holding a certain nationality, relate to and mesh with the principle of non-discrimination on grounds of nationality that forms the cornerstone of the EU integration process.

Chapters 3 to 14 of Part IV list and explain the association agreements and cooperation mechanisms examined in this contribution. It is no secret that some legal frameworks provide for a closer cooperation with the EU, and consequently more extensive rights for the respective nationals, than others. This is evident, for example, for the Europe Agreements that have led to the EU enlargements of 2004 and of 2007; also, the treaty with Switzerland on the "free movement of persons" speaks for itself. Against this background Chapters 3 to 14 are structured by starting with the frameworks endowing individuals with the most advantageous legal positions, followed by those which stipulate a less beneficial regime. Association, cooperation and partnership agreements are legally binding for all contracting parties, whereas umbrella frameworks such as the ENP and the Euro-Mediterranean Partnership allow for policy collaboration on a more flexible basis. Interestingly enough, the EU has introduced customs unions establishing a free trade area with a common external tariff with only three countries: Turkey, Andorra and San Marino.

While the EU entered into association agreements with the OECD countries of Iceland, Norway and Liechtenstein (in the EEA framework), Switzerland, Turkey,

See website of the Treaties Office Database of the European External Action Service: $<$ http://ec.europa.eu/world/agreements/default.home.do>, last accessed on 7 July 2012. 
Israel and Chile, it is important to take into account that no comparable international agreements containing migration-related provisions with other OECD countries, such as Japan, the United States, Australia, New Zealand and Canada were concluded. ${ }^{2}$ Yet, nationals of these other OECD states benefit from favourable rules concerning entry and residence either based on the EU visa policy or based on bilateral regulation.

\section{Differential Treatment and the Prohibition of Nationality DISCRIMINATION}

The assorted association, cooperation and partnership agreements that are analysed in this Part IV constitute the legal basis for the more generous treatment that some third-country nationals enjoy. The question arises how this difference in treatment is compatible with the prohibition of nationality discrimination. It must be borne in mind that the rules found in the Treaty and in EU secondary legislation prohibiting discrimination by reason of nationality are merely specific enunciations of the general principle of equality which is one of the fundamental principles of EU law and which requires that similar situations shall not be treated differently unless differentiation is objectively justified. ${ }^{3}$ It was emphasized that "cet arrêt [Ruckdeschel] institue donc par la voie jurisprudentielle une règle de droit supérieure non écrite d'application générale."

The TEU enumerates equality as one of the values upon which the Union is founded along with the rights of persons belonging to minorities. ${ }^{5}$ In the context of establishing an internal market, the EU shall combat social exclusion and discrimination. ${ }^{6}$ Article 18 TFEU enshrines the principle of non-discrimination on grounds of nationality. Article 6(1) TEU sets forth that the EU recognises the rights, freedoms and principles set out in the EU Charter, which shall have the same legal value as the Treaties. It has been predicted that the Court will refer to the EU Charter more extensively and use it as a seminal tool for interpretation in the time to come this assumption has already materialised; with regard to equality, the EU Charter is said to have great potential with a Title III devoted to equality. ${ }^{7}$ The EU Charter provides for a general right to non-discrimination in Article 21(1) according to which "any discrimination based on any ground such as sex, race, colour, ethnic or social origin, genetic features, language, religion or belief, political or any other opinion, membership of a national minority, property, birth, disability, age or sexual

2 However, the EU-Israel Euro-Mediterranean Agreement only marginally touches upon migration issues.

3 Case 152/73 Sotgiu [1974] ECR 153, para. 11; Case 117/76 and Case 16/77 Ruckdeschel [1977] ECR 1753, para. 7. K. Lenaerts, 'L'égalité de traitement en droit communautaire - un principe aux apparences multiples', 27 Cabiers de droit européen (1991), 3, p. 6.

Art. 2 TEU.

Art. 3(3) TEU.

M. Bell, 'The Principle of Equality: Widening and Deepening', in: P. Craig and G. De Búrca (eds.), The Evolution of EU Law (2nd edn. Oxford University Press, Oxford 2011), p. 629; the Court has started extensively to make reference to the Charter, see inter alia Case C-104/10 Kelly [2011] Judgment of 21 July 2011, not yet reported, para. 55; Joined Cases C-159/10 and C-160/10 Fuchs [2011] Judgment of 21 July 2011, not yet reported, para. 62; Case C-300/11 ZZ [2011] Order of 10 October 2011, not yet reported, para. 10. 
orientation shall be prohibited." This clause does not list nationality as a prohibited ground for discrimination. Yet, Article 21(2) of the EU Charter specifies that discrimination on grounds of nationality shall be prohibited "within the scope of application of the Treaties and without prejudice to any of their specific provisions". In other words, discrimination on the basis of nationality is only permitted if in conformity with EU law. ${ }^{8}$ It must be borne in mind that the provisions of the EU Charter are addressed to the institutions, bodies, offices and agencies of the Union, and to the Member States only when they are implementing Union law.'

Discriminatory treatment can be direct or indirect/covert. In Sotgiu, a dispute that dealt with the separation allowance for workers employed remote form the place of residence, the Court ruled in 1974 that the rules concerning equality of treatment, both in the Treaty and in Article 7 of Regulation (EU) No 492/2011 [equal treatment in working conditions], forbade not only overt discrimination by reason of nationality but also all covert forms of discrimination which, by the application of other criteria of differentiation, in fact lead to the same result. The Court continued that "this interpretation, which is necessary to ensure the effective working of one of the fundamental principles of the Community, is explicitly recognised by the fifth Recital of the Preamble of Regulation (EU) No 492/2011 which requires that equality of treatment of workers shall be secured 'in fact and in law'."10 The Court extended its conclusions on indirect discrimination to third-country nationals in PokrzeptowiczMeyer. ${ }^{11}$

As a side note, the Treaty of Amsterdam created a legal base in Article 13 EC (now Article 19 TFEU) to pass legislation with a view to combating discrimination based on sex, racial and ethnic origin, religion or belief, disability, age or sexual orientation. ${ }^{12}$ This legislative power resulted in the adoption of Council Directive 2000/43/EC on equal treatment in relation to race and Council Directive 2000/78/EC on equal treatment in employment and occupation. ${ }^{13}$ Before the insertion of the Article $13 \mathrm{EC}, \mathrm{EU}$ endeavours to combat discrimination have concentrated mostly on forms of discrimination on grounds of nationality and gender. ${ }^{14}$ It has been emphasised that EU anti-discrimination law has developed significantly since the entry into force of the Amsterdam Treaty - just as the area of

Art. 21(2) of the EU Charter.

Art. 51(1) of the EU Charter.

Case 152/73 Sotgiu [1974] ECR 153, para. 11.

Case C-162/00 Pokrzeptowicz-Meyer [2002] ECR I-1049.

M. Bell, 'The New Article 13 EC Treaty: A Sound Basis for European AntiDiscrimination Law?', 6 Maastricht Journal of European and Comparative Law (1999), 5; L. Waddington, 'Testing the Limits of the EC Treaty Article on Non-Discrimination', 28 Industrial Law Journal (1999), 133.

13 Council Directive 2000/43/EC of 29 June 2000 implementing the principle of equal treatment between persons irrespective of racial or ethnic origin; Council Directive 2000/78/EC of 27 November 2000 establishing a general framework for equal treatment in employment and occupation; D. Schiek, 'A New Framework on Equal Treatment of Persons in EC Law?', 8 European Law Journal (2002), 290.

14 See Chapter 2 'Emerging Rights of Social Citizenship? Discrimination on Grounds of Nationality and Gender', in: M. Bell, Anti-Discrimination Law and the European Union (Oxford University Press, Oxford 2002). 
migration policy - but that EU law displayed protection gaps for third-country nationals as the prohibition of non-discrimination partly excluded the latter group. ${ }^{15}$

\subsection{The Non-Discrimination Principle in Article 18 TFEU}

Article 18 TFEU stipulates that "within the scope of application of the Treaties, and without prejudice to any specific provisions contained therein, any discrimination on grounds of nationality shall be prohibited." This principle of non-discrimination on grounds of nationality, first laid down in Article 7 of the EEC Treaty, has formed part and parcel of EU law and the development thereof. The principle has been the linchpin for creating an internal market in the EU in that its economic rationale prohibits any discrimination based on national origin or nationality aiming at the free movement of goods, services, capital, and persons. Notably, the principle has provided the Court of Justice with a basis to annul any norm which gives rise to nationality discrimination - and the Court has used it in a dynamic way. ${ }^{16}$ To be covered by the principle of non-discrimination on the basis of nationality, a situation has to fall "within the scope of application of the Treaties", which means that the unequal treatment must occur in a field to which the Treaties apply. ${ }^{17}$ Thus, the Court held in Gravier that the imposition of a registration fee for vocational training asked from a French student who wanted to study in Belgium, where the same fee was not imposed on Belgian students, constituted a discrimination on grounds of nationality contrary to Article 18 TFEU, and that access to vocational training was likely to promote the free movement of persons throughout the EU. ${ }^{18}$ Moreover, the principle of non-discrimination on grounds of nationality in Article 18 TFEU applies "without prejudice to any provision contained in the Treaty". The Court clarified that Article 18 TFEU is a general principle that is given concrete form in respect of specific situations.$^{19}$ For example, Article 45 TFEU on the free movement of workers and Article 49 TFEU on the freedom of establishment constitute such rules specifying the general prohibition of nationality discrimination. Once such a rule exists, the latter is applicable, either by itself or in conjunction with Article 18 TFEU. ${ }^{20}$

In the past the principle of non-discrimination on grounds of nationality contained in Article 18 TFEU was applied exclusively to Member States' nationals, first in view of

15 E. Muir, 'Enhancing the Protection of Third-Country Nationals Against Discrimination: Putting EU Anti-Discrimination Law to the Test', 18 Maastricht Journal of European and Comparative Law (2011), 136.

E. Bribosia and A. Weyembergh, 'Nouveaux instruments normatifs et nouvelles avancées jurisprudentielles en matière de lutte contre les discriminations sur base de la nationalité après le traité d'Amsterdam', in: E. Bribosia and others (eds.), Union européenne et nationalités: le principe de non-discrimination et ses limites (Bruylant, Bruxelles 1999), p. 239; K. Lenaerts, 'L'égalité de traitement en droit communautaire - un principe aux apparences multiples', 27 Cabiers de droit européen (1991), 3.

17 Case C-293/83 Gravier [1985] ECR 593.

18 Ibid., para. 24.

19 Case 186/87 Cowan [1989] ECR 195, para. 14.

20 See in this regard D. Martin and E. Guild, Free Movement of Persons in the European Union (Butterworths, London 1996), p. 14. 
economically active persons as has been explained above. ${ }^{21}$ In V atsouras, a judgment that the Court handed down in 2009, the application of Article 18 TFEU to thirdcountry nationals was explicitly ruled out:

"That provision [Article 18 TFEU] concerns situations coming within the scope of Community law in which a national of one Member State suffers discriminatory treatment in relation to nationals of another Member State solely on the basis of his nationality and is not intended to apply to cases of a possible difference in treatment between nationals of Member States and nationals of non-member countries."22

The dispute concerned two Greek nationals who had asked for financial assistance in the host Member State. The German court turned to the Court of Justice for clarification and asked whether Article 24(2) of Directive 2004/38/EC established a derogation from the principle of equal treatment in that the host Member State is not obliged to confer entitlement to social assistance during the first three months of residence to persons other than workers, self-employed persons, persons who retain such status and members of their families. The German court was not sure how this provision meshed with Article 18 TFEU, in conjunction with Article 45 TFEU, and wanted to know whether Article 18 TFEU precluded national rules which excluded nationals of Member States from the receipt of social assistance benefits which were granted to irregular immigrants.

The Court of Justice made clear that the general prohibition to discriminate on grounds of nationality did not apply to a possible difference in treatment between nationals of Member States and nationals of non-member countries without, however, providing additional explanation for this approach. ${ }^{23} \mathrm{E}$. Muir indicated that the Court consequently did not follow the "much more cautious formula" that AG Ruiz-Jarabo Colomer had suggested in the underlying dispute. ${ }^{24}$ AG Ruiz-Jarabo Colomer opined that EU law did not provide for rules that resolve issues of difference in treatment between EU nationals and non-member nationals who are subject to the law of the host Member State. ${ }^{25}$ E. Muir stressed that this formula would have allowed "a distinction between (i) third-country nationals whose situation falls within the scope of national law and (ii) third-country nationals whose situation is comparable to that of EU citizens or to that of other third-country nationals as a result of EU law. In this second setting, Article 18 TFEU might have been applicable." 26 The Court's judgment, in the view of the author, seemed to exclude

See Part II, Section 2.1.2.2 above on the Status of Third-Country Nationals under the EEC Treaty.

Joined Cases C-22 and C-23/08 V atsouras [2009] ECR I-4585, para. 52.

By implication, Art. 18 TFEU does thus not prevent cases of reverse discrimination, such as in Vatsouras, to occur in which third-country nationals are treated more favourably than Member States' nationals.

E. Muir, 'Enhancing the Protection of Third-Country Nationals Against Discrimination: Putting EU Anti-Discrimination Law to the Test', 18 Maastricht Journal of European and Comparative Law (2011), 136, pp. 143-144.

Opinion of AG Ruiz-Jarabo Colomer, delivered on 12 March 2009, para. 66, Joined Cases C-22 and C-23/08 V atsouras [2009] ECR I-4585.

E. Muir, 'Enhancing the Protection of Third-Country Nationals Against Discrimination: Putting EU Anti-Discrimination Law to the Test', 18 Maastricht Journal of European and Comparative Law (2011), 136, p. 144. 
third-country nationals completely from the ratione personae of Article 18 TFEU, and thus from its scope of protection against nationality discrimination. This implied the exclusion of migration law from the coverage of Article 18 TFEU. ${ }^{27}$

\subsection{General Non-Discrimination Clauses in Association Agreements}

General non-discrimination clauses that prohibit discrimination based on nationality are only present in the EU legal frameworks with the EEA, Switzerland and Turkey. As has been pointed out, these clauses are specific enunciations of the general principle of equality which is one of the fundamental principles of EU law. ${ }^{28}$ The EEA Agreement includes such a non-discrimination provision in Article 4, qualified by the provisio "within the scope of application of this agreement, and without prejudice to any special provisions contained therein." 29 Article 24 of Directive 2004/38/EC on the right of EU citizens and their family members to move and reside freely within the territory of the Member States, which is applicable to EEA nationals, sets out equal treatment with nationals within the scope of the Treaty. ${ }^{30}$

The EU-Switzerland FMP Agreement sets out the principle of non-discrimination on grounds of nationality in Article 2 in application of and in accordance with the provisions of Annexes I, II and III of the Treaty. ${ }^{31}$ This rule is reciprocal and more specific seeing that the principle of non-discrimination is applicable to residents lawfully resident in the territory of the other contracting party. Article 9 of Annex I of the FMP Agreement entitled "equal treatment" is more explicit, in that it follows the pattern of Articles 7, 8 and 9 of Regulation (EU) No 492/2011: equal treatment shall be ensured in relation to employment and working conditions, tax concessions and welfare benefits, education and vocational training, membership of trade unions, and housing. 32

According to Article 9 of the Ankara Agreement the contracting parties recognise that any discrimination on grounds of nationality shall be prohibited in accordance with the principle laid down in Article 7 of the Treaty establishing the Community (Article 18 TFEU). ${ }^{33}$ While this provision stipulates the general right to nondiscrimination, Article 37 of the Additional Protocol and Article 10(1) of Decision No 1/80 contain the non-discrimination principle for Turkish workers with regard to working conditions and remuneration. In Commission v. The Netherlands the Court held

$27 \quad$ Ibid

28 Case 152/73 Sotgiu [1974] ECR 153, para. 11; Case 117/76 and Case 16/77 Ruckdeschel [1977] ECR 1753, para. 7.

$29 \quad$ Agreement on the European Economic Area, OJ L 1, 3 January 1994, p. 3.

30 Directive 2004/38/EC of the European Parliament and the Council of 29 April 2004 on the right of citizens of the Union and their family to move and reside freely with in the territory of the Member States.

31 Agreement between the European Community and its Member States, of the one part, and the Swiss Confederation, of the other, on the free movement of persons, OJ L 114, 30 April 2002, p. 6.

32 Regulation (EU) No 492/2011 of the European Parliament and of the Council of 5 April 2011 on freedom of movement for workers within the Union.

33 Agreement establishing an Association between the European Economic Community and Turkey (Ankara Agreement) signed at Ankara on 12 September 1963, OJ L 361, 31 December 1977, p. 1; see Art. 2. 
that the non-discrimination principles contained in Article 9 of the Ankara Agreement and in Article 10(1) of Decision No 1/80 contributed to facilitating the progressive integration of migrant Turkish workers and Turkish nationals who move for the purposes of establishment or in order to provide services in a Member State, and that therefore the fees required from Turkish nationals for residence permits must be proportionate to those required from Union citizens on the basis of the nondiscrimination principles and the stand-still clauses enshrined in Article 13 of Decision No 1/80 and Article 41 of the Additional Protocol. ${ }^{34}$ In Akdas, a case that concerned the exportability of a supplement to a Dutch invalidity benefit for former Turkish workers, the Court opined that Article 9 of the Ankara Agreement cannot be applied in cases where a lex specialis exists, such as Article 3(1) of Decision No 3/80, which constitutes the concrete expression of Article 9 of the Ankara Agreement in the field of social security. ${ }^{35}$ Article 3(1) of Decision No 3/80, in turn, applied "subject to the special provisions of this Decision"; the first subparagraph of Article 6(1) of Decision No 3/80 (laying down the export of certain benefits) constitutes such a special provision according to the Court.

\subsection{Extending Article 18 TFEU to Third-Country Nationals?}

Commentators have highlighted that from the wording of the provision itself it is not apparent why the non-discrimination principle should apply to EU nationals only. It is true that Article 18 TFEU is to be found in Part II of the TFEU under the heading "Non-Discrimination and Citizenship of the Union". Nevertheless, Article 18 TFEU states that any discrimination on grounds of nationality shall be prohibited within the scope of application of the Treaties. A number of scholars have discussed this controversial coverage issue. One viewpoint was that Article 18 TFEU was not applicable to Title V TFEU because it contained specific rules. ${ }^{36}$ This stance appears odd seeing that the principle of non-discrimination precedes all other Titles of the Treaty, and one may wonder whether it is legitimate to exclude one Title from the scope of application of Article 18 TFEU without further specification.

Other academics took the view that the legal situation has changed with the inclusion of Title IV EC under the Amsterdam Treaty (now Title V TFEU), which could arguably have created a basis for third-country nationals to fall within the scope of the Treaties. ${ }^{37}$ E. Guild and S. Peers emphasised that third-country nationals have at the outset - fallen within the scope of EU law seeing that it would have been difficult or even impossible to restrict many aspects of health, consumer and

34 Case C-92/07 Commission v. The Netherlands [2010] ECR I-06383.

35 Case C-485/07 Akdas [2011] Judgment of 26 May 2011, not yet reported.

36 P. De Bruycker, 'L'émergence d'une politique européenne d'immigration', in: P. De Bruycker (ed.), L'émergence d'une politique européenne d'immigration (Bruylant, Bruxelles 2003), p. 46.

37 See P. Boeles, 'Europese burgers en derdelanders: wat betekent het verbod van discriminatie naar nationaliteit sinds Amsterdam?', 12 Sociaal-Economische Wetgeving (2005), 500, pp. 509-510; R. Cholewinski, 'Borders and Discrimination in the European Union', ILPA/Migration Policy Group (London/Brussels 2002), pp. 41-42. 
environment policies to EU citizens only. ${ }^{38}$ Admittedly, as has been pointed out by K. Groenendijk, the very fact that Title IV EC was inserted into the Treaty stipulating a special regime for third-country nationals as regards admission, residence and expulsion implied that differences in treatment in relation to Member States' nationals were envisaged. ${ }^{39}$ The author stressed, however, that this did not preclude the application of Article 18 TFEU to distinctions made between different groups of third-country nationals solely on grounds of nationality. For instance, differential treatment in visa policy could be justified, as a general rule, by foreign policy objectives and the necessity to control migration flows. ${ }^{40}$

The question regarding the personal scope of Article 18 TFEU was also the subject of some debate in a dispute that the Federal Administrative Court of Germany (Bundesverwaltungsgericht) decided on 30 March 2010; the latter court, however, did not refer the case to the Court of Justice for a preliminary ruling although it concerned the interpretation of EU law. ${ }^{41}$ The case dealt with the issue as to whether the issuance of visas for the purpose of family reunification could be refused by the German authorities because the applicant's Turkish spouse did not prove to possess a basic knowledge of German.

According to the Bundesverwaltungsgericht, this language requirement neither violated norms stipulated in the Grundgesetz (the German Constitution), such as the protection of family life and the principle of equal treatment, nor was it incompatible with the ECHR or EU law, including Council Directive 2003/86/EC on the right to family reunification. ${ }^{42}$ The fact that some third-country nationals did not have to prove such language skills at all (or alternatively, at a later point in time after entry), as they were exempted from visa requirements, was justified in the view of the German court because Germany enjoyed wide discretion in maintaining foreign relations with third countries; this included according third-country nationals privileges as regards entry and residence. ${ }^{43}$ The judgment is of interest for a number of reasons. The focus here will be on the reasoning of the Bundesverwaltungsgericht as to why the principle of nondiscrimination on grounds of nationality in EU law did not apply to third-country Peers and N. Rogers (eds.), EU Immigration and Asylum Law (Martinus Nijhoff, Leiden 2006), pp. 81-114.

$39 \quad$ K. Groenendijk, 'Citizens and Third-Country Nationals: Differential Treatment or Discrimination', in: J.-Y. Carlier and E. Guild (eds.), L'avenir de la libre circulation des personnes dans l'UE (Bruylant, Bruxelles 2006), p. 85. Ibid.; K. Groenendijk refers to R. Cholewinski, 'Borders and Discrimination in the European Union', ILPA/Migration Policy Group (London/Brussels 2002).

41 Urteil des Bundesverwaltungsgerichts of 30 March 2010, BVerwG 1 C 8.09 (VG 35 V 47.08); see R. Marx, 'Sprachnachweis und Ehegattennachzug', Zeitscbrift für Ausländerrecht und Ausländerpolitik (2011), 15.

42 Council Directive 2003/86/EC of 22 September 2003 on the right to family reunification.

43 Urteil des Bundesverwaltungsgerichts of 30 March 2010, BVerwG 1 C 8.09, paras. 5960 . 
nationals. ${ }^{44}$ The latter court indicated that this position accrued from a teleological interpretation in that:

- the principle in Article 18 TFEU was a sine qua non for a well-functioning internal market and the integration process of the Member States and their citizens - to the exclusion of third-country nationals;

- the integration of legally resident third-country nationals was important, but not the motif of the European idea - correspondingly, EU law regulated the position of third-country nationals in a much less detailed way than the position of EU citizens;

- there were fundamental differences between internal market integration and EU migration law considering that the Member States maintained a greater scope of action as regards EU migration law;

- the general application of the prohibition of nationality discrimination to thirdcountry nationals would moreover render the leeway in formulating differentiating trade policies and the utilisation of economic areas practically impossible;

- the extension of the personal scope of Article 18 TFEU would in addition contradict the objective of Union citizenship providing EU nationals with a special set of rights;

- there was no necessity on the basis of EU law to compel Member States to grant third-country nationals rights as a general rule which they accorded usually on the basis of reciprocity;

- third-country nationals could rely on the prohibition of nationality discrimination only in exceptional cases provided that their situation fell under EU law and that in addition a specific norm of EU law governing their legal position included the protection set out by the general principle of non-discrimination on grounds of nationality (the court made reference to academic literature on Article 18 TFEU) - this stance was in the view of the German court supported by the fact that Recital 5 of the family reunification Directive specified the prohibition of discrimination on various grounds other than nationality. ${ }^{45}$

The decision of the Bundesverwaltungsgericht has been criticised. Most of the reasons stated justified the differential treatment concerning the right to entry and residence between EU citizens and third-country nationals, while the main issue at stake was whether differences among third-country nationals could be justified because persons of certain non-EU nationalities were exempted from passing the language test. ${ }^{46} \mathrm{~K}$. Groenendijk considered the listing of such reasons by the Bundesverwaltungsgericht as "implicit fear" that the extension of the scope of application of the principle of nondiscrimination on grounds of nationality to third-country nationals would "amount to

$44 \quad$ Interestingly, the Bundesverwaltungsgericht did not refer to the Vatsouras case: Joined Cases C-22 and C-23/08 Vatsouras [2009] ECR I-4585.

45 Urteil des Bundesverwaltungsgerichts of 30 March 2010, BVerwG 1 C 8.09, paras. 65 and 67.

46 K. Groenendijk, 'Are Third-Country Nationals Protected by the Union Law Prohibition of Discrimination on Grounds of Nationality?', in: K. Barwig and R. Dobbelstein (eds.), Den Fremden akzeptieren - Festscbrift für Gisbert Brinkmann (Nomos, Baden-Baden 2012), 131, pp. 136-137. 
or result in granting free movement rights to third-country nationals generally." 47 As regards the last aspect mentioned by the German court - that third-country nationals had to additionally be covered by a specific norm of EU law so as to be able to rely on the general principle of non-discrimination on grounds of nationality - the scholar expressed his firm doubts: first, this extra requirement was not backed by the Bundesverwaltungsgericht and second, it would render the general principle of the prohibition of nationality discrimination practically meaningless. ${ }^{48}$

In light of the questionable traditional interpretation of the principle of nondiscrimination on grounds of nationality, there have been calls for reconsidering its scope of application. In this context, B. de Witte asked:

\footnotetext{
"Can one really defend the view that, as a matter of EU law, the EU Commission would be entitled to give agricultural price support to a farmer who is an EU citizen while denying it to his similarly situated neighbour who happens to be a third-country national? Or that a Member State would be able to grant parental leave to EU citizens but not to their legally resident neighbours who happen to have the nationality of a non-EU country?"49
}

The scholar pointed out that the reference to the "scope of the Treaties" would be the indicator for a differing level of protection that EU citizens enjoy on the one hand, and that third-country nationals enjoy on the other hand. While the former would profit from a very far-reaching - "almost unlimited" - equal treatment as promoted by the Court with its case law on EU citizenship, the latter's claim to equality of treatment "would be limited to situations covered by European Union policies, such as agriculture or gender equality." ${ }^{50}$ Likewise, it has been suggested that the scope of Article 18 TFEU should be revised to guarantee at least a minimum level of protection for third-country nationals against discrimination based on nationality. ${ }^{51}$ The argument that Article 18 TFEU should be applicable to thirdcountry nationals because of the insertion of Title V TFEU is reasonable indeed. The provisio "within the scope of the Treaties" may be interpreted so as to include thirdcountry nationals under association agreements that were concluded under Article 217 TFEU. ${ }^{52}$ This stance is substantiated by the Court's ruling in Echouikh in which the Court held that Article 18 TFEU applied independently only to situations governed by EU law in regard to which the Treaty laid down no specific rules

Ibid., p. 136

Ibid., p. 138

B. De Witte, 'Nationals, EU Citizens and Foreigners: Discrimination on Grounds of Nationality in EU Law', EUI (2010), pp. 13-14.

50 Ibid., p. 14.

51 E. Muir, 'Enhancing the Protection of Third-Country Nationals Against Discrimination: Putting EU Anti-Discrimination Law to the Test', 18 Maastricht Journal of European and Comparative Law (2011), 136, pp. 143-147.

Even though P. Boeles excluded third-country nationals covered by association agreements from the scope of his model "to avoid unnecessary complications in developing his argumentation", see below; P. Boeles, "Europese burgers en derdelanders: wat betekent het verbod van discriminatie naar nationaliteit sinds Amsterdam?', 12 Sociaal-Economische Wetgeving (2005), 500, p. 510. 
prohibiting discrimination referring to Sürül.53 The Court further explained that the general principle found specific expression in the field of social security, inter alia in Article 65 of the Euro-Mediterranean Agreement with Morocco. ${ }^{54}$ This reveals the clear link between Article 18 TFEU and other non-discrimination provisions to be found in a number of association agreements.

What would be the consequences of applying Article 18 TFEU to third-country nationals? It has been emphasised that this scenario - the application of the general prohibition of nationality discrimination to third-country nationals - would not entail that every difference in treatment on the basis of nationality is prohibited; rather, the provision would preclude direct and indirect distinctions that are not justified, in that they do not have a legitimate aim or use disproportionate means to attain their objective. ${ }^{55}$ Academics stressed that the application of Article 18 TFEU to thirdcountry nationals would not be so "revolutionary", because the intrinsic difference anchored in nationality between nationals and aliens would persist and not question the Member States' competence to regulate entry and residence of foreigners on their territories. ${ }^{56}$ The Member States' competence to determine the volumes of admission of labour migrants is explicitly confirmed in the Lisbon Treaty under Article 79(5) TFEU.

\subsection{Article 21(2) EU Charter, the General Principle of Non-Discrimination and Article 14 ECHR}

The entry into force of the Lisbon Treaty reinforced the prohibition of nationality discrimination seeing that the EU Charter - including Article 21(2) that is almost identical to the wording of Article 18 TFEU - was conferred the quality of EU primary law. The question arises as to how Article 18 TFEU relates to Article 21(2) EU Charter - do the two provisions have the same meaning? In the judgment mentioned above, the German Federal Administrative Court took the view that the two rules do set out the same scope of protection against nationality discrimination. The German court argued that in accordance with Article 52(2) of the EU Charter, the exercise of Article 21(2) EU Charter, having the degree of a basic law, must be effected under the conditions and within the limits defined in Article 18 TFEU. As a result, Article 21(2) EU Charter did not provide for a more advanced level of protection than Article 18 TFEU. ${ }^{57}$

53 Case C-262/96 Sürül [1999] ECR I-2685, para. 64: “[...] Article 3(1) of Decision No $3 / 80$ constitutes merely the implementation and the concrete expression, in the particular field of social security, of the general principle of non-discrimination on grounds of nationality laid down in Article 9 of the [Ankara] Agreement, which refers to Article 7 of the EEC Treaty (now, after amendment, Article 18 TFEU)."

54 Case C-336/05 Echouikh [2006] ECR I-5223, para. 63.

55 C. Hublet, 'The Scope of Article 12 of the Treaty of the European Communities vis-àvis Third-Country Nationals: Evolution at Last?', 15 European Law Journal (2009), 757, pp. 770-771; Case C-85/96 Martínez Sala [1998] ECR I-2691, para. 64.

56 Ibid., p. 771; P. Boeles, 'Europese burgers en derdelanders: wat betekent het verbod van discriminatie naar nationaliteit sinds Amsterdam?', 12 Sociaal-Economische Wetgeving (2005), 500, p. 500

57 Urteil des Bundesverwaltungsgerichts of 30 March 2010, BVerwG 1 C 8.09, para. 63. 
It was emphasised that this approach is in line with the Charter's official explanation of Article 21(2) that explicitly states that the latter provision corresponds to Article 18(1) TFEU and "must be applied in compliance with that Article." ${ }_{58}$ However, K. Groenendijk advocated a different reading of Article 21(2) of the EU Charter for a number of reasons. ${ }^{59}$ He pointed out, inter alia, that the provision was "not burdened with the historical role of Article 6 EEC Treaty and Article 12 EC in convincing Member States to abolish discrimination of nationals of other Member States". He took the view that the contextual setting of Article 21(2) of the EU Charter had to be taken into consideration: the rule has the heading "Non-discrimination" under Title III on "Equality" in a Charter that accords fundamental rights - to a large extent - to "everyone". In addition, the author stressed that the interpretation of the Bundesverwaltungsgericht of Article 21(2) of the EU Charter deprived the provision of its effet utile. ${ }^{60}$

Concerning the argument of the Bundesverwaltungsgericht that the general inclusion of third-country nationals as beneficiaries under Article 21(2) of the EU Charter would be a Wertungswiderspruch (an inconsistency of values/a contradictory outcome) in terms of Article 15(3) of the EU Charter granting third-country nationals merely equal working conditions, the author underscored that this explicit difference in treatment would only pose a problem if such treatment could not be justified. ${ }^{61}$ In case neither Article 18 TFEU nor 21(2) of the EU Charter provided protection for third-country nationals, K. Groenendijk concluded that they could still rely on the Union law general principle of non-discrimination as enshrined in Article 20 of the EU Charter - if they fell within the scope of Union law; while the latter principle admittedly might not attain the high standards of protection that the Court of Justice introduced as regards justifications of differential treatment between Member States' nationals, it would nevertheless require (a lower standard of) objective justification when treating third-country nationals in a different way although their situations are comparable. ${ }^{62}$ In other words, differences in treatment based on nationality between third-country nationals are possible where those persons are in comparable situations, 2007, p. 2; K. Groenendijk, 'Are Third-Country Nationals Protected by the Union Law Prohibition of Discrimination on Grounds of Nationality?', in: K. Barwig and R. Dobbelstein (eds.), Den Fremden akzeptieren - Festschrift für Gisbert Brinkmann (Nomos, Baden-Baden 2012), 131, p. 135. Ibid.

$60 \quad$ Ibid., pp. 135-136.

$61 \quad$ Ibid., pp. 136-137; Urteil des Bundesverwaltungsgerichts of 30 March 2010, BVerwG 1 C 8.09, para. 66; under Art. 15(3) of the EU Charter third-country nationals who are authorised to work in the territories of the Member States are entitled to equivalent working conditions to those of Union citizens; Art. 15(2) of the EU Charter restricts the freedom to seek employment, to work, to exercise the right of establishment and to provide services in any Member State to Union citizens. Prohibition of Discrimination on Grounds of Nationality?', in: K. Barwig and R. Dobbelstein (eds.), Den Fremden akzeptieren - Festscbrift für Gisbert Brinkmann (Nomos, Baden-Baden 2012), 131, pp. 137-138; Art. 20 of the EU Charter specifies that "everyone is equal before the law." 
but this must be objectively justified in line with Article 20 of the EU Charter and the general principle of non-discrimination. ${ }^{63}$

This approach is sensible taking into account that the growing number of thirdcountry nationals in the EU do form part and parcel of Union law at this juncture; other views simply misconceive the wording of the Treaties in today's context. In pertinent case law on Article 14 ECHR, the ECtHR confirmed the possibility to justify differential treatment in disputes relating to nationality discrimination. ${ }^{64}$ In the deportation case of C. $v$. Belgium, the Strasbourg court held that preferential treatment granted to nationals of other Member States was objectively and reasonably justified since the EU Member States formed a special legal order, which had, in addition, established its own citizenship. ${ }^{65}$ In Gaygusuz. v. Austria, a case delivered shortly after, the ECtHR ruled that although states enjoyed a certain margin of appreciation in assessing whether and to what extent differences in otherwise similar situations justify a different treatment, very weighty reasons would have to be put forward before the Court for it to rule that a difference of treatment, based exclusively on the ground of nationality, would be compatible with the Convention. ${ }^{66}$ The ECtHR decided in favour of the Turkish applicant: by denying the right to unemployment benefits to Mr. Gaygusuz because of his nationality, the Austrian state had violated Article 14 ECHR taken in conjunction with Article 1 of Protocol No 1. In light of this case law, Article 52(3) of the EU Charter provides support for the view that Article 21(2) of the EU Charter cannot be construed so as to afford less protection than Article 14 ECHR. ${ }^{67}$ Article 52(3) of the EU Charter stipulates that where the rights it lays down correspond to rights guaranteed by the ECHR, the meaning and scope of those rights shall be the same as those laid down by the said Convention and that "this provision shall not prevent Union law providing more extensive protection."

\subsection{Justifying Differential Treatment among Third-Country Nationals}

It is striking that the Bundesverwaltungsgericht presented only two policy objectives in its judgment of 30 March 2010 to substantiate its position that differential treatment among third-country nationals was justified - despite this being the central point of contention. The Bundesverwaltungsgericht argued, firstly, that the visa exemptions for certain third-country nationals (and their spouses) were based on the wide discretion that Germany enjoyed in shaping its external relations with third countries. ${ }^{68}$

63 K. Groenendijk substantiated his reasoning by referring to Case C-300/04 Eman [2006] ECR I-8055, paras. 57 and 61.

64 For a more detailed discussion of Art. 14 ECHR see Part III, Section 2.1.4 on the Prohibition of Discrimination (Art. 14 and Protocol No 12).

65 C. v. Belgium (Application No. 21794/93) Judgment of 7 August 1996, paras. 37-38.

66 Gaygusur v. Austria (Application No. 17371/90) Judgment of 16 September 1996, 23 EHRR 364, para. 42; see also Kona Poirrez v. France (Application No. 40892/98) Judgment of 30 December 2003, 40 EHRR 34, para. 46 and Andrejeva v. Lativa (Application No. 55707/00) Judgment of 18 February 2009.

67 K. Groenendijk, 'Are Third-Country Nationals Protected by the Union Law Prohibition of Discrimination on Grounds of Nationality?', in: K. Barwig and R. Dobbelstein (eds.), Den Fremden akzeptieren - Festschrift für Gisbert Brinkmann (Nomos, Baden-Baden 2012), 131, p. 135.

68 Urteil des Bundesverwaltungsgerichts of 30 March 2010, BVerwG 1 C 8.09, paras. 5960. 
Secondly, the German court made clear that the general application of the prohibition of nationality discrimination to third-country nationals would restrict the possibilities to set in place differing trade policies and economic areas. ${ }^{69}$ Arguably, these reasons are legitimate to exempt certain third-country nationals from language requirements. However, it is indeed not apparent how such justifications are relevant to achieve the ultimate aim of the Directive on family reunification, that is to say the facilitation of the migrants' integration into the host Member State, and how nationality is a determining factor as to whether or not a person is capable of integrating. ${ }^{70}$

Turning from these considerations explaining the German position to the European level, one can ascertain that the EU approach is conspicuously alike: in the field of EU visa policy one criterion that is taken into account for the determination which nationals of third countries are subject to visa requirements and which nationals are not, are the EU's external relations. ${ }^{71}$ In the context of association, cooperation and partnership agreements, preferential treatment is granted to a highly varying degree to the nationals of the respective state parties, usually in a reciprocal manner. The EU concluded such agreements to provide a legal framework for close economic relations, for general cooperation purposes, and - in the case of association agreements - for an accession perspective. ${ }^{72}$ It was the EU legislator together with the state party concerned that decided on the scope of rights on which third-country nationals can rely on the basis of these agreements. EU secondary legislation acknowledges this difference in treatment. The directives that the EU adopted in the area of legal migration relating to third-country nationals all apply without prejudice to more favourable provisions of bilateral and multilateral agreements between the EU or the EU and its Member States on the one hand and third countries on the other. By allowing explicitly for more beneficial treatment provided for by association or cooperation agreements, the directives were designed to take into account the rules of such earlier concluded agreements.

The question arises how the Court of Justice has dealt with the differential treatment of third-country nationals set forth in such agreements in disputes before it. The case law indicates that the Court has accepted these differences in treatment when interpreting the various agreements; for the drawing of analogies (or the refusal to do so, respectively) the Court attached major importance to the nature, spirit and purpose of the agreement in question. With regard to the Europe Agreements, the Court decided that the concept of "establishment" had the same meaning and scope as the identical term referred to in the EC Treaty. ${ }^{73}$ The Court pointed to the Vienna

\footnotetext{
$69 \quad$ Ibid., para. 65.

70 K. Groenendijk, 'Are Third-Country Nationals Protected by the Union Law Prohibition of Discrimination on Grounds of Nationality?', in: K. Barwig and R. Dobbelstein (eds.), Den Fremden akzeptieren - Festschrift für Gisbert Brinkmann (Nomos, Baden-Baden 2012), 131, p. 140.

71 See Recital 5 of Council Regulation (EC) No 539/2001 of 15 March 2001 listing the third countries whose nationals must be in possession of visas when crossing the external borders and those whose nationals are exempt from that requirement; see also Part V, Section 2 on Entry Rights and EU Visa Policy.

72 See Part II, Section 2.1.2.5 on the Incorporation of Migration in Association Agreements.

73 See for example Case C-268/99 Jany [2001] ECR I-8615, para. 50.
} 
Convention of 23 May 1969 on the Law of Treaties and stressed that an international treaty had to be construed not solely by reference to the terms in which it was worded but also in light of its objectives, its purpose and its context. The Court made clear that the purpose of the Europe Agreements was to establish an association designed to promote the expansion of trade and harmonious economic relations between the contracting parties in order to foster dynamic economic development and prosperity in the respective country with a view to facilitating its accession to the Community. The Court concluded that because nothing in the context or purpose of these agreements suggested that they intended to give the expression "economic activities as self-employed persons" any meaning other than its ordinary meaning of economic activities carried on by a person outside any relationship of subordination with regard to the conditions of work or remuneration and under his own personal responsibility, no difference in meaning could be distinguished between the activities as self-employed persons referred to in Article 52 of the Treaty and the economic activities as self-employed persons referred to in the Europe Agreements. ${ }^{74}$

In Kondova, the Court observed that the right to the same treatment as nationals with regard to establishment, as defined in the Europe Agreement with Bulgaria in wording similar or identical to that of Article 52 of the EC Treaty (now Article 49 TFEU), did include the rights of entry and residence by referring to case law on the EC Treaty and on the Community association with Turkey. ${ }^{75}$ However, the Court also made clear subsequently that a mere similarity in wording of a provision in the EC Treaty and an international agreement between the Community and a nonmember country was not sufficient to give to the wording of that agreement the same meaning as it has in the EC Treaty. ${ }^{76}$ The extension of the interpretation in such a case depended, inter alia, on the aim pursued by each provision in its own particular context and a comparison of the objective and context of the agreement and the EC Treaty. Then the Court distinguished the Europe Agreement with Bulgaria from the EC Treaty by pointing out that the former was designed simply to create a framework for Bulgaria's integration into the Community, with a view to its possible accession, whereas the purpose of the EC Treaty was to create an internal market. Therefore, the Court concluded that the rights of entry and residence conferred on Bulgarian nationals as corollaries of the right of establishment were not absolute privileges, inasmuch as their exercise could be limited by the rules of the host Member State concerning entry, stay and establishment of Bulgarian nationals. ${ }^{77}$

Within the scope of the EU-Turkey association, the Court emphasised in Birden and confirmed in Kury that for the purpose of determining the concept of a "worker" under Article 6(1) of Decision No 1/80, reference should be made to the interpretation of the concept of a "worker" under Community law. The Court based its reasoning in Birden on the wording of Article 12 of the Ankara Agreement and

\footnotetext{
74 Case C-268/99 Jany [2001] ECR I-8615, paras. 35-38.

75 Case C-235/99 Kondova [2001] ECR I-6427, para. 50, referring to Case 48/75 Royer [1976] ECR 497, paras. 31-32; Case C-37/98 Savas [2000] ECR I-2927, paras. 60 and 63.

76 Case C-235/99 Kondova [2001] ECR I-6427, para. 51, referring inter alia to Case 270/80 Polydor [1982] ECR 329, paras. 14-21; Case C-312/91 Metalsa [1993] ECR I-3751, paras. 11-20.

77 Case C-235/99 Kondova [2001] ECR I-6427, paras. 52-54.
} 
Article 36 of the Additional Protocol, which determine that the free movement rules under Articles 45, 46 and 57 TFEU must be extended, as far as possible, to Turkish workers who enjoy the rights conferred by Decision No $1 / 80 .{ }^{78}$

In Ziebell the Court held in more general terms that in deciding whether a provision of EU law lends itself to application by analogy under the EEC-Turkey Association, a comparison had to be made between the objective pursued by the association agreement and the context of which it formed a part, on the one hand, and those of the EU law instrument in question, on the other. ${ }^{79}$ In this case the Court of Justice dismissed the extension of the enhanced protection against the expulsion of EU citizens under Article 28(3)(a) of Directive 2004/38/EC to Turkish nationals. The Court ruled that the transposition of the principles underlying the EU freedom of movement could be justified only by the objective of progressively securing freedom of movement for Turkish workers pursued by the EEC-Turkey association. However, Article 12 of the Ankara Agreement, in referring to the EC Treaty provisions relating to the free movement of workers, confirmed that the purpose underpinning that association was solely economic in nature. ${ }^{80}$

By comparison, Directive 2004/38/EC sought - far from pursuing a purely economic objective - to facilitate the exercise of the primary and individual right to move and reside freely within the territory of the Member States (that was conferred directly on EU citizens by the Treaty). Thus, the protection against expulsion measures granted by Directive 2004/38/EC constituted a strong system of protection, which provided for greater guarantees where the degree of integration of EU nationals in the host Member State was high, taking into account the fundamental status EU citizenship. The Court concluded that this system of protection could not be applied to Turkish nationals because of the substantial differences in the wording, the object and purpose between the rules relating to the EEC-Turkey association and EU law concerning citizenship in that the former association was based on an economic rationale being restricted to the gradual achievement of the free movement of workers. ${ }^{81}$

The Court made reference to case law established under the Ankara association to substantiate its reasoning within the scope of the Maghreb agreements. The Sürül judgment was cited in Alami to underpin that the principle of equal treatment in social security required that the persons who fell under this principle could claim social security benefits under the same conditions as nationals of the host Member State. ${ }^{82}$ However, in view of substance, the drawing of analogies between the Ankara Agreement and the Maghreb is not unfettered. In El-Yassini the Court stated that the case law on the Ankara Agreement could not be applied by analogy to the EECMorocco Agreement due to substantial differences in the wording, purpose and

78 Case C-1/97 Birden [1998] ECR I-7747, paras. 23-24; Case C-188/00 Kury [2000] ECR I-10691, paras. 30-31. Case C-371/08 Ziebell [2011] Judgment of 8 December 2011, not yet reported, para. 62. See also opinion of AG Bot, delivered on 14 April 2011, paras. 44-46, in Ziebell. Case C-371/08 Ziebell [2011] Judgment of 8 December 2011, not yet reported, paras. 63-74.

82 Case C-23/02 Alami [2003] ECR I-1399, para. 31; Case C-262/96 Sürül [1999] ECR I2685. 
objective of the rules governing the EU-Turkey relations on the one hand, and the EU-Morocco relations on the other. The applicant invoked case law on the Ankara Agreement that recognised employment rights entailing a right of residence. However, the Court rejected to consider this case law in the underlying dispute because, unlike the former Agreement, the EEC-Morocco Agreement neither provided Morocco with the possibility to accede to the EU nor did it envisage progressively securing the free movement of workers. Moreover, the EEC-Morocco Council had not adopted provisions analogous to Article 6(1) of Decision No 1/80 of the EEC-Turkey Association Council, which sets out specific rights for the progressive integration of Turkish workers into the labour force of the host Member State. ${ }^{83}$

How did the Court construe the agreements that provide for the closest form of economic cooperation with the EU, that is to say the EEA Agreement and FMP Agreement with Switzerland? In Commission v. Belgium the Court emphasised Article 6 of the EEA Agreement, which states that

"in so far as they are identical in substance to the corresponding rules of the Treaty and to acts adopted in application of the Treaty, the provisions of the [EEA] Agreement are, in their implementation and application, to be interpreted in conformity with the relevant rulings of the Court given prior to the date of signature of [EEA] Agreement." ${ }^{84}$

Along these lines the Court found that the guarantees provided by Article 36 of the EEA Agreement on the freedom to provide services and Article 49 EC (now Article 56 TFEU) must be given an identical and uniform interpretation. ${ }^{85}$ Likewise, in Commission v. Spain the Court held that in so far as the provisions of Article 36 of the EEA Agreement have the same legal scope as the substantially identical provisions of Article $49 \mathrm{EC}$, its consideration on the justification of discrimination in case law established in the Community context could be transposed to the EEA context. ${ }^{86}$

With regard to the FMP Agreement, the Court made clear in Graf and Engel that the latter Agreement fell within the more general context of relations between the EU and the Swiss Confederation, which, although it did not opt to participate either in the EEA or in the Union's internal market, is nevertheless linked to the Union by numerous agreements covering a wide range of areas and prescribing rights and specific obligations analogous, in some respects, to those laid down by the Treaty. The general objective of these agreements, including the Agreement at issue in the main proceedings, is to strengthen the economic ties between the EU and the Swiss Confederation." 87 In this case the Court decided that the reasons, exhaustively listed in Article 5(1) of Annex I to the FMP Agreement, as justifications for derogation from the fundamental rules of the latter, such as the principle of equal treatment,

83 Case C-416/96 El-Yassini [1999] ECR I-1209, paras. 49-61; see also E. Guild, Immigration Law in the European Community (Kluwer Law International, The Hague 2001), pp. 85-86.

84 Case C-522/04 Commission v. Belgium [2007] ECR I-5701, paras. 43 et seq.

85 Ibid.

86 Case C-153/08 Commission v. Spain [2009] ECR I-9735, paras. 36-48.

87 Case C-506/10 Graf and Engel [2011] Judgment of 6 October 2011, not yet reported, para. 33. 
must be interpreted in a restrictive manner. While the case law on EU citizenship cannot, by analogy, be applied to EEA and Swiss nationals, EEA nationals (to whom the scope of application of Directive 2004/38/EC has been extended) can - as opposed to Turkish nationals - rely on the enhanced protection against expulsion under Article 28(3)(a) of Directive 2004/38/EC. In conclusion, the Court has thus made the interpretation of a provision or concept existent in one legal framework in relation to another conditional on the objective pursued by an agreement and by each provision in its own particular context.

\subsection{Rethinking Nationality as Decisive Factor for the Legal Position?}

In an interesting but somewhat contentious contribution, P. Boeles questioned the traditional difference in treatment made on grounds of nationality between the three categories of Member States' nationals, EU citizens, and third-country nationals in immigration law - and suggested a new model with regard to the prohibition of nationality discrimination. This model accepts that conducting immigration policies is a legitimate objective for the Member States, but it allows them to differentiate between the afore-mentioned groups of individuals in the scope of their policies only on the basis of their current residence status, not on the basis of nationality. ${ }^{88}$

Measures relating to immigration law, which concern the nationals of other Member States or third-country nationals, and which cannot be taken vis-à-vis own nationals, are only justified provided that they are suitable and proportionate. In a nutshell, a direct distinction on grounds of nationality may not be made in respect of granting rights and imposing obligations; a distinction, which is suitable and proportionate to the aim pursued on grounds of the current residence status of non-nationals, is admissible if in accordance with the fundamental rights guaranteed by EU law. Thus, the author proposed residence status as the decisive criterion in immigration law, and - at the time in the absence of relevant case law as regards third-country nationals the latter supported his viewpoint by referring to case law dealing with EU nationals.

In Martinez Sala the Court ruled that an EU citizen lawfully residing in the territory of another Member State could rely on Article 18 TFEU in all situations which fell within the scope ratione materiae of EU law, including the situation where that Member State delayed or refused to grant a benefit to that claimant that was provided to all persons lawfully resident in the territory of that state on the ground that the claimant was not in possession of a document which nationals of that same state were not required to have and the issue of which may be delayed or refused by the authorities of that state. ${ }^{89} \mathrm{P}$. Boeles further made reference to Trojani in which a non-active EU national could invoke the prohibition of nationality discrimination in order to be granted a social benefit in a situation where he had lawfully resided for a certain period in the host Member State and where he was in possession of a residence permit..$^{90}$ According to the author, the Court's approach in requiring a sufficient degree of legal residence in order to invoke the principle of non-discrimination on

88
P. Boeles, 'Europese burgers en derdelanders: wat betekent het verbod van discriminatie naar nationaliteit sinds Amsterdam?', 12 Sociaal-Economische Wetgeving (2005), 500, p. 509-510; P. Boeles uses the Dutch term "actuele verblijfspositie". Case C-85/96 Martínez Sala [1998] ECR I-2691, para. 63. Case C-456/02 Trojani [2002] ECR I-7573. 
grounds of nationality to challenge the refusal to be granted social assistance conformed to his model: the Court made a distinction, suitable and proportionate to the aim to be achieved, on the basis of residence status. The author underscored that he could see no ground why this way of reasoning should not also be applied to requests for social assistance made by third-country nationals. ${ }^{91}$

While these considerations provide food for thought and a new perspective on nationality and its link to immigration law, they seem in the final analysis far-fetched and unrealistic to provide a sound basis for a policy. As P. Boeles remarked, nationality has the central function to determine the legal position of the nationals of a state, which includes an "absolute" right of residence. Such a residence right of nationals is characterised in that it cannot - as opposed to foreigners - be taken away from them without the (rare) withdrawal of nationality. ${ }^{92}$ The ECtHR's view in Moustaquim v. Belgium, in which it was ruled that nationals cannot be compared to aliens because the former have a right to abode in their own country and cannot be expelled from it, constitutes the other extreme view. ${ }^{93}$ In the light of these different positions, the following approach appears to be the most reasonable: the length of legal residence should be the decisive factor for the scope of rights that immigrants enjoy in the host country.

This approach is in fact already reflected in EU law, such as in the EU-Turkey association and Council Directive 2003/109/EC on the status of third-country nationals who are long-term residents. ${ }^{94}$ The latter directive provides third-country nationals who have lawfully and continuously resided in the territory of a Member State for a period of five years with the possibility to obtain long-term resident status. Long-term resident status guarantees a more secure legal position in the host Member State, equal treatment with nationals of the Member State concerned in specified areas, as well as enhanced protection against expulsion. Moreover, longterm residents can acquire the right to reside in the territory of another Member State if certain conditions are met. However, it is true that residence status cannot be used as criterion for the purpose of determining rights relating to entry; these rights are, on the national and EU level, still subject to nationality discrimination even if the differences in treatment are justified by considerations relating to external relations. ${ }^{95}$

91 See P. Boeles, 'Europese burgers en derdelanders: wat betekent het verbod van discriminatie naar nationaliteit sinds Amsterdam?', 12 Sociaal-Economische Wetgeving (2005), 500, pp. 511-512; interestingly, in the Metock case the prior unlawful residence of a spouse of a EU citizen did not prevent the individual in question to rely on the provisions of Directive 2004/38/EC of the European Parliament and of the Council of 29 April 2004 on the right of citizens of the Union and their family members to move and reside freely within the territory of the Member States: Case C-127/08 Metock and Others [2008] ECR I-6241.

92 The right to leave any country, including his own, and to return to his country is acknowledged under international law, see Art. 13(2) UDHR; Art. 2 of Protocol No 4 to the ECHR; Art. 12 ICCPR.

93 Moustaquim v. Belgium (Application No. 12313/86) Judgment of 18 February 1991, 13 EHRR 802.

94 Council Directive 2003/109/EC of 25 November 2003 concerning the status of thirdcountry nationals who are long-term residents.

95 For more information see Part V, Section 2 on Entry Rights and EU Visa Policy. 
After the fall of the Soviet Union, between 1991 and 1996, the Community signed association agreements with the Central and Eastern European States, the so-called "Europe Agreements". ${ }^{96}$ It is noticeable that the Member States were more cautious in the drafting of these agreements on account of the extensively-interpreted case law of the Court of Justice on the Ankara Agreement and on the cooperation agreements with the Maghreb countries. ${ }^{97}$ Moreover, the political and economic conditions had changed; the Member States' protectionist attitudes were reflected in their restrictive labour immigration policies. ${ }^{98}$ This, notwithstanding the Europe Agreements, represented "a great opening towards these countries [...]; they contain similar, if not identical, provisions and they recognise the accession to the European Union as final objective". ${ }^{99}$ In total, ten Europe Agreements were concluded with Hungary, Poland, the Czech Republic, Slovakia, Romania, Bulgaria, the Baltic states (Latvia, Lithuania and Estonia) and Slovenia with the objective to establish a political dialogue; to promote economic relations and create a free trade area with a view to supporting the countries' transition into a market economy; to provide an overall framework for the gradual integration into the EU; and to foster financial, cultural and social cooperation. The approach to transpose common economic, commercial and political objectives should pave the way for future accession - a plan that successfully materialised in 2004 and 2007 in the form of enlargement. ${ }^{100}$ It has been stressed that the movement of natural persons could also been excluded from the scope of the Europe Agreements at the stage of negotiation, however, the reasons for their inclusion prevailed in the end. Unlike the common view that it was first and foremost the people from third countries who wished to enter the EU as economic migrants, one must not fail to recognise that it was also the aspiration of nationals of Member States to be granted easier access to the labour markets of the Central and Eastern European States. The reciprocal nature of the rights on labour market access was

96

For an overview on the Europe Agreements see Chapter 1 of P. Van den Bempt and G. Theelen, From Europe Agreements to Accession (European Interuniversity Press, Bruxelles 1996).

J. Niessen, 'Association Agreements - Part of the Developing Immigration Policy of the European Union', in: E. Antalovsky and others (eds.), Assoziierungsabkommen der EU mit Drittstaaten (Manz Verlag, Wien 1998), p. 27.

N. Rogers and R. Scannell, Free Movement of Persons in the Enlarged European Union (Sweet \& Maxwell, London 2005), p. 285.

B. Melis, Negotiating Europe's Immigration Frontiers (Kluwer Law International, The Hague 2001), p. 104; see also M. Maresceau and E. Montaguti, 'The Relations between the European Union and Central and Eastern Europe: A Legal Appraisal', 32 Common Market Law Review (1995), 1327.

100

Europe Agreements OJ L 347, 31 December 1993, p. 2 (Hungary); OJ L 348, 31 December 1993, p. 2 (Poland); OJ L 360, 31 December 1994, p. 2 (Czech Republic); OJ L 359, 31 December 1994, p. 2 (Slovak Republic); OJ L 357, 31 December 1994, p. 2 (Romania); OJ L 358, 31 December 1994, p. 3 (Bulgaria); OJ L 26, 2 February 1998, p. 3 (Republic of Latvia); OJ L 51, 20 February 1998, p. 3 (Republic of Lithuania); OJ L 68, 9 March 1998, p. 3 (Republic of Estonia); OJ L 51, 26 February 1999, p. 3 (Republic of Slovenia). 
moreover sought by the EU that strongly supported the incorporation of migrationrelated rules into the Europe Agreements. ${ }^{101}$

Despite the fact that the Europe Agreements are outdated by now, they are still a valuable source of case law in which the Court confirmed a set of (directly applicable) rights to the nationals of the respective states. Importantly, the free movement of workers was (and still is in some cases) partly temporarily restricted on grounds of transitional agreements laying down derogations which allowed the EU-15 to limit labour market access to the acceded Central and Eastern European states. ${ }^{102}$ The Europe Agreements all display a similar structure: the core agreement is supplemented by a number of annexes, protocols and declarations, and all agreements comprise a Title on the "movement of workers, establishment, and supply of services". 103 The heading was a bit misleading considering that the legal rules neither governed the first entry of workers to the territory of a Member State nor provided for access to the labour markets for the latter. ${ }^{104}$

\section{THE EEA COOPERATION}

The EU's external engagement with Iceland, Norway and Liechtenstein dates back to the beginning of the 1970s. Back then the alliance was based on bilateral free trade agreements that the Community had concluded with the former EFTA countries to foster trade relations. ${ }^{105}$ The EFTA was founded in 1960 by seven countries including Austria, Denmark, Norway, Portugal, Sweden, Switzerland and the UK in order to enhance economic cooperation and promote prosperity. After a period characterised by competition, the trade relations between the EFTA countries and the Community intensified when Denmark, the UK and Ireland joined the Community in $1973 .{ }^{106}$ Considering that some states did not aspire to full membership of the Community but still sought closer economic cooperation, the creation of the EEA was seen as a pragmatic alternative. Negotiations on the EEA

101 E. Guild, Immigration Law in the European Community (Kluwer Law International, The Hague 2001), p. 177.

102

On the transitional arrangements, see K. Inglis, 'Treading the Tightrope between Flexibility and Legal Certainty', in: D. Hanf and R. Muñoz (eds.), La libre circulation des personnes - États des lieux et perspectives (Cahiers du Collège d'Europe, Bruxelles 2007).

For an indepth analysis of the provisions on workers, establishment and services consult D. Martin and E. Guild, Free Movement of Persons in the European Union (Butterworths, London 1996), pp. 295-345.

See in this regard the Declaration of the European Community to the Final Act on Chapter I of Title IV of the Hungarian Europe Agreement, in which "the Community declares that nothing in the provisions of Chapter I 'Movement of workers' shall be construed as impairing any competence of Member States as to the entry into and stay on their territories of workers and their family members".

The Community concluded free trade agreements with Austria, Sweden, Switzerland, Portugal, Iceland, Norway and Finland; these agreements were terminated for most of the EFTA countries which acceded to the EU.

A. Lazowski, 'EEA Countries (Iceland, Liechtenstein and Norway)', in: S. Blockmans and A. Lazowski (eds.), The European Union and Its Neighbours: A Legal Appraisal of the EU's Policies of Stabilisation, Partnership and Integration (T.M.C. Asser Press, The Hague 2006), pp. 98-101. 
began in 1990 and culminated in the signing of the EEA Agreement in 1992.107 Today, the EEA is made up of the 27 EU Member States and Iceland, Norway and Liechtenstein; however, Iceland submitted its application for EU membership in July 2009. ${ }^{108}$ Because of a negative referendum, Switzerland did not accede to the EEA in 1992 as envisaged.

The EEA Agreement provides the nationals of Iceland, Norway and Liechtenstein with the most advantageous status in the EU, in comparison to other third-country nationals, except for Swiss nationals who also benefit from extensive free movement rights. The three states take part in the Schengen cooperation which has the objective to abolish internal border controls, to reinforce external border controls and to establish a harmonised visa policy; the Principality of Liechtenstein is a member of the Schengen area since 19 December 2011.109 On the basis of a cooperation agreement, Iceland and Norway accepted the Schengen Convention and the Schengen acquis and were given associate membership in 1996. A new Schengen Association Agreement, which was concluded between Norway, Iceland and the EU under Article 6 of the Schengen Protocol, ensured the Schengen association of both countries after the integration of the Schengen framework into the EC Treaty in 1999. ${ }^{110}$

The EEA Agreement, which was concluded between the Community, its Member States and the EFTA states of Iceland, Norway and Liechtenstein, aims to promote a continuous and balanced strengthening of trade and economic relations between the contracting parties with equal conditions of competition, and the respect of the same rules, with a view to creating a dynamic and homogeneous EEA. ${ }^{111}$ A negative referendum prevented Switzerland from the EEA membership in December 1992; however, as an EFTA state, Switzerland holds close bilateral relations on political, economic and cultural issues with the EU. The contracting parties signed the EEA Agreement on 2 May 1992 and it entered into force on 1 January 1994. As an initiative of Jacques Delors, who was President of the European Commission at that time, the EEA Agreement extends the internal market rules to Iceland, Norway and Liechtenstein and thus allows for the free movement of goods, services, capital and persons throughout the EEA zone so as to guarantee a single homogeneous market. Besides ensuring the application of the four freedoms, the Agreement also includes provisions on competition in order to stipulate equal conditions for economic actors, horizontal rules relevant to the four freedoms and cooperation outside the four freedoms. ${ }^{112}$ Institutional rules provide for the establishment of joint bodies: the

107 Agreement on the European Economic Area (EEA Agreement), OJ L 1, 3 January 1994, p. 3.

108 Conclusions of the 32nd Meeting of the European Economic Area Council, document number: EEE 1610/09 of 16 November 2009. See Council of the European Union, "Schengen enlargement: Liechtenstein to become 26th member state" of 13 December 2011, document number: 18446/11. Agreement concluded by the Council of the European Union and the Republic of Iceland and the Kingdom of Norway concerning the latters' association with the implementation, application and development of the Schengen acquis, OJ L 176, 10 July 1999 , p. 36.

111 See 4th preambular paragraph to the EEA Agreement and Art. 1 of the EEA Agreement.

112 Parts IV, V and VI of the EEA Agreement. 
EEA Council gives the political impetus for the transposition and assesses the implementation of the EEA Agreement, while the EEA Joint Committee is in charge of the effective implementation and operation of the Agreement. ${ }^{113}$ Emphasis is put on the uniform interpretation and application of the EEA Agreement and those provisions of Community legislation which are reproduced in this Agreement. To this end, Article 6 of the EEA Agreement stipulates that the identical provisions shall be construed in conformity with the relevant rulings of the Court of Justice given prior to the date of the signature of the Agreement. However, the Court also construed provisions of the EEA Agreement after its signature in conformity with rulings on provisions of the EC Treaty: in Commission v. Belgium it held that the guarantees provided by Article 36 of the EEA Agreement on the freedom to provide services and Article 49 EC (now Article 56 TFEU) must be given an identical and uniform interpretation. ${ }^{114}$ The Court made the same finding in relation to Article 40 of the EEA Agreement on the freedom of movement of capital and Article 56 EC (now Article 63 TFEU). ${ }^{115}$ In Rimband the Court confirmed that, although restrictions on the free movement of capital between nationals of states party to the EEA Agreement had to be assessed in the light of Article 40 of that Agreement and Annex XII thereto, those provisions have the same legal scope as Article 63 TFEU. However, it specified that "it should be borne in mind that the case law concerning restrictions on the exercise of the freedoms of movement within the European Union cannot be transposed in its entirety to movements of capital between Member States and non-Member States, since such movements take place in a different legal context."'116

Article 7 of the EEA Agreement states that secondary legislation referred to shall be binding upon the contracting parties and be made part of their internal legal order. The EEA Joint Committee is responsible for keeping the developments of the case law of the ECJ and the EFTA Court under constant review. ${ }^{117}$ Next, two organs were established: the EFTA Surveillance Authority, which monitors the fulfilment of the obligations under the EEA Agreement and the EFTA Court. ${ }^{118}$ The EFTA Court was established with the approval of the ECJ after the latter had first delivered a negative opinion on the envisaged creation of an EEA Court. ${ }^{119}$ The initially proposed system of judicial supervision, an EEA Court comprised of ECJ judges and persons appointed by EEA/EFTA states, was found to be incompatible with the EC Treaty as it would have affected the autonomy of the Community legal order which had to be guaranteed by the Court of Justice itself in accordance with Article 164 EEC Treaty. ${ }^{120}$

\footnotetext{
113 See Arts. 89 and 92 of the EEA Agreement.

114 Case C-522/04 Commission v. Belgium [2007] ECR I-5701, para. 44 et seq.

115 Case C-540/07 Commission v. Italy [2009] ECR I-10983, para. 65 et seq.

116 Case C-72/09 Rimband [2010] ECR I-10659, paras. 22 and 40.

117 See 15th preambular paragraph to the EEA Agreement and Art. 105 of the EEA Agreement.

118 Arts. 108 and 109 of the EEA Agreement.

119 Opinion 1/92 EEA Agreement II [1992] ECR I-2821.

120 Opinion 1/91 EEA Agreement [1991] ECR 6079, para. 35; B. Brandtner, 'The Drama of the EEA Comments on Opinions 1/91 and 1/92', 3 European Journal of International Law (1992), 300; M. Cremona, 'The "Dynamic and Homogeneous" EEA: Byzantine Structures and Variable Geometry', 19 European Law Review (1994), 508, pp. 514-517.
} 
The EFTA Court and the EFTA Surveillance Authority shall pay due account to the principles laid down by the relevant rulings, given by the Court of Justice after the date of signature of the EEA Agreement, in the interpretation and application of the Agreement as well as of the Surveillance and Court Agreement. ${ }^{121}$ According to Article 108(2) EEA Agreement, only EFTA states fall under the jurisdiction of the EFTA Court which has jurisdiction on actions concerning the surveillance procedure regarding the EFTA states' appeals concerning competition decision taken by the EFTA Surveillance Authority and dispute settlement between two or more EFTA states. $^{122}$ While the principle of state liability was explicitly acknowledged by the EFTA Court, the issue with regard to the Community principles of direct effect and primacy is more ambiguous. ${ }^{123}$ In Restamark the EFTA Court ruled on the "quasidirect effect" of EEA law. ${ }^{124}$ Even before this decision was handed down, however, scholars emphasised that the principles of direct effect and primacy form integral part of the EEA legal framework. ${ }^{125}$ It has been asserted that the EEA Agreement goes beyond the scope of a usual free trade agreement because it aims at a high degree of integration and does not preclude the possibility for EFTA states to join the EU.126 Finally, the EEA Agreement specifies that a state that applies for EU membership shall also apply to become a member to the EEA Agreement. ${ }^{127}$ In line with this rule, the EEA Agreement was extended to the Member States that joined the EU in 2004 and in 2007 respectively, on the basis of EEA Accession Agreements. ${ }^{128}$ These agreements took over most of the transitional arrangements provided for in the EU Accession Treaty. Protocol No 15 to the EEA Agreement stipulates transitional rules on the restriction of the free movement of persons, on behalf of Switzerland and Liechtenstein on the one hand and the EEA- and EU Member States on the other. These restrictions terminated on 1 January 1998.

See Art. 3(2) of the Agreement between the EFTA States on the Establishment of a Surveillance Authority and a Court of Justice ("Surveillance and Court Agreement").

For more detailed information on the EFTA Court, see J. Forman, 'The EEA Agreement Five Years On: Dynamic Homogeneity in Practice and its Implementation by the two EEA Courts', 36 Common Market Law Review (1999), 751, pp. 767-778.

EFTA Court Case E-9/97 Sveinbjoernsdóttir, decided on 10 December 1998, paras. 62 and 63.

EFTA Court Case E-1/94 Restamark, decided on 16 December 1994.

W. Gerven, 'The Genesis of EEA Law and the Principles of Primacy and Direct Effect', 16 Fordham International Law Journal (1992), 955; L. Sevon and M. Johansson, 'The Protection of the Rights of Individuals under the EEA Agreement', 24 European Law Review (1999), 373.

See Case T-115/94 Opel Austria [1997] ECR II-39, para. 107; EFTA Court Case E9/97 Sveinbjoernsdóttir, decided on 10 December 1998, para. 59; 14th preambular paragraph to the EEA Agreement.

See Art. 128 of the EEA Agreement and the 2004 and 2007 EEA Enlargement Agreements.

Agreement on the participation of the Czech Republic, the Republic of Estonia, the Republic of Cyprus, the Republic of Latvia, the Republic of Lithuania, the Republic of Hungary, the Republic of Malta, the Republic of Poland, the Republic of Slovenia and the Slovak Republic in the European Economic Area, OJ L 130, 29 April 2004, p. 3; Agreement on the participation of the Republic of Bulgaria and Romania in the European Economic Area, OJ L 221, 25 August 2007, p. 15. 
In 1960 Switzerland was a founding member of the EFTA. In order to deepen economic integration outside of the EFTA, 12 years later the Swiss authorities concluded a Free Trade Agreement with the Community aiming to abolish the tariff barriers for industrial products. ${ }^{129}$ Since Switzerland did not accede to the EEA in 1992, the EFTA state continued to hold bilateral relations with the Community based on the Free Trade Agreement of 1972. The cooperation between the Community and Switzerland was reinforced by a first package of seven bilateral agreements signed in 1999 (Bilateral Agreements I) ${ }^{130}$ and a second package signed in 2004 (Bilateral Agreements II $)^{131}$ dealing with different policy areas. ${ }^{132}$ The first package of bilateral agreements included inter alia the Agreement on the Free Movement of Persons which is a mixed agreement because the Community shared the competences on the conclusion with the Member States. As a consequence, all contracting parties had to ratify the agreement according to the relevant constitutional provisions in the different national legal orders before they could enter into force. ${ }^{133}$ Just as EEA nationals, on the basis of the EEA Cooperation, Swiss nationals enjoy extensive free movement rights on the basis of the Agreement on the Free Movement of Persons between Switzerland, the Community and its Member States.

Switzerland participates in the Schengen cooperation on the abolition of internal border checks. Switzerland's Schengen association is governed by one of the agreements under the Bilateral Agreements II, the Agreement on the Swiss association to the Schengen acquis entered into force on 1 March 2008. ${ }^{134}$

129 Agreement between the European Economic Community and the Swiss Confederation, OJ L 300, 31 December 1972, p. 189.

130 The Bilateral Agreements I concern the free movement of persons, agriculture, transport, research, and technical barriers to trade and government procurement, OJ L 11430 April 2002, pp. 1-480; see also R. Bieber, 'Quelques remarques à l'occasion de l'entrée en vigueur des accords bilateraux suisse-CE', in: R. Bieber (ed.), Mélanges en Phonneur de Bernard Dutoit (Librairie Droz, Genève 2002), pp. 13-20.

131 The Bilateral Agreements II address the following subject-matters: taxation of savings, cooperation in the field of police and justice, processed agricultural products, statistics, the fight against fraud, media, education and vocational training, asylum and migration, youth, and pensions.

132 C. Kaddous, 'The Relations between the EU and Switzerland', in: A. Dashwood and M. Maresceau (eds.), Law and Practice of EU External Relations: Salient Features of a Changing Landscape (Cambridge University Press, Cambridge 2008), pp. 227-269; A. Lazowski, 'Switzerland', in: S. Blockmans and A. Lazowski (eds.), The European Union and Its Neighbours: A Legal Appraisal of the EU's Policies of Stabilisation, Partnership and Integration ('T.M.C. Asser Press, The Hague 2006), pp. 165-173.

133 S. Breitenmoser, 'Sectoral Agreements between the EC and Switzerland: Contents and Context', 40 Common Market Law Review (2003), 1137, p. 1143; C. Reymond, 'Institutions, Decision-Making Procedure and Settlement of Disputes in the European Economic Area', 30 Common Market Law Review (1993), 449, p. 450.

134 Agreement between the European Union, the European Community and the Swiss Confederation on the Swiss Confederation's association with the implementation, application and development of the Schengen acquis, OJ L 53, 27 February 2008, p. 52; Council Decisions 2004/849/EC (OJ L 368, 15 December 2004, p. 26) and 2004/860/EC (OJ L 370, 17 December 2004, p. 78); for more information see: F. 
Already in 1993 the Commission envisaged the conclusion of a bilateral instrument covering the free movement of persons due to the considerable number of EU citizens living and residing in Switzerland at that time. This plan was implemented with a multilateral agreement between Switzerland, the Community and the EU Member States, which was signed in 1999 and entered into force on 1 June 2002 (FMP Agreement), governing the EU's relations with Switzerland concerning the movement of persons. ${ }^{135}$ After the Swiss people had rejected the EEA participation of their country in 1992, it approved the FMP Agreement with a vast majority in May of 2000. ${ }^{136}$ The FMP Agreement forms part of the Bilateral Agreements I and provides for the gradual, reciprocal and policed liberalization of the parties' labour markets. Difficult negotiations preceded the adoption of the FMP Agreement, solved by, among other things, the incorporation of a number of transitional arrangements. ${ }^{137}$ The three annexes on free movement of persons (Annex I), the coordination of social security schemes (Annex II) and on mutual recognition of professional qualifications (Annex III) and the protocols form an integral part of the FMP Agreement. ${ }^{138}$ Notwithstanding the gradual autonomous assimilation of Swiss law to the acquis communautaire, the FMP Agreement falls, in principle, under public international law and must hence be construed in line with the 1969 Vienna Convention of the Law of Treaties in view of its general functioning. "With regard to the substantive content which is part of the acquis communautaire, however, application and interpretation have to follow the rules and standards set by the European institutions". 139

The objectives of the FMP Agreement are listed in Article 1:

- to accord a right of entry, residence, access to work as employed or self-employed person and the right to stay in the territory of the parties;

- to facilitate the provision of services;

- to accord a right of entry and residence to persons without an economic activity in the host country;

- to accord the same living, employment and working conditions as those accorded to nationals.

Filliez, 'Schengen/Dublin: The Association Agreements with Iceland, Norway and Switzerland', in: B. Martenczuk and S. Van Thiel (eds.), Justice, Liberty, Security: New Challenges for EU External Relations (VUBPRESS, Brussels 2008), pp. 145-183; C. Kaddous and M. Jametti Greiner, Accords Bilatéraux II Suisse - Union Européenne et Autres Accords Récents (Helbing \& Lichtenhahn, Basel 2006).

135 Agreement between the European Community and its Member States, of the one part, and the Swiss Confederation, of the other, on the free movement of persons, OJ L 114, 30 April 2002, p. 6; for a legal analysis of each provision contained in the FMP Agreement, see A. Borghi, La libre circulation des personnes entre la Suisse et PUE (Éditions interuniversitaires suisses, Genève 2010).

136 The Swiss people voted with $67 \%$ in favor of the bilateral agreements between Switzerland and the EU on 21 May 2000.

137 A. Lazowski, 'Switzerland', in: S. Blockmans and A. Lazowski (eds.), The European Union and Its Neighbours: A Legal Appraisal of the EU's Policies of Stabilisation, Partnership and Integration (T.M.C. Asser Press, The Hague 2006), p. 155.

138 Art. 15 of the FMP Agreement.

139 S. Breitenmoser, 'Sectoral Agreements between the EC and Switzerland: Contents and Context', 40 Common Market Law Review (2003), 1137, pp. 1139 and 1144. 
In Grimme the Court held that the freedom of establishment guaranteed by the FMP Agreement for the benefit of natural persons could not be interpreted as also applying to legal persons because the objectives laid down in Article 1 of the FMP Agreement are established for the benefit of nationals of the contracting parties. ${ }^{140}$ Article 2 of the FMP Agreement contains the principle of non-discrimination on grounds of nationality. Annexes I to III specify substantive rights listed in Articles 3 to 9 , which are subject to analysis below.

The FMP Agreement stipulates extensive and complex transitional arrangements in Article 10 in accordance with Chapter VII of Annex I. Firstly, Switzerland can maintain quotas in relation to access to the Swiss labour market for EU nationals pursuing an economic activity for five years, excluding those nationals who reside on Swiss territory for less than four months (para. 1). In this regard Switzerland shall, however, reserve at least 115,500 new residence permits for stays between four months and less than one year, as well as 15,000 new residence permits for stays equal to, or exceeding, one year (para. 3). Secondly, the contracting parties may maintain controls on the priority of workers integrated in the regular labour market and wage and working conditions applicable to nationals of the other contracting parties, including service providers referred to in Article 5 of the FMP Agreement, for a maximum period of two years. Conversely, this is not applicable to service providers who are covered by a specific agreement between the contracting parties. The Joint Committee reviews these restrictions and decides whether they need to be maintained (para. 2). Workers and self-employed persons, who at the time of the entry into force of the FMP Agreement were authorised to pursue an economic activity, also do not fall within the scope of application of Article 10(2) as outlined in Article 10(5) of the FMP Agreement. Thirdly, a safeguard clause allows Switzerland to limit unilaterally the number of new residence permits for the following two years to the average of the three preceding years plus $5 \%$, if faced with a major influx of workers or self-employed persons from the EU (a rise of 10\% or more in relation to the three preceding years for either category). This derogatory regime applies after five years and up to twelve years after the entry into force of the agreement (para. 4). Yet, this derogation cannot be invoked to undercut the number of new residence permits each year as referred to in Article 10(3) of the FMP Agreement (para. 4). Frontier workers are exempted from any quantitative restrictions (para. 7).

A supplementary protocol extended the FMP Agreement to the ten Member States which joined the EU in 2004 by introducing transition periods which allowed for labour market restrictions until 30 April 2011, at the latest. ${ }^{141}$ The transition periods applied to employed persons and service providers in certain sectors from the 2004 accession Member States, except for Malta and Cyprus. Moreover, a derogatory regime in form of a second protocol applies to nationals of Bulgaria and Rumania

140 Case C-351/08 Grimme [2009] ECR I-10777, paras. 37-39.

141 Protocol to the Agreement between the European Community and its Member States, of the one part, and the Swiss Confederation, of the other, on the free movement of persons regarding the participation, as contracting parties, of the Czech Republic, the Republic of Estonia, the Republic of Cyprus, the Republic of Latvia, the Republic of Lithuania, the Republic of Hungary, the Republic of Malta, the Republic of Poland, the Republic of Slovenia and the Slovak Republic pursuant to their Accession to the European Union, OJ 2006 L 89, 28 March 2006, p. 28. 
which sets out labour market restrictions until 31 May 2016. The limitations on the access to economic activities for EU citizens expired for nationals of the former EU15 on 1 June 2007.

Article 11 of the FMP Agreement sets out the rules on the processing of appeals: any person who falls under this agreement shall be provided with a right to appeal to the competent authorities in matters concerning the application of the agreement (para. 1). Decisions must be taken within a reasonable time (para. 2) and there must be the possibility of appeal (para. 3). It is pointed out that there is no single judicial body which observes the application and guarantees a uniform interpretation of the agreement. Hence, a divergent reading of provisions of the FMP Agreement by different courts in the contracting parties is possible. This scenario is at least, to a certain extent, curtailed as EU Member States can suspend a pending case and ask the ECJ for a preliminary ruling under Article 267 TFEU. ${ }^{142}$ The ECJ has jurisdiction as the provisions of an international agreement, which the EU has concluded, form integral part of Community law from their coming into force. ${ }^{143}$

More favourable national provisions for the nationals of the contracting parties and their families are not precluded by the FMP Agreement (Article 12). Moreover, the stand-still clause enshrined in Article 13 prohibits the introduction of more restrictive measures with regard to each other's nationals in the fields covered by the FMP Agreement. Article 14 provides for the establishment of a Joint Committee composed of the representatives of the contracting parties which is responsible for the management and the proper application of the FMP Agreement. The Joint Committee issues recommendations and takes decisions by mutual agreement where the FMP Agreement provides for this possibility (para. 1). In the event of serious economic or social difficulties, the Committee shall examine the appropriate measures to remedy the problematic situation (para. 2).

Article 16 of the FMP Agreement is central as this provision aims to guarantee homogeneity: the contracting parties shall take the necessary measures to ensure that the rights and obligations equivalent to those contained in the legal acts of the European Community, to which reference is made, are applied between them. Insofar as the application of the agreement involves concepts of Community law, account shall be taken of the relevant case law of the ECJ prior to the signature date of the FMP Agreement. The subsequent case law shall be notified to the Swiss authorities and the implications of such case law shall be determined by the Joint Committee (Article 16 paras. 1 and 2). The Court clarified that Article 16(1) of the FMP Agreement provided for the application of the acquis communautaire between the contracting parties only in the framework of the objectives of the Agreement and that the application of the acquis communautaire is subject to reference being made to rights and obligations equivalent to those contained in the EU's legal acts. ${ }^{144}$ Thus, the interpretation of EU law on the internal market cannot automatically be applied by

142 C. Kaddous, 'The Relations between the EU and Switzerland', in: A. Dashwood and M. Maresceau (eds.), Law and Practice of EU External Relations: Salient Features of a Changing Landscape (Cambridge University Press, Cambridge 2008), p. 241.

143 Case C-181/73 Haegeman [1974] ECR 449, paras. 5-6.

144 Case C-351/08 Grimme [2009] ECR I-10777, paras. 37-39. 
analogy to the interpretation of the FMP Agreement, unless there are express provisions to that effect in the FMP Agreement itself. ${ }^{145}$

Article 17(1) sets out the obligation to report envisaged changes of domestic legislation, which affects the FMP Agreement, as well as changes in the case law of authorities against whose decisions there is no judicial remedy. The Joint Committee holds an exchange of views in this instance (para. 2). Article 18 specifies the amendment procedure. The contracting parties shall submit the proposal to the Joint Committee. While amendments, in principle, enter into force after the completion of the respective internal procedures, amendments to Annexes II and III, which shall be adopted by Joint Committee decision, enter into force immediately after the decision.

Article 19 lays down the rules for the settlement of disputes. The contracting parties can bring a contentious issue concerning the interpretation or application of the FMP Agreement to the Joint Committee which may settle them. Articles 20 to 22 govern the relationship with other bilateral agreements, such as double taxation treaties. Article 23 secures acquired rights by private individuals in the case of termination or non-renewal. Article 24 determines the territorial scope and Article 25 stipulates that the seven agreements can only enter into force in case of the approval of all of them, and if any of them is terminated, the other agreements are also terminated.

Since the entering into force of the FMP Agreement on 1 June 2002, Swiss courts have, on numerous occasions, dealt with disputes on the interpretation and application of the rules contained in the agreement. The Swiss jurisdiction has consistently decided cases before it with reference to case law of the Court of Justice and secondary EU legislation. ${ }^{146}$ This holds true for the judgments delivered before and after the signature of the FMP Agreement on 21 June 1999. This approach is interesting to point out taking into account that the legal obligation to consider the relevant case law of the ECJ only covers case law prior to the signature date of the FMP Agreement. ${ }^{147}$ Consequently, generally speaking, Swiss courts de facto follow the stance taken by the Court of Justice in Luxembourg with regard to the interpretation and the application of the FMP Agreement; this practice is, however, neither discussed nor expounded in the case law. ${ }^{148}$ In 2005, the Federal Supreme Court of Switzerland delivered a judgment which concerned the question whether a vendor selling standing orders via the telephone falls under the concept of a worker within the scope of the FMP Agreement. The Swiss Court ruled in the affirmative and made extensive reference to ECJ case law on the autonomous Community notion of workers. ${ }^{149}$ It stated that the qualification of a worker must be interpreted in consideration of relevant case law of the Court of Justice before the signature of the

145 Case C-541/08 Fokus Invest [2010] ECR I-01025, para. 28; on the specific question of how EU citizenship and relevant case law on the subject matter relates to the FMP Agreement, see A. Borghi, La libre circulation des personnes entre la Suisse et PUE (Éditions interuniversitaires suisses, Genève 2010), pp. 318-321. See for example judgments of the Federal Supreme Court of Switzerland, BGE 130 II 493, BGE 129 II 249, BGE 131 V 209.

147 See Art. 16 of the FMP Agreement.

148 A. Epiney, 'Die schweizerische Rechtsprechung zum Personenfreizügigkeitsabkommen - ein Überblick', Annuaire du droit de la migration 2004/2005 (2005), 141, p. 155.

149 Judgment of the Federal Supreme Court of Switzerland, BGE 131 II 339, paras. 3.13.4. 
FMP Agreement and "le cas échéant, le Tribunal fédéral peut également s’inspirer des arrêts rendus postérieurement à cette date, surtout s'ils ne font que préciser une jurisprudence antérieure". ${ }^{150}$ Thus, the Federal Supreme Court of Switzerland can be "inspired" by case law of the Court of Justice after the signature of the FMP Agreement, in particular in cases where this case law specifies earlier case law. ${ }^{151}$

The literature devotes attention to the question how a demarcation can be drawn between case law decided before and after the signature of the FMP Agreement. While it is easy to distinguish between judgments depending on whether they were delivered before or after 21 June 1999, it is more intricate to determine whether the latter judgments represent new case law within the meaning of Article 16(2) of the FMP Agreement. It remains unclear where the benchmark is to be set seeing that many of the Court's rulings merely confirm and specify existing jurisprudence. ${ }^{152}$ Lastly, there is still the possibility for the contracting parties under Article 19 FMP Agreement to bring a matter of dispute with regard to the interpretation or application of the FMP Agreement to the Joint Committee which then settles the dispute.

\section{THE EU-TURKEY RELATIONS}

In 1963, the Community first established relations with the Turkish Republic by signing the Ankara Agreement on an association with the objective to enhance trade cooperation between the parties, promote Turkey's economic development and improve the living and employment conditions of the Turkish people. ${ }^{153}$ The Ankara Agreement entered into force on 1 December 1964 and provided for the incremental development of a customs union, to be introduced in three stages. ${ }^{154}$ Article 28 of the Ankara Agreement sets out the possibility for Turkey to obtain EU membership. Yet, the wording of the agreement is rather general in nature: it envisages a programme to be implemented by means of decisions taken by the Association Council. ${ }^{155}$ The Ankara Agreement is inspired by Treaty rights, for instance, Article 12 refers to Articles 48, 49 and 50 EC (Articles 45, 46 and 57 TFEU) which the contracting

See also judgment of the Federal Supreme Court of Switzerland, BGE 130 II 493, para. 3.1. For a discussion on whether the ECJ case law on social security is to be taken into consideration by Switzerland, see E. Imhof, 'Das Freizügigkeitsabkommen EGSchweiz und seine Auslegungsmethode', 5-6 Zeitschrift für europäisches Sozial- und Arbeitsrecht (2007), 217.

152 For a discussion see A. Epiney, 'Zur Bedeutung der Rechtsprechung des EuGH für die Anwendung und Auslegung des Personenfreizügigkeitsabkommen', 141 Zeitschrift des Bernischen Juristenvereins (2005), 1, pp. 17-31; K. Pärli, 'Arbeitsrechtliches Diskriminierungsverbot europäischer Wanderarbeitnehmer nach Gemeinschaftsrecht und nach dem Personenfreizügigkeitsrecht mit der Schweiz', Zeitschrift für europäisches Sozial- und Arbeitsrecht (2007), 21, pp. 28-29. Agreement establishing an Association between the European Economic Community and Turkey (Ankara Agreement) signed at Ankara on 12 September 1963, OJ L 361, 31 December 1977, p. 1; see Art. 2 of the Ankara Agreement.

154 See Arts. 2, 3, 4 and 5 of the Ankara Agreement.

155 See Arts. 6 and 22 of the Ankara Agreement. 
parties agreed to take into account in order to secure the freedom of movement for workers between them. ${ }^{156}$

The Ankara Agreement was supplemented by the Additional Protocol that the parties signed on 23 November 1970; it became effective three years later, on 1 January 1973. The Additional Protocol sets forth provisions relating to the conditions, arrangements and timetables for the implementation of the transitional period. ${ }^{157}$ Article 36 of the Additional Protocol lays down that the freedom of movement of workers between the Member States and Turkey should be established by progressive stages and, at the latest, 23 years after the entry into force of the Ankara Agreement. This implementation date of 1996 was, however, not met. A non-discrimination clause for Turkish citizens and Member States' nationals in employment conditions is enshrined in Article 37 of the Additional Protocol. Article 41(1) of the Additional Protocol includes a stand-still clause according to which the contracting parties shall refrain from introducing, between themselves, any new restrictions on the freedom of establishment and the freedom to provide services. This stand-still provision has direct effect, and it has induced the Court to hand down landmark judgments in the field of freedom of establishment and freedom to provide services. ${ }^{158} \mathrm{Next}$, it is specified that Turkey shall not receive more favourable treatment than the Member States grant to each other in fields covered by the Additional Protocol. ${ }^{159}$

With a view to ensuring the implementation and the progressive development of the association, the parties meet in an Association Council that consists of members of the governments of the Member States and members of the Council and of the Commission on the one hand and of members of the Turkish government on the other. The Association Council has decision-making power to attain the objectives of the Agreement. ${ }^{160}$ In line with this setting, the Association Council has adopted a number of implementing decisions including Decision No 1/95 on implementing the final phase of the customs union and Decision No 1/98 on the trade regime for agricultural products. ${ }^{161}$ The decisions containing pertinent provisions for the movement of Turkish nationals are Decision No 2/76 on the implementation of Article 12 of the Ankara Agreement, Decision No 1/80 on the development of the Association, and Decision No 3/80 on the application of the social security schemes of the Member States to Turkish workers and members of their families. ${ }^{162}$ Decision

\footnotetext{
156 See Art. 12 of the Ankara Agreement.

157 See Art. 1 of the Provisional Protocol No 1 to the Ankara Agreement.

158 Case C-37/98 Savas [2000] ECR I-2927, paras. 46-54; Case C-16/05 Tüm and Dar [2007] ECR I-7415; Case C-228/06 Soysal [2009] ECR I-1031.

159 See Art. 59 of the Additional Protocol.

160 See Arts. 6, 22 and 23 of the Ankara Agreement.

161 Decision No 1/95 of the EC-Turkey Association Council of 22 December 1995 on implementing the final phase of the Customs Union (96/142/EC); Decision No 1/98 of the EC-Turkey Association Council of 25 February 1998 on the trade regime for agricultural products (98/223/EC).

162 Decision No 2/76 of the EC-Turkey Association Council of 20 December 1976 on the implementation of Art. 12 of the Ankara Agreement; Decision No 1/80 of the ECTurkey Association Council of 19 September 1980 on the development of the Association; Decision No 3/80 of the EC-Turkey Association Council of 19 September 1980 on the application of the social security schemes of the Member States to Turkish workers and members of their families.
} 
No 1/80 superseded Decision No 2/76 in 1980 as the latter's temporal scope was limited to four years; it contained initial rules for the implementation of Article 36 of the Additional Protocol. The legal sources listed along with the extensive case law of the Court on these sources must be considered as a whole to determine properly the scope of rights within EU law upon which Turkish nationals can rely. In view of the free movement of workers, the Court ruled that Article 12 of the Ankara Agreement and Article 36 of the Additional Protocol do not have direct effect because they essentially set out a programme and are not sufficiently precise and unconditional to constitute rules of Community law directly applicable in the internal legal order of the Member States. ${ }^{163}$ The Court took the same stance with regard to the freedom of establishment (Article 13 of the Ankara Agreement) and by analogy it can be reasoned that the same applies for the freedom to provide services (Article 14 of the Ankara Agreement). ${ }^{164}$

It is not a coincidence that the Ankara Agreement contains references to the movement of workers taking into account the labour market demands prevailing in Western European states at the time. ${ }^{165}$ The legal framework determining the rules applicable to Turkish nationals appear rather fragmented on grounds of the different legal sources and the dynamic development instigated by case law handed down by the Court of Justice. The original EEC-Turkey association has formed the foundation for the evolution of the movement regime for Turkish citizens. By adopting a proactive attitude and by construing the relevant legislation extensively, the Court has, over time, considerably strengthened the legal position of Turkish nationals in the EU. In return, Member States had to accept that their competence to regulate immigration matters for Turkish nationals has progressively been curtailed. Recent case law even suggests an overhaul of the often repeated stance that the provisions of the EU-Turkey association do not encroach upon the competence retained by the Member States to regulate both the entry into their territories of Turkish nationals and the conditions under which they make take up their first employment. ${ }^{166}$ The question arises whether Community law still merely regulates the situation of Turkish workers already lawfully integrated into the labour force of Member States. Importantly, until the point in time that Turkey joins the Union as a fully-fledged Member State, the legal rules of the Ankara Agreement and the implementing measures will continue to govern the movement of persons between the EU and Turkey and will thus be of relevance for the longstanding association.

In 2013, the $50^{\text {th }}$ anniversary of the signing of the Ankara Agreement will be commemorated. The EU-Turkey association is the oldest of its kind. The question

163 Case C-12/86 Demirel [1987] ECR I-3719, paras. 23 and 25.

164 On the freedom of establishment, see Case C-37/98 Savas [2000] ECR I-2927, paras. $41-45$.

165 On the labour demand in post-war Europe, see A. Akgündüz, Labour Migration from Turkey to Western Europe, 1960-1974 (Amsterdam University Press, Amsterdam 2007), pp. 131-139; the bilateral recruitment agreement between Germany and Turkey was signed on 30 October 1961, see A. Yollu-Tok, '50 Jahre Anwerbeabkommen mit der Türkei - Zur Lage der Türkeistämmigen auf dem sich wandelnden Arbeitsmarkt’, 61 Aus Politik und Zeitgescbicbte (2011), 22, pp. 22-23. 
arises where Turkey stands today with regard to obtaining EU membership. ${ }^{167}$ In December 2004, the European Council stated that Turkey had made decisive progress in its reform process. ${ }^{168}$ Seeing that Turkey had sufficiently complied with the Copenhagen criteria, the accession negotiations were opened on 3 October 2005. The 2005 Turkey Progress Report indicated that the candidate country made efforts in some areas such as company and intellectual property law and in executing decisions of the ECtHR, while improvements in other fields were limited, for instance as regards the fight against torture and ill-treatment and the freedom of expression and religion. ${ }^{169}$ The revised Accession Partnership for Turkey of 2008 has determined principles, priorities and conditions for the Turkey's accession to the EU; the priorities are subdivided into short-term and medium-term priorities which are subject to a monitoring mechanism. The list of these priorities is quite extensive, and Turkey will still have to make substantial efforts to fulfil all requirements. ${ }^{170}$ This finding was confirmed in the 2011 Turkey Progress Report, which pointed out that the accession negotiations have continued but that the EU expected Turkey to lift all restrictions on the movement of goods regarding Cyprus. ${ }^{171}$ The Report stated that negotiations have been opened on 13 chapters, only one of which was provisionally closed. With regard to the freedom of movement for workers hardly any progress has been made. ${ }^{172}$

\section{THE EU AND THE WESTERN BALKAN COUNTRIES: STABILISATION AND ASSOCIATION}

After the Balkan wars, the EU had a special interest to restore peace in South-Eastern Europe with the implementation of the Dayton/Paris peace agreements, to promote political stability, and to stimulate economic prosperity. The EU first established formalised relations with the Western Balkan countries in 1996 with the adoption of the so-called regional approach addressed to the states of Former Yugoslavia. The Council indicated that the regional approach was primarily directed towards those countries of the region for which the EU had not laid down directives for the negotiation of association agreements back then (Albania and four of the five successor republics of former Yugoslavia: Bosnia and Herzegovina, Croatia, the Federal Republic of Yugoslavia and the FYROM). ${ }^{173}$ Future agreements with these countries were said to be useful to consolidate peace, to ensure political stability, to

167 G. Avci, 'Turkey’s Slow Candidacy: Insurmountable Hurdles to Membership or Simple Euro-Scepticism', in: A. Çarkoğlu and B. Rubin (eds.), Turkey and the European Union (Frank Cass, London 2003), pp. 149-170; for a scenario of the EU's foreign policy orientation after Turkey's accession to the EU, see S. Laçiner, M. Özcan and İ. Bal, European Union with Turkey: The Possible Impact of Turkey's Membership on the European Union (USAK, Ankara 2005).

168 Brussels Presidency Conclusions of 16 and 17 December 2004, para. 18.

169 European Commission, Turkey Progress Report 2005, SEC(2005) 1426, 9 November 2005.

Council Decision 2008/157/EC of 18 February 2008 on the principles, priorities and conditions contained in the Accession Partnership with the Republic of Turkey and repealing Decision 2006/35/EC.

171 European Commission Staff Working Paper, SEC(2011) 1201, 12 October 2011.

172 Ibid., pp. 55-56.

173 See European Commission, $\operatorname{COM}(96)$ 476, 2 October 1996, p. 1; European Commission Communication, $\operatorname{COM}(1999)$ 235, 26 May 1999, p. 2. 
foster economic development and to promote the cooperation between those countries, with their neighbours and with the EU. The agreements should take into consideration the special nature of each country's individual situation, and their conclusion should be made contingent on the countries' willingness to establish peace and to respect human rights, minorities and democratic principles. ${ }^{174}$ Until 1999 two of such cooperation agreements had been concluded with Albania and the FYROM. ${ }^{175}$

A year later, a number of economic and political conditions were agreed upon by the General Affairs Council with a view to establish a coherent and transparent policy for bilateral relations with each country as regards trade, financial support and economic cooperation and contractual relations. ${ }^{176}$ From 1997 to 2000, the Commission drew up conditionality reports assessing the progress achieved in each country. These conditionality reports were taken into account by the General Affairs Council which decided on further action. In 1999, the regional approach developed into the Stabilisation and Association Process offering the five countries in South-Eastern Europe a more advanced relationship. Stability in the region still stood on shaky ground as inter-ethnic tensions in the Kosovo conflict demonstrated. The EU recognised its responsibility to help solving the difficult and unstable situation on the spot and to draw the region closer to the prospect of EU integration. ${ }^{177}$ The Council pointed out that the Stabilisation and Association Process should cover the conclusion of SAAs, autonomous trade measures and economic relations, assistance for democratisation and civil society, humanitarian aid for refugees, returnees and other persons of concern, cooperation in justice and home affairs and the development of a political dialogue. ${ }^{178}$ According to the Commission, this change only related to the nature of the envisaged contractual relations: instead of concluding cooperation agreements, stabilisation and association agreements were offered to the countries in question. Hence, for the negotiations on the SAAs, the economic and political conditions laid down in 1997 still needed to be met. ${ }^{179}$

The European Council explicitly set out the possibility for the Western Balkan countries to accede to the EU in 2000 at the Santa Maria da Feira summit declaring that "all the countries concerned are potential candidates for EU membership". The integration of the countries into Europe by means of political dialogue, liberalisation of trade and collaboration in justice and home affairs was firmly endorsed. ${ }^{180}$ The Second Annual Report, setting out the progress for South-Eastern Europe, states that the SAAs draw heavily on the Europe Agreements that had been concluded with the former candidate countries in Central and Eastern Europe but that they differ to the extent that the objectives of stabilisation and association require the proper

174 See Council Conclusions of the General Affairs Council of 26 February 1996.

175 Agreement between the European Economic Community and the Republic of Albania, on trade and commercial and economic cooperation, OJ L 343, 25 November 1992, p. 2; Cooperation Agreement between the European Community and the former Yugoslav Republic of Macedonia, OJ L 348, 18 December 1997, p. 2; see European Commission Communication, COM(1999) 235, 26 May 1999, p. 3.

176 See Council Conclusions of the General Affairs Council of 29 April 1997.

177 European Commission Communication, COM(1999) 235, 26 May 1999, pp. 1-4.

178 Council Conclusions of the General Affairs Council of 21-22 June 1999.

179 European Commission Communication, COM(2000) 49, 2 March 2000, p. 2.

$180 \quad$ Santa Maria da Feira Presidency Conclusions of 19 and 20 June 2000, para. 67. 
balance. ${ }^{181}$ The Thessaloniki Agenda for the Western Balkans confirms and prioritises the accession perspective for the Balkans to become an integral part of unified Europe. The agenda foresaw, moreover, the drawing up of so-called European Partnerships that identify priorities for action for each country, modelled after the Accession Partnerships used for the Central and Eastern EU Member States before their accession. As regards cooperation in justice and home affairs, the EU put emphasis on fighting irregular migration, concluding readmission agreements and facilitating travel opportunities. ${ }^{182}$ Today, Croatia, the FYROM and Montenegro are candidate countries, while Albania, Bosnia and Herzegovina, Serbia and Kosovo have the status of potential candidate countries. The Commission published the enlargement strategy 2010-2011 including the state of play for the Western Balkan countries in November $2010 .{ }^{183}$ The SAAs are very similar to one another.

The EU has concluded six SAAs with the Western Balkan countries out of which four have entered into force. ${ }^{184}$ The SAAs resemble each other both in content and structure. The preambles of all SAA stipulate the EU's readiness to integrate the respective country into the political and economic mainstream of Europe and set out the goal of EU membership. All SAAs establish an association with the EU and have the following objectives:

- to provide a framework for political dialogue, allowing the development of close political relations between the parties;

- to support the efforts of the respective country to develop its economic and international cooperation, also through the approximation of its legislation to that of the EU;

- to support the efforts of the respective country to complete the transition into a functioning market economy, to promote harmonious economic relations and gradually develop a free trade area;

- to foster regional cooperation in all fields covered by the SAAs.

181 European Commission, $\operatorname{COM}(2002)$ 163, 3 April 2002, pp. 4-8.

182 Council Conclusions of the General Affairs and External Relations Council of 16 June 2003, pp. 10-16.

183 European Commission Communication, $\operatorname{COM}(2010)$ 660, 9 November 2010.

184 Stabilisation and Association Agreement between the European Communities and their Member States, of the one part, and the Republic of Albania, of the other part, OJ L 107, 28 April 2009, p. 166; Stabilisation and Association Agreement between the European Communities and their Member States, of the one part, and the Republic of Croatia, of the other part, OJ L 26, 28 January 2005, p. 3; Stabilisation and Association Agreement between the European Communities and their Member States, of the one part, and the former Yugoslav Republic of Macedonia, of the other part, OJ L 84, 20 March 2004, p. 13; Stabilisation and Association Agreement between the European Communities and their Member States of the one part, and the Republic of Montenegro, of the other part, OJ L 108, 29 April 2010, p. 3; Stabilisation and Association Agreement between the European Communities and their Member States, of the one part, and the Republic of Serbia of the other part, signed on 29 April 2008; Stabilisation and Association Agreement between the European Communities and their Member States, of the one part, and Bosnia and Herzegovina, of the other part, signed on 16 June 2008; as of 22 October 2011, the SAAs with Albania, Croatia, Macedonia and Montenegro have entered into force; the ratifications of the SAAs with Serbia and Bosnia and Herzegovina are pending. 
The SAAs with Albania, Montenegro, Serbia and Bosnia and Herzegovina set out the additional aims:

- to support their efforts to strengthen democracy and the rule of law;

- to contribute to their political, economic and institutional stability, as well as to the stabilisation of the region.

\section{The EU RELATIONS WITH SAN MARINO AND ANDORRA}

The EU first established relations with the microstate of San Marino that is surrounded by Italy in February of 1983, followed by negotiations on a Cooperation and Customs Union Agreement that was signed in 1991.185 This agreement has notably created a customs union, but it has also consolidated the political and social relations between the contracting parties by providing a legal basis for cooperation. According to an Aide Memoire "San Marino economy is closely intertwined with the European one and its culture and history clearly reflect its century-old strong ties with Europe. Therefore, devising new forms of collaboration over and above the Cooperation and Customs Union Agreement now in force can no longer be procrastinated, since San Marino belongs to Europe, not only from a geographical point of view."186

The Principality of Andorra and the EU first signed an Agreement (in the form of an Exchange of Letters) establishing a customs union in 1990 which entered into force soon thereafter. ${ }^{187}$ In 2004, the parties furthermore concluded a Cooperation Agreement that extended the scope for collaboration covering inter alia transport, culture, social provisions, education, information exchange, regional policy and environment; this agreement became applicable in 2005. ${ }^{188}$

\section{The European Neighbourhood Policy CoOperation}

\subsection{Backeground and Objectives}

The biggest EU enlargement, involving the accession of ten new Member States on 1 May 2004, was not only, in itself, a major step forward in the European integration process but the EU's external frontiers assumed a new dimension. ${ }^{189}$ After the accession of Bulgaria and Romania in January 2007, the Union's neighbours today are

Agreement on Cooperation and Customs Union between the European Economic Community and the Republic of San Marino, OJ L 84, 28 March 2002, p. 43.

Aide-Memoire on the EU-San Marino relations, available on the website of the EEAS: $<$ http://eeas.europa.eu/sanmarino/index_en.htm>, last accessed on 15 January 2012. Agreement in the form of an Exchange of Letters between the European Economic Community and the Principality of Andorra, OJ L 374, 31 December 1990, p. 14.

Cooperation Agreement between the European Community and the Principality of Andorra, OJ L 135, 28 May 2005, p. 14.

J. Rupnik, 'L'Europe et ses Périphéries', in: J. Rupnik (ed.), Les Banlieues de l'Europe - Les Politiques de Voisinage de l'Union Européenne (Presses de Sciences Po, Paris 2007), pp. 9-40; N. Tocci, 'Does the ENP respond to the EU's Post-Enlargement Challenges?', 40 The International Spectator (2005), 21. 
Russia, Belarus, Ukraine and the Republic of Moldova in the east, while the entry into the EU of Malta and Cyprus constituted an extension in the southern European region. The process of enlargement raises questions concerning the geographical limits of the Union: how large can the EU eventually become? Can the often invoked "absorption capacity", which was later renamed into "integration capacity", serve as a justification to pause or even stop the enlargement process? Next, what strategy shall be employed with regard to the EU's neighbouring countries in order to prevent the emerging of new dividing lines?

In 2002, Romano Prodi delivered a speech in which he proposed for the EU "to share everything but its institutions" with the neighbouring states. With this statement the President of the European Commission at that time envisaged "the extension of the set of principles, values and standards which define the very essence of the EU". The creation of a common market offering free trade, an investmentfriendly environment, the approximation of legislation, as well as a single currency, forms the core area in this respect. ${ }^{190}$ The Commission came up with an approach that became known as the ENP addressing part of these issues. In March 2003, the Commission indicated the EU's interest in establishing closer relations with its new neighbours. It issued a Communication labelled "Wider Europe - Neighbourhood: A New Framework for our Eastern and Southern Neighbours" that suggested an integrated approach in setting up an area of peace, stability and prosperity - a "ring of friends" - with the neighbouring countries to promote peaceful and cooperative external relations. ${ }^{191}$

The Commissioner for External Relations, Chris Patten, commented on the Communication by stating that “over the last decade, the Union's most successful EU foreign policy instrument has undeniably been the promise of EU membership. This is not sustainable. For the coming decade, we need to find new ways to export the stability, security and prosperity we have created within the enlarged EU. We should begin by agreeing on a clearer vision for relations with our neighbours." 192 Despite the geographical proximity, the strategy is therefore unequivocally addressed to the states that currently are not prospective members of the EU. The Commission took the view that regional and sub-regional integration must be fostered so as to stimulate economic growth, social cohesion and political stability. On the basis of a number of incentives such as the extension of the internal market, preferential trading relations, support in conflict prevention and perspectives for the movement of persons, the Commission envisaged, as a long-term objective, EU cooperation with the neighbouring states that resembles the EEA. The ENP is supposed to supplement and build upon existing frameworks such as association and partnership agreements providing for legislative and regulatory approximation. Moreover, Action Plans shall be drafted and stipulate the existing and future collaboration, policy goals

190 R. Prodi, 'A Wider Europe - A Proximity Policy as the Key to Stability', Speech delivered on 5 December 2002 at the Sixth ECSA World Conference on Peace, Stability and Security, Brussels.

191 European Commission Communication, COM(2003) 104, 11 March 2003.

192 See Europa, press release "Wider Europe Neighbourhood: proposed new framework for relations with the EU's Eastern and Southern Neighbours", IP/03/358 of 11 March 2003. 
and benchmarks tailored to the specific needs and capacities of the respective country. ${ }^{193}$

The European Council welcomed this initiative with a view to reinforcing shared values and furthering common interests at the Thessaloniki summit in June 2003.194 One year later, the Commission specified its view on the ENP in a strategy paper on the basis of negotiations with the relevant Council's working groups, exploratory talks with the partner states in Eastern Europe and the Southern Mediterranean, as well as assessments on the present situation in the countries concerned. ${ }^{195}$ According to the Strategy Paper, the ENP intends to enhance regional and sub-regional cooperation concerning political, economic, cultural and social aims as provided for in the actions plans. The privileged links with the EU are based on shared values including democracy, good governance, rule of law, respect for human rights and the principles of market economy.

Great is attached importance to the use of Action Plans. They contain a common set of principles but simultaneously lay down the short and medium-term key priorities for each partner state. The Action Plans shall be agreed upon by the EU and its partner states by common consent. The progress achieved will be monitored by bodies established under the Partnership and Cooperation Agreements or the Association Agreements respectively. The monitoring bodies comprise representatives of the partner countries, the Member States, the Commission and the Council Secretariat. This setup promotes the idea of joint ownership and facilitates cooperation. In addition, the Commission will draw up progress reports with evaluations on past action and possible future activities according to which the Action Plans can be adapted. The Action Plans envisage collaboration in a broad range of fields including economy, business, employment, social policy, security issues, transport, energy, environment, research, people-to-people contacts and justice and home affairs.

The Commission stressed the added value that the ENP will entail such as the moving from cooperation to a process of integration, the increase of political cooperation and the reinforcement of economic and social relations. Furthermore, the ENP supports the EU's aims in the area of foreign policy and it provides a platform to work out unresolved issues. The ENP reinforces EU action as regards regional cooperation in Eastern Europe and the Mediterranean in the South and the ENP is coupled with the EU-Africa Strategy. ${ }^{196}$ The ENP complements the European Security Strategy, announced in December 2003, that depicts the key threats Europe is facing in the 21st century and identifies strategic objectives to address the EU's main challenges and imminent dangers. Substantive emphasis is put

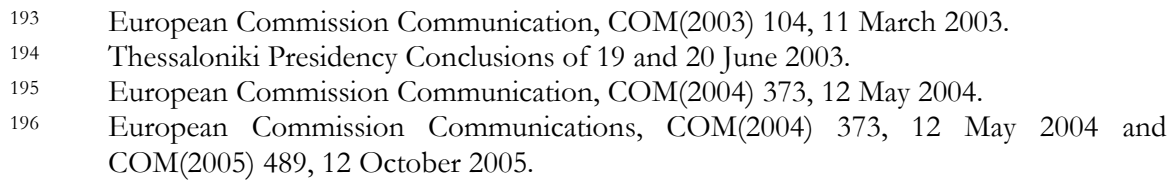


on the pursuit of a multilateral approach and the building of security in the neighbourhood. ${ }^{197}$

\subsection{ENP Partner States and Regional Frameworks}

The Treaty on European Union as amended by the Treaty of Lisbon contains an explicit reference in Article 8 concerning the EU's relationship with neighbouring states. According to that provision, the Union shall develop a special relationship with neighbouring countries, aiming to establish an area of prosperity and good neighbourliness, founded on the values of the Union and characterised by close and peaceful relations based on cooperation. To this end, the Union may conclude specific agreements with the countries concerned.

The ENP comprises 16 immediate neighbouring countries to the EU, regardless of whether the border is a land or sea border. These states are Algeria, Armenia, Azerbaijan, Belarus, Egypt, Georgia, Israel, Jordan, Lebanon, Libya, Moldova, Morocco, the Occupied Palestinian Territory, Syria, Tunisia and Ukraine. The ENP does not apply to the candidate and potential candidate countries. EU candidate countries are Croatia, Iceland, the FYROM, Montenegro and Turkey; the potential EU candidate countries are Albania, Bosnia and Herzegovina, Serbia and Kosovo under the UN Security Council Resolution $1244 .{ }^{198}$ It is important to note that Russia does not participate in the ENP despite its central role as an EU neighbouring country. ${ }^{199}$ Instead, a Strategic Partnership between Russia and the EU was set up during the St. Petersburg Summit in May 2003 on the creation of four policy areas, so-called "common spaces". 200

The ENP will be differentially applied to the various partners. The regional dimensions of the ENP include the Eastern Partnership, the Union for the Mediterranean, as well as the Black Sea Synergy.

First, the "Eastern Partnership" builds upon the aims set out in the ENP and consists of a bi- and a multilateral track covering Armenia, Azerbaijan, Belarus, Georgia, Moldova and Ukraine. Association agreements, the establishment of a comprehensive and deep free trade area and progressive visa liberalisation, among other things, will intensify the bilateral engagement. The multilateral track is envisaged to create policy platforms on democracy and good governance, economic integration, energy security and contacts between people. ${ }^{201}$ In 2011, the Commission

197 Council of the European Union, "A Secure Europe In A Better World - The European Security Strategy”, 12 December 2003.

198 Designated EU candidate and potential candidate countries as of 6 December 2011.

199 The 2003 and 2004 Commission Communications refer extensively to Russia but finally Russia was not included in the ENP framework, see European Commission Communications, COM(2003) 104, 11 March 2003; COM(2004) 373, 12 May 2004.

200 The four common spaces refer to economic and environmental issues, external security, freedom, security and justice and research and education including cultural aspects; for more information see Part IV, Section 10 on the EU-Russia Relations.

European Commission Communication, COM(2008) 823, 3 December 2008; see also Council of the European Union, "Joint Declaration of the Prague Eastern Partnership Summit" of 7 May 2009. 
proposed further political and operational cooperation to consolidate the Eastern Partnership. The Commission emphasised the establishment of common justice and home affairs space and, in particular, it stressed the aim to enhance the mobility of citizens in a secure and well-managed environment. ${ }^{202}$ Two other, broader, consultation forums exist in which all Eastern Partnership states participate: the Prague Process on building migration partnerships covers the EU Member States, Eastern and South-Eastern European countries and Central Asian countries, providing a platform for cooperation as regards migration management; the Budapest Process promoting information exchange in migration matters also includes the U.S., Canada and Australia. ${ }^{203}$

Second, the "Barcelona Process: Union for the Mediterranean" was launched in 2008 at the Paris Summit for the Mediterranean and ties into the Euro-Mediterranean Partnership. ${ }^{204}$ The Union for the Mediterranean embraces all EU Member States and 16 countries across the Mediterranean and the Middle East but not all of them are covered by the ENP. ${ }^{205}$ The Union for the Mediterranean continues with the achievements made under the Barcelona Process, including the strengthening of democracy and stability and the setting up of a Euro-Mediterranean free-trade area. The Union for the Mediterranean also comprises a bi-and multilateral approach, and it aims at greater involvement of all parties concerned. Next, the Mediterranean partnership provides for an institutional framework and a number of regional projects promoting economic integration. ${ }^{206}$ Some analysts, however, took a sceptical view of the idea to apply the tools of regionalism to the Mediterranean, and it has been pointed out that the liaison necessitates a geographical balance considering that the stability and security of the EU is contingent on the stability, security and development of the Mediterranean countries. ${ }^{207}$

Third, the "Black Sea Synergy" was initiated in 2007 with the objective to create a cooperation framework within the Black Sea Region but also between the region and the EU.208 The main fields of cooperation include governance and democracy, migration, the "frozen" conflicts, energy and transport. In addition, emphasis was put

European Commission Communication, COM(2011) 564, 26 September 2011.

Ibid., pp. 19-20; the second ministerial conference on the Prague Process was conducted under the Polish Presidency at the beginning of November 2011 in Poznań where the parties adopted an Action Plan for 2012 to 2016.

Euro-Mediterranean Partnership, "Joint Declaration of the Paris Summit for the Mediterranean" of 13 July 2008, document number: EURO-MED 1/2/08.

The countries located in the Mediterranean and the Middle East are Albania, Algeria, Bosnia and Herzegovina, Croatia, Egypt, Israel, Jordan, Lebanon, Libya, Mauritania, Monaco, Montenegro, Morocco, Occupied Palestinian Territory, Syria, Tunisia, and Turkey.

European Commission Communication, COM(2008) 319, 20 May 2008.

F. Attina, 'The Euro-Mediterranean Partnership Assessed: The Realist and Libera Views', 8 European Foreign Affairs Review (2003), 181; see also E. Philippart, 'The EuroMediterranean Partnership: A Critical Evaluation of an Ambitious Scheme', 8 European Foreign Affairs Review (2003), 201.

The Black Sea region covers Greece, Bulgaria, Romania, and Moldova in the west, Ukraine and Russia in the north, Georgia, Armenia and Azerbaijan in the east, and Turkey in the south, see European Commission Communication, $\operatorname{COM}(2007)$ 160, 11 April 2007. 
on an enhanced role of the civil society actors, such as greater engagement of international organisations in the process. ${ }^{209}$ The Commission assessed the implementation of the Black Sea Synergy initiative in 2008. It took notice of the parties' preference to establish a long-term Black Synergy partnership and stressed the complex environment in which this regional cooperation takes place..$^{210}$

EU relations with the countries in the neighbouring regions existed before the launching of the ENP in 2004. The distinct partnership and cooperation agreements with the countries in Eastern Europe, as well as the association agreements with the Mediterranean states provide for the contractual basis of this collaboration. ${ }^{211}$ The ENP builds on these agreements by determining the key priorities that are included in the Action Plans. By the beginning of 2012, all ENP partners except for Syria, Libya and Belarus have concluded such an agreement with the EU. The EU-Syria relations are regulated by a cooperation agreement which dates back to $1977 .{ }^{212} \mathrm{~A}$ revised draft association agreement has been negotiated but the EU made clear that Syria's violent oppression of public protests since March 2011 has brought about a stagnation phase; as a response to these developments, the EU has suspended new bilateral cooperation programmes, and it has imposed restrictive measures on the Syrian government. ${ }^{213}$ Following the Arab Spring, the revolution by the Libyan people and the downfall of the Gaddafi regime, the EU welcomed the appointment of a transitional government in Libya and affirmed its support in building an EULibya partnership under the ENP. ${ }^{214}$ The EU's relations with Belarus have worsened because of the continuing repression of civil society, opposition parties and independent media in 2011.215 Restrictive measures have been reinforced until October 2012; for a long time, the EU has demanded a large-scale advancement from the Belorussian authorities in view of democracy, the rule of law and human rights protection. ${ }^{216}$

12 ENP states decided to govern their relations by use of Action Plans. Algeria, Belarus, Libya and Syria demonstrated no interest in drafting such Actions Plans with the EU. As far as the nature of the Action Plans is concerned, it must be highlighted that they are merely political accords and therefore not legally binding instruments. Their content is jointly decided by the EU and the respective partner state on the basis of common consent. Despite the multilateral approach of the ENP, its

\footnotetext{
$209 \quad$ European Commission Communication, $\operatorname{COM}(2007)$ 160, 11 April 2007.

210 European Commission Communication, $\operatorname{COM}(2008)$ 391, 19 June 2008.

211 European Commission Communication, COM(2004) 373, 12 May 2004, p. 7.

212 Cooperation Agreement between the European Economic Community and the Syrian Arab Republic, OJ L 269, 27 September 1978, p. 2.

213 Council of the European Union, "Syria - Draft Council Conclusions, Foreign Affairs Council" of 23 May 2011, document number: 10557/11.

214 Council of the European Union, "Libya - Council Conclusions" of 14 November 2011, document number: 16871/11.

215 Council of the European Union, "EU reinforces restrictive measures concerning Belarus" of 10 October 2011, document number: 15310/11. European Commission Communication, COM(2008) 164, 3 April 2008.
} 
implementation proceeds to a great extent on a bilateral level. ${ }^{217}$ Most Action Plans were negotiated in 2005 and 2006 respectively. ${ }^{218}$

\begin{tabular}{|c|c|c|}
\hline & ENP Action Plan & $\begin{array}{l}\text { Agreement } \\
\text { (entry into force) }\end{array}$ \\
\hline Algeria & No & $\begin{array}{l}\text { Euro-Mediterranean Agreement } \\
(2005)\end{array}$ \\
\hline Armenia & Yes & $\begin{array}{l}\text { Partnership and Cooperation } \\
\text { Agreement }(2000)\end{array}$ \\
\hline Azerbaijan & Yes & $\begin{array}{l}\text { Partnership and Cooperation } \\
\text { Agreement (1999) }\end{array}$ \\
\hline Belarus & No & No \\
\hline Egypt & Yes & $\begin{array}{l}\text { Euro-Mediterranean Agreement } \\
(2004)\end{array}$ \\
\hline Georgia & Yes & $\begin{array}{l}\text { Partnership and Cooperation } \\
\text { Agreement (1999) }\end{array}$ \\
\hline Israel & Yes & $\begin{array}{l}\text { Euro-Mediterranean Agreement } \\
(2000)\end{array}$ \\
\hline Jordan & Yes & $\begin{array}{l}\text { Euro-Mediterranean Agreement } \\
\text { (2002) }\end{array}$ \\
\hline Lebanon & Yes & $\begin{array}{l}\text { Euro-Mediterranean Agreement } \\
(2006)\end{array}$ \\
\hline Libya & No & No \\
\hline Moldova & Yes & $\begin{array}{l}\text { Partnership and Cooperation } \\
\text { Agreement (1998) }\end{array}$ \\
\hline Morocco & Yes & $\begin{array}{l}\text { Euro-Mediterranean Agreement } \\
(2000)\end{array}$ \\
\hline $\begin{array}{l}\text { Occupied Palestinian } \\
\text { Territory }\end{array}$ & Yes & $\begin{array}{l}\text { Euro-Mediterranean Interim } \\
\text { Association Agreement on } \\
\text { Trade and Cooperation (1997) }\end{array}$ \\
\hline Syria & No & Cooperation Agreement (1978) \\
\hline Tunisia & Yes & $\begin{array}{l}\text { Euro-Mediterranean Agreement } \\
\text { (1998) }\end{array}$ \\
\hline Ukraine & Yes & $\begin{array}{l}\text { Partnership and Cooperation } \\
\text { Agreement (1998) }\end{array}$ \\
\hline
\end{tabular}

\subsection{Implementing the ENP}

The Commission has reported regularly on the implementation process of the ENP. In 2006, the Commission first acknowledged the ENP's value and the progress made by most neighbouring countries in promoting economic and political development. The ENP proved not only to be a framework that allowed for improved dialogue between the EU and its neighbours but it also served to deepen and strengthen their relationship and promote reform processes. The Commission indicated that, although the ENP must be distinguished from EU enlargement, European partner states are not per se excluded from future EU membership. ${ }^{219}$

217 M. Comelli, 'The Challenges of the European Neighbourhood Policy', 39 The International Spectator (2004), 97, p. 102.

218 European Commission Communication, $\operatorname{COM}(2006)$ 726, 4 December 2006, p. 2.

219 European Commission Communication, $\operatorname{COM}(2006)$ 726, 4 December 2006. 
In June 2007, under the German Presidency, the General Affairs and External Relations Council adopted the Presidency Progress Report on the strengthening of the ENP. According to that document, the ENP played a pivotal role in the EU's foreign policy in that it provided for a single policy framework, while offering a privileged partnership that allowed for a flexible and differentiated approach towards the Eastern and Southern partner states. Negotiations proceeded with Ukraine and Morocco and Action Plans with Armenia, Azerbaijan, Georgia, Egypt and Lebanon started to be transposed. Major importance was attached to increased economic integration on the basis of bilateral free trade agreements. The Progress Report also highlighted the extension of the Global Approach to Migration to the neighbouring Eastern and South-Eastern regions especially with regard to the fight against irregular migration. The Council endorsed the Presidency's Progress Report and confirmed the importance of the ENP in deepening the EU's relations with its neighbours. ${ }^{220}$

The Commission issued a subsequent evaluation on the ENP in December 2007 which tied into the previous assessment in saying that a good result had been achieved already but further action was required for an effective transposition. This time the Commission stressed mobility as a key foreign policy priority and made clear that the revised European visa policy provides for higher security standards and a facilitated travel regime for bona fide travellers. Next, the conclusion of pilot mobility partnerships was suggested with selected ENP countries in order to manage migration more effectively. To date three mobility partnerships have been concluded, two with Cape Verde and Moldova in 2008 and one with Georgia in 2009.221 Moreover, Member States could better take advantage of existing mechanisms such as the Local Border Traffic Regulation or the Schengen acquis so as to ameliorate bilateral collaboration of Member States with neighbouring states. Cautiously, the Commission held out the prospect of opening up the Member States' labour markets, although the admission of third-country nationals to the territory of a Member State for the purpose of work is a Member State competence as laid down in Article 79(5) TFEU. ${ }^{222}$

The Commission's progress report of 3 April 2008 describes the ENP as "gradually establishing itself as a mutually beneficial partnership for reform and development [...] promoting regional cooperation beyond the borders of the Union". ${ }^{223}$ Concerning political dialogue, it was welcomed that all Eastern ENP partner states that have set out Action Plans also became members of the Council of Europe and the Organisation for Security and Co-operation in Europe (OSCE). Moreover, these ENP countries experienced a democratisation process such as a strengthening of the separation of powers, more transparent elections, at least in some states and more independent judicial bodies. By comparison, political reform in the Southern partner countries was rather slow-moving. ${ }^{224}$ Most ENP states displayed a steady economic growth and accelerating rates of job creation in 2007. This resulted in declining average unemployment rates in both the Mediterranean and the Eastern partner

$220 \quad$ Council of the European Union, "Strengthening the European Neighbourhood Policy - Council Conclusions" of 19 June 2007, document number: 11016/07.

$221 \quad$ As of 6 March 2012.

222 European Commission Communication, COM(2007) 774, 5 December 2007.

223 European Commission Communication, $\operatorname{COM}(2008)$ 164, 3 April 2008, p. 2.

224 Ibid. 
countries. 225 The Commission launched the implementation of initiatives of the Black Sea Synergy dealing with energy, environment, migration, fishery and transport, and it was granted observer status in the Organisation of the Black Sea Economic Cooperation. ${ }^{226}$ In 2008, events, such as the Georgian-Russian conflict in August 2008, as well as Israel's intervention in the Gaza Strip, adversely affected the transposition of the ENP. In addition, the global economic crisis had a major impact on the ENP partner countries. Notably, the Eastern partner states suffered a setback in regard to international capital, credit markets and lower export prices for goods. The International Monetary Fund (IMF) provided financial support for Ukraine, Georgia, Belarus and Moldova. Due to less engagement in the international financial sector, the Mediterranean region was not as strongly affected by the economic crisis. The regional cooperation under the ENP was enhanced: the Union for the Mediterranean provided for new initiatives including a Mediterranean solar energy plan and the de-pollution of the Mediterranean Sea; the Black Sea Synergy was established and generated positive reactions from NGOs; and the proposal for the Eastern Partnership was implemented in order to deepen relations with the Eastern European and Southern Caucasus countries. ${ }^{227}$

The years 2009 to 2011 further marked decisive developments for the consolidation of the ENP, including the entry into force of the Treaty of Lisbon in 2009, Article 8 of which envisages developing a special relationship with neighbouring countries; the establishment of the post of the High Representative and the EEAS that equip the EU with new actors enhancing contacts with states in the region; the EU's objective to promote political dialogue and to achieve "a very substantial degree" of economic integration with the Eastern and Southern neighbouring countries; and, the Arab Spring that started in December of 2010 first in Tunisia and subsequently triggered revolutionary movements in a number Arab countries. ${ }^{228}$ In the light of these latter developments, the EU has affirmed its support by creating a partnership for democracy and shared prosperity with countries in the Southern Mediterranean that aims to promote democratic transformation and institution building. ${ }^{229}$

Questions relating to mobility, especially in the Mediterranean region, ranked high on the 2010 justice and home affairs agenda with a focus on mobility partnerships, visa facilitation and readmission agreements and border management. ${ }^{230}$ The Commission welcomed the "historic events" that have occurred in the Southern Mediterranean

225 European Commission, DG for Economic and Financial Affairs, "European Neighbourhood Policy: Economic Review of EU Neighbour Countries”, Occasional Papers No 40, August 2008, pp. 20 and 40.

European Commission Communication, COM(2008) 164, 3 April 2008.

European Commission Communication, COM(2009) 188/3, 23 April 2009.

European Commission Communication, COM(2010) 207, 12 May 2010; European Commission/High Representative of the European Union for Foreign Affairs and Security Policy, Joint Staff Working Paper, SEC(2011) 645, 25 May 2011; European Commission/High Representative of the European Union for Foreign Affairs and Security, Joint Communication, COM(2011) 200, 8 March 2011. Affairs and Security Joint Communication, COM(2011) 200, 8 March 2011. Affairs and Security Policy Joint Staff Working Paper, SEC(2011) 645, 25 May 2011, pp. 8-9. 
region since the end of 2010 because they "have provided unique opportunities for the people of those countries to express more freely their wish for true democracy, respect for human rights and fundamental freedoms, more impartial and better functioning state institutions and a fairer use of public resources." ${ }^{231}$ Considering that these events have led to large movements of people and with a view to creating an enhanced ENP vis-à-vis the Southern Mediterranean partner countries, the Commission proposed the dialogue for migration, mobility and security in May 2011 in accordance with the EU's Global Approach to Migration. This dialogue determines measures for short, medium and long-term responses to the migration flows originating in North Africa, including humanitarian assistance, a stronger involvement of FRONTEX, the implementation of Regional Protection Programmes, stimulating the growth of prosperity to fight the root causes of migration, as well as the use of mobility partnerships. ${ }^{232}$

\subsection{The EU Relations with the Maghreb States Algeria, Morocco, Tunisia}

Community trade agreements with Morocco and Tunisia were superseded by cooperation agreements signed on 25, 26 and 27 April 1976 respectively, with all three Maghreb countries, including Algeria, to manifest and reinforce their relations with the EEC. ${ }^{233}$ The EEC endorsed these agreements in three Council Regulations of 26 September 1978.234 The Cooperation Agreements were adopted with the objective to promote overall cooperation between the contracting parties with a view to contributing to the economic and social development of the Maghreb country and helping to strengthen relations between the parties. The Cooperation Agreements all contained an identical Title III on the cooperation in the field of labour including non-discrimination clauses in view of employment conditions for the worker in question and in view of social security for the worker and his or her family members. ${ }^{235}$ It is worth quoting this Title (of the Morocco Cooperation Agreement) in full:

\section{TITLE III COOPERATION IN THE FIELD OF LABOUR}

Article 40

The treatment accorded by each Member State to workers of Moroccan nationality employed in its territory shall be free from any discrimination based on nationality, as regards working conditions or remuneration, in relation to its own nationals.

231 European Commission Communication, $\operatorname{COM}(2011)$ 292, 24 May 2011, p. 2.

232 Ibid.; on the EU's reaction to the migration influx from the Mediterranean, see also European Commission Communication, COM(2011) 248, 4 May 2011.

233 Cooperation Agreement between the European Economic Community and the People's Democratic Republic of Algeria, OJ L 263, 27 September 1978, p. 2; Cooperation Agreement between the European Economic Community and the Kingdom of Morocco, OJ L 264, 27 September 1978, p. 2; Cooperation Agreement between the European Economic Community and the Republic of Tunisia, OJ L 265, 27 September 1978, p. 2.

234 Council Regulation (EEC) No 2210/78, Council Regulation (EEC) No 2211/78, and Council Regulation (EEC) No 2212/78 of 26 September 1978.

235 See Arts. 38-41 of the Algeria Cooperation Agreement; Arts. 40-43 of the Morocco Cooperation Agreement and Arts. 39-42 of the Tunisia Cooperation Agreement. 
Morocco shall accord the same treatment to workers who are nationals of a Member State and employed in its territory.

\section{Article 41}

1. Subject to the provisions of the following paragraphs, workers of Moroccan nationality and any members of their families living with them shall enjoy, in the field of social security, treatment free from any discrimination based on nationality in relation to nationals of the Member States in which they are employed.

2. All periods of insurance, employment or residence completed by such workers in the various Member States shall be added together for the purpose of pensions and annuities in respect of old age, invalidity and death and also for that of medical care for the workers and for members of their families resident in the Community.

3. The workers in question shall receive family allowances for members of their families who are resident in the Community.

4. The workers in question shall be able to transfer freely to Morocco, at the rates applied by virtue of the law of the debtor Member State or States, any pensions or annuities in respect of old age, death, industrial accident or occupational disease, or of invalidity resulting from industrial accident or occupational disease.

5. Morocco shall accord to workers who are nationals of a Member State and employed in its territory and to the members of their families, treatment similar to that specified in paragraphs 1,3 and 4 .

Article 42

1. Before the end of the first year following entry into force of this Agreement, the Cooperation Council shall adopt provisions to implement the principles set out in Article 41.

2. The Cooperation Council shall adopt detailed rules for administrative cooperation providing the necessary management and control guarantees for the application of the provisions referred to in paragraph 1.

\section{Article 43}

The provisions adopted by the Cooperation Council in accordance with Article 42 shall not affect any rights or obligations arising from bilateral agreements linking Morocco and the Member States where those agreements provide for more favourable treatment of nationals of Morocco or of the Member States.

The Euro-Mediterranean Agreements signed with Algeria, Morocco and Tunisia in 2002, 1996 and 1995 respectively, replaced the Cooperation Agreements as well as the agreements between the European Coal and Steel Community and the Maghreb countries. ${ }^{236}$ The Euro-Mediterranean Agreements with Algeria, Morocco and

236 Euro-Mediterranean Agreement establishing an Association between the European Community and its Member States, of the one part, and the People's Democratic 
Tunisia are structured in a similar way and they establish associations between the EU, its Member States and the Maghreb country in question. They were concluded with the aim to promote political dialogue, to enhance economic and social relations and to encourage cooperation with the Maghreb countries (see respective Article 1). ${ }^{237}$ On the basis of these agreements, the contracting parties agreed to form a free trade area over a transitional period lasting a maximum of 12 years (respective Article $6)$.

\subsection{The EU Relations with Egypt, Israel, Jordan and Lebanon}

The EU relations with the populous Northern African country of Egypt date back to the 1960s. The 1976 EU-Egypt Cooperation Agreement first set out the contractual relations; it was replaced by the Euro-Mediterranean Agreement signed on 25 June 2001 and effective since 1 June 2004.238 The treaty forms the legal basis to promote the political dialogue, economic and social relations and gradually to establish the liberalisation of goods, services and capital. The third cooperation agreement between the Israeli state and the European Community signed in 1975 was superseded by the Euro-Mediterranean Agreement signed on 20 November 1995..$^{239}$ This Association Agreement entered into force on 1 June 2000 and provides a framework for political dialogue and cooperation in trade, as well as regional cooperation in areas of mutual interest. ${ }^{240}$ The EU's diplomatic relations with Jordan were first established in 1977 and a year thereafter the cooperation agreement entered into force. ${ }^{241}$ The contractual relations are currently governed by the EuroMediterranean Agreement with Jordan which was signed on 24 November 1997 and

Republic of Algeria, of the other part, OJ L 265, 10 October 2005, p. 2; EuroMediterranean Agreement establishing an Association between the European Communities and their Member States, of the one part, and the Kingdom of Morocco, of the other part, OJ L 70, 18 March 2000, p. 2; Euro-Mediterranean Agreement establishing an Association between the European Communities and their Member States, of the one part, and the Republic of Tunisia, of the other part, OJ L 97, 30 March 1998, p. 2; see Art. 110(2) of the Euro-Mediterranean Agreement with Algeria and Art. 96(2) of the Euro-Mediterranean Agreements with Morocco and Tunisia.

The Euro-Mediterranean Agreements with Morocco and Tunisia additionally set out to foster their development and prosperity, as well as that of their peoples; the EuroMediterranean Agreement with Algeria moreover emphasises the facilitation of human exchanges.

238 Cooperation Agreement between the European Economic Community and the Arab Republic of Egypt, OJ L 266, 27 September 1978, p. 2; Euro-Mediterranean Agreement establishing an Association between the European Communities and their Member States, of the one part, and the Arab Republic of Egypt, of the other part, OJ L 304, 30 September 2004, p. 39.

239 Euro-Mediterranean Agreement establishing an Association between the European Communities and their Member States, of the one part, and the State of Israel, of the other part, OJ L 147, 21 June 2000, p. 3; Agreement between the European Economic Community and the State of Israel, OJ L 136, 28 May 1975, p. 3 (Israel III).

240 See Art. 1 of the Euro-Mediterranean Agreement with Israel.

241 Cooperation Agreement between the European Economic Community and the Hashemite Kingdom of Jordan, OJ L 268, 27 September 1978, p. 2. 
became effective on 1 May 2002.242 The Agreement provides a framework for political dialogue and closer cooperation with regard to trade, living and employment conditions and regional matters. ${ }^{243} \mathrm{~A}$ free trade area is envisaged to be established by 2014. ${ }^{244}$ A Cooperation Agreement between the Community and Lebanon entered into force in 1975 and this agreement first regulated their relations in view of economic, technical and financial issues. ${ }^{245}$ It was replaced by a Euro-Mediterranean Agreement signed on 17 June 2002 that entered into force four years later on 1 April 2006.246 The Euro-Mediterranean Agreement establishing an association was concluded with the aim to enhance the political dialogue, gradually to liberalise trade in goods, services and capital and to promote the social and cultural relations between the parties.

9.6 The EU Relations with the Eastern ENP States Armenia, Azerbaijan, Belarus, Georgia, Moldova and Ukraine

All Eastern Partnership countries (Armenia, Azerbaijan, Belarus, Georgia, Moldova and Ukraine) concluded a PCA with the EU except for Belarus. ${ }^{247}$ They are all mixed agreements concluded between the Community, its Member States and the respective country and they provide the current legal framework for cooperation. Under the Eastern Partnership, the EU negotiates new association agreements that would constitute the basis for an even closer relationship. ${ }^{248}$ Such association agreements providing for enhanced cooperation are discussed with Armenia and Azerbaijan. ${ }^{249}$

Euro-Mediterranean Agreement establishing an Association between the European Communities and their Member States, of the one part, and the Hashemite Kingdom of Jordan, of the other part, OJ L 129, 15 May 2002, p. 3.

Art. 1 of the Euro-Mediterranean Agreement with Jordan.

Art. 6 of the Euro-Mediterranean Agreement with Jordan.

Agreement in the form of an exchange of letters renewing the Agreement on trade and technical cooperation between the European Economic Community and the Member States, of the one part, and the Lebanese Republic, of the other part, OJ L 278, 29 October 1975, p. 22 (Lebanon I).

Euro-Mediterranean Agreement establishing an Association between the European Community and its Member States, of the one part, and the Republic of Lebanon, of the other part, OJ L 143, 30 May 2006, p. 2.

Partnership and Cooperation Agreement between the European Communities and their Member States, of the one part, and the Republic of Armenia, of the other part, OJ L 239, 9 September 1999, p. 3; Partnership and Cooperation Agreement between the European Communities and their Member States, of the one part, and the Republic of Azerbaijan, of the other part, OJ L 246, 17 September 1999, p. 3; Partnership and Cooperation Agreement between the European Communities and their Member States, of the one part, and Georgia, of the other part, OJ L 205, 4 August 1999, p. 3; Partnership and Cooperation Agreement between the European Communities and their Member States, of the one part, and the Republic of Moldova, of the other part, OJ L 181, 24 June 1998, p. 3; Partnership and Cooperation Agreement between the European Communities and their Member States, and Ukraine, OJ L 49, 19 February 1998, p. 3.

European Commission Communication, COM(2008) 823, 3 December 2008, p. 4.

See EP resolutions of 18 April 2012 containing the EP's recommendations to the Council, the Commission and the European External Action Service on the negotiations of the EU-Azerbaijan Association Agreement (2011/2316(INI)) and on the negotiations of the EU-Armenia Association Agreement (2011/2315(INI)). 
The EU-Ukraine Cooperation Council has continued negotiations a new association agreement on the basis of an association agenda, which prepares the way for entry into force of the latter agreement; political developments, however, have slowed down progress in the past. 250 Since the provisions that deal with migration are similarly worded in all the PCAs, they are outlined and discussed under the same headings. Importantly, the PCAs concluded with Moldova and Ukraine contain additional provisions concerning the coordination of social security and irregular migration. ${ }^{251}$

The preambles of the PCAs give some indication on the prominence of migrationrelated matters: while the cooperation for the prevention and control of irregular immigration is vital and "constitutes one of the primary objectives" of the agreements with Armenia, Azerbaijan and Georgia, the parties to all agreements are merely "conscious of the need to improve conditions [...] in the areas such as [...] labour, provision of services [...]." Article 1 of the PCAs defines the objectives of agreements; these are to develop the contracting parties' political relations, to consolidate democracy and economic development in the respective Eastern partner state and to reinforce collaboration in other fields including cultural, financial and technological matters. ${ }^{252}$

\subsection{The Mobility Partnerships with Moldova and Georgia}

Mobility partnerships were concluded with Moldova in May 2008 and with Georgia in November 2009.253 15 EU Member States participate in the mobility partnership with Moldova, as well as the Commission, FRONTEX and the European Training Foundation. ${ }^{254}$ Moldova, with its communist past, is said to be one of the poorest countries in Europe. In recent years the country has experienced considerable emigration on the one hand and high remittance inflows on the other. ${ }^{255}$ These socioeconomic circumstances are reflected by Moldova's priorities under the mobility partnership framework: the Moldovan government is interested in the area of migration and development, particularly in return migration. Thus, projects were suggested that improve the capacities of the Moldovan National Employment Agency and that facilitate and cheapen the transfer of remittances. On the Member

250 Council of the European Union, EU-Ukraine Cooperation Council 15th Meeting, document number: 9993/12 (Presse 206) of 15 May 2012.

251 See Arts. 24-26 of the PCA with Moldova; Arts. 25-27 of the PCA with Ukraine.

252 For a detailed analysis of migration-related rules in cooperation frameworks with Georgia and Moldova, see K. Eisele and A. Wiesbrock, 'Enhancing Mobility in the European Neighborhood Policy? The Cases of Moldova and Georgia', 36 Review of Central and East European Law (2011), 127.

253 Council of the European Union, Joint Declaration on a Mobility Partnership between the European Union and the Republic of Moldova, document number: 9460/08 of 21 May 2008; Council of the European Union, Joint Declaration on a Mobility Partnership between the European Union Georgia, document number: 16396/09 of 20 November 2009.

254 The participating EU Member States are Bulgaria, the Czech Republic, Cyprus, France, Germany, Greece, Italy, Lithuania, Poland, Portugal, Romania, Slovakia, Slovenia, Sweden, and Hungary.

255 M. Siegel, Money and Mobility: Migration and Remittances (Doctoral Dissertation, Boekenplan, Maastricht 2010), p. 66. 
State side, the main interest related to strengthening labour migration, curbing irregular migration and enhancing the protection of trafficking victims. ${ }^{256}$ The mobility partnership with Georgia was signed by 16 EU Member States in November of 2009.257 Just like the Joint Declaration on the EU-Moldova mobility partnership, the Joint Declaration on the EU-Georgia mobility partnership contains an Annex, which sets out various objectives and a number of proposed activities relating to:

- mobility, legal migration, integration and migration and development;

- asylum policy and the protection of refugees;

- border management, identity and travel documents, fight against illegal migration and human trafficking;

- and readmission policy.

IOM has pointed out that since the signing of the mobility partnership with Georgia migration management has been high on the agenda; IOM has provided technical support under the latter framework, in particular with regard to readmission issues. ${ }^{258}$

Russia's legal bonds with the EU date back to 24 June 1994 when the parties signed the PCA, the current framework governing the EU-Russia relations effective since 1 December 1997.259 It was concluded for an initial period of 10 years but is automatically renewed year by year provided that neither party denounces it. ${ }^{260}$

The objectives of the partnership are:

to provide a framework for political dialogue;

to promote trade relations based on the principles of market economy;

to strengthen political and economic freedoms;

to support Russian efforts to consolidate its democracy and to turn into a functioning market economy;

- to provide a basis for economic, social, financial and cultural cooperation;

- to promote activities of joint interest;

- to integrate Russia in the wider cooperation with Europe;

European Commission Staff Working Document, SEC(2009) 1240, 18 September 2009, p. 5; for a detailed overview of the ongoing projects, the completed projects and the projects for consideration, consult the scoreboard of the EU-Moldova mobility partnership, available on the website of the Moldovan Ministy of Foreign Affairs and European Integration: <http://www.mfa.gov.md/mobility-partnership-en/>, last accessed on 17 December 2011.

257 The participating EU Member States are Belgium, Bulgaria, the Czech Republic, Denmark, Estonia, France, Germany, Greece, Italy, Latvia, Lithuania, the Netherlands, Poland, Romania, Sweden and the United Kingdom.

258 See website IOM on Georgia: <http://iom.int/jahia/Jahia/georgia >, last accessed on 17 December 2011.

259 Agreement on partnership and cooperation establishing a partnership between the European Communities and their Member States, of one part, and the Russian Federation, of the other part, OJ L 327, 28 November 1997, p. 3. Art. 106 of the PCA with Russia. 
- to establish conditions for a free trade area between Russia and the EU.

The PCA with Russia contains an equal treatment clause in relation to employment and sets out rules on the coordination of social security for nationals of the other party. The right of establishment is reserved for companies to set up subsidiaries and branches. ${ }^{261}$ Also, the cross-border supply of services is reserved to companies: representatives of companies, who are admitted for temporary entry into the territory of the other party to negotiate sales of cross-border services, are prohibited to make direct sales to the general public or to supply services themselves. ${ }^{262}$ Article 50 of the PCA with Russia specifies that without prejudice to key personnel employed in subsidiaries and representatives of companies negotiating sales of cross-border services, no provision of Chapters II, III and IV of the PCA shall be interpreted as giving the right to, inter alia, nationals of the contracting parties to enter, or stay in the territory of the other party in any capacity whatsoever and in particular as a shareholder or partner in a company or manager or employed thereof, or supplier or recipient of services.

\section{THE EU-AFRICA/ACP RELATIONS}

The history of European colonialisation on the African continent and the subsequent post-colonial struggles for independence laid the foundations for a longstanding interrelationship between Europe and Africa. Since the late 1990s, the EU has promoted the idea of a reinforced political dialogue with African states which culminated in the first EU-Africa summit held in April 2000. The Cairo meeting centred on regional integration, integration of Africa into the world economy, human rights, democratic principles, good governance, peace-building and conflict prevention, as well as development issues - key areas, which dominate the agendas still today. In 2005, the Council adopted an EU Strategy for Africa, but it was clear that this Strategy reflected the European priorities for Africa only. ${ }^{263}$ These developments paved the way for an Africa-EU partnership based on joint ownership, in which the African and European counterparts would have an equal say. ${ }^{264}$ Moreover, in 2006 two conferences were organised, in Rabat and Tripoli respectively, which had a special focus on migration and development. At the EU-Africa summit adopted in December 2007, the Joint Africa-EU Strategy was based on the input of representatives of the EU, EU Member States, the African Union Commission, African states and civil society. The new strategy complements the cooperation frameworks that had shaped EU-Africa relations by then. These include the Cotonou Agreement, successor to the Yaoundé and Lomé Agreements, which sets out the contractual relations between 79 ACP countries and the 27 EU Member States; the Euro-Mediterranean Partnership, that developed on the basis of the 1995 Barcelona Process, encompasses 16 Mediterranean countries and the 27 EU Member States and complements the ENP; and the 1994 Cooperation Agreement between the EU and

\footnotetext{
261 Arts. 28(1) and 30(a) of the PCA with Russia.

262 Arts. 36 and 37 of the PCA with Russia.

263 Council of the European Union, Council Conclusions on an EU Strategy for Africa, document number: 14831/05 of 22 November 2005.

264 ECDPM, 'The EU-Africa Partnership in Historical Perspective', Issue Paper I (2006), pp. 2-4.
} 
South Africa on trade and development. ${ }^{265}$ Since 2001 annual EU-Africa Ministerial Troika meetings have been held to encourage the EU-Africa dialogue.

\subsection{The 2006 Rabat and Tripoli Conferences}

In the capital of Morocco, the Euro-African Ministerial Conference on Migration and Development held in July of 2006 brought together representatives of 60 African and European states, as well as regional and international organisations to discuss the migration phenomenon in relation to development processes. It is important to keep in mind that migration was in the limelight of the political agendas of policymakers: less than a year earlier the EU had been accused of being a "Fortress Europe" when the attempt of African migrants to cross the Spanish territories of Ceuta and Melilla in Northern Africa failed tragically and the EU Global Approach to Migration was adopted in the aftermath. The governments that participated in the Rabat Conference confirmed their responsibility to intensify the cooperation and the dialogue on migratory questions and their development dimensions, in particular with regard to the 2006 UN High Level Dialogue on Migration and Development. ${ }^{266}$

The concertedly elaborated Action Plan stressed the need for concrete and swift action in order to make the "new dynamic born from the organisation of this conference" more visible and credible. ${ }^{267}$ Action should be undertaken on the basis of ownership, adherence and partnership in the spirit of the dialogue set out in Article 13 of the Cotonou Agreement. The Action Plan suggested measures in four policy areas including migration and development; legal migration; irregular migration; police and judicial cooperation and assistance for victims, as well as a financing framing and a follow-up mechanism. In the field of migration and development, the Action Plan contained the most extensive proposals. The promotion of development should be fostered by improving economic cooperation and regional integration, by reducing the costs of transferring remittances, as well as by creating Euro-African networks and platforms for research activities and entrepreneurial projects, professional training and knowledge sharing of business development. With a view to generate skills and know-how in African countries, the exchange of professionals and students should be facilitated by return policies and partnerships between various institutions.

In the area of legal migration, the Rabat Action Plan recommended information campaigns for legal migration channels and their improvement, training that facilitates the integration of migrants in the host societies and access to education facilities in the receiving country. In addition to promoting circular and temporary migration, a "joint reflection on the transfer of migrants' pension rights" was submitted. With regard to irregular migration, the Action Plan encouraged voluntary

265 V. Tywuschik and A. Sherriff, 'Beyond Structures? Reflections on the Implementation of the Joint Africa-EU Strategy', ECDPM Discussion Paper 87 (2009), pp. 2-3. available at: <http://www.maec.gov.ma/migration/Doc/RABAT\%20DECLARATION_EN.pdf $>$, last accessed on 30 March 2011. migration/Doc/PA\%20final\%20EN.pdf >, last accessed on 3 November 2011. 
return, efficient readmission systems, enhanced border control and policies supporting the re-integration of returned migrants. ${ }^{268}$

Commitments were further elucidated in the Tripoli Joint Africa-EU Declaration on Migration and Development of November 2006. ${ }^{269}$ Foreign ministers, ministers in charge of migration and of development issues from Africa and EU Member States, as well as EU and AU officials convened in Tripoli to further tackle migration-related concerns and possible development-conducive policy solutions. The Tripoli meeting integrated the migration and development debate in the broader context of peace and security and human rights. The parties acknowledged that conflict prevention and peace building is fundamental to address one of the root causes of forced migration. Moreover, the protection of the human rights of migrants and the well-being of the individual was underscored. This is an interesting aspect seeing that the parties recognised that the individual serves as a basis of policies that aim to turn the migration process into a factor conducive for development. In this regard the implementation and non-discriminatory application of core human rights instruments and the fight against racism and xenophobia and the right to equal treatment were considered as crucial elements. Yet, only the preamble to the Declaration mentions the importance that State parties attach to the UN Convention of the Rights of Migrant Workers and their Families and the Cotonou and Euro-Mediterranean Agreements. New elements of the Tripoli Declaration concern, among other things, the consideration of how migration can be made an essential part of poverty reduction strategies; realising intra-African free movement of labour; strengthening the role of diasporas; promoting the mutual recognition of academic qualifications; pursuing a holistic approach in the area of migration; addressing skill shortages caused by brain drain; and protecting the rights of refugees. ${ }^{270}$

\subsection{The Africa-EU Partnership on MME and the 2008 Paris Conference}

The Africa-EU Partnership on Migration, Mobility and Employment (MME) was adopted under the Joint Africa-EU Strategy in 2007. ${ }^{271}$ The Joint Africa-EU Strategy envisaged promoting:

- the Africa-EU political partnership;

peace, security and democratic governance;

human rights, fundamental freedoms and gender equality;

sustainable economic development;

regional and continental integration in Africa;

- the achievement of all the MDGs in all African countries by 2015;

268

See 2006 Rabat Conference Action Plan, available at: <http://www.maec.gov.ma/migration/Doc/PA\%20final\%20EN.pdf>, last accessed on 3 November 2011.

2006 Tripoli Joint Declaration on Migration and Development, available at: <http://www.carim.org/public/polsoctexts/PS2REG003_EN.pdf>, last accessed on 3 November 2011.

See 2006 Tripoli Joint Declaration on Migration and Development, available at: $<$ http://www.carim.org/public/polsoctexts/PS2REG003_EN.pdf>, last accessed on 3 November 2011.

Council of the European Union, The Africa-EU Strategic Partnership - A Joint Africa EU Strategy, document number: 16344/07 (Presse 291) of 9 December 2007. 
- effective multilateralism;

- a broad-based and wide-ranging people-centred partnership.

The Joint Africa-EU Strategy makes reference to the Tripoli EU-Africa Ministerial Conference on Migration and Development and reiterates the aim to maximise the development impact of migration by remittances, diaspora engagement, capacity building as regards migration management and the protection of the human rights of migrants. The implementation of the Joint Africa-EU Strategy is guaranteed by successive Action Plans that identify strategic priorities and actions. The first Action Plan agreed upon in Lisbon covers the period 2008 to 2010 and defines eight separate Africa-EU thematic partnerships. These partnerships relate to peace and security; democratic governance and human rights; trade, regional integration and infrastructure; the MDGs; energy; climate change; migration, mobility and employment; science information society and space. The first Action Plan emphasised that each partnership is open for a wide range of actors including the African Union (AU) and European Commission, the AU and EU Councils, African and EU Member States, AU and European Parliaments, as well as civil society actors, international and regional organisations, the private sector and research institutions. ${ }^{272}$ The organisation of regular summits between African and EU political leaders, meetings of other stakeholders, the setting up of expert groups and the drawing up of annual reports forms part of the initiative. ${ }^{273}$

The MME "will ensure that better managed-migration and employment issues become an essential part of poverty reduction strategies or other national development and co-development strategies of African countries. The partnership will ensure that migration and employment works for sustainable development and that all relevant international agreements and declarations are implemented." The MME partnership determines three priority actions:

- to implement the Declaration of the Tripoli Ministerial Conference on Migration and Development;

- to implement the EU-Africa Plan of Action on people trafficking;

- and to implement and follow-up the 2003 Ouagadougou Declaration and Action Plan on employment and poverty alleviation in Africa.

First, by transposing the Declaration of the Tripoli Ministerial Conference on Migration and Development, the partnership envisages to facilitate mobility in Africa and the EU and to better manage legal migration between the continents, to address the root causes of migratory flows, to tackle irregular migration flows and to address the problems of migrants residing in EU and African countries. According to the partnership, these objectives should be achieved by a number of activities such as the use of migration profiles, closer cooperation on international protection, action to combat exploitation, discrimination and social exclusion of migrant workers, ethical

272 On the involvement of the various actors in the Joint Africa EU Strategy, see V. Tywuschik and A. Sherriff, 'Beyond Structures? Reflections on the Implementation of the Joint Africa-EU Strategy', ECDPM Discussion Paper 87 (2009).

273 Council of the European Union, The Africa-EU Strategic Partnership - A Joint Africa EU Strategy, document number: 16344/07 (Presse 291) of 9 December 2007. 
recruitment and facilitate circular migration. Second, the MME partnership aims to tackle human trafficking by urging the parties to ratify the relevant conventions, to raise awareness, to strengthen the preventive measures and to enhance assistance and protection for victims. Third, the MME partnership has the goal to create better employment in Africa in conformity with the UN "Decent Work for All" Agenda. In a nutshell, this agenda, which the ILO developed, takes into account that decent work is vital to people's well-being: next to providing a source of income, work contributes to the social and economic advancement of individual, their families and communities. The ILO puts the Decent Work Agenda into practice by means of four strategic pillars: job creation, rights at work, social protection and social dialogue. ${ }^{274}$ For better and more employment, the Decent Work Agenda should be integrated into the national development strategies and a link between skill training and the needs of the local labour markets should be established. Furthermore, the quality of African universities could be boosted and investment in microfinance schemes intensified. ${ }^{275}$

The second Euro-African Ministerial Conference on Migration and Development was organised on 25 November 2008 in Paris. ${ }^{276}$ It tied in with the previous EUAfrica policies and conferences relating to migration issues and by adverting to the interdependence of the African migratory routes, it set out a three-year cooperation programme (2009 to 2011). Following the original EU Global Approach to Migration, this cooperation programme concentrates on three thematic areas - the organisation of legal migration, the fight against irregular migration and synergies between migration and development - and is thereby said to embark upon a new phase aimed at clarifying the areas of bi-and multilateral action and concrete implementation measures. Such action includes inter alia facilitating legal migration opportunities, improving document security and supporting the social and economic development of the source countries. Under this Paris Declaration the parties further agreed to carry out follow-up meetings and assessments on the various EU-Africa migration initiatives.

\subsection{The 2010 Tripoli Africa-EU Summit and the 2011 Dakar Strategy}

Following the Cairo and Lisbon meetings in 2000 and 2007 respectively, the third Africa-EU summit took place in November 2010 in Tripoli, Libya, under the heading "Investment, Economic Growth and Job Creation". The summit in Tripoli revitalised the EU-Africa relations and gave weight to key challenges including climate change, conflict prevention, the MDGs and HIV/AIDS to name just a few. It was pointed out that the private sector plays a key role in advancing sustainable and balanced economic growth presupposing a well-governed business environment,

274 See ILO website on "Decent Work": <http://www.ilo.org/global/about-theilo/decent-work-agenda/lang--en/index.htm>, last accessed on 4 November 2011.

275 Council of the European Union, The Africa-EU Strategic Partnership - A Joint Africa EU Strategy, document number: 16344/07 (Presse 291) of 9 December 2007.

276 See Three-Year Cooperation Programme (2009-2011) of the second Euro-African Ministerial Conference on Migration and Development, held on 25 November 2008 in Paris: $\quad<$ http://www.dialogueuroafricainmd.net/web/uploads/cms/Paris\%20Conference_Migration $\% 20$ Development $\% 20-\% 20$ Final $\% 20$ statement.pdf $>$, last accessed on 16 December 2011. 
a liaison with the public sector, greater productivity, education and technology transfers and the social protection of workers both in formal and informal economies. ${ }^{277}$ The Action Plan, based on the Joint Strategy and agreed upon at the Tripoli gathering, set out the planned activities and goals for the time period 2011 to 2013. The Action Plan underscored the conjunction between economic cooperation, regional integration and collaboration in the thematic partnerships of the Joint Strategy: "peace and security, democratic and economic governance and respect for human rights are prerequisites of development." It also highlighted the need to invest in Africa's human capital by skills development and innovation, in combination with social and labour market policies. In view of the MME partnership, the Action Plan re-emphasised its original policy goals such as enhanced mobility and the need to ensure human rights of migrants. ${ }^{278}$

The third Euro-African Ministerial Conference on Migration and Development was held on 23 November 2011 in Dakar where the participating governments decided on a new agenda for 2012 to 2014. ${ }^{279}$ Based on the Rabat Declaration and the Paris Cooperation programme, the Dakar Strategy identified further principles and elements for collaboration in the field of linking migration to development in a fruitful way: action should be taken in a flexible, balanced and coherent way on the basis of shared responsibility by all partners; the thematic framework reiterates the three pillars, as initially set out by Global Approach to Migration, but, in addition, explicitly incorporates the objective to guarantee migrants' rights and integration.

\subsection{The Cotonou Agreement}

The Cotonou Agreement is the result of a long-term and close cooperation between the EU and the ACP States in economic, political, social and developmental subjectmatters. ${ }^{280}$ It constitutes a key accord in the EU's external relations and was renewed in March 2010. The Cotonou Agreement comprises, at present, 79 ACP countries and 27 EU Member States and superseded the Yaoundé and Lomé Conventions. The Cotonou Agreement was signed on 23 June 2000 and entered into force on 1 April

277 Tripoli Declaration, 3rd Africa-EU Summit, 29-30 November 2010, available at: $<$ http://www.africa-eu-partnership.org/sites/default/files/doc_tripoli_declaration_en.pdf $>$, last accessed on 4 November 2011.

278 Joint Africa EU Strategy, Action Plan 2011-2013, Introductory Part, available at: http://www.africa-eu-partnership.org/sites/default/files/doc_jaes_action_plan_2011_13_en.pdf $>$, last accessed on 4 November 2011.

279 Dakar Strategy (2012-2014) of the third Euro-African Ministerial Conference on Migration and Development, held on 23 November 2008 in Dakar: <http://ec.europa.eu/home-affairs/news/intro/docs/Dakar\%20strategy_\%20-

Ministerial $\% 20$ declaration $\% 20$ migration $\% 20$ and $\% 20$ development_\%20EN.PDF $>$, last accessed on 16 December 2011.

280 Partnership agreement between the members of the African, Caribbean and Pacific Group of States of the one part, and the European Community and its Member States, of the other part, signed in Cotonou on 23 June 2000, OJ L 317, 15 December 2000, p. 3 (Cotonou Agreement I). 
2003. An agreement that amended the Cotonou Agreement was adopted in 2005, and a second revision was signed on 22 June $2010 .^{281}$

\subsubsection{From Yaoundé I to Lomé IVbis}

The original Yaoundé Agreement, between the EEC and 18 African states, was concluded in 1963 and was valid for five years and provided commercial benefits and financial support to former colonies. ${ }^{282}$ The period from 1969 until 1975 was covered by Yaoundé II. ${ }^{283}$ After its expiration, it merged into the Lomé I Convention, extending its scope to Britain, which had joined the Community in 1973 and to 46 ACP States. ${ }^{284}$ Lomé II and III followed in 1979 and 1984 respectively. ${ }^{285}$ Lomé IV was valid for an exceptional ten-year period with amendments made in 1995.286 The initial objective of the Lomé Agreements was the promotion and consolidation of the economic development of the ACP States. Over time, this objective was amended by including a political, cultural and social dimension and by setting out an approach based on mutual interest and solidarity. In particular, ACP States were granted nonreciprocal preferences for most exports from ACP to EEC States, predominately including primary products: petrol, coffee, cocoa and cotton. A stronger emphasis was put on equality between partners and the sovereign right of states to stipulate their own policies. The parties also included respect for human rights and the rule of law, as well as the promotion of good governance and democracy as crucial elements of the partnership in the course of time. Lomé IV subsequently encompassed 71 ACP States and 15 EC Member States. ${ }^{287}$ The Lomé accords were heavily criticised

281 Agreement amending the Partnership Agreement between the members of the African, Caribbean and Pacific Group of States, of the one part, and the European Community and its Member States, of the other part, OJ L 209, 11 August 2005, p. 27 (Cotonou Agreement II); Agreement amending for the second time the Partnership Agreement between the members of the African, Caribbean and Pacific Group of States, of the one part, and the European Community and its Member States, of the other part, OJ L 287, 4 November 2010, p. 3 (Cotonou Agreement III); the agreement is pending as of 23 November 2011.

282 Convention d'association entre la Communauté économique européenne et les États africains et malgache associés à cette Communauté, JO 93 du 11 juin 1964, p. 1431 (Yaoundé I).

283 Convention d'association entre la Communauté économique européenne et les États africains et malgache associés à cette Communauté, JO L 282 du 28 décembre 1970, p. 2 (Yaoundé II).

284 ACP-EEC Convention of Lomé, OJ L 25, 30 January 1976, p. 2 (Lomé I).

285 Second ACP-EEC Convention, OJ L 347, 22 December 1980, p. 2 (Lomé II); Third ACP-EEC Convention, OJ L 86, 31 March1986, p. 3 (Lomé III).

286 Fourth ACP-EEC Convention, OJ L 229, 17 August 1991, p. 3 (Lomé IV); Agreement amending the fourth ACP-EC Convention of Lomé, OJ L 156, 29 May 1998, p. 3 (Lomé IV bis); for more information on the Lomé IV Convention, see G. Scappucci, 'EU-ACP Relations in the 1990s', in: C. Cosgrove-Sacks and G. Scappucci (eds.), The European Union and Developing Countries: The Challenge of Globalization (Palgrave Macmillan, Basingstoke 1999), pp. 109-126.

287 See website of DG DEVCO, European Commission: < http://ec.europa.eu/europeaid/where/acp/overview/lome-convention/lomeitoiv_en.htm>, last accessed on 14 October 2011; M.-F. Jarret and F.-R. Mahieu, 'Ethique et Développement dans le Système de Lomé', in: M.-F. Labouz (ed.), Le Partenariat de PUnion Europénne avec les pays tiers (Bruylant, Bruxelles 2000), pp. 59-60; E. Guild, 
with regard to their vague phrasing and their protectionist nature on the part of the EU. In addition, it is emphasised that the framework neither stimulated a dynamic development nor prevented the marginalisation of ACP States with respect to global competition. ${ }^{288}$ This last aspect was particularly striking: there is evidence that the duty-free trade arrangements under Lomé based on non-reciprocity were not effective in boosting economic growth. Eurostat figures indicate that the share of ACP products in total EU imports from third countries dropped from approximately $8 \%$ in 1980 to about $3 \%$ in 2001.289

\subsubsection{The ACP Conventions and Migration}

The Yaoundé Conventions did not contain any provisions relating to migration. However, the first Lomé Convention included an Article 62 under Title V that stated that in respect to arrangements concerning establishment and the provision of services the ACP States on the one hand and the Member States on the other should treat nationals and companies of both parties on a non-discriminatory basis. This equal treatment clause was, however, restricted: if a party was unable to provide such treatment, the other party was not bound to provide such treatment for this activity to the nationals and companies of the state concerned. In Razanatsimba a Madagascan applicant claimed that he was entitled to be admitted for pupillage at the Lille bar, on the basis of Article 62 of Lomé I, which was denied by the French authorities because he did not possess French nationality. ${ }^{290}$ The Court of Justice ruled that the provision invoked did not purport to provide equality of treatment between nationals of an ACP State and those of a Member State and that it was not contrary to Article 62 for a Member State to reserve more favourable treatment to nationals of one ACP State, provided that such treatment resulted from an international agreement comprising reciprocal rights and advantages. As a consequence, the Court concluded that Article 62 did not give an ACP national the right to establish himself in a Member State without any conditions as to nationality, in so far as the right to practice professions reserved by the legislation of that state to its own nationals is concerned. The outcome of this case is disputable, and one may wonder what the Court thought the actual purpose of Article 62 of Lomé I was. It is clear that the second sentence of Article 62 already deprives the provision of its substance. A right to equal treatment regarding establishment and services is not found in later ACP conventions.

The Lomé II Convention included a Joint Declaration on equal treatment in working conditions and social security for ACP nationals. Following long negotiations, two Joint Declarations on migrant workers and ACP students were inserted into the

Immigration Law in the European Community (Kluwer Law International, The Hague 2001), pp. 105-106. 
Lomé III Convention. ${ }^{291}$ This convention was equipped with "a more human dimension" seeing that "regardless of race, religion and culture, he [man] must be the actor and beneficiary of the development process" according to P. Barry who was presiding the Council at the time. ${ }^{292}$ Annex IX to the Lomé III Convention enshrined a Joint Declaration on ACP migrant workers and ACP students in the Community. This Declaration basically stipulated that foreign workers shall not be discriminated against and that training of ACP nationals shall be enhanced, in particular with regard to reintegration in their country of origin.

Annex X to the Lomé III Convention laid down a Joint Declaration on workers who are nationals of one of the contracting parties and are legally resident in the territory of a Member State or an ACP State, which enshrined a precisely formulated equal treatment clause for workers legally employed in the territory of another party as regards working conditions and pay. Next, such workers and their family members were also accorded non-discrimination based on nationality in respect of social security benefits linked to employment. More favourable treatment arising from bilateral agreements binding the ACP and the Member State was not excluded by the provisions. Finally, it was laid down that the matters referred to in this Declaration should be resolved satisfactorily and through bilateral negotiations with a view to concluding appropriate agreements.

Hence, on the basis of this latter Declaration, legally resident workers enjoyed a right to equal treatment in view of working conditions and social security - the question arises whether these provisions qualified for direct effect. There is no doubt that the equal treatment clauses were phrased in a strong fashion, stipulating a clear and precise obligation incumbent upon the state parties: "The Member State/Each ACP State shall accord $[. .$.$] ]". The Declaration is worded in unequivocal terms to be invoked$ by individuals before national courts and it is unconditional. This strong wording indicates the direct effect of theses provisions notwithstanding the caveat in paragraph 4 referring to the handling of discrepancies. D. Martin and E. Guild pointed out that "the Court has on many occasions confirmed its competence to interpret these [international] agreements, any 'question' deriving from the implementation of the Annex could be submitted to it in accordance with Article 177 EC (preliminary references)". ${ }^{293}$ Thus, in their opinion, paragraph 4 cannot frustrate the direct effect - a view, which is supported by the similar wording of paragraph 1 of the Declaration in comparison to Article 40 of the 1976 Morocco Cooperation Agreement, to which the Court accorded direct effect in Kziber. ${ }^{294}$ The authors also made clear that the position of the equal treatment clauses in the Annex did not impinge on whether it entailed direct effect or not. By reference to Drake and Chiquita, the authors stated that it was unequivocal that no hierarchy between the provision of a text and those of an Annex exists and that a rule in a Protocol can be

\footnotetext{
291 The Courier ACP-EC, 'ACP-EEC Convention - Lomé III', No 89 January-February 1985, Special Issue, p. 25.

292 P. Barry and The Courier ACP-EC, 'ACP-EEC Convention - Lomé III', No 89 January-February 1985, Special Issue, p. 7.

293 D. Martin and E. Guild, Free Movement of Persons in the European Union (Butterworths, London 1996), p. 293.

294 Case C-18/90 Kziber [1991] ECR I-199.
} 
directly effective. ${ }^{295}$ Importantly, the subsequent Lomé Conventions (Lomé IV and Lomé IVbis) contained the same Joint Declarations whereas they are not found in the Cotonou Agreement.

\subsubsection{Objectives and Principles of the Cotonou Agreement}

The Cotonou Agreement enhances existent cooperation while maintaining the Lomé acquis in mainly providing the ACP States with trade preferences and financial assistance. ${ }^{296}$ It was concluded for period of 20 years with a possibility for regular revision. The innovative modifications relate firstly to the nature of the accord: as opposed to the Lomé Conventions, the Cotonou Agreement is a shortened and simplified legal framework setting out the goals, principles and tools for its implementation. Secondly, as laid down in Article 1, its principle aim is to reduce and ultimately eradicate poverty in accordance with the objectives of sustainable development and the successive integration of the ACP States into the world economy. Thirdly, the principles that govern the cooperation have been amended: the equality and sovereignty of states to determine priorities, as well as the respect for human rights, democratic principles and the rule of law are attributed major significance. ${ }^{297}$ The new principles concern the participation of other sectors of society to stimulate cooperation, dialogue and the fulfilment of mutual obligations and regionalisation and differentiation (cooperation dependent on a country's level of development, its needs and its performance). ${ }^{298}$ Fourthly, a deep and comprehensive political dialogue will form part of the collaboration. Fifthly, trade arrangements have been altered and specified in a WTO-compatible system which provides the possibility to conclude Economic Partnership Agreements (EPAs) so as to liberalise trade on a reciprocal basis or to continue non-reciprocal preferences for leastdeveloped countries after 2007.299 Lastly, financial assistance is dependent on need and performance, where the latter is evaluated by criteria such as effective implementation of operations, institutional reforms, poverty reduction, sustainable development instruments and the effective use of resources. Next, NGOs and

295 D. Martin and E. Guild, Free Movement of Persons in the European Union (Butterworths, London 1996), p. 293; Case C-12/93 Drake [1994] ECR I-4337, para. 20; Case C469/93 Chiquita [1995] ECR I-4533.

296 For more details see J.C. Gautron, 'De Lomé à Cotonou: rupture et continuité conventionelles', in: A. De Walsche and G. Vandersanden (eds.), Mélanges en hommage à Jean-Victor Louis (Université Libre de Bruxelles, Bruxelles 2003), pp. 79-93. In accordance with Art. 96 of the Cotonou Agreement "appropriate measures" can be taken if a state does not comply with its obligations regarding human rights, democratic principles and the rule of law, including suspension as a measure of last resort. On the issue of regional integration, see E. De Vos, 'The Cotonou Agreement: A Case of Forced Regional Integration?', in: G. Kreijen (ed.), State, Sovereignty, and International Governance (Oxford University Press, Oxford 2002), pp. 497-518.

299 Such an EPA was concluded with the Caribbean States in 2008, Economic Partnership Agreement between the CARIFORUM States, of the one part, and the European Community and its Member States, of the other part, OJ L 289, 30 October 2008, p. 3; this EPA includes a Title II on investment, trade in services and e-commerce but it is explicitly stated that the parties remain competent to regulate the entry and temporary stay of natural persons, see Art. 60(5); as of 24 November 2011 the ratification process has not been finalised. 
community organisations dealing with cooperation are supported. ${ }^{300}$ The Cotonou Agreement contains a novel provision dealing with migration issues in its Article 13.

In 2005, the Cotonou Agreement was first amended in accordance with Article 95. ${ }^{301}$ The adjustments intended to consolidate the effectiveness and quality of the accord and generally to improve its transposition. Contentwise the alignments concerned inter alia the inclusion of non-state actors in development strategies, a regular and formally-established political dialogue on human rights, democratic principles and the rule of law and the facilitation of investments, in particular in view of reciprocal regional cooperation. 302 The second revision of the Cotonou Agreement took place in 2010.303 The 2010 review strengthened regional integration within the ACP group of states but also in the EU-ACP relations. Moreover, peace building and conflict prevention, food security, HIV/AIDS and the climate change were agenda items taken into consideration in the new consolidated version of the Cotonou Agreement. None of the revision processes entailed amendments as regards Article 13 on migration, although upgrades and adjustments had been suggested. ${ }^{304}$

\subsection{The Mobility Partnership with Cape Verde}

The mobility partnership with Cape Verde was concluded in May 2008 with four Member States, and with the Netherlands joining this partnership as a signatory at a later stage. ${ }^{305}$ The mobility partnership was labelled as "a unique element of the closer relationship between the EU and Cape Verde."306 The Cape Verdean authorities prioritised border management, security of identity and travel documents, as well as mobility and visa facilitation; thus, projects in these fields have been agreed upon with EU and Member States' support, such as a working arrangement with FRONTEX, an EU visa facilitation agreement and assistance for return migrants.

300 O. Babarinde and G. Faber, 'From Lomé to Cotonou: Business as Usual?', 9 European Foreign Affairs Review (2004), 27, pp. 35-38.

301 Agreement amending the Partnership Agreement between the members of the African, Caribbean and Pacific Group of States, of the one part, and the European Community and its Member States, of the other part, OJ L 209, 11 August 2005, p. 27 (Cotonou Agreement II).

302 R. Atzeni, 'L'article 13 de l'Accord de Cotonou et la compétence communautaire en matière de conclusion d'accords de réadmission', 42 Revue trimestrielle de droit européen (2006), 621, pp. 628-629.

303 Agreement amending for the second time the Partnership Agreement between the members of the African, Caribbean and Pacific Group of States, of the one part, and the European Community and its Member States, of the other part, OJ L 287, 4 November 2010, p. 3 (Cotonou Agreement III); the agreement is pending as of 23 November 2011.

304 E. Koeb and H. Hohmeister, 'The Revision of Article 13 on Migration of the Cotonou Partnership Agreement: What's at Stake for the ACP?', ECDPM Briefing Note (Maastricht 2010).

305 The participating EU Member States are Spain, France, Luxembourg, Portugal and the Netherlands.

306 Council of the European Union, Joint Communiqué - EU-Cape Verde political dialogue meeting at ministerial level, document number: 5796/10 of 27 January 2010, p. 3. 
The Member States have had a stake in preventing and reducing irregular migration flows to the EU. 307

\section{The EU-Latin AND CENTRAL AMERICA RELATiOnS}

Despite the close historical and cultural ties between Europe and Latin America and repeated expressions of interest, a first rapprochement only occurred in 1971 with the conclusion of a trade agreement with Argentina. ${ }^{308}$ Why did it take comparatively long to establish relations with the Latin American continent whereas the Community had been a lot quicker in making a connection with Africa? It seems that the Community at the time hesitated to set a foot in the "front yard" of the United States. Besides, Spain and Portugal did not form part of the Community yet and the geographical position of Latin America implied a great distance to Europe. ${ }^{309}$ The Community signed further economic agreements with Uruguay and Brazil in 1973 and a cooperation treaty with Mexico in 1975. ${ }^{310}$ At least the agreements concluded with Uruguay, Brazil and Mexico stipulate most-favoured-nation treatment with regard to the sale, purchase, transport, distribution and use of goods and services on the internal market. Apart from that, they do not touch upon labour or migration matters. It is interesting to note that most Latin American countries (13 out of 17) are exempted from visa requirements for short-term stays in accordance with Council Regulation No 539/2001 and its amending acts. ${ }^{311}$ However, nationals of Bolivia, Colombia, Ecuador and Peru must still be in possession of a visa to enter an EU Member State.

\subsection{The EU-LAC Strategic Partnership and Migration}

In 1999, the EU and the Latin American and Caribbean countries (LAC) met in Rio de Janeiro to create a Strategic Partnership between them to enhance collaboration

European Commission Staff Working Document, SEC(2009) 1240, 18 September 2009, pp. 4-5; for further information see N. Reslow, 'Deciding on EU External Migration Policy: The Member States and the Mobility Partnerships', Journal of European Integration (2011), 1.

Commercial Agreement between the European Economic Community and the Republic of Argentina, OJ L 249, 10 November 1971, p. 18.

309 C. Flaesch-Mougin, Les accords externes de la Communauté économique européenne: essai d'une typologie (Éditions de L’Université de Bruxelles, Bruxelles 1979), pp. 272-277.

310 Commercial Agreement between the European Economic Community and the Eastern Republic of Uruguay, OJ L 333, 4 December 1973, p. 2; Trade Agreement between the European Economic Community and the Federal Republic of Brazil, OJ L 102, 11 April 1974, p. 24; Agreement between the European Economic Community and the United Mexican States, OJ L 247, 23 September 1975, p. 11; for an overview of the EU-Latin America relations, see also C. Flaesch-Mougin and J. Lebullenger, 'Les relations contractuelles de l'Union européenne avec les pays et groupement latinoaméricains', in: European Communities (ed.), The European Union in a Changing World (European Commission, Bruxelles 1996), pp. 581-628.

311 Council Regulation (EC) No 539/2001 of 15 March 2001 listing the third countries whose nationals must be in possession of visas when crossing the external borders and those whose nationals are exempt from that requirement. 
and to deepen the political dialogue. ${ }^{312}$ The Commission affirmed the EU's intention to build "a genuine alliance" with Latin America and to support the countries' efforts in strengthening democracy, stability, security and sustainable development in 2005; reference was also made to the challenge that many countries of origin are confronted with because of migration flows to Europe and to the development potential of the migration process and of migrants. ${ }^{313}$ During a special summit on migration, the EU and the LAC governments, in Quito in March 2004, agreed on key issues that needed to be tackled including a comprehensive approach to migration, the respect for the human rights of migrants and their families, the importance of remittances and the contribution of migrants to home and host country, as well as the prevention of irregular migration flows. ${ }^{314}$ Follow-up meetings were held in Cartagena in 2006 and Brussels in 2008 respectively. ${ }^{315}$

The 2008 EU-LAC summit in Lima focused on poverty reduction, sustainable development with respect to environment, climate change and energy but it also touched upon migration issues. In the final declaration, the parties set out the commitment to create a comprehensive approach to migration including "the orderly management of migratory flows, focusing on the mutual benefits for countries of origin and destination and fostering the recognition and public awareness of the important economic, social and cultural contribution of migrants to the host societies." The framework should also cover the migration-development-nexus, as well as regular and irregular migration. ${ }^{316}$ The EU-LAC Structured and Comprehensive Dialogue on Migration was launched in June 2009 with a view to transpose the commitments laid down at the 2008 Lima meeting. The Structured Dialogue zeros in on identifying common challenges with respect to EU-LAC migration and it allows for an exchange of views and promotes mutual understanding in migration matters that concern both partners. ${ }^{317}$ The EU Global Approach to

312 The EU-LAC cooperation covers the following countries and regions: Mexico, Central America (Costa Rica, El Salvador, Guatemala, Honduras, Nicaragua and Panama), and the Caribbean (13 countries); South America comprises the Andean Community (Colombia, Ecuador, Bolivia, Peru) and Mercosur (Argentina, Brazil, Uruguay, Paraguay and Venezuela) plus Chile.

313 European Commission Communication, $\operatorname{COM}(2005)$ 636, 8 December 2005, pp. 8 and 12.

314 Council of the European Union, Meeting between the European Union and the Latin American and Caribbean countries on Migration - Quito, 4-5 March 2004, document number: 7267/04 of 11 March 2004.

315 Meeting of Experts between the European Union and the Latin American and Caribbean Countries on Migration (1-2 March 2006), Report Adopted by the Plenary Session, available at: < http://eeas.europa.eu/la/migration/2006_cartegena_en.pdf>, last accessed on 11 November 2011; Council of the European Union, Third Experts Meeting on Migration between the European Union and the Countries of Latin America and the Caribbean (Brussels, 10-11 March 2008), document number: 7640/08 of 14 March 2008.

316 V Latin America and Caribbean-European Union Summit, Lima Declaration of 16 May 2008, para. 27.

317 See document "Launch of the EU- LAC Dialogue on migration, 30 June - Brussels", available at: <http://www.europarl.europa.eu/intcoop/eurolat/working_group_migration/meetings/27_28_01_2010_brussels/dossier/basis_en.pdf>, last accessed on 28 November 2011. 
Migration served as an orientation: the Structured Dialogue likewise displays the three dimensions on:

- enhancing the positive synergies on migration and development;

- better organising regular migration;

- addressing irregular migration.

The Heads of State and Government at the 6th EU-LAC meeting, held in May 2010 in Madrid, welcomed the kick-off of the Structured Dialogue on Migration and endorsed it in the Madrid Action Plan. This Action Plan schedules arrangements for the time period 2010 to 2012 and the main measures envisaged in the field of migration relate to enhanced cooperation, the magnitude of the human movements at issue, the respect of the migrants' human rights and three dimensions of the Global Approach. ${ }^{318}$ It is noticeable that the adherence to human rights is of fundamental importance in the framework of the Structured Dialogue; in comparison, this particular aspect is not similarly tabled in the Global Approach.

\subsection{The EU-Chile Association Agreement}

The EU signed an association agreement with Chile on 18 November 2002; the treaty entered into force on 1 March 2005. ${ }^{319}$ The agreement established a political and economic association between the EU and Chile with a view to deepen the relationship in all areas covered. Article 20 of the EU-Chile Agreement lays down that the parties shall support and intensify cooperation with each other, reflecting the growing importance of services in the development and growth of their economies. Title III of the EU-Chile Agreement contains rules specifying trade in services and establishment; the latter only covers the establishment of companies, not that of the self-employed. ${ }^{320}$ Based on Article 94, the parties reciprocally commit to liberalise trade in services in line with the GATS and to improve the investment environment.

\subsection{Cooperation Agreement with the Andean Community}

On 15 December 2003, the Andean Community (Bolivia, Colombia, Ecuador, Peru and Venezuela) signed a "political dialogue and cooperation agreement" with the Community which will replace the 1993 cooperation agreement once the former enters into force. ${ }^{321}$ The 2003 agreement aims to strengthen and deepen the relations

318 Council of the European Union, EU-LAC SUMMIT, Madrid, 18 May 2010 "Towards a new stage in the bi-regional partnership: innovation and technology for sustainable development and social inclusion" Madrid Action Plan 2010-012, document number: 10449/1/10 REV 1, 15 November 2010. Agreement establishing an Association between the European Community and its Member States, of the one part, and the Republic of Chile, of the other part, OJ L 352, 30 December 2002, p. 3.

320 See Art. 131(d) of the EU-Chile Agreement; see also Annex VII setting forth the schedule of specific commitments on services and Annex VIII laying down the schedule of specific commitments on financial services.

321 Political Dialogue and Cooperation Agreement between the European Community and its Member States, of the one part, and the Andean Community and its Member Countries (Bolivia, Colombia, Ecuador, Peru and Venezuela), of the other part, signed 
of the parties in all fields covered by developing their political dialogue (also on migration issues) and reinforcing their cooperation with an association agreement held out in prospect. The parties underpin the respect for human rights, democratic principles and the rule of law and affirm their commitment to promote sustainable development. ${ }^{322}$ According to Article 49, the parties agree to cooperate in migration matters, which include the joint management of migration flows between their territories, irregular migration, smuggling and human trafficking, as well as the root causes of migration. Cooperation shall be based on the principles of international protection (the Geneva Refugee Convention is explicitly mentioned) and focus on the admission rules, the rights and the status of the persons admitted, the fair treatment and integration of the legal residents into society, education and training of legal migrants and measures against racism.

Venezuela declared its withdrawal from the agreement in 2006, and the Commission recommended the amendment of the cooperation agreement accordingly. ${ }^{323} \mathrm{Next}$, the Commission proposed the Council to open the negotiation on an association agreement with the Andean Community in 2006. The European Parliament gave a recommendation in respect of this future association agreement. ${ }^{324}$ Under point (o) the Parliament expressed that with regard to migration, it recommends to include "provisions designed to reinforce the fundamental, labour and civil rights of legal migrants, particularly with regard to their social security, wherever they may be and establish mechanisms to facilitate sending remittances, making such operations cheaper and more transparent and secure, at the same time tackling the basic causes of migration". The European Parliament thus took a proactive stance highlighting the need for a secure legal status of migrants with a legal residence.

\subsection{Cooperation Agreement with the Republics of Costa Rica, El Salvador, Guatemala, Honduras, Nicaragua and Panama}

Just like in the case of the Andean Community, another "political dialogue and cooperation agreement" with the Republics of Costa Rica, El Salvador, Guatemala, Honduras, Nicaragua and Panama was concluded on the same date (15 December 2003) that will supersede the 1993 Community cooperation agreement with the Central American states. ${ }^{325}$ The 2003 cooperation agreement is moreover very

on 15 December 2003, ratification pending as of 20 May 2012; Framework Agreement on Cooperation between the European Economic Community and the Cartagena Agreement and its member countries, namely the Republic of Bolivia, the Republic of Colombia, the Republic of Ecuador, the Republic of Peru and the Republic of Venezuela, OJ L 127, 29 April 1998, p. 11.

322 Arts. 1 to 3 of the Cooperation Agreement between the European Community and its Member States, of the one part, and the Andean Community and its Member Countries.

323 European Commission Recommendation, COM(2007) 353, 26 June 2007.

324 European Parliament Recommendation of 15 March 2007 to the Council on the negotiating mandate for an association agreement between the European Union and its Member States, of the one part, and the Andean Community and its member countries, of the other part (2006/2221(INI)), OJ C 301E, 13 December 2007, p. 238.

325 Political Dialogue and Cooperation Agreement between the European Community and its Member States, of the one part, and the Republics of Costa Rica, El Salvador, Guatemala, Honduras, Nicaragua and Panama, signed on 15 December 2003, 
similar, in view of structure and content, to the one with the Andean Community, emphasising the strengthening of economic and political relations, as well as collaboration concerning poverty reduction, development cooperation, democratic structures and human rights. ${ }^{326}$ Article 49 of the 2003 cooperation agreement is almost identical to Article 49 of the agreement with the Andean Community in that is also covers cooperation in migration matters, including the joint management of migration flows, irregular migration, human trafficking, the root causes of migration, international protection; the next cooperation shall centre on the admission rules, the rights and the status of persons admitted, fair treatment and integration policies for all legally residing non-nationals, education of migrants, measures against racism and human rights of migrants.

\subsection{EU-Trade Agreement with Colombia and Peru}

The EU concluded a trade agreement with Colombia and Peru in 2010 which was signed on 13 April 2011 in Brussels; yet, the agreement has not come into force yet. ${ }^{327}$ Title IV of this trade agreement concerns trade in services, establishment and electronic commerce. Under Article 107, the parties agree on the progressive liberalisation of services, establishment and electronic commerce and recognise their WTO commitments in this regard. The agreement contains provisions on the GATS four modes of supply, the scope of application with respect to cross-border trade in services, market access and national treatment. ${ }^{328}$ Articles 121 to 128 (Chapter 4) of the trade agreement enshrine detailed rules on the temporary presence of natural persons for business purposes, such as key personnel, graduate trainees and contractual service suppliers. In order to become effective, all contracting parties have to ratify the trade agreement.

In the 1970s the Community also entered into relations with countries on the Asian continent. The UK's accession to the Community in 1973 provided an impulse in this regard seeing that the UK had already established a close alliance with the Commonwealth countries Sri Lanka, India, Malaysia, Pakistan, Singapore and Bangladesh. A declaration of intent to the UK accession treaty confirmed that the Community would examine the possibilities to develop a commercial relationship with these countries; yet, it has been pointed out that the Community rather imposed measures, in the framework of the generalised system of preferences, upon these

ratification pending as of 20 May 2012; Framework Cooperation Agreement between the European Economic Community and the Republics of Costa Rica, El Salvador, Guatemala, Honduras, Nicaragua and Panama, OJ L 63, 12 March 1999, p. 39.

326 European Community and its Member States, of the one part, and the Republics of Costa Rica, El Salvador, Guatemala, Honduras, Nicaragua and Panama.

Trade Agreement between the European Union and its Member States and Colombia and Peru; ratification pending as of 15 March 2012, text available at: <http://trade.ec.europa.eu/doclib/docs/2011/march/tradoc_147704.pdf>, last accessed on 15 March 2012; see A. Willis, 'EU signs trade deals with EU and Colombia', EU Observer, 14 April 2011. 
developing countries with respect to finished or semi-finished products. ${ }^{329}$ Trade agreements have successively been concluded with India, Sri Lanka, Pakistan and Bangladesh. ${ }^{330}$ Migration matters were not mentioned in these agreements and still today the revised agreements in force do not address the status or movement of persons whatsoever. ${ }^{331}$ The EU and India are interested in collaborating on migration issues, including facilitating legal migration and preventing irregular migration. For this purpose a research project is carried out by the European University Institute in partnership with the Indian Council of Overseas Employment, the Indian Institute of Management Bangalore, and Maastricht University with a view to consolidate a constructive dialogue and bring together scholars and policy makers. ${ }^{332}$

Likewise, the cooperation agreement that the Community concluded with Indonesia, Malaysia, the Philippines, Singapore and Thailand in 1980, as well as the 1985 EECChina trade agreement, focus exclusively on trade relations (and on development cooperation in the case of the former). ${ }^{333}$ Since 1996 the EU convenes on a regular basis with the Asian heads of government at the Europe-Asia Meeting which is a platform for political dialogue for discussing topics relating to trade, education, transport, culture, finance but also immigration. ${ }^{334}$

At the turn of the millennium the Community concluded PCAs with five Central Asian countries Kazakhstan, Kyrgyz Republic, Tajikistan, Turkmenistan and Uzbekistan. ${ }^{335}$ To date only the PCA with Turkmenistan has not entered into

329 C. Flaesch-Mougin, Les accords externes de la Communauté économique européenne: essai d'une typologie (Editions de L’Université de Bruxelles, Bruxelles 1979), pp. 278-279.

330 Commercial Cooperation Agreement between the European Economic Community and the Republic of India, OJ L 82, 27 March 1974, p. 2; Agreement on commercial cooperation between the European Economic Community and the Republic of Sri Lanka, OJ L 247, 23 September 1975, p. 2; Commercial Cooperation Agreement between the European Economic Community and the Islamic Republic of Pakistan, OJ L 168, 28 June 1976, p. 1; Commercial Cooperation Agreement between the European Economic Community and the People's Republic of Bangladesh, OJ L 319, 19 November 1976, p. 1.

331 Cooperation Agreement between the European Community and the Republic of India on partnership and development, OJ L 223, 27 August 1994, p. 24; Cooperation Agreement between the European Community and the Democratic Socialist Republic of Sri Lanka on partnership and development, OJ L 85, 19 April 1995, p. 33; Cooperation agreement between the European Community and the Islamic Republic of Pakistan, relating to the partnership and to development, OJ L 378, 23 December 2004, p. 23; Cooperation Agreement between the European Community and the People's Republic of Bangladesh on partnership and development, OJ L 118, 27 April 2001, p. 48.

See website India-EU Migration, available via: < http://www.india-eu-migration.eu/>, last accessed on 15 June 2012.

333 Cooperation Agreement between the European Economic Community and Indonesia, Malaysia, the Philippines, Singapore and Thailand, OJ L 144, 10 June 1980, p. 2.

334 For more information see website of the 8th ASEM summit that took place on 4-5 October 2010 in Brussels: <http://www.asem8.be/>, last accessed on 26 November 2011.

335 Partnership and Cooperation Agreement between the European Communities and their Member States and the Republic of Kazakhstan, OJ L 196, 28 July 1999, p. 3; Partnership and Cooperation Agreement establishing a partnership between the European Communities and their Member States, of the one part, and the Kyrgyz 
force. ${ }^{336}$ All PCAs are similar as regards their content: they aim to promote cooperation and consolidate the rule of law, democratic principles, economic and social relations between the respective country and the Community. It has been criticised that, despite the emphasis on democracy, the PCAs largely focus on economic and financial cooperation. ${ }^{337}$ All PCAs include provisions on labour conditions and the cross-border supply of services. In 2007, the EU adopted a "New Strategy for Partnership" with the five central Asian countries Kazakhstan, Kyrgyz Republic, Tajikistan, Turkmenistan and Uzbekistan under the German Presidency of the European Council. ${ }^{338}$ The focus of this Strategy lies in reinforcing the political dialogue between the partners in the areas of security and stability (building inter alia on the PCAs); democratisation processes and human rights protection; setting up education initiatives; promotion of trade relations; strengthening energy and transport links; fostering environmental sustainability; building and intercultural dialogue. The Strategy mentions migration in the context of border management, irregular migration and human trafficking; yet, reference to the EU's Global Approach to Migration is made deeming migration as one of the major global challenges of the 21st century. Next, the EU has offered support to the Central Asian countries as regards managing migration in a more balanced manner, such as establishing functioning systems to match labour demand and supply, facilitating integration of legal migrants and providing international protection to asylum seekers and refugees. The New Strategy has been considered as very ambitious and although the Asian nations have been given the opportunity to present and integrate their own policy priorities, the EU's influence remains marginal in comparison to Russia and China in the region. ${ }^{339}$

On 10 May 2010, the EU and the Republic of Korea signed a new framework agreement on the basis of which the parties agreed to cooperate in the fields of

Republic, of the other part, OJ L 196, 28 July 1999, p. 48; Partnership and Cooperation Agreement establishing a partnership between the European Communities and their Member States, of the one part, and the Republic of Tajikistan, of the other part, OJ L 350, 29 December 2009, p. 3; Partnership and Cooperation Agreement establishing a partnership between the European Communities and their Member States, of the one part, and the Republic of Turkmenistan, of the other part, signed on 25 May 1998 (see European Commission Communication, COM(97) 693, 6 February 1998); Partnership and Cooperation Agreement establishing a partnership between the European Communities and their Member States, of the one part, and the Republic of Uzbekistan, of the other part, OJ L 229, 31 August 1999, p. 1.

336 As of 27 November 2011, see however: Interim Agreement between the European Community, the European Coal and Steel Community and the European Atomic Energy Community, of the one part, and Turkmenistan, of the other part, on trade and trade-related matters, OJ L 80, 26 March 2011, p. 21.

337 S. Urdze, 'The Tool Kit of the EU-Central Asia Cooperation', in: A. Warkotsch (ed.), The European Union and Central Asia (Routledge, Abingdon 2011), pp. 22-32, p. 27.

338 Council of the European Union, "The EU and Central Asia: Strategy for a New Partnership", document number: 10113/07 of 31 May 2007; for an analysis of the bilateral cooperation with the Central Asian countries, see N. Kassenova, 'EU-Central Asian Bilateral Cooperation', in: A. Warkotsch (ed.), The European Union and Central Asia (Routledge, Abingdon 2011), pp. 48-62.

339 A. Schmitz, 'The Central Asia Strategy: An Exercise in the EU Foreign Policy', in: A. Warkotsch (ed.), The European Union and Central Asia (Routledge, Abingdon 2011), pp. 13 and 18. 
irregular migration, smuggling and human beings trafficking and to include migration matters in the national strategies for economic and social development of the areas from which migrants originate. ${ }^{340}$ The consideration of migration issues in the EUAsia relations is very marginal or non-existent; the migration-related rules in the PCAs concluded with the Central Asian countries are likewise rather weak.

\section{The EU's ReLations with the GulF REgion and the MidDle East}

The EU's relations with the countries located in the Gulf Region are organised within the framework of the Cooperation Council for the Arab States of the Gulf (GCC). This regional organisation was established in 1981 and comprises the following states: Bahrain, Kuwait, Oman, Qatar, Saudi Arabia and the United Arab Emirates. The GCC envisages promoting coordination, integration and collaboration among its members in a number of areas. ${ }^{341}$ The Community formalised its relations with the GCC by concluding a cooperation agreement in 1988 with the objective to create an institutional and contractual framework for strengthening cooperation in different fields, including trade and energy but also to support the GCC's role in contributing to peace and stability in the region. ${ }^{342}$ Cooperation in services shall merely be broadened and consolidated; labour and migration are not covered by this 1988 cooperation agreement.

The Community launched a dialogue with Iran in 1998 with a view to build up contractual relations for cooperation with the Islamic Republic; negotiations for a trade and cooperation agreement were launched in 2002, but at this point in time the political and economic relations between the EU and Iran are suspended because of Iran's unwillingness to cooperate in matters relating to its nuclear programme. ${ }^{343}$ The EU-Iraq relations are planned to be reinforced on the basis of a PCA to create a legal framework for political dialogue, foreign and security policy, human rights protection and trade-related matters. ${ }^{344}$ The PCA has the objective to liberalise trade in services (in line with GATS) and establishment. ${ }^{345}$ The EU collaborates with Yemen on the basis of a cooperation agreement that was signed in 1997. This cooperation agreement aims to foster economic and political relations, democratic reform and

340 See Art. 33(1) of the Framework Agreement between the European Union and its Member States, on the one part, and the Republic of Korea, on the other part, signed on 10 May 2010; ratification pending as of 15 March 2012.

341 See website of the GCC, available at: <http://www.gcc-sg.org/eng/>, last accessed on 28 November 2011.

342 Cooperation Agreement between the European Economic Community, of the one part, and the countries parties to the Charter of the Cooperation Council for the Arab States of the Gulf (the State of the United Arab Emirates, the State of Bahrain, the Kingdom of Saudi Arabia, the Sultanate of Oman, the State of Qatar and the State of Kuwait) of the other part, OJ L 54, 25 February 1989, p. 3. See Council of the European Union, EU-Presidency and Commission Joint Press Release on the opening of the negotiations with Iran of 12 December 2002, available at: <http://www.consilium.europa.eu/ueDocs/cms_Data/docs/pressdata/en/er/73726.pdf>, last accessed on 27 November 2011.

344 European Commission Communication, $\operatorname{COM}(2010)$ 638, 5 November 2010.

345 See Section II on Trade in Services and Establishment of the draft PCA with Iraq; European Commission Communication, $\operatorname{COM}(2010)$ 638, 5 November 2010. 
development cooperation. ${ }^{346}$ The EU's relations with the Gulf countries and the states located in the Middle East thus do not incorporate provisions on labour or migration.

Part IV has demonstrated that the EU's external relations today are made up of numerous agreements that the EU has concluded with third states and other regional entities so as to impart a legal form to economic and political cooperation. The scope of these agreements differs to a great extent: the EEA Agreement provides for the closest association in that the agreement extends the application of legislation on the four fundamental freedoms in the internal market to the EEA zone but additionally determines cooperation in areas that fall outside the scope of the fundamental freedoms; in contrast, commercial agreements, such as the ones negotiated in 1973 with India and Brazil are pure trade agreements in that they do not cover other fields of an economic, political or social nature.

Part IV has illustrated that the spectrum between these two extremes is quite broad; depending on the interests of the EU, the Member States and the respective third party, the most suitable agreement is selected. However, the EU has also designed and utilised overarching forms of political collaboration, such as the ENP that covers 16 neighbouring countries and the 27 EU Member States to extend its sphere of influence the immediate neighbouring regions. Undoubtedly, the distinct forms of cooperation have an impact on their enforcement; however, all forms of cooperation turn the parties in question into "partners" and provide the EU with a tool to reach out.

In Chapter 2 of Part IV the question was discussed how the differential treatment, which is supported by the various migration regime applicable to third-country nationals under association, cooperation and partnership agreements, is compatible with the prohibition of nationality discrimination. Importantly, the Court of Justice ruled in Vatsouras that only Member States' nationals could invoke Article 18 TFEU, which prohibits discrimination on grounds of nationality within the scope of application of the Treaties, and without prejudice to any specific provisions contained therein. ${ }^{347}$

However, the non-application of Article 18 TFEU to third-country nationals setting out the general principle of non-discrimination on grounds of nationality, which is one of the fundamental principles of EU law, has been criticised. Commentators have highlighted that from the wording of the provision itself it is not apparent why the provision should apply to EU nationals only. Exclusively the agreements concluded with the EEA, Switzerland and Turkey contain general non-discrimination clauses that prohibit discrimination based on nationality. Equality of treatment is vital for the integration and the protection of non-nationals in the country of residence, especially against the backdrop of their vulnerable position in relation to nationals. The entry Yemen, OJ L 72, 11 March 1998, p. 18.

347 Joined Cases C-22 and C-23/08 V atsouras [2009] ECR I-4585, para. 52.
} 
into force of the Treaty of Lisbon has contributed to strengthening equal treatment for third-country nationals seeing that the EU Charter provides for nondiscrimination on a variety of grounds; discrimination on the basis of nationality is explicitly prohibited within the scope of application of the Treaties and without prejudice to any of their specific provisions. ${ }^{348}$

348 Art. $21 \mathrm{EU}$ Charter. 



\section{Part V : The Legal Position of Third-Country Nationals: Entry, Employment and Residence Rights}

Parts V to VII of this dissertation address the question as to how privileged treatment of third-country nationals translates into a special legal status on the basis of EU law. These analyses are important to arrive at a conclusion concerning the central question posed by this research project. For this purpose, Part V concentrates on entry, employment and residence rights of third-country nationals. ${ }^{1}$ Under the EU visa policy the so-called black and white list determines whether a third-country national must be in possession of a visa or not to enter the territory of an EU Member State for short-term stays. Some privileged third-country nationals even enjoy entry rights for the purposes of taking up employment and other favourable rules relating to residence based on association agreements. With the adoption of a number of directives in the area of legal migration, the legal position of all thirdcountry nationals, irrespective of nationality, has been reinforced, inter alia as regards entry, employment and residence, as well as family reunification. The various legal sources have created a very fragmented set of rights applicable to third-country nationals made up of association regimes and bolstering EU secondary legislation. The case law of the Court of Justice has played an important role in strengthening the rights of third-country nationals, in particular for Turkish nationals. Most association agreements oblige the parties to grant the respective nationals equal treatment in relation to working conditions - a concept that the Court has given wide meaning, yet, to the exclusion of access to employment.

\section{ENTRY RIGHTS AND EU VISA POLICY}

The visa policies of the Member States and the EU, by way of a complex interaction, determine under what conditions a third-country national is permitted to enter the territory of an EU Member State and/or the Schengen area. The requirement to hold a visa as opposed to being able to freely enter a Member State can constitute a major obstacle to movement, even before a journey has started. By virtue of the competence that the Community was given in 1995, a regulation was adopted which listed the third countries whose nationals are required to have and from whom the Member States are obliged to require a visa. ${ }^{2}$ S. Peers emphasised that the imposition of visas concerned predominantly African and Asian states, as well as some countries located in Latin America, Central and Eastern Europe, the Caribbean and the Indian

1 The term "entry" used in this dissertation includes "first admission"; the Oxford English Dictionary defines "entry" inter alia as the right or opportunity of entering; admission.

2 Council Regulation (EC) No 2317/95 of 25 September 1995 determining the third countries whose nationals must be in possession of visas when crossing the external borders of the Member States (annulled in 1997, and replaced by Council Regulation (EC) No 574/1999 of 12 March 1999 determining the Non-EU Member Countries whose nationals must be in possession of visas when crossing the external borders of the Member States). 
and Pacific Oceans. ${ }^{3}$ Since the integration of the Schengen acquis into the EU legal framework with the Treaty of Amsterdam of 1997, the competence for external border checks and short-term visa policy has resided with the EU (under the former first pillar of the EU until the entry into force of the Treaty of Lisbon). ${ }^{4}$ This formed the legal basis to adopt Council Regulation No 539/2001 that sets out a white and a black list determining which nationals of third countries enjoy visa-free travel to and throughout the Schengen area for a period up to three months and which nationals do not. ${ }^{5}$ Pursuant to the Preamble of Council Regulation No 539/2001, the determination as to whether a country is placed on the white or the black list is based on a "case-by-case assessment of a variety of criteria relating inter alia to illegal immigration, public policy and security and to the European Union's external relations with third countries, consideration is also being given to the implications of regional coherence and reciprocity." 6 The lists have been amended several times moving countries from the white to the black list and the other way around. Importantly, since the incorporation of the Schengen acquis into the EU legal order, Ireland and the UK have not participated in visa-related measures with the exception of the UK's opt-in to the 2002 amended visa format regulation. The Schengen acquis has not yet fully been extended to the EU Member States Bulgaria, Cyprus and Romania. $^{7}$

\subsection{The Schengen White List: Privileged Third-Country Nationals}

Like the 1995 visa regulation, the white list of amended Council Regulation No $539 / 2001$, listing the countries whose nationals are exempted from visa obligations, covers mostly industrialised countries: all states that are member to the OECD, other than Turkey, are on the white list; the white list contains 39 states as of December 2011.8 Council Regulation No 539/2001 moved Hong Kong, Macao, Bulgaria and Romania from the black to the white list. While the transfer of Bulgaria and Romania was connected to the launch of accession negotiations, for Hong Kong and Macao it was a "trade-off" in that subsequently two EU readmission agreements were signed covering not only their own "citizens" but also persons who had only traversed their territories. ${ }^{9}$ Visa liberalisation talks for nationals of the Western Balkan countries have started in 2003 leading to the signature of visa facilitation agreements in 2007;

3 S. Peers, EU Justice and Home Affairs Law (3rd edn. Oxford University Press, Oxford 2011), p. 250.

$4 \quad$ See Art. 77 TFEU (former Art. 62 EC).

5 Council Regulation (EC) No 539/2001 of 15 March 2001 listing the third countries whose nationals must be in possession of visas when crossing the external borders and those whose nationals are exempt from that requirement.

6 Recital 5 of the Preamble to Council Regulation (EC) No 539/2001 of 15 March 2001 listing the third countries whose nationals must be in possession of visas when crossing the external borders and those whose nationals are exempt from that requirement. As of 17 May 2012.

8 The visa imposition for Turkish nationals in EU Member States that did not have such a visa requirement at the time of the entry into force of the 1970 Additional Protocol to the Ankara Agreement violates EU-Turkey association law in accordance with the Court's ruling in Soysal; see Section on the right to provide services for Turkish nationals.

9 S. Peers, EU Justice and Home Affairs Law (3rd edn. Oxford University Press, Oxford 2011), p. 251. 
today, all nationals of the Western Balkan countries (with the exception of citizens of Kosovo) are granted visa-free travel to the Schengen area with the special requirement of biometric passports for nationals of Albania and of Bosnia and Herzegovina. ${ }^{10}$ Moreover, in 2006 the Council decided to include six states situated in the Pacific and Indian Oceans - Antigua and Barbuda, the Bahamas, Barbados, Mauritius, Saint Kitts and Nevis and the Seychelles - in the white list. The EU has conducted a visa dialogue with the Eastern ENP partner states Armenia, Azerbaijan, Belarus, Georgia, Moldova and Ukraine since 2008. ${ }^{11}$ Nationals of Switzerland and the EEA states are not listed in the white list; these nationals enjoy visa-free travel on the basis of the respective agreements which have been concluded with the EU.

\subsection{Visa-Free Travel for EEA and Swiss Nationals}

EEA nationals and their families have the right of entry and residence in an EU Member State or an EFTA state in compliance with Annex $V$ to the EEA Agreement, which extends the scope of Directive 2004/38/EC of the European Parliament and the Council. ${ }^{12}$ The latter Directive provides for a single legal framework on the right of EEA citizens and their family members to move and reside freely within the territory of the Member States and has created a treaty-based right of residence for EEA citizens. Directive 2004/38/EC repeals a number of previous directives. Article 2(2) of Directive 2004/38/EC defines family members as the spouse; the partner with whom the EEA citizen has a registered partnership, on the basis of the legislation of a Member State, if the legislation of the host Member State treats registered partnerships as equivalent to marriage and in accordance with the conditions laid down in the relevant legislation of the host Member State; the direct descendants who are under the age of 21 or are dependants and those of the spouse or the partner; the dependent direct relatives in the ascending line and those of the spouse or the partner. Articles 4 and 5 of Directive 2004/38/EC lay down the corollary rights of exit of and entry to an EEA state for EEA citizens and their families, who require a valid identity card or passport - or in the case of a family member holding the nationality of a third country, a valid residence card or an entry visa either in accordance with Council Regulation (EC) No 539/2001 or in accordance with the national laws of Ireland, the UK, Bulgaria, Cyprus and Romania. ${ }^{13}$ Article 6 of Directive 2004/38/EC stipulates the right of residence for EEA citizens for up to three months without any conditions other than holding a

For the amendment of the visa lists in respect to nationals of the FYROM, Montenegro and Serbia, see Council Regulation (EC) No 1244/2009 of 30 November 2009 amending Regulation (EC) No 539/2001 listing the third countries whose nationals must be in possession of visas when crossing the external borders and those whose nationals are exempt from that requirement; Council of the European Union, Visa liberalisation of Albania and Bosnia and Herzegovina, document number: 15957/10 of 8 November 2010.

11 European Commission Communication, $\operatorname{COM}(2008)$ 823, 3 December 2008.

12 Directive 2004/38/EC of the European Parliament and the Council of 29 April 2004 on the right of citizens of the Union and their family members to move and reside freely within the territory of the Member States.

13 Council Regulation (EC) No 539/2001 of 15 March 2001 listing the third countries whose nationals must be in possession of visas when crossing the external borders and those whose nationals are exempt from that requirement. 
valid identity card or passport and not becoming an unreasonable burden on the social assistance system of the host state under Article 14 of the Directive.

The right of entry and residence can be restricted on grounds of public policy, public security and public health. The restrictions are concretised in Articles 27 to 33 of Directive 2004/38/EC and they partly codify the case law of the Court on the subject matter. Article 27 of Directive 2004/38/EC lays down the general principles: EEA States may restrict the freedom of movement and residence on grounds of public policy, public security and public health but the grounds may not be invoked to serve economic ends (para. 1). The measures taken by reason of public policy or public security must be proportionate and based exclusively on the personal conduct of the individual concerned. Previous criminal convictions do not in themselves constitute grounds for taking such measures. Moreover, the personal conduct concerned must represent a genuine, present and sufficiently serious threat affecting one of the fundamental interests of society (para. 2). ${ }^{14}$

The Court of Justice held that the notion of public policy must be interpreted restrictively so that its scope cannot be determined unilaterally by each Member State without being subject to control by the Community institutions. Nevertheless, the Court continued, the concept of public policy may vary from one country to another and from one period to another, and it is thus necessary to allow the competent national authorities an area of discretion within the limits of the Treaty. ${ }^{15}$ Before expulsion on grounds of public policy or public security can take place, Member States shall take account of the individual's duration of stay, his/her age, state of health, family and economic situation, social and cultural integration into the host state and the links with the country of origin, in accordance with Article 28 of Directive 2004/38/EC. EEA citizens or their family members who have the right of permanent residence may only be expelled on serious grounds of public policy or public security (para. 2). Expulsion measures cannot be taken against EEA citizens who have resided in the host state for the previous ten years or minors, except for imperative grounds of public security (para. 3).

The FMP Agreement specifies the entry rules for Swiss nationals. The right of entry of nationals of one contracting party (Switzerland or an EU Member State) and of their family members into the territory of the other contracting party must be guaranteed simply upon production of a valid passport or identity card (Article 3 of the FMP Agreement in conformity with Article 1(1) of Annex I). Such a right of entry is extended to posted workers under Article 17 of Annex I. It is specified that no entry visa or equivalent requirement may be demanded, save in respect of family members and posted workers who do not have the nationality of a contracting party. Moreover, the contracting party concerned shall grant these persons every facility for obtaining any necessary visa. ${ }^{16}$ Article 3 of Annex I lays down rules on family members who may join the person who has the right of residence and is a national of the contracting parties (para. 1). Family members include, whatever their nationality,

See Case 30/77 Boucherau [1977] ECR 1999.

Case 41/74 V an Duyn v. Home Office [1974] ECR I-01337, para. 18.

Art. 1 of Annex I of the Agreement between the European Community and its Member States, of the one part, and the Swiss Confederation, of the other, on the free movement of persons, OJ 2002 L 114, 30 April 2002, p. 6. 
the spouse; their relatives in the descending line who are under the age of 21 or dependent; and their relatives in the ascending line who are dependent. In case of students, family members are the spouse and the dependent children. Moreover, the contracting parties shall facilitate the admission of other family members (para. 2).

Article 5 of Annex I stipulates that the rights granted under the FMP Agreement can be restricted on grounds of public policy, public security or public health and again, reference is made to EC legislation. ${ }^{17}$ In Graf and Engel, the Court clarified that the reasons, exhaustively listed in Article 5(1) of Annex I to the FMP Agreement as justifications for derogation from the fundamental rules of the latter, such as the principle of equal treatment, must be interpreted strictly. The Court provided further background stating that

"[ $[\mathrm{t}$ is important to note that the Agreement falls within the more general context of relations between the European Union and the Swiss Confederation, which, although it did not opt to participate either in the European Economic Area or in the Union's internal market, is nevertheless linked to the Union by numerous agreements covering a wide range of areas and prescribing rights and specific obligations, analogous, in some respects, to those laid down by the Treaty. The general objective of these agreements, including the Agreement at issue in the main proceedings, is to strengthen the economic ties between the European Union and the Swiss Confederation." 18

\subsection{The Schengen Black List: Non-Privileged Third-Country Nationals}

The visa black list includes more than three times more states than the visa white list, starting with Afghanistan through to Zimbabwe. Since the adoption of Council Regulation No 539/2001, some countries were moved from the white to the black list, primarily because of concerns relating to irregular migration and/or crime. ${ }^{19}$ Thus, visa requirements for the Schengen area have been imposed on nationals of Ecuador from 2003 and on nationals of Bolivia from 2006..$^{20}$

17 All three acts referred to have been repealed. The subject-matter is now covered by Directive 2004/38/EC of the European Parliament and the Council of 29 April 2004 on the right of citizens of the Union and their family members to move and reside freely within the territory of the Member States.

18 Case C-506/10 Graf and Engel [2011] Judgment of 6 October 2011, not yet reported, para. 33.

19 Council Regulation (EC) No 539/2001 of 15 March 2001 listing the third countries whose nationals must be in possession of visas when crossing the external borders and those whose nationals are exempt from that requirement.

20 See Council Regulation (EC) No 453/2003 of 6 March 2003 amending Regulation (EC) No 539/2001 listing the third countries whose nationals must be in possession of visas when crossing the external borders and those whose nationals are exempt from that requirement; Council Regulation (EC) No 1932/2006 of 21 December 2006 amending Regulation (EC) No 539/2001 listing the third countries whose nationals must be in possession of visas when crossing the external borders and those whose nationals are exempt from that requirement. 


\subsection{Entry Rights Compared}

Currently, only EEA and Swiss nationals have the right to freely enter and reside in an EU Member State on the basis of an association agreement (the EEA Agreement and the FMP Agreement respectively). While the right of entry for EEA and Swiss nationals applies to all EU Member States (general protocols extend the scope of application of the agreements to the acceding Member States), the visa black and white lists, as set forth in Council Regulation No 539/2001, apply to the countries that form part of the Schengen area. Council Regulation No 539/2001 has been strongly criticised as stipulating arbitrary and imprecise criteria, (such as those concerning irregular immigration, public policy and security and external relations) allowing for a highly discretionary application in practice; "also, despite some liberalisation, the EU visa black list arguably breaches the principle of nondiscrimination, particularly given the application of visa requirements to nearly all countries with a majority of black or Muslim population." 21

E. Guild and D. Bigo emphasised that the "black list approach" punished government policy on the one hand and social individual practices of an identifiable local or ethnic group on the other when listing a country as a whole.22 As a consequence, nationals of a state classified as "precarious" by the Commission need to be in possession of a visa regardless of personal characteristics and behaviour; hence, the authors concluded that living in such a "precarious" country could almost be equated to having committed an offence. The authors also highlighted that visabound states are usually countries that exhibited a high migration rate. They indicated a "virtual delocalisation" for nationals of black list countries because these individuals face the "first" border in their own country, notably at a Schengen consulate, which decides on admission. This approach of "border shifting", that entails the admission decision being taken before the actual journey has started, is said to be part of the Schengen strategy. In contrast, this procedure provides for advantageous treatment of nationals of states that are exempt from the visa requirement as no selection on the spot is imposed upon their citizens and generally less strict controls are carried out at the borders. Not surprisingly, these white list countries all seem to be developed states, future EU Member States or countries of South or North America. Family members of third-country nationals lawfully residing in the territory of a Member State can be granted a right of entry to a Member State in accordance with Council Directive 2003/86/EC family reunification. ${ }^{23}$

\section{ENTRY RigHTS FOR THE PURPOSE OF FAMILY REUNIFICATION}

By virtue of family reunification schemes, states determine the immigration conditions under which family members of migrants who lawfully reside on their territories may join the latter person(s). Many constitutions acknowledge special

\footnotetext{
21 S. Peers, EU Justice and Home Affairs Law (3rd edn. Oxford University Press, Oxford 2011), pp. 255-256.

22 E. Guild and D. Bigo, 'La mise à l'écarts des étrangers - La logique du Visa Schengen', 49 Cultures \& Conflits (2003), 82-95.

23 Council Directive 2003/86/EC of 22 September 2003 on the right to family reunification.
} 
protection of the family and immigration for the purpose of family reunification is a well recognised ground among countries to grant individuals access to and residence in their territories. In particular, family reunification enables families to live and settle together, and it facilitates establishing family life in a country other than the country of origin. Being reunited with the nuclear family also promotes the integration of migrants into the host society, and it renders their specific position as a non-national more stable. The right to respect for family life and for the unity of the family is laid down as a fundamental right in Article 8 ECHR and Article 7 of the EU Charter. ${ }^{24}$ The ECtHR in Strasbourg and more recently the Court of Justice in Luxembourg have endorsed this right and have produced a considerable amount of case law. Already in the context of the EU free movement rules, family members of Member States' nationals have enjoyed a set of rights irrespective of their nationality. Former Regulation No 1612/68 (now Regulation (EU) No 492/2011) on the freedom of movement for workers allowed family members to join the Community worker in the host Member State, to work and for children to receive an education. ${ }^{25}$ This Regulation has the objective to ensure the freedom of movement for workers which, in turn, in accordance with the principles of liberty and dignity, requires the best possible conditions for the integration of the Community worker's family in the society of the host country. ${ }^{26}$

\subsection{EEA Nationals}

EEA citizens and their families enjoy the right of entry and residence in an EU Member State or an EFTA state on the basis of Directive 2004/38/EC. ${ }^{27}$ Family members within the meaning of the Directive are: the spouse; the partner with whom the Union citizen has a contracted partnership, if recognised by the host Member State; the direct descendants who are under the age of 21 or are dependant and those of the spouse or partner; the dependent direct relatives in the ascending line and those of the spouse or partner. ${ }^{28}$ EEA nationals and their families may freely exit or enter an EEA state with a valid identification, or in the case of a family member holding the nationality of a third country, a valid residence card or an entry visa. ${ }^{29}$ Article 6 of Directive 2004/38/EC stipulates the right of residence for EEA citizens for up to three months without any conditions other than holding a valid identity

See also Part III, Section 2.1.2 on the Right to Respect for Family Life (Art. 8 ECHR). Regulation (EU) No 492/2011 of the European Parliament and of the Council of 5 April 2011 on freedom of movement for workers within the Union.

Case C-308/89 Di Leo [1990] ECR I-4185, para. 13.

Annex $\mathrm{V}$ to the EEA Agreement extends the scope of application of Directive 2004/38/EC of the European Parliament and the Council of 29 April 2004 on the right of citizens of the Union and their family members to move and reside freely within the territory of the Member States.

See Arts. 2 and 3 of Directive 2004/38/EC of the European Parliament and the Council of 29 April 2004 on the right of citizens of the Union and their family members to move and reside freely within the territory of the Member States.

Some third-country nationals require an entry visa in accordance with Council Regulation (EC) No 539/2001, or in conformity with the national laws of Ireland or the UK, as these countries do not take part in the common EU visa policy. Note also that Bulgaria, Cyprus and Romania are not yet members to the Schengen area yet. 
card or passport. ${ }^{30}$ The same applies to third-country family members who have valid identification accompanying the Union citizen. Article 7 of the Directive enshrines the right of residence for more than three months for EEA citizens and their families who are workers or self-employed persons, or have sufficient resources and comprehensive sickness insurance cover, or are enrolled at a private or public establishment and have comprehensive sickness insurance cover. Family members who do not hold the nationality of an EEA state are to be issued a residence permit. ${ }^{31}$ Family members retain their right of residence in the event of death or departure of the EEA citizen subject to the conditions under Article 12, or in the event of divorce, annulment of marriage or termination of registered partnership subject to the conditions under Article 13 of the Directive.

EEA citizens and their families who have resided legally for a continuous period of five years in the host state shall have the right of permanent residence there in accordance with Article 16 of the Directive. Once acquired, the right of permanent residence shall be lost only through absence from the host Member State for a period exceeding two consecutive years. In the case of retirement, incapacity, or death, Article 17 determines shorter periods for workers and their family members to be eligible for permanent residence in the host state. Family members of EEA citizens who have the right of residence are entitled to take up employment or selfemployment. ${ }^{32}$ The right of entry and residence of Union citizens and their family members can be restricted on grounds of public policy, public security and public health. ${ }^{33}$

\subsection{Swiss Nationals}

The FMP Agreement concluded with the Swiss Confederation specifies that the right of entry of nationals of one contracting party and of their family members into the territory of the other contracting party must be guaranteed simply upon the production of a valid passport or identity card..$^{34}$ Article 3 of Annex I lays down rules on family members who may join the person who has the right of residence and is a national of the contracting parties (para. 1). Family members include, whatever their nationality, the spouse; their relatives in the descending line who are under the age of 21 or dependent; and their relatives in the ascending line who are dependent. In the case of students, family members are the spouse and the dependent children. Moreover, the contracting parties shall facilitate the admission of other family members (para. 2). As a general rule, family members enjoy the right to take up an

30 However, Union citizens may not become an unreasonable burden on the social assistance system of the host Member State in line with Art. 14 of the Directive.

31 Arts. 9 and 10 of Directive 2004/38/EC of the European Parliament and the Council of 29 April 2004 on the right of citizens of the Union and their family members to move and reside freely within the territory of the Member States.

32 Art. 23 of Directive 2004/38/EC of the European Parliament and the Council of 29 April 2004 on the right of citizens of the Union and their family members to move and reside freely within the territory of the Member States.

33 Arts. 27 to 33 of Directive 2004/38/EC of the European Parliament and the Council of 29 April 2004 on the right of citizens of the Union and their family members to move and reside freely within the territory of the Member States.

34 Art. 3 of the FMP Agreement in conformity with Art. 1(1) and Art. 3(1) of Annex I, see also Art. 7(d) of the FMP Agreement. 
economic activity, and the children shall be admitted to general education, apprenticeships, and vocational training courses on equal terms with nationals of the host state, if those children are living in its territory (paras. 5 and 6). ${ }^{35}$ The rights granted under the FMP Agreement can be restricted on grounds of public policy, public security or public health. ${ }^{36}$ Persons who do not pursue an economic activity and their family members have the right to reside in the territory of the other contracting party if they dispose of sufficient financial means and an all-risk sickness insurance cover. ${ }^{37}$ Students must in addition be registered in an approved establishment for the purpose of following a vocational training course.

\subsection{Turkish Nationals}

Decision No 1/80 does not grant a right of entry for the purpose of family reunification to family members of Turkish workers. Thus, Member States are, in principle, free to control first admission of Turkish nationals to their territory. ${ }^{38}$ Accordingly, the rights that aim to promote family unity under Article 7 of Decision No 1/80 can only be relied upon once the family member of the Turkish worker has entered the Member State. In this context, Article 7(1) sets forth the right for family members of a Turkish worker duly registered as belonging to the labour force of a Member State, who have been authorised to join him, to respond to any employment offer after they have been legally resident for at least three years in that Member State.

\subsection{Other Sources of EU Law Applicable to Third-Country Nationals}

With the adoption of Council Directive 2003/86/EC, family reunification has become a legally enforceable right for third-country nationals lawfully residing in the territory of a Member State. ${ }^{39}$ The Directive applies in cases where the sponsor has a residence permit issued by a Member State valid for one year or more who has reasonable prospects of obtaining the right of permanent residence. ${ }^{40}$ In accordance with Article 4 of Council Directive 2003/86/EC, family members are, as a rule, defined as the sponsor's spouse and the minor children of the sponsor and of his/her spouse including adopted children. Member States may require the sponsor to have adequate accommodation for his/her family; sickness insurance for himself/herself and his/her family members; as well as stable, regular and sufficient resources without recourse to the social assistance system of the Member State concerned. ${ }^{41}$

\footnotetext{
See also Art. 7(e) of the FMP Agreement.

Art. 5 of Annex I of the FMP Agreement.

Chapter 5 of Annex I of the FMP Agreement.

Case C-369/01 Abatay and Others [2003] ECR I-12301, paras. 63 and 65.

Council Directive $2003 / 86 /$ EC of 22 September 2003 on the right to family reunification.

40 Art. 3(1) of Council Directive 2003/86/EC of 22 September 2003 on the right to family reunification.

41 Art. 7 of Council Directive 2003/86/EC of 22 September 2003 on the right to family reunification; on the notion of "recourse to the national social assistance system" see Case C-578/08 Chakroun [2010] ECR I-01839; A. Wiesbrock, 'Court of Justice of the European Union: The Right to Family Reunification of Third-Country Nationals under EU Law; Decision of 4 March 2010, Case C-578/08 Rhimou Chakroun v. Minister van Buitenlandse Zaken', 6 European Constitutional Law Review (2010), 462.
} 
Member States can moreover require the sponsor to have legal residence in their territory for a period not exceeding two years, before having his/her family members join him/her. ${ }^{42}$ As soon as the application for family reunification has been accepted, the Member State concerned shall authorise the entry of the family members and shall grant them a first residence permit of at least a year. ${ }^{43}$

Council Directive 2009/50/EC on the conditions of entry and residence of thirdcountry nationals for the purposes of highly qualified employment provides for derogations as regards the application of Council Directive 2003/86/EC. ${ }^{44}$ This implies inter alia that the integration conditions and measures referred to in Council Directive 2003/86/EC may only be applied after the persons concerned have been granted family reunification. Moreover, residence permits for family members of EU Blue Card holders shall be granted, where the conditions for family reunification are fulfilled, at the latest within six months from the date on which the application was lodged. 45

Article 7 of the Charter lays down that everyone has the right to respect for his or her private and family life, home and correspondence. ${ }^{46}$ The personal scope of the provision is inclusive ("everyone") as it covers EU citizens just the same as thirdcountry nationals. Article 7 is likely to qualify for direct effect in the future. ${ }^{47}$ The wording of this provision is practically the same as in Article 8(1) of the ECHR; the $\mathrm{EU}$ is bound to guarantee the fundamental rights that the ECHR sets out. Moreover, under the Charter the family enjoys legal, economic and social protection. ${ }^{48}$ The Court of Justice in Luxembourg has kept an eye on the developments in Strasbourg with regard to Article 8 ECHR. ${ }^{49}$ It made explicit reference to the right to respect for family life and the clarifying ECtHR case law in Carpenter in which it found that Article $49 \mathrm{EC}$, read in the light of the fundamental right to respect for family life, is to be interpreted as precluding a refusal, by the Member State of origin of a provider of services established in that Member State who provides services to recipients established in other Member States, of the right to reside in its territory to that

Art. 8 of Council Directive 2003/86/EC of 22 September 2003 on the right to family reunification.

Art. 13 of Council Directive 2003/86/EC of 22 September 2003 on the right to family reunification.

Council Directive 2009/50/EC of 25 May 2009 on the conditions of entry and residence of third-country nationals for the purposes of highly qualified employment. See Art. 15 of Council Directive 2009/50/EC of 25 May 2009 on the conditions of entry and residence of third-country nationals for the purposes of highly qualified employment.

Art. 51 of the EU Charter enshrines that the provisions of the Charter are addressed to the institutions, bodies, offices and agencies of the Union with due regard for the principle of subsidiarity and to the Member States only when they are implementing Union law.

4 A German higher administrative court lodged a reference for a preliminary ruling on 28 January 2011 in which it extensively referred to the EU Charter, and to its importance when interpreting other sources of EU law, see Case C-40/11 Yoshikazu Iida v. City of Ulm, referring court: Verwaltungsgerichtshof Baden-Württemberg, OJ C 145, 14 May 2011, p. 5; see also opinion of AG Trstenjak, delivered on 15 May 2012. Art. 33(1) of the EU Charter. See Part III, Section 2.1.2 on the Right to Respect for Family Life (Art. 8 ECHR). 
provider's spouse, who is a national of a third country. ${ }^{50}$ Importantly, M. Carpenter, the Philippine wife of the British service provider, had no legal residence in the UK. In Baumbast the Court of Justice reiterated that Regulation (EU) No 492/2011 must be interpreted in the light of the requirement of respect for family life laid down in Article 8 ECHR seeing that this requirement is one of the fundamental rights which, according to settled case law, are recognised by Community law. ${ }^{51}$ In Akrich, in which the Court of Justice expressly referred to the case law of the Strasbourg court, the UK had to accept the protection of Mr and Mrs Akrich's family life because the couple's marriage was genuine and lawful in nature. Contrary to the finding in Carpenter, however, in that case, the Court seemed to require the prior lawful residence in an EU Member State for third-country national family members of EU nationals to make use of their free movement rights. ${ }^{52}$ In turn, the ruling in the Akrich case was said to be overturned in Metock in which the Court held that thirdcountry national family members of EU citizens were entitled to enjoy free movement rights notwithstanding their irregular stay in an EU Member State. ${ }^{53}$

In the case of PPU McB the Court of Justice ruled on the interaction between Article 7 of the Charter and Article 8(1) ECHR stating that Article 7 contains rights corresponding to those guaranteed by Article 8(1) of the ECHR and that therefore Article 7 of the Charter must be given the same meaning and the same scope as Article 8(1) of the ECHR, as interpreted by the case law of the European Court of Human Rights. ${ }^{54}$ In Dereci and Others, the Court had to decide on whether the thirdcountry family members of Union citizens could rely on EU law for a right of residence in Austria. ${ }^{55}$ The Court emphasised that on the basis of Article 51 of the Charter it had to interpret, in the light of the Charter, the law of the EU within the limits of the powers conferred on it; it found that it was up to the referring national court to take a decision in the underlying dispute but provided guidance in ruling that

"if the referring court considers, in the light of the circumstances of the disputes in the main proceedings, that the situation of the applicants in the main proceedings is covered by European Union law, it must examine whether the refusal of their right of residence undermines the right to respect for private and family life provided for in Article 7 of the Charter. On the other hand, if it takes the view that that situation is not covered by European Union law, it must undertake that examination in the light of Article 8(1) of the ECHR. All the Member States are, after all, parties to the ECHR which enshrines the right to respect for private and family life in Article 8." 56

Case C-60/00 Carpenter [2002] ECR I-6279, paras. 41-46.

Case C-413/99 Baumbast [2002] ECR I-07091, para. 72.

Case C-109/01 Akrich [2004] ECR I-9607.

Case C-127/08 Metock and Others [2008] ECR I-6241.

Case C-400/10 PPU McB [2010] ECR I-08965, para. 53; the Court refers to Case C450/06 V arec [2008] ECR I-581, para. 48.

See also Case C-34/09 Zambrano [2010] Judgment of 8 March 2011, not yet reported, in which the European citizenship of a child entailed a right of residence for the thirdcountry national father, although the child had never left its Member State of birth; the Court held that Art. 20 TFEU precluded national measures which had the effect of depriving citizens of the Union of the genuine enjoyment of the substance of the rights conferred by virtue of their status as citizens of the Union.

Case C-265/11 Dereci and Others [2011] Judgment of 15 November 2011, not yet reported, paras. 72-73. 


\subsection{Family Reunification Rights Compared}

EEA and Swiss nationals enjoy the most extensive rights in the field of family reunification. EEA nationals can rely on Directive 2004/38/EC which guarantees EEA citizens and their family members the right of entry and residence in an EU Member State or an EFTA state. ${ }^{57}$ Swiss nationals and their family members have the right of entry into the territory of a contracting party on the basis of the FMP Agreement. ${ }^{58}$ By contrast, the EU-Turkey association does not provide for a right of entry to be reunited for family members of Turkish workers. The rights accorded within the scope of Article 7 of Decision No 1/80 require that the family member of the Turkish worker has already entered a Member State of the EU. Today, however, third-country nationals have a right to family reunification by virtue of Council Directive 2003/86/EC if lawfully residing in the territory of a Member State. ${ }^{59}$ In addition, the EU Charter and the ECHR set out the fundamental right to respect for family life. ${ }^{60}$ The Court of Justice in Luxembourg has made reference to the interpretation and application of the ECHR by the European Court of Human Rights in Strasbourg in view of Article 8 ECHR in its own case law concerning matters of family reunion and family life.

\subsection{Nationals of the Former Europe Agreement States}

Nationals falling under of the former Europe Agreements enjoyed a right to access the labour market of a Member State (and a concomitant right of entry and residence) only for the purposes of self-employment. ${ }^{61}$ However, Article 37(1), second indent, of the Polish Europe Agreement granted the legally resident spouse and children of a worker legally employed in a Member State access to the labour market during the worker's authorised stay. ${ }^{62}$ Seasonal workers and workers falling under a bilateral agreement, within the meaning of Article 41, were exempted from this employment right, unless otherwise provided by such agreements. This employment right for family members of workers was a dependent right, because it was connected to the workers legal employment in a Member State. In order to benefit from the provision, the residence of families had to be legal. It was argued that such a right to access the labour market implied a national rule enabling the worker to be joined by his family seeing that otherwise the right would be rendered nugatory. This

\footnotetext{
$57 \quad$ Annex $\mathrm{V}$ to the EEA Agreement extends the scope of application of Directive 2004/38/EC of the European Parliament and the Council of 29 April 2004 on the right of citizens of the Union and their family members to move and reside freely within the territory of the Member States.

58 Art. 3 of the FMP Agreement in conformity with Art. 1(1) and Art. 3(1) of Annex I, see also Art. 7(d) of the FMP Agreement.

59 Council Directive 2003/86/EC of 22 September 2003 on the right to family reunification.

60 Art. 7 of the EU Charter; Art. 8(1) ECHR.

61 See Part VII, Section 2. on the right of establishment; on the concurrent right of entry and residence, see Case C-257/99 Barkoci and Malik [2001] ECR I-6557, paras. 44 and 54.

62 For illustration purposes, reference is made to the Europe Agreement with Poland.
} 
interpretation, it was stated, found support under Article 8 ECHR setting out the right to respect family life, to which the Court made reference in the past, as well as the case law of Article 7(1) of Decision No 1/80 in the context of Turkish family members. ${ }^{63}$

\subsection{EEA Nationals}

Article 28 of the EEA Agreement sets out the freedom of movement for workers in the territory of an EU Member State or EFTA state and mirrors Article 45 TFEU. This freedom includes, among other things, the right to accept offers of employment actually made and the right to move freely for this purpose in an EU Member State or an EFTA state in conformity with Article 28(3)(a) and (b) of the EEA Agreement. The scope of application is specified in Annex $\mathrm{V}$ to the EEA Agreement which originally referred to six Community acts that were incorporated into the EEA Agreement with decisions issued by the EEA Joint Committee. In the course of time, Annex $\mathrm{V}$ was adapted to the newly passed secondary EU legislation. The most important acts in this respect are Directive 2004/38/EC of the European Parliament and the Council, 64 Regulation (EU) No 492/201165 and Council Directive 77/486/EC. ${ }^{66}$ Regulation (EU) No 492/2011 on the free movement of workers within the EU fleshes out substantive rights of workers and their families, and it specifies the principle of equal treatment contained in Article 45 TFEU, Article 28 of the EEA Agreement and Article 24 of Directive 2004/38/EC. Article 1 of Regulation (EU) No 492/2011 stipulates the right to take up employment in another Member State under the same conditions as nationals.

\subsection{Swiss Nationals}

The FMP Agreement lists, among the objectives in Article 1, inter alia to accord a right of entry, residence and access to work as employed or self-employed person. Article 3 of the FMP Agreement states that the right of residence and access to an economic activity shall be ensured in accordance with the transitional limitations set out in Article 10 of the FMP Agreement and Chapter VII of Annex I. Article 2 of Annex I indicates that this right shall be substantiated through the issue of a residence permit and that it includes the corollary rights to visit another contracting party, or to remain there after a period of employment of less than one year in order to seek employment and to reside there for a reasonable amount of time.

63 N. Rogers and R. Scannell, Free Movement of Persons in the Enlarged European Union (Sweet \& Maxwell, London 2005), pp. 292-293.

64 Directive 2004/38/EC of the European Parliament and the Council of 29 April 2004 on the right of citizens of the Union and their family members to move and reside freely within the territory of the Member States.

65 Regulation (EU) No 492/2011 of the European Parliament and of the Council of 5 April 2011 on freedom of movement for workers within the Union.

66 Council Directive 77/486/EC of 25 July 1977 on the education of the children of migrant workers; see Art. 2 of Decision of the EEA Joint Committee No 158/2007 of 7 December 2007 amending Annex V (Free movement of workers) and Annex VIII (Right of establishment) to the EEA Agreement. 
Article 8 of Annex I lays down that employed persons shall have the right to geographical and occupational mobility throughout the territory of the host state. As S. Peers pointed out, there are no rules on access to employment; instead the notion of geographical and occupational mobility is used. ${ }^{67}$ While geographical mobility relates to changes in the place of work and residence, occupational mobility refers to changes of employer, employment or status (Article 8(2) of Annex I). ${ }^{68}$

\subsection{Other Sources of EU Law Applicable to Third-Country Nationals}

As regards EU secondary legislation, only the researchers' Directive sets out a right of entry provided that the admission conditions in Article 7 are fulfilled. ${ }^{69}$ Thirdcountry researchers who apply to be admitted to the territory of a Member State, under the researchers' Directive, to carry out a research project require a hosting agreement of a research institution that wishes to host the person in question. ${ }^{70}$ Any research organisation wishing to host a researcher under the procedure of this Directive shall be approved by the respective Member State. ${ }^{71}$ The admission conditions for a third-country national who applies for an EU Blue Card are stipulated in Article 5 of the EU Blue Card Directive; the applicant must inter alia present a valid work contract or a binding job offer for highly qualified employment of at least a year and comply with the salary threshold. ${ }^{72}$ However, the Member States explicitly reserved the right to determine the volume of admission of third-country nationals entering the territory for the purposes of highly qualified employment. ${ }^{73}$ Under Article 11 of Directive 2011/98/EU on a single permit, holders of a single permit are authorised, during its period of validity, to enter and reside in the territory of the Member State issuing the single permit provided that the holder meets all admission requirements in accordance with national law. ${ }^{74}$ Article 1(2) of Directive $2011 / 98 /$ EU on a single permit preserves the Member States' powers concerning the admission of third-country nationals to their labour markets.

The EU Charter recognises in Article 15(1) that everyone has the right to engage in work and to pursue a freely chosen or accepted occupation. The freedom to seek

67 S. Peers, 'The EC-Switzerland Agreement on Free Movement of Persons: Overview and Analysis', 2 European Journal of Migration and Law (2000), 127, p. 133.

68 Ibid.

69 Council Directive 2005/71/EC of 12 October 2005 on a specific procedure for admitting third-country nationals for the purposes of scientific research.

70 Art. 6 of Council Directive 2005/71/EC of 12 October 2005 on a specific procedure for admitting third-country nationals for the purposes of scientific research.

71 Art. 5 of Council Directive 2005/71/EC of 12 October 2005 on a specific procedure for admitting third-country nationals for the purposes of scientific research.

72 Art. 5 of Council Directive 2009/50/EC of 25 May 2009 on the conditions of entry and residence of third-country nationals for the purposes of highly qualified employment.

73 Art. 6 of Council Directive 2009/50/EC of 25 May 2009 on the conditions of entry and residence of third-country nationals for the purposes of highly qualified employment.

74 Directive 2011/98/EU of the European Parliament and of the Council of 13 December 2011 on a single application procedure for a single permit for third-country nationals to reside and work in the territory of a Member State and on a common set of rights for third-country workers legally residing in a Member State. 
employment, to work, to exercise the right of establishment and to provide services in any Member State on the basis of the Charter is explicitly reserved for Union nationals. ${ }^{75}$

\subsection{Entry Rights for the Purpose of Employment Compared}

Exclusively EEA and Swiss nationals enjoy the right to freely enter an EU Member State for the purpose of engaging in an economic activity. Nationals who fell under the Former Europe Agreements enjoyed a right to access the labour market of a Member State to take up a self-employed activity only. Next, individuals who fall under the scope of application of the researchers' Directive and whose stay is governed by a hosting agreement concluded with an approved research institution have an entry right to the Member State to carry out a research project in the EU. The Member States firmly reserved their right to determine the volumes of thirdcountry nationals they allow to enter their territories in the framework of the EU Blue Card Directive and the single permit Directive respectively. The right to engage in work, as recognised in the EU Charter, does not entail a right of entry.

\section{EMPLOYMENT AND RESIDENCE RIGHTS}

\subsection{EEA Nationals}

Article 28 of the EEA Agreement sets out the freedom of movement for workers in the territory of an EU Member State or EFTA state. This freedom also implies the right of residence in an EU Member State or an EFTA state for employment purposes or after having been employed there, subject to limitations justified on grounds of public policy, public security, or public health (Article 28(3) EEA Agreement). The provisions do not apply to employment in the public service as enshrined in Article 28(4) of the EEA Agreement. The scope of application is clarified in Annex V to the EEA Agreement, which refers to Directive 2004/38/EC of the European Parliament and the Council, ${ }^{76}$ Regulation (EU) No 492/2011 ${ }^{77}$ and Council Directive $77 / 486 /$ EC. $^{78}$

Articles 1 to 6 of Regulation (EU) No 492/2011 concern the eligibility for employment: this includes the right to take up employment in another Member State under the same conditions as nationals (Article 1), the prohibition of discrimination when concluding and performing employment contracts (Article 2), the prohibition of direct and indirect discriminatory rules and practices with regard to the application for and offers of employment, or the right to take up and pursue employment, except for linguistic knowledge required by reason of the nature of the post to be filled

\footnotetext{
75 See Art. 15(2) of the EU Charter.

76 Directive 2004/38/EC of the European Parliament and the Council of 29 April 2004 on the right of citizens of the Union and their family members to move and reside freely within the territory of the Member States.

77 Regulation (EU) No 492/2011 of the European Parliament and of the Council of 5 April 2011 on freedom of movement for workers within the Union.

78 Council Directive 77/486/EC of 25 July 1977 on the education of the children of migrant workers.
} 
(Article 3), the prohibition of quotas (Article 4(1)), the right to the same assistance by employment offices (Article 5) and the prohibition to set up medical, vocational or other criteria which are discriminatory on grounds of nationality for the engagement and recruitment (Article 6). ${ }^{79}$

In view of the conditions of residence for EEA citizens, Directive 2004/38/EC is pertinent: Article 6 of the Directive stipulates the right of residence for EEA citizens for up to three months without any conditions other than holding a valid identity card or passport and not becoming an unreasonable burden on the social assistance system of the host state under Article 14 of the Directive. Article 7 enshrines the right of residence for more than three months for EEA citizens and their families who are workers or self-employed persons, or have sufficient resources and comprehensive sickness insurance cover, or are enrolled at a private or public establishment and have comprehensive sickness insurance cover.

An EEA citizen shall retain the status as a worker or a self-employed person for the purposes of Article 7(1)(a) of the Directive, if s/he is temporarily unable to work as the result of an illness or accident; or if $\mathrm{s} /$ he is in duly recorded involuntary unemployment after having been employed for more than one year and has registered as a job-seeker; or if s/he is in duly recorded as being involuntarily unemployed after completing a fixed-term employment contract of less than a year or after having become involuntarily unemployed during the first twelve months and has registered as a job-seeker; or if s/he embarks on vocational training. Recital 9 of the Directive further states that EEA citizens shall have the right of residence for a period not exceeding three months, without prejudice to a more favourable treatment applicable to job-seekers as recognised by the case law of the Court of Justice. Article 8 specifies that the host state may require EEA citizens to register with the relevant authorities. Family members, who do not hold the nationality of an EEA state, are to be issued a residence permit in accordance with Articles 9 and 10. Family members retain their right of residence in the event of death or departure of the EEA citizen subject to the conditions under Article 12, or in the event of divorce, annulment of marriage or termination of registered partnership subject to the conditions under Article 13 of the Directive.

EEA citizens and their families who have resided legally for a continuous period of five years in the host state shall have the right of permanent residence there in accordance with Article 16 of the Directive. This right is neither affected by temporary absences, as laid down in Article 16(3), nor by a period of absence not exceeding two consecutive years, as provided for in Article 16(4). In the case of retirement, incapacity, or death, Article 17 determines shorter periods for workers and their family members to be eligible for permanent residence in the host state. Articles 19 to 21 govern the administrative formalities. Family members of EEA citizens who have the right of residence are entitled to take up employment or selfemployment under Article 23. The Directive includes a general equal treatment clause in Article 24, for EEA citizens and their families residing in the host state, which applies within the scope of the Treaty and is subject to such specific provisions as are expressly provided for in the Treaty. The right of entry and residence can be

79 Regulation (EU) No 492/2011 of the European Parliament and of the Council of 5 April 2011 on freedom of movement for workers within the Union. 
restricted on grounds of public policy, public security and public health; these restrictions are laid down in Articles 27 to 33 of Directive 2004/38/EC. Article 28 of the Directive specifies the protection system of EEA nationals against expulsion that increases gradually with the length of residence. Before taking an expulsion decision, the authorities of the respective Member State shall take into account how long the individual concerned has resided in its territory, his/her age, state of health, family and economic situation, social and cultural integration into the host Member State and the extent of his/her links with the country of origin. Once an EEA national has the right of permanent residence in a Member State, an expulsion decision against him/her or his/her family members may only be taken on serious grounds of public policy and public security. An expulsion decision may only be taken on imperative grounds of public security, as defined by the Member States, if an EEA national has resided in the territory of the host Member State for the previous ten years; or if s/he is a minor.

\subsection{Swiss Nationals}

Swiss nationals have the right to reside and pursue an economic activity in an EU Member State in accordance with the transitional limitations set out in Article 10 of the FMP Agreement and Chapter VII of Annex I (Article 3 of the FMP Agreement and Article 2 of Annex I to the FMP Agreement). This right shall be substantiated through the issue of a residence permit and it includes the corollary rights to visit another contracting party, or to remain there after a period of employment of less than one year in order to seek employment, and to reside there for a reasonable amount of time. The contracting parties may require nationals of the other contracting party to report their presence in the territory. ${ }^{80}$ Article 3 of Annex I lays down rules on family members who may join the person who has the right of residence and is a national of the contracting parties. Article 8 of Annex I lays down that employed persons shall have the right to geographical and occupational mobility throughout the territory of the host state.

As a general rule, family members enjoy the right to take up an economic activity, and the children shall be admitted to general education, apprenticeships and vocational training courses on equal terms with nationals of the host state, if those children are living in its territory (paras. 5 and 6). Next, nationals of the contracting parties are authorised to stay in the territory of another contracting party after their economic activity has finished (Article 4 of Annex I). Express reference is made to the relevant EU legislative acts. ${ }^{81}$ Article 5 of Annex I stipulates that the rights granted under the FMP Agreement can be restricted on grounds of public policy, public security or public health and again, reference is made to EU legislation. ${ }^{82}$

$80 \quad$ Art. 2 of Annex I to the FMP Agreement.

81 Both acts referred to have been repealed; the subject-matter is now covered by Directive 2004/38/EC of the European Parliament and the Council of 29 April 2004 on the right of citizens of the Union and their family members to move and reside freely within the territory of the Member States.

82 All three acts referred to have been repealed; in the EU context, the subject-matter is now covered by Directive 2004/38/EC of the European Parliament and the Council of 29 April 2004 on the right of citizens of the Union and their family members to 
In accordance with Articles 7 and 13, frontier workers are not required to dispose of a residence permit, however, the contracting parties may nevertheless issue special permits to frontier workers. Employment in the public service may be refused, and a self-employed person may be denied the right to pursue an economic activity involving the exercise of public authority (Articles 10 and 16 of Annex I). Chapter 5 of Annex I deals with persons not pursuing an economic activity. Such persons and their family members have the right to reside in the territory of the other contracting party if they dispose of sufficient financial means and an all-risk sickness insurance cover. In addition, students must be registered in an approved establishment for the purpose of following a vocational training course, however, the access to vocational training or maintenance grants is not covered by the FMP Agreement as stipulated in Article 24(4) of Annex I.

\subsection{Turkish Nationals ${ }^{83}$}

Decision No $1 / 80$ is the most pivotal instrument for Turkish workers and their families in the complex regime that regulates the EU-Turkey relations. Decision No $1 / 80$ aims to improve the treatment accorded to Turkish workers and their family members by Decision No 2/76 in that it guarantees an advanced set of rights upon which these individuals can rely.

It must be pointed out that the provisions of Decision No 1/80 become applicable only once the Turkish worker lawfully resides and works in the territory of a Member State in conformity with the national immigration rules. The Court has consistently held that the Member States are competent to govern the initial entry and employment conditions for Turkish workers. ${ }^{84}$ In other words, Decision No 1/80 does not encroach upon the competence retained by the Member States to regulate both the entry into their territory of Turkish nationals and the conditions under which they may take up their first employment but merely regulates (in Article 6) the situation of Turkish workers who are already integrated into the labour force of the host Member State. ${ }^{85}$ Nonetheless Member States are bound by the principle of proportionality when restricting rights granted under Community law. ${ }^{86}$

move and reside freely within the territory of the Member States, however, the scope of application of the latter Directive has not (yet) been extended to Switzerland in the framework of the FMP Agreement; on the interpretation of Art. 5 of Annex I of the FMP Agreement, see Case C-506/10 Graf and Engel [2011] Judgment of 6 October 2011, not yet reported, para. 33 . An earlier version of this Section was published in K. Eisele, 'The Movement Regime of Turkish Citizens based on the Ankara Association - An Ever-Growing Mosaic of Rights?', in: H. Kabaalioğlu, A. Ott and A. Tatham (eds.), EU and Turkey: Bridging the Differences (Economic Development Foundation İstanbul 2011), pp. 31-66, which also contains an analysis on how EU secondary legislation enhances the legal status of Turkish migrants. Case C-237/91 Kus [1992] ECR I-6781, para. 25; Case C-340/97 Nazli [2000] ECR I957, para. 29.

85 Case C-98/96 Ertanir [1997] ECR I-5179, para. 23.

86 T. Tridimas, The General Principles of EU Law (2nd edn. Oxford University Press, Oxford 2006), Chapter 5. 
The central provision for Turkish workers is Article 6(1) of Decision No 1/80 which sets out a temporal framework that allows for gradual access to the labour market. It lays down that a Turkish worker duly registered as belonging to the labour force of a Member State is entitled, in that Member State, after one year's legal employment, to a renewed work permit, if a job is available; after three years of legal employment the worker is entitled to respond to another job opening in the same occupation with an employer of his choice subject to priority for Community workers; after four years of legal employment the worker enjoys free access to any paid employment of his choice. Put differently, the longer a Turkish worker is legally employed in a Member State, the more rights he acquires. According to settled case law, the aim of Article $6(1)$ is to progressively consolidate the position of Turkish workers in the host Member State. ${ }^{87}$ In Sevince the Court of Justice first ruled that Article 6(1) had direct effect and that the right of legal employment necessarily implied a corollary right to legal residence seeing that otherwise the right of access to the labour market and the right to legal employment would be rendered meaningless. ${ }^{88}$ Moreover, a Turkish worker could rely on the right to free movement under the Ankara Association, even if the purpose for which he entered the host Member State no longer exists. Where such a worker satisfied the conditions set out in Article 6(1) of Decision No 1/80, his right of residence in the host Member State could not be made subject to additional conditions as to the existence of interests capable of justifying residence or as to the nature of employment. ${ }^{89}$

Article 6 has been subject to numerous proceedings in which the Court clarified the scope and meaning of the provision. The concept of a "worker", the prerequisite of being "duly registered as belonging to the labour force" and the notion of "legal employment" require further elucidation as they form preconditions for Article 6 to apply. Next, some remarks are made with regard to the time frames set out in the provision and the implications of Article 6(2) regulating interruptions of periods of legal employment. Finally, this section sketches out the circumstances under which the right of residence can be terminated.

\subsubsection{The Concept of a "Worker"}

In order to come within the scope of Article 6(1) of Decision No 1/80, the Turkish national in question must first of all qualify as a worker as defined in Community law. The Court made clear that from the wording of Article 12 of the Ankara Agreement and Article 36 of the Additional Protocol that the free movement rules under Articles 45, 46 and 57 TFEU must be extended, so far as possible, to Turkish workers who enjoy the rights conferred by Decision No $1 / 80 . .^{90}$ As a result, a worker is any person who, for a certain period of time, performs services for and under the direction of another person in return for remuneration. ${ }^{91}$ The economic activity must be effective and genuine in nature, to the exclusion of activities on such a small scale as to be regarded as purely marginal and ancillary. ${ }^{92}$ According to the Birden judgment, neither

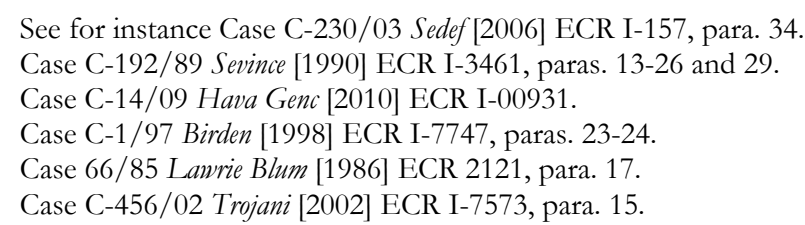


the origin of the funds from which the person is paid, nor the "sui generis" nature of the employment relationship under national law, nor the level of productivity of the person concerned can have any consequence in regard to whether or not the person is to be regarded as a worker. ${ }^{93}$ In casu the Turkish national was remunerated by a publicly financed programme with the objective to facilitate his reintegration into the general labour market. ${ }^{94}$ In the case of Günaydin, it was found that a Turkish citizen who had followed a vocational training programme and, at the end of his studies, was in paid employment qualified as a worker for the purpose of Article 6(1) of Decision No $1 / 80.9^{5}$

Kurz concerned a Turkish national who was authorised to accept an apprenticeship training position in Germany and who worked during the course of his training; hence, he had to be considered as a worker within the scope of Article 6(1). ${ }^{96}$ The fact that a Turkish national was granted leave to enter a Member State as an au pair or as a student could not deprive that person of the status of worker and prevent the person in question from being considered as "duly registered as belonging to the labour force" of that Member State within the meaning of Article 6(1) of Decision No $1 / 80$ as the Court ruled in Payir. ${ }^{97}$ When determining whether the objective conditions set out in the provision are met, the aim pursued in permitting the persons concerned to enter the Member State in question is of no importance because Article 6(1) does not make recognition of the rights which it confers on Turkish workers dependent on any condition connected with the reason for which the right to enter, work or reside was initially granted. ${ }^{98}$

The Court's judgment in Genc demonstrates that even the exercise of minor employment can confer the status of a worker upon a Turkish national, provided that the employment in question is real and genuine. ${ }^{99}$ In this case, Mrs Genc was engaged for 5.5 hours per week to carry out cleaning activities. Indicators on whether a professional activity is "real and genuine" relate, next to the number of working hours and the level of remuneration, to the right to paid leave, to the continued payment of wages in the event of sickness, to a contract of employment which is subject to the relevant collective agreement and the duration of the contractual relationship. According to the Court, the consideration of these factors allow for an overall assessment of the employment relationship. ${ }^{100}$ This case law reveals that the Court has continued to construe the concept of a worker broadly, not only in the Community context but also in relation to an association with a third country.

Case C-1/97 Birden [1998] ECR I-7747, para. 28.

By way of comparison see Case 344/87 Bettray [1989] ECR 1621.

Case C-36/96 Günaydin [1997] ECR I-5143.

Case C-188/00 Kurz [2000] ECR I-10691, paras. 30-36.

Case C-294/06 Payir and Others [2008] ECR I-203.

Ibid., para. 40.

Case C-14/09 Hava Genc [2010] ECR I-00931.

Case C-14/09 Hava Genc [2010] ECR I-00931, paras. 25-28; on the "worker" notion in Payir and Genc see S. Carrera and A. Wiesbrock, "Whose Citizenship to Empower in the Area of Freedom, Security and Justice? The Act of Mobility and Litigation in the Enactment of European Citizenship', Centre for European Policy Studies Working Document (2010), pp. 12-14. 


\subsubsection{The Condition of Being "Duly Registered as Belonging to the Labour Force"}

Turkish workers must also meet the condition of being "duly registered as belonging to the labour force" of a Member State to be able to rely on Article 6(1) of Decision No 1/80. With reference to its decision in Lopes da Veiga, the Court established in Bozkurt that, in order to determine whether a Turkish worker was to be regarded as belonging to the labour market of a Member State, it had to be ascertained whether the legal relationship of employment could be located within the territory of a Member State or retained a sufficiently close link with that territory. ${ }^{101}$ With a view to establishing whether a Turkish national employed as an international lorry driver retained a sufficiently close link with the territory of the Netherlands, the national court, in that case, was advised to take into consideration the place where the worker was hired, the territory on which the paid employment was based and the applicable national legislation in the field of employment and social security law. ${ }^{102}$ Thus, the Court again relied on case law involving Union citizens that concerned a similar question: Lopes da Veiga dealt with the application of Regulation (EU) No 492/2011 for a Portuguese national employed on a vessel flying the Dutch flag. ${ }^{103}$

In the Birden judgment delivered in 1998, the Court specified that the notion of "duly registered as belonging to the labour force" had to be regarded as applying to all workers who have complied with the requirements laid down by law and regulation in the Member State concerned and were thus entitled to pursue an occupation in its territory. The Court continued that it could not be interpreted as applying to the labour market in general as opposed to a specific market with a social objective supported by the public authorities. ${ }^{104}$ The late application for the extension of his residence permit did not alter the fact that the Turkish worker was considered as duly belonging to the labour force of the host Member State as the residence permit issued by national authorities was only declaratory in character. Although Member States can require foreigners on their territories to hold a valid residence permit, and although they can impose penalties for violation of this obligation, Member States are nevertheless not entitled to adopt disproportionate measures in comparison with similar domestic cases. ${ }^{105}$

\subsubsection{The Prerequisite of "Legal Employment"}

Article 6(1) of Decision No $1 / 80$ additionally requires that the Turkish worker pursues employment, which is "legal". In line with the Court's reasoning in Sevince and Kurz the legality of employment was not contingent on the possession of a residence permit but it nevertheless presupposed a stable and secure situation as a member of the labour force and, by virtue of this, implied the existence of an

\footnotetext{
101 Case 9/88 Lopes da Veiga [1989] ECR 2989; Case C-434/93 Bozkurt [1994] ECR I-1475, para. 22.

102 Case C-434/93 Bozkurt [1994] ECR I-1475, para. 23.

103 Regulation (EU) No 492/2011 of the European Parliament and of the Council of 5 April 2011 on freedom of movement for workers within the Union.

104 Case C-1/97 Birden [1998] ECR I-7747, para. 51.

105 Case C-329/97 Ergat [2000] ECR I-1487, paras. 52-62.
} 
undisputed right of residence. ${ }^{106}$ The situation of the worker in the case concerned was not considered as stable and secure given that he was authorised to work only until the decision on his appeal against the refusal of a right of residence would be taken. To put it another way, it followed from Sevince that the term "legal employment" did not cover the situation of a Turkish worker who has been legally able to continue his employment only by reason of the suspensory effect deriving from his appeal pending a final decision concerning the extension of his residence permit. In Güzeli, the Court explicitly stated that the concept of "legal employment" is a Community law concept. ${ }^{107}$

The Court reiterated its ruling in Kus and argued that the same logic applied to cases where suspension was not an automatic outcome of judicial proceedings but is ordered retroactively by a court. The suspension was only effective for the duration of the proceedings and permitted the person who initiated them to stay and work on a provisional basis pending a final decision on his right of residence. This conclusion was valid even though the person concerned had obtained a first instance judgment, which upheld his right of residence but which did not provide him with a definite right of residence, since it was challenged and could possibly be overruled. Thus, legal employment was not present as long as it was not definitely established whether the person concerned had a right of residence. Otherwise, a judicial decision finally refusing him that right would be rendered nugatory, and he would be able to acquire the rights provided for in Article 6(1) during a period where he did not fulfil the conditions of the provision. ${ }^{108}$

While Kus did not meet the requirement to be legally employed for four years, he did qualify for the one-year period of legal employment under the first indent of Article 6(1) and could consequently ask for the renewal of his work and his residence permit. The fact that he had entered the Member State to marry a national of that country and that the couple divorced at a later point in time, was irrelevant. ${ }^{109}$ The key issue at stake in Sevince and Kus was the temporary nature of the right to work to the exclusion of stability and security which legal employment by definition necessitated. ${ }^{110}$ Periods of employment of a Turkish worker under a residence permit obtained as a result of fraudulent conduct, which led to a conviction, could not be regarded as legal for the purposes of the application of Article 6(1) of Decision No $1 / 80 . .^{111}$

\subsubsection{Periods of Employment under Article 6(1)}

Various legal disputes arose before the Court that concerned the interpretation of the time frames which the three indents of Article 6(1) lay down in order to secure the

106 Case C-192/89 Sevince [1990] ECR I-3461, para. 30; Case C-188/00 Kurz [2000] ECR I10691, para. 48.

107 Case C-4/05 Güreli [2006] ECR I-10279, para. 38.

108 Case C-237/91 Kus [1992] ECR I-6781, paras. 11-16.

109 Ibid., paras. 19-36.

110 T. Theele, 'Rights of Turkish Workers on the Basis of the EEC/ Turkey Association Agreement', in: H. Schneider (ed.), Migration, Integration and Citizenship - A Challenge for Europe's Future, Volume II (Forum Maastricht, Maastricht 2005), p. 148. 
gradual access to the labour market for Turkish workers in the host Member State. After one year of legal employment, a Turkish worker has the right to a renewed work permit with the same employer on the basis of the first indent of Article 6(1). In 1994, the Court ruled that a Turkish worker could not rely on the provision for an extension of his work permit in a situation where he had worked for more than one year for his first employer and then for some ten months for another employer as this would run counter to the principle of priority for Community nationals. ${ }^{112}$

The same provision does not specify whether the completion of one year's legal employment must be a period of employment with the employer for whom the renewal of the permit is sought, or whether it may be a period comprised of employment with different employers. This issue was at stake in Eker in which the Court expounded that the extension of a Turkish worker's residence permit was dependent on the legal and continuous employment for one year with the same employer. Otherwise the coherence of the system of the gradual integration of Turkish workers in the host state's labour force would be disrupted. Only after three years of legal employment can the Turkish worker respond to another job offer with an employer of his choice for the same occupation in conformity with the second indent of Article 6(1). ${ }^{113}$

The limited duration of an employment contract and its restriction to a specific occupation does not prevent a Turkish worker from relying on the first indent of Article 6(1), if he meets the requirements set out in the provision, in order to seek the renewal of his residence permit. Furthermore, Article 6(3) prohibits Member States from adopting legislation that excludes, at the outset, whole categories of Turkish migrant workers from the rights conferred by the three indents of Article 6(1). ${ }^{114}$ In the ruling of Güreli, the Court stated that the first indent of Article 6(1) implied that a Turkish worker could rely on the rights conferred upon him by that provision only where his paid employment with a second employer complied with the conditions laid down by law in the host Member State governing entry into its territory and employment. ${ }^{115}$

The third indent of Article 6(1) specifies that, after four years of legal employment, Turkish workers have free access to any paid employment of their choice. Enjoyment of the rights conferred on a Turkish worker by the third indent of Article 6(1) presupposes, in principle, that the person concerned has already fulfilled the conditions set out in the second indent of Article 6(1). ${ }^{116}$

A Turkish worker who has been legally employed for more than four years in a Member State and voluntarily quitted his job enjoys the right of residence for a reasonable period for the purpose of seeking new paid employment, provided that he continues to be duly registered as belonging to the labour force of the Member State concerned and complies with the national legislation there. ${ }^{117}$ In casu a Turkish

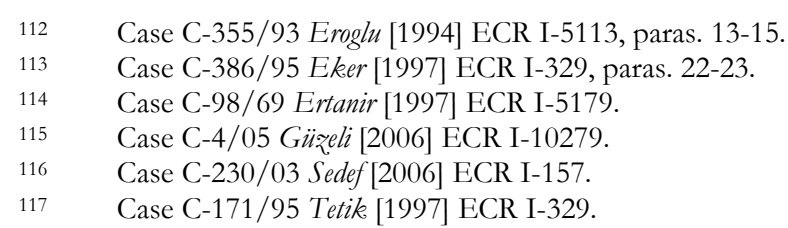


seaman terminated his employment contract on a German vessel in order to find new work on land. The Court made clear that the third indent of Article 6(1) did not only provide the Turkish worker with the right to respond to a prior job offer but also the unconditional right to seek and take up any employment freely chosen by the person concerned, regardless of the principle of priority of Community workers. According to the Court (which made reference to its decision in Antonissen ${ }^{118}$ ), although Turkish workers did not profit from free movement rights within the Community, they nevertheless must be able, for a reasonable period, to seek new employment effectively and must have a corresponding right of residence during that period, notwithstanding the fact that he terminated his previous employment contract himself without entering immediately into a new employment relationship. By taking this stance, the Court did not follow the Opinion of AG Elmer who had argued that there is nothing in Decision No 1/80 to support the existence of a right of residence after the termination of a previous employment with a view to seeking new work. ${ }^{119}$

The serving of a prison sentence does not forfeit the right of free access to any paid employment of a Turkish national under the third indent of Article 6(1) because he is not in employment, even for several years, if his absence from the labour market in the host Member State was only temporary. ${ }^{120}$

\subsubsection{The Cessation of the Right of Residence}

The right of residence of Turkish workers may be terminated on account of different reasons such as retirement, incapacitation, voluntary unemployment and public policy, considering that Article 6 only provides rights for Turkish nationals who are employed and belong to the labour force of a host Member State.

Article 6(2) of Decision No 1/80 stipulates that the concept of "legal employment" covers annual holidays, absences on account of maternity leave or an accident at work, as well as short periods of sickness. By contrast, periods of involuntary unemployment (duly certified by the relevant authorities) and long absences for reasons of sickness shall not be not treated as periods of legal employment but they shall not affect the rights obtained on the basis of previous employment. This provision aims to regulate the implications that come with interruptions of employment for the application of Article 6(1). Thus, the temporary absences listed in the first sentence of Article 6(2) are treated as periods of legal employment, particularly in calculating the length of the period of legal employment required in order to acquire the right of free access to any paid employment.

On the other hand, periods of involuntary unemployment and absences due to longterm sickness, which cannot be considered as periods of legal employment, are merely taken into consideration so as to safeguard the rights acquired by the worker as a result of previous periods of employment. Subsequently, the Court specified that Article 6(2) ensured the continuation of the right to employment and inevitably

Ibid., paras. 26-30; Case C-292/89 Antonissen [1991] ECR I-745. See Opinion of AG Elmer, delivered on 14 November 1996, Case C-171/95 Tetik, para. 24.

Case C-340/97 Ną̧li [2000] ECR I-957; Case C-383/03 Doğan [2005] ECR I-6237. 
presupposed the capability to continue working. ${ }^{121}$ It was the Court's judgment in Bozkurt that first clarified the scope of this article. The case concerned a Turkish worker legally employed as a lorry driver who was duly registered as belonging to the labour force in the Netherlands. After working for almost ten years for a Dutch company he was the victim of an accident at work and as a result thereof severely incapacitated. In this context, the Court held that Article 6(2) did not confer the right on a Turkish national who had ceased to belong to the legitimate labour force of a Member State to remain in the territory of that state following retirement or an accident at work rendering him permanently incapacitated. Such a person was no longer available as a member of the labour force as he did not and would not engage in economic activities anymore. ${ }^{122} \mathrm{~A}$ right to stay on the territory must either stem from national law or from secondary EU legislation, such as Council Directive 2003/109/EC, which provides for long-term resident status for third-country nationals who have resided legally and continuously in the territory of a Member State for five years. ${ }^{123}$

Apart from reasons relating to retirement and incapacitation, a Turkish worker also ceases to belong to the legitimate labour force of a Member State because of unemployment which is of a voluntary and permanent nature. As a consequence, employment rights under the third indent of Article 6(1) and the concomitant right of residence may be limited on account of the fact that the Turkish national concerned has failed to find new paid employment within a reasonable time after the end of a prison term. ${ }^{124}$

Article 14(1) of Decision No 1/80 sets out that the rights of Turkish workers and their family members may be restricted on grounds of public policy, public security or public health. The Court indicated the parameters on how to construe this provision in the Nazli case. It held that Article 14(1) had to be construed as precluding the expulsion of a Turkish national, who enjoyed a right granted directly by Decision No $1 / 80$, following a criminal conviction when the expulsion was ordered as a deterrent to other aliens without the personal conduct of the person concerned giving reason to believe that he would commit other serious offences prejudicial to the requirements of public policy in the host Member State. ${ }^{125}$ Once more, the Court referred to Community law for the interpretation of EU-Turkey association law, this time in relation to the public policy exception. ${ }^{126}$ It indicated to earlier case law which suggested that the concept of public policy involved the existence of a genuine and sufficiently serious threat to one of the fundamental interests of society; that the public policy exception had to be interpreted restrictively; and that Community law precluded the expulsion of a Member State national on

\footnotetext{
121 Case C-434/93 Bozkurt [1994] ECR I-1475, para. 38.

122 Case C-434/93 Bozkurt [1994] ECR I-1475, paras. 32-42.

123 Council Directive 2003/109/EC of 25 November 2003 concerning the status of thirdcountry nationals who are long-term residents.

124 Case C-383/03 Doğan [2005] ECR I-6237.

125 Case C-340/97 Nazli [2000] ECR I-957.

$126 \quad$ Ibid., paras. 55-56.
} 
general preventive grounds without account being taken of the personal conduct of the offender. ${ }^{127}$

In the Cetinkaya decision, it was specified in greater detail that, when reviewing the lawfulness of the expulsion of a Turkish national, Article 14 required national courts to take into consideration factual matters which occurred after the final decision of the competent authorities and which no longer justify a limitation of the rights of the person concerned within the meaning of that provision. ${ }^{128}$ The Court substantiated this reasoning with its ruling in Orfanopoulos and Oliveri in which it held that, when reviewing the lawfulness of the expulsion of a Union citizen, national courts must take into account the factual matters which occurred after the final decision of the competent authorities which may point to the cessation or substantial diminution of the present threat which the conduct of the person concerned constitutes to the requirements of public policy. ${ }^{129}$

Turkish nationals enjoy the same procedural guarantees as Community nationals once their rights under Decision No 1/80 are terminated. The Court's judgment in Dörr and Ünal illustrated that the procedural guarantees available to Community nationals against the decision refusing renewal of a residence permit or against an expulsion decision, as enshrined in Articles 8 and 9 of Council Directive 64/221/EC, also applied to Turkish nationals whose legal status was defined by Articles 6 or 7 of Decision No 1/80. The Court took this stance stating that the effectiveness of judicial protection of individual rights in relation to residence and employment for Turkish workers and their family members had to be ensured. Today, Article 28 of Directive 2004/38/EC regulates the protection against expulsion for EU citizens. It has been argued that the enhanced protection for EU citizens, who have the right of permanent residence, for minors and for EU citizens having resided in the host Member State for ten years, can be extended to Turkish nationals if complying with the prerequisites listed in Article 28. ${ }^{130}$ First, however, the Court reiterated on several occasions that the right of residence of a Turkish worker in the host Member State could not be made subject to additional conditions once the requirements set out in Article 6(1) of Decision No 1/80 are fulfilled. ${ }^{131}$ Second, this this viewpoint - the extension of the enhanced protection against expulsion of EU citizens under Article 28(3)(a) of Directive 2004/38/EC to Turkish nationals - was explicitly rejected by the Court of Justice in Ziebell. ${ }^{132}$

The case of Ziebell concerned a Turkish national who satisfied all the conditions required to enjoy the legal status provided for in the second indent of Article 7(1) of Decision No 1/80 before an expulsion decision was taken against him because of a series of crimes he had committed, including aggravated theft, gang-related robbery, grievous bodily harm and money counterfeiting. Mr Ziebell first argued that it is the

127 Case 30/77 Boucherean [1977] ECR 1999, para. 35; Case C-348/96 Calfa [1999] ECR I11, paras. 22-27; Case 67/74 Bonsignore [1975] ECR 297, para. 7. Case C-476/02 Cetinkaya [2004] ECR I-10895.

Case C-493/01 Orfanopoulos and Oliveri [2004] ECR I-5257, para. 82. P. Boeles and M. Den Heijer, European Migration Law (Intersentia, Leiden 2009), p. 105. Case C-1/97 Birden [1998] ECR I-7747, para. 37; Case C-188/00 Kurz [2000] ECR I10691, para. 68; Case C-14/09 Hava Genc [2010] ECR I-00931, para. 38.

132 Case C-371/08 Ziebell [2011] Judgment of 8 December 2011, not yet reported. 
Court's settled case law to apply the guarantees of free movement to Turkish nationals with rights under the EEC-Turkey Association; second, he indicated that he had resided lawfully in the host Member State for over 10 consecutive years, and hence the protection against expulsion that he enjoyed was regulated by Article 28(3)(a) of Directive 2004/38/EC - the relevant condition thereunder, namely that imperative grounds of public security justify expulsion, was not satisfied in his case he opined. The Court confirmed that Mr Ziebell could rely on Article 14(1) of Decision No 1/80, and that it had, in previous case law, construed the public policy exception and the procedural guarantees under Article 14(1) of Decision No 1/80 by analogy with the principles recognised for EU nationals in connection with Article 48(3) EEC. ${ }^{133}$

Yet, the Court of Justice dismissed Mr Ziebell's arguments and held that it was not possible to extend the scheme of protection against expulsion enjoyed by Union citizens, as provided for in Article 28(3)(a) of Directive 2004/38/EC, to the guarantees against expulsion for Turkish nationals on the following grounds: "[]]n deciding whether a provision of EU law lends itself to application by analogy under the EEC-Turkey association, a comparison must be made between the objective pursued by the Association Agreement and the context of which it forms a part, on the one hand, and those of the European Union law instrument in question, on the other." 134 The Court continued that such a transposition of the principles underlying the freedom of movement under EU law could be justified only by the objective of progressively securing freedom of movement for Turkish workers pursued by the EEC-Turkey association, as laid down in Article 12 of the Association Agreement; however, Article 12, in referring to the Treaty provisions relating to the free movement of workers, confirmed that the purpose underpinning that association was solely economic in nature. 135

By comparison, Directive 2004/38/EC, based on Articles 12 EC, 18 EC, 40 EC, 44 $\mathrm{EC}$ and $52 \mathrm{EC}$, aimed - far from pursuing a purely economic objective - to facilitate the exercise of the primary and individual right to move and reside freely within the territory of the Member States that was conferred directly on EU citizens by the Treaty and aimed in particular to strengthen that right. In the light of this, the protection against expulsion measures granted by Directive 2004/38/EC constituted a strong system of protection which provided for greater guarantees where the degree of integration of EU citizens in the host Member State was high, taking into account the fundamental status EU citizenship. The Court concluded that this system of protection could not be transferred to Turkish nationals because of the substantial differences in the wording, the object and purpose between the rules relating to the EEC-Turkey association and EU law concerning citizenship in that the former association was based on an economic rationale being restricted to the gradual achievement of the free movement of workers. ${ }^{136}$

133 Case C-371/08 Ziebell [2011] Judgment of 8 December 2011, not yet reported, paras. 51-52.

134 Case C-371/08 Ziebell [2011] Judgment of 8 December 2011, not yet reported, para. 62.

135 See also opinion of AG Bot, delivered on 14 April 2011, paras. 44-46, on the case.

136 Case C-371/08 Ziebell [2011] Judgment of 8 December 2011, not yet reported, paras. 63-74. 
Against the background of the repeal of Directive 64/221/EC, - in the case of a third-country national such as Mr Ziebell, who has been residing lawfully and continuously in the host Member State for more than 10 years, - recourse had to be made to Article 12 of Directive 2003/109/EC, which applied a rule of minimum protection against expulsion for any national of a non-Member State who holds the status of long-term lawful resident in the territory of a Member State. The Court of Justice repeated that the public policy exception was a derogation from the free movement of workers which must be interpreted strictly and that measures on grounds of public policy or public security could only be taken following a case-bycase assessment showing that the personal conduct of the individual concerned at present constituted a genuine and sufficiently serious threat to a fundamental interest of society subject to the principle of proportionality and the fundamental rights of the person concerned, in particular, the right to privacy and family life. ${ }^{137}$

\subsubsection{Residence and Employment Rights of Family Members}

Articles 7 and 9 of Decision No 1/80 provide rights for the family members of a Turkish worker duly registered as belonging to the labour force of a Member State. From the outset, it must be pointed out that Decision No 1/80 does not grant a right of entry for the purpose of family reunification and that Member States are thus in principle free to control first admission of Turkish nationals to their territory. ${ }^{138}$ Accordingly, the rights deriving from Articles 7 and 9 of Decision No 1/80 become applicable only once the family member has entered the Member State. This discretion is, however, now limited by Council Directive 2003/86/EC on the right to family reunification. ${ }^{139} \mathrm{~J}$. Bast emphasised in this context that the fragmented regulatory content of Article 7 of Decision No 1/80, which challenges the idea that EU-Turkey association law provides for a coherent legal status, was mitigated by Council Directive 2003/86/EC that stipulates the possibility to be granted first admission - which in turn paves the way to benefit from Article 7 of Decision No $1 / 80$ - and which has also created a right to family reunification for the sponsor. ${ }^{140}$

Article 7 of Decision No 1/80 aims to endorse family unity: Article 7(1) stipulates the right for family members of a Turkish worker duly registered as belonging to the labour force of a Member State, who have been authorised to join him, to respond to any employment offer after they have been legally resident for at least three years in that Member State. In addition, they shall enjoy free access to any paid employment of their choice provided they have been legally resident there for at least five years. Article 7(2) lays down that children of Turkish workers who have completed a course of vocational training in the host country may respond to any offer of employment there, irrespective of the length of time they have been resident in that Member State, provided one of their parents has been legally employed in the Member State concerned for at least three years.

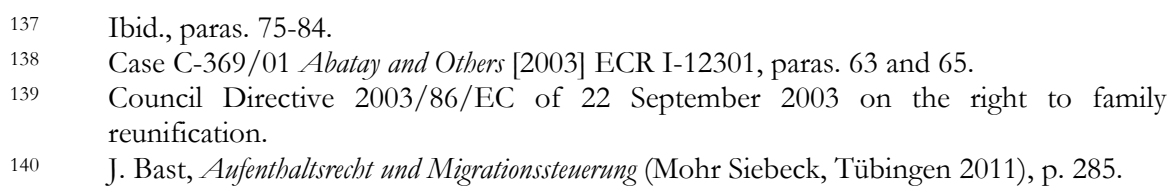


In Kadiman and Eroglu the Court ruled on the direct effect of Article 7(1) and (2) respectively. ${ }^{141}$ The term "family member" is not defined in the provision itself but case law indicates that the concept must be construed in a uniform manner at the Community level and with reference to Community law, in order to ensure its consistent application in the Member States. ${ }^{142}$ As a consequence, a stepson who is under the age of 21 or is a dependent of a Turkish worker qualifies as a family member of that worker and can rely on Article 7(1) provided that he has been duly authorised to join that worker in the host Member State. ${ }^{143}$ Article 7(1) also covers a person who has attained majority and is the child of a Turkish worker, even though the person was born in and has always resided in the host state. ${ }^{144}$ Importantly, the Court held that the nationality of the family member of a Turkish worker is of no relevance for the application of Article 7(1) of Decision 1/80.145 Children fall within the scope of "family members" and they benefit from a more advantageous legal position under Article 9 of Decision No 1/80. Article 9 establishes the right of Turkish children residing legally in a Member State of the Community with their parents, who are or have been legally employed in that Member State, to be admitted to courses of general education, apprenticeship and vocational training under the same educational entry qualifications as the children of nationals of that Member State. Moreover, in that Member State they are eligible to benefit from the advantages provided for under the national legislation in this area. In Gürol the Court held that Article 9 had direct effect and that the child of a Turkish worker who was enrolled at a higher education institution as a student fell under the scope of that Article, although she was not living with her parents anymore. The Court decided that she could invoke Article 9 in order to claim equal treatment in relation to study grants. ${ }^{146}$

In order to benefit from the residence right under Article 7(1) of Decision No 1/80, the family member of a Turkish worker can in principle be required to live with the latter for an uninterrupted period of three years. However, objective reasons may justify that the family member lives apart from the Turkish worker. ${ }^{147}$ The Court clarified in Altun that the child of a Turkish worker may enjoy rights arising from Article 7(1) where, during the three-year period when the child was co-habiting with the worker, the latter was working for two and a half years before being unemployed for the following six months. The fact that the Turkish worker was first granted the right of residence as a political refugee does not prevent his family members from relying on the respective provision. The Court continued its broad interpretation of Article 7(1) in Ergat, where it stated that once the three-year period set out in Article 7(1) has lapsed, Member States are prohibited from attaching new conditions to the

141 Case C-351/95 Kadiman [1997] ECR I-2133, paras. 27-28; Case C-355/93 Eroglu [1994] ECR I-5113, para. 17.

142 Case C-275/02 Ayaz [2004] ECR I-8765, paras. 38-48; for a detailed analysis on the concept of family members of Turkish workers, see A.P. van der Mei, 'The BozkurtInterpretation Rule and the Legal Status of Family Members of Turkish Workers under Decision 1/80 of the EEC-Turkey Association Council', 11 European Journal of Migration and Law (2009), 367, pp. 370-377.

143 Case C-275/02 Ayaz [2004] ECR I-8765.

144 Case C-476/02 Cetinkaya [2004] ECR I-10895.

145 Case C-451/11 Dülger [2012] Judgment of 19 July 2012, not yet reported.

146 Case C-374/03 Gürol [2005] ECR I-6199.

147 Case C-351/95 Kadiman [1997] ECR I-2133. 
residence of a family member of a Turkish national. ${ }^{148}$ Article 7(1) sets out rights for family members of Turkish workers concerning access to employment but it does not impose an obligation on the family members to make use of them. ${ }^{149}$ The Court of Justice ruled in Peblivan that the marriage of the daughter of a Turkish worker, with whom she had resided under one roof for more than three years in the Netherlands, did not result in the dissolution of the family ties with her father. In that case, the Dutch authorities had wrongfully withdrawn Ms Pehlivan's residence permit arguing that, by getting married, the family links with her father were broken, which led in turn to the cessation of rights acquired in her capacity as a family member of a Turkish worker. It follows from the judgment that the creation of a new family bond, for instance by wedlock, does not necessarily entail the breaking of a previously existing family unity. ${ }^{150}$

Article 7(2) of Decision No 1/80 was subject to discussion in Akman. ${ }^{151}$ The Court was asked whether for a child of a Turkish worker to have the right of extension of his residence permit the employed parent must be resident in the Member State, or even still be in an employment relationship, at the time when the child wishes to gain access to the labour market of the host state after having completed a course of vocational training there. The Court answered in the negative and ruled in favour of the applicant.

It has been pointed out that the proactive stance of the Court has provided family members of Turkish nationals with sound residence rights, even more advantageous than those enjoyed by the Turkish workers themselves. While the latter's right of residence is contingent on belonging to the labour force of the host Member State, family members profit from a quasi-permanent right of residence once they may take up employment on the basis of Article 7(1). ${ }^{152}$ From the Derin case it follows that a Turkish national who has acquired the right of free access to any paid employment of his choice under the second indent of Article 7(1) of Decision No 1/80 loses the right of residence which is a corollary of that right of free access only in two situations: first, in the circumstances where Article 14(1) applies (grounds of public policy, public security and public health) and second, if he leaves the territory of the Member State concerned for a significant length of time without a legitimate reason. ${ }^{153}$ In the underlying case this interpretation was applied to the son of a Turkish worker over the age of 21, who lived independently in the Member State and was not able to join the labour force there for several years as he was serving a prison sentence. Likewise, as soon as the family member of a Turkish worker enjoys the rights relating to the legal status conferred on the basis of the second indent of Article 7 of Decision No 1/80, the family member does not lose those rights on account of his divorce, which took place after those rights were acquired. ${ }^{154}$ In Kabveci

148 Case C-329/97 Ergat [2000] ECR I-1487, para. 38.

149 Case C-373/03 Aydinli [2005] ECR I-6181, para. 29.

150 Case C-484/07 Pehlivan [2011] Judgment of 16 June 2011, not yet reported; see case note K. Eisele, 'Case C-484/07 Pehlivan', 18 Maastricht Journal of European and Comparative Law (2011), 573.

151 Case C-210/97 Akman [1998] ECR I-7519.

152 P. Boeles and M. Den Heijer, European Migration Law (Intersentia, Leiden 2009), p. 108.

153 Case C-325/05 Derin [2007] ECR I-6495; see also Case C-502/04 Torun [2006] ECR I1563.

154 Case C-303/08 Bozkurt [2010] Judgment of 22 December 2010, not yet reported. 
and Inan the Court clarified that the family members of a Turkish worker duly registered as belonging to the labour force of a Member State can still rely on Article 7 of Decision No 1/80 once that worker has acquired the nationality of the host Member State while retaining his Turkish nationality. ${ }^{155}$

\subsection{Nationals of Algeria, Morocco and Tunisia}

Nationals of Algeria, Morocco and Tunisia do not enjoy specific employment or residence rights on the basis of the respective Euro-Mediterranean Agreements. However, in very particular cases, the principle of equal treatment in working conditions can implicate a right of residence, that is, when the validity of a work permit granted by a Member State exceeds the validity of the residence permit. The Court first dealt with this legal question in El-Yassini where the applicant faced an expulsion decision and confirmed its stance later in Gattoussi. ${ }^{156}$

The Joint Declarations to Article 64 of the Euro-Mediterranean Agreements with Morocco and Tunisia (on the right to equal treatment in working conditions) lay down that, without prejudice to the conditions and procedures applicable in each Member State, the parties will examine the matter of labour market access of the spouse and children of the workers legally employed on the territory of a Member State and legally resident under family reunification arrangements, except for seasonal workers, those on secondment or on placement, for the duration of the worker's authorised stay. Furthermore, it is specified that, with regard to the absence of discrimination as regards redundancy, the equal treatment clauses relating to working conditions may not be invoked to obtain renewal of a residence permit. The granting, renewal or refusal of a residence permit shall be governed by the legislation of each Member State and the bilateral agreements and conventions in force between Tunisia/Morocco and the Member States. ${ }^{157}$

\subsection{Other Sources of EU Law Applicable to Third-Country Nationals}

EU secondary legislation provides certain categories of third-country nationals with employment and residence rights: once legally admitted to an EU Member State, third-country national researchers and EU Blue Card holders are eligible for a residence permit of generally at least a year in the host Member State. If the conditions are met, the Member States shall renew the validity of the residence permit in accordance with the specific rules. ${ }^{158}$

155 Joined Cases C-7/10 and C-9/10 Kabveci and Inan [2012] Judgment of 29 March 2012, not yet reported; compare, however, the Court's judgment in McCarthy according to which a EU citizen could not rely on her dual nationality to claim rights from Directive 2004/38/EC: Case C-434/09 McCarthy [2011] Judgment of 5 May 2011, not yet reported.

156 Case C-416/96 El-Yassini [1999] ECR I-1209 and Case C-97/05 Gattoussi [2006] ECR I-11917; see Section on the the right to equal treatment in working conditions.

157 See joint declarations relating to Art. 64(1) of the Euro-Mediterranean Agreements with Tunisia and Morocco.

158 Art. 8 of Council Directive 2005/71/EC of 12 October 2005 on a specific procedure for admitting third-country nationals for the purposes of scientific research; Art. 7(2) 
Holders of a single permit are entitled, during its period of validity, to enter and reside in the territory of the Member State issuing the single permit provided that the holder meets all admission requirements in accordance with national law. ${ }^{159}$ Next, third-country workers enjoy equal treatment with nationals of that Member State where they reside as regards: working conditions, including pay and dismissal as well as health and safety at the workplace; and advice services offered by employment offices in accordance with Article 12(1)(a) and (h) of Directive 2011/98/EU on single permit. ${ }^{160}$

For third-country nationals who are long-term residents, the right of residence is not strictly bound to employment. However, to acquire this status in the first place, the third-country national in question must dispose of stable and regular resources, which are sufficient to maintain himself/herself and his/her family without recourse to the social assistance system, next to a comprehensive sickness insurance as specified in Article 5(1) of Directive 2003/109/EC. ${ }^{161}$ A long-term residence permit shall at least be valid for five years and be automatically renewable on expiry. ${ }^{162}$ Third-country nationals holding long-term resident status enjoy protection against expulsion from a Member State's territory: they may only be expelled if the person concerned constitutes an actual and sufficiently serious threat to public policy or public security. ${ }^{163}$ Long-term residents acquire the right to reside in another Member State in accordance with Articles 14 and 15 of Directive 2003/109/EC.

On top of that, long-term residents are entitled to equal treatment with nationals as regards access to employment and self-employed activity, provided that such activities do not entail being involvement in the exercise of public authority. ${ }^{164}$ Member States may restrict this equal treatment concerning access to employment and self-employed activities for long-term residents in cases where, in line with national or EU legislation, these activities are reserved to nationals, EU or EEA

of Council Directive 2009/50/EC of 25 May 2009 on the conditions of entry and residence of third-country nationals for the purposes of highly qualified employment.

159 Art. 11 of Directive 2011/98/EU of the European Parliament and of the Council of 13 December 2011 on a single application procedure for a single permit for third-country nationals to reside and work in the territory of a Member State and on a common set of rights for third-country workers legally residing in a Member State.

160 The third-country workers referred to under Art. 12 are defined in Art. 3(1)(b) and (c) of Directive 2011/98/EU, meaning: third-country nationals who have been admitted to a Member State for purposes other than work in accordance with Union or national law, who are allowed to work and who hold a residence permit in accordance with Regulation (EC) No 1030/2002; and third-country nationals who have been admitted to a Member State for the purpose of work in accordance with Union or national law. Council Directive 2003/109/EC of 25 November 2003 concerning the status of thirdcountry nationals who are long-term residents; see also Case C-578/08 Chakroun [2010] ECR I-01839.

162 Art. 8(2) of Council Directive 2003/109/EC of 25 November 2003 concerning the status of third-country nationals who are long-term residents.

163 Art. 12 of Council Directive 2003/109/EC of 25 November 2003 concerning the status of third-country nationals who are long-term residents.

164 Art. 11(1)(a) of Council Directive 2003/109/EC of 25 November 2003 concerning the status of third-country nationals who are long-term residents. 
citizens. ${ }^{165}$ Council Directive 2003/86/EC on the right to family reunification provides admitted family members with the right to work or to engage in a selfemployed activity; the same rights apply to family members of a long-term thirdcountry resident who has moved to another Member State. ${ }^{166}$

\subsection{Employment and Residence Rights Compared}

EEA and Swiss nationals and their family members benefit from the most favourable employment and residence rules in the EU. In line with Regulation (EU) No 492/2011 and Directive 2004/38/EC, EEA nationals have a residence right in an EU Member State inter alia for the purposes of taking up employment, to pursue studies or remain there after having been employed. EEA citizens and their families who have legally resided in the host Member State for a continuous period of five years acquire the right of permanent residence. Swiss nationals enjoy similar farreaching rights relating to residence and employment on the basis of a special regime provided for in the FMP Agreement.

The EU-Turkey association law provides Turkish nationals with work and residence rights that are - unlike the legal schemes applicable to EEA and Swiss nationals strictly connected to the purpose of employment. While the Court in the past has extensively referred to case law and concepts established under the EU free movement rules when interpreting the rules for Turkish nationals, it cautiously rejected the extension of the enhanced protection against expulsion for EU citizens to Turkish nationals in the case of Ziebell. ${ }^{167}$ It is clear that the fundamental status of EU citizenship cannot be applied to Turkish nationals, however, the Court's argumentation in casu that EU-Turkey association was purely economic in nature is not convincing. Firstly, the association does not only aim at enhancing trade and economic relations but also at improving the employment and living conditions of the Turkish people. Secondly, the association envisages EU membership and this fact should be factored in when construing the Ankara Agreement and implementing legislation. Under Article 6(1) of Decision No 1/80, the longer a Turkish worker is legally employed in a Member State, the more extensive the rights of the Turkish worker and his/her family members become. This system aims to progressively consolidate the position of Turkish workers in the host Member State.

Third-country nationals who come within the scope of the researchers', the EU Blue Card, the single permit, or the long-term residents' Directive can make use of the specfic residence and employment rights provided in each of these legal instruments which apply irrespective of nationality.

165 Art. 11(3)(a) of Council Directive 2003/109/EC of 25 November 2003 concerning the status of third-country nationals who are long-term residents.

166 Art. 14(1)(b) of Council Directive 2003/86/EC of 22 September 2003 on the right to family reunification and Art. 21(3) of Council Directive 2003/109/EC of 25 November 2003 concerning the status of third-country nationals who are long-term residents.

167 Case C-371/08 Ziebell [2011] Judgment of 8 December 2011, not yet reported. 
The obligation not to discriminate with regard to working conditions is enshrined in most association agreements in a reciprocal manner. However, it is remarkable that the wording changed in the agreements concluded more recently. As a general rule, equal treatment in employment situations can only be invoked if the worker is authorised to work and legally resident in an EU Member State. Under certain specific circumstances, the right to equal treatment can entail a right of residence. ${ }^{168}$ The Court of Justice has given the notions of "worker" and "working conditions" a broad meaning with regard to EU nationals but also - as this contribution demonstrates - with regard to third-country nationals in extensive case law. In this respect, the Court held, as early as in 1974, that a separation allowance, paid in addition to wages, falls within the concept of "conditions of employment and work" without it being necessary to define whether the payment is made by virtue of an option or an obligation, either statutory or contractual. ${ }^{169}$

\subsection{Nationals of the Former Europe Agreement States}

The Europe Agreements neither set out a right of access to the labour market of a Member State for the purpose of employment nor guaranteed the protection of residence for nationals of Central and Eastern European countries who were already residing in the EU. However, every Europe Agreement contained an equal treatment clause with regard to working conditions. It has been pointed out that labour market access was an issue which the Member States preferred to govern on a bilateral basis rather than at the EU level. ${ }^{170}$

Article 37(1), first indent, of the Europe Agreement concluded with Poland stipulated that the treatment accorded to Polish workers legally employed in the territory of a Member State shall be free from any discrimination based on nationality, as regards working conditions, remuneration and dismissal, as compared to its own nationals subject to the conditions and modalities applicable in each Member State. ${ }^{171}$ Article 37(2) laid down the reciprocal obligation for Poland to accord treatment referred to in Article 37(1) to workers holding the nationality of a Member State and their family members. Articles 41 and 42 of the Polish Europe Agreement stipulated further possibilities to enhance the mobility of workers taking into account the labour market situation in the Member States.

Thus, a worker holding the respective nationality enjoyed the right to equal treatment under Article 37(1) only if s/he is legally resident and employed in a Member State as confirmed in Pokrzeptowicz-Meyer, a legal dispute that concerned the validity of a fixedterm contract of a Polish language assistant. ${ }^{172}$ In this judgement the Court declared the equal treatment provision to be directly effective because it was sufficiently

\footnotetext{
168 Case C-97/05 Gattoussi [2006] ECR I-11917.

169 Case 152/73 Sotgiu [1974] ECR 153.

170 E. Guild, Immigration Law in the European Community (Kluwer Law International, The Hague 2001), pp. 182-183.

171 For illustration purposes reference is made to the Europe Agreement with Poland.

172 Case C-162/00 Pokrzeptowicz-Meyer [2002] ECR I-1049, para. 21.
} 
precise, clear and unconditional to be relied upon by individuals and corroborated by the purpose and nature of the agreement. According to the Court, this outcome was neither altered by the provisio "subject to the conditions and modalities applicable in each Member State" since it would render the provision meaningless and deprive it of any practical effect. Nor did Article 58(1) affect the direct effect of the equal treatment clause for Polish workers. Article 58(1) guaranteed the right of the parties to apply their laws regarding entry, stay, labour conditions and establishment of natural persons and supply of services, provided that they did not apply them in a manner as to nullify or impair the benefits accruing to any party under the terms of a specific provision of this agreement. ${ }^{173}$

The Court referred extensively to its decision in Spotti in which it had established that the equal treatment provision for Member States' nationals as regards working conditions applies to direct and indirect forms of discrimination. ${ }^{174}$ In PokerzeptowiczMeyer the applicant could consequently rely on Article 37(1) which was interpreted in the same way as Article 39(2) EC (now Article 45(2) TFEU) and successfully challenged a German rule according to which positions for foreign-language assistants may be filled by means of fixed-term contracts of employment, whereas, for other teaching staff performing special duties, recourse to such contracts must be individually justified by an objective reason. As a result, this ruling illustrated that the scope of the equal treatment clauses in the Europe Agreements and that of Article 39(2) EC was the same and that the case law of the free movement of persons in the EU context could be transposed to the Europe Agreements. ${ }^{175}$ The Court affirmed its line of interpretation in Deutscher Handballbund in which it adjudicated that a sporting rule of the German Handball Federation, which limited the number of nonEEA players a club was authorised to field in a match, was in breach of the equal treatment provision in the Europe Agreement with Slovakia. ${ }^{176}$ This case extended the Bosman ruling to third countries. ${ }^{177}$ The sporting rule at hand challenged by a Slovakian professional sportsman lawfully employed in Germany did not concern the employment of professional players, on which there is no restriction but the extent to which their clubs may field them in official matches and that participation in such matches is the essential purpose of their activity. ${ }^{178}$

With regard to the temporal effect of the equal treatment clause, the Court clarified that such a rule applied immediately to employment contracts still running and rejected arguments that the general principles of EU law entailed that only the matters of law and fact which existed at the time of the conclusion of that contract applied to its application. ${ }^{179}$

\footnotetext{
173 Case C-162/00 Pokrzeptowicz-Meyer [2002] ECR I-1049, paras. 19-30.

174 Case C-272/92 Spotti [1993] ECR I-5185, paras. 16-18.

175 Ibid., paras. 39 and 44; N. Rogers and R. Scannell, Free Movement of Persons in the Enlarged European Union (Sweet \& Maxwell, London 2005), p. 288.

176 Case C-438/00 Deutscher Handballbund [2003] ECR I-4135.

177 For a discussion, see F. Hendrickx, 'The European Non-EU Player and the KolpakCase', International Sports Law Journal (2003), 12.

178 Case C-438/00 Deutscher Handballbund [2003] ECR I-4135, para. 45.

179 Case C-162/00 Pokrzeptowicz-Meyer [2002] ECR I-1049, paras. 46-57.
} 
In a case decided in July of 2011, the limits of the equal treatment obligation in employment conditions were defined: the highest judicial authority in the EU held in Pavlov that the principle of non-discrimination contained in the former Europe Agreement concluded with Bulgaria (Article 38(1)) did not preclude, prior to Bulgaria's accession to the EU, national legislation under which a Bulgarian national, on grounds of a nationality requirement, was not put on the list for trainee lawyers and, consequently, was unable to obtain a certificate of entitlement to appear in court. ${ }^{180}$ Referring to Morgenbesser, it first clarified that the activities of a trainee lawyer constitute a practical part of the training necessary for access to the regulated profession of lawyer and that therefore the inclusion on the list of trainee lawyers constitutes a prerequisite of becoming a lawyer. ${ }^{181}$ The Court then emphasised that nothing in the Europe Agreement allowed it to be deduced that the contracting parties intended to eliminate all discrimination based on nationality as regards access to regulated professions by Bulgarian nationals. The Court added that "regulated professions" are dealt with under the rules of establishment in Article 47 of the Europe Agreement with Bulgaria, regarding access to regulated professions, without imposing an obligation in that connection not to discriminate on grounds of nationality - not in Chapter I on "movement of workers". 182

The outcome of the reasoning was in line with the opinion of AG Mengozzi. ${ }^{183}$ After concluding that Article 38(1) was, in his view, directly applicable, the AG relied on the Court's judgment in Pokrzeptowicz-Meyer for his analysis. In the latter case, the Court established that the underlying prohibition of discrimination has the same meaning as the one stipulated in Article 39(2) of the EC Treaty (now Article 45(2) TFEU). This interpretation, according to the AG, is transposable to Article 38(1) of the former Europe Agreement with Bulgaria with regard to its objective. The AG stated that, in line with earlier case law, "a provision such as the afore-mentioned Article 38 does not set out a principle of free movement of Bulgarian workers within the Union, but it does introduce in their favour, from the moment when they are lawfully employed in the territory of a Member State, a right to equal treatment in regard to working conditions of the same scope as that conferred in similar terms by the Treaty on nationals of the Union." 184

Coming to the preliminary conclusion that this case was one of discrimination, which was seemingly not justified, the AG stressed that "the Gordian knot is not severed" because it is questionable whether the legal basis of Article 38(1) of the former Europe Agreement with Bulgaria covered the situation at stake. ${ }^{185}$ The AG pointed out that although there are indications as to why the refusal to put Mr Pavlov on the list for trainee advocates could be construed as directly affecting activities relating to

180 Case C-101/10 Pavlow [2011] Judgment of 7 July 2011, not yet reported.

181 Case C-313/01 Morgenbesser [2003] ECR I-13467, para. 51.

182 Case C-101/10 Pavlov [2011] Judgment of 7 July 2011, not yet reported, para. 27.

183 Opinion of AG Mengozzi of 17 March 2011 in Case C-101/10 Pavlov [2011] Judgment of 7 July 2011, not yet reported.

184 C-162/00 Pokrzeptowicz-Meyer [2002] ECR I-1049, paras. 40-41; Case C-438/00 Deutscher Handballbund [2003] ECR I-4135, paras. 34-35; Case C-265/03 Simutenkov [2005] ECR I-2579, para. 6.

185 Opinion of AG Mengozzi of 17 March 2011 in Case C-101/10 Pavlov [2011] Judgment of 7 July 2011, not yet reported, para. 46. 
"employment". ${ }^{186}$ He took the view that the type of employment carried out by $\mathrm{Mr}$ Pavlov could be considered as the employment of a trainee lawyer for the following reasons: there would be a real risk of circumvention of national legislation if professional organisations were bound by the description of an employment as provided for in a work contract; moreover, as established in previous case law, the notion of working conditions related to the legal rules applicable to the employment relationship as well as the advantages, material or other, granted to the workers but not the conditions of access to a profession in themselves. ${ }^{187}$ The AG distinguished Lawrie-Blum pointing out that the applicant in the main proceedings - a UK national who wanted to be admitted as a trainee teacher to the practical training required to teach in secondary schools in Germany - suffered discrimination with regard to access to employment, not as regards working conditions. ${ }^{188}$ While admitting that the Court has been generous in its reading of association agreements, the AG concluded that the element of connection, which supported an analogical interpretation of provisions in international agreements and those contained in the Treaty, is missing in the underlying case and that the limits of the association of non-member countries did not provide for protection as granted by the Treaty establishing the Union. ${ }^{189}$

\subsection{EEA Nationals}

Article 28 of the EEA Agreement sets out the freedom of movement for workers in the territory of an EU Member State or EFTA state and reflects Article 45 TFEU. The terminology used - freedom of movement for workers - indicates the broad scope of this provision. This freedom includes inter alia the abolition of discrimination based on nationality with regard to employment, remuneration and other conditions relating to work and employment in line with Article 28(2) EEA Agreement. The scope of application is specified in Annex V to the EEA Agreement which originally referred to six Community acts that were incorporated into the EEA Agreement with decisions issued by the EEA Joint Committee. Article 7(1) of Regulation (EU) No 492/2011 (of EEA relevance) specifies that "a worker who is a national of a Member State may not, in the territory of another Member State, be treated differently from national workers by reason of his nationality in respect of any conditions of employment and work, in particular as regards remuneration, dismissal, and, should he become unemployed, reinstatement or re-employment."

The principle of non-discrimination in Article 45 TFEU and Article 28 of the EEA Agreement respectively, is a lex specialis to the general principle of non-discrimination

The AG in this respect referred to (1) the fact that the inclusion on the list for trainee lawyers marked the start of period for the calculation of training required to become a qualified lawyer; (2) only a listed trainee lawyer may seek the power of representation; and (3) the Austrian authorities approved that Mr Pavlov was a trainee lawyer, and thus the refusal to list him could be understood as a limitation of the activities that the person may exercise in the context of his "employment", in other words his working conditions as interpreted in Deutscher Handballbund. ECR I-1049.

188 Case 66/85 Lawrie-Blum [1986] ECR 2121.

189 Opinion of AG Mengozzi of 17 March 2011 in Case C-101/10 Pavlov [2011] Judgment of 7 July 2011, not yet reported, para. 64. 
on grounds of nationality as enshrined in Article 18 TFEU and Article 4 of the EEA Agreement. ${ }^{190}$ The ECJ ruled that Article 45 TFEU can be directly effective in vertical and horizontal relationships; it can thus be relied upon by individuals against public authorities and private parties. ${ }^{191}$ It is specified that the equal treatment between workers of the EU Member States and the EEA states must be guaranteed with regard to employment, remuneration and other working conditions. The ECJ construed these conditions broadly and made clear that the rule on nondiscrimination on grounds of nationality covers direct and indirect discrimination, as well as obstacles to market access even if they are non-discriminatory. ${ }^{192}$ As opposed to direct discrimination, rules involving indirect discrimination and obstacles to market access can be justified if they are necessary and appropriate for achieving a public interest aim. ${ }^{193}$ The EEA framework on the free movement of workers and self-employed persons also applies to situations where an EFTA national moves to another EFTA state in order to pursue an economic activity there. ${ }^{194}$

The notion of a worker is not defined in EU/EEA legislation, but the Court interpreted the term as a Community concept. ${ }^{195}$ It is important to note that the case law in the field of free movement of workers is, by analogy, applicable for the interpretation of the EEA framework. ${ }^{196}$ The Court held that the concept of a worker must be defined in accordance with objective criteria which distinguish the employment relationship by reference to the rights and duties of the persons concerned. The essential feature of an employment relationship, however, is that for a certain period of time a person performs services for and under the direction of another person in return for which $\mathrm{s} /$ he receives remuneration. ${ }^{197} \mathrm{~A}$ person who works part-time falls under scope of Community law if the activity pursued is not purely marginal and ancillary, notwithstanding the fact that the remuneration is below the minimum legal wage. ${ }^{198}$ The exact nature of the legal relationship under which such services are performed is of no importance since the rule of non-discrimination covers all work or services in identical terms. Therefore, the rule of nondiscrimination applies in judging all legal relationships in so far as these relationships, by reason either of the place where they are entered into or of the place where they take effect, can be located within the territory of the Community. ${ }^{199}$ In extensive case

S. Norberg and others, The European Economic Area: EEA law: A Commentary on the EEA Agreement (Fritzes, Stockholm 1993), p. 404.

Case 167/73 Commission v. French Republic [1974] ECR 359, para. 35; Case C-281/98 Angonese [2000] ECR I-4139, para. 36.

See Case C-212/99 Commission v. Italy [2001] ECR I-4923; Case C-258/04 Ioannidis [2005] ECR I-8275; Case C-415/93 Bosman [1995] ECR I-4921.

See for instance Case C-379/87 Groener [1989] ECR 3967.

S. Norberg and others, The European Economic Area: EEA Law: A Commentary on the EEA Agreement (Fritzes, Stockholm 1993), pp. 402-403.

Case 75/63 Hoekstra [1963] ECR 177, para. 1.

As regards the freedom to provide services, the Court decided that the guarantees provided by Art. 36 of the EEA Agreement and Art. 56 TFEU must be given an identical and uniform interpretation, see Case C-522/04 Commission v. Belgium [2007] ECR I-5701, para. 44 et seq.

Case 66/85 Lawrie Blum [1986] ECR 2121, para. 17.

Case C-53/81 Levin [1982] ECR 1035, paras. 15-17.

Case 36/74 Walrave and Koch [1974] ECR 1405, paras. 7 and 28. 
law, the Court clarified the concept of a worker. ${ }^{200}$ In Saunders the Court adjudicated that the free movement provision cannot be applied to situations which are wholly internal to a Member State, in other words, where there is no factor connecting them to any of the situations envisaged by Community law. ${ }^{201}$

Article 7(4) of Regulation (EU) No 492/2011 (of EEA relevance) furthermore lays down that any clause of a collective or individual agreement or of any other collective regulation concerning eligibility for employment, employment, remuneration and other conditions of work or dismissal shall be null and void in so far as it lays down or authorises discriminatory conditions in respect of workers who are nationals of the other Member States. ${ }^{202}$ In Kristiansen the Belgian national employment office had wrongfully refused to take into consideration the services performed by Mrs Kristiansen, an EEA national who had worked for the Commission as a temporary staff member for four years, resided in Belgium and was entitled to unemployment benefits paid under the EC's conditions of employment. Mrs Kristiansen also claimed that the time period she spent as a post-graduate student, before she had started to work at the Commission, should be considered as an occupational activity. The Court ruled, however, that the non-discrimination provision in Article 7(4) of Regulation (EU) No 492/2011 did not preclude deeming a person carrying on an activity as a post-graduate student, in a Member State, to be a trainee fellowship student, who is not entitled to unemployment benefits under the national system. ${ }^{203}$ The Court made clear that the relationship between the Community system of unemployment benefits and those of the Member States is a complementary one which cannot be disregarded by a Member State in the application of its system of unemployment benefits. ${ }^{204}$

\subsection{Swiss Nationals}

Article 7(a) of the FMP Agreement stipulates that the contracting parties shall provide for the right to equal treatment with nationals in respect of access to and pursuit of an economic activity and living, employment and working conditions in accordance with Annex I of the FMP Agreement. The latter annex sets out the rules on the free movement of persons. The provision on equal treatment in Article 9 of Annex I of the FMP Agreement prohibits differential treatment by reason of nationality for persons employed in the territory of the other contracting party, who are nationals of a contracting party, compared to national employed persons, as regards conditions of employment and working conditions and especially as regards pay, dismissal, or reinstatement, or re-employment if he becomes unemployed.

\footnotetext{
200 See in this regard M. Condinanzi, A. Lang and B. Nascimbene, Citizenship of the Union and Free Movement of Persons (Martinus Nijhoff Publishers, Leiden 2008); F. Weiss and F. Wooldridge, Free Movement of Persons Within the European Community (Kluwer Law International, The Hague 2002).

$201 \quad$ Case 175/78 R. v. Saunders [1979] ECR 1129, para. 11.

202 Regulation (EU) No 492/2011 of the European Parliament and of the Council of 5 April 2011 on freedom of movement for workers within the Union.

203 Case C-92/02 Kristiansen [2003] ECR I-14597, para. 40.

204 Case C-92/02 Kristiansen [2003] ECR I-14597, para. 35.
} 
Chapter 2 of Annex I stipulates provisions applicable to workers including provisions on residence, frontier workers, geographical and occupational mobility, equal treatment and an exception on public service employment. The provision on equal treatment in Article 9 of Annex I follows the pattern of Articles 7,8 and 9 of Regulation (EU) No 492/2011. ${ }^{205}$ Equal treatment shall be ensured in relation to inter alia employment and working conditions. Article 9(4) of Annex I of the FMP Agreement states that any clause of a collective or individual agreement, or in any other collective arrangements regulation concerning access to employment, employment, remuneration and other conditions of work or dismissal, shall be automatically void insofar as it provides for or authorises discriminatory conditions with respect to foreign employed persons who are nationals of the contracting parties. Article 9 of Annex I extends to self-employed persons in conformity with Article 15 of Annex I. As S. Peers points out, there are no rules on access to employment; instead, the notion of geographical and occupational mobility is used. ${ }^{206}$ While geographical mobility relates to changes in the place of work and residence, occupational mobility refers to changes of employer, employment or status (Article 8(2) of Annex I).207

In Zentralbetriebsrat der Landeskrankenbäuser Tirols, an Austrian court referred questions to the Court concerning the interpretation of Article 9(1) of Annex I of the FMP Agreement. ${ }^{208}$ The national court asked whether periods of employment completed in Switzerland before the entry into force of the FMP Agreement must be taken into account when calculating the remuneration of contractual public servants working in Austria. A number of employees of the State of Tirol were previously employed in Swiss health institutions, but the periods prior to 1 June 2002 - the date of the entry into force of the FMP Agreement - were not taken into consideration for calculating their salaries. After the AG had delivered his opinion, the case was removed from the register. In his opinion, the AG confirmed the Court's jurisdiction and approved the direct effect of Article 9(1) of Annex I of the FMP Agreement. Furthermore, he took the view that the latter provision should be construed in line with the interpretation on Article 45 TFEU and other provisions prohibiting discrimination in employment in agreements with non-member countries. ${ }^{209}$

In Grimme the applicant was not able to rely on Article 9 of Annex I to the FMP Agreement, which guarantees equal treatment of employed persons who are nationals of a contracting Party in the territory of another contracting party, because $\mathrm{Mr}$ Grimme was a German national who carried out his activity as an employee for the Hamburg branch of Bertil Grimme in Germany. As a result, the Court opined that

205

207

208

Case $C-339 / 0$ August 2006, OJ C 294, 2 December 2006, p. 35; the Opinion of AG Ruiz-Jarabo Colomer was delivered on 6 June 2006.

209 See Opinion of AG Ruiz-Jarabo Colomer, paras. 37-45 of 6 June 2006 on Case C339/05 Zentralbetriebsrat der Landeskrankenhäuser Tirols, removed by Order of 4 August 2006, OJ C 294, 2 December 2006, p. 35. 
there could be no question of discrimination by the authorities of a contracting party against a national of another contracting party. ${ }^{210}$

\subsection{Turkish Nationals}

Title II of the Additional Protocol concerning the movement of persons and services specifies the principle of non-discrimination with regard to employment conditions in its Article 37: "As regards conditions of work and remuneration, the rules which each Member State applies to workers of Turkish nationality employed in the Community shall not discriminate on grounds of nationality between such workers and workers who are nationals of other Member States of the Community." This principle is further qualified in Article 10(1) of Decision No 1/80 referring to "Turkish workers duly registered as belonging to their [of the Member States'] labour forces”. These Turkish workers and their family members shall, moreover, be entitled, on the same footing as EU workers, to assistance from the employment services in their search for employment. ${ }^{211}$

In Wählergruppe Gemeinsam, Article 10(1) of Decision No 1/80 was attributed direct effect and successfully invoked in a legal dispute in which Turkish workers were denied the right to stand as a candidate for the elections of a chamber of workers in Austria because they did not hold Austrian nationality. ${ }^{212}$ In legal proceedings against the Netherlands, the Commission successfully contested the fees required from Turkish nationals for residence permits: the Court made clear that these charges must be proportionate to those asked from Union citizens on the basis of the nondiscrimination principles (Articles 9 of the Ankara Agreement and 10(1) of Decision No 1/80) and the stand-still clauses (Article 13 of Decision No 1/80 and Article 41 of the Additional Protocol). ${ }^{213}$ In particular, the Court argued that the nondiscrimination clauses aimed to promote the integration of migrant Turkish workers and Turkish nationals who move for the purposes of establishment or in order to provide services in a Member State.

\subsection{Nationals of the Western Balkan Countries}

The SAAs with the Western Balkan countries (Albania, Croatia, the FYROM and Montenegro, Serbia and Bosnia and Herzegovina) all contain the same equal treatment clause in view of employment. ${ }^{214}$ It enshrines that, "subject to the conditions and modalities applicable in each Member State, treatment accorded to workers who are nationals of $[. .$.$] and who are legally employed in the territory of a$ Member State shall be free of discrimination based on nationality, as regards working condition, remuneration or dismissal, compared to nationals of that Member State."

\footnotetext{
210 Case C-351/08 Grimme [2009] ECR I-10777, paras. 46-49.

211 Art. 10(2) of Decision No 1/80.

212 Case C-171/01 Wählergruppe Gemeinsam [2003] ECR I-4301.

213 Case C-92/07 Commission v. The Netherlands [2010] ECR I-06383.

214 See Art. 46 of the SAA with Albania; Art. 47 of the SAA with Bosnia and Herzegovina; Art. 45 of the SAA with Croatia; Art. 44 of the SAA with Macedonia; Art. 49 of the SAA with Montenegro; Art. 49 of the SAA with Serbia.
} 
The Member States must accord treatment free from any discrimination based on nationality to workers of San Marino nationality, employed in their territory, compared to its own nationals as regards working conditions or remuneration in line with Article 20 of the Cooperation and Customs Union Agreement between the EU and the Republic of San Marino. The formulation in the Cooperation Agreement concluded with Andorra is weaker: the contracting parties shall avoid all discrimination based on nationality against workers who are nationals of the other contracting party and legally resident on their respective territories with regard to working conditions, pay and redundancy. ${ }^{215}$

\subsection{Nationals of the Mediterranean ENP States}

\subsubsection{Nationals of Algeria, Morocco and Tunisia}

The Euro-Mediterranean Agreements with the Maghreb countries Algeria, Morocco and Tunisia all contain a Title VI on cooperation in social and cultural matters, including a chapter 1 on workers. Under this chapter 1 on workers, the association agreements stipulate an identical equal treatment provision in view of employment conditions. It is interesting to point out that the former equal treatment provisions in the Cooperation Agreements were slightly amended in the new version of the EuroMediterranean Agreements in that non-discrimination in view of dismissal was explicitly added for paid employment on a permanent basis. Thus, the provision enshrines that the treatment accorded by each Member State to Maghreb workers employed in its territory shall be free from any discrimination based on nationality, as regards working conditions, remuneration and dismissal, relative to its own nationals. Maghreb workers who are allowed to undertake paid employment in a Member State on a temporary basis enjoy equal treatment in view of working conditions and remuneration. ${ }^{216}$

The Euro-Mediterranean Agreements with the Maghreb countries include a new rule that did not exist in the Cooperation Agreements. This rule lays down that the provisions of this chapter on workers shall not apply to nationals of the parties residing or working illegally in the territory of their host country. ${ }^{217}$ In other words, the rights to equal treatment in working conditions and in social security issues seem to be forfeited if a national of the parties has an unauthorised status. H. Verschueren emphasised that it is unclear what exactly is meant by the term "illegally" and he stressed that the derogation covered both illegally resident nationals, as well as illegally employed nationals who have legal residence. ${ }^{218}$ The Euro-Mediterranean

\footnotetext{
215 Art. 5 of the EU-Andorra Cooperation Agreement.

216 See Art. 67 of the Euro-Mediterranean Agreement with Algeria; Art. 64 of the EuroMediterranean Agreements with Morocco and Tunisia.

217 See Art. 69 of the Euro-Mediterranean Agreement with Algeria; Art. 66 of the EuroMediterranean Agreements with Morocco and Tunisia.

218 H. Verschueren, 'Social Security Co-ordination in the Agreements between the EU and Mediterranean Countries, in particular Turkey and the Maghreb Countries', in: D.
} 
Agreements with Morocco and Tunisia contain a Joint Declaration that states that with regard to the absence of discrimination as regards redundancy, Article 64(1) of the Euro-Mediterranean Agreement may not be invoked to obtain renewal of a residence permit. The granting, renewal or refusal of a residence permit shall be governed by the legislation of each Member State and the bilateral agreements and conventions in force between Tunisia/Morocco and the Member States. ${ }^{219}$

The Court had already indicated in Kziber that the equal treatment clause relating to employment conditions contained in Article 40(1) of the EEC-Morocco Cooperation Agreement is capable of having direct effect. ${ }^{220}$ This was confirmed for the first time in El-Yassini.221 In that case, the Court was asked whether this equal treatment clause included security of employment where the applicant was granted limited leave only and faced an expulsion decision. The Court first stated that it is clear from case law that Article 48(3) EC Treaty (Article 45(3) TFEU) allows Member States to take measures on grounds of public policy, public security or public health, in view of nationals of other Member States, which cannot apply to their own nationals inasmuch as under international law they may not expel them from the national territory or deny them entry to it. As a consequence to this, the situation must be the same in relation to an agreement concluded between the EU and a third country, such as the EEC-Morocco Agreement. In accordance with the opinion of AG Léger, the Court decided that the equal treatment provision on working conditions ipso facto cannot imply that the Member States are prohibited from refusing to extend the residence permit of a Moroccan migrant worker employed on its territory, even though such a measure, by its very nature, could not be taken against a national of the Member State concerned.222 Moreover, an international treaty should be construed in reference to its wording but also in the light of its objectives and purpose. Considering the substantial differences of the wording of the objectives and purpose of the EEC-Morocco Agreement on the one hand and the Ankara Agreement on the other, the former cannot be interpreted in analogy to the latter. Thus, the Court concluded that the Member States enjoy discretion in determining whether or not to extend the residence permit of a Moroccan worker lawfully employed in the host Member State when the initial reason for the grant of his leave to stay no longer exists by the time his residence permit expires. Yet, the situation would be different if the national court were to find that the host Member State has granted the Moroccan worker specific rights in relation to employment which were more extensive than the rights conferred upon him by that State under his residence permit.

The legal dispute in Gattoussi dealt with a Tunisian national who married a German citizen and legally entered Germany in 2002 for the purpose of family reunification. ${ }^{223}$ While the German authorities issued Mr Gattoussi a temporary residence permit, he received a work permit of indefinite duration. Upon notice by

Pieters and P. Schoukens (eds.), The Social Security Co-ordination Between the EU and NonEU Countries (Intersentia, Antwerp 2009), p. 46. Tunisia and Morocco.

Case C-18/90 Kziber [1991] ECR I-199, para. 22.

Case C-416/96 El-Yassini [1999] ECR I-1209.

Case C-416/96 El-Yassini [1999] ECR I-1209, paras. 45-46.

Case C-97/05 Gattoussi [2006] ECR I-11917. 
Mr Gattoussi's wife that she and her husband were living apart, the mayor of Rüsselsheim curtailed the period of validity of Mr Gattoussi's residence permit and asked Mr Gattoussi to leave Germany without delay. This way of proceeding was justified on the grounds that he was no longer living with his wife, - the reason he was granted a residence permit in the first place - that the work permit of indefinite duration did not give rise under German law to a continued residence and employment right and that Mr Gattoussi had no independent right to remain. The dispute was dealt with by the Administrative Court in Darmstadt, which suspended the proceedings and asked the Court in a preliminary ruling whether Article 64 of the Euro-Mediterranean Agreement had any effect on the right to remain.

By following the approach taken in well-established case law, in a first step the Court made clear that Article 64(1) of the Euro-Mediterranean Agreement had direct effect. $^{224}$ In its reasoning, the Court extensively referred to the El-Yassini ruling stating that the circumstances of the cases are comparable. Contrary to the considerations of the German government, the Court held that a Tunisian national, under certain circumstances, can rely on the prohibition of discrimination in Article 64(1) of the Euro-Mediterranean Agreement for the purpose of contesting a measure taken by a Member State in the limitation of his right to remain. If Member States could limit the effectiveness of this provision by using national law, not only would it undermine the provisions of an EU agreement concluded with a third country, but it would also jeopardise the uniform application of that principle. The Court reiterated that if a host state has previously granted the migrant worker specific rights relating to employment, which are more extensive than the right of residence conferred on him by that state, it cannot then reopen the question on that worker's situation on grounds unrelated to the protection of a legitimate national interest such as public security, public policy or public health, also with regard to the principles of the protection of legitimate expectations and of legal certainty. 225 Hence, Article 64(1) of the Euro-Mediterranean Agreement may have effects on the right of a Tunisian national to remain in the territory of a Member State in the case where that person has been duly permitted by that state to work there for a period extending beyond the period of validity of his permission to remain.

The case law on the equal treatment clause in social security matters of the cooperation agreements is fully transposable to the Euro-Mediterranean Agreements which is identically worded and has objectives which may be viewed as directly furthering those on which the Cooperation Agreement is based. ${ }^{226}$ By analogy, the case law on the equal treatment clause relating to employment conditions is transposable to the identical provision in the respective Euro-Mediterranean Agreements.

6.7.2 Nationals of Egypt, Israel, Jordan and Lebanon

Chapter 1 of Title VI of the Euro-Mediterranean Agreement with Egypt deals with dialogue and cooperation in social matters. Article 62 states that "the parties reaffirm

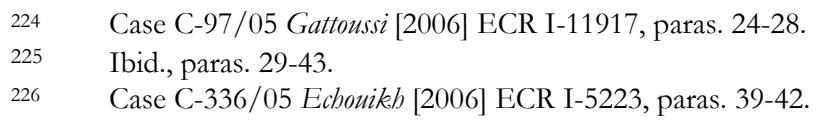


the importance they attach to the fair treatment of their workers legally residing and employed in the territory of the other party". This is not the equal treatment provision known from other association agreements. It is merely recognition of the significance of according fair treatment to the workers of another party. The question arises immediately as to what fair treatment means. Hence, the provision contains a weak commitment to ensure "fair treatment" and cannot be equalised with a nondiscrimination clause. Next, the Member States and Egypt, at the request of any of them, agree to initiate talks on reciprocal bilateral agreements related to the working conditions and social security rights of Egyptian and Member State workers legally resident and employed in their respective territory. On the basis of Article 63 of the Euro-Mediterranean Agreement with Egypt, the parties shall conduct regular dialogue concerning social matters which are of interest to them including migrant communities' living and working conditions, legal and irregular migration, as well as actions to encourage equal treatment between Egyptian and EU nationals, mutual knowledge of cultures and civilisations, the furthering of tolerance and the removal of discrimination. The dialogue shall promote progress in field of movement of workers and equal treatment and social integration of Egyptian and EU nationals legally residing in the territory of their host countries. The wording of these provisions is remarkable seeing that they enable the parties to enter into negotiations but they do not entail any obligations.

The Euro-Mediterranean Agreement concluded with Israel does not contain any references as regards equal treatment in view of working conditions whatsoever. Article 57 of the Euro-Mediterranean Agreement stipulates that the parties shall cooperate with regard to defining areas of mutual interest concerning immigration policies and increasing the effectiveness of measures aimed at preventing or curbing irregular migration flows.

Article 80 of the Euro-Mediterranean Agreement with Jordan envisages the establishment of a regular dialogue concerning social matters of mutual interest. This dialogue is aimed at fostering the movement of workers and the equal treatment and social integration of Jordanian and EU nationals legally residing in their host countries and shall inter alia focus on problems related to migrant communities' living and working conditions and projects on the equality of treatment for Jordanian and EU nationals.

The envisaged dialogue under Article 64 of the Euro-Mediterranean Agreement with Lebanon shall cover, among other things, the living and working conditions of migrant communities, legal and irregular migration, as well as schemes and programmes encouraging equal treatment between Lebanese and Community nationals. In a Joint Declaration relating to workers (Article 65 of the Agreement), the parties reaffirm the importance they attach to the fair treatment of foreign workers legally employed in their territory. The Member States moreover agree that, if Lebanon so requests, they are each prepared to negotiate bilateral agreements relating to the working conditions, remuneration, dismissal and social security rights of Lebanese workers legally employed on their territory. 
The PCAs concluded with Armenia, Azerbaijan, Belarus, Georgia, Moldova and Ukraine contain a Title IV on provisions affecting business and investment, as well as a Chapter I under this Title on labour conditions. Chapter I lays down that the EU and the Member States shall endeavour to ensure that the treatment accorded to nationals of the respective partner country legally employed in the territory of a Member State shall be free of any discrimination based on nationality, as regards working conditions, remuneration or dismissal, as compared to its own nationals subject to the laws, procedures and conditions applicable in each Member State. The wording of the equal treatment clause is very weak. The parties shall merely endeavour to ensure equal treatment for nationals of the other contracting parties. Arguably, these clauses do not qualify for direct effect in line with the case of the Court of Justice.

\subsection{Nationals of Russia}

Chapter I of Title IV of the PCA with Russia sets forth labour provisions. According to Article 23(1), the EU and its Member States shall ensure, subject to the laws, conditions and procedures applicable in each Member State, that the treatment accorded to Russian nationals, legally employed in the territory of a Member State, shall be free from any discrimination based on nationality, as regards working conditions, remuneration or dismissal, compared to its own nationals. Russia shall, subject to the conditions and modalities applicable in Russia, accord treatment referred to in paragraph 1 to nationals of a Member State who are legally employed in its territory (Article 23(2)). Articles 26 and 27 of the PCA with Russia set out tasks for the Cooperation Council. First, the Cooperation Council shall examine how the working conditions of businessmen can be improved in accordance with the international commitments of the Parties. ${ }^{227}$ Moreover, the Cooperation Council shall make recommendations for the implementation of Articles 23 and 26.228

In its first judgment on the PCA with Russia, the Court gave an interpretation of the scope of the equal treatment provision in Article 23(1). Simutenkov concerned a professional Russian football player who challenged a rule of the Royal Spanish Football Federation which stipulates a limited number of players from countries outside the EEA for competitions at national level. He argued that this rule, which makes a distinction between EEA players and non-EEA players, is in contradiction to Article 23(1) of the PCA in view of Russian players as it limits the exercise of his profession. In her opinion AG Stix-Hackl first examined the direct effect of Article 23(1) of the PCA. Considering the wording of the provision, she concluded that the majority of the language versions, the original English version of the text, as well as the intention of the parties, indicate the obligation, which the provision sets out and thus its binding and direct effect. This finding is confirmed by the purpose and the nature of the agreement: with reference to Article 31(1) of the Vienna Convention of the Law of Treaties (a treaty provision must be interpreted in good faith in accordance with the ordinary meaning to be given to its terms in their context and in the light of its object and purpose), the AG found that although the PCA was more 
advanced than the former trade agreement with Russia, it lagged behind the Europe Agreements. Next, the PCA neither had the objective to establish an association, nor did it provide for accession to the EU. Yet, the AG argued that the prospect of accession is not decisive in the AG's view for a provision to be directly effective, as the case law on the Maghreb cooperation agreements has illustrated. ${ }^{229}$ She added that the comparison of the objectives of the PCA with Russia and the objectives of the cooperation agreements with Algeria and Morocco demonstrate that they correspond in many respects. Just like the Europe Agreement, the PCA with Russia aimed at the gradual integration between the parties; this being a decisive factor as to why some provisions of the Europe Agreements were held to be directly effective. ${ }^{230}$

The AG stressed that this outcome was not altered by the fact that Article 23(1) of the PCA with Russia was subsumed under the heading "Chapter I Labour Conditions" and the analogous chapter in the Europe Agreements was entitled "Chapter I Movement of Workers". Nor was the direct effect of Article 23(1) called into question by Articles 27 and 48 of the PCA with Russia in the view of AG StixHackl. Article 27 lays down that the Cooperation Council makes recommendations for the implementation of Articles 23 and 26, thus the Council shall facilitate the implementation of the latter provisions. Article 48, which stipulates that "for the purpose of this Title, nothing in this agreement shall prevent the parties from applying their laws and regulations regarding entry and stay, work, labour conditions and establishment of natural persons and supply of services, provided that, in so doing, they do not apply them in a manner as to nullify or impair the benefits accruing to any party under the terms of a specific provision of the agreement", did likewise not hinder Article 23(1) from setting out a clear obligation. The AG supported her view by indicating to the case law on the corresponding provisions in the Agreements with Slovakia and Poland and concluded that Article 23(1) of the PCA with Russia has direct effect. ${ }^{231}$ In a next step, the AG scrutinised the scope of Article 23(1) in relation to Article 45 TFEU. For determining the scope of the nondiscrimination rule, she stated that it must be ascertained whether the rule in question in the main proceedings constitutes an employment condition. By reference to the Court's decision in Deutscher Handballbund, the AG reasoned that a rule of a sports federation laying down the circumstances under which professional sportsmen engage in gainful employment falls under Article 23(1) which is worded almost identically as the provisions in the former case. ${ }^{232}$ Therefore, she concluded that the principles of the Bosman case on Article 45 TFEU can be applied to Article 23(1).233

The AG rejected that the sporting rule at issue regulates access to employment of professional players but such clauses "concern the extent to which their clubs may field them in official matches and that participation in such matches is the essential purpose of those players' activity". ${ }^{234}$ The sporting rule in question has direct

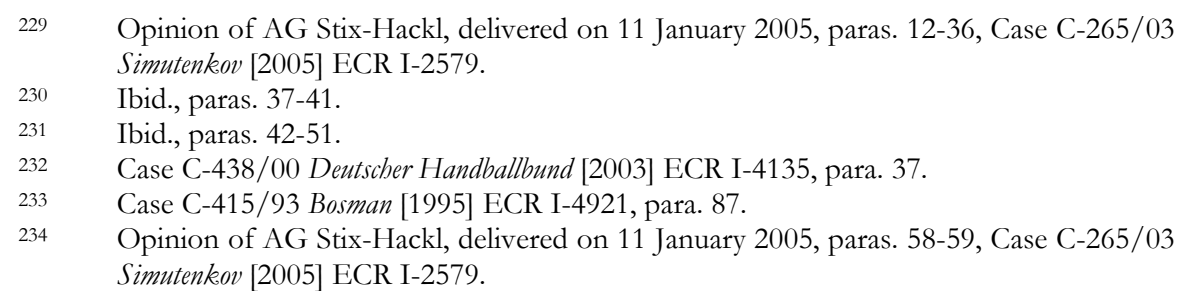


consequences for the participation in games of a Russian soccer player legally employed in a Member State, and hence such a rule affects the working conditions within the scope of Article 23(1).

Lastly, the AG examined whether the sporting rule at issue constitutes a discrimination prohibited by Article 23(1). Again an analogy was drawn to Bosman and Deutscher Handballbund in which the Court held that sporting rules allowing only a limited number of players who are nationals of other Member States to play for matches are incompatible with Article 45(2) TFEU. Seeing that the right of nondiscrimination contained in Article 23(1) has the same scope as the right accorded in Article 45(2) TFEU, the interpretation of the latter provision can be transposed to the former provision. Moreover, the sporting rule in the underlying case corresponded to the challenged sporting rules in Bosman and Deutscher Handballbund. In conclusion, the AG took the position that Article 23(1) of the PCA with Russia precluded a rule under which a sports federation of a Member State applies a provision to a professional Russian sportsman, lawfully employed by a football club of such a federation, which lays down that clubs may use only a limited number of players from states outside the EEA in competitions at national level.

The Court followed the opinion of the AG and also adopted the two-step approach to answer the question referred. ${ }^{235}$ Yet, it did so with a much shorter reasoning. In view of the direct effect of Article 23(1), the Court first of all reiterated that since the effect of provisions of the PCA with Russia within the legal systems of the parties to the PCA has not been clarified therein, it is for the Court to determine the effect in the same way as any other question of interpretation concerning the application of agreements with the EU. Then it pointed out that a provision in an agreement concluded by the EU with a non-member country must be regarded as being directly applicable when, regard being had to its wording and to the purpose and nature of the agreement, the provision contains a clear and precise obligation which is not subject, in its implementation of effects, to the adoption of any subsequent measure referring to Gloszczuk and Wählergruppe Gemeinsam. ${ }^{236}$ These requirements are fulfilled in view of Article 23(1).

This interpretation could neither be called into question by the phrase "subject to the laws, conditions and procedures applicable in each Member State", which precedes Article 23(1) nor by Article 48, which allows for the application of the Member States' laws in view of entry and stay, work, labour conditions and establishment of natural persons and supply of services, to the extent that they do not impair the benefits accruing on the basis of a provision of the agreement. By the same token, Article 27 could not be construed in a way so as to prevent Article 23(1) from having direct effect. The latter provision aimed to facilitate the prohibition of nondiscrimination but cannot be regarded as limiting the immediate application of that prohibition. To support this position, the Court indicated to case law on the Ankara Agreement, as well as on the EEC-Morocco Cooperation Agreement. ${ }^{237}$ The purpose

235 Case C-265/03 Simutenkov [2005] ECR I-2579.

236 Case C-63/99 Gloszczuk [2001] ECR I-6369, para. 30; Case C-171/01 Wäblergruppe Gemeinsam [2003] ECR I-4301, para. 54.

237 Case C-18/90 Kziber [1991] ECR I-199, para. 19; Case C-262/96 Sürül [1999] ECR I2685, para. 66. 
and nature of the PCA did not prevent the direct effect of Article 23(1). As has been ruled in earlier cases, the restriction of the PCA in establishing a partnership, rather than setting out an association or future accession between the parties, is not such as to prevent some of its provisions from having direct effect. ${ }^{238}$

To determine the scope of Article 23(1), the Court referred exclusively to its judgments in Deutscher Handballbund and Bosman. Deutscher Handballbund likewise concerned a sporting rule, limiting the number of professional players coming from non-member countries, which was held to be contrary to an equal treatment clause concerning employment conditions in the former Europe Agreement with Slovakia. The Court made clear that sporting rule at issue related to working conditions and that the ruling in Bosman in the EU context could be transposed to the Association Agreement with Slovakia. The Court detected that the wording of Article 23(1) of the PCA with Russia is very similar to the first indent of Article 38(1) in the Association Agreement with Slovakia and that the interpretation of the latter provision can be applied to Article 23(1).

Neither the context nor the purpose of the PCA with Russia indicated that the equal treatment clause of Article 23(1) should be interpreted differently than what the ordinary sense of the words suggested, regardless of the fact that the PCA with Russia did not envisage an association but intended to ensure the gradual integration between Russia and a wider area of cooperation in Europe. By implication, Article 23(1) stipulated a right to equal treatment in working conditions in the same scope as that which, in similar terms, Member States' nationals are recognised as having under the EC Treaty (TFEU). This precluded any limitation on grounds of nationality as the Court established in Deutscher Handballbund and Bosman. ${ }^{239}$

This limitation based on nationality may not be applied in matches between teams that are carried out to represent countries. However, this limitation does apply in official matches between clubs. No objective justification has been submitted to the Court for the difference in treatment between EEA players and players from Russia. In the light of this, the Court concluded that Article 23(1) of the PCA with Russia precludes the application to a professional Russian sportsman, who is lawfully employed by a club in a Member State, of a sporting rule, which provides that clubs may only field a limited number of non-EEA players in competitions at the national level.

\subsection{Nationals of the ACP States}

While non-discrimination plays a prominent role in Article 13 of the Cotonou Agreement, only its paragraph 3 stipulates a clear and enforceable right to nondiscrimination in working conditions for ACP nationals. Article 13(1) and (2) specify loose commitments in the field of non-discrimination, including an in-depth political dialogue, the parties' international law obligations to respect human rights and to abolish all forms of discrimination, in particular on the grounds of origin, sex, race, 
language and religion and the fair treatment of third-country nationals legally residing in their territories, in that they shall be granted rights and obligations comparable to national citizens.

Article 13(3) of the Cotonou Agreement stipulates that the treatment accorded by each Member State to ACP workers legally employed in its territory, in view of working conditions, remuneration and dismissal, shall be free from any discrimination based on nationality relative to its own nationals. In turn, each ACP State accords comparable non-discriminatory treatment to workers who are nationals of a Member State and who are legally employed in its territory. The first sentence of Article 13(3) regarding equal treatment for ACP workers arguably qualifies for direct effect considering its clear, precise and unconditional wording and the Court's judgment in Simutenkov. ${ }^{240}$ No case has been decided by the Court yet in this respect but analogies can be drawn.

\subsection{Nationals of the Central Asian Countries}

The PCAs that the Community concluded with the five Central Asian countries Kazakhstan, Kyrgyz Republic, Tajikistan, Turkmenistan and Uzbekistan all contain a provision on labour conditions that envisages equal treatment in working conditions under the respective Title IV (provisions affecting business and investment). ${ }^{241}$ For the nationals of the five Central Asian countries, this equality in treatment is rather weak as the Community and the Member States shall merely endeavour to ensure that the treatment accorded to nationals of the Asian country concerned, legally employed in the territory of a Member State, shall be free from any discrimination based on nationality, as regards working conditions, remuneration or dismissal, compared to its own nationals. This equal treatment "commitment" is in principle reciprocal, however the PCAs with Uzbekistan and the Kyrgyz Republic contain a real equal treatment obligation in that the latter states shall, in turn, ensure equal treatment in working conditions. The Cooperation Council concerned shall take implementing measures in this regard.

\subsection{Other Sources of EU Law Applicable to Third-Country Nationals}

The EU Charter stipulates in Article 15(3) that nationals of third countries who are authorised to work in the territories of the Member States are entitled to working conditions equivalent to those of citizens of the Union. With regard to dismissal, the EU Charter provides protection against unjustified dismissal for every worker in accordance with Union law and national laws and practices. ${ }^{242}$ Article 31 of the EU Charter guarantees the right to fair and just working conditions which respect the health, safety and dignity of workers, as well as the right to the limitation of maximum working hours, to daily and weekly rest periods and to an annual period of paid leave.

Case C-265/03 Simutenkov [2005] ECR I-2679.

All the PCAs, except for the one concluded with Turkmenistan, have entered into force as of 6 December 2011.

Art. 30 of the EU Charter. 
Next, the three Council directives on long term resident status for third-country nationals, ${ }^{243}$ on the admission conditions for highly qualified workers (EU Blue Card) ${ }^{244}$ and for researchers, ${ }^{245}$ all postulate equal treatment with nationals in working conditions, including pay and dismissal - for EU Blue Card holders this equal treatment also applies to health and safety requirements at the workplace. For longterm residents Member States may restrict equal treatment concerning access to employment and self-employed activities in cases where, in line with national or EU legislation, these activities are reserved to nationals, EU or EEA citizens. ${ }^{246}$ Thirdcountry workers enjoy equal treatment with nationals of the Member State where they reside as regards: working conditions, including pay and dismissal as well as health and safety at the workplace; and advice services offered by employment offices in accordance with Article 12(1)(a) and (h) of Directive 2011/98/EU on a single permit. $^{247}$

\subsection{Equal Treatment in Working Conditions Compared}

In his opinion in the Pavlov case, AG Mengozzi encapsulated the Court's approach as regards the compatibility test of a national rule with a clause in an association agreement stipulating equal treatment in working conditions. According to the AG, the Court, assessed whether the rule referred to indeed covered working conditions and, secondly, whether the rule indeed constituted discrimination prohibited by the association agreement concerned. ${ }^{248}$ Working conditions comprise the legal rules applicable to the employment relationship concerned as well as the advantages, material or other, granted to the workers, such as:

- a grant of a separation allowance to compensate for the inconveniences suffered by a worker separated from his home;

- a national rule under which nationals of a third country with which the Community has concluded an association agreement may fill a post for foreign

243 Art. 11(1)(a) of Council Directive 2003/109/EC of 25 November 2003 concerning the status of third-country nationals who are long-term residents.

244 Art. 14(1)(a) of Council Directive 2009/50/EC of 25 May 2009 on the conditions of entry and residence of third-country nationals for the purposes of highly qualified employment.

245 Art. 12(b) of Council Directive 2005/71/EC of 12 October 2005 on a specific procedure for admitting third-country nationals for the purposes of scientific research.

246 Art. 11(3)(a) of Council Directive 2003/109/EC of 25 November 2003 concerning the status of third-country nationals who are long-term residents.

247 Directive 2011/98/EU of the European Parliament and of the Council of 13 December 2011 on a single application procedure for a single permit for third-country nationals to reside and work in the territory of a Member State and on a common set of rights for third-country workers legally residing in a Member State; the third-country workers referred to under Art. 12 are defined in Art. 3(1)(b) and (c) of Directive 2011/98/EU, meaning: third-country nationals who have been admitted to a Member State for purposes other than work, in accordance with Union or national law, who are allowed to work and who hold a residence permit in accordance with Regulation (EC) No 1030/2002; and third-country nationals who have been admitted to a Member State for the purpose of work in accordance with Union or national law.

248 Opinion of AG Mengozzi of 17 March 2011 in Case C-101/10 Pavlov [2011] Judgment of 7 July 2011, not yet reported, para. 39. 
language assistants only by means of contracts of employment for a definite period;

- legislation allowing only national researchers to be registered on the organisation chart of the national research council where that registration determines contract duration and career development. ${ }^{249}$

By way of contrast, working conditions do not include the conditions of access to a profession in themselves. ${ }^{250}$ AG Mengozzi emphasised, in this context, the Court's three-stage procedure: first, it had to determine whether the association agreement prohibited discrimination; then, it had to examine the scope of this prohibition on discrimination and particularly whether this scope might be comparable to that conferred on a similar provision contained in the EC Treaty; finally, if the two previous questions had received an affirmative reply, it remained to be verified whether the discrimination could be objectively justified. ${ }^{251}$

Despite the fact that not all the equal treatment provisions as regards working conditions that can be found in association, cooperation and partnership agreements require legal residence or legal employment explicitly, it can be inferred that, in order for a third-country national to successfully invoke such a provision, he or she must have an authorised status, a work permit in the Member State of residence and the discrimination at hand must relate to working conditions. The Court has ruled on some of the equal treatment provisions as regards working conditions contained in association agreements but not on all. However, the existing case law indicates that a number of the provisions qualify for direct effect by implication. This certainly holds true for the non-discrimination rules in the SAAs concluded with the Western Balkan countries, seeing that the equal treatment clause in the SAAs for workers is identically worded as the one in the PCA with Russia. Considering the precise, clear and unconditional wording of the latter provision, in addition to the Simutenkov ruling and the fact that the SAAs aim at the integration of the respective Western Balkan countries into the EU, the direct effect of latter provisions can be implied. ${ }^{252}$

In the same vein, Article 13(3) of the Cotonou Agreement can be said to be directly effective: similar to the objectives of the PCA with Russia, the Cotonou Agreement aims to "promote and expedite the economic, cultural and social development of the ACP States, with a view to contributing to peace and security and to promoting a stable and democratic political environment". 253 The Cotonou Agreement differs from the PCA with Russia in so far as the reduction and eventual eradication of poverty are attributed top priority. In this context it is crucial to recall that the objective of an association or cooperation agreement that the EU has concluded with a third country is not of importance in view of the direct effect of a provision therein,

\footnotetext{
249 See Case 152/73 Sotgin [1974] ECR 153, para. 8; Case C-162/00 Pokrzeptowicz-Meyer [2002] ECR I-1049, para. 39; Case 225/85 Commission v. Italy [1987] ECR 2625. See Opinion of AG Mengozzi of 17 March 2011 in Case C-101/10 Pavlov [2011], para. 57; Case C-101/10 Pavlov [2011] Judgment of 7 July 2011, not yet reported.

251 Opinion of AG Mengozzi of 17 March 2011 in Case C-101/10 Pavlov [2011] Judgment of 7 July 2011, not yet reported, para. 39 .

252 Case C-265/03 Simutenkov [2005] ECR I-2679.

253 See Art. 1 of the Cotonou Agreement.
} 
as the Court made clear in 1991 in Kziber. ${ }^{254}$ The comparison of the equal treatment clauses, in view of employment conditions in the Cotonou Agreement on the one hand and in the PCA with Russia on the other, has been subject to academic deliberation. It has been suggested that the Member States' obligation to guarantee equal treatment is anchored in a stronger fashion in the PCA with Russia than in the Cotonou Agreement when interpreted literally, seeing that in the former treaty the Member States "shall ensure that the treatment accorded to Russian nationals $[\ldots]$ shall be free from any discrimination based on nationality". ${ }^{255}$ Still, there is strong evidence that ACP workers can directly rely on Article 13(3), taking into account that the provision is identically worded as the equal treatment clauses as regards working conditions for Maghreb workers contained in the Euro-Mediterranean Agreements, which were held to be directly effective in the case of the agreements with Morocco and Tunisia. ${ }^{256}$ The Court held in El-Yassini and Gattoussi that the equal treatment rule in employment may have effects on the right of a Tunisian national to remain in the territory of a Member State in a case where that person has been duly permitted by that state to work there for a period extending beyond the period of validity of his permission to remain. ${ }^{257}$

By contrast, the equal treatment provisions in the PCAs with the Eastern ENP partner states arguably do not entail direct effect considering the weak wording: the parties shall merely endeavour to ensure equal treatment for nationals of the other contracting parties. The question arises whether the obligation for a party to endeavour to ensure equal treatment is sufficient for the Court to accord it direct effect in the future. In other words, is the provision clear, precise and not subject to further implementing measures? Can the obligation to make efforts to ensure nondiscrimination be equalised with the obligation to ensure non-discrimination? Certainly, the effet utile of that provision is undermined if individuals could not invoke it directly before national courts. On the other hand, a counter-argument relates to the fact that the equal treatment provision is addressed to the contracting parties and thus states, only. In the past however, this has not prevented the Court from attributing direct effect to a treaty provision. Taking into account the wording of the provision and the fact that major importance was attached to the literal meaning in the Simutenkov ruling, it must be concluded that nationals of the Eastern ENP partners that have concluded a PCA with the EU cannot invoke the equal treatment provision before national courts. ${ }^{258}$

Lastly, it must be borne in mind that the Charter has the same legal status as the Treaties - and thus constitutes primary EU law. It remains to be seen how the Court will interpret the Charter which sets forth working conditions equivalent to those of citizens of the Union for third-country nationals who are authorised to work in the territories of the Member States in Article 15(3). The wording of the provision raises

\footnotetext{
254 Case C-18/90 Kziber [1991] ECR I-199, para. 21.

255 K.A. Schuilenburg, 'The ECJ Simutenkov Case: Is Same Level Not Offside After All?', No 13 Policy Papers on Transnational Economic Law (2005), p. 6.

256 See Case C-416/96 El-Yassini [1999] ECR I-1209; Case C-97/05 Gattoussi [2006] ECR I-11917.

257 Ibid.

258 Case C-265/03 Simutenkov [2005] ECR I-2679.
} 
the question as to whether "equivalent" must be construed as "same" or merely as "corresponding" as this difference in interpretation can affect the outcome.

The right to become a member of a trade union and the right stand for elections for bodies representing employees in a company enables migrant workers to actively participate and organise the work environment in the host country.

\subsection{EEA Nationals}

Article 8 of Regulation (EU) No 492/2011, that is of relevance for the EEA, requires equality of treatment for workers who are nationals of a Member State and who are employed in the territory of another EEA state as regards membership of trade unions and the exercise of rights attaching thereto, including the right to vote. While workers may be excluded from taking part in the management of bodies governed by public law and from holding an office governed by public law, the person concerned shall have the right to be eligible to be a member of workers' representative bodies in the undertaking. In the dispute of $A S T I$, the Court held that the exercise of the trade union rights referred to in Article 8 of Regulation (EU) No 492/2011 extended the notion of trade-union organisations in the strict sense and included the participation of workers in bodies which, while not being, trade-union organisations in law, perform similar functions as regards the defence and representation of workers' interests. ${ }^{259}$ In Commission v. Austria, the Court clarified that the Republic of Austria had failed to fulfil its obligations under Article 39 EC (now Article 45 TFEU), Article 8 of Regulation (EU) No 492/2011 and Article 28 of the EEA Agreement by denying workers who are nationals of other EU Member States or the EEA the right to stand for election to workers' chambers. By denying workers, who are nationals of a non-Member State with which the Community has concluded an agreement prohibiting discrimination, as regards conditions of work, against any such workers legally employed in a Member State, the right to stand for election to works councils and the general assemblies of workers' and employees' chambers, the Austrian authorities have not complied with the obligations under those agreements. ${ }^{260}$

\subsection{Swiss Nationals}

A Swiss national who is employed in an EU Member State enjoys equal treatment in terms of membership of trade union organisations and exercise of union rights, including the right to vote and right of access to executive or managerial positions within a trade union organisation. Such a person has the right to be eligible for election to bodies representing employees in an undertaking but $\mathrm{s} /$ he may be excluded from involvement in the management of public law bodies and from holding an office governed by public law. ${ }^{261}$

\footnotetext{
259 Case C-213/90 ASTI [1991] ECR I-3507.

260 Case C-465/01 Commission v. Austria [2004] ECR I-8291.

261 Art. 9(5) of Annex I of the FMP Agreement.
} 
While EU-Turkey association law does not provide for a right to join trade unions and stand for elections, the Court held in Wäblergruppe Gemeinsam that Article 10(1) of Decision No 1/80 on equal treatment in working conditions had direct effect and could successfully be invoked by Turkish workers who were denied the right to stand as a candidate for the elections of a chamber of workers in Austria because they did not hold Austrian nationality. ${ }^{262}$ By implication, in order to be able to rely on the said provision, the Turkish nationals in question must meet the conditions set out in Article 6(1) of Decision No 1/80.263

\subsection{Other Sources of EU Law Applicable to Third-Country Nationals}

The freedom of assembly and association as laid down in Article 12 of the EU Charter includes the right of everyone to form and join trade unions for the protection of his or her interests. EU Blue Card holders and third-country workers under Directive 2011/98/EC enjoy equal treatment regarding freedom of association and affiliation and membership of an organisation representing workers or employers or of any organisation whose members are engaged in a specific occupation, including the benefits conferred by such organisations, without prejudice to the national provisions on public policy and public security. ${ }^{264}$ Third-country nationals holding long-term resident status have a right to equal treatment with nationals in view of freedom of association and affiliation and membership of an organisation representing workers or employers or of any organisation whose members are engaged in a specific occupation, including the benefits conferred by such organisations, without prejudice to the national provisions on public policy and public security. However, the Member State concerned may restrict equal treatment to cases where the registered or usual place of residence of the long-term resident lies within the territory of the Member State concerned. ${ }^{265}$

262 Case C-171/01 Wählergruppe Gemeinsam [2003] ECR I-4301.

263 Art. 6(1) of Decision No $1 / 80$ requires Turkish nationals to have the status of a "worker", to be "duly registered as belonging to the labour force" and to be in "legal employment", see Part V, Section 5.3 on the employment and residence rights of Turkish nationals.

264 Art. 14(1)(b) of Council Directive 2009/50/EC of 25 May 2009 on the conditions of entry and residence of third-country nationals for the purposes of highly qualified employment; Art. 12(1)(b) of Directive 2011/98/EU of the European Parliament and of the Council of 13 December 2011 on a single application procedure for a single permit for third-country nationals to reside and work in the territory of a Member State and on a common set of rights for third-country workers legally residing in a Member State; the third-country workers referred to under Art. 12 are defined in Art. 3(1)(b) and (c) of Directive 2011/98/EU on a single permit, meaning: third-country nationals who have been admitted to a Member State for purposes other than work in accordance with Union or national law, who are allowed to work and who hold a residence permit in accordance with Regulation (EC) No 1030/2002; and third-country nationals who have been admitted to a Member State for the purpose of work in accordance with Union or national law.

265 Arts. 11(1)(g) and 2 of Council Directive 2003/109/EC of 25 November 2003 concerning the status of third-country nationals who are long-term residents. 
EEA and Swiss nationals employed in an EU Member State are entitled to equal treatment in terms of membership of trade union organisations and the exercise of union rights, including the right to vote and to the right to stand for election to workers' chambers. ${ }^{260}$ Next, Turkish workers have the right to join trade union and stand for elections in conformity with Article 10(1) of Decision No 1/80 on equal treatment in working conditions. ${ }^{267}$ The EU Charter has strengthened the right of third-country nationals specifying the right of everyone to form and join trade unions for the protection of his or her interests. ${ }^{268} \mathrm{EU}$ Blue Card holders, third-country workers under Directive 2011/98/EC, and long-term residents may claim equal treatment with nationals of the Member State where they reside with regard to freedom of association and affiliation and membership of an organisation representing workers or employers or of any organisation whose members are engaged in a specific occupation. ${ }^{269}$

\section{8}

\section{CONCLUSION TO PART V}

The preceding legal analysis of the broad range of rights relating to entry, employment (including the right to join trade unions and exercise union rights) and residence, as well as family reunification reveals a great fragmentation and differentiation of the EU's migration policy. As regards entry rights for short-term stays the EU visa policy stipulates whether a third-country national needs to be in possession of a visa or not. Contingent on the applicable legal regime, third-country nationals may either benefit from the freedom of movement in the EU, such as Swiss citizens, or they can merely rely on a weak equal treatment clause regarding working conditions, such as Azerbaijani nationals. The legal position accorded to nationals of the state party to an association agreement with the EU is conditional upon whether a framework envisages future association, as in the case of Turkey and the Western Balkan countries, or simply cooperation, as in the case of Russia or Armenia. As is particularly evident from the bulk of case law on the Ankara Agreement, the Court of Justice has, in many instances, made reference to case law on the EU free movement rules, pointing to Turkey's accession perspective as a candidate country. The Court's generally favourable stance as regards third-country nationals under international agreements is attested in rulings on other agreements too. One can readily assume that the Court's extensive interpretation of employment and residence rules in these agreements has caused the Member States to avoid phrasing subsequent agreements

\footnotetext{
266 See Art. 8 of Regulation (EU) No 492/2011; Case C-465/01 Commission v. Austria [2004] ECR I-8291; Art. 9(5) of Annex I of the FMP Agreement. Case C-171/01 Wählergruppe Gemeinsam [2003] ECR I-4301.

Art. 12 of the EU Charter.

Art. 14(1)(b) of Council Directive 2009/50/EC of 25 May 2009 on the conditions of entry and residence of third-country nationals for the purposes of highly qualified employment; Art. 12(1)(b) of Directive 2011/98/EU of the European Parliament and of the Council of 13 December 2011 on a single application procedure for a single permit for third-country nationals to reside and work in the territory of a Member State and on a common set of rights for third-country workers legally residing in a Member State; Art. 11(1)(g) of Council Directive 2003/109/EC of 25 November 2003 concerning the status of third-country nationals who are long-term residents.
} 
in a similar strong way. With a more restrictive wording the Council aimed to bar direct effect, as is apparent from the formulation of the equal treatment provisions concerning working conditions in the PCAs with the Eastern ENP countries.

The Charter, as well as the five directives that have been adopted on the basis of Title $\mathrm{V}$ TFEU, have considerably buttressed the legal status of all third-country nationals. As concerns family reunion, for instance, the EU Charter and the ECHR set out the fundamental right to respect for family life. ${ }^{270}$ In addition, all third-country nationals enjoy a right to family reunification on the basis of Council Directive 2003/86/EC if lawfully residing in the territory of a Member State. ${ }^{271}$ Council Directive 2003/109/EC has created the long-term resident status for third-country nationals who have lawfully and continuously resided in the territory of a Member State for a period of five years. ${ }^{272}$ This status enhances the legal position and the protection of third-country nationals in the host Member State, and facilitates their integration into the host society. Long-term residents can also acquire the right to reside in the territory of another Member State if certain conditions are met. Other employmentrelated rights have been promoted: under the EU Charter everyone has now the right to form and join trade unions for the protection of his or her interests - a right, which was also incorporated in a number of other directives in the area of legal migration, such as the EU Blue Card Directive. ${ }^{273}$

$270 \quad$ Art. 7 of the EU Charter; Art. 8(1) ECHR.

271 Council Directive 2003/86/EC of 22 September 2003 on the right to family reunification.

272 Council Directive 2003/109/EC of 25 November 2003 concerning the status of thirdcountry nationals who are long-term residents.

273 See Art. 14(1)(b) of Council Directive 2009/50/EC of 25 May 2009 on the conditions of entry and residence of third-country nationals for the purposes of highly qualified employment. 



\section{Part VI : The Legal Position of Third-Country Nationas: Social Security Rights}

Part VI contributes to answering the questions of this dissertation, that is how a privileged legal position of a third-country national holding a certain nationality differs from a "non-privileged" one, by focusing on the specific field of social security. To this end, Part VI explains how social security issues are regulated for nationals of third countries, how different regimes function for nationals holding a specific nationality and how the Court of Justice has created a solid foundation that has clarified the social security position of individuals within the scope of some of such legal regimes. Social security protection of third-country workers and their family members in the EU is vital for ensuring their well-being and for promoting their integration process in the host country. Such protection provides for a "social safety net" because it covers risks that individuals may face in the case of social hardship and poverty which can caused by various circumstances, such as unemployment and disease.

For Community workers and self-employed persons, as well as their family members moving within the Community, it was originally Council Regulation (EC) No $1408 / 71$ on the coordination of social security schemes that provided for equal treatment in social security matters, the coordination thereof, the aggregation of employment and insurance periods for the purpose of calculating benefits and the possibility to export such benefits. ${ }^{1}$ With these principles set out in Council Regulation (EC) No 1408/71, the Community aimed to ensure a secure social security position for workers employed in a Member State other than that of their nationality, seeing that an omission of such coordination would have discouraged workers to migrate in the first place. ${ }^{2}$ In particular, the non-recognition of social security contributions made in one country to the benefit scheme in another country would have constituted a serious obstacle to the free movement of persons. The latter regulation was repealed by Regulation (EC) No 883/2004 that entered into force in May of $2010 .^{3}$

Council Regulation (EEC) No 1408/71 of 14 June 1971 on the application of social security schemes to employed persons, self-employed persons, and to members of their families moving within the Community.

F. Pennings, European Social Security Law (5th edn. Intersentia, Antwerp 2010), p. 3.

Regulation (EC) No 883/2004 of the European Parliament and of the Council of 29 April 2004 on the coordination of social security systems; see also Commission Regulation (EU) No 1244/2010 of 9 December 2010 amending Regulation (EC) No $883 / 2004$ of the European Parliament and of the Council on the coordination of social security systems and Regulation (EC) No 987/2009 of the European Parliament and of the Council laying down the procedure for implementing Regulation (EC) No 883/2004; as well as Regulation (EU) No 465/2012 of the European Parliament and of the Council of 22 May 2012 amending Regulation (EC) No 883/2004 on the coordination of social security systems and Regulation (EC) No 987/2009 laying down the procedure for implementing Regulation (EC) No 883/2004. 
In the light of carefully aligning the movement rules applicable to EU nationals to third-country nationals, the coordination of social security schemes has first been extended to third-country nationals by Council Regulation (EC) No 859/2003, which in the meantime has been replaced by Regulation (EU) No 1231/2010. ${ }^{4}$ This extension has strengthened the social security rights of third-country nationals subject to the condition that they have moved within the EU. Yet, nationals of certain third countries are eligible for more beneficial treatment in that the social security coordination applies without the requirement of moving to another Member State by virtue of the respective applicable legislation, such as an association agreement or a decision dealing with matters of social security. ${ }^{5}$ Other third-country nationals can merely rely on the EU Charter that recognises the entitlement to social security benefits and social advantages in accordance with Union and national legislation and practices. ${ }^{6}$

\section{COORDINATION OF SOCIAL SECURITY AND CONCOMITANT Rights}

\subsection{Regulation (EU) No 1231/2010: Extending Social Security Coordination to Third- Country Nationals}

The coordination of social security for third-country nationals is regulated by a complex regime that has extended rules that have first been only applicable to EU nationals and their family members that have made use of their free movement rights. ${ }^{7}$ With the adoption of Council Regulation (EC) No 859/2003, social security coordination has been extended, for the first time, to third-country nationals who were not already covered by those provisions solely on the grounds of their nationality in 2003. ${ }^{8}$ In the meantime, Council Regulation (EC) No 859/2003 has

4 Council Regulation (EC) No 859/2003 of 14 May 2003 extending the provisions of Regulation (EEC) No 1408/71 and Regulation (EEC) No 574/72 to nationals of third countries who are not already covered by those provisions solely on the ground of their nationality; Regulation (EU) No 1231/2010 of the European Parliament and of the Council of 24 November 2010 extending Regulation (EC) No 883/2004 and Regulation (EC) No $987 / 2009$ to nationals of third countries who are not already covered by these Regulations solely on the ground of their nationality.

5 See for instance the EEA Agreement and Council Decision of 21 October 2010 on the position to be taken by the European Union within the Stabilisation and Association Council established by the Stabilisation and Association Agreement between the European Communities and their Member States, of the one part, and the Republic of Croatia, of the other part, with regard to the adoption of provisions on the coordination of social security systems - Draft - Decision No .../... of the Stabilisation and Association Council established by the Stabilisation and Association Agreement between the European Communities and their Member States, of the one part, and the Republic of Croatia, of the other part, of ... with regard to the provisions on the coordination of social security systems contained in the Stabilisation and Association Agreement (2010/702/EU).

$6 \quad$ Art. 34(2) of the EU Charter.

7 Or alternatively, as regards Council Regulation (EEC) No 1408/71: employed persons and self-employed persons who are nationals of a Member State, as well as their family members, who made use of their free movement rights.

8 Council Regulation (EC) No 859/2003 of 14 May 2003 extending the provisions of Regulation (EEC) No 1408/71 and Regulation (EEC) No 574/72 to nationals of third 
been repealed by Regulation (EU) No 1231/2010 which, in turn, has extended Regulation (EC) No 883/2004 and implementing Regulation (EC) No 987/2009 to nationals of third countries who are not already covered by those provisions solely on the grounds of their nationality. 'Which persons fall within the personal scope of application of Regulation (EU) No 1231/2010? Regulation (EU) No 1231/2010 applies to nationals of third countries, as well as their family members and survivors, who are not already covered by Regulation (EC) No 883/2004 and Regulation (EC) No $987 / 2009$ solely on the ground of their nationality, provided that they have legal residence in a Member State and that they are in a situation which is not confined, in all respects, within a single Member State; thus, the situation has to be characterised by a cross-frontier element. ${ }^{10}$ Denmark and the UK have not been taking part in the adoption of this latter Regulation. ${ }^{11}$

For a better understanding of this intricate legal regime, it important to point out that Regulation (EC) No 883/2004 consolidated the regime for EU nationals and replaced the frequently amended Council Regulation (EEC) No 1408/71 on the application of social security schemes to employed persons, to self-employed persons and to members of their families moving within the Community and updated Council Regulation (EEC) No 574/72 which covers the rules on the implementation of the former regulation. ${ }^{12}$ A.P. van der Mei has pointed out that there are four basic principles that determine the application of the latter two regulations. First, Article 3(1) of Council Regulation (EEC) No 1408/71 lays down the principle of equal treatment in all EEA states, meaning that all persons who fall under the Regulation have the same obligations and benefits under the legislation of the host state as nationals of that state. Second, migrants can only be obliged to adhere to a social security system of one state which is, as a general rule, the state of employment (under Article 11(3)(e) of Regulation (EC) No 883/2004 it is the state of residence

countries who are not already covered by those provisions solely on the ground of their nationality.

See Regulation (EU) No 1231/2010 of the European Parliament and of the Council of 24 November 2010 extending Regulation (EC) No 883/2004 and Regulation (EC) No $987 / 2009$ to nationals of third countries who are not already covered by these Regulations solely on the ground of their nationality; Regulation (EC) No 883/2004 of the European Parliament and of the Council of 29 April 2004 on the coordination of social security systems.

10 See R. Cornelissen, 'The European Co-ordination of Social Security and Third Country Nationals', in: D. Pieters and P. Schoukens (eds.), The Social Security Co-ordination Between the EU and Non-EU Countries (Intersentia, Antwerp 2009), pp. 10-12; on the connection of immigration policy and social security, and more specifically the 'legal residence test', see G. Vonk and S. van Walsum, 'Access Denied. Towards a New Approach to Social Protection for Formally Excluded Migrants', in: G. Vonk (ed.), Cross-Border Welfare State (Intersentia, Antwerp 2012), pp. 21-23.

11 See Recitals 18 and 19 of the Preamble of Regulation (EU) No 1231/2010 of the European Parliament and of the Council of 24 November 2010.

12 Council Regulation (EEC) No 1408/71 of 14 June 1971 on the application of social security schemes to employed persons, self-employed persons, and to members of their families moving within the Community; Council Regulation (EEC) No 574/72 of 21 March 1972 laying down the procedure of implementing Council Regulation (EEC) No 1408/71 of 14 June 1971 on the application of social security schemes to employed persons, self-employed persons, and to members of their families moving within the Community. 
for non-economically active persons). Articles 13 to 17 of the Regulation set out the rules on the determination of the applicable legislation to prevent conflicts of law. Third, the aggregation of insurance periods in another state than that of employment must be taken into consideration to determine the amount of benefit. Finally, the payment of benefits is not contingent upon the place of residence in the state which is responsible for allocating the benefit. This has been labelled as the principle of exportability of benefits. ${ }^{13}$ Community legislation in this field intends to coordinate the national social security legislation, not to harmonise it. ${ }^{14}$ While these principles remain valid for the application of Regulation (EC) No 883/2004, this latter regulation now provides for improved social security coordination with clearer rules. The new framework has solved a number of contentious issues. In particular, Regulation (EC) No 883/2004 covers all EU nationals who are insured under national law - and in doing so promotes European citizenship -, as well as stateless persons, refugees and their family members. Moreover, Regulation (EC) No $883 / 2004$ has reinforced the principle of equal treatment in that it sets forth the cross-border recognition of facts or events, and the instrument has strengthened access to cross-border health care by incorporating the principles set out in relevant case law. ${ }^{15}$

For a long time, the extension of Council Regulation (EC) No 1408/71 to thirdcountry nationals moving with the EU was notably a taboo for the Member States and simply unthinkable. The Porto conference in November of 1994 on social security marked the beginning of a new era in which attitudes have gradually changed by discussing the facts and myths on migration in the European context. ${ }^{16}$ Under the French presidency in the first half of 1995, the Commission put forward an initiative proposing that third-country nationals should have access to health care in crossborder, emergency situations. However, the proposal was neglected in the end because of the UK's opposition which frustrated a positive, unanimous decision. Two years later the Commission came up with a second proposal that extended the scope of Council Regulation (EC) No 1408/71 to nationals of third countries. This time Denmark, Ireland and the UK paralysed the course of action because these countries regarded the legal basis (today Articles 45 TFEU and 48 TFEU) as inadequate for the suggested amendment. ${ }^{17}$ The Gaygusur judgment of the European Court of Human Rights dealing with social security rights as property rights, the Tampere summit of 1999 and the Khalil decision of 2001 on the application of

13 A.P. van der Mei, Free Movement of Persons Within the European Community - Cross-Border Access to Public Benefits (Hart Publishing, Oxford 2003), pp. 63-64.

14 See Recital 4 of the Preamble to Council Regulation (EEC) No 1408/71 of 14 June 1971 on the application of social security schemes to employed persons, self-employed persons, and to members of their families moving within the Community.

15 R. Cornelissen, 'The European Co-ordination of Social Security and Third Country Nationals', in: D. Pieters and P. Schoukens (eds.), The Social Security Co-ordination Between the EU and Non-EU Countries (Intersentia, Antwerp 2009), p. 14; see Arts. 2, 5 and 20 (2) of Regulation (EC) No 883/2004 as well as Case C-56/01 Inizan [2003] ECR I12403 and Case C-372/04 Watts [2006] ECR I-4325.

16 Conference on "Social Security in Europe - Equality between Nationals and NonNationals", organised by the European Commission on 12-14 November 1994 in Oporto, Portugal.

17 Interview with a Commission official of DG Employment, Social Affairs and Equal Opportunities, European Commission, held on 2 February 2011. 
Council Regulation (EC) No $1408 / 71$ to stateless persons, encouraged the Commission to draft a new proposal to extend Council Regulation (EC) No 1408/71 to third-country nationals with Article 63(4) EC (Article 79 TFEU) in 2002.18 This proposal led to the adoption of Council Regulation (EC) No 859/2003 on 14 May 2003 with reservations made by Germany and Austria with respect to family benefits. ${ }^{19}$ However, the cross-border element that is required for Council Regulation (EC) No 859/2003 to be applicable "does not always guarantee that third-country nationals residing legally in a Member State are treated equally as Community nationals in that Member State." 20

\subsection{Nationals of the Former Europe Agreement States}

The Europe Agreements did not contain much in view of social security matters. The fact that they did not even lay down an equal treatment clause in view of social security has been criticised seeing that non-discrimination is considered to be the basis for a system that aims to coordinates social security effectively. ${ }^{21}$ Yet, it was regulated that - with a view to coordinating social security systems - for workers legally employed in a Member State and for their family members legally resident there:

- all periods of insurance, employment or residence completed by such workers in the various Member States should be added together for the purpose of pensions and annuities in respect of old age, invalidity and death and for the purpose of medical care for such workers and such family members;

- any pensions or annuities in respect of old age, death, industrial accident or occupational disease, or of invalidity resulting therefrom, with the exception of non-contributory benefits, should be freely transferable at the rate applied by virtue of the law of the debtor Member State or Member States;

- the worker in question should receive family allowances for their members of the families as defined. ${ }^{22}$ 'EC Social Security Coordination Excluding Third-Country nationals: Still in Line with Fundamental Rights after the Gaygusuz Judgment?', 34 Common Market Law Review (1997), 991.

19 Council Regulation (EC) No 859/2003 of 14 May 2003 extending the provisions of Regulation (EEC) No 1408/71 and Regulation (EEC) No 574/72 to nationals of third countries who are not already covered by those provisions solely on the ground of their nationality.

20 R. Cornelissen, 'The European Co-ordination of Social Security and Third Country Nationals', in: D. Pieters and P. Schoukens (eds.), The Social Security Co-ordination Between the EU and Non-EU Countries (Intersentia, Antwerp 2009), p. 11.

21 S. Pizarro, 'The Agreements on Social Security between the Community and Third States: Legal Basis and Analysis', Records of the Seminar Social Security in Europe: Social Security in Europe: Equality between Nationals and Non-Nationals, Oporto, 10 12 November 1994 (1995), p. 115.

22 See for instance Arts. 38 and 39 of the Europe Agreement with Poland. 


\subsection{EEA Nationals}

The right of equal treatment in employment matters, as provided for in Article 28(2) of the EEA Agreement and in EU secondary legislation integrated into the EEA legal framework would not have been fully effective if safeguards ensuring social security had not been incorporated. In this regard, Article 29 of the EEA Agreement states that the contracting parties shall firstly, in the field of social security for workers and self-employed persons, secure the aggregation of all periods taken into account under the laws of the several countries for the purpose of acquiring and retaining the right of benefit and of calculating the amount of benefit and secondly, the payment of benefits to persons resident in the territories of the contracting parties. This provision is almost identically phrased as Article 48(1) TFEU. Annex VI to the EEA Agreement on social security expands coverage of pertinent EU legislation in this area to the EEA. Importantly, an EEA Joint Committee decision adopted on 1 July 2011 has extended the scope of application of Regulation (EC) No 883/2004 to the EEA states. ${ }^{23}$

Regulation (EC) No 883/2004 applies to sickness benefits, maternity and equivalent paternity benefits, invalidity benefits, old-age benefits, survivors' benefits, benefits in respect of accidents at work or occupational diseases, death grants, unemployment benefits, pre-retirement benefits and family benefits. ${ }^{24}$ With regard to the personal scope, the regulation covers Member States' nationals, stateless persons and refugees residing in a Member State who are or have been subject to the legislation of one or more Member States, as well as to the members of their families and to their survivors; the Regulation also applies to the survivors of persons who have been subject to the legislation of one or more Member States, irrespective of the nationality of such persons, where their survivors are Member States' nationals or stateless persons or refugees residing in one of the Member States. ${ }^{25}$ On the basis of Article 4 of Regulation (EC) No 883/2004, persons that fall under the scope of this Regulation - including EEA nationals - shall enjoy the same benefits and be subject to the same obligations under the legislation of any Member State as the nationals thereof.

Next, the aggregation of periods is guaranteed: the institution of a Member State whose legislation makes the right to benefits, the coverage by legislation, or the access to or the exemption from insurance conditional upon the completion of insurance, employment, self-employment or residence periods shall take into account insurance, employment, self-employment or residence periods completed under the legislation of any other Member State as though they were periods completed under the legislation which it applies. ${ }^{26}$ Article 7 of Regulation (EC) No 883/2004 provides for the exportability of benefits: cash benefits payable under the legislation of one or more Member States or under the present Regulation shall not be made subject to

23 Decision of the EEA Joint Committee No 76/2011 of 1 July 2011 amending Annex VI (Social Security) and Protocol 37 to the EEA Agreement, OJ L 262, 6 October 2011, p. 33; Regulation (EC) No 883/2004 of the European Parliament and of the Council of 29 April 2004 on the coordination of social security systems.

24 Art. 3(1) of Regulation (EC) No 883/2004.

25 Art. 2 of Regulation (EC) No 883/2004.

26 Art. 6 of Regulation (EC) No 883/2004. 
any reduction, amendment, suspension, withdrawal or confiscation on account of the fact that the beneficiary or his/her family members reside in a Member State other than that in which the institution responsible for providing benefits is situated. Article 11 of the Regulation stipulates that persons who are covered by Regulation (EC) No 883/2004 shall be subject to the legislation of a single Member State which is usually the state of employment. Article 11 to 16 set out rules on the determination of the applicable legislation with a view to prevent conflicts of law. The Court decided in Kauer, a case with an EEA connection (Austria being an EEA state at the time), whether periods of child-rearing in an EEA state were to be treated for the purposes of old-age insurance when such periods completed in the national territory were indeed treated as substitute periods for the purposes of old-age insurance. In that case, the Court took a positive stance and held that amended Council Regulation (EEC) No 1408/71, in conjunction with Articles 18, 39 and 43 EC (Articles 21, 45 and 49 TFEU), precluded national legislation under which such child-rearing periods were only considered if they were completed after the entry into force of the regulation in the first state and where the applicant has received cash maternity allowances for the children concerned under the legislation of the same state. ${ }^{27}$

In line with Article 101 of the EEA Agreement and Protocol 37 to the EEA Agreement, the Administrative Commission on Social Security for Migrant Workers was established. The composition, the working methods, and the tasks of this Commission are enshrined in Articles 71 and 72 of Regulation (EC) No 883/2004. The Commission has a number of duties including the administration and interpretation of the provisions of the applicable secondary legislation. Although the interpretations of the Commission are not legally binding, they have an authoritative character with regard to the practical application for the coordination of the national social security schemes. The interpretations that are pertinent for the EEA are listed as decisions in Annex VI as acts of which the contracting parties shall either take due account or note. Corresponding with the sectoral adaptation II of Annex VI, the EEA Joint Committee is responsible for the duties of the Administrative Commission in the EEA context. ${ }^{28}$

\section{$2.4 \quad$ Swiss Nationals}

Article 8 of the FMP Agreement indicates that the contracting parties shall coordinate their social security systems in order to secure equality of treatment; to determine the applicable legislation; to aggregate all periods taken into account by the national legislation of the country concerned for the purpose of calculating, acquiring and retaining benefits; to pay benefits to persons residing in the territory of a contracting party; and to foster mutual administrative assistance between authorities. The provision on equal treatment in Article 9 of Annex I of the FMP Agreement also covers welfare benefits for employed persons and their family members. ${ }^{29}$

27 Case C-28/00 Kauer [2002] ECR I-1343, para. 52.

28 S. Norberg and others, The European Economic Area: EEA law: A Commentary on the EEA Agreement (Fritzes, Stockholm 1993), pp. 421-422.

29 See M.V. Brombacher Steiner, 'Die soziale Sicherheit im Abkommen über die Freizügigkeit der Personen', in: C. Kaddous and D. Felder (eds.), Accords Bilatéraux 
Article 1(1) of Annex II to the FMP Agreement on the coordination of social security schemes specifies that the parties will apply all the EU acts, to which reference is made, that are in force at the date of the signature of the Agreement and as amended by Section A of this Annex, or rules equivalent to such acts. On 16 December 2011, Annex II to the FMP Agreement was amended, and today Regulation (EC) No $883 / 2004$ (as well as implementing and amending legislation) determines the social security coordination between the contracting parties. ${ }^{30}$ Article 1(2) of Annex II states that the term "Member State(s)" contained in the acts referred to in section A of Annex II shall be understood to include Switzerland, in addition to the States covered by the relevant EU acts. ${ }^{31}$ Next, the contracting parties shall take into account the EU acts referred to in Section B, and they shall take note of the EU acts listed in Section $\mathrm{C}$ in line with Article 2 of Annex II.

There have been quite a number of proceedings on the FMP Agreement in the field of social security. The Court decided in Xbymshiti that a third-country national who is lawfully resident in a Member State and works in Switzerland cannot rely on Council Regulation (EC) No 859/2003 (now Regulation (EU) No 1231/2010), which extends the coordination of the social security schemes to third-country nationals who are not already covered by those provisions solely on the ground of their nationality, because that Regulation was not among the EU acts mentioned in Section A of Annex II of the FMP Agreement. ${ }^{32}$ As a result, the Member State concerned was under no obligation to apply the EU rules on the coordination of the social security schemes to that employee and his spouse.

In Grimme the Court ruled that a German national, who is a member of the board of a company limited by shares governed by Swiss law and employed in Germany, could be obliged to join the German statutory pension insurance scheme. This requirement was not incompatible with the FMP Agreement, although members of the board of a company limited by shares governed by German law were not obliged to join that insurance scheme. ${ }^{33}$ In particular, Mr Grimme, as a German national, could not rely on the Article 9 of Annex to the FMP Agreement, which provides for equal treatment in working conditions. The case of Bergström concerned the issue as to whether periods of insurance, employment or self-employment completed in Switzerland have to be taken into consideration upon a Member State national's return to the EU in order to acquire the right to family benefits there. ${ }^{34}$ AG Mazák

Suisse - Union Européenne: Commentaires (Helbing \& Lichtenhahn, Basel 2001), pp. 353368.

$30 \quad$ Council Decision of 16 December 2011 on the position to be taken by the European Union in the Joint Committee established under the Agreement between the European Community and its Member States, of the one part, and the Swiss Confederation, of the other, on the free movement of persons as regards the replacement of Annex II to that Agreement on the co-ordination of social security schemes (2011/863/EU); Regulation (EC) No 883/2004 of the European Parliament and of the Council of 29 April 2004 on the coordination of social security systems; on the personal and material scope of Regulation (EC) No 883/2004, see Section 2.3 on EEA nationals.

31 This was confirmed in Case C-16/09 Schwemmer [2010] ECR I-09717, para. 31.

32 Case C-247/09 Xhymshiti [2010] Judgment of 18 November 2010, not yet reported.

33 On the basis of Arts. 1, 5, 7 and 16 of the FMP Agreement as well as Arts. 12, 17 and 19 of Annex I to the FMP Agreement; Case C-351/08 Grimme [2009] ECR I-10777. Case C-257/10 Bergström [2011] Judgment of 15 December 2011, not yet reported. 
took the view that that the objectives of the FMP Agreement would be greatly compromised if the competent authority of a Member State could disregard such periods unless the relevant periods completed in Switzerland were added to some hypothetical minimum period of insurance, employment or self-employment in the Member State of the competent institution. ${ }^{35}$ As regards the level of the family benefit, the AG considered that the FMP Agreement and Articles 3(1) and 72 of Council Regulation (EC) No 1408/71 did not require income earned in Switzerland to be equated with domestic income in the determination of the entitlement to family benefit in the form of income-related benefit for childcare but that the income levels in the Member State of the competent institution should rather be taken as a comparator or a point of reference. The Court followed the AG in deciding that, where the legislation of a Member State makes the award of a family benefit conditional upon completion of periods of insurance, employment or selfemployment, the competent institution of that Member State must take into account, for those purposes, periods completed in their entirety in the Swiss Confederation. ${ }^{36}$ In a second step, the Court held that where the amount of a family benefit falls to be determined in accordance with the rules governing sickness benefit, that amount awarded to a person who has fully completed the necessary employment periods for acquiring that right in the territory of the other Contracting Party - must be calculated by taking into account the income of a person who has comparable experience and qualifications and who is similarly employed in the Member State in which that benefit is sought. ${ }^{37}$

The dispute in Schwemmer concerned the question whether the German authorities were entitled to reduce the child benefit to which Mrs Schwemmer was entitled under German legislation in respect of the children concerned - such right not being subject to conditions of insurance, employment or self-employment - by an amount corresponding to the family benefits which would be due in Switzerland, according to those same authorities, to the former husband of Mrs Schwemmer, if only he applied for them. ${ }^{38}$

The Court took the view that such a right to benefits under the legislation of a Member State in which one parent resided with the children in favour of which those benefits were granted, which was not subject to conditions of insurance, employment or self-employment, could not be partially suspended in the situation at hand. The situation involved a former spouse - the other parent of the children concerned who would in principle be entitled to family benefits under the legislation of the State of employment, either simply by virtue of the national legislation of that State, or in application of Article 73 of Council Regulation (EEC) No 1408/71 but did not actually draw those benefits because he had not applied for them.

35 Opinion of AG Mazák, delivered on 21 June 2011, Case C-257/10 Bergström [2011] Judgment of 15 December 2011, not yet reported.

36 In conformity with Art. 8(c) of the FMP Agreement and Art. 72 of Council Regulation (EEC) $1408 / 71$.

37 Case C-257/10 Bergström [2011] Judgment of 15 December 2011, not yet reported.

38 Case C-16/09 Schwemmer [2010] ECR I-09717. 


\subsection{Turkish Nationals}

Turkish workers and their family members lawfully residing in an EU Member State are eligible for social security benefits. In 1980, the Association Council adopted a legal regime to coordinate the social security schemes in the Member States as regards Turkish workers and their family members based on Article 39(1) of the Additional Protocol: Decision No 3/80.39 Article 39(2) of the Additional Protocol lays down that the implementing measure must enable Turkish workers to aggregate periods of insurance or employment completed in individual Member States in respect of a number of benefits, as well as regards the provision of health services for workers and their families residing in the Community. ${ }^{40}$ Yet, the implementing measure shall not create an obligation on Member States to take into account periods completed in Turkey. Moreover, the payment of family allowances, in case the worker's family resides in the EU, and the transfer of old-age pensions, death benefits and invalidity pensions to Turkey are guaranteed. ${ }^{41}$ The coordination rules with regard to social security also contribute to progressively securing the free movement of Turkish workers between the parties and within the EU Member States. ${ }^{42}$

Decision No 3/80 partly copies rules laid down in Regulation (EEC) No 1408/71 which coordinates national social security legislation so as to protect the social security rights of persons moving within the EU, or Decision No 3/80 extensively refers to them. ${ }^{43}$ The question arises what happens in cases where such a reference to Council Regulation (EC) No 1408/71 is made considering that this instrument has been repealed by Regulation (EC) No 883/2004. ${ }^{44}$ According to Recital 44 of the Preamble to the latter Regulation, Regulation (EEC) No 1408/71 remains in force and continues to have legal effect for the purposes of certain Community acts and agreements to which the Community is party, in order to secure legal certainty. This is specified in Article 90(1)(c) of Regulation (EC) No 883/2004 which states that Regulation (EEC) No 1408/71 remains in force as regards agreements which contain a reference to the latter Regulation, for as long as those agreements have not been modified in the light of this Regulation. It remains questionable whether the legal regime under Regulation (EC) No 883/2004 can be used for interpretative purpose when applying Decision No 3/80 without the adoption of a decision by the EUTurkey Association Council. However, contrary to the case of Ziebell, in which the

39 Decision No 3/80 of the EC-Turkey Association Council of 19 September 1980 on the application of the social security schemes of the Member States to Turkish workers and members of their families.

40 Art. 10 of Decision No $3 / 80$ refers in this respect to Art. 18 of Regulation (EEC) No $1408 / 71$.

$41 \quad$ Arts. 39(3) and (4) of the Additional Protocol.

42 H. Verschueren, 'Social Security Co-ordination in the Agreements between the EU and Mediterranean Countries, in particular Turkey and the Maghreb Countries', in: D. Pieters and P. Schoukens (eds.), The Social Security Co-ordination Between the EU and NonEU Countries (Intersentia, Antwerp 2009), p. 23.

43 Council Regulation (EEC) No 1408/71 of 14 June 1971 on the application of social security schemes to employed persons, self-employed persons, and to members of their families moving within the Community.

44 Regulation (EC) No 883/2004 of the European Parliament and of the Council of 29 April 2004 on the coordination of social security systems. 
Court held that enhanced protection against expulsion for EU citizens under Directive 2004/38/EC could not be extended to a Turkish national, the provisions of Regulation (EC) No 883/2004 have already been extended to third-country nationals on the basis of Regulation (EU) No 1231/2010.45

The ratione personae of Decision No 3/80 covers Turkish workers who are or have been subject to the legislation of one or more Member States; to their family members, resident in the Member States; and to the survivors of these workers. ${ }^{46}$ The term "worker" is defined, in principle, as any person who is insured, compulsorily or on an optional continued basis, against one or more of the contingencies covered by the branches of a social security scheme for employed persons (almost identical definition as under Council Regulation (EEC) No 1408/71), while "family members" are defined in line within Article 1 of Regulation (EEC) No 1408/71.47 Article 3 of Decision No 3/80 stipulates an equal treatment clause for issues concerning social security. Article 4 of Decision No 3/80 lists the following branches of social security to which it is applicable:

- Sickness and maternity benefits;

- Invalidity benefits, including those intended for maintenance or improvement of earning capacity;

- Old-age benefits;

- Survivors' benefits;

- Benefits in respect of accidents at work and occupational diseases;

- Death grants;

- Unemployment benefits;

- Family benefits.

The benefits enumerated are identical to the ones listed in Council Regulation (EEC) No 1408/71 and specific benefits are also defined in reference to this Regulation. Decision No 3/80 further determines that recipients of specific benefits may export these benefits when residing in Turkey or in a Member State other than that in which the payment is distributed.48 Article 6(1) of Decision No 3/80 guarantees the export of benefits: "[S]ave as otherwise provided in this Decision, invalidity, old-age or survivors' cash benefits and pensions for accidents at work or occupational diseases, acquired under the legislation of one or more Member States, shall not be subject to any reduction, modification, suspension, withdrawal or confiscation by reason of the

45 See Regulation (EU) No 1231/2010 of the European Parliament and of the Council of 24 November 2010 extending Regulation (EC) No 883/2004 and Regulation (EC) No $987 / 2009$ to nationals of third countries who are not already covered by these Regulations solely on the ground of their nationality; Directive 2004/38/EC of the European Parliament and of the Council of 29 April 2004 on the right of citizens of the Union and their family members to move and reside freely within the territory of the Member States.

46 Art. 2 of Decision No 3/80 of the EC-Turkey Association Council of 19 September 1980 on the application of the social security schemes of the Member States to Turkish workers and members of their families.

47 See Art. 1 of Decision No 3/80 of the EC-Turkey Association Council of 19 September 1980 on the application of the social security schemes of the Member States to Turkish workers and members of their families.

48 Art. 6 of Decision No 3/80. 
fact that the recipient resides in Turkey or in the territory of a Member State other than that in which the institution responsible for payment is situated." Article 9 of Decision No $3 / 80$ provides the rules for the determination of the applicable legislation to Turkish workers in the Community in that it refers to Articles 13, 14, 15 and 17 of Regulation No 1408/71.

Prior to the case law handed down by the ECJ on Decision No 3/80, the legal relevance of Decision No 3/80 was unclear: for a successful transposition of decisions adopted by the Association Council, the Council has to approve them unanimously in the form of an implementing decision on behalf of the Union. Although the Commission proposed such an implementing decision to the Council in 1983, it was not adopted by the latter. ${ }^{49}$ Contrary to the assertions of some Member States, the Court made clear, in its first ruling on Decision No 3/80, Taflan-Met - that in the absence of any provisions on its entry into force, it follows from the binding character, which the Agreement attaches to the decisions of the EU-Turkey Association Council, that Decision No 3/80 entered into force on the date of its adoption, that is to say, 19 September 1980. Since that point in time, the Court continued, the Decision is binding on the contracting parties. ${ }^{50}$

The case Taflan-Met concerned the claims of widows of Turkish workers for widow pensions in the Netherlands, where their husbands had resided and had been employed. On account of the fact that the applicants' husbands had died in Turkey, the claims were denied, because "the Dutch social security system is based on risk which implies that insured persons or their survivors are only entitled to receive benefits when the insured risk materialises at a time when the insured is covered by the Netherlands legislation". ${ }^{1}$ Yet, the Court denied the direct effect of Articles 12 (on invalidity benefits) and 13 (on old-age and death pensions) of Decision No 3/80 arguing that the Decision should have been implemented by a subsequent act of the Council. According to the Court, an analogy must be drawn between Decision No 3/80 and Regulation No 1408/71: the former refers to terms of some provisions to Council Regulation (EC) No 1408/71 and to its implementing Regulation No $574 / 72 .{ }^{52}$ The Court pointed out that when comparing these legislative instruments, Decision No 3/80 did not contain a large number of precise, detailed provisions, even though these were considered indispensible for the implementation of Council Regulation (EC) No 1408/71 within the Union. The Court concluded that, even though some of its provisions were precise and clear, Decision No 3/80 could not be

49

A.P. van der Mei, Free Movement of Persons Within the European Community - Cross-Border Access to Public Benefits (Hart Publishing, Oxford 2003), p. 174; see European Commission, $\operatorname{COM}(83)$ 13, Proposal for a Council Regulation (EEC) implementing within the European Economic Community Decision No 3/80 of the EEC-Turkey Association Council on the application of the social security schemes of the Member States of the European Communities to Turkish workers and members of their families, OJ C 110, 25 April 1983, p. 1.

50 Case C-277/94 Taflan-Met [1996] ECR I-4085, paras. 17-22.

51 A.P. van der Mei, Free Movement of Persons Within the European Community - Cross-Border Access to Public Benefits (Hart Publishing, Oxford 2003), p. 174.

52 Council Regulation (EEC) No 574/72 of 21 March 1972 laying down the procedure for implementing regulation (EEC) No $1408 / 71$ on the application of social security schemes to employed persons, to self-employed persons and to their families moving within the Community. 
applied as long as supplementary implementing measures have not been adopted by the Council. ${ }^{53}$

The reasoning in Taflan-Met has been subject to debate. The Court's ruling that Decision No 3/80 entered into force on the day of its adoption was welcomed. This outcome, it was argued, was in line with the binding effect of decisions taken by the Association Council on the basis of Article 22 of the Ankara Agreement - an aspect which the AG seemed to ignore in his opinion on the case. ${ }^{54}$ However, S. Peers considered the judgment of Taflan-Met as "simply wrong" and "wholly illogical" concerning equality rights in the field of social security because the Court had already decided that the right to non-discrimination in social security for Maghreb nationals did not require any implementing measure. ${ }^{55} \mathrm{H}$. Verschueren referred to Decision No 3/80 as a "living corpse" - the oxymoron highlights the nature of the legal instrument after Taflan-Met: while the Court confirmed the legal existence of Decision No 3/80, it rendered the latter inoperative by making its application conditional on implementing measures, which have not been adopted. The author criticised that the Court did not consider in detail whether Articles 12 and 13 of Decision No 3/80 could nevertheless be applied under certain circumstances. In addition, he indicated to Article 32 of Decision No 3/80 which asks the Community and Turkey to take the necessary steps to implement the Decision and posed the question whether the Community could not have been held liable for having omitted to take the necessary implementing measures. ${ }^{56}$ Indeed, Article 32 of Decision No 3/80 is formulated in clear terms, imposing an obligation to act on both parties in this context.

Only three years later, the Court adjusted its approach - if not to say overturned its ruling in Taflan-Met - and decided in favour of the direct effect of Article 3 of Decision No $3 / 80$ on equal treatment in Sürül.57 In the Court's view, Article 3 of Decision No 3/80 must be distinguished from Articles 12 and 13 of the same Decision as the former has direct effect in that it lays down in clear, precise and unconditional terms a prohibition of discrimination, based on nationality, against persons who are residents in a Member State and to whom Decision No 3/80 applies. ${ }^{58}$ As a result, a Turkish national covered by Decision No 3/80, who lawfully resides in the territory of a Member State, may not be required to hold a particular type of residence permit in order to qualify for family allowances. Sürül marked the first concrete step in strengthening the social security rights of Turkish nationals, but

53 Case C-277/94 Taflan-Met [1996] ECR I-4085, paras. 23-38.

54 M. Bulterman, 'Case C-277/94 Taflan-Met and Akol [1996] ECR I-4085', 34 Common Market Law Review (1997), 1497, pp. 1503-1504.

55 S. Peers, 'Equality, Free Movement and Social Security', 22 European Law Review (1997), 342, p. 351; S. Peers, 'Social Security Equality for Turkish Nationals', 24 European Law Review (1999), 627, p. 629.

56 H. Verschueren, ' $\mathrm{Na}$ het arrest Taflan-Met: is er leven na de dood? Besluit 3/80 (sociale zekerheid) van de Associatie EEG-Turkije bestudeerd', 2 Migrantenrecht (1997), 29, pp. 33-34.

57 Case C-262/96 Sürül [1999] ECR I-2685; the Court's decision in Sürül eviscerated earlier reasoning against the direct effect of Art. 3 of Decision No 3/80, see J. Delbrück and C. Tietje, 'Die Frage der unmittelbaren Anwendbarkeit des Assoziationsbeschlusses EWG/Türkei Nr. 3/80', 1 Zeitschrift für Ausländerrecht und Ausländerpolitik (1995), 29.

58 Case C-262/96 Sürül [1999] ECR I-2685, paras. 48-74. 
it also underpinned the general tendency to prohibit discrimination of third-country nationals in social security matters at that time. ${ }^{59}$ In Sürül the Court limited the temporal effect of the judgment stating that the direct effect of Article 3 of Decision No 3/80 may not be relied on in support of claims concerning benefits in view of periods prior to the date of this judgment with the exception of those persons, who before that date, initiated proceedings or made an equivalent claim. ${ }^{60}$

The Court's rulings in Kocak and Örs and Öztürk reiterated the direct applicability of Article 3 of Decision No 3/80 as established in Sürül. ${ }^{61}$ The Court made clear in Kocak and Örs that Member States may, for the purposes of awarding a retirement pension, take as the conclusive date of birth the one given in the first declaration made by the person concerned and allow another date of birth to be taken into account only if the original copy of document evidencing the other date of birth was issued before the first declaration was made. Moreover, the principle of nondiscrimination embodied in Article 3(1) of Decision No 3/80 prohibits not only overt discrimination based on nationality but also all covert forms of discrimination which, by applying other distinguishing criteria, achieve the same result in practice. ${ }^{62}$ The Öztürk case concerned national legislation which made the entitlement to old-age pensions in the event of unemployment conditional on the receipt of unemployment insurance benefits prior to the application for the pension. By referring to Alami, a case on the non-discrimination clause stipulated in Article 41 of the EEC-Morocco Cooperation Agreement, the Court ruled that Article 3(1) of Decision No 3/80 precluded such a requirement for the purpose of qualifying for an old-age pension. ${ }^{63}$

The question as to whether other provisions qualify for direct effect was considered by $\mathrm{H}$. Verschueren who indicated to Article 6(1) of Decision No 3/80 on the exportability of pension rights and annuities. ${ }^{64}$ In this context, the Court delivered an interesting judgment in May 2011 with its decision in Akdas. ${ }^{65}$ The case dealt with the pertinent question whether it must be feasible for Turkish nationals to export social security benefits including special non-contributory cash benefits to Turkey. The crux of the underlying legal dispute concerned the role, which Article 59 of the Additional Protocol would play in the reasoning of the Court. Article 59 stipulates that "in the fields covered by this Protocol Turkey shall not receive more favourable treatment than that which Member States grant to one another pursuant to the Treaty establishing the Community". The Court construed this provision as the requirement not to put Turkish nationals into a more favourable position than EU nationals. ${ }^{66}$ In Akdas the respondents who had worked in the Netherlands and who, after having

H. Verschueren, 'The Sürül Judgment: Equal Treatment for Turkish Workers in Matters of Social Security', 1 European Journal of Migration and Law (1999), 371, p. 383.

For a critical discussion on the limited retrospective effect of the Sürül judgment, see S. Peers, 'Social Security Equality for Turkish Nationals', 24 European Law Review (1999), 627, pp. 632-633. Joined Cases C-102/98 and 211/98 Kocak and Örs [2000] ECR I-1287; Case C-373/02 Öztürk [2004] ECR I-3605. Joined Cases C-102/98 \& 211/98 Kocak and Örs [2000] ECR I-1287, para. 39. Case C-23/02 Alami [2003] ECR I-1399, para. 38. As confirmed in Case C-485/07 Akdas [2011] Judgment of 26 May 2011, not yet reported.

Ibid. Case C-228/06 Soysal [2009] ECR I-1031, para. 61. 
become incapacitated for work, applied for and obtained an invalidity pension. Seeing that this pension was lower than the minimum wage, the respondents concerned also obtained a supplementary benefit. On grounds of the incapacitation for work, the respondents returned to Turkey and continued to receive the two different benefits there. Changes in Dutch legislation induced the Dutch authorities to withdraw the supplementary benefit progressively, against which the respondents instituted proceedings.

The Centrale Raad van Beroep that dealt with the case at hand on appeal halted the procedure and asked the Court in Luxembourg whether Article 6(1) of Decision No $3 / 80$ had direct effect. If this was the case, the Court wanted to know how, firstly, the amendments to Council Regulation (EC) No 1408/71 with regard to special noncontributory benefits and secondly, Article 59 of the Additional Protocol, affected the application of Article 6(1) of Decision No 3/80. Finally, the Court inquired how Article 9 of the Ankara Agreement had to be considered and interpreted in the underlying case. In its grounds for the judgment, the Court first came straight to the conclusion that Article 6(1) of Decision No 3/80 qualified for direct effect. Neither the provision "save as otherwise provided in this Decision", nor the purpose and the nature of the Ankara Agreement altered this outcome. ${ }^{67}$ Next, the Court reasoned that Article 6(1) of Decision No 3/80 must be interpreted as precluding national legislation that withdraws a supplementary benefit from former Turkish migrant workers who returned to Turkey after losing their right to remain in the host Member State because they became incapacitated there. How did the Court reach this conclusion?

The Court first examined the material scope of Article 6(1) and reasoned that the invalidity benefit, as well as the supplementary benefit, were to be subsumed under Article 4(1)(b) of Decision No 3/80 and were subsequently covered by Article 6(1). The transfer of the two types of benefits took place in accordance with Article 39(4) of the Additional Protocol which stipulated the exportability of old-age pensions, death benefits and invalidity pensions obtained in the Member States. ${ }^{68}$ As regards the personal scope, the Court pointed out that Article 6(1) of Decision No 3/80 covered the respondents in the main proceedings because they were Turkish workers who received invalidity benefits acquired in a Member State and now resided in the Turkish Republic. As a result, the respondents were entitled to the continued payment of the supplementary benefit under Article 6(1) of Decision No 3/80. The Court resumed that this finding could not be called into question by the fact that the system under Council Regulation (EC) No 1408/71 differed from that under Decision No 3/80: Council Regulation (EC) No 1408/71, as amended by Regulation No 1247/92, expressly included special non-contributory cash benefits in the material scope of the former Regulation but excluded the portability of such benefits to other Member States. ${ }^{69}$

67 Case C-485/07 Akdas [2011] Judgment of 26 May 2011, not yet reported, paras. 67-74.

68 Case C-485/07 Akdas [2011] Judgment of 26 May 2011, not yet reported, paras. 75-78.

69 Council Regulation (EEC) No 1247/92 of 30 April 1992 amending Regulation (EEC) No $21408 / 71$ on the application of social security schemes to employed persons, to self-employed persons and to members of their families moving within the Community. 
According to the Court, this outcome could not be regarded as incompatible with Article 59 of the Additional Protocol because first, Article 39(4) of the Additional Protocol explicitly enshrined the exportability to Turkey of certain social benefits; second, under the first indent of Article 2 of Decision No 3/80, it is laid down that the Decision shall apply to Turkish workers "who are or have been subject to the legislation of one more Member States"; third, the rules on special non-contributory cash benefits under Council Regulation (EC) No 1408/71 could not be extended to Decision No 3/80 as this would constitute an amendment, the power for which lay exclusively with the Association Council; fourth, the situation of former Turkish migrant workers could not, for the purposes of applying Article 59 of the Additional Protocol, usefully be compared to that of an EU national who may freely move and reside, leave and return to a Member State and in doing so either loses or obtains the right to be awarded such a special non-contributory benefit. In respect of former Turkish migrant workers, incapacitation did not entail the right to remain in a Member State under Article 6 of Decision No 1/80, and hence it could not be claimed that the persons concerned left the host Member State out of their own volition, the Court reasoned. Indeed, in previous case law the Court had established that Article 59 of the Additional Protocol demands the overall more beneficial treatment of EU nationals in comparison with Turkish nationals. ${ }^{70}$ Moreover, the Court took the view that it is up to the competent legislator - the EU-Turkey Association Council - to adopt a legislative act restricting the export rights for Turkish nationals in this regard.

Finally, with regard to the question how Article 9 of the Ankara Agreement relates to the situation at hand, the Court concluded that Article 6(1) of Decision 3/80 is a lex specialis specialis - so to say - to Article 9 of the Ankara Agreement (Article 3(1) of Decision 3/80 as a concrete expression of Article 9 of the Ankara Agreement and Article 6(1) of Decision 3/80 as a special provision that must be taken account of when applying Article 3(1) of Decision 3/80). As opposed to the non-discrimination rules in Article 9 of the Ankara Agreement and Article 3(1) of Decision 3/80, Article 6(1) of Decision 3/80 does not provide room for justifications by Member States for indirect discrimination based on nationality. Next, the referring court, when communicating its doubts on the interpretation of Article 9 of the Ankara Agreement, stated that it would be grateful for guidance to assess the conformity of the national legislation in question with the fundamental rights such as those guaranteed by the ECHR and the first Additional Protocol. Yet, the Court in answering the preliminary ruling procedure made no reference whatsoever to the ECHR.

The Akdas decision raises some fundamental issues. ${ }^{71}$ The judgment allows former Turkish migrant workers to export not only pensions and annuities but also special non-contributory benefits to Turkey. It is clear that the Dutch state is not happy with the ruling seeing that it remains to be seen what the outcome and actual financial implications of the judgment are. The possibility to transfer social security benefits is

70 See Case C-325/05 Derin [2007] ECR I-6495.

71 For discussions of the case, see P.E. Minderhoud, 'Noot Akdas', 9 Jurisprudentie V reemdelingenrecht (2011/276), 1204; K. Eisele and A.P. van der Mei, Portability of Social Benefits and Reverse Discrimination of EU Citizens vis-à-vis Turkish Nationals: Comment on Akdas', 37 European Law Review (2012), 204. 
very much in line with the migration and development considerations as set out by the EU's Global Approach to Migration. ${ }^{72}$ With regard to temporary and virtual return of migrants, the Commission has stressed the importance of being able to continue to contribute to and benefit from social security schemes, especially from health insurance and pension schemes. ${ }^{73}$ This developmental aspect of the transfer of social security benefits to the country of origin is not touched at all in the ruling. It is interesting to point out, however, that, in the case of Günaydin concerning the question whether a Turkish national, who did a vocational training programme and was in paid employment after finishing this programme, could be regarded as a worker for the purpose of Article 6(1) of Decision No 1/80, the role of development policy was put forward in support of the Member State's point of view. ${ }^{74}$ The German authorities argued that the extension of his residence permit was refused because he was neither entitled to an unrestricted residence permit nor could he rely on the principle of legitimate expectations; moreover, the extension of his residence "would be contrary to German development aid policy which was intended to encourage foreigners trained in that Member State to work in their countries of origin." 75

\subsection{Nationals of the Western Balkan Countries}

All SAAs concluded with the Western Balkan countries (except for Kosovo) contain the same the social security coordination rules which, however, do not provide for equal treatment in the field of social security. The SAAs state that rules shall be laid down for workers having the nationality of one of the Western Balkan countries legally employed in the territory of a Member State and their family members legally resident there. ${ }^{76}$ For this purpose, the Stabilisation and Association Council shall adopt a decision which should not affect any rights or obligations arising from bilateral agreements where the latter provide for more favourable treatment, governing that:

- all periods of insurance, employment or residence completed by such workers in the various Member States shall be added together for the purpose of pensions and annuities in respect of old age, invalidity and death and for the purpose of medical care for such workers and such family members;

- any pensions or annuities in respect of old age, death, industrial accident or occupational disease, or of invalidity resulting therefrom, with the exception of non-contributory benefits, shall be freely transferable at the rate applied by virtue of the law of the debtor Member State or Member States;

- the worker in question shall receive family allowances for their members of the families as defined above.

\footnotetext{
72 European Commission Communication, $\operatorname{COM}(2008)$ 611, 8 October 2008, p. 2.

73 European Commission Communication, $\operatorname{COM}(2005)$ 390, 1 September 2005, pp. 28 30.

Case C-36/96 Günaydin [1997] ECR I-5143.

Ibid., para. 12.

See for instance Art. 47(1) of the SAA with Croatia.
} 
In accordance with Article 47 of the SAA with Croatia and Article 46 of the SAA with the FYROM, the respective Stabilisation and Association Councils have adopted two identically worded draft decisions for the coordination of the social security systems. ${ }^{77}$ These draft decisions define "worker" and "family member" for the purposes of the Member States' legislation in conformity with Articles 1(a) and (i) of Regulation (EC) No 883/2004. ${ }^{78}$ "Benefits" is defined as old-age pensions, survivors" pensions, pensions in respect of accidents at work and occupational diseases, invalidity pensions related to accidents at work and occupational diseases and family allowances. "Exportable benefits" in relation to the Member States means: old-age pensions, survivors' pensions, pensions is respect of accidents at work and occupational diseases, invalidity pensions related to accidents at work and occupational diseases, with the exception of special non-contributory cash benefits. Most importantly, these draft decisions stipulate an equal treatment clause: workers of Croatian and Macedonian nationality legally employed in a Member State and any family members legally residing with them shall, with regard to the benefits as defined, enjoy treatment free from any discrimination based on nationality relative to nationals of the Member States in which those workers are employed. Furthermore, residence clauses are waived in view of exportable benefits as defined, (with the exception of special non-contributory cash benefits) in that the latter shall not be subject to any reduction, modification, suspension, withdrawal or confiscation by reason of the fact that the beneficiary is residing, for the purpose of a benefit under the legislation of a Member State, within the territory of Croatia [or the FYROM respectively]. The draft decisions also set out rules on further cooperation such as information exchange, administrative assistance and checks, as well as regards medical examinations.

77 Council Decision of 21 October 2010 on the position to be taken by the European Union within the Stabilisation and Association Council established by the Stabilisation and Association Agreement between the European Communities and their Member States, of the one part, and the former Yugoslav Republic of Macedonia, of the other part, with regard to the adoption of provisions on the coordination of social security systems (2010/701/EU); Council Decision of 21 October 2010 on the position to be taken by the European Union within the Stabilisation and Association Council established by the Stabilisation and Association Agreement between the European Communities and their Member States, of the one part, and the Republic of Croatia, of the other part, with regard to the adoption of provisions on the coordination of social security systems - Draft — Decision No .../... of the Stabilisation and Association Council established by the Stabilisation and Association Agreement between the European Communities and their Member States, of the one part, and the Republic of Croatia, of the other part, of ... with regard to the provisions on the coordination of social security systems contained in the Stabilisation and Association Agreement (2010/702/EU).

78 Regulation (EC) No 883/2004 of the European Parliament and of the Council of 29 April 2004 on the coordination of social security systems. 
Workers of San Marino nationality and their family members living with them, enjoy equal treatment with the nationals of the Member State in which they are employed in the field of social security. ${ }^{79}$ Such workers also have the right to:

- the aggregation of the periods of employment insurance, and residence for the purpose of calculating benefits;

- family allowances for members of their family who resident in the Community;

- the free transfer to San Marino of any pensions or annuities in respect of disability, old age, death, industrial accident or occupational disease. ${ }^{80}$

\subsection{Nationals of the Mediterranean ENP States}

\subsubsection{Nationals of Algeria, Morocco and Tunisia}

The Euro-Mediterranean Agreements concluded with Algeria, Morocco and Tunisia all comprise a Title VI on cooperation in social and cultural matters that incorporates rules in the field of social security. The provisions in question are identically worded in all three Euro-Mediterranean Agreements. It is stipulated that workers of the contracting parties and any family members living with them shall enjoy treatment free of any discrimination based on nationality relative to the nationals of the host country in which they are employed in the area of social security.

The application of other coordination rules contained in Articles 42 EC (Article 48 TFEU) is excluded except if the Association Councils adopt provisions in this regard. ${ }^{81}$ For the purpose of pensions and annuities in respect of old age, invalidity and survivors' benefits, family, sickness and maternity benefits and medical care for Maghreb workers and their family members resident in the EU, all periods of insurance, residence or employment completed by such workers in the various Member States shall be added together. ${ }^{82}$ Family, sickness and maternity benefits were added to the Euro-Mediterranean Agreements. Workers of the contracting parties shall receive family allowances for family members resident in the host state. ${ }^{83}$ Although the provision on family allowances has not been changed in the EuroMediterranean Agreements, it was still criticised that the workers in question are only eligible for family allowances for family members resident in the Union. This way, it was argued, the immigration authorities can exclude such family members of a Maghreb migrant worker from the award of benefits on a discretionary basis while, at

79 Art. 21(1) of the Agreement on Cooperation and Customs Union between the European Economic Community and the Republic of San Marino.

80 See Art. 21 of the Agreement on Cooperation and Customs Union between the European Economic Community and the Republic of San Marino.

81 See Art. 68(1) of the Euro-Mediterranean Agreement with Algeria; Art. 65(1) of the Euro-Mediterranean Agreements with Morocco and Tunisia.

82 See Art. 68(2) of the Euro-Mediterranean Agreement with Algeria; Art. 65(2) of the Euro-Mediterranean Agreements with Morocco and Tunisia.

83 See Art. 68(3) of the Euro-Mediterranean Agreement with Algeria; Art. 65(3) of the Euro-Mediterranean Agreements with Morocco and Tunisia. 
the same time, having the authority to stipulate quotas and even to refuse entry for family members. ${ }^{84}$ The adoption of Directive 2003/86/EC on the right to family reunification has remedied the latter aspect as the legal instrument defines the conditions of the exercise of the right to family reunification by third-country nationals residing lawfully in the territory of the Member States. ${ }^{85}$ Once family members of Maghreb workers are legally resident in a Member State, the right to receive family allowances is guaranteed.

Next, such workers shall be able to freely transfer, at the rates applied by virtue of the legislation of the debtor contracting state or states, any pensions or annuities in respect of old age; survivor status; industrial accident or occupational disease; or of invalidity resulting therefrom, except in the case of special non-contributory benefits, to their home state. ${ }^{86}$ The fact that special non-contributory benefits are exempted from the free transfer to the Maghreb states under Euro-Mediterranean Agreements is new. The rule that special non-contributory benefits are excluded from the free transfer of benefits to the home country has raised concerns. A. Boudahrain emphasised that "the non-provision of non-contributory benefits financed out of taxation and hence based on national solidarity [...] is intolerable in so far as Maghreb migrant workers pay the same taxes and at the same rates as their fellow workers in their country of employment." 87 Contrary to this statement, one has to bear in mind that these non-contributory benefits are, as a general rule, intended to bolster the social security status of individuals residing within the territory of the respective state, such as a supplementary loss-of-earnings benefit which raises the income to a level that is, at the maximum, equal to the minimum wage applicable in that state. ${ }^{88}$ It is important to note that Article 69 of the Euro-Mediterranean Agreement with Algeria and Article 66 of the Euro-Mediterranean Agreements with Morocco and Tunisia exclude the application of the provisions of this chapter to nationals of the parties residing or working irregularly in the territory of their host country.

The Association Council shall adopt provisions to implement the principles set out in Article 68 of the Euro-Mediterranean Agreement with Algeria and Article 65 of the Euro-Mediterranean Agreements with Morocco and Tunisia, respectively, within one year after the entry into force of the Euro-Mediterranean Agreement. ${ }^{89}$ Moreover, the Maghreb', 53 International Social Security Review (2000), 47, pp. 60-61.

85 Council Directive 2003/86/EC of 22 September 2003 on the right to family reunification. See Art. 68(4) of the Euro-Mediterranean Agreement with Algeria; Art. 65(4) of the Euro-Mediterranean Agreements with Morocco and Tunisia. A. Boudahrain, 'The Insecure Social Protection of Migrant Workers from the Maghreb', 53 International Social Security Review (2000), 47, p. 60. See in this respect Case C-485/07 Akdas [2011] Judgment of 26 May 2011, not yet reported.

89 The word usage of principles rather than rights and obligations in this context was considered as remarkable by H. Verschueren, 'Social Security Co-ordination in the Agreements between the EU and Mediterranean Countries, in particular Turkey and the Maghreb Countries', in: D. Pieters and P. Schoukens (eds.), The Social Security Coordination Between the EU and Non-EU Countries (Intersentia, Antwerp 2009), pp. 35-36, 47. 
Association Council shall adopt rules to ensure the management and monitoring of the provisions adopted. ${ }^{90}$ Under the Spanish presidency in 2010, efforts were made that led to a number of draft decisions with regard to the adoption of provisions on the coordination of social security, including for Algeria, Morocco and Tunisia. ${ }^{91}$ These draft decisions set forth an equal treatment clause for Maghreb workers legally employed in a Member State and any family members legally residing with them as regards the benefits as defined. Next, residence clauses are waived in view of exportable benefits as defined (with the exception of special non-contributory cash benefits) in that the latter shall not be subject to any reduction, modification, suspension, withdrawal or confiscation by reason of the fact that the beneficiary is residingwithin the territory of Algeria, Morocco and Tunisia for the purpose of a benefit under the legislation of a Member State.

The question arises as to why the Association Councils have only taken steps to enact these decisions in 2010 although already the Cooperation Agreements of 1976 with the Maghreb states foresaw that implementing measures should be taken within one year after the entry into force of these agreements. This inactivity can be explained by the fact that the Maghreb states, as well as the Member States, simply had no interest in adopting such rules at that time. ${ }^{92}$ Finally, the Euro-Mediterranean Agreements with the Maghreb countries specify that these provisions, adopted by the Association Council for the purpose of coordinating social security, shall not affect any rights or obligations arising from bilateral agreements linking a Maghreb country and a Member State where those agreements provide for more favourable treatment of nationals of that Maghreb country or of the Member States. ${ }^{93}$

In 1991, the Court first held in Kziber that Article 41(1) of the EEC-Morocco Cooperation Agreement on social security had direct effect taking into account the wording, purpose and nature of the agreement and considering that the provision was clear, precise and unconditional. Article 41(1) laid down the principle of nondiscrimination in the field of social security, which is capable of directly governing the legal situation of individuals. ${ }^{94}$ The view of the Commission and the Belgian and French authorities that Article 41(1) did not entail direct effect because the application of this principle would be subject to action by the Cooperation Council in line with Article 42 of the agreement was rejected. In conclusion, neither the fact that no implementing decision was taken by the Cooperation Council in conformity with Article 42(1) of the EEC-Morocco Cooperation Agreement, nor the fact that the Agreement did not refer to Morocco's association with or future accession to the EU prevented the Court from according direct effect to the equal treatment provision on

90 See Art. 70 of the Euro-Mediterranean Agreement with Algeria; Art. 67 of the EuroMediterranean Agreements with Morocco and Tunisia. Draft decisions on the coordination of social security systems have also been taken in
view of Croatia, the FYROM, and Israel; interview with a Commission official of DG Employment, Social Affairs and Equal Opportunities, European Commission, held on 2 February 2011.

92 Interview with a Commission official of DG Employment, Social Affairs and Equal Opportunities, European Commission, held on 2 February 2011.

93 Art. 71 of the Euro-Mediterranean Agreement with Algeria; Art. 68 of the EuroMediterranean Agreements with Morocco and Tunisia. Case C-18/90 Kziber [1991] ECR I-199, paras. 15-23. 
social security. ${ }^{95}$ The Court had taken a different approach under the EU-Turkey association: Taflan-Met had suggested that Decision No 3/80 could be applied as long as supplementary implementing measures have not been adopted by the Council. ${ }^{96}$ However, in the subsequent case of Sürül, the Court "adjusted" the Taflan-Met reasoning and decided in favour of the direct effect of Article 3 of Decision No 3/80 on equal treatment in social security matters. ${ }^{97}$

The Court ruled on the direct effect of Article 39(1) of the EEC-Algeria Cooperation Agreement which enshrined the non-discrimination principle as regards social security for Algerian workers and their family members in Krid. According to the Court, the provision in question set out a clear and precise obligation and was unconditional in nature. This obligation - the prohibition of discrimination on grounds of nationality - was moreover confirmed by the objective of the agreement: to promote economic and social relations between the contracting parties. ${ }^{98}$ The direct effect of Article 39(1) of the EEC-Algeria Cooperation Agreement was confirmed in Bababenini in which the Court made clear that this provision precludes a Member State from refusing to grant a benefit, provided for under its legislation in favour of nationals resident in that state and irrespective of whether they have been working in an employed capacity, to the disabled spouse of a retired Algerian worker who lives with her husband in the Member State in question, on the ground that she is of Algerian nationality and has never been engaged in a trade or profession. ${ }^{99}$ The fact that these provisions entailed direct effect provided the basis for the Court to produce extensive case law on the cooperation agreements. The Court in particular gave clarifications on the notions of a worker, family members and social security for the purpose of the cooperation agreements. Moreover, the Court stated that the nondiscrimination provision, in view of social security matters, means that the persons referred to by that provision must be treated as if they were nationals of the Member States concerned and that consequently, in awarding social security benefits, the competent authorities cannot impose upon these persons more or stricter conditions than those applicable to nationals of that Member State. ${ }^{100}$

\subsubsection{The Concept of "Social Security"}

In Krid the Court confirmed the Kziber judgment in qualifying the term "social security" used in Article 39(1) of the EEC-Algeria Cooperation Agreement as bearing the same meaning as the identical term used in Regulation No 1408/71. ${ }^{101}$ This analogy was reiterated in subsequent case law. ${ }^{102} \mathrm{H}$. Verschueren opined that the

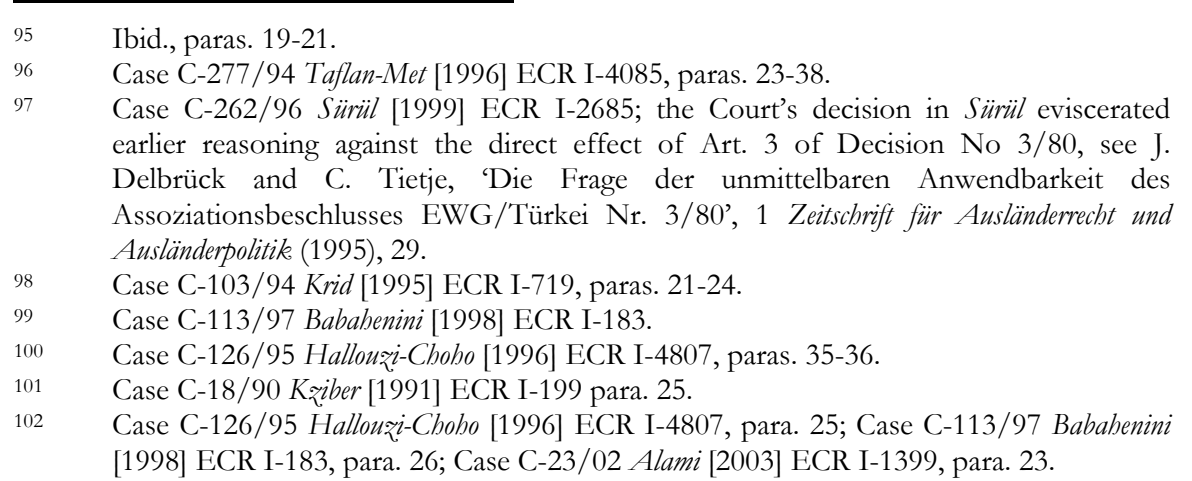


dispute in Krid clarified that special non-contributory benefits also fell within the scope of Council Regulation (EC) No 1408/71 on the basis of Article 4(1) and, hence, fall under the scope of cooperation agreements. ${ }^{103}$ In the latter case a supplementary allowance from the National Solidarity Fund was assessed to constitute a benefit that falls under the field of social security within the meaning of that provision. ${ }^{104}$ Therefore, the widow of an Algerian worker, who lived in the Member State in which the worker was employed and received a survivor's pension there, cannot be denied a supplementary benefit which is provided for by national legislation for its own nationals who are resident in that state, by a national solidarity fund, on grounds of her Algerian nationality.

In Hallouri-Choho the Court ruled that the spouse of a Moroccan worker was eligible for a transitional benefit under the Dutch general old-age insurance scheme, provided for by national legislation, as she fulfilled the residence criteria on the basis of Article 41(1) of the EEC-Morocco Cooperation Agreement. ${ }^{105}$ The Court came to this conclusion by ruling that the transitional benefit came within the scope of the social security notion contained in the equal treatment provision on social security issues. Yousfi dealt with the refusal of the Belgian State to grant a disability benefit to a worker of Moroccan nationality who suffered an accident at work. ${ }^{106}$ The Court followed the considerations of AG Tesauro and held that Article 41(1) of the EECMorocco Cooperation Agreement precluded national legislation from refusing to grant a disablement allowance, provided for under its legislation in favour of nationals residing in that state for at least five years, to a Moroccan national suffering permanent incapacity for work following an industrial accident occurring in that state and who has resided in that state for more than five years on the ground that the person concerned is Moroccan. In particular, the Court made clear that even if Council Regulation (EC) No 1408/71, prior to its amendment by Council Regulation No $1247 / 92$, did not specifically mention benefits for disabled people, it has nevertheless consistently held that disability benefits fell within the substantive scope of Council Regulation (EC) No 1408/71 by virtue of Article 4(1)(b), which expressly refers to an "invalidity benefit". ${ }^{107}$

In Fahmi the Court adjudicated that Member States were not prevented from gradually abolishing an allowance for dependent children aged between 18 and 27 years pursuing studies provided that its abolition did not involve discrimination on grounds of nationality. ${ }^{108}$ Moreover, the Court held that neither a Moroccan worker nor his children could invoke Article 41 of the EEC-Morocco Cooperation Agreement in order to obtain study finance where the dependent children of a Moroccan worker did not reside in the Union. In 2003, the Court made clear in Alami that Article 41(1) of the EEC-Morocco Cooperation Agreement had to be

103 H. Verschueren, 'Social Security Co-ordination in the Agreements between the EU and Mediterranean Countries, in particular Turkey and the Maghreb Countries', in: D. Pieters and P. Schoukens (eds.), The Social Security Co-ordination Between the EU and NonEU Countries (Intersentia, Antwerp 2009), p. 38.

104 Case C-103/94 Krid [1995] ECR I-719, paras. 32-37.

105 Case C-126/95 Hallouri-Choho [1996] ECR I-4807.

106 Case C-58/93 Yousfi [1994] ECR I-199.

107 Ibid., para. 25; see also Case 187/73 Callemeyn [1974] ECR 553, para. 15; Case C310/91 Scbmid [1993] ECR I-3011, para. 10. Case C-33/99 Fahmi [2001] ECR I-2415. 
construed in a way so as to cover a seniority supplement to an unemployment benefit for which a former Moroccan worker, resident in a Member State, had applied. This outcome was not altered by the fact that the Moroccan worker was employed earlier in a different Member State with which the current Member State of residence had not concluded an international agreement stipulating that account is being taken of work carried out in another Member State, even though no such condition was imposed on workers who are nationals of that host Member State. With reference to Kziber, the Court decided that, although Article 41(2) of the EEC-Morocco Cooperation Agreement did not mention unemployment benefits among the schemes to which the aggregation of insurance or employment periods applied, this could not result in the exclusion from the concept of social security, within the meaning of the Agreement, of those unemployment benefits, which are traditionally regarded as a branch of social security. ${ }^{109}$

The concept of social security is now explicitly defined under the EuroMediterranean Agreements in line with Article 4 of Council Regulation (EC) No $1408 / 71$ and in conformity with case law covering sickness and maternity benefits, invalidity, old-age and survivors' benefits, industrial accident and occupational disease benefits and death, unemployment and family benefits; it does not expressly cover paternity benefits and pre-retirement benefits, which were added under Regulation (EC) No 883/2004. ${ }^{110}$

The Court has confirmed that the following benefits fall under the "social security" notion within the meaning of the Euro-Mediterranean Agreements:

- unemployment allowance for young workers (Kziber $)^{111}$ and seniority supplement to an unemployment benefit (Alami); ${ }^{112}$

allowance for disabled people (Yousfi, Babahenini, Mesbab); ${ }^{113}$

- $\quad$ supplementary allowance from the national solidarity fund (Krid);114

- $\quad$ armed services invalidity pension (Echouik $h$ ); ${ }^{115}$

- Statutory Guaranteed Income for Elderly Persons (El Youssfi). ${ }^{116}$

The Court indicated in Echouikh that the case law on the non-discrimination provision of the Morocco Cooperation Agreement in Article 41(1) is fully transposable to the first subparagraph of Article 65(1) of the Euro-Mediterranean Agreement which is formulated in identical terms to the former and, moreover, has

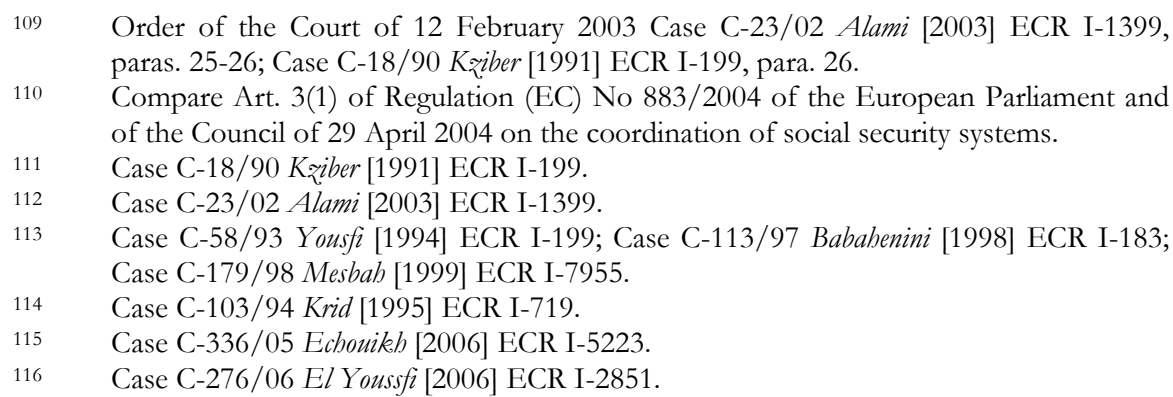


aims which may be viewed as directly furthering those on which the Cooperation Agreement is based. ${ }^{117}$

\subsubsection{The Concept of a "Worker" in Social Security Matters}

First, it is important to note that the notion of a "worker" in matters of social security differs from the one that applies to issues of employment. This distinction is relevant for EU citizens just as for third-country nationals. To recall, for EU citizens, the concept of a "worker" under Article 45 TFEU covers any person who, for a certain period of time, performs services for and under the direction of another person in return for remuneration. ${ }^{118}$ In addition, the economic activity must be effective and genuine in nature, to the exclusion of activities on such a small scale as to be regarded as purely marginal and ancillary. ${ }^{119}$ By comparison, Regulation (EC) No 883/2004 on the coordination of social security systems defines "activity as an employed person" as any activity or equivalent situation treated as such for the purposes of the social security legislation of the Member State in which such activity or equivalent situation exists. ${ }^{120}$

The Court introduced an autonomous interpretation of the notion of a "worker" as regards the social security provision under the Cooperation Agreements with the Maghreb countries. In Kziber the Court made clear that the said notion in this context included active workers and those who have left the labour market after reaching the age required for receipt of an old-age pension or after becoming the victims of the materialisation of one of the risks which entitles one to social security benefits. Hence, with this approach, the Court followed a different path and did not refer to Council Regulation (EC) No 1408/71 for interpretation purposes (as the Court had done for the purpose of construing the term of "social security"). ${ }^{121}$ The case of Kziber concerned the question whether the Belgian authorities could refuse the daughter of a Moroccan worker an unemployment allowance for young workers, the so-called allocation d'attente, on the basis of her nationality. ${ }^{122}$ The Court drew the boundaries of the status of "worker" in the order of Haddad in which it held that a Moroccan student who was the unemployed wife of a Moroccan national who was also unemployed, both resident in a Member State, did not qualify as a family member of a worker under Article 41(1) of the EEC-Morocco Cooperation Agreement and could therefore not claim a disability allowance in her favour. In that case, the couple was insured on a voluntary basis under the sickness insurance

117 Case C-336/05 Echouikh [2006] ECR I-5223, paras. 39-42.

118 Case 66/85 Lawrie Blum [1986] ECR 2121, para. 17.

119 Case C-456/02 Trojani [2002] ECR I-7573, para. 15.

120 Art. 1(a) of Regulation (EC) No 883/2004 of the European Parliament and of the Council of 29 April 2004 on the coordination of social security systems.

121 Council Regulation (EC) No 1408/71 defined employed persons generally as any person who is insured for one or more of the contingencies covered by the branches of a social security scheme for employed persons under the legislation of a Member State (see Art. 1(a) of Council Regulation (EC) No 1408/71). Case C-18/90 Kziber [1991] ECR I-199. 
scheme of the state in question but it was not proven that the applicant lived with a Moroccan worker with whom she had a close family relationship. ${ }^{123}$

\subsubsection{The Concept of "Family Members" in Social Security Matters}

The meaning of the notion of "family members" depends on the context and the framework in which it is used. A "family member" of a Union citizen, as defined under Directive 2004/38/EC on the right of citizens of the Union to move and reside freely and their family members within the territory of the Member States, means the spouse; the partner with whom the Union citizen has contracted a registered partnership, on the basis of the legislation of a Member State (if the legislation of the host Member State treats registered partnerships as equivalent to marriage and in accordance with the conditions laid down in the relevant legislation of the host Member State); the direct descendants who are under the age of 21 or are dependants and those of the spouse or partner; the dependent direct relatives in the ascending line and those of the spouse or partner. ${ }^{124}$ In the field of social security coordination Regulation (EC) No 883/2004 defines "member of the family", in general terms, as any person defined or recognised as a member of the family or designated as a member of the household by the legislation under which benefits are provided; or by the legislation of the Member State in which s/he resides with regard to benefits in kind pursuant to Title III, Chapter 1 on sickness, maternity and equivalent paternity benefits. ${ }^{125}$

The Court held in Kiiber that, as regards the scope of the rights of a family member of a Moroccan worker living with him, the principle of freedom from all discrimination, based on nationality, in the field of social security, meant that such a person, who satisfied all the conditions laid down by national legislation for the purposes of entitlement to the unemployment allowances provided for the benefit of young persons in search of employment, could not be refused those benefits on the ground of his nationality. ${ }^{126}$ In other words, qualifying a person as a "family member" of a Maghreb worker means that the person satisfies all the conditions laid down by national legislation for the purposes of entitlement to the specific benefits. As a result, Article 41(1) of the EEC-Morocco Cooperation Agreement precluded a Member State from refusing to grant an allocation d'attente provided by its legislation for young persons in search of employment and falling within the category of unemployment benefits, to a family member of a Moroccan worker living with him, on the basis of the person's nationality. The Court thus did not agree with AG van Gerven who argued that the Kermaschek rule should also apply to Article 41(1) of the EEC-Morocco Cooperation Agreement. ${ }^{127}$ According to the Kermaschek rule, a distinction must be drawn between workers and family members as the first category of people may claim rights envisaged by Council Regulation (EC) No 1408/71 as

123 Order of the Court of 27 April 2004 in Case C-358/02 Haddad [2004] ECR I-1562.

124 Directive 2004/38/EC of the European Parliament and of the Council of 29 April 2004 on the right of citizens of the Union and their family members to move and reside freely within the territory of the Member States.

125 Art. 1(i) of Regulation (EC) No 883/2004 of the European Parliament and of the Council of 29 April 2004 on the coordination of social security systems.

126 Case C-18/90 K₹iber [1991] ECR I-199, para. 28.

127 Case 40/76 Kermaschek [1976] ECR 1669. 
rights of their own, whereas family members could only claim derived rights in their capacity. In the opinion of the AG, it was unacceptable that family members of Moroccan nationals could possibly enjoy more extensive rights than family members of Community nationals. ${ }^{128}$ Yet, there were strong indications that "the possibility of Maghreb nationals receiving greater benefits than Community nationals was always more theoretical than real, even before Cabanis-Issarte". ${ }^{129}$ In subsequent cases, the Court reasserted that there was no need to distinguish between personal and derived rights when applying Article 41 of the EEC-Morocco Cooperation Agreement to Moroccan workers and family members. ${ }^{130}$

Clarity in view of social security claims by a family member of a former Moroccan worker who had acquired the citizenship of the host Member State was provided in Mesbab. ${ }^{131}$ In this case, the Court decided that the applicant, the mother-in-law of a Belgian worker of Moroccan origin, could not rely on Article 41(1) of the EECMorocco Cooperation Agreement and invoke that worker's Moroccan nationality for the purposes of obtaining a disability allowance. The Court explained that the applicant's son-in-law had acquired Belgian nationality before the applicant started to live with him and before she submitted the respective claim to the Belgian authorities. The Court distinguished the facts of the underlying case from Micheletti arguing that the migrant worker in the former case, in addition to having the nationality of a non-member country, held the nationality of a Member State in which he set up his home and carried out his occupational activity. Moreover, unlike the situation in Micheletti which concerned the freedom of establishment, the legislation of the Member State at stake did not affect any freedom of movement emphasising the purpose of the agreement: the consolidation of the social security position of Moroccan nationals in the host Member State. ${ }^{132}$ In Mesbah the Court moreover specified that it followed from the very wording of that provision that the rule of equal treatment was not exclusively for the benefit of the migrant worker's spouse and children; the more general expression "members of the family" in Article 41(1) of the EEC-Morocco Cooperation Agreement was thus capable of covering other relatives of the worker, such as, in particular, relatives in the ascending line. ${ }^{133}$

Joint Declarations to the Euro-Mediterranean Agreements with Morocco and Tunisia lay down that the term "family members" is defined according to the national legislation of the host country concerned. However, the Court seemed to ignore these declarations in the case of El Youssfi confirming the broad interpretation of "family members" of migrant workers. ${ }^{134}$

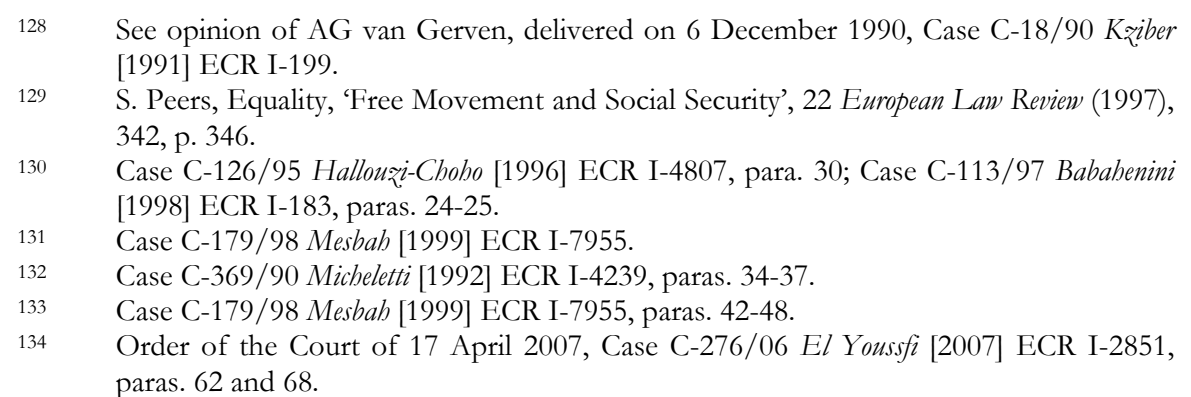




\subsubsection{Nationals of Egypt, Israel, Jordan and Lebanon}

While Israeli nationals are granted a number of rights in the field of social security, the situation is different for nationals of Egypt, Jordan and Lebanon within the framework of the Euro-Mediterranean Agreements concerned.

Article 64 of the Euro-Mediterranean Agreement with Israel stipulates that, in order to coordinate the social security regimes of Israeli workers legally employed in a Member State and of their family members legally resident there, subject to the conditions and modalities applicable in each Member State, the aggregation of employment, insurance and residence periods for the purpose of calculating benefits shall be ensured, and the export of benefits and the right to receive family allowances shall be guaranteed.

The Association Council shall decide on the provisions for the implementation of the objectives contained in Article 64.135 Finally, Article 66 enshrines that the arrangements decided by the Association Council shall not affect the rights and obligations resulting from bilateral agreements between Israel and the Member States where these agreements provide for more favourable treatment. In conformity with Article 64, the Association Council adopted a draft decision on the coordination of social security systems. ${ }^{136}$ Like the other draft decisions on social security coordination with the three Maghreb countries, Croatia and the FYROM, this decision contains an equal treatment clause in view of social security: workers of Israeli nationality, legally employed in a Member State and any family members legally residing with them, shall enjoy, with regard to the benefits as defined, treatment free from any discrimination based on nationality relative to nationals of the Member States in which those workers are employed. The draft decision also provides for the possibility to export benefits as defined, in that the latter shall not be subject to any reduction, modification, suspension, withdrawal or confiscation by reason of the fact that the beneficiary is residing for the purpose of a benefit under the legislation of a Member State, within the territory of Israel.

Article 62 of the Euro-Mediterranean Agreement with Egypt merely emphasises "the importance they [the parties] attach to the fair treatment of their workers legally residing and employed in the territory of the other party, and that the Member States and Egypt, at the request of any of them, agree to initiate talks on reciprocal bilateral agreements related to the working conditions and social security rights of Egyptian and Member State workers legally resident and employed in their respective territory". First, this is a declaration of intent, a recognition to accord fair treatment to the workers of another party. The question arises immediately what "fair treatment" means. Hence, the provision contains a weak commitment to ensure "fair treatment" and cannot be equalised with a non-discrimination clause. On the basis of Article 63 of the Euro-Mediterranean Agreement, the parties shall conduct regular dialogue

135 Art. 65 of the Euro-Mediterranean Agreement with Israel.

136 Council Decision of 21 October 2010 on the position to be taken by the European Union within the Association Council set up by the Euro-Mediterranean Agreement establishing an association between the European Communities and their Member States, of the one part, and the State of Israel, of the other part, with regard to the adoption of provisions on the coordination of social security systems (2010/700/EU). 
concerning social matters which are of interest to them including the furthering of tolerance and the removal of discrimination.

Article 80 of the Euro-Mediterranean Agreement with Jordan envisages the establishment of a regular dialogue concerning social matters of mutual interest. This dialogue is aimed at fostering the movement of workers and the equal treatment and social integration of Jordanian and Community nationals legally residing in their host countries. In a Joint Declaration relating to workers (Article 65 of the Agreement), the parties reaffirm the importance they attach to the fair treatment of foreign workers legally employed on their territory. The Member States moreover agree that, if Lebanon so requests, they are each prepared to negotiate bilateral agreements relating to the working conditions, remuneration, dismissal and social security rights of Lebanese workers legally employed on their territory.

\subsection{Nationals of the Eastern ENP States}

Only the PCAs concluded with Moldova and Ukraine, which were both signed in 1994, include additional provisions under the chapter concerning labour conditions relating to the coordination of social security. ${ }^{137}$ In view of social security, it is laid down that the parties shall conclude agreements that coordinate, subject to the conditions and modalities applicable in the Member States, the social security systems for workers of Moldovan or Ukrainian nationality, respectively, legally employed in the territory of a Member State. It is further specified that these agreements shall, in particular, include provisions which ensure, first, that all periods of insurance, employment or residence completed by such workers in the various Member States shall be added together for the purpose of pensions in respect of old age, invalidity and death and for the purpose of medical care for such workers. Second, these provisions shall ensure that old age, death, industrial accident or occupational disease, or of invalidity resulting therefrom, with the exception of non-special contributory benefits, shall be freely transferable at the rate applied by virtue of the law of the debtor Member State or States. These agreements shall not affect any rights or obligations arising from bilateral agreements between a Member State and Moldova, or Ukraine, respectively, which provide for more favourable treatment for the nationals of both parties. ${ }^{138}$ No such agreements have been concluded under the PCAs between the EU, the Member States and Moldova or Ukraine, respectively, to date, which means that neither Moldovan nor Ukrainian nationals enjoy any social security rights based on the PCAs at this moment. ${ }^{139}$

\subsection{Nationals of Russia}

Article 24 of the PCA with Russia enshrines rules regarding the coordination of social security. To coordinate the social security systems, the parties shall conclude agreements containing the necessary provisions, subject to the conditions and

137 See Arts. 24-25 of the PCA with Moldova; Arts. 25-26 of the PCA with Ukraine.

138 Art. 25 of the PCA with Moldova; Art. 26 of the PCA with Ukraine.

139 According to the website of the Treaties Office Database of the European External Action Service: <http://ec.europa.eu/world/agreements/default.home.do>, last accessed on 15 March 2012. 
modalities of each Member State, applicable to Russian workers legally employed in a Member State and, where applicable, for their family members legally resident there. These agreements shall contain provisions to ensure that:

- all periods of insurance, employment or residence completed by such workers in the various Member States shall be added together for the purpose of pensions in respect of old age, invalidity and death and for the purpose of medical care for such workers and where applicable for such family members;

- any pensions in respect of old age, death, industrial accident or occupational disease, or of invalidity resulting therefrom, with the exception of special noncontributory benefits, shall be freely transferable at the rate applied by the virtue of the law of the debtor Member State or States;

- the workers in question shall, where applicable, receive family allowances for the above mentioned members of their family. ${ }^{140}$

A Joint Declaration in relation to Article 24 lays down that the notion "members of their families" is defined in accordance with the national legislation of the host country concerned. Article 25 stipulates that the measures to be taken in conformity with Article 24 of this Agreement shall not affect any rights or obligations arising from bilateral agreements linking the Member States and Russia where those agreements provide for more favourable treatment of nationals of the Member States or of Russia. ${ }^{141}$

\subsection{Other Sources of EU Law Applicable to Third-Country Nationals}

The EU Charter sets forth that "everyone residing and moving legally within the European Union is entitled to social security benefits and social advantages in accordance with Union law and national laws and practices." 142 The Union, moreover, "recognises and respects" the entitlement to social security benefits and social services providing protection in cases such as maternity, illness, industrial accidents, dependency or old age and in the case of loss of employment, in accordance with the rules laid down by Union law and national laws and practices. ${ }^{143}$ However, the EU Charter does not set out equal treatment in the field of social security.

The directives setting out the admission conditions for highly qualified workers (EU Blue Card) ${ }^{144}$ for researchers, ${ }^{145}$ for third-country workers under Directive

\footnotetext{
140 Art. 24(1) of the PCA with Russia.

141 To date no such agreement on the coordination of social security has been concluded with Russia, see website of the Treaties Office Database of the European External Action Service: <http://ec.europa.eu/world/agreements/default.home.do>, last accessed on 10 January 2012.

142 Art. 34(2) of the EU Charter.

143 Art. 34(1) of the EU Charter.

144 Art. 14(1)(e) of Council Directive 2009/50/EC of 25 May 2009 on the conditions of entry and residence of third-country nationals for the purposes of highly qualified employment.

145 Art. 12(c) of Council Directive 2005/71/EC of 12 October 2005 on a specific procedure for admitting third-country nationals for the purposes of scientific research.
} 
2011/98/EU, ${ }^{146}$ as well as the Directive on long-term resident status for thirdcountry nationals ${ }^{147}$ enshrine equal treatment rules in matters of social security with nationals. For third-country long-term residents, the legal obligation to ensure such equal treatment moreover covers social assistance and social protection as defined by national law. However, this treatment is not granted unconditionally: the Member States may restrict equal treatment to cases where the place of residence of the longterm resident, or that of family members for whom she/he claims benefits, lies within the territory of the Member State concerned. ${ }^{148}$ Moreover, Member States may limit equal treatment in respect of social assistance and social protection to core benefits in conformity with Article 11(4) of the Directive on long-term resident status. ${ }^{149}$ Such a limitation is neither contained in the Blue Card nor in the researchers' directives: EU Blue Card holders and researchers, falling under Council Directive 2005/71/EC, shall enjoy equal treatment as regards branches of social security as defined in Council Regulation No 1408/71.150

Third-country workers have the right to equal treatment with nationals of that Member State where they reside concerning the branches of social security as defined in Regulation (EC) No 883/2004 under Article 12(1)(e) of Directive 2011/98/EU on a single permit. ${ }^{151}$ This right to equal treatment in social security may be restricted by Member States unless the third-country worker in question is in employment or has been in employment for a minimum period of six months and is registered as unemployed. The Member States may decide that family benefits shall not apply to third-country nationals who have been authorised to work in the territory of a Member State for a period not exceeding six months, to third-country nationals who have been admitted for the purpose of study, or to third-country nationals who are allowed to work on the basis of a visa. ${ }^{152}$ Article 12(4) of Directive 2011/98/EU on a single permit enshrines a rule on the portability of pension benefits in that "[T]hird-

146 Art. 12(1) of Directive 2011/98/EU on a single permit.

147 Art. 11(1)(d) of Council Directive 2003/109/EC of 25 November 2003 concerning the status of third-country nationals who are long-term residents.

148 Art. 11(2) of Council Directive 2003/109/EC of 25 November 2003 concerning the status of third-country nationals who are long-term residents.

149 A. Farahat convincingly questioned the legality of this restriction pointing to the requirements of Art. 9 ICESCR as interpreted in the General Comments No. 19 and 20, which require that a restriction, such as in Art. 11(4) of Council Directive 2003/109/EC, must be reasonable and justified: A. Farahat, 'Is there a Human Right to Equal Social Security? EU Migration Law and the Requirements of Art. 9 ICESCR', in: M. Maes, M.-C. Foblets and Ph. De Bruycker (eds.), External Dimensions of European Migration and Asylum Law and Policy (Bruylant, Bruxelles 2011), 529-548, pp. 544-545. Council Regulation (EEC) No 1408/71 of 14 June 1971 on the application of social security schemes to employed persons, self-employed persons, and to members of their families moving within the Community; the Annex of Council Regulation (EC) No $859 / 2003$ on family benefits applies accordingly.

151 The third-country workers referred to under Art. 12 are defined in Art. 3(1)(b) and (c) of Directive 2011/98/EU for a single permit, meaning: third-country nationals who have been admitted to a Member State for purposes other than work in accordance with Union or national law, who are allowed to work and who hold a residence permit in accordance with Regulation (EC) No 1030/2002; and third-country nationals who have been admitted to a Member State for the purpose of work in accordance with Union or national law. Art. 12(2)(b) of Directive 2011/98/EU on a single permit. 
country workers moving to a third country, or their survivors who reside in a third country and who derive rights from those workers, shall receive, in relation to old age, invalidity and death, statutory pensions based on those workers' previous employment and acquired in accordance with the legislation referred to in Article 3 of Regulation (EC) No 883/2004, under the same conditions and at the same rates as the nationals of the Member States concerned when they move to a third country." Hence, in relations to the specific kind of pensions mentioned, third-country workers shall be treated equally with Member States' nationals moving to a country outside the EU.

\subsection{Social Security Rights Compared}

First, the current legal regime on the social security coordination for third-country nationals is governed by Regulation (EU) No 1231/2010. ${ }^{153}$ Regulation (EU) No $1231 / 2010$ is applicable to nationals of third countries, as well as their family members and survivors, who are not already covered by Regulation (EC) No $883 / 2004$ and Regulation (EC) No 987/2009 solely on the ground of their nationality, provided that they have legal residence in a Member State and that they are in a situation which is not confined in all respects within a single Member State. Second, most directives in the field of legal migration contain an equal treatment obligation in matters of social security with nationals, including the directives setting out the admission conditions for highly qualified workers (EU Blue Card), ${ }^{154}$ for researchers, ${ }^{155}$ for third-country workers under Directive 2011/98/EU, ${ }^{156}$ as well as the Directive on long-term resident status for third-country nationals; ${ }^{157}$ long-term residents, in addition, enjoy equal treatment with regard to social assistance and social protection as defined by national law.

Third, the landscape of social security rights as laid down in association agreements is very diverse, ranging from the full extension of Regulation (EC) No 883/2004 to equal treatment provisions to enabling clauses that envisage the conclusion of social security agreements. There is a clear link between the scope of rights granted and the objective of the agreement concerned: the closer the relations between the EU and a third-country, the more extensive is the social security protection afforded. The Europe Agreements contained rules on the aggregation of employment and insurance periods for the purpose of calculating benefits, on the export of benefits, as well as on family allowances. ${ }^{158}$ EEA and Swiss nationals benefit from the most extensive set of social security rights seeing that they can rely - on the basis of extending

153 Regulation (EU) No 1231/2010 of the European Parliament and of the Council of 24 November 2010 extending Regulation (EC) No 883/2004 and Regulation (EC) No $987 / 2009$ to nationals of third countries who are not already covered by these Regulations solely on the ground of their nationality. Art. 14(1)(e) of Council Directive 2009/50/EC of 25 May 2009 on the conditions of entry and residence of third-country nationals for the purposes of highly qualified employment.

155 Art. 12(c) of Council Directive 2005/71/EC of 12 October 2005 on a specific procedure for admitting third-country nationals for the purposes of scientific research.

156 Art. 12(1) of Directive 2011/98/EU on a single permit.

157 Art. 11(1)(d) of Council Directive 2003/109/EC of 25 November 2003 concerning the status of third-country nationals who are long-term residents.

158 See Arts. 38 and 39 of the Europe Agreement with Poland. 
legislation - on Regulation (EC) No 883/2004; these nationals come within the scope of the latter regulation in the first Member State to which they move and reside. ${ }^{159}$ Likewise for Turkish nationals, Decision No 3/80 on the application of social security schemes remains relevant since its scope of application covers situations that are restricted to one Member State; in other words, it stipulates rules relating to social security in the context between Turkey and one Member State. ${ }^{160}$

Fourth, another privileged group of third-country nationals that enjoys more extensive rights in the area of social security are those nationals who fall under one of the draft decisions on the coordination of social security systems adopted in October of 2010, including Algerian, Moroccan, Tunisian, Croatian, Macedonian and Israeli nationals. The Member States are bound to treat the latter third-country nationals equally with nationals in view of certain social security benefits (including old-age pensions, survivors' pensions, pensions in respect of accidents at work and occupational diseases, invalidity pensions, family allowances); the Member States must also ensure the exportability of such benefits to the exclusion of special noncontributory cash benefits and family allowances. The draft decisions provide for information exchange, administrative assistance and further cooperation. As opposed to Regulation (EU) No 1231/2010, the application of the draft decisions is not limited to situations that have a transfrontier element. ${ }^{161}$ The close cooperation promoted by the 1976 Cooperation Agreements with the Maghreb countries can be explained on grounds of the close historical ties with the former colonial power of France. The Court in Luxembourg has interpreted the rights contained in these Cooperation Agreements in favour of Maghreb nationals, and it has produced considerable case law, which is fully transposable to the Euro-Mediterranean Agreements.

A comparison of the different association frameworks reveals that equal treatment in view of social security is only partly anchored in the EU's relations with third countries. Nationals of the EEA states, Switzerland, Turkey and of the Maghreb states Algeria, Morocco and Tunisia enjoy a directly applicable right to equal treatment in matters of social security stipulated in the respective frameworks. Nationals of Croatia, the FYROM and Israel are granted such a right on the basis of draft decisions coordinating social security systems. ${ }^{162}$ It is interesting to point out

Legislative acts that are identified as being relevant to the EEA and to FMP Agreement with Switzerland need to be transposed in accordance with the respective procedures to be applicable.

Compare the scope of application of Regulation (EU) No 1231/2010 of the European Parliament and of the Council of 24 November 2010 extending Regulation (EC) No 883/2004 and Regulation (EC) No 987/2009 to nationals of third countries who are not already covered by these Regulations solely on the ground of their nationality. See respective Art. 2(a) of the draft decisions.

162 Council Decision of 21 October 2010 on the position to be taken by the European Union within the Stabilisation and Association Council established by the Stabilisation and Association Agreement between the European Communities and their Member States, of the one part, and the Republic of Croatia, of the other part, with regard to the adoption of provisions on the coordination of social security systems - Draft Decision No .../... of the Stabilisation and Association Council established by the Stabilisation and Association Agreement between the European Communities and their Member States, of the one part, and the Republic of Croatia, of the other part, of ... 
that such a draft decision for Israel was adopted although the Euro-Mediterranean Agreement with Israel does not provide for comparable rules for the adoption of such a decision. However, it was argued that the Agreement provided a "sufficient" legal basis for cooperation in social matters so that the draft decision could nonetheless be adopted. In this respect, it is important to note that it has been under the aegis of former DG RELEX that the association and cooperation agreements have been drafted. ${ }^{163}$ In comparison to Turkish nationals who have to rely on Decision No 3/80, Maghreb nationals can directly invoke the non-discrimination clause on social security contained in the respective association agreement in accordance with ECJ case. ${ }^{164}$ It has been criticised that the Court provides no explanation for the differential approach taken in view of Maghreb nationals on the one hand and with regard to Turkish nationals on the other. ${ }^{165}$ Finally, the Court specified for both categories, Maghreb workers and their family members, autonomous definitions in the context of the Cooperation Agreements, as reiterated in case law on the Euro-Mediterranean Agreement with Morocco. ${ }^{166}$

\section{CONCLUSION TO PART VI}

Social security policies and laws aim to reduce the risk of being exposed to poverty because of unemployment, disability, sickness and other contingencies. Such policies and laws are consequently of major importance for individuals in general and for migrants in particular considering that non-nationals are more likely to be in a vulnerable situation than nationals. Equality of treatment in matters of social security puts legally residing foreign (non-EU) nationals and their family members in the same position as nationals of the Member State of residence; yet, third-country nationals face the additional requirement of being in a situation that involves at least two Member States, in other words, there must be a trans-frontier element present to qualify for social security coordination at the European level. As a result, Member States have been under the obligation to apply the relevant legislation in the area of social security to non-EU nationals, and the status of all third-country nationals has been strengthened in view of social security rights subject to the condition of having moved within the EU. The foundations for this re-thinking in European migration policy that has entailed the gradual consideration of third-country nationals in view of

with regard to the provisions on the coordination of social security systems contained in the Stabilisation and Association Agreement (2010/702/EU); Council Decision of 21 October 2010 on the position to be taken by the European Union within the Stabilisation and Association Council established by the Stabilisation and Association Agreement between the European Communities and their Member States, of the one part, and the former Yugoslav Republic of Macedonia, of the other part, with regard to the adoption of provisions on the coordination of social security systems (2010/701/EU). Opportunities, European Commission, held on 2 February 2011. See inter alia Cases C-18/90 Kziber [1991] ECR I-199, para. 15; C-103/94 Krid [1995] ECR I-719, paras. 21-24; C-113/97 Babahenini [1998] ECR I-183, paras. 17-18. Or Not To Move? The Response of the Judiciary', 45 Common Market Law Review (2009), 1621, pp. 1653-1654.

166 Order of the Court of 17 April 2007, Case C-276/06 El Youssfi [2007] ECR I-2851, paras. 62 and 68. 
social security protection was laid down at the Porto conference of November 1994. ${ }^{167}$ The coordination of social security schemes applicable to EU nationals has first been extended to third-country nationals by Council Regulation (EC) No $859 / 2003$ which has been replaced, in the meantime, by Regulation (EU) No 1231/2010.168 The adoption of Regulation (EU) No 1231/2010 undoubtedly constitutes a milestone for the social security protection of third-country nationals, irrespective of nationality.

However, in the past, social security rules had already been incorporated into association agreements on the basis of which certain nationals find themselves in a more privileged position as regards treatment in social security matters as Part VI has shown. The direct effect of a non-discrimination clause in matters of social security was first established in Kziber. ${ }^{169}$ The Member States were struck by this decision on the legal enforceability of the non-discrimination clause which they had not anticipated at the time. ${ }^{170}$ It has been pointed out that this led to an interaction between the legislator and the Court's case law seeing that "after the Kziber judgment of January 1991, the Council has refused to include an unconditionally-worded equal treatment provision in any association or cooperation agreement concluded with a third country [in relation to social security]". ${ }^{171}$ In this regard, it is self-evident that the EEA Agreement and the FMP Agreement with Switzerland constitute exceptions to the rule in providing a status similar to that of EU citizens. It is noticeable that the more recently concluded association agreements, including the Euro-Mediterranean Agreements with Algeria, Morocco and Tunisia, specify that the provisions of the chapter on workers only apply to nationals of the parties residing or working legally in the territory of their host country. ${ }^{172}$ With this safeguard, the Member States' intended to rule out the reliance of undocumented migrants on their national social security systems. ${ }^{173}$

167 Conference on "Social Security in Europe - Equality between Nationals and NonNationals", organised by the European Commission on 12-14 November 1994 in Oporto, Portugal.

168 Council Regulation (EC) No 859/2003 of 14 May 2003 extending the provisions of Regulation (EEC) No 1408/71 and Regulation (EEC) No 574/72 to nationals of third countries who are not already covered by those provisions solely on the ground of their nationality; Regulation (EU) No 1231/2010 of the European Parliament and of the Council of 24 November 2010 extending Regulation (EC) No 883/2004 and Regulation (EC) No 987/2009 to nationals of third countries who are not already covered by these Regulations solely on the ground of their nationality.

169 Case C-18/90 Kriber [1991] ECR I-199.

170 Interview with a Commission official of DG Employment, Social Affairs and Equal Opportunities, European Commission, held on 2 February 2011.

171 R. Cornelissen, 'The European Co-ordination of Social Security and Third Country Nationals', in: D. Pieters and P. Schoukens (eds.), The Social Security Co-ordination Between the EU and Non-EU Countries (Intersentia, Antwerp 2009), p. 12.

172 Art. 69 of the Euro-Mediterranean Agreement with Algeria; Art. 66 of the EuroMediterranean Agreements with Morocco and Tunisia.

173 On the social security status of irregular migrant workers see K. Kapuy, 'European and International Law in Relation to the Social Security of Irregular Migrant Workers', in: D. Pieters and P. Schoukens (eds.), The Social Security Co-ordination Between the EU and Non-EU Countries (Intersentia, Antwerp 2009), pp. 115-155. 



\section{Part VII : The Legal Position of Third-Country Nationals: Other Economic and Social Rights}

The legal position of third-country nationals is made up of a set of different rights. Next to rights concerning employment, residence and social security, third-country nationals can benefit from other economic and social rights - to complete the analyses of Parts V and VI, Part VII discusses the scope of these additional rights. In a first step, the economic rights relating to establishment and the provision of services, as well as the recognition of diplomas, which facilitates access to employment, are explored. In a second step, social rights, such as the right to education, rights in matters of housing and the right to social and tax advantages are examined.

Just like employment, residence and social security rights, these other economic and social rights were first granted within the scope of the association agreements with third countries, inspired by the free movement rules first applicable to Community workers. The expansion of these free movement rules to all EU citizens by the introduction of European citizenship with the Treaty of Maastricht has again rubbed off on third-country nationals: the transfer of competences in migration issues that was realised by the Treaty of Amsterdam contributed considerably in building a comprehensive protection regime for third-country nationals. For instance, once a third-country national has acquired long-term resident status, the person concerned may claim equal treatment for, among other things, education and vocational training and tax benefits. ${ }^{1}$ As regards the exercise of economic activities relating to establishment and the provision of services, importantly, certain third-country nationals enjoy more extensive rights based on the respective association agreements. For example, some agreements contain a right to establishment as a self-employed person in the EU for nationals of the contracting parties, including nationals of the EEA, Switzerland and the Western Balkan countries.

Numerous association agreements set forth a right to provide services in conformity with the rules of the GATS that promote the liberalisation of trade in services in the world economy. Other rights, such as the mutual recognition of diplomas and professional qualifications, facilitating access to employment in the EU, are exclusively granted to EEA and Swiss nationals on the basis of the respective association agreements; yet, some directives integrated a right to equal treatment as regards the recognition of professional diplomas. Again, the various sources of law must be taken into account for such an analysis; the association agreements are the starting point.

\section{THE RIGHT TO ESTABLISHMENT}

The right to establishment allows economic actors, including persons and companies, to carry on an economic activity in one or more Member States on a stable and

Council Directive 2003/109/EC of 25 November 2003 concerning the status of thirdcountry nationals who are long-term residents 
continuous basis. For persons, the freedom of establishment, generally speaking, relates to taking up and pursuing economic activities as self-employed persons, as well as setting up and managing businesses. The freedom of establishment is one of the fundamental freedoms that is central for the effective operation and functioning of the EU's internal market. Under the Treaty framework, the principle of freedom of establishment is guaranteed in Article 49 TFEU: restrictions on the freedom of establishment of nationals of a Member State in the territory of another Member State shall be prohibited. This study is restricted to the right of natural persons to establish themselves as self-employed in the territory of a Member State. It must be pointed out that some agreements, such as the ones concluded with Russia and the Maghreb states, define "establishment" as the right of companies to take up economic activities by means of setting-up subsidiaries and branches in the territory of the other contracting party; this form of establishment is not considered in the present dissertation.

\subsection{Nationals of the Former Europe Agreement States}

The establishment rules under the Europe Agreements resembled each other with the exception of the Europe Agreements concluded with Lithuania, Latvia, Estonia and Slovenia; for these latter agreements the establishment provisions were only addressed to companies. ${ }^{2}$ Articles 44 to 54 of the Europe Agreement with Poland (Chapter II of Title IV) contained rules on establishment in the Member States. ${ }^{3}$ The right to establishment translated into an obligation, on behalf of the Member States, to grant treatment no less favourable than that accorded to their own companies and nationals for purpose of establishment and for the operation of companies. ${ }^{4}$ The provision was reciprocal in nature and thus also valid for EU companies and nationals aiming at establishing themselves in a Central or Eastern European country. "Establishment" as regards nationals was defined as "the right to take up and pursue economic activities as self-employed persons and to set up and manage undertakings, in particular companies, which they effectively control." 5

As the Court has made clear in Gebhard, the concept of establishment within the meaning of the Treaty is a very broad one allowing nationals to participate, on a stable and continuous basis, in the economic life of a Member State other than his state of origin. ${ }^{6}$ Self-employment, in addition, covers a person who is established in one Member State and would like to practice as a lawyer in another Member State and wishes to set up a chamber abroad to this end. ${ }^{7}$ In Jany the Court first ruled on

2 A. Böcker and E. Guild, Implementation of the Europe Agreements in France, Germany, the Netherlands and the UK: Movement of Persons (Platinium, London 2002), p. 14.

3 For illustration purposes reference is made to the Europe Agreement with Poland.

$4 \quad$ See Art. 44(1) and (3) of the Europe Agreement with Poland; the Europe Agreements concluded with Hungary, the Baltic States and Slovenia stipulated a delay for the application of the right to establishment for natural persons, see E. Guild and others, A Guide to the Right of Establishment under the Europe Agreements (Baileys Shaw \& Gillett in association with the Immigration Law Practitioners' Association, London 1996), p. 6.

$5 \quad$ Art. 44 (4)(a)(i) of the Europe Agreement with Poland.

$6 \quad$ Case C-55/94 Gebhard [1995] ECR I-4165, para. 25; see also Case 2/74 Reyners [1974] ECR 631, para. 21. Case 107/83 Klopp [1984] ECR 2971. 
the notion of self-employment within the scope of the Europe Agreements. ${ }^{8}$ It held that the right of establishment as stipulated in the Europe Agreements (Article 44(4)(a)(i) of the Europe Agreement with Poland) had to be construed to the effect that the "economic activities as self-employed persons" referred to had the same meaning and scope as the identical term referred to in the EC Treaty. ${ }^{9}$ In that legal dispute, the Court was faced with the sensitive question as to whether prostitutes of Polish and Czech origin could be regarded as self-employed persons for the purposes of the respective Europe Agreements. The Court stated that "prostitution can be regarded as a commercial activity, it is sufficient to hold that prostitution is an activity by which the provider satisfies a request by the beneficiary in return for consideration without producing or transferring material goods."10

The direct effect of the right to establishment for individuals as contained in the Europe Agreements had already been established in three previous cases which had all been submitted to the Court by the High Court in London in 1998 and 1999. ${ }^{11}$ Kondova concerned a Bulgarian student who had entered the UK for a short-term work stay. Shortly after her arrival, she made a request for political asylum and acknowledged that this request was the true intention of her journey to the UK. The British authorities turned down her asylum application and asked her to leave the country by virtue of her irregular status. However, Ms Kondova stayed in UK territory, started working as a self-employed cleaner and claimed a right of residence there on the basis of the Europe Agreement with Bulgaria. In Gloszczuk a Polish national, who was joined by his wife in the UK, overstayed his tourist visa and established himself as a self-employed building contractor. The couple sought to regularise their stay by relying on the right to establishment under the pertinent Europe Agreement. Lastly, the dispute of Barkoci and Malik dealt with Czech nationals who arrived in the UK seeking asylum. Before their asylum applications were considered, both nationals requested to establish themselves as self-employed persons. Other Member States intervened in all three cases which demonstrates the political sensitivity of the issue at hand at the time.

According to the Court, the right of establishment under the Europe Agreements implied a concurrent right of entry to and residence in the Member States. However, such rights conferred on Czech nationals as corollaries of the right of establishment were not absolute privileges, inasmuch as their exercise might, where appropriate, be limited by the rules of the host Member State regarding entry, stay and establishment of Czech nationals. ${ }^{12}$ These domestic rules, applicable to natural persons, are subject to the condition that they do not nullify or impair the benefits accruing to the Czech Republic under the Europe Agreement. The question arose in which cases national restrictions on the right to establishment could legitimately be imposed. The Court

Case C-268/99 Jany [2001] ECR I-8615.

Ibid., para. 50.

10 Ibid., para. 48; for a case that involved Member States' nationals, see Case C-115 and 116/81 Adoui [1982] ECR 1665.

11 Case C-235/99 Kondova [2001] ECR I-6427, para. 34; Case C-63/99 Gloszcruk [2001] ECR I-6369, para. 33; Case C-257/99 Barkoci and Malik [2001] ECR I-6557, para. 34; as has been predicted, see E. Guild and others, A Guide to the Right of Establishment under the Europe Agreements (Baileys Shaw \& Gillett in association with the Immigration Law Practitioners' Association, London 1996), p. 8.

12 Case C-257/99 Barkoci and Malik [2001] ECR I-6557, paras. 44 and 54. 
found that the need for Czech nationals to make clear that they intended to become self-employed in the host Member State was not such as to render it impossible or excessively difficult for those nationals to exercise the rights accorded to them under the Europe Agreement. ${ }^{13}$ In conclusion, the Europe Agreement, therefore, did not in principle preclude a system of prior control by which the competent immigration authorities could ask the applicant to demonstrate that he or she genuinely intends to become self-employed, possesses sufficient financial resources and has reasonable chances of success. ${ }^{14}$

To what extent can the jurisprudence of the Court in Luxembourg on Member States' nationals in the field of self-employment be applied, by analogy, to nationals of countries with which the EU has concluded a Europe Agreement? A. Böcker concluded that the case law in the context of EU nationals can be relied upon in the framework of the Europe Agreements, considering that the concept of establishment has the same meaning. ${ }^{15}$ Other authors accepted the same meaning of the right to establishment as clarified by the Court but they took the view that "this does not mean that the interpretation of Article 43 (now Article 49 TFEU) can in all respects be extended to the Europe Agreements."16 This latter perception was, in fact, confirmed in Kondova in which the Court first observed that the right to the same treatment as nationals with regard to establishment, as defined in the Europe Agreement in wording similar or identical to that of Article 52 of the EC Treaty (now Article 49 TFEU), did include the rights of entry and residence by referring to case law on the EC Treaty and on the Community association with Turkey. ${ }^{17}$

However, the Court subsequently also made clear that a mere similarity in wording of a provision in the EC Treaty and an international agreement between the Community and a non-member country was not sufficient to give to the wording of that agreement the same meaning as it had in the EC Treaty. ${ }^{18}$ The extension of the interpretation in such a case depended, inter alia, on the aim pursued by each provision in its own particular context and a comparison of the objective and context of the agreement and the EC Treaty. Then the Court distinguished the Europe Agreement with Bulgaria from the EC Treaty by pointing out that the former was designed simply to create a framework for Bulgaria's integration into the Community, with a view to its possible accession, whereas the purpose of the EC Treaty was to create an internal market. Therefore, the Court concluded that the rights of entry and residence conferred on Bulgarian nationals, as corollaries of the right of establishment, were not absolute privileges, inasmuch as their exercise could be limited by the rules of the host Member State concerning entry, stay and

\footnotetext{
13 Ibid., para. 73.

14 Case C-257/99 Barkoci and Malik [2001] ECR I-6557, para. 83.

15 A. Böcker and E. Guild, Implementation of the Europe Agreements in France, Germany, the Netherlands and the UK: Movement of Persons (Platinium, London 2002), p. 18.

16 N. Rogers and R. Scannell, Free Movement of Persons in the Enlarged European Union (Sweet \& Maxwell, London 2005), pp. 297-298.

17 Case C-235/99 Kondova [2001] ECR I-6427, para. 50, referring to Case 48/75 Royer [1976] ECR 497, paras. 31-32; Case C-37/98 Savas [2000] ECR I-2927, paras. 60 and 63.

18 Case C-235/99 Kondova [2001] ECR I-6427, para. 51, referring inter alia to Case 270/80 Polydor [1982] ECR 329, paras. 14-21; Case C-312/91 Metalsa [1993] ECR I-3751, paras. 11-20.
} 
establishment of Bulgarian nationals. ${ }^{19}$ In Panayotova the Court confirmed that the right to establishment, as contained in the Europe Agreements with Poland, Bulgaria and Slovenia, did not preclude Member State legislation involving a system of prior control which made entry into the territory of that Member State, with a view to becoming a self-employed person, conditional on the issue of a temporary residence permit. Such a system could legitimately make granting that permit subject to the condition that the person concerned must show that he genuinely intended to take up an activity as a self-employed person without, at the same time, entering into employment or having recourse to public funds and that he possessed, from the outset, sufficient financial resources for carrying out the activity as a self-employed person and had reasonable chances of success. ${ }^{20}$

\subsection{EEA Nationals}

Chapter 2 of the EEA Agreement sets out the rules on the right of establishment. Article 31 of the EEA Agreement corresponds to Article 49 TFEU: it prohibits restrictions on the freedom of establishment of a national of an EU Member State or an EFTA state in the territory of any other of these states. This also applies to the setting up of agencies, branches or subsidiaries. Freedom of establishment includes the right to take up and pursue activities as self-employed persons and to set up and manage undertakings under the conditions laid down for its own nationals by the law of the country where such establishment is effected, subject to the provisions of chapter 4. Article 31(2) of the EEA Agreement stipulates that Annexes VIII to XI contain specific provisions on the right of establishment. Annex VIII sets out sectoral adaptations and special rules for nationals of Norway, Iceland and the EU Member States who wish to reside in Liechtenstein. Moreover, it is specified that the transitional arrangements for the Member States which joined the EU in 2004 and 2007 apply. The acts referred to include the General Programme for the abolition of restrictions on the freedom to provide services, ${ }^{21}$ the General Programme for the abolition of restrictions on freedom of establishment ${ }^{22}$ and Directive 2004/38/EC 23 on the right of citizens of the Union to move and reside freely and their family members within the territory of the Member States.

Article 32 of the EEA Agreement excludes the application of Chapter 2, so far as any given contracting party is concerned, to activities which, in that contracting party, are connected, even occasionally, with the exercise of official authority. Article 33 of the EEA Agreement stipulates that the provisions of the chapter shall not prejudice the applicability of provisions laid down by law, regulation or administrative action providing for special treatment for foreign nationals on grounds of public policy, public security or public health. Moreover, for the purposes of this chapter,

19 Case C-235/99 Kondova [2001] ECR I-6427, paras. 52-54.

20 Case C-327/02 Panayotova [2004] ECR I-11055.

21 General Programme for the abolition of restrictions on the freedom to provide services, OJ No 2, 15 January 1962, p. 32.

22 General Programme for the abolition of restrictions on freedom of establishment, OJ No 2, 15 January 1962, p. 36.

23 Directive 2004/38/EC of the European Parliament and of the Council of 29 April 2004 on the right of citizens of the Union and their family members to move and reside freely within the territory of the Member States. 
companies or firms, established in accordance with the law of an EC Member State or an EFTA state and having their registered office, central administration or principal place of business within the territory of the contracting parties, shall be treated in the same way as natural persons who are nationals of EC Member States or EFTA states. In this respect "companies or firms" mean companies or firms constituted under civil or commercial law, including cooperative societies and other legal persons governed by public or private law, save for those which are non-profitmaking (Article 34). Finally, the principle of mutual recognition of professional qualifications, in accordance with Annex VII to the EEA Agreement, shall apply to this chapter.

The ECJ has handed down cases on the interpretation and application of the principle on the freedom of establishment concerning nationals of Member States. This case law is arguably relevant for the interpretation of the EEA rules. ${ }^{24}$ First, the ECJ construed the concept of "establishment" extensively in Reyners in 1974 and, subsequently in Gebhard some 20 years later. ${ }^{25}$ In the latter case, the Court made clear that "establishment" in the meaning of the Treaty is a broad one, allowing a Community national to participate, on a stable and continuous basis, in the economic life of a Member State other than his or her state of origin and to profit therefrom, so contributing to economic and social interpenetration within the Community in the sphere of activities as self-employed persons. In addition, the Court first ruled in Reyners that Article 43 EC (now Article 49 TFEU) can be directly invoked by individuals, notwithstanding the fact that the implementing measures had not been adopted by the Council in that case; the prerequisites for direct effect as stipulated in $V$ an Gend en Loos were thus arguably not met. ${ }^{26}$

The right of establishment can also be extended to non-discriminatory measures as the Court pointed out in Klopp, which dealt with the setting up of a subsidiary in another Member State and in Kraus, where the Court held that Member States are required to take all appropriate measures to ensure fulfilment of the obligations arising out of the Treaty and to abstain from any measure which could jeopardise the attainment of the Treaty objectives. As a consequence, Article $48 \mathrm{EC}$ and $52 \mathrm{EC}$ (Article 54 TFEU and Article 59 TFEU) preclude any national measure liable to hamper or render less attractive the exercise of fundamental freedoms guaranteed by the Treaty. According to the Court, the situation would be different only if such a measure pursued a legitimate objective compatible with the Treaty and was justified by pressing reasons of public interests, however, the measure must furthermore be appropriate for ensuring attainment of the objective pursued and not go beyond what

$24 \quad$ As regards the freedom to provide services, the Court decided that the guarantees provided by Art. 36 of the EEA Agreement and Art. 56 TFEU must be given an identical and uniform interpretation, see Case C-522/04 Commission v. Belgium [2007] ECR I-5701, para. 44 et seq.

25 Case 2/74 Reyners [1974] ECR 63, para. 21; Case C-55/94 Gebhard [1995] ECR I-4165, para. 25.

26 Case 26/2 Van Gend en Loos [1963] ECR 1. 
is necessary for that purpose. ${ }^{27} \mathrm{Next}$, individuals can invoke Article 49 TFEU against their state of origin, as long as the situation is not wholly internal. ${ }^{28}$

\subsection{Swiss Nationals}

Article 4 of the FMP Agreement states that the right of residence and access to an economic activity shall be guaranteed. ${ }^{29}$ Chapter 3 of Annex I provides for specific provisions applicable to self-employed persons respectively such as procedural rules on residence, geographical and occupational mobility, frontier workers and public service employment. Furthermore, Article 15(1) of Annex I sets out an equal treatment clause for self-employed persons as regards access to self-employed activity and the pursuit thereof. In conformity with Article 15(2) of Annex I, equal treatment shall also be ensured in relation to tax concessions and welfare benefits, vocational training, membership of trade unions and housing.

The Court ruled on the scope of Article 15 of Annex I to the FMP Agreement setting out the equal treatment of self-employed persons in Stamm and Hauser. It held that the provision extends to self-employed frontier workers within the meaning of Article 13 of Annex I. ${ }^{30}$ Stamm and Hauser concerned a Swiss farmer who concluded an agricultural lease with a German national in respect of agricultural land situated in Germany. This lease was annulled by a local court on the ground that the lease implied an "unsound" distribution of land use. The Court concluded that the equal treatment clause on self-employed persons, contained in Article 15(1) of Annex I to the Agreement, included self-employed frontier workers since chapter II of Annex I comprises Articles 12 to 16 and nothing indicates that Articles 14 to 16 of the Annex should be applied solely to self-employed persons and not to self-employed frontier workers within the meaning of Article 13 of Annex I. ${ }^{31}$

The Court substantiated its finding by pointing to the wording of Article 15(2) of Annex I: "The provisions of Article 9 of this Annex shall apply mutatis mutandis to the self-employed persons referred to in this chapter". ${ }^{32}$ In the dispute of Graf and Engel, the Court of Justice ruled that the German legislation, on the basis of which the Agricultural Office had requested the immediate termination of an agricultural lease between a German and a Swiss national, contravened Article 15(1) of Annex I to the Agreement. ${ }^{33}$ The Agricultural Office objected to the land lease agreement at hand arguing that it distorted competition and involved an unsound distribution of land. The Court adjudicated that the prohibition of the agricultural lease constituted an indirect discrimination, which could not be objectively justified by the fact that Swiss

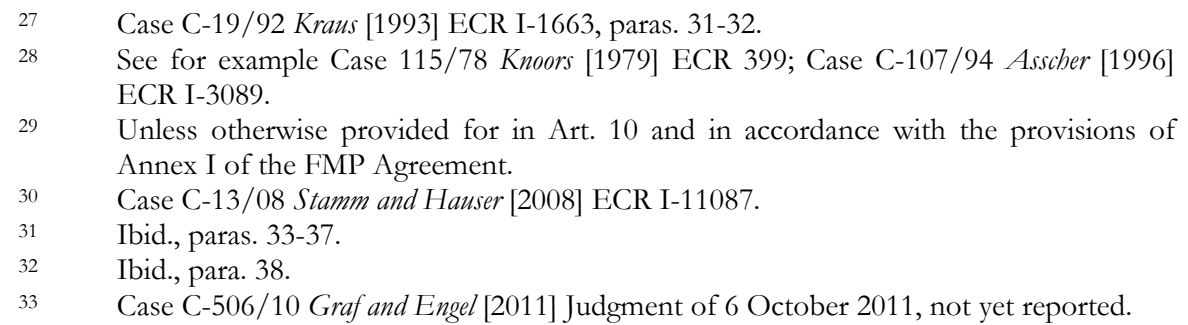


frontier workers could receive considerably more in Switzerland for produce grown in Germany than they would if they sold it in Germany. ${ }^{34}$

\subsection{Turkish Nationals}

Turkish nationals do not have a right to establishment on the basis of the EU-Turkey association law but the Ankara Agreement indicates that the contracting parties shall be guided by Articles 52 to 56 and Article 58 of the Treaty establishing the Community (Articles 49 to 52 and Article 54 TFEU) for the purpose of abolishing restrictions on the freedom of establishment between them. ${ }^{35}$ Next, the stand-still clause, contained in Article 41(1) of the Additional Protocol, prohibits novel restrictions on the freedom of establishment and the freedom to provide services. The Court made clear in Savas that Articles 13 of the Ankara Agreement and Article 41(2) of the Additional Protocol did not entail direct effect. However, Article 41(1) of the Additional Protocol was held to be directly applicable and prohibited the introduction of new national restrictions on the freedom of establishment and right of residence of Turkish nationals, as from the date on which the Protocol entered into force in the host Member State. Article 41(1) of the Additional Protocol is not in itself capable of conferring upon a Turkish national a right of establishment and a corollary right of residence in a Member State in whose territory he has established himself as a self-employed person, in violation of domestic immigration law. ${ }^{36}$ The Savas case dealt with a couple who had entered the UK as tourists and who overstayed their visas in breach of the UK immigration rules. Four years later, they started to operate a business without the necessary authorisation and another two years later they applied for leave to remain in the UK. The UK authorities issued a deportation order and the legal dispute was only suspended when the Queen's Bench Division of the High Court of Justice of England decided to stay the proceedings and refer the case to the ECJ for a preliminary ruling.

The Court specified in the Tüm and Dar judgment that Article 41(1) of the Additional Protocol prohibits the introduction, as from the entry into force of that protocol in view of the Member State concerned, of any new restrictions on the exercise of freedom of establishment, including those relating to the substantive and/or procedural conditions governing the first admission into the territory of that state, of Turkish nationals intending to establish themselves in business there on their own account. ${ }^{37}$ The case concerned two rejected asylum seekers in the UK who were initially granted temporary admission and who had started to operate businesses there. They both claimed their cases to be assessed under the 1973 UK Immigration Rules because the stand-still provision in Article 41(1) of the Additional Protocol also applied to conditions relating to entry of Turkish nationals into the territory of a Member State. The UK government submitted in turn that the stand-still provision did not cover the applicants considering that the provision only covered Turkish nationals who lawfully entered a Member State and subsequently established themselves there by setting up a business. According to the UK authorities, the applicants did not "enter" the UK for the purpose of immigration, hence the more

Ibid., paras. 26-30.

Art. 13 of the Ankara Agreement.

Case C-37/98 Savas [2000] ECR I-2927.

Case C-16/05 Tüm and Dar [2007] ECR I-7415. 
restrictive 1994 Immigration Rules applied that require foreign nationals who seek to establish themselves in the UK to be in possession of an entry clearance. ${ }^{38}$

The Court took the view that the stand-still clause did not call into question the Member State's competence to conduct their national immigration policy. It continued that the mere fact that, as from its entry into force, such a clause imposed on those states a duty not to act, which has the effect of limiting, to some extent, their room of manoeuvre on such matters does not mean that the very substance of their sovereign competence in respect of aliens should be regarded as having been undermined. According to the Court, Article 41(1) of the Additional Protocol referred, in a general way, to new restrictions inter alia, on the freedom of establishment; it did not limit its sphere of application by excluding, as did Article 13 of Decision No $1 / 80$, certain specific aspects from the sphere of protection afforded on the basis of the first of those two provisions. Moreover, the Court added that Article 41(1) of the Additional Protocol aimed to create conditions conducive to the progressive establishment of the freedom of establishment by way of an absolute prohibition on national authorities from creating any new obstacle to the exercise of that freedom by making the conditions which exist at a given time more stringent, so as not to render the gradual securing of that freedom between the Member States and the Republic of Turkey more difficult. Therefore, Article 41(1) of the Additional Protocol must be regarded as also being applicable to rules governing the first admission of Turkish nationals into a Member State where they intended to establish themselves. ${ }^{39}$ By taking this stance, the Court did not agree with AG Geelhoed who had taken the position of the UK authorities. ${ }^{40}$

\subsection{Nationals of the Western Balkan Countries}

The SAAs all set forth similar rules with regard to establishment. ${ }^{41}$ Establishment explicitly includes for nationals, the right to take up economic activities as selfemployed persons and to set up undertakings, which they effectively control. With the exception of the SAA concluded with the FYROM, it is specified in the other SAAs that the provisions of the chapter on establishment do not apply to those who are not exclusively self-employed. Upon the entry into force of the respective SAAs, as regards the establishment of companies of the other contracting party, as a general rule the parties shall mutually grant treatment no less favourable than that accorded to their own companies or to any third-country company, whichever is better; the same applies to the operation of subsidiaries and branches. Five years (or four years in the case of Croatia, Montenegro and Serbia) after the entry into force of the SAA, arrangements shall be made to extend the provisions on the establishment of nationals of both parties to take up economic activities as self-employed persons. Stand-still clauses in each SAA prevent the contracting parties from introducing discriminatory measures. The respective Stabilisation and Association Councils shall

Ibid., paras. 35-43.

Ibid., paras. 58-63.

Opinion of AG Geelhoed, delivered on 12 September 2006, Case C-16/05 Tüm and Dar.

41 Arts. $49-56$ of the SAA with Albania; Arts. 48-55 of the SAA with Croatia; Arts. 47-54 of the SAA with Macedonia; Arts. 52-58 of the SAA with Montenegro; Arts. 50-56 of the SAA with Bosnia and Herzegovina; Arts. 52-58 of the SAA with Serbia. 
take steps for the mutual recognition of qualifications. Moreover, detailed rules on the deployment of key personnel are specified for the companies of one contracting party established in the other party. The SAAs concluded with the FYROM, Croatia and Albania contain rules on the basis of which these countries can adopt derogatory measures for a limited period of time and subject to strict conditions as the establishment of EU companies and nationals of certain industries. ${ }^{42}$

\subsection{Chilean Nationals}

While the Association Agreement with Chile does not contain a right of establishment for natural persons, Article 94(2) targets the "improvement of the investment environment and, in particular, the conditions of establishment between the parties, on the basis of the principle of non-discrimination." With regard to establishment, it is laid down that each party shall grant treatment no less favourable to legal and natural persons performing a like economic activity than it accords to is own legal and natural persons. ${ }^{43}$

\subsection{All Other Third-Country Nationals}

Third-country nationals holding another nationality other than those discussed above do not have a right to establish themselves in a Member State on the basis of an association agreement. Directive $2011 / 98 / \mathrm{EU}$ on a single permit explicitly excludes self-employed workers from its scope of application. ${ }^{44}$ Likewise Article 15(2) of the EU Charter excludes third-country nationals from the freedom to exercise the right to establishment that is reserved for Union citizens only.

\subsection{The Right to Establishment Compared}

The comparison of the various association agreements unveils that only nationals of the EEA states, Switzerland and the Western Balkan countries may benefit from the right to establishment as a self-employed person in the EU today. Most Europe Agreements allowed nationals of the contracting parties to establish themselves in the territory of another contracting party before the 2004 and 2007 EU accessions took place. Since the enlargements, nationals of the former Europe Agreement states enjoy the right of establishment under Article 49 TFEU. The Court held that the right of establishment under the Europe Agreements implied a concurrent right of entry to and residence in the Member States; however, such rights were not absolute privileges, inasmuch as their exercise could be limited by the rules of the host Member State regarding entry, stay and establishment. ${ }^{45}$ While the Court has not yet

42 Art. 56 of the SAA with Albania; Art. 55 of the SAA with Croatia; Art. 54 of the SAA with Macedonia.

43 In the sectors inscribed in Annex X of the Association Agreement with Chile, and subject to any conditions and qualifications set out therein, see Art. 132. Art. 3(2)(k) of Directive 2011/98/EU of the European Parliament and of the Council of 13 December 2011 on a single application procedure for a single permit for thirdcountry nationals to reside and work in the territory of a Member State and on a common set of rights for third-country workers legally residing in a Member State. Case C-257/99 Barkoci and Malik [2001] ECR I-6557, paras. 44 and 54. 
ruled on the right of nationals of Norway, Iceland and Liechtenstein to establish themselves in a Member State, the Court has adjudicated on the freedom of establishment of Member States' nationals in which it interpreted the notion of "establishment" extensively. This case law is also of relevance for the interpretation of the EEA rules. ${ }^{46}$ The SAAs with the Western Balkan countries stipulate that arrangements shall be made to extend the provisions on the establishment of nationals of both parties to take up economic activities as self-employed persons only four or five years after their respective entry into force. Chilean nationals merely have the right to be treated equally in matters of establishment when performing a like economic activity. ${ }^{47}$

\section{The Right to Provide SERVICES}

Trade in services is pivotal for the growth and development of the world economy and, over the last decades, the services sector has steadily expanded. ${ }^{48}$ Within the framework of the Treaty, services are normally provided for remuneration and they are subsidiary, meaning that a commercial activity only falls under services if it is not covered by rules relating to the freedom of movement for goods, capital and persons. ${ }^{49}$ The right of establishment and the freedom to provide services have many characteristics and provisions in common, and the dividing line between both areas has not always been easy to draw.

The Court of Justice made clear in Gebhard that the important criteria for establishment relate to an economic activity that is carried out on a stable and continuous basis from an established undertaking in a Member State other than the state of origin. By comparison, the service provider moves to another Member State so as to pursue an economic activity there on a temporary basis. The temporary nature must be determined by the duration, regularity, periodicity or continuity of the activity concerned, and service providers may equip themselves with some form of infrastructure in the host Member State. ${ }^{50}$ For services provided within the EU, the EU legislator adopted Directive 2006/123/EC in December of 2006; this legislative instrument has the objective to facilitate the supply of services in the internal market and applies exclusively to services supplied by providers established in a Member State. 51 Considering that a lot of the association agreements refer to the international regime that regulates trade in services, an overview of the GATS is provided below.

\footnotetext{
46 As regards the freedom to provide services, the Court decided that the guarantees provided by Art. 36 of the EEA Agreement and Art. 56 TFEU must be given an identical and uniform interpretation, see Case C-522/04 Commission v. Belgium [2007] ECR I-5701, para. 44 et seq.

47 In the sectors inscribed in Annex X of the Association Agreement with Chile, and subject to any conditions and qualifications set out therein, see Art. 132 of the Association Agreement with Chile.

48 See Preamble of the GATS.

49 Art. 57 TFEU.

50 Case C-55/94 Gebhard [1995] ECR-I4165, paras. 25-27.

51 Directive 2006/123/EC of the European Parliament and of the Council of 12 December 2006 on services in the internal market.
} 
The multilateral trade negotiations of the Uruguay Round have led to the adoption of the GATS, which is an international framework that governs trade in the services sector since it entry into force in January 1995. The main purpose of the GATS is comparable to that of the GATT, namely providing a set of rules which defines a policy to boost economies and to serve as a reliable basis for universal trade and equal treatment. The GATS aims to promote economic performance through enhancing a competitive atmosphere by setting out globally recognised rules in the service sector. The GATS also fosters a strong development in the service branch, because services not only become accessible on a world-wide scale, but a transparent setting supports a smooth trade procedure as well. Liberalised markets stimulate innovations which put the service consumer eventually in a privileged position by means of lower prices and better quality. Moreover, technology transfer plays an important role: through service commitments foreign direct investment can be expedited which often results in a spill-over effect of new technologies.

The agreement has two parts; the first part sets out the framework with general provisions and rules. These include unconditional obligations, measures applicable to every state such as the most-favoured-nation treatment which requires states not to discriminate but to treat all foreign partners equally. Another obligation demands from Member States to publish adopted measures and to respond to information requests submitted by other nations. The second part of the GATS comprises listings which lay down each Member State's individual commitments. They refer on the one hand to the degree to which market access in a specified sector is provided to external providers and on the other hand they stipulate equal treatment of domestic and foreign providers, once a foreign provider has been admitted to operate in the territory of the respective Member State. It is at the discretion of each state to identify the commitments it is willing to make and the range it shall cover. It goes without saying that the commitments undertaken are often connected with a state's national policy.

According to Article I:1, the GATS applies to measures by Members affecting trade in services; the agreement covers, in essence, all services which are subject to global trade, excluding services provided to the public in the exercise of governmental authority as stipulated in Article I:3. A service which is carried out in the exercise of governmental authority is defined in the same provision as any service which is supplied neither on a commercial basis, nor in competition with one or more service suppliers. The expression "trade in services" relates to four modes of supply. ${ }^{2}$ For the purpose of this section, Mode 4 concerning the "movement of natural persons" is of relevance. Mode 4 relates to a situation where foreign individuals temporarily travel to another state with a view to supply services there. ${ }^{53}$ It was the trade ministries, not the ministries dealing with migration, that insisted on the inclusion of

52 The four modes of supply are cross-border supply, consumption abroad, commercial presence, and the movement of natural persons.

53 For a discussion on whether employment could also fall under the framework of GATS, see L.A. Winters and others, 'Liberalising Temporary Movement of Natural Persons: An Agenda for the Development Round', 26 The World Economy (2003), 1137, pp. 1153-1155. 
Mode 4 in the GATS after long negotiations during the Uruguay Round. ${ }^{54}$ Partly, the association and cooperation agreements make explicit reference to the GATS as is outlined in detail below.

\subsection{Nationals of the Former Europe Agreement States}

The former Europe Agreements all contained a Chapter III setting out provisions on the progressive liberalisation of the supply of services between the Community and the Central or Eastern European country in question. For this purpose, the respective parties were under the obligation to permit the temporary movement of natural persons providing the service or those who are employed by the service provider as key personnel as defined, where those representatives will not be engaged in making direct sales to the general public or in supplying services themselves. ${ }^{55}$ Special rules applied to transport services. The Europe Agreements concluded with Latvia, Lithuania, Estonia and Slovenia included an additional rule that prohibited rendering the conditions for the supply of services significantly more restrictive compared to the situation existing on the day preceding the day of entry into force of the respective agreement.

\subsection{EEA Nationals}

Chapter 3 of the EEA Agreement lays down the provisions which deal with services. Article 36(1) of the EEA Agreement prohibits restrictions on the freedom to provide services within the territory of the contracting parties in respect of nationals of EU Member States and EFTA States who are established in an EU Member State or an EFTA State, other than that of the person for whom the services are intended, within the framework of the provisions of the EEA Agreement. This rule reflects Article 56 TFEU. Next, Article 36(2) specifies that Annexes IX to XI contain specific provisions on the freedom to provide services: Annex IX concerns financial services; the acts referred to deal with insurance, banks and other credit institutions, stock exchange and securities, occupational retirement provisions and provisions applying to all kinds of financial services. Annex $\mathrm{X}$ sets out rules on services in general. The only act referred to in this Annex is Directive 2006/123/EC on services in the internal market. ${ }^{56}$ Annex XI contains rules on electronic communication, audiovisual services and information society. The acts referred to are classified as follows: telecommunication services, postal services, data protection, information society services and audiovisual services. According to Article 37 of the EEA Agreement, services within the meaning of this Agreement are normally provided for remuneration, in so far as they are not governed by the provisions relating to freedom of movement for goods, capital and persons. Services include, in particular, activities of an industrial and commercial character, activities of craftsmen and of the professions. The person providing the service may, in order to do so, temporarily

54 J. Niessen, 'Negotiating the Liberalization of Migration: Is GATS a Vehicle or a Model for Global Migration Governance?', European Policy Centre Issue Paper No. 6 (Brussels 2003), p. 4.

55 See for instance Art. 55(2) of the Europe Agreement with Poland.

56 Directive 2006/123/EC of the European Parliament and of the Council of 12 December 2006 on services in the internal market. 
pursue his or her activities in the state where the service is provided, under the same conditions as are imposed by that state on its own nationals. Freedom to provide services in the field of transport shall be governed by the provisions of chapter 6 (Article 38 of the EEA Agreement). In addition, the provisions of Articles 30 and 32 to 34 of the EEA Agreement shall apply to matters covered by this chapter (Article 39 of the EEA Agreement).

The Court found in Commission v. Belgium that the guarantees provided by Article 36 of the EEA Agreement on the freedom to provide services and Article 49 EC (now Article 56 TFEU) must be given an identical and uniform interpretation. ${ }^{57}$ Likewise, in Commission v. Spain, the Court held that, in so far as the provisions of Article 36 of the EEA Agreement have the same legal scope as the substantially identical provisions of Article $49 \mathrm{EC}$, its consideration on the justification of discrimination in case law established in the Community context could be transposed to the EEA context. ${ }^{58}$ This latter case concerned a fiscal exemption for winnings from lotteries and games of chance organised in a Member State by certain public bodies established in that Member State and pursuing social or charitable non-profit-making activities, without that same exemption being granted to winnings from lotteries and games of chance organised by bodies and entities established in another Member State of the EU or EEA and pursuing the same type of activities. In her opinion in the case Commission v. Portuguese Republic, AG Kokott stated that the findings made in relation to the alleged infringements of the provisions of the EC Treaty applied in corresponding fashion to Articles 36 [and 40] of the EEA Agreement; yet a difference might arise where the exchange of information between the tax authorities was at issue, inasmuch as Council Directive 77/799/EEC of 19 December 1977, concerning mutual assistance by the competent authorities of the Member States in the field of direct taxation, as amended by Council Directive 92/12/EEC of 25 February 1992, did not apply in the EEA States. ${ }^{59}$

The Court first held in the Van Binsbergen case that Article 49 EC (Article 56 TFEU) was capable of entailing direct effect. ${ }^{60}$ In this judgment, the Court clarified that a Member State may take measures in order to prevent the exercise by a person providing services and whose service is entirely or principally directed towards its territory for the purpose of avoiding the professional rules of conduct which would be applicable if established within that state. ${ }^{61}$ In order to qualify an activity as a service, remuneration must be present. It is irrelevant whether the person who receives the service is the same person who provides remuneration. ${ }^{62}$ The determination of the commercial character of services becomes trickier when remuneration is provided for by the state. While the economic nature of state education was denied in Humbel, the Court indicated in Wirth that education financed primarily from private funds could constitute a service within the meaning of the

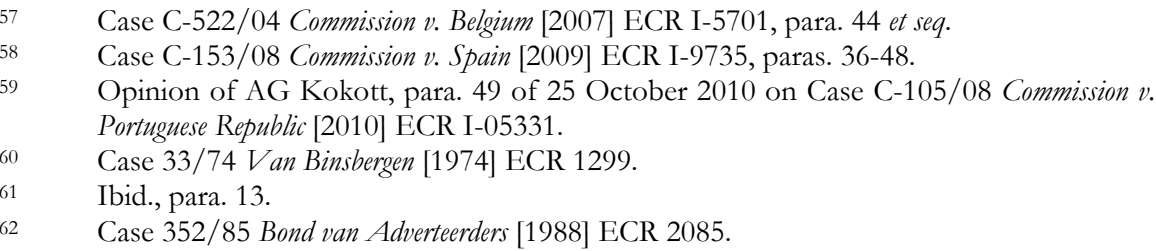


Treaty. ${ }^{63}$ In contrast, in the field of health care, the transfrontier provision of medical treatment was indeed considered as falling under Article 49 EC (Article 56 TFEU). ${ }^{64}$ The concept of services is also applicable to service recipients. ${ }^{65}$ The question as to whether the freedom of establishment and the freedom to provide and receive services can be relied upon by individuals, not only against the state but also against private parties, remains unclear.

\subsection{Swiss Nationals}

Article 5 FMP Agreement lays down that those providing services shall have the right to do so in the territory of the other contracting party for a period not exceeding 90 days of actual work per calendar year without prejudice to other specific agreements. For this purpose service providers have the right of entry into and residence in the territory of the other party, or where they have received the authorisation to provide a service from the competent authorities. The right of entry and residence extends to service receivers; the transitional arrangements in the FMP Agreement do no apply to service providers and receivers. ${ }^{66}$ Chapter 4 of Annex I of the FMP Agreement concerns service providers and substantiates the rule set out in Article 5 FMP Agreement. Article 17 of Annex I prohibits any restrictions of the provision of services that do not exceed 90 days per year and any restrictions on the right of entry and residence for service providers covered by Article 5(2) of the FMP Agreement, including posted third-country national employees. It has been argued that this Chapter constitutes a "mix of provisions" as it is partly influenced by two directives on the provision of services ${ }^{67}$ and EC Treaty rules on services. ${ }^{68}$ The Final Act of the FMP Agreement contains a Joint Declaration setting out the general liberalisation of service provision on the basis of the acquis communautaire.

In Hengartner and Gasser, it was held that the FMP Agreement did not preclude a Swiss national, as a service recipient, from being subjected to a higher tax than EU citizens for the right to hunt in the territory of a Member State. The Court explained that the FMP Agreement did not contain any specific rule intended to allow service recipients to benefit from the principle of non-discrimination in connection with the application of fiscal provisions relating to the commercial transactions whose subject was the provision of services. ${ }^{69}$ The Court largely followed the reasoning of the AG,

Case 263/86 Humbel [1988] ECR 5365; Case C-109/92 Wirth [1993] ECR I-6447.

Case 158/96 Kobll [1998] ECR I-1931; Case C-157/99 Geraets-Smits/Peerbooms [2001] ECR I-5473; Case C-372/04 Watts [2006] ECR I-4325.

Case 286/82 and 26/83 Luisi and Carbone [1984] ECR 377.

Art. 5(1) to (4) of the FMP Agreement.

Council Directive 73/148/EEC of 21 May 1973 on the abolitions of restrictions on movement and residence within the Community for nationals of Member States with regard to establishment and the provision of service, repealed by Directive 2004/38/EC, and Directive 96/71/EC of the European Parliament and the Council of 16 December 1996 concerning the posting of workers in the framework of the provision of services.

S. Peers, 'The EC-Switzerland Agreement on Free Movement of Persons: Overview and Analysis', 2 European Journal of Migration and Law (2000), 127, p. 134. Case C-70/09 Hengartner and Gasser [2010] ECR I-07223, para. 40. 
however, it decided that the activity at issue must be classified as a provision of services. ${ }^{70}$

\subsection{Turkish Nationals}

Just as in the case of freedom of establishment, the Ankara Agreement does not contain a right of Turkish nationals to provide services in the territory of an EU Member State. Again, the rules on the freedom to provide services in the EU context (Articles 51, 52 and 54 to 61 TFEU) shall give guidance in order to abolish restrictions on that freedom for Turkish nationals. ${ }^{71}$ In Abatay and Others it was decided that Article 41(1) of the Additional Protocol is applicable to international road haulage of goods originating in Turkey, where those service are carried out in the territory of a Member State and that the provision can be relied on not only by an undertaking established in Turkey, which performs services in a Member State but also by the employees of such an undertaking. ${ }^{72}$

The Soysal case concerned Turkish lorry drivers employed by a company established in Turkey from whom the German authorities required Schengen visas to enter German territory. ${ }^{73}$ The applicants argued that such visa requirements for Turkish workers engaged in the cross-border transport of goods was in breach of the standstill provision contained in Article 41(1) of the Additional Protocol because, at the time the Additional Protocol entered into force, Turkish nationals engaged in the provision of services in Germany, such as the applicants in the main proceedings, had the right to enter German territory for those purposes without first having to obtain a visa. The Court granted the claim of the applicants pointing out that national legislation, which makes the provisions of services by Turkish nationals conditional on the issuing of a visa, which can moreover not be required from Community nationals, is liable to interfere with the actual exercise of that freedom, especially on grounds of the additional and recurrent administrative and financial burdens involved in obtaining such a permit which is valid for a limited time. Next, the Court indicated that where such a visa is denied, legislation of that kind prevents the exercise of that freedom. Consequently, such legislation must be considered as a new restriction within the meaning of Article 41(1) of the Additional Protocol of the right of Turkish nationals resident in Turkey to freely provide services in Germany. The Court also made clear that this conclusion is not altered by the fact that the legislation in force merely implements a provision of EU secondary legislation. ${ }^{74}$

The implications of the Soysal judgment are far-reaching. ${ }^{75}$ First, Soysal implies that different visa rules apply to Turkish citizens in the 27 EU Member States contingent on the national the visa rules applicable at the time of the entry into force of the Additional Protocol in the respective State. Second, one may wonder whether the

70 See Opinion of AG Jääskinen of 20 May 2010 on Case C-70/09 Hengartner and Gasser [2010] ECR I-07223.

Art. 14 of the Ankara Agreement.

Case C-369/01 Abatay and Others [2003] ECR I-12301.

Case C-228/06 Soysal [2009] ECR I-1031.

Ibid.

K. Hailbronner, 'Visafreiheit für türkische Staatsangehörige? Zum Soysal-Urteil des EuGH', 12 Neue Zeitschrift für V erwaltungsrecht (2009), 760. 
outcome of Soysal applies equally to service providers and to service recipients "which seems to be contributing to cold feet in some Member States ministries". ${ }^{76}$ ECJ case law explicitly recognises that the provision of services includes the freedom to receive services. ${ }^{77}$ In this context, S. Peers emphasises the Bickel and Franz decision in which the Court held that the freedom to provide services "covers all nationals of Member States who, independently of other freedoms guaranteed by the Treaty, visit another Member State where they intend or are likely to receive services". The author concludes that any Turkish national who visits an EU Member State is covered by the stand-still clause subject to the condition that the free movement principles apply "as far as possible" to the Ankara Agreement. ${ }^{78}$ A case that will clarify the situation of Turkish nationals is pending. ${ }^{79}$ It is of importance that the Commission monitors and ensures the Member States' compliance with the Soysal judgment and its correct implementation into national law. In order to ensure coherence within the EU, it has been suggested to remove Turkey from the visa black list, also with a view to the EU visa policy for the Balkan countries. ${ }^{80}$

\subsection{Nationals of the Western Balkan Countries}

The SAAs concluded with the Western Balkan states aim gradually to liberalise trade in services. All SAAs contain similar rules on the supply of services. ${ }^{81}$ First, it is stipulated that the respective contracting parties undertake to take the necessary steps to allow progressively the supply of services by companies and nationals of the said parties which are established in the territory of a party other than that of the person for whom the services are intended; and that implementing measures shall be adopted four or five years after the entry into force of the agreement at hand. Second, a stand-still clause in each SAA prevents the parties from taking measures or actions which render the conditions for the supply of services significantly more restrictive as compared to the situation existing before the entry into force of the respective SAA. Special rules are laid down for the supply of transport services.

\footnotetext{
${ }_{76}$ K. Groenendijk and E. Guild, Visa Policy of Member States and the EU towards Turkish Nationals after Soysal, 249 Economic Development Foundation Publications, Second revised and updated version (İstanbul 2011), p. 65.

77 See Joined Cases 286/82 and 26/83 Luisi and Carbone [1984] ECR 377; Case 186/87 Cowan [1989] ECR 195; Case C-243/01 Gambelli [2003] ECR I-5145.

78 S. Peers, 'EC Immigration Law and EC Association Agreements: Fragmentation or Integration?', 34 European Law Review (2009), 628, p. 632.

79 Case C-221/11 Demirkan, reference for a preliminary ruling lodged on 11 May 2011.

80 K. Groenendijk and E. Guild, 'Visa Policy of Member States and the EU towards Turkish Nationals after Soysal, 249 Economic Development Foundation Publications, Second revised and updated version (İstanbul 2011), p. 61.

81 Arts. 57-59 of the SAA with Albania; Arts. 56-58 of the SAA with Croatia; Arts. 55-57 of the SAA with Macedonia; Arts. 59-61 of the SAA with Montenegro; Arts. 57-59 of the SAA with Bosnia and Herzegovina; Arts. 59-61 of the SAA with Serbia.
} 


\subsection{Nationals of the Mediterranean ENP States}

\subsubsection{Nationals of Algeria, Morocco and Tunisia}

The Euro-Mediterranean Agreements with Morocco and Tunisia contain an almost identical Title III on the right of establishment (of companies) and services. The parties agree to integrate the liberalisation of services within the scope of these agreements (respective Articles 31(1)). The Association Councils make recommendations in this regard, and the parties shall reaffirm their obligations under the GATS. It is specifically stipulated that the most-favoured-nation treatment is not applicable to:

- advantages granted by either party under the terms of an agreement of the type defined in Article V of the GATS or to measures taken on the basis of such an agreement;

- other advantages granted in accordance with the list of exemptions from the most-favoured-nation treatment annexed by either party to the GATS. ${ }^{82}$

The Morocco Agreement includes an additional paragraph 4 which concerns liberalising services in the international maritime transport sector. Special rules apply for cooperation in financial services. ${ }^{83}$

The Euro-Mediterranean Agreement with Algeria is formulated in a slightly more detailed manner as regards trade in services: Title III of the agreement explicitly sets out the reciprocal commitment of the most-favoured-nation treatment obligation as recognised under Article II.1 of the GATS. ${ }^{84}$ In other words, the EU and its Member States shall grant Algerian suppliers no less favourable treatment than that accorded to like service suppliers as specified in the schedule of specific commitments taken by the EU and its Member States under the GATS to which it is annexed. Just as in the agreements with Morocco and Tunisia, exceptions to this general rule relate to advantages accorded by either party that fall under Article V of the GATS, or measures taken on the basis of such an agreement and other advantages granted in accordance with the list of the most-favoured-nations exemptions annexed to the GATS. ${ }^{85}$ A service supplier is defined as any natural or legal person who supplies a service from the territory of one party to the service consumer of the other party. ${ }^{86}$ Article 34 lays down the specific rules on air, inland waterway or land transport or to national shipping (cabotage).

Article 35 contains some exemptions on the application of Title III concerning domestic regulation; these include inter alia that Title III shall be applied subject to limitations to the Article justified on grounds of public policy, public security and

\footnotetext{
82 Respective Art. 31(2) and 32 of the Euro-Mediterranean Agreements with Morocco and Tunisia.

83 Art. 53 of the Euro-Mediterranean Agreements with Morocco and Tunisia; Art. 57 of the Euro-Mediterranean Agreement with Algeria.

84 Art. 30(1) of the Euro-Mediterranean Agreement with Algeria.

85 Arts. 30(2) and (3) of the Euro-Mediterranean Agreement with Algeria.

86 Art. 36(a) of the Euro-Mediterranean Agreement with Algeria.
} 
public health. In addition, they shall not apply to activities which are connected with the exercise of official authority in the territory of either party. Next, nothing in the agreement shall prevent the parties from applying their laws regarding entry, stay, labour conditions and establishment of natural persons and supply of services as long as they are not applied in manner as to nullify or impair the benefits accruing to any party under the terms of a provision of this agreement (Article 35(2) and (6)). Article 37 specifies that the parties shall consider the establishment of an "economic integration agreement" as defined in Title V of the GATS.

\subsubsection{Nationals of Egypt, Israel, Jordan and Lebanon}

The Euro-Mediterranean Agreements concluded with Egypt, Israel, Jordan and Lebanon contain provisions on the cross-border supply of services. These provisions mostly refer to the liberalisation of the provision of services by companies. Title III of the Euro-Mediterranean Agreement with Egypt governs the right of establishment and the supply of services. Under Article 29(1), the parties affirm their commitments in the framework of the GATS, and in particular the commitment to accord each other most-favoured-nation treatment in trade in services sectors covered by these commitments. Article 29(2) of the Euro-Mediterranean Agreement specifies that, in accordance with the GATS, the treatment set out in paragraph 1 shall not apply firstly, to advantages accorded by either party under the provisions of an agreement as defined in Article V of the GATS or under measures adopted on the basis of such an agreement and, secondly, to other advantages accorded pursuant to the list of most-favoured-nation exemptions annexed by either party to the GATS. The approximation of rules in the area of financial services is laid down in Article 49 of the Euro-Mediterranean Agreement with Egypt.

The Euro-Mediterranean Agreement establishing an association between the EU, its Member States and Israel provides for a right of establishment and supply of services in its Title III. In conformity with Article 29(1), the Parties agree to widen the scope of the Agreement to cover the right of establishment of companies of one party in the territory of another party and the liberalisation of the provision of services by one party's companies to consumers of services in the other. According to Article 30(1), the parties reaffirm their obligations under the GATS, particularly the obligation to grant reciprocal most-favoured-nation treatment in the services sectors covered by that obligation. Article 30(2) lays down that, in accordance with the GATS, this treatment shall not apply to first, advantages accorded by either party under the terms of an agreement of the type defined in Article V of the GATS, nor to measures taken on the basis of such an agreement. Second, the treatment set out in paragraph 1 shall not apply to other advantages granted in accordance with the list of most-favourednation exemptions annexed by either party to the GATS. Under Article 48, the parties cooperate on the adoption of common rules and standards in the field of financial services.

Title III of the Euro-Mediterranean Agreement with Jordan deals with the right of establishment and services. Articles 37 to 39 lay down rules on the cross-border supply of services. The formulation of Article 37 is not very strong: the parties shall use their best endeavours progressively to allow the supply of services by Community or Jordanian companies which are established in the territory of a party other than that 
of the person for whom the services are intended, taking into account the development of the services sector in the parties. Title III of the Euro-Mediterranean Agreement with Lebanon concerns the right of establishment and supply of services. Article 30(1) enshrines that treatment by either party to the other with respect to the right of establishment and the supply of services shall be based on each party's commitments and other obligations under the GATS. This provision takes effect from the date of the final accession of Lebanon to the WTO. Article 50 sets out the rules on financial services.

\subsection{Nationals of the Eastern ENP States}

All PCAs contain an identical Chapter III setting out rules on the cross-border supply of services between the Union and the respective Eastern ENP countries. The parties shall take the necessary measures progressively to allow the supply of services by companies established in a party other than that of the person for whom the services are intended, considering the development of the service sectors in the parties. ${ }^{87}$ The parties shall work together with the objective to establish a market-oriented service sector in the Eastern contracting parties. ${ }^{88}$ The parties shall also apply effectively the principle of unrestricted access to the international maritime market and traffic on a commercial basis. ${ }^{89}$ In this regard, the parties have to ensure the equal treatment of ships with regard to access to ports open to international trade, the use of infrastructure and auxiliary maritime services of the ports, as well as fees, customs facilities and the assignment of berths and facilities for loading and unloading. ${ }^{90} \mathrm{Next}$, nationals and companies of the Community shall be free to provide international seariver services in the inland waterways of the Eastern partner state and vice versa. ${ }^{91}$ Finally, it is specified that specific agreements can be concluded to regulate transport by road, rail, inland waterways and as regards air transport. ${ }^{92}$ The EU concluded agreements governing certain aspects of air services with Armenia, Azerbaijan, Georgia, Moldova and Ukraine. ${ }^{93}$

Chapter IV of all PCAs contain general provisions. Firstly, the provisions of Title IV shall be applied subject to the limitations justified on grounds of public policy, public security and public health and secondly, they shall not apply to activities which are connected with the exercise of official authority. ${ }^{94}$ Moreover, under Title IV, the parties may apply their laws and regulations regarding entry and stay, work, labour conditions and establishment of natural persons and supply of services, provided that they do not apply them in a manner as to nullify or impair the benefits accruing to any party from a specific provision of this agreement. ${ }^{95}$ In addition, it is stipulated that treatment accorded by one party to the other, as from the day one month prior

See for instance Art. 30(1) of the PCA with Armenia. See for example Art. 37 of the PCA with Moldova. See for example Art. 32 of the PCA with Azerbaijan. See for instance Art. 32(3) of the PCA with Georgia. See for example Art. 32(4) of the PCA with Armenia See for example Art. 40 of the PCA with Ukraine. See for instance Agreement between the European Community and the Republic of Armenia on certain aspects of air services, OJ L 50, 21 February 2009, p. 22.

See for example Art. 34 of the PCA with Georgia. See for example Art. 35 of the PCA with Azerbaijan. 
to GATS entering into force, in respect of sectors or measures covered by GATS, shall in no case be more favourable than that granted by such first party under the provisions of GATS. This rule can be regarded as a restriction to introduce more advantageous treatment, which unfolds its effect one month before the entry into force of the GATS obligations. However, no account shall be taken of treatment accorded by the parties pursuant to commitments stemming from economic integration agreements in conformity with Article 5 of the GATS for the purposes of Chapter II (on the establishment and operation of companies), Chapter III (on crossborder supply of services) and Chapter IV (general provisions) of PCAs. ${ }^{96}$ Without prejudice to the special rules applicable to key personnel of companies, no provision of Chapters II, III and IV shall be interpreted as giving nationals of one contracting party the right to enter, or stay in the territory of another contracting party in any capacity whatsoever. ${ }^{97}$ The PCAs enshrine specific rules on postal services and telecommunications, as well as financial services. The latter type of service is specified in Annexes III of the PCAs with Armenia, Azerbaijan and Georgia and Annexes V of the PCAs with Moldova and Ukraine. A rule regarding visa conditions can be found in the Joint Declarations of the PCAs with Armenia, Azerbaijan and Georgia: the sole fact of requiring a visa for natural persons of certain parties and not for those of others shall not be regarded as nullifying or impairing benefits under a specific commitment.

\subsection{Nationals of Russia}

Chapter III of the PCA with Russia specifies the regulation of cross-border supply of services. For the sectors listed in Annex 5 to the PCA, first the most-favoured-nation treatment applies and second, the temporary movement of natural persons who are representatives of an EU or Russian company, with the objective to provide crossborder services, shall be permitted. ${ }^{98}$ Each party may regulate the conditions of crossborder supply into its territory for the sectors designated in Annex 5, and a stand-still clause inhibits that the supply of services between the parties is rendered more restrictive. A special legal rule applies to services of the transport sector. ${ }^{99}$ Under the general provisions it is specified that the Cooperation Council shall make recommendations for the further liberalisation of trade in services.

Like in other regimes, Title III is subject to limitations on grounds of public policy, public security and public health, and the Title does not apply to activities which are connected with the exercise of official authority. ${ }^{100}$ Article 50 of the PCA with Russia stipulates that no provision in Chapters II, III and IV shall be interpreted as giving the right to inter alia nationals of the Member States or of Russia to enter, or stay in the territory either party in any capacity whatsoever and in particular as a shareholder or partner in a company or manager or employed thereof or supplier or recipient of services. ${ }^{101}$ Treatment granted by either party to the other in respect of sectors or

See for instance Arts. 43 and 44 of the PCA with Moldova.

See for example Art. 40 of the PCA with Azerbaijan.

Arts. 36 and 37 of the PCA with Russia.

Arts. 39 and 43 of the PCA with Russia.

Arts. 46 and 47 of the PCA with Russia.

Without prejudice to Arts. 32 (on the employment of key personnel in companies) and 37 (on the temporary movement of natural persons in accordance with Annex 5 setting 
measures under the GATS shall in no case be more favourable than that accorded by such first party under the provisions of the GATS; the other party shall be informed of the assumed obligations in the framework of the GATS and the adaptations resulting therefrom for the PCA. ${ }^{102}$

\subsection{Chilean Nationals}

Under Article 94, the parties make a reciprocal commitment to liberalise trade in services in accordance with the GATS and to improve the investment environment. Article 95 defines trade in services in conformity with the GATS four modes of supply, including Mode 4 on the movement of natural persons and refers to a number of services included, such as financial, audio-visual and air transport services. As regards market access, the parties shall accord treatment to services and service suppliers of the other party no less favourable than that provided for under the terms and limitations agreed in its schedule. ${ }^{103}$ Article $98(1)$ stipulates that each party grants to services and service suppliers of the other party treatment no less favourable than that it accords to its own like services and service suppliers in the sectors inscribed in its schedule. It is specified that, in view of the movement of natural persons, the parties shall review the rules and conditions applicable with the aim of achieving further liberalisation. ${ }^{104}$

\subsection{Nationals of the Central Asian Countries}

In the framework of the PCAs concluded with the five Central Asian countries Kazakhstan, Kyrgyz Republic, Tajikistan, Turkmenistan and Uzbekistan, the respective parties have agreed to take the necessary steps to allow progressively the supply of services (under Chapter III of PCA concerned) with the aim of developing a market-oriented service sector in the Asian country at hand. The field of transport is subject to specific regulation. ${ }^{105}$

\subsection{All Other Third-Country Nationals}

Other agreements do not contain specific rights for third-country nationals in view of the provision of services in the territory of an EU Member State.

\subsection{The Right to Provide Services Compared and the Potential of the GATS}

The juxtaposition of the various rules relating to the cross-border supply of services demonstrates that only EEA and Swiss nationals are granted a right to freely provide services in a Member State of the EU. In the case of Swiss nationals, the provision of services is restricted to 90 days of actual work per calendar year without prejudice to

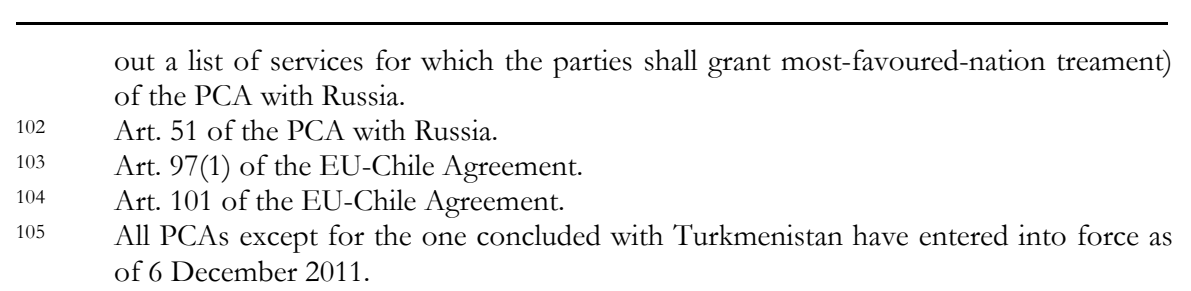


other specific agreements. ${ }^{106}$ However, other association agreements do promote the gradual liberalisation of trade in services, frequently by reaffirming obligations under the GATS, including the reciprocal grant of the most-favoured-nation treatment. The Additional Protocol to the Ankara Agreement contains a stand-still provision that prohibits new restrictions on the freedom to provide services and this stand-still has been invoked in a number of disputes before the Court of Justice, prominently in Soysal challenging visa requirements for Turkish service providers. ${ }^{107}$

According to the WTO Annual Report "services are the most important economic activity in many countries when measured as a share of overall production, and they are the single largest source of employment."108 In 2004, the World Bank pointed out that "little has been done to loosen conditions governing the temporary movement of natural persons supplying services (Mode 4)" and stressed that "Mode 4 today [in 2004] accounts for less than $2 \%$ of the total value of services trade". With almost all commitments made for highly-skilled manpower, the liberalising efforts of Mode 4 had little impact on developing countries because their comparative advantage relates to the export of labour intensive services provided by low and medium qualified personnel. ${ }^{109}$ This is why developing countries have a strong interest that states stipulate more commitments in such sectors for which they can provide and export personnel including computer and information services, tourism, construction, health and transport services. ${ }^{110}$

Interestingly enough, the relative welfare gains are higher for developing countries compared to industrialised nations particularly as regards Mode 4 seeing that the benefits for individuals and for businesses would also be advantageous for developing countries. ${ }^{111}$ Thus, there is agreement as to the potential beneficial effects of temporary movement of natural persons, particularly for developing countries, but it is the political sensitivity and increasing security concerns that prevent the receiving states from making stronger committments in the field of the trade in services. ${ }^{112} \mathrm{~B}$. Hoekman and Ç. Özden pointed out that specific commitments allowing for greater EU market access for service providers - through the trans-frontier movement of natural persons - in the framework of third-country agreements could maximise the

\footnotetext{
106 See Art. 5 of the FMP Agreement.

107 Art. 41(1) of the Additional Protocol to the Ankara Agreement; Case C-228/06 Soysal [2009] ECR I-1031.

108 WTO, Annual Report 2011 (WTO, Geneva 2011), p. 19.

109 WorldBank, 'Labor Mobility and the WTO: Liberalizing Temporary Movement', Global Economic Prospects 2004 - Realizing the Development Promise of the Doha Agenda (World Bank, Washington, D.C. 2003), p. 144.

110 J. Niessen, Negotiating the Liberalization of Migration: Is GATS a Vehicle or a Model for Global Migration Governance?', European Policy Centre Issue Paper No. 6 (Brussels 2003), p. 5; O. Cattaneo and J. Nielsen, Service Providers on the Move: The Economic Impact of Mode 4 (OECD Working Party of Trade Committee, Paris 2003), p. 22.

111 OECD, GATS: The Case for Open Services Markets (OECD, Paris 2002), p. 37; O. Cattaneo and J. Nielsen, Service Providers on the Move: The Economic Impact of Mode 4 (OECD Working Party of Trade Committee, Paris 2003), p. 22.

112 WorldBank, 'Labor Mobility and the WTO: Liberalizing Temporary Movement', Global Economic Prospects 2004 - Realiring the Development Promise of the Doba Agenda (World Bank, Washington, D.C. 2003), p. 144.
} 
potential welfare gains for the EU and the country in question. ${ }^{113}$ They analysed whether trade in services could serve as an alternative to migration along the following facets: the EU labour markets feature a growing need for foreign workers owing to the demographic change, while the population growth in developing countries in particular in Africa and the Middle East is forecasted to increase considerably in the future. Policy makers in Europe could better promote temporary labour movement schemes addressing labour market shortages against the backdrop of prevailing negative attitudes towards migrants and immigrant communities. Moreover, temporary migration would not only be likely to mitigate brain drain in the countries of origin but would also generate higher flows of remittance to the source countries. Next, returnees would bring back valuable know-how and skills acquired in the posted country. Lastly, facilitated access to providing services in the EU would minimise irregular migration influxes. The authors see the main challenge in ensuring that policies stimulating temporary migration actually guarantee that the movement is in fact temporary in nature. ${ }^{114}$ This could be ensured by asking for a deposit of a lump-sum payment to be refunded to the person after return to the home state; or, in relation to Mode 4, by introducing a so-called "contract-based" movement of service suppliers that is designed for the provision of a specific service and is not linked to individuals. Such contract-based movement leaves it up to the companies having obtained a contract for carrying out a task for a firm located in the EU. The authors indicate that the EU has started to incorporate this option in the context of the Economic Partnership Agreement with the Caribbean in 2008.115

Next, the OECD is of the view that the potential to be exploited in the field of trade in services is sizable. ${ }^{116}$ The OECD regards a reinforced use of Mode 4 as entailing benefits in three stages: first, during the phase of departure, the workers providing services abroad are, for a certain period of time, no longer available on the labour market of the country of origin and, consequently, their absence reduces the pressure on domestic labour market. The economic impact greatly depends on the length of the stay and type of work to be carried out abroad. In addition, the departure of such workers may cause a drop in the unemployment rate of the sending country and can help to sustain the wage level in the respective service sector. However, in practice, the number of people moving under Mode 4 is still small in scale, and the personnel who moves is often young and well-qualified and can easily find a job, and is - once sent abroad - difficult to replace in the domestic labour market. Second, during the stay in the host country activities under Mode 4 entail income transfers in that "the repatriation of the earnings received abroad adds to the inflow of foreign exchange, and contributes to increasing the national wealth". ${ }^{117}$ The sum of remittances sent to the country of origin can vary substantially, and the use of remittances has consequences on their impact. Third, the phase of return under Mode 4 - where movement is defined as temporary - entails positive ramifications as the persons who

113 B. Hoekman and C.. Özden, 'The Euro-Mediterranean Partnership: Trade in Services as an Alternative to Migration?', 48 Journal of Common Market Studies (2010), 835, pp. 836-837.

$114 \quad$ Ibid., pp. 837-846.

115 Ibid., pp. 846-847.

116 OECD, GATS: The Case for Open Services Markets (OECD, Paris 2002).

117 O. Cattaneo and J. Nielsen, Service Providers on the Move: The Economic Impact of Mode 4 (OECD Working Party of Trade Committee, Paris 2003), p. 24. 
return have acquired skills and knowledge which can in turn lead to higher wages. Such returnees constitute valuable human capital that contributes to the development and economic expansion of the home state. ${ }^{118}$

Academics have indicated that exploiting differences forms the foundation of international trade in goods or in other sectors: the bigger the difference, the theory says, the bigger are the potential benefits from opening up trade on a global scale. Along these lines, the movement of low and medium skilled workers from developing to developed countries with a view to providing services is the most promising option. ${ }^{119}$ Service providers generally fall under the national immigration rules and may face visa-related barriers such lengthy visa procedures or the refusal of granting an entry authorisation. To overcome this impediment to trade in services, the introduction of a "GATS visa" has been suggested by the Indian government and in the form of a model approach has also been proposed by the EU and the U.S. Such a GATS visa would allow temporary entry which would be granted upon confirmation by the destination country. Such a GATS visa could considerably improve market access but it would, at the same time, require regulation, and it would be difficult to obtain the approval of the sceptical WTO members. ${ }^{120}$ The question was posed whether the GATS has the potential to establish itself as a migration governance system. ${ }^{121}$ This would imply that Mode 4 relates to international migration which was vehemently denied by various scholars because the mobility under Mode 4 has neither political, social nor cultural implications that international migration involves, nor does a shift of residence takes place; solely the economic results of temporary movement of natural persons are for the most part those of migration. ${ }^{122}$

\section{The ReCOGNITION OF QUALIFICATIONS}

The recognition of academic and professional qualifications that attest a certain competence forms a seminal step to open up labour markets for workers holding diplomas of different education systems than that of the state in which they seek employment. For the completion of the EU's internal market and thus, the achievement of the free movement of persons, the repudiation of diplomas and qualifications has proven to be a major obstacle in the historical development of the EU and to this very day. ${ }^{123}$ In 1999, the European Ministers for Education launched

\footnotetext{
118 Ibid., pp. 23-25.

119 L.A. Winters and others, 'Liberalising Temporary Movement of Natural Persons: An Agenda for the Development Round', 26 The World Economy (2003), 1137, pp. 1137$1138,1142,1159$

120 A. Mattoo and A.G. Carzaniga, Moving People to Deliver Services (World Bank Washington, D.C. 2003), pp. 52-53.

121 J. Niessen, 'Negotiating the Liberalization of Migration: Is GATS a Vehicle or a Model for Global Migration Governance? ', European Policy Centre Issue Paper No. 6 (Brussels 2003).

122 L.A. Winters and others, 'Liberalising Temporary Movement of Natural Persons: An Agenda for the Development Round', 26 The World Economy (2003), 1137, p. 1140.

H. Schneider and S. Claessens, 'The Recognition of Diplomas and the Free Movement of Professionals in the European Union', in: H. Schneider (ed.), Migration, Integration and Citizenship (Forum Maastricht, Maastricht 2005), pp. 123-166; for an indepth study on
} 
the Bologna Process with the objective of creating the European Higher Education Area dovetailing academic degrees throughout Europe. With the signature of the Bologna Declaration, 29 European countries confirmed their political intention to reform and harmonise their higher educational systems; third countries may join the Bologna Process, and to date 47 European countries proclaimed their participation. While the Bologna aims seem very ambitious, their implementation proves difficult: higher education is a sensitive and controversial subject-matter for European states, evidenced by the approach taken outside the EU setting to safeguard national sovereignty. ${ }^{124}$ For nationals of an EU Member State, Directive 2005/36/EC provides the legal framework for the recognition of professional qualifications by the host Member State for regulated professions pursued on either an employed or selfemployed basis. ${ }^{125}$

\subsection{EEA Nationals}

Article 30 of the EEA Agreement stipulates the obligation for the EEA states to take the necessary measures concerning the mutual recognition of qualifications so as to facilitate the taking up and pursuing of activities as workers and self-employed persons, as well as the coordination of the national provisions in the contracting parties in respect of taking up and pursuing activities as workers and self-employed persons. This rule corresponds to Article 53(1) TFEU which, in contrast, only refers to self-employed persons under Chapter 2 TFEU on the right of establishment. Today, the notions of workers and self-employed persons are on an equal footing as a result of further progress in the field of mutual recognition of qualifications. ${ }^{126}$ Annex VII to the EEA Agreement specifies the legal instruments whose application is extended for EEA purposes to the recognition for professional qualifications. Annex VII contains three different categories including a general system, the recognition of professional experience and automatic recognition, legal professions and commerce and intermediaries. Amended Directive 2005/36/EC on the recognition of professional qualifications constitutes the main tool under the first category. ${ }^{127}$

\subsection{Swiss Nationals}

According to Article 9 of the FMP Agreement, the parties shall take measures relating to the mutual recognition of qualifications so as to facilitate the access to and the pursuit of economic activities for employed and self-employed persons, as well as persons providing services. Section A of Annex III lists Community acts and

the recognition of diplomas in the European Community, see H. Schneider, Die Anerkennung von Diplomen in der Europäischen Gemeinschaft (METRO, Maastricht 1995).

S. Garben, 'The Bologna Process: From a European Law Perspective', 16 European Law Journal (2010), 186.

Directive 2005/36/EC of the European Parliament and of the Council of 7 September 2005 on the recognition of professional qualifications, consolidated version of 24 March 2011.

S. Norberg and others, The European Economic Area: EEA Law: A Commentary on the EEA Agreement (Fritzes, Stockholm 1993), p. 422.

Directive 2005/36/EC of the European Parliament and of the Council of 7 September 2005 on the recognition of professional qualifications. 
amending legislation, which the contracting parties must apply and which are in force at the date of signature of the Agreement, in the field of the mutual recognition of professional qualifications. First, reference is made to the general system based on Council Directive 89/48/EEC setting out rules on the recognition of highereducation diplomas ${ }^{128}$ and Council Directive 92/51/EEC stipulating provisions on the recognition of professional education and training. ${ }^{29}$ Second, a list of Community legislation covering different occupational areas follows including legal professions, medical and paramedical activities, architecture, commerce and intermediaries, industry and small craft industries, activities incidental to transport, film industry, agriculture and other sectors. Section B sets out the Community acts of which the parties shall take note. ${ }^{130}$

\subsection{Other Sources of EU Law Applicable to Third-Country Nationals}

Council Directive 2003/109/EC on long-term resident status, the EU Blue Card Directive, the researchers' Directive and Directive 2011/98/EU on a single permit all contain the same provision: the persons covered shall enjoy equal treatment with nationals of the Member State concerned as regards the recognition of professional diplomas, certificates and other qualifications in accordance with the relevant national procedures. ${ }^{131}$ This rule raises some fundamental questions: first, the equal treatment concerning recognition of qualification is granted in relation to nationals of a Member State, not with regard to EU nationals to whom Directive 2005/36/EC on the recognition of professional qualifications applies - however, qualifications that nationals have obtained are normally not subject to recognition procedures. Second, one may wonder what exactly is meant by the addition "in accordance with the relevant national procedures". How can a fair system be ensured in which Member States do not invoke their national rules and procedures to circumvent the equal treatment accorded by the said directives? Third, does the equal treatment cover

128 Council Directive 89/48/EEC of 21 December 1988 on a general system for the recognition of higher-education diplomas awarded on the completion of professional education and training of at least three years' duration.

129 Amended Council Directive 92/51/EEC of 18 June 1992 on a second general system for the recognition of professional education and training to supplement Directive 89/48/EEC.

130 For more information, see M. Wild, 'Die Anerkennung von Diplomen im Rahmen des Abkommens über die Freizügigkeit der Personen', in: C. Kaddous and D. Felder (eds.), Accords Bilatéraux Suisse - Union Européenne: Commentaires (Helbing \& Lichtenhahn, Basel 2001), pp. 383-403.

131 Art. 11(1)(c) of Council Directive 2003/109/EC of 25 November 2003 concerning the status of third-country nationals who are long-term residents; Art. 14(1)(d) of Council Directive 2009/50/EC of 25 May 2009 on the conditions of entry and residence of third-country nationals for the purposes of highly qualified employment; Art. 12(a) of Council Directive 2005/71/EC of 12 October 2005 on a specific procedure for admitting third-country nationals for the purposes of scientific research; Art. 12(1)(d) of Directive 2011/98/EU of the European Parliament and of the Council of 13 December 2011 on a single application procedure for a single permit for third-country nationals to reside and work in the territory of a Member State and on a common set of rights for third-country workers legally residing in a Member State; the third-country workers referred to under Art. 12 are defined in Art. 3(1)(b) and (c) of Directive 2011/98/EU on a single permit. 
qualifications issued by Member States and third states alike? Considering that this is not specified one may well assume so.

\subsection{The Recognition of Qualifications Compared}

Only EEA and Swiss nationals can rely on extended EU legislation for the purposes of having their professional qualification recognised in a Member State. EEA nationals enjoy the legal regime under Directive 2005/36/EC on the recognition of professional qualifications, whereas the FMP Agreement extended "previous" EU legislation to Swiss nationals, such as Council Directive 89/48/EEC setting out rules on the recognition of higher-education diplomas and Council Directive 92/51/EEC stipulating provisions on the recognition of professional education and training. Long-term residents, EU Blue Card holders, researchers, and third-country workers falling under the respective directives are eligible for equal treatment concerning the recognition of professional diplomas, certificates and other qualifications in accordance with the relevant national procedures of a Member State.

\section{5}

\section{THE Right TO EDUCATION}

The right to education enables migrants to obtain an education, to follow a vocational formation or an advanced training and to pursue studies in the territory of the host country. A distinction can be drawn between the right of a migrant worker to pursue vocational training and the right of his/her children to be admitted to courses of general education or vocational training. While the right to education allows workers to specialise and to study further in the field of their occupational activity or in another area of interest, the right to receive school education is of major importance for migrant children as it allows them to participate in the host society, to learn the language and to improve their language skills, and to be exposed to the culture and customs of the host country.

\subsection{EEA Nationals}

Article 7(3) of Regulation (EU) No 492/2011 stipulates that a worker shall, by virtue of the same right and under the same conditions as national workers, have access to training in vocational schools and retraining centres. ${ }^{132}$ Article 10 of Regulation (EU) No 492/2011 enshrines the right to education for the children of a worker or former worker, who reside in the host state, under the same conditions as nationals. This rule was interpreted extensively by the Court so that it includes inter alia not only the admission but also the general measures intended to facilitate educational attendance April 2011 on freedom of movement for workers within the Union; see Annex V of the EEA Agreement and Art. 2 of Decision of the EEA Joint Committee No 158/2007 of 7 December 2007 amending Annex V (Free movement of workers) and Annex VIII (Right of establishment) to the EEA Agreement. 
such as an educational grant and the children's right to education after the parents' return to the state of origin. ${ }^{133}$

Directive 2004/38/EC has repealed Council Directive 93/96/EEC on the right of residence for students but the former piece of legislation follows the basic conditions attached to the right of residence as established in the latter. Article 7 of Directive 2004/38/EC enshrines the right of residence for more than three months for EEA citizens and their family members who are enrolled at a private or public establishment for the principle purpose of following a course of study, including vocational training, who have comprehensive sickness insurance cover and who dispose of sufficient resources for themselves and their family members so as not to become a burden on the social assistance system of the host Member State during the period of residence. ${ }^{134}$ Thus, student status of EEA nationals entails a residence right provided that the person concerned has sufficient resources and sickness insurance cover. While transfrontier access to education and increased mobility of students in Europe is desirable with a view to enhancing the free movement of persons in the EU, Member States are also eager to secure and protect their financial and educational interests. ${ }^{135}$ The Member States' power to pursue these latter objectives has, however, gradually been curtailed by the Court's case law that has generally been favourable to students.

While the Court had observed in its early case law that maintenance grants for students, contrary to fees or grants covering such fees for courses, did not fall under the general prohibition of discrimination in Article 12 EC (now Article 18 TFEU), it changed its stance in Grzelcayk in which it ruled that withdrawing or not renewing the residence permit of a migrant student could not become the automatic consequence of a person having recourse to the host Member States' social assistance system stressing the fundamental status of Union citizenship. ${ }^{136}$ The Court likewise attached great importance to the status of Union citizenship in the case of Bidar of 2005 in which it held that maintenance grants and study loans for students lawfully resident in the host Member States were covered by Article 12 EC (now Article 18 TFEU) and that the latter provision precluded national legislation that grants students the right to assistance covering their maintenance costs only if they are settled in the host

133 Case 9/74 Casagrande [1974] ECR 773, para. 9; Joined Cases 389 and 390/87 Eternach and Moritz [1989] ECR I-7091; See Chapter 1 of G. Gori, Towards an EU Right to Education (Kluwer Law International, The Hague 2001).

134 Directive 2004/38/EC of the European Parliament and the Council of 29 April 2004 on the right of citizens of the Union and their family members to move and reside freely within the territory of the Member States.

135 In this regard see A.P. van der Mei, 'Freedom of Movement for Students: In Search of a More Satisfactory Balance between the Goal to Promote Student Mobility and the Need to Protect Education Systems', in: H. Schneider (ed.), Migration, Integration and Citizenship (Forum Maastricht, Maastricht 2005), pp. 167-186; see also Case C-73/08 Bressol [2010] ECR I-2735, in which the Court made clear that national legislation, which limited the number of students not regarded as resident in Belgium who may enrol for the first time in medical courses at higher education establishments, violated Arts. 18 and 21 TFEU, unless the referring court that legislation is justified in the light of the objective of protection of public health.

136 See Case 197/86 Brown [1988] ECR 3205; Case 39/86 Lair [1988] ECR 3161; Case C357/89 Raulin [1992] ECR I-1027; Case C-184/99 Grzelcayle [2001] ECR I-6193. 
Member State, while precluding a national of another Member State from obtaining the status of settled person as a student even if that national is lawfully resident and has received a substantial part of his secondary education in the host Member State and has consequently established a genuine link with the society of that Member State. ${ }^{137}$ The Court further developed the rights of students to financial support in Morgan and Bucher in which it adjudicated that Articles 17 and 18 EC (now Articles 20 and 21 TFEU) on EU citizenship precluded a national rule that made the export of education or training grants for studies in a Member State, other than the Member State of which the students applying for such assistance are nationals, dependent on a continuation of education or training pursued for at least one year in the Member State of origin of those students. ${ }^{138}$ In Förster the Court decided in favour of the Dutch government that had requested the repayment of student support granted to a German national after she had stopped being in part-time employment alongside her studies in the Netherlands. ${ }^{139}$ The applicant had attempted to challenge a five-year residence requirement claiming that it was incompatible with the general prohibition of discrimination under EU law and the principle of legal certainty.

\subsection{Swiss Nationals}

A national of a contracting party (Switzerland or an EU Member State) employed in the territory of another contracting party is entitled, on the same basis and on the same terms as national employed persons, to education in vocational training establishments and in vocational retraining and occupational rehabilitation centres in accordance with Article 9(3) of Annex I of the FMP Agreement. Persons of the contracting parties not pursuing an economic activity, including students and their family members, enjoy the right to reside in the territory of the other contracting party if they dispose of sufficient financial means not to have to apply for social assistance benefits during their stay and all-risks sickness insurance cover. ${ }^{140}$ Students must, in addition, be registered in an approved establishment for the purpose of following, as his principal activity, a vocational training course; it is laid down that the access to vocational training or maintenance grants given to students is not covered by the FMP. ${ }^{141}$

\subsection{Turkish Nationals}

Article 9 of Decision No 1/80 establishes the right of Turkish children residing legally in a Member State of the EU with their parents, who are or have been legally employed in that Member State, to be admitted to courses of general education, apprenticeship and vocational training under the same educational entry qualifications as the children of nationals of that Member State. Moreover, in that Member State they are eligible to benefit from the advantages provided for under the

137 Case C-209/03 Bidar [2005] ECR I-2119; on the judgment of Bidar see also C. Barnard, 'Case C-209/03, R (on the application of Danny Bidar) v. London Borough of Ealing, Secretary of State for Education and Skills', 42 Common Market Law Review (2005), 1465. 138 Joined Cases C-11/06 and C-12/06 Morgan and Bucher [2007] ECR I-9161.

139 Case C-158/07 Förster [2008] ECR I-8507.

140 Art. 6 of the FMP Agreement in conjunction with Art. 24(1) of Annex I of the FMP Agreement.

141 Art. 24(4) of Annex I of the FMP Agreement. 
national legislation in this area. In Gürol the Court held that Article 9 had direct effect and that the child of a Turkish worker who was enrolled at a higher education institution as a student fell under the scope of that provision, although she was no longer living with her parents. The Court decided that she could invoke Article 9 in order to claim equal treatment in relation to study grants. ${ }^{142}$ Article 9 of Decision No $1 / 80$ only becomes applicable once the children have entered the Member State and legally reside there with their parents.

\subsection{Other Sources of EU Law Applicable to Third-Country Nationals}

According to Article 14 of the EU Charter, everyone has the right to education and to have access to vocational and continuing training, including the possibility to receive free compulsory education. Council Directive 2004/114/EC has created a legal regime setting out the admission conditions for third-country nationals to enter and reside in the EU for more than three months for the purposes of studies, pupil exchange, unremunerated training or voluntary service, provided that they have inter alia sickness insurance and sufficient resources. ${ }^{143}$

EU Blue Card holders enjoy equal treatment in terms of education and vocational training. ${ }^{144}$ The Member State concerned may restrict this equal treatment as regards study and maintenance grants and loans or other grants and loans regarding secondary and higher education and vocational training. In addition, access to university and post-secondary education may be subject to specific prerequisites in accordance with national law, and the Member State concerned may restrict equal treatment to cases where the registered or usual place of residence of the EU Blue Card holder lies within its territory under Article 14(2) of the EU Blue Card Directive. Long-term resident third-country nationals enjoy equal treatment with nationals as regards education and vocational training, including study grants in accordance with national law, but equal treatment may be restricted to cases where the place of residence of the long-term resident, or that of family members for whom the benefits are claimed, lies within the territory of the Member State concerned. Next, appropriate language proficiency for access to education and training may be required for the latter persons and for university studies specific educational prerequisites can be demanded. ${ }^{45}$ Directive 2011/98/EU on a single permit ensures equal treatment for third-country workers with nationals of the Member State where they reside in respect to education and vocational training in line with Article 12(1)(c). ${ }^{146}$ Member States may restrict this equal treatment to:

142 Case C-374/03 Gürol [2005] ECR I-6199.

143 Council Directive 2004/114/EC of 13 December 2004 on the conditions of admission of third-country nationals for the purposes of studies, pupil exchange, unremunerated training or voluntary service.

144 Art. 14(1)(c) of Council Directive 2009/50/EC of 25 May 2009 on the conditions of entry and residence of third-country nationals for the purposes of highly qualified employment.

145 Arts. 11(1)(b), 2 and 3(b) of Council Directive 2003/109/EC of 25 November 2003 concerning the status of third-country nationals who are long-term residents.

146 Directive 2011/98/EU of the European Parliament and of the Council of 13 December 2011 on a single application procedure for a single permit for third-country 
- limiting its application to those third-country workers who are in employment or who have been employed and who are registered as unemployed;

- excluding those third-country workers who have been admitted to their territory in conformity with Directive 2004/114/EC;

- excluding study and maintenance grants and loans or other grants and loans;

- laying down specific prerequisites including language proficiency and the payment of tuition fees, in accordance with national law, with respect to access to university and post-secondary education and to vocational training which is not directly linked to the specific employment activity.

Family members admitted to the territory of a Member State under the family reunification scheme are entitled to access to education in the same way as the sponsor. ${ }^{147}$ The same applies to family members of a third-country national who is a long-term resident and who has moved to another Member State. ${ }^{148}$ In 2006, the EU concluded an agreement renewing/establishing a framework of cooperation in higher education and training with the U.S. and Canada respectively. ${ }^{149}$ These agreements envisage improving the quality of human resources, including the acquisition of skills and contribute to transatlantic exchanges between the EU and U.S. (or Canadian) citizens. For this purpose, each party shall make its best efforts to facilitate entry to and exit from its territory of personnel and students of the other party engaged in cooperative activities.

\subsection{The Right to Education Compared}

Both EEA and Swiss nationals enjoy a right of entry to and residence in the territory of a Member State in order to pursue studies there. EEA nationals and their family members who are enrolled at a private or public establishment for the principle purpose of following a course of study, including vocational training, are merely required to have comprehensive sickness insurance cover and sufficient resources for

nationals to reside and work in the territory of a Member State and on a common set of rights for third-country workers legally residing in a Member State; the third-country workers referred to under Art. 12 are defined in Art. 3(1)(b) and (c) of Directive 2011/98/EU on a single permit, meaning: third-country nationals who have been admitted to a Member State for purposes other than work in accordance with Union or national law, who are allowed to work and who hold a residence permit in accordance with Regulation (EC) No 1030/2002; and third-country nationals who have been admitted to a Member State for the purpose of work in accordance with Union or national law.

Art. 14(1)(a) of Council Directive 2003/86/EC of 22 September 2003 on the right to family reunification.

Art. 21(3) of Council Directive 2003/109/EC of 25 November 2003 concerning the status of third-country nationals who are long-term residents.

Agreement between the European Community and the United States of America renewing a programme of cooperation in higher education and vocational education and training, OJ L 346, 9 December 2006, p. 34; Agreement between the European Community and the Government of Canada establishing a framework for cooperation in higher education, training and youth, OJ L 397, 30 December 2006, p. 15. 
themselves and their family members. ${ }^{150}$ Swiss nationals employed in a Member State are granted equal treatment with regard to education in vocational training establishments; non-economically active Swiss nationals, including students and their family members enjoy the right to reside in a Member State if they dispose of sufficient financial means and all-risks sickness insurance cover. ${ }^{151}$

Turkish children residing legally in a Member State of the Community with their parents who are or have been legally employed in that Member State are to be admitted to courses of general education, apprenticeship and vocational training under the same educational entry qualifications as the children of nationals of that Member State. ${ }^{152}$ The EU Charter enshrines that everyone shall have the right to education and access to vocational and continuing training including the possibility to receive free compulsory education. The EU adopted Council Directive 2004/114/EC laying down the admission conditions for third-country nationals to enter and reside in the EU for the purposes of studies, pupil exchange, unremunerated training or voluntary service provided that they have, among other things, sickness insurance and sufficient resources. ${ }^{153}$ EU Blue Card holders, longterm residents and third-country workers under Directive 2011/98/EU on a single permit enjoy equal treatment in terms of education and vocational training subject to the prevailing particularities of each directive. ${ }^{154}$ Moreover, admitted family members of a long-term resident who has moved to another Member State, as well as those family members admitted under the family reunification scheme are entitled in the same way as the sponsor to access to education. ${ }^{155}$

\section{RightS IN MATTERS OF HOUSING}

\subsection{EEA Nationals}

EEA nationals who are employed in the territory of another EEA state shall enjoy all the rights and benefits accorded to national workers in matters of housing, including

150 Art. 7 of Directive 2004/38/EC of the European Parliament and the Council of 29 April 2004 on the right of citizens of the Union and their family members to move and reside freely within the territory of the Member States.

151 Art. 9(3) of Annex I of the FMP Agreement; Art. 6 of the FMP Agreement in conjunction with Art. 24(1) of Annex I of the FMP Agreement.

152 Art. 9 of Decision No $1 / 80$.

153 Council Directive 2004/114/EC of 13 December 2004 on the conditions of admission of third-country nationals for the purposes of studies, pupil exchange, unremunerated training or voluntary service.

154 Art. 14(1)(c) of Council Directive 2009/50/EC of 25 May 2009 on the conditions of entry and residence of third-country nationals for the purposes of highly qualified employment; Art. 11(1)(b) of Council Directive 2003/109/EC of 25 November 2003 concerning the status of third-country nationals who are long-term residents; Art. 12(1)(c) of Directive 2011/98/EU of the European Parliament and of the Council of 13 December 2011 on a single application procedure for a single permit for thirdcountry nationals to reside and work in the territory of a Member State and on a common set of rights for third-country workers legally residing in a Member State.

Art. 21(3) of Council Directive 2003/109/EC of 25 November 2003 concerning the status of third-country nationals who are long-term residents; Art. 14(1)(a) of Council Directive 2003/86/EC of 22 September 2003 on the right to family reunification. 
ownership of the housing s/he needs in accordance with Article 9(1) of Regulation (EU) No 492/2011 which is of relevance for the EEA. ${ }^{156}$ Such workers may, having the same right as nationals, put his/her name down on the housing lists in the region in which $\mathrm{s} / \mathrm{he}$ is employed, where such lists exist; s/he shall enjoy the resultant benefits and priorities. If his/her family has remained in the country from where $\mathrm{s} /$ he came, they shall be considered for this purpose as residing in the said region, where national workers benefit from a similar presumption. ${ }^{157}$ The Court precluded nationality requirements for access to social housing at reduced-rate mortgage loans for self-employed persons infringed the rules on the freedom of establishment and the freedom to provide services. ${ }^{158}$

\subsection{Swiss Nationals}

A Swiss national who is employed in an EU Member State enjoys all the rights and all the advantages accorded to national employed persons in terms of housing, including ownership of the housing s/he needs in line with Article 9(6) of Annex I of the FMP Agreement. Such a worker shall also have the same rights as nationals to register on the housing lists in the region in which he is employed, where such lists exist; s/he shall enjoy the resultant benefits and priorities. If his/her family has remained in the state of origin, s/he shall be considered for this purpose as residing in the said region, where national workers benefit from a similar presumption. Chapter 6 of Annex I of the FMP Agreement provides for rules on the purchase of immoveable property. On the basis of Article 25(1) of Annex I, nationals of the contracting parties who have a right of residence and whose principal residence is in the host state enjoy the same rights as nationals concerning the purchase of immovable property. This right is conferred on a person who has a right of residence but not the principal residence in the host state where the purchase of immovable property is necessary for his economic activity (para. 2). Frontier workers also enjoy the same rights as nationals where the purchase of the immovable property is necessary for pursuing an economic activity or as a secondary residence (para. 3). Leaving the host state does not result in any obligations to sell the acquired property. It is furthermore stipulated that the Agreement does not affect rules applying to pure capital investment or business of unbuilt land and apartments. The relevance of this last provision is not clear, particularly considering that Swiss nationals can directly rely on Article 63 TFEU on the free movement of capital between Member States and Member States and third countries. ${ }^{159}$

In Fokus Invest $A G$, the Court confirmed its earlier position stating that Article 25 of Annex I to the FMP Agreement must be interpreted as meaning that the equal treatment obligation only applies to natural persons for the purposes of the

\footnotetext{
156 Regulation (EU) No 492/2011 of the European Parliament and of the Council of 5 April 2011 on freedom of movement for workers within the Union.

157 Art. 9(2) of Regulation (EU) No 492/2011 of the European Parliament and of the Council of 5 April 2011 on freedom of movement for workers within the Union.

158 Case 63/86 Commission v. Italian Republic [1988] ECR 29.

159 S. Peers, 'The EC-Switzerland Agreement on Free Movement of Persons: Overview and Analysis', 2 European Journal of Migration and Law (2000), 127, p. 135.
} 
acquisition of immovable property. ${ }^{160}$ It added that Article 64(1) TFEU must be interpreted as meaning that the relevant Austrian provisions that require foreign nationals, acquiring immovable property situated in the province of Vienna, to obtain authorisation in respect of that acquisition or else produce a confirmation that the conditions laid down for the exemption from that requirement are satisfied, constitute a restriction on the free movement of capital which is permitted with regard to Switzerland as a third country.

\subsection{Other Sources of EU Law Applicable to Third-Country Nationals}

In order to combat social exclusion and poverty, the Union recognises and respects the right to social and housing assistance so as to ensure a decent existence for all those who lack sufficient resources, in accordance with the rules laid down by Union law and national laws and practices under Article 34(3) of the EU Charter. The EU Charter recognises the right to (immovable) property in Article 17(1) which specifies that everyone has the right to own, use, dispose of and bequeath his or her lawfully acquired possessions.

Member States are under the obligation to grant equal treatment to EU Blue Card holders in respect of access to goods and services and the supply of goods and services made available to the public, including procedures for obtaining housing. ${ }^{161}$ Third-country researchers falling within the scope of Council Directive 2005/71/EC enjoy equal treatment concerning access to goods and services and the supply of goods and services made available to the public; housing is not specifically mentioned in this provision however. ${ }^{162}$ Long-term resident third-country nationals have the right to equal treatment in view of access to goods and services and the supply of goods and services made available to the public and to procedures for obtaining housing. ${ }^{163}$ Articles 12(1)(g) and 2(d) of Directive 2011/98/EU on a single permit stipulate equal treatment for third-country workers with nationals of the Member State where they reside as regards access to goods and services and the supply of goods and services made available to the public including procedures for obtaining housing as provided by national law, without prejudice to the freedom of contract in accordance with Union and national law; this right may be limited to those thirdcountry workers who are in employment, and it may be restricted to access to housing. ${ }^{164}$

Case C-541/08 Fokus Invest [2010] ECR I-01025; Case C-351/08 Grimme [2009] ECR I10777, paras. 37-39.

161 Art. 14(1)(g) of Council Directive 2009/50/EC of 25 May 2009 on the conditions of entry and residence of third-country nationals for the purposes of highly qualified employment.

Art. 12(e) of Council Directive 2005/71/EC of 12 October 2005 on a specific procedure for admitting third-country nationals for the purposes of scientific research. Art. 11(1)(f) Council Directive 2003/109/EC of 25 November 2003 concerning the status of third-country nationals who are long-term residents; this right may be restricted to cases where the registered or usual place of residence of the long-term resident, or that of family members for whom $\mathrm{s} /$ he claims benefits, lies within the territory of the Member State concerned (Art. 11(2) of the Directive).

164 Directive 2011/98/EU of the European Parliament and of the Council of 13 December 2011 on a single application procedure for a single permit for third-country 


\subsection{Rights in Matters of Housing Compared}

EEA and Swiss workers are endowed with the right to equal treatment as regards housing, including ownership of the housing. ${ }^{165}$ The EU Charter recognises the right to (immovable) property according to which everyone has the right to own, use, dispose of and bequeath his or her lawfully acquired possessions. ${ }^{166}$ EU Blue Card holders, researchers, third-country workers, and long-term residents falling under the respective directives are entitled to equal treatment to access to goods and services and the supply of goods and services made available to the public, including housing. ${ }^{167}$

\section{THE Right to SOCIAL AND TAX ADVANTAgES}

To provide migrant workers with the same social and tax advantages as nationals of a Member State promotes their economic and social integration in the host country. Such integration measures in turn strengthen social stability and coherence in a society. The Court of Justice clarified the meaning of "social advantages" under the Treaty framework and construed the notion extensively. In this respect, "social advantage", as stated in Article 7(2) of Regulation (EU) No 492/2011, covers all the advantages which, whether or not linked to a contract of employment, are generally granted to national workers primarily because of their objective status as workers or by virtue of the mere fact of their ordinary residence on the national territory, and the extension of those social advantages to migrant workers therefore seems likely to facilitate their mobility within the EU. ${ }^{168}$ To determine whether a benefit is a social

nationals to reside and work in the territory of a Member State and on a common set of rights for third-country workers legally residing in a Member State; the third-country workers referred to under Art. 12 are defined in Art. 3(1)(b) and (c) of Directive 2011/98/EU on a single permit, meaning: third-country nationals who have been admitted to a Member State for purposes other than work in accordance with Union or national law, who are allowed to work and who hold a residence permit in accordance with Regulation (EC) No 1030/2002; and third-country nationals who have been admitted to a Member State for the purpose of work in accordance with Union or national law.

165 Art. 7(2) of Regulation (EU) No 492/2011 of the European Parliament and of the Council of 5 April 2011 on freedom of movement for workers within the Union; Art. 9(6) of Annex 1 of the FMP Agreement.

166 Art. 17(1) of the EU Charter.

167 Art. 14(1)(g) of Council Directive 2009/50/EC of 25 May 2009 on the conditions of entry and residence of third-country nationals for the purposes of highly qualified employment; Art. 12(e) of Council Directive 2005/71/EC of 12 October 2005 on a specific procedure for admitting third-country nationals for the purposes of scientific research; Arts. 12(1)(g) and 2(d) of Directive 2011/98/EU of the European Parliament and of the Council of 13 December 2011 on a single application procedure for a single permit for third-country nationals to reside and work in the territory of a Member State and on a common set of rights for third-country workers legally residing in a Member State; Art. 11(1)(f) Council Directive 2003/109/EC of 25 November 2003 concerning the status of third-country nationals who are long-term residents. 
advantage or a tax advantage, the Court held that it is necessary to examine its purpose and the conditions on which it is granted. ${ }^{169}$

\subsection{EEA Nationals}

Article 7(2) of Regulation (EU) No 492/2011, of relevance for the EEA, sets forth that workers shall enjoy the same social and tax advantages as national workers in the territory of another Member State. ${ }^{170}$ In Geven the Court found that the status of migrant workers did not in any way prevent the persons concerned from being able to claim the equal treatment prescribed by Article 7(2) of Regulation (EU) No $492 / 2011$ in relation to the grant of social advantages, and that frontier workers can rely on the provisions of Article 7 of Regulation (EU) No 492/2011 on the same basis as any other worker to whom that provision applies. ${ }^{171}$ The term "social advantage" within the meaning of Article 7(2) of Regulation (EU) No 492/2011 includes income guaranteed to elderly people by the legislation of a Member State, as well as the grant of the savings-pension bonus generally granted to workers on the basis of their objective status as workers. ${ }^{172}$

In Martinez Sala the Court made clear that a child-raising allowance granted to parttime workers constituted "social advantages". ${ }^{173}$ The Court concluded in NinniOrasche that in the field of assistance for university education, a national of a Member State, other than the host Member State, who had engaged in occupational activity in that host state and then undertaken university studies there leading to a professional qualification had to be regarded as having retained his status as a worker entitled as such to benefit from Article 7(2) of Regulation (EU) No 492/2011, provided that there was continuity between the previous occupational activity and the studies pursued. This latter condition, the Court continued, however could not be imposed if the migrant worker became involuntarily unemployed and was obliged to undertake occupational retraining. ${ }^{174}$ "Social advantages" under Article 7(2) of Regulation (EU) No 492/2011 include also interest-free loans granted on child birth; ${ }^{175}$ fares reduction cards for large families for railway transport; ${ }^{176}$ as well as the entitlement that the criminal proceedings against a migrant worker take place in a language other than the language normally used in court proceedings, under the same conditions as national workers. ${ }^{177}$

What is the relationship between Regulation (EU) No 492/2011 and the rules on social security coordination as regards "social advantages"? The Court specified that since Regulation (EU) No 492/2011 was of general application regarding the free

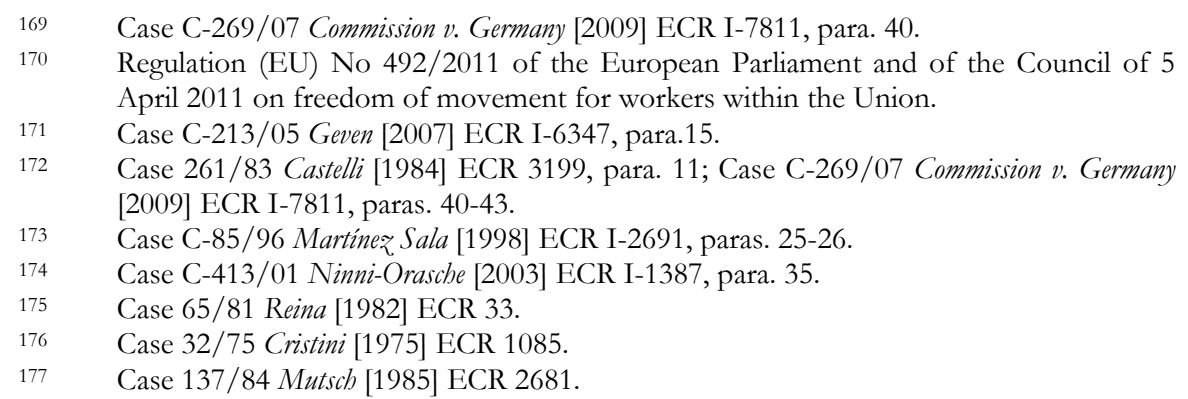


movement of workers, Article 7(2) could be applied to social advantages which, at the same time, fell specifically within the scope of former Regulation No 1408/71.178 Considering that the latter Regulation has been repealed, the relevant applicable reference scheme today is Regulation (EC) No 883/2004. ${ }^{179}$

\subsection{Swiss Nationals}

In conformity with Article 9(2) of Annex I of the FMP Agreement, a Swiss national employed in an EU Member State and his or her family members (as referred to in Article 3 of Annex I of the FMP Agreement) enjoy the same tax concessions and welfare benefits as national employed persons and their family members.

\subsection{Other Sources of EU Law Applicable to Third-Country Nationals}

Article 34(2) of the EU Charter sets out that everybody residing and moving legally within the European Union is entitled to social security benefits and social advantages in accordance with Union law and national laws and practices. Researchers covered by Council Directive 2005/71/EC have the right to equal treatment in view of tax benefits (Article 12(d) of the Directive). ${ }^{180}$ Third-country nationals with long-term resident status have the right to equal treatment with nationals concerning social assistance and social protection as defined by national law, as well as tax benefits; yet, the Member State concerned may restrict equal treatment to cases where the registered or usual place of residence of the long-term resident, or that of family members for whom s/he claims benefits, lies within the territory of the Member State concerned. ${ }^{181}$ In Kamberaj the Court held that Article 11(1)(d) of Council Directive 2003/109/EC precluded a law, which provides, with regard to the grant of a housing benefit, for different treatment for long-term residents pursuant to the provisions of that Directive compared to that accorded to nationals residing in the same province or region when the funds for the benefit are allocated, in so far as such a benefit falls within one of the three categories referred to in that provision and Article 11(4) of that Directive does not apply. ${ }^{182}$ Directive $2011 / 98 / \mathrm{EU}$ on a single permit contains the right to equal treatment for thirdcountry workers with nationals of the Member State where they reside with regard to tax benefits, in so far as the worker is deemed to be resident for tax purposes in the Member State concerned under Article 12(1)(f). ${ }^{183}$ Member States can limit the

Case C-111/91 Commission v. Luxembourg [1993] ECR I-817, para. 22.

Regulation (EC) No 883/2004 of the European Parliament and of the Council of 29 April 2004 on the coordination of social security systems; an explicit change of reference has, however, only been stipulated for Directive 98/49/EC of 29 June 1998 on safeguarding the supplementary pension rights of employed and self-employed persons moving within the Community, see Art. 90(2) of Regulation (EC) No $883 / 2004$.

Council Directive 2005/71/EC of 12 October 2005 on a specific procedure for admitting third-country nationals for the purposes of scientific research.

Arts. 11(1)(d), (e) and 2 of Council Directive 2003/109/EC of 25 November 2003 concerning the status of third-country nationals who are long-term residents.

Case C-571/10 Kamberaj [2012] Judgment of 24 April 2012, not yet reported.

Directive 2011/98/EU of the European Parliament and of the Council of 13 December 2011 on a single application procedure for a single permit for third- 
application of this rule to cases where the registered or usual place of residence of the family members of the third-country worker, for whom s/he claims benefits, lies in the territory of the Member State concerned. ${ }^{184}$

\subsection{The Right to Social and Tax Advantages Compared}

Arguably, the social advantages are the most important rights for migrant workers in that they stimulate integration in the host state. Employed persons holding the nationality of an EFTA state find themselves in a privileged position. Such workers shall enjoy the same social and tax advantages as national workers in the territory of another EEA state. ${ }^{185}$ The concept of social advantage covers all the advantages which, whether or not linked to a contract of employment, are generally granted to national workers primarily because of their objective status as workers or by virtue of the mere fact of their ordinary residence in the national territory, and the extension of those social advantages to migrant workers therefore seems likely to facilitate their mobility within the Community. ${ }^{186}$ Likewise, a Swiss worker employed in a Member State and his or her family members enjoy the same tax concessions and welfare benefits of national employed persons and their family members. ${ }^{187}$

The EU Charter does not provide for equal treatment as regards social or tax advantages but clarifies that everybody residing and moving legally within the EU is entitled to social advantages in accordance with Union law and national laws and practices. ${ }^{188}$ Equal treatment is prescribed for researchers, long-term residents, and third-country workers (in so far as the worker is deemed to be resident for tax purposes in the Member State concerned) within the scope of the respective directives. ${ }^{189}$ Third-country long-term residents, equal treatment applies also to social assistance and social protection as defined by national law. ${ }^{190}$

country nationals to reside and work in the territory of a Member State and on a common set of rights for third-country workers legally residing in a Member State; the third-country workers referred to under Art. 12 are defined in Art. 3(1)(b) and (c) of Directive 2011/98/EU on a single permit, meaning: third-country nationals who have been admitted to a Member State for purposes other than work in accordance with Union or national law, who are allowed to work and who hold a residence permit in accordance with Regulation (EC) No 1030/2002; and third-country nationals who have been admitted to a Member State for the purpose of work in accordance with Union or national law.

184 See Art. 12(2)(c) of Directive 2011/98/EU on a single permit.

185 Art. 7(2) of Regulation (EU) No 492/2011 of the European Parliament and of the Council of 5 April 2011 on freedom of movement for workers within the Union.

186 Case C-85/96 Martínez. Sala [1998] ECR I-2691, para. 25.

187 Art. 9(2) of Annex I of the FMP Agreement.

188 Art. 34(2) of the EU Charter.

189 Art. 12(d) of Council Directive 2005/71/EC of 12 October 2005 on a specific procedure for admitting third-country nationals for the purposes of scientific research; Arts. 11(1)(e) and 2 of Council Directive 2003/109/EC of 25 November 2003 concerning the status of third-country nationals who are long-term residents; Art. 12(1)(f) of Directive 2011/98/EU of the European Parliament and of the Council of 13 December 2011 on a single application procedure for a single permit for third- 
Part VII has demonstrated that third-country nationals are eligible for a number of economic and social rights alongside rights that relate to entry, employment, residence and social security. In Part VII, the right to establishment; the right to provide services; the mutual recognition of qualifications; the right to education; rights in matters of housing; the right to social, tax and other advantages have been examined. The legal analysis and comparison of such rights has revealed that EEA and Swiss nationals are by far the most privileged group of third-country nationals in all categories considered. This result does not come as a surprise taking into account the structure and scope of the EEA Agreement and the FMP Agreement with Switzerland. ${ }^{191}$ Individuals possessing the nationality of Iceland, Norway, Liechtenstein and Switzerland can rely on legislation that either fully extends the area of application of the free movement rules applicable to EU citizens to EEA and Swiss nationals, or alternatively, those nationals are entitled to particularly advantageous regulations. Turkish nationals also have a special status because the EU-Turkey association law provides for a legal regime that has originally granted rights to Turkish nationals in anticipation of Turkey's accession to the EU. On the basis of this regime, such nationals can, for instance, assert a right to stand-still in matters of establishment and the provision of services. While a right to provide services in the EU is reserved to EEA and Swiss nationals, a lot of the association agreements stipulate the gradual liberalisation of trade in services in conformity with the GATS as this research has shown.

Other third-country nationals who come within the scope of application of one of the directives examined can, in many instances, claim a right to equal treatment concerning inter alia education and vocational training and the recognition of diplomas. Except for the economic rights on establishment and the provision of services, the other rights considered in Part VII also promote the integration of thirdcountry nationals residing lawfully in the EU. To recall, the Tampere Conclusions of 1999 first set forth the objective to ensure fair treatment of third-country nationals, to achieve a more vigorous integration policy aiming at granting rights and obligations comparable to those of EU citizens and to enhance non-discrimination in economic, social and cultural life. ${ }^{192}$

country nationals to reside and work in the territory of a Member State and on a common set of rights for third-country workers legally residing in a Member State. Art. 11(d) of Council Directive 2003/109/EC of 25 November 2003 concerning the status of third-country nationals who are long-term residents.

191 See also Parts V and VI on the extensive set of rights granted to EEA and Swiss nationals in this regard.

192 Tampere Presidency Conclusions of 15 and 16 October 1999, para. 18. 


\section{Part VIII : Conclusions}

This research project has provided an in-depth analysis and comparison of the different sets of rights that non-EU nationals arriving at and residing in the Union enjoy. The dissertation investigated the reasons why third-country nationals possessing a certain nationality enjoy a privileged legal position on the basis of EU law, and in which respects such a privileged position differs from a "non-privileged" one. By detailing and examining the various sources of law that make up the EU migration law acquis, next to the international human rights standards upon which non-EU nationals can rely, this analytical study allows a number of conclusions to be drawn.

\subsection{The Link between Migration Policy and External Relations}

First of all, external relations and migration are two policy fields that are intrinsically linked. The Member States' national immigration policies are addressed to foreigners who wish to enter and reside on their territories, and as a general rule their alignment depends on the foreign relations that a Member State maintains with the third state in question. It has been demonstrated that foreign relations and political ties are in the same way decisive for the determination of the EU's migration policy, and thus ultimately for the individual holding the nationality of a third state. For instance, the Preamble to Council Regulation (EC) No 539/2001 listing the third countries whose nationals must be in possession of visas when crossing the external borders and those whose nationals are exempt from that requirement explicitly states that the determination as to whether a country is put on the visa white or the black list is, inter alia, contingent on the Union's external relations with third countries. ${ }^{1}$

Immigration and entry policies are determined and stipulated subject to the foreign relations with a particular third country because migration has always been a very delicate subject-matter for states touching the core rights of sovereignty. Another prime example in this respect is seen in association agreements that the EU first concluded in the 1960s to enhance the economic and political relations with third states, and to prepare the partner country for EU accession in some cases. As regards the nature of such association agreements the Court made clear that they create special, privileged links with a non-Member State. ${ }^{2}$ This dissertation has illustrated how those special, privileged links are reflected in the rules concerning the treatment and the movement of third-country nationals contained in the agreements. Hence, certain third-country nationals have come under the scope of EEC law as early as with the conclusion of the first association agreements which have for the first time established a connection between migration matters and the EU's external relations. These linkages give evidence of an external dimension of migration policy since the very beginning of EEC system.

$1 \quad$ Recital 5 of the Preamble to Council Regulation (EC) No 539/2001 of 15 March 2001 listing the third countries whose nationals must be in possession of visas when crossing the external borders and those whose nationals are exempt from that requirement.

$2 \quad$ Case C-12/86 Demirel [1987] ECR I-3719, para. 9. 


\subsection{The Incorporation of Migration into the EU Legal Framework: The Changing External Dimensions}

Second, this dissertation has shown how the external dimensions of EU migration policy differ against the background of the far-reaching developments transforming migration from a "component" in association agreements into an autonomous EU policy field.

Competences in the field of migration have only step-by-step been incorporated into the EU treaty framework providing a legal foundation for the emergence of a European migration regime as depicted in Part II. While the rules set forth in the Rome Treaty of 1957 did not explicitly provide for the basic distinction between nationals of the Member States and nationals of third countries it soon became clear that the EEC provisions on the free movement of persons were reserved for Member States' nationals. Hence, a "first" external dimension developed on the basis of the rules concerning the status and/or movement of third-country nationals, which were only gradually and as a "byproduct" incorporated into association agreements. Most agreements set forth post-entry rights that can only be invoked once a third-country national has (legal) residence in a Member State. While the objective of creating equality of treatment played somewhat a role for the inclusion of equal treatment clauses in employment matters in the agreements, other rather nonaltruistic reasons were also important, for instance, the aim of the Community and the Member States to prevent wage dumping. The EEC introduced labour rules for Community workers because of economic considerations - to achieve the free movement of workers in the EEC - and the legal measures taken fertilised debates and later policy action with regard to third-country national workers.

The Treaty of Maastricht that entered into force in 1993 enabled the Member States to cooperate in justice and home affairs, including issues concerning migration, on the basis of an established, intergovernmental mechanism. In addition, the Community was given competences in the field of visa policy which subsequently led to the adoption of the visa white and black lists.

It was the signature of the Treaty of Amsterdam in 1997 that first equipped the Union with broader powers to legislate in the field of immigration and asylum under Title IV EC. On the basis of Title IV EC (now Title V TFEU), the EU institutions have adopted a set of EU secondary legislation that sets forth a sectoral regime for third-country nationals. ${ }^{3}$ Today, the set of EU secondary legislation adopted under Title V TFEU includes Council Directive 2003/86/EC on the right to family reunification, ${ }^{4}$ Council Directive 2003/109/EC concerning the status of thirdcountry nationals who are long-term residents, ${ }^{5}$ Council Directive 2004/114/EC on

3 European Commission, proposal for a Council Directive on the conditions of entry and residence of third-country nationals for the purpose of paid employment and selfemployed economic activities, $\operatorname{COM}(2001)$ 386, 11 July 2001; European Commission Communication, Policy Plan on legal migration, COM(2005) 669, 21 December 2005.

4 Council Directive 2003/86/EC of 22 September 2003 on the right to family reunification.

5 Council Directive 2003/109/EC of 25 November 2003 concerning the status of thirdcountry nationals who are long-term residents. 
the conditions of admission of third-country nationals for the purposes of studies, pupil exchange, unremunerated training or voluntary service, ${ }^{6}$ Council Directive $2005 / 71 / \mathrm{EC}$ on a specific procedure for admitting third-country nationals for the purposes of scientific research, ${ }^{7}$ Council Directive 2009/50/EC on the conditions of entry and residence of third-country nationals for the purposes of highly qualified employment, ${ }^{8}$ and Directive 2011/98/EU of the European Parliament and of the Council on a single application procedure for a single permit for third-country nationals to reside and work in the territory of a Member State and on a common set of rights for third-country workers legally residing in a Member State. ${ }^{?}$

At a conference on economic migration organised in May 2012, C. Malmström, the European Commissioner for home affairs, pointed out that the common approach suggested by the Commission was replaced by a sectoral approach in the field of labour migration, which had been the only viable option for the Member States; in this regard, she assessed the EU Blue Card as having "a good but limited impact only." 10 In 2010, the Commission proposed two additional directives concerning the admission of third-country seasonal workers and of third-country intra-corporate transferees; both frameworks are being negotiated. ${ }^{11} \mathrm{R}$. Cholewinski emphasised that

"[T]he distinction formulated between highly skilled and lower skilled third-country national workers in the adopted Blue Card Directive and the [proposed] General Framework Directive, with a view to attracting more skilled migrants by granting them more rights, runs not only in the face of coherence but also equity [...] The principle of non-discrimination applicable to all human beings regardless of their nationality, skill level, or immigration status is rooted in international human rights law as well as in instruments adopted at the regional level [...]".12

There is no doubt that the sectoral approach pursued, next to the gradual, hesitant integration of migration issues into the EU framework, has contributed considerably to creating a very fragmented and selective migration regime for third-country nationals.

6 Council Directive 2004/114/EC of 14 December 2004 on the conditions of admission of non-EU nationals for the purposes of studies, pupil exchange, unremunerated training or voluntary service.

7 Council Directive 2005/71/EC of 12 October 2005 on a specific procedure for admitting third-country nationals for the purposes of scientific research.

8 Council Directive 2009/50/EC of 25 May 2009 on the conditions of entry and residence of third-country nationals for the purposes of highly qualified employment. Directive 2011/98/EU of the European Parliament and of the Council of 13 December 2011 on a single application procedure for a single permit for thirdcountry nationals to reside and work in the territory of a Member State and on a common set of rights for third-country workers legally residing in a Member State. Statement by C. Malmström at the conference: "EU Migration Policy: The Search for Skills", held on 29 May 2012 at IPC Residence Palace in Brussels (organised by European Voice); see also European Commission Communication, COM(2012) 250, 30 May 2012, p. 6.

11 European Commission, $\operatorname{COM}(2010)$ 379, 13 July 2010; European Commission, $\operatorname{COM}(2010) 378,13$ July 2010.

12 R. Cholewinski, 'The External Dimension of the EU Immigration Policy', in: M. Maes, M.-C. Foblets and Ph. De Bruycker (eds.), External Dimensions of European Migration and Asylum Law and Policy (Bruylant, Bruxelles 2011), 485-500, p. 491. 
These legal developments were preceded, and later accompanied, by policy discussions and measures: already in 1974 the Council was urged to adopt an action programme for migrant workers and their family members to address the migration phenomenon, and to improve the social and educational conditions of migrant workers and their families. At the beginning of the 1990s, in the wake of the large influx of refugees and undocumented migrants coming to Europe, it was the Commission that pointed out that migration should be managed in cooperation with the sending countries with the objective to keep potential migrants in the areas of origin.

The EU Heads of State and Government first jointly formulated the call for a comprehensive and integrated approach to migration in more detail at the Tampere European Council in 1999 stressing the need to build partnerships with countries of origin and transit, to ensure fair treatment for lawfully residing third-country nationals, to manage migration more effectively, and to assimilate the legal status of third-country nationals to that of Member States' nationals. While not being discussed in greater detail in this study, the fight against irregular migratory movements undoubtedly also played a crucial role in formulating this comprehensive approach: major efforts on behalf of the EU and the Member States were made to strengthen readmission policies and to enhance border security and control. Subsequently, in 2005 it was proclaimed that the EU's Global Approach to Migration, according to the Commission, epitomises the external dimension of the EU's migration policy.

The Global Approach to Migration, which became the GAMM in 2011, has constituted a promising, new impetus in the eyes of the Commission to establish genuine and balanced "partnerships" with third countries in the field of migration. In the framework of this book, doubts have been expressed as concerns the "globality" of the GAMM and its supposed orientation on mobility; however, the fact that the GAMM endeavours to be migrant-centred and emphasises the human rights of migrants as a cross-cutting theme is an improvement to the 2005 Global Approach to Migration. Important tools for the implementation of GAMM are mobility partnerships, which aim to offer a framework to manage migration effectively. Mobility partnerships are designed as initiatives of political cooperation that operate without any kind of legal review and provide the parties involved with great flexibility.

The Deputy Minister of Foreign Affairs and European Integration of the Republic of Moldova, N. Gherman, in June of 2012 reported the manifold added value that the mobility partnership concluded with Moldova implicated for her country. Indicating the high number of Moldovan migrants living abroad, the Deputy Minister emphasised the major progress that has been made since the conclusion of the mobility partnership with the implementation of more than 80 projects and initiatives. The Deputy Minister, in addition, expressed her hope that this success could serve as an example for other third states with which the EU has either concluded, or envisaged to conclude, a mobility partnership. ${ }^{13}$ It must be borne in

13 Speech of the Deputy Minister of Foreign Affairs and European Integration of the Republic of Moldova, N. Gherman, delivered at the conference: "Mobility 
mind that the "success" of this mobility partnership is due to the active dialogue and participation on behalf of Moldova and also Moldova's acceptance to implement the Member States' requests under the mobility partnership. In fact, research has provided a much more nuanced picture of the initiative, as this dissertation has indicated. It has been argued that the Member States' interests dominate the content of the mobility partnerships: enhanced legal migration opportunities, such as visa facilitation, are traded on unequal terms for readmission commitments and stricter border control. This loose form of a "pick-and-choose" cooperation secures that the competence of the participating Member States is not affected, and leaves the judicial authority of the Court deliberately out of the game. The invention of mobility partnerships illustrates that the need for an effective management of migration is urgent, while migration issues are still considered to be a highly sensitive subjectmatter by the Member States. One has to keep in mind that only certain countries "qualify" for the conclusion of a mobility partnership, which - once more promotes a piecemeal approach rather than a common European approach in migration matters.

\subsection{Difference in Treatment among Third-Country Nationals}

Third, this book has set forth that there is a major difference in treatment among third-country nationals under EU law; as has been indicated, this fact can be attributed to the nexus between external relations' and migration policies. It is true that all third-country migrants who reside in the Union enjoy human rights protection, both under international law instruments and regional frameworks as elaborated in Part III. The prohibition of discrimination plays a central role in such human rights treaties and exceptions to this rule are only permissible if the difference in treatment pursues a legitimate aim, can be objectively justified and is proportionate to the objectives sought to be achieved. By contrast, the legal position of thirdcountry nationals under the various sources of EU law can differ substantially, as was detailed and expounded in Parts V to VII. The differential treatment granted to thirdcountry nationals makes it difficult to speak of one single, unitary group of thirdcountry nationals constituting the counterpart to EU nationals. The rules permitting this difference in treatment find their legal bases in the distinct association, cooperation and partnership agreements, which have served as a starting point for the legal analysis.

Importantly, third-country nationals can rely on such agreements only if they possess the nationality of one of the contracting state parties. This makes the scope of application of association agreements exclusive. The underlying study has highlighted to what extent this legal position may vary depending on the applicable association agreement and/or cooperation framework. Only for a small, privileged group of third-country nationals these rights are indeed "as near as possible to those enjoyed by EU citizens". ${ }^{14}$ The agreements and frameworks were concluded for distinct purposes, which are reflected by the particular objective pursued, as well as the

Partnerships: Past, Present and Future", held on 27 June 2012 at Hotel Crowne Plaza in Brussels (organised by ICMPD).

14 As envisaged for third-country nationals who reside on a long-term basis in an EU Member State, see Tampere Presidency Conclusions of 15 and 16 October 1999, para. 21. 
content, design and nature of the cooperation mechanism in question. Part IV has detailed the full range of the association and cooperation regimes that the EU has established, and which are pertinent for the status of third-country nationals.

The geographical coverage is broad and generally speaking it has become clear that those agreements that set out an EU accession perspective are more comprehensive as regards rules on the status and/or movement of persons than those agreements that merely aim to promote trade relations. There are two exemptions to this rule: the EEA Agreement and the FMP Agreement with Switzerland. Part IV has propounded that both agreements were elaborated as alternatives to EU membership. Other frameworks merely serve as a platform for cooperation, such as the mobility partnerships or the Africa-EU Partnership on MME adopted in the context of the Joint Africa-EU Strategy in 2007. It is clear that the latter instruments are first and foremost "dialogue-based": rather than granting third-country nationals concrete entry, employment or residence rights, they set out policy objectives, strategies and priorities with the partner state(s) concerned in the field of migration.

In Parts V to VII the scope of entry, residence and employment rights; social security rights; and other economic and social rights of third-country nationals has been explored. This breakdown has rendered a nuanced examination of the various rights, which considered together determine the respective legal position of third-country nationals under EU law, possible, and it has facilitated a direct comparison in this respect. The comparative studies in Parts V, VI and VII have made clear that EEA and Swiss nationals are by far the most privileged group of third-country nationals who can rely on a wide scope of rights ranging from entry to employment to social security rights that are comparable to the set of rights granted to Member States' nationals.

Assessing the status of EEA and Swiss nationals in isolation, it can be concluded that their legal position is similar, or "approximated" to that of Member States' nationals seeing that they profit from essentially the same free movement rights as those individuals holding the nationality of an EU Member State. For instance, EEA and Swiss nationals may freely enter and reside in an EU Member State to engage in an economic activity, and they can rely on extended EU legislation for the purposes of having their professional qualification recognised in a Member State. One has to keep in mind, however, that EEA and Swiss nationals cannot rely on the concept of Union citizenship and the related case law of the Court of Justice, although it has been contended that this viewpoint is not as clear as it might seem. ${ }^{15}$

As has been indicated, a second group of privileged third-country nationals are those covered by an agreement that foresees the possibility of future EU membership, such as the Ankara Agreement and the SAAs with the Western Balkan countries. These agreements do not set out the free movement of persons, but they do integrate certain beneficial rights for nationals of the contracting parties - yet, among these agreements that envisage "association", the scope of rights awarded can differ substantially. It has been demonstrated that Turkish nationals hold a special status under the EU-Turkey association law: for instance, Turkish workers can rely on a

15 S. Peers, 'The EC-Switzerland Agreement on Free Movement of Persons: Overview and Analysis', 2 European Journal of Migration and Law (2000), 127, p. 137. 
temporal framework that allows for gradual access to the labour market and Turkish nationals are eligible to export social security benefits including special noncontributory cash benefits to Turkey. Unlike the agreements applicable to EEA and Swiss citizens, the EU-Turkey association law provides Turkish nationals with work and residence rights that are connected to the purpose of employment. How can Turkish nationals then be classified? D. Martin referred to AG Darmon who - in his opinion in the early case of Kus - made clear that "Turkish workers cannot be assimilated to Community nationals [...] but Turkish workers are no longer in the situation of nationals of other non-member countries." 16 This leaves Turkish workers thus with a status in a grey area on the scale somewhat closer to EEA and Swiss nationals who could be considered at the top when compared to other third-country nationals.

In comparison with Turkish nationals, nationals of Western Balkan countries who fall under the scope of application of an SAA do not enjoy specific employment rights but they have the right to take up economic activities as self-employed persons in a Member State. Despite the fact that the Euro-Mediterranean Agreements concluded with Algeria, Morocco and Tunisia do not set out an accession perspective, workers holding the nationality of such a Maghreb country, and any family members living with them, enjoy treatment free of any discrimination based on nationality relative to the nationals of the host country in which they are employed in the area of social security. These are examples for rules laying down special treatment under association, cooperation and partnership agreements that the EU has concluded with third countries - the actual list is much longer as the dissertation has illuminated; however, these examples give a taste of the broad range of rights granted to non-EU nationals on the basis such agreements.

Other sources of EU law cover third-country nationals irrespective of nationality. The EU Charter applies for example to a great extent to everyone. In order to fall within the scope of application of such EU secondary legislation in the field of legal migration referred to other criteria are determining, such as the length of residence, professional qualification, or family relations. The legal instruments examined in this respect are the Directive on long-term resident status for third-country nationals, ${ }^{17}$ the EU Blue Card Directive, ${ }^{18}$ the Directive on the admission conditions for researchers, ${ }^{19}$ Directive 2011/98/EU on a single permit, ${ }^{20}$ and Council Directive

16 See D. Martin, 'The Privileged Treatment of Turkish Nationals', in: E. Guild and P. Minderhoud (eds.), The First Decade of EU Migration and Asylum Law (Martinus Nijhoff Publishers, Leiden 2012), pp. 75-91, who refers to the Opinion of AG Darmon in Case C-237/91 Kus [1993] ECR I-6783, paras. 64-65.

17 Art. 11(1)(a) of Council Directive 2003/109/EC of 25 November 2003 concerning the status of third-country nationals who are long-term residents.

18 Art. 14(1)(a) of Council Directive 2009/50/EC of 25 May 2009 on the conditions of entry and residence of third-country nationals for the purposes of highly qualified employment.

19 Art. 12(b) of Council Directive 2005/71/EC of 12 October 2005 on a specific procedure for admitting third-country nationals for the purposes of scientific research.

20 Directive 2011/98/EU of the European Parliament and of the Council of 13 December 2011 on a single application procedure for a single permit for third-country nationals to reside and work in the territory of a Member State and on a common set of rights for third-country workers legally residing in a Member State; the third-country 
$2003 / 86 /$ EC on family reunification. ${ }^{21}$ In the field of social security, the general coordination scheme applicable to EU citizens has been extended to third-country nationals provided that they have their legal residence in a Member State and that they are in a situation which is not confined, in all respects, within a single Member State. Council Regulation (EC) No 859/2003 has in the meantime been replaced by Regulation (EU) No $1231 / 2010.22$ How is the ambitious objective announced at the Tampere European Council to approximate the status of third-country nationals to that of nationals of the Member States to be assessed? While the adoption of the pertinent EU secondary legislation has certainly contributed to strengthening the legal position of third-country nationals, and - and at least to a certain degree - adjusted the level of those third-country migrants who benefit from such more favourable rules under association agreements, an authentic approximation of rights enjoyed by third-country nationals and by Member States' nationals is far from being achieved. The afore-mentioned directives constitute a first step in putting into effect the envisaged approximation of legal positions. One has to distinguish between the Directives on family reunification, on long-term resident status, on social security coordination and on a single permit that are applicable to all third-country nationals, and the other sectoral directives that apply to researchers and highly-skilled workers those categories of third-country nationals that the EU particularly aims to attract coming to the EU.

It has been claimed that in EU migration law "residence is supplementing and even replacing nationality as the main criterion in the determination of rights of nonnationals." ${ }^{23}$ It is true that residence is supplementing nationality in this context seeing that for the first set of directives the period of residence is crucial for the scope of rights granted to third-country nationals. Moreover, it is attractive to think out of the box and consider residence as a connecting factor for the legal position of non-EU citizens. ${ }^{24}$ However, it is far-fetched to state that residence replaces nationality as a criterion today. Nationality remains decisive for third-country nationals who have a privileged status under association agreements; this status is maintained under the pertinent directives in that they apply without prejudice to more favourable provisions of bilateral and multilateral agreements. Effectively, such

workers referred to under Art. 12 are defined in Art. 3(1)(b) and (c) of Directive 2011/98/EU, meaning: third-country nationals who have been admitted to a Member State for purposes other than work in accordance with Union or national law, who are allowed to work and who hold a residence permit in accordance with Regulation (EC) No 1030/2002; and third-country nationals who have been admitted to a Member State for the purpose of work in accordance with Union or national law. Council Directive 2003/86/EC of 22 September 2003 on the right to family reunification.

Council Regulation (EC) No 859/2003 of 14 May 2003 extending the provisions of Regulation (EEC) No 1408/71 and Regulation (EEC) No 574/72 to nationals of third countries who are not already covered by those provisions solely on the ground of their nationality; Regulation (EU) No 1231/2010 of the European Parliament and of the Council of 24 November 2010 extending Regulation (EC) No 883/2004 and Regulation (EC) No 987/2009 to nationals of third countries who are not already covered by these Regulations solely on the ground of their nationality. Discrimination', in: J.-Y. Carlier and E. Guild (eds.), L'avenir de la libre circulation des personnes dans l'UE (Bruylant, Bruxelles 2006), p. 100. See Recommendations and Outlook below. 
agreements form - along with the relevant case law of the Court of Justice, EU secondary legislation, as well as pertinent provisions of the EU Charter and of the ECHR, including the Strasbourg case law - part and parcel of the EU migration law acquis that developed in a piecemeal manner. The different legal sources of law forming a landscape of separate migration regimes account for a high degree of fragmentation of the latter acquis; however, they partly also complement each other. In the light of this fragmentation, this book has demonstrated that a common EU migration policy does not exist to date, and is at this point in time far from being put in place. In the same way this book has argued that it is difficult to speak of one single, unitary group of third-country nationals taking into account that the applicable legal regimes may greatly influence the rights awarded and thus the legal position of the third-country national in question.

\subsection{The Role of the Court of Justice in Strengthening Migrants' Rights}

Fourth, one EU actor has played a salient role in strengthening the legal position of third-country nationals: the Court of Justice in Luxembourg. The Court of Justice has produced an enormous amount of case law interpreting provisions of the various association agreements, the most prominent example being the case law for Turkish nationals which has added up to over 50 judgments clarifying the meaning of the EUTurkey association law for Turkish individuals. In a lot of these judgments dealing with the association agreements the Court has construed the provisions at stake extensively in favour of third-country nationals; by giving such provisions a broad meaning the Court has proactively contributed to protecting migrants' rights.

As early as in 1974 the Court ruled that an international agreement concluded by the EEC formed an integral part of the Community legal order as of the date of its entry into force. ${ }^{25}$ In the case of Sevince the Court confirmed its jurisdiction as regards Association Council decisions by deciding that they formed an integral part of the Community legal order; this finding, the Court clarified, was reinforced by the function of Article 238 EC (Article 217 TFEU), which was to ensure the uniform application and interpretation of all provisions of the Community legal system. ${ }^{26}$ In Sevince, the Court also ruled for the first time on the direct effect of Article 6(1) of Decision No 1/80 because the provision was clear, precise and unconditional and in line with the purpose and nature of the latter decision that formed part of the Ankara Agreement. ${ }^{27}$ The Court confirmed the direct effect of a provision of the EECMorocco Cooperation Agreement in Kziber, which had direct consequences for a young Moroccan national who was eligible for an unemployment allowance. ${ }^{28}$ The interpretation on the direct effect of provisions concerning rights for persons in association agreements was confirmed in latter cases, such as Gloszczuk, Wäblergruppe Gemeinsam and Simutenkov. ${ }^{29}$

Case C-181/73 Haegeman [1974] ECR 449, para. 5.

Case C-192/89 Sevince [1990] ECR I-3461, paras. 8-12.

Ibid.

Case C-18/90 Kziber [1991] ECR I-199.

Case C-63/99 Gloszcruk [2001] ECR I-6369, para. 30; Case C-171/01 Wählergruppe Gemeinsam [2003] ECR I-4301, para. 54; Case C-265/03 Simutenkov [2005] ECR I-2579, para. 21. 
In Simutenkov, the Court held that the direct effect of some provisions in the PCA with Russia was not impaired by the purpose and nature of the PCA that established a partnership, rather than setting out an association or future accession between the parties. ${ }^{30}$ However, the nature, the spirit and the purpose of the agreement in question are decisive for determining whether a concept can be interpreted by analogy with a Union concept or not: the similar wording of the EEC Treaty and of an international agreement between the Community and a non-member country was not sufficient to give the wording in the international agreement the same meaning as it had in the EEC Treaty (unless there were express provisions to that effect laid down by the agreement itself) as the Court held in Polydor. ${ }^{31}$

The question of whether a similar or identical wording of a provision in an international agreement had to be interpreted in the same way as its counterpart contained in the EC Treaty was contingent on the objective pursued by each provision in its own particular context and a comparison between the objectives and context of the agreement and those of the Treaty. ${ }^{32}$ For example, the Court gave the concept of a "worker" within the scope of Article 6(1) of Decision No 1/80 relevant for Turkish workers the same meaning as under Community law. ${ }^{33}$ Contrarily, the Court ruled in Ziebell that Turkish nationals could not rely on the enhanced protection against expulsion provided for in Article 28(3)(a) of Directive 2004/38/EC, which applied to EU citizens exclusively. ${ }^{34}$ This diverging way of interpretation raises questions with regard to coherence, predictability and legal certainty concerning the case law on the EU-Turkey association law. Next, the Court referred to the latter case law for interpreting principles under the Maghreb cooperation agreements, such as the principle of equal treatment in social security. ${ }^{35}$

More generally, in Jany the Court made reference to the Vienna Convention of 23 May 1969 on the Law of Treaties stating that an international treaty had to be interpreted not solely by reference to the terms in which it was worded but also in light of its objectives, its purpose and its context. ${ }^{36}$ In this sense, the Court has set itself guidelines for the interpretation of association agreements, and in doing so it clearly approved the differential treatment of third-country nationals under the various association agreements which it has construed in reference to their respective aims and purposes. The questions arise whether the Court of Justice can validly be accused of judicial activism, and whether the Court has maybe even exceeded its competences by interpreting certain provisions extensively in favour of third-country migrants. There is no doubt that the Court has substantially contributed to the development of Union law in general, and - as this dissertation has demonstrated that the Court has actively contributed to the protection of migrants' rights under EU

30 Case C-265/03 Simutenkov [2005] ECR I-2579, para. 28; see also Case C-113/97 Babahenini [1998] ECR I-183, para. 17; Case C-162/96 Racke [1998] ECR I-3655, paras. 34-36.

Case 270/80 Polydor [1982] ECR 329, paras. 15-19.

Case C-312/91 Metalsa [1993] ECR 3751, para. 11.

Case C-188/00 Kurz [2000] ECR I-10691, paras. 30-31.

Case C-371/08 Ziebell [2011] Judgment of 8 December 2011, not yet reported.

Case C-23/02 Alami [2003] ECR I-1399, para. 31.

Case C-268/99 Jany [2001] ECR I-8615, para. 35. 
law in particular. It is not for nothing that the Court was labelled the most vigorous defender of the rights of third-country nationals. ${ }^{37}$

It has been pointed out that "there seem to be good reasons for activism on part of the Court" on the basis of the teleological method of interpretation, which the Court has predominantly applied, although the concept of judicial activism has in itself been considered as a rather relative and vague judicial term. ${ }^{38}$ Arguably, however, it is farfetched to deem this interpretative pattern as ultra vires. One could argue au contraire that the Court has given meaning to the respective provisions as highest judicial authority in the Union with a focus on the aim, purpose and the objective of a provision. In other words, the Court has given substance to the rights that were - at some point adopted - by the EU legislator with a specific purpose. With respect to the measures adopted under Title IV of the Treaty of Amsterdam in the field of immigration and asylum, one has to bear in mind that this EU secondary legislation was subject to a restricted jurisdiction of the Court of Justice until the entry into force of the Treaty of Lisbon because preliminary rulings could only be lodged by courts of last instance. ${ }^{39}$ Today all courts have the possibility to submit preliminary references to the Court of Justice, which consolidates the coherent interpretation of EU immigration and asylum law throughout the Union. This change is undoubtedly to be welcomed and answered calls from academia. The prior situation has been assessed as "a disgraceful anomaly that must be corrected as soon as possible." ${ }^{40}$

\subsection{Third-Country Nationals and Equality of Treatment}

Fifth, it has been explained how the principle of equality of treatment, which requires that similar situations shall not be treated differently unless the differentiation concerned is objectively justified, relates to third-country nationals. ${ }^{41}$ The Court of Justice held in Vatsouras that only Member States' nationals could rely on Article 18 TFEU, which prohibits discrimination on grounds of nationality within the scope of application of the Treaties, and without prejudice to any specific provisions contained therein. ${ }^{42}$ The Court made clear that Article 18 TFEU applied to situations coming within the scope of Union law in which a Member State national suffered discriminatory treatment in relation to nationals of another Member State solely on the basis of his nationality; Article 18 TFEU was not intended to apply to cases of a possible difference in treatment between nationals of Member States and nationals of non-member countries. As a result, Article 18 TFEU is not an obstacle to the differential treatment that the various groups of third-country nationals enjoy under

\footnotetext{
37 S. Peers, 'Towards Equality: Actual and Potential Rights of Third-Country Nationals in the European Union', 33 Common Market Law Review (1996), 7.

T. Tridimas, 'The Court of Justice and Judicial Activism', 21 European Law Review (1996), 199.

39 See former Art. 68(1) EC.

40 S. Peers, 'The Jurisdiction of the Court of Justice Over EC Immigration and Asylum Law: Time For a Change?', in: A. Baldaccini, E. Guild and H. Toner (eds.), Whose Freedom, Security and Justice? EU Immigration and Asylum Law and Policy (Hart Publishing, Oxford 2007), pp. 85-108.

41 See Section 2. of Part IV.

42 Joined Cases C-22 and C-23/08 Vatsouras [2009] ECR I-4585, para. 52.
} 
EU law. ${ }^{43}$ As has been pointed out, the Court's judgment in Vatsouras was criticised in particular on grounds of the fact that the Court did not account for its decision to preclude third-country nationals from the personal scope of Article 18 TFEU.

Scholars have discussed the question as to whether the latter provision covered thirdcountry nationals or not in a very dynamic way. Proponents of the theory that the scope of application of Article 18 TFEU includes EU nationals and non-EU nationals alike rely on a textual interpretation of Article 18 TFEU and emphasise the introduction of Title IV EC under the Treaty of Amsterdam (now Title V TFEU) on the basis of which third-country nationals come now within the scope of the Treaties. Opponents have stressed the fact that Article 18 TFEU is set forth in the section on "Non-Discrimination and Citizenship of the Union" in the Treaty, and that Title IV EC (now Title $V$ TFEU) provides for specific rules for third-country nationals regarding admission and residence. Ignoring the outcome in Vatsouras and assuming that Article 18 TFEU applied to third-country nationals, it has been highlighted that the distinctions made between different groups of third-country nationals made on grounds of nationality could still be justified. In this vein, foreign policy objectives, as well as the national interest to manage migration, allowed for example for differential treatment in entry and visa policy. ${ }^{44}$ Thus, even if third-country nationals fell under the scope of application of Article 18 TFEU, some third-country nationals would be more "more equal" than others but this difference in treatment would be justified. However, from a more normative viewpoint, it is of vital importance that nondiscrimination extends in a more coherent way to third-country nationals when aiming to build a common European migration policy.

Just as the Court of Justice in Luxembourg, the Bundesverwaltungsgericht in Germany took the view that the ratione personae of Article 18 TFEU did not cover third-country nationals in a judgment of 2010.45 The reasoning of the German court raised questions: only two of the arguments aimed to justify differences in treatment among third-country nationals - which was at stake in the legal dispute - whereas the other arguments put forward related to differences in treatment among EU citizens and third-country nationals. The Bundesverwaltungsgericht argued that the differential treatment among third-country nationals was justified because Germany could exercise discretion in granting visa exemptions for certain third-country nationals to build its external relations with third countries. ${ }^{46} \mathrm{Next}$, the Bundesverwaltungsgericht pointed out that Germany was free to determine its trade policies and economic areas with different partners, and that this discretion would be limited if the prohibition of

43 E. Muir, 'Enhancing the Protection of Third-Country Nationals Against Discrimination: Putting EU Anti-Discrimination Law to the 'Test', 18 Maastricht Journal of European and Comparative Law (2011), 136, p. 144. K. Groenendijk, 'Citizens and Third-Country Nationals: Differential Treatment or
Discrimination', in: J.-Y. Carlier and E. Guild (eds.), L'avenir de la libre circulation des personnes dans l'UE (Bruylant, Bruxelles 2006), p. 85; K. Groenendijk refers to R. Cholewinski, 'Borders and Discrimination in the European Union', ILPA/Migration Policy Group (London/Brussels 2002).

45 Urteil des Bundesverwaltungsgerichts of 30 March 2010, BVerwG 1 C 8.09 (VG 35 V 47.08).

46 Urteil des Bundesverwaltungsgerichts of 30 March 2010, BVerwG 1 C 8.09, paras. 5960 . 
nationality discrimination applied generally to third-country nationals. ${ }^{47}$ While these arguments may indeed justify the exemption of certain third-country nationals from language requirements, it was rightly stressed that they were unrelated to the objective of facilitating the integration of migrants into the society of the host Member State. ${ }^{48}$ Since the entry into force of the Treaty of Lisbon another provision was adopted that prohibits discrimination on grounds of nationality: Article 21(2) of the EU Charter. The Bundesverwaltungsgericht opined that Article 21(2) EU Charter and Article 18 TFEU, which are worded almost identically, have the same meaning and provide for the same level of protection against nationality discrimination. ${ }^{49}$ The official explanation of the EU Charter advocates this interpretation specifying that Article 21(2) EU Charter corresponds to Article 18(1) TFEU and must be applied in compliance with that provision. ${ }^{50}$ One may wonder then, however, what the exact added value of Article 21(2) of the EU Charter is. ${ }^{51}$ Importantly, the ECtHR ruled that discrimination based on nationality leading to differential treatment was in accordance with Article 14 ECHR if objectively and reasonably justified. ${ }^{52}$ The ECtHR has ruled that states would have to indicate very weighty reasons before the Court for it to rule that a difference of treatment, based solely on the grounds of nationality, would be compatible with the ECHR. ${ }^{53}$

This dissertation has shown that equality of treatment for third-country nationals under the various sources of EU law is awarded in a manifold, highly selective way. The reason for this "patchwork of rights" are the different sources of law that apply depending on a variety of criteria: the distinct association agreements and cooperation mechanisms apply exclusively to third-country nationals who hold a certain nationality, and equality of treatment is for the most part stipulated in terms of a specific, limited realm, such as equal treatment in working conditions. The EU secondary legislation adopted under Title $V$ TFEU provides for equal treatment in a number of specified areas (as has been analysed) to those third-country nationals to whom the respective legislative instrument applies. In addition, the application of the general principle of non-discrimination on grounds of nationality to third-country nationals has its limits. While the objective of approximating the legal status of (supposedly all) third-country nationals to that of Member States' nationals is far from being achieved, it must be acknowledged that the set of adopted EU secondary legislation has undoubtedly improved the legal situation and protection of all thirdcountry nationals lawfully coming to and/or residing in an EU Member States. The

$47 \quad$ Urteil des Bundesverwaltungsgerichts of 30 March 2010, BVerwG 1 C 8.09, para. 65.

48 K. Groenendijk, 'Are Third-Country Nationals Protected by the Union Law Prohibition of Discrimination on Grounds of Nationality?', in: K. Barwig and R. Dobbelstein (eds.), Den Fremden akzeptieren - Festschrift für Gisbert Brinkmann (Nomos, Baden-Baden 2012), 131, p. 140.

49 Urteil des Bundesverwaltungsgerichts of 30 March 2010, BVerwG 1 C 8.09, para. 63.

50 Explanations Relating to the Charter of Fundamental Rights, OJ C 303, 14 December 2007 , p. 2.

51 K. Groenendijk, 'Are Third-Country Nationals Protected by the Union Law Prohibition of Discrimination on Grounds of Nationality?', in: K. Barwig and R. Dobbelstein (eds.), Den Fremden akzeptieren - Festschrift für Gisbert Brinkmann (Nomos, Baden-Baden 2012), 131, pp. 137-138.

$52 \quad$ C. $v$. Belgium (Application No 21794/93) Judgment of 7 August 1996, paras. 37-38.

53 Gaygusuz v. Austria (Application No 17371/90) Judgment of 16 September 1996, 23 EHRR 364, para. 42. 
Directive on long-term resident status has enhanced the legal position of all thirdcountry nationals who have resided in the EU for at least five years, and the Directive on family reunification allows for the reunion of families in a Member State. The Directives on the admission conditions for researchers and highly skilled workers (EU Blue Card) have created a legal regime for certain categories of third-country nationals that are also applicable irrespective of nationality. In addition, the Directive on a single permit and on a common set of rights for third-country workers has facilitated the admission procedures of third-country nationals who wish to reside and work in the EU by introducing a permit that combines work and residence authorisations. The adoption of this EU secondary legislation, which does not discriminate on the basis of nationality, is to be welcomed. However, these instruments set out the "lowest common denominator", and thus they do not strive to meet the objective of adapting the position of third-country nationals to that of nationals of the Member States. ${ }^{54}$

\section{RECOMMENDATIONS AND OUTLOOK}

On the basis of the final conclusions, I would like to make a number of policy recommendations to improve EU migration law and policy as it stands today.

\section{1) Build an EU Migration Policy that Promotes an Inclusive Union}

This dissertation has argued that a common EU migration policy, which applies to all third-country nationals on equal terms, is not in place today and may - as an objective to be achieved - even be considered as utopian when taking into account the existing different legal migration regimes for certain groups of third-country nationals. The highly fragmented approach that the EU migration law acquis reflects could, however, be transformed into a common migration regime with improved equality of treatment of all third-country nationals (see next recommendation). Thirdcountry nationals who make up about $4 \%$ of the total population residing in the EU should feel welcomed and the Union should be inclusive. It is up to the national and supranational policy makers to put in place the required policies and a legal framework, which is not based on a "lowest common denominator" thinking.

\section{2) Improve Equality of Treatment for All Third-Country Nationals}

There is no doubt that equality of treatment is of vital importance for a European migration policy that acknowledges migrant communities - in equal measure - as a culturally, economically and socially enriching group of individuals for the host Member States and that facilitates their integration into the host society. Is it really inconceivable to extend equality of treatment in a more coherent way to all thirdcountry nationals? P. Boeles has suggested an immigration policy in which exceptions to equal treatment of third-country nationals would have to be based on residence rule which applied prior to the entry into force of the Treaty of Lisbon, see S. Peers, 'An EU Immigration Code: Towards a Common Immigration Policy', 14 European Journal of Migration and Law (2012), 33-61, p. 36. 
status and not nationality. ${ }^{55}$ Under his model, measures concerning immigration law, which affect the nationals of other Member States or third-country nationals, and which cannot be taken vis-à-vis own nationals, are only justified provided that they are suitable and proportionate. It has been pointed out that such a model, which effectively disregards nationality, is an interesting theory, which is, however, not suitable for Realpolitik. Nevertheless, certain elements of this theory could be used: for instance, in view of entry rights nationality could remain the decisive criterion for short- (EU visa black and white list) and long-term stays (Member State's competence). However, the length of legal residence could become the decisive factor for the scope of rights that immigrants enjoy in the host country after having resided a certain period in that country. This system is reflected in Council Directive 2003/109/EC on the status of third-country nationals who are long-term residents. ${ }^{56}$ While it has rightly been pointed out that "[T]he Long-Term Residents Directive forms part of a cautious legislative approach adopted by the Community in relation to EU immigration policy", the former piece of legislation nonetheless lays the foundation for a policy that is not connected to the nationality of an individual. ${ }^{57}$ Thus, it is conceivable that, under a truly common European immigration regime, residence could replace nationality as the key criterion in the determination of rights of non-nationals in the future. ${ }^{58}$

\section{3) Increase Transparency and Raise Awareness}

A first step to tackle the current, fragmented state of play in EU migration policy would be to improve the transparency of the complex structures that shape the EU migration law acquis. The secondary EU legislation adopted under Title $\mathrm{V}$ of the Treaty of Lisbon is often represented as a foundation for a common immigration policy neglecting the various association, cooperation and partnership agreements that also have legal implications for certain groups of third-country nationals. Moreover, policy makers should raise awareness of the EU migration law acquis for civil society with a special focus on (potential) migrants. In this regard it is also to be welcomed that the EU launched the so-called EU Immigration Portal in November of $2011 .{ }^{59}$ The EU Immigration Portal is an online initiative that provides up-to-date, hands-on information for foreign nationals interested in moving to the EU, as well as for migrants who are already established in the EU and wish to move to another Member State. Depending on the status of the individual concerned, the Portal details EU and national visa and immigration rules and procedures applicable in the

55 P. Boeles, 'Europese burgers en derdelanders: wat betekent het verbod van discriminatie naar nationaliteit sinds Amsterdam?', 12 Sociaal-Economische Wetgeving (2005), 500.

56 Council Directive 2003/109/EC of 25 November 2003 concerning the status of thirdcountry nationals who are long-term residents.

57 S. Boelaert-Suominen, 'Non-EU Nationals and the Council Directive 2003/109/EC on the Status of Third-Country Nationals who are Long-Term Residents: Five Paces Forward and Possibly Three Paces Back', 42 Common Market Law Review (2005), 1011, p. 1049.

58 See in this regard K. Groenendijk, 'Citizens and Third-Country Nationals: Differential Treatment or Discrimination', in: J.-Y. Carlier and E. Guild (eds.), L'avenir de la libre circulation des personnes dans l'UE (Bruylant, Bruxelles 2006), p. 100.

59 EU Immigration Portal, see website: <http://ec.europa.eu/immigration/>, last accessed on 17 July 2012. 
Member State of destination in addition to the rights upon which they can rely there. Next to setting out the legal migration opportunities, the Portal clarifies the risks of migrating to the EU without proper documentation, including smuggling and trafficking in human beings. ${ }^{60}$ The Portal does not, however, specify rights of migrants, which they enjoy on the basis of their nationality. While the Portal provides for a link to the decisions of the Court of Justice it is clear that a person who has no EU law background will face difficulties in reading and understanding the relevant judgments handed down by the Court. Moreover, the adoption of an EU immigration code could contribute to making EU immigration legislation more transparent. The Commission envisages making a proposal on such a code in 2013; however, the idea actually dates back to the 2009 Stockholm Programme. ${ }^{61}$ While the code formed part of the draft Stockholm Programme of 16 October 2009, the final version does not contain a reference to an immigration code. ${ }^{62}$

\section{4) Introduce an Amended and Comprehensive EU Immigration Code}

Policy makers should consider introducing an amended and comprehensive EU immigration code based on the existing acquis communautaire. Such an immigration code could serve as a legal basis to consolidate and improve immigration legislation, and enhance coherence. It has been emphasised that such an immigration code would provide for a simplified and fairer set of standard procedural rules, clearer rules on labour migration, amended rules on researchers and students, and improved rules on family reunification and on long-term residence. ${ }^{63} \mathrm{In}$ fact, the EU is obliged to develop a common immigration policy under Article 79(1) TFEU, which implies that an immigration code must enhance the degree of harmonisation in comparison to the current rules. ${ }^{64}$ Such a higher level of harmonisation could consist of broadening the personal scope of EU law; involve a greater intensity of harmonisation; and set higher standards for the persons concerned. ${ }^{65}$ Subsequently, an immigration code would enhance protection of third-country nationals but again would apply without prejudice to more favourable rules of bi- or multilateral agreements. ${ }^{66}$ Policy makers could also consider incorporating an overview of such more favourable rules. An immigration code would in addition provide added value in that it would practically combine all legislative instruments in one document and

60

See Europa, press release "Moving to the EU? Good advice is now just a few clicks away", IP/11/1370, 18 November 2011.

The Stockholm Programme - An Open and Secure Europe Serving and Protecting Citizens, OJ C 115, 4 May 2010, p. 1; see also Council of the European Union, "European Council 10/11 December 2009 Conclusions", document number: EUCO 6/09 of 11 December 2009.

2 Council of the European Union, "Multiannual Programme for an Area of Freedom, Security and Justice serving the Citizen (The Stockholm Programme)", document number: 14449/09 of 16 October 2009.

S. Peers, 'Statewatch Analysis - A Proposal for an EU Immigration Code', see $<$ http://www.statewatch.org/analyses/no-167-immigration-code-steve-peers.pdf>, last accessed on 17 July 2012, pp. 4-5.

S. Peers, 'An EU Immigration Code: Towards a Common Immigration Policy', 14 European Journal of Migration and Law (2012), 33-61, p. 36.

Ibid.

See Art. 4 of the draft EU immigration code on the relationship with national and international law. 
ideally present the immigration rules in a comprehensible way to (potential) migrants. This, in turn, would increase legal certainty.

\title{
5) Strengthen the Rights-Based Approach for Migrants
}

To achieve the Tampere objectives, and especially to attain the approximation of rights of third-country nationals to that of Member States, the EU migration policy should be pursued on the basis of a rights-based approach that places migrants and family members at the centre of attention. This is not an easy task considering that the various existing frameworks have emerged gradually and they are country- or region-specific framed in accordance with the EU's and the Member States' foreign policy aims. Importantly, on the initiative of the Commission, an overarching policy has been formulated: the renewed GAMM of 2011 takes the afore-mentioned concerns - the protection of the migrants' human rights and the focus on the individual - into account, which is to be assessed as a positive sign. The four pillars of the GAMM cover legal economic migration, irregular migration, and migration and development, international protection and asylum; the Commission has considered these pillars as equally important. ${ }^{67}$ Again, an EU immigration code could remedy the situation and enshrine the human rights dimension in a legally binding document.

\section{6) Promote Migration as a Positive Phenomenon from which Societies Benefit}

The viewpoint that the four pillars of the GAMM are equally important has been contested: Charles Clarke, former UK Home Secretary, has suggested a different ordering. In his opinion the second pillar on preventing and reducing irregular migration and trafficking in human beings is more important than the remaining three pillars, because

\begin{abstract}
"it is the area which gives rise $[\ldots]$ to the greatest doubts and uncertainties in the population about where we stand. Remember, many people in the population see the EU as a threat on this migration question, rather than the potential solution in these areas. The idea of the pillars is good but, as I said a moment ago, I do not think it is sufficiently prioritised and I think the prevention and reduction of irregular migration, the second pillar, needs to go up right the agenda." ${ }^{\prime} 8$
\end{abstract}

This statement echoes the thinking of a (former) national policymaker from a country that holds a derogatory position as regards EU migration law but it bluntly unveils the sentiments the British, and arguably other European nations, associate with immigrants. Ignorance provides breeding ground for prejudices, mistrust and fear towards immigrant communities and the migration phenomenon in general, culminating in some cases tragically in xenophobic and racist attitudes. Times of economic downturns and hardship usually exacerbate such developments as rightwing and anti-immigrant propaganda becomes more popular. In particular during elections, migration is a hot-button issue that tends to be polarised and instrumentalised by political parties to bid for votes; this could be observed in a

67 European Commission Communication, $\operatorname{COM}(2011)$ 743, 18 November 2011, p. 7.

68 House of the Lords - The Select Committee on the European Union, Inquiry on EU's Global Approach on Migration and Mobility, Evidence Session No. 5, 18 July 2012. 
number of EU Member States during the global financial and economic crisis that has hit the EU hard. Governments and parliaments - national and European policymakers alike - should take action, raise awareness and enlighten their populations on migration issues in a matter-of-fact and evidence-based fashion. Civil society, international and non-governmental organisation but also the private sector plays a crucial role in this undertaking. In this sense, the EU's GAMM is certainly a step into the right direction, and the Commission has to be given credit for the public consultation it launched between April and June 2012 calling upon citizens, organisations and public authorities to contribute to the Commission Communication on the Global Approach to Migration. ${ }^{69}$ Within the scope of the Europe 2020 Strategy that set out the Union's ten-year growth strategy, migration and mobility envisage to contribute to the EU's economic vitality and competitiveness. The demographic change Europe is facing requires an adaptable workforce equipped with the necessary skills to respond to the labour market demands, in this context a "demand-driven" legal immigration policy is under discussion. $^{70}$

\section{7) Reinforce the Institutional Framework Dealing with Migration Issues}

An enhanced cooperation on the institutional level would facilitate the organisation of regular dialogues and information exchange on how to manage international migration better between key organisations and stakeholders. While the Global Migration Group, the Global Forum on Migration and Development, as well as the High-Level Dialogue on International Migration and Development, provide platforms in this regard, a strategic partnership has been launched for EU migration issues in July 2012. The IOM, the Commission and the EEAS have agreed to strengthen collaboration with regard to migration, development, humanitarian and human rights issues. ${ }^{71}$ The primary aims of the partnership are to promote and consolidate cooperation between IOM and the Commission services (DG HOME, DG DEVCO/EuropeAid and DG ECHO) and the EEAS concerning their respective policies, legislative and operational initiatives, research and data, lessons learned and best practices. It is much to be hoped that this strategic partnership is effectively put into practice and used for fruitful policy discussions on how to better manage migration.

\section{8) Encourage the Ratification of the UN Migrant Worker Convention}

The UN Migrant Worker Convention has created a comprehensive, international legal framework for the protection of migrant workers and their family members but regrettably to date not a lot of states have ratified this convention. In particular, the EU Member States should be encouraged to adhere to this legal framework to increase the number of ratifications of wealthier, industrialised countries in the world,

69 See website of DG HOME of the European Commission on the public consultation of the Global Approach to Migration: < http://ec.europa.eu/dgs/home-affairs/what-isnew/public-consultation/2011/consulting_0021_en.htm>, last accessed on 29 July 2012.

70 European Commission Communication, $\operatorname{COM}(2011)$ 743, 18 November 2011, p. 4.

$71 \quad$ IOM Press Briefing Note, "IOM, European Commission and European External Action Service Strengthen Partnership” of 16 July 2012. 
and thereby contribute to promote a more secure legal position of migrant workers and their family members. 

Part IX : Schematic Overview of the Legal Position of Third-Country Nationals

This Part IX reproduces the findings made with regard to the legal position of thirdcountry nationals of Parts V to VII in charts. This visualisation by means of charts helps to understand the differences in treatment of non-EU nationals in a more tangible and comprehensive way and renders a direct comparison possible. The Charts follow the approach of Parts V to VII in that they are focus on entry, employment and residence rights; social security rights; and other economic and social rights. 


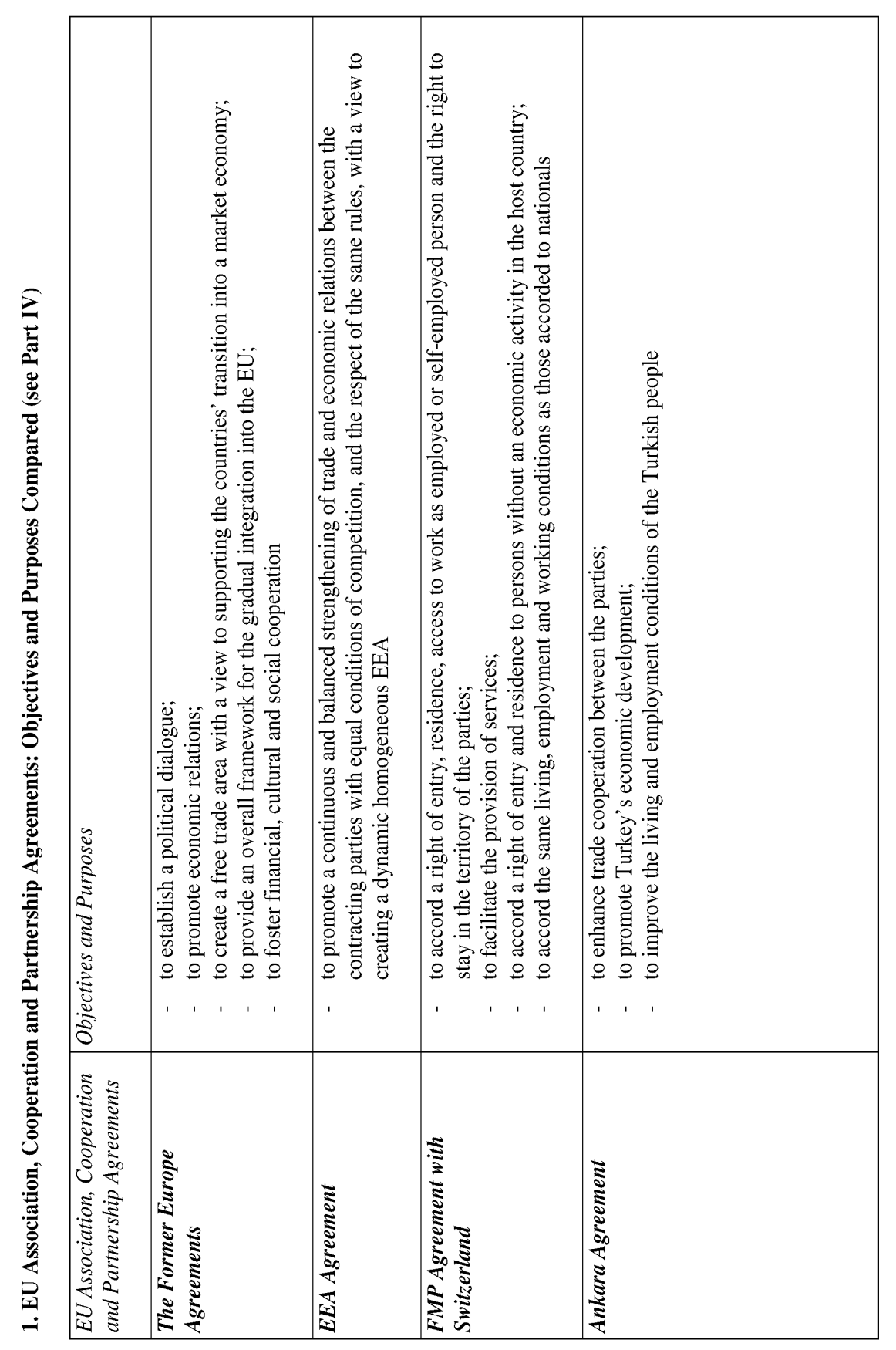




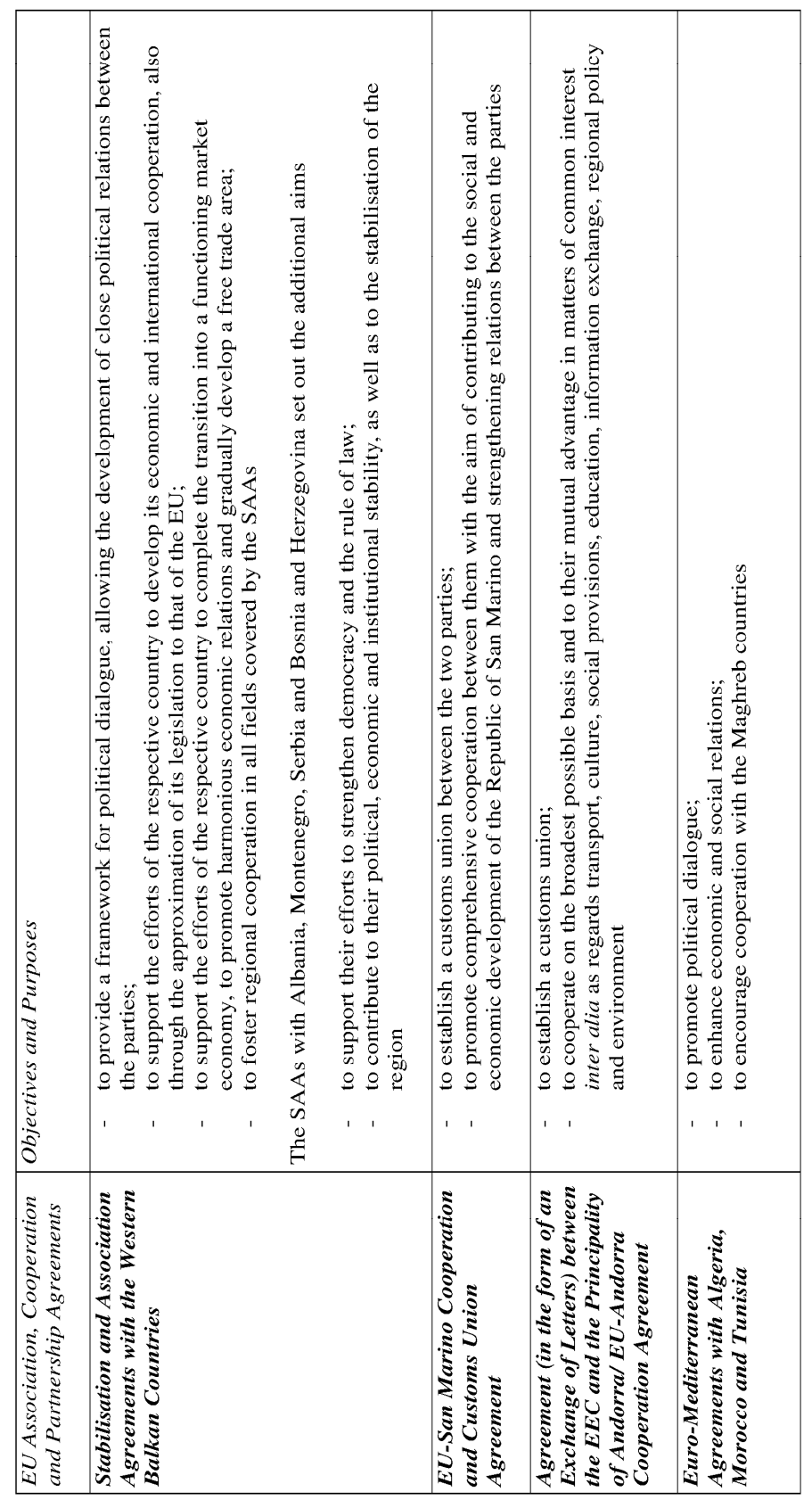




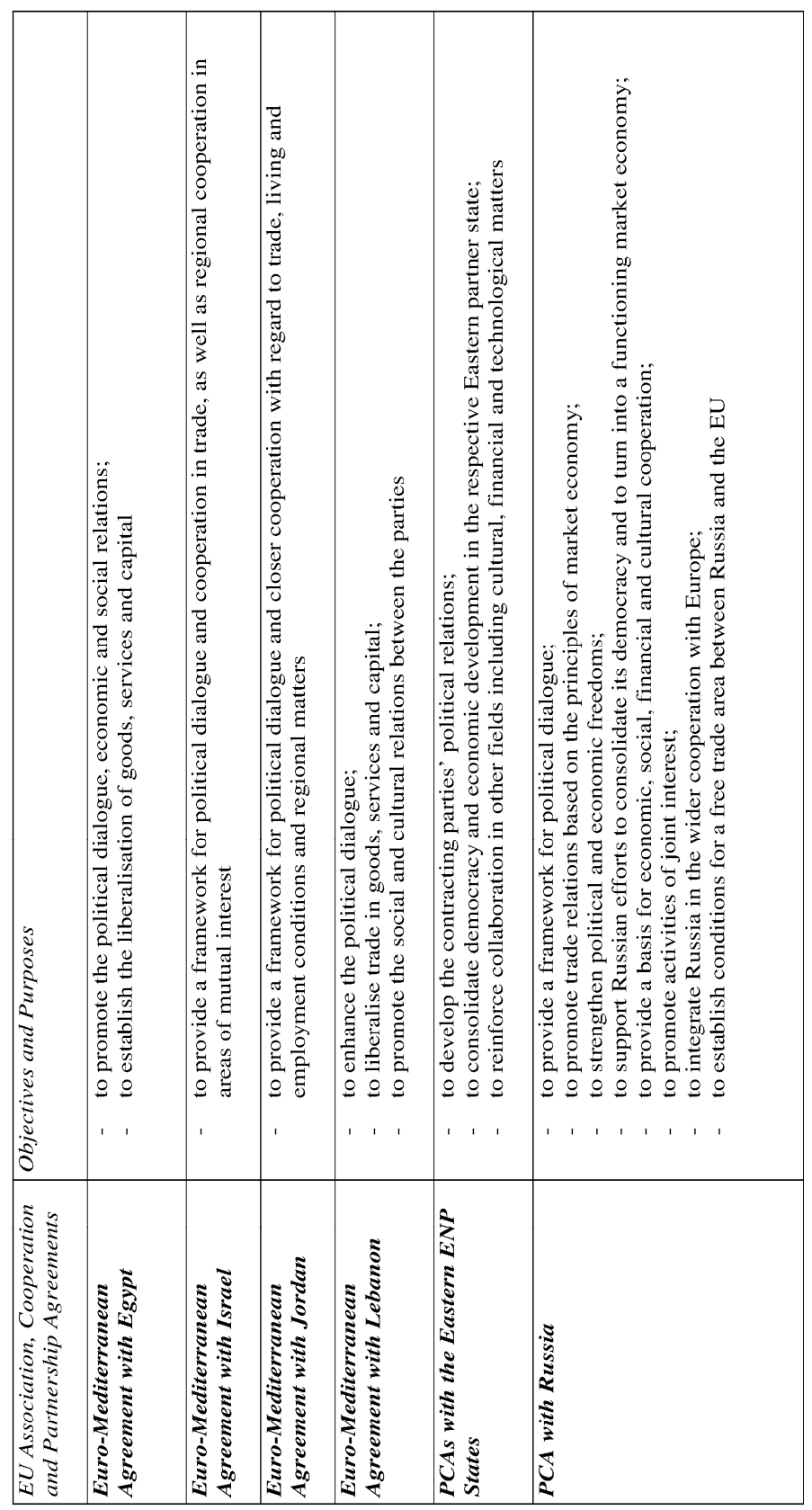




\begin{tabular}{|c|c|c|c|c|c|c|}
\hline $\begin{array}{l}0 \\
\\
\\
\end{array}$ & 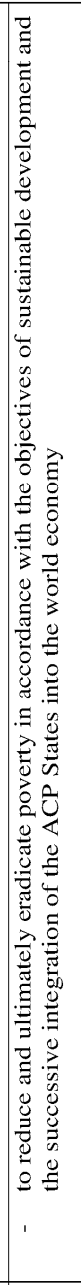 & 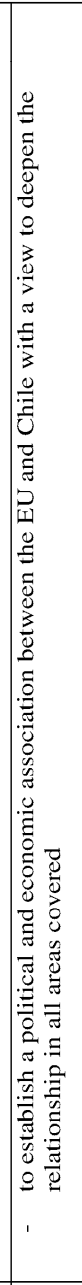 & 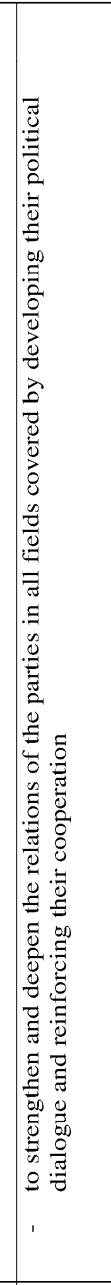 & 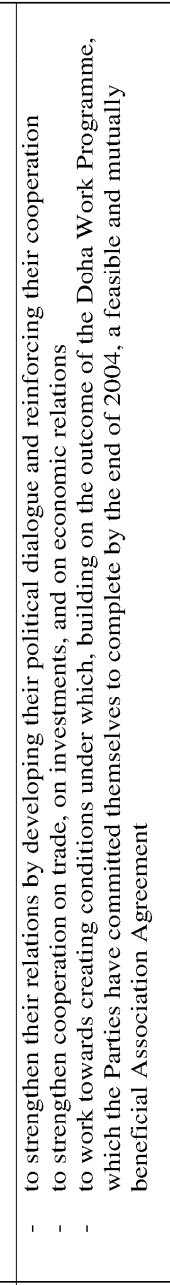 & 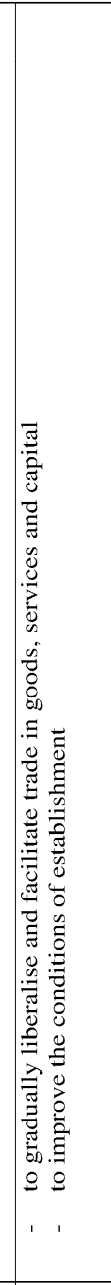 & 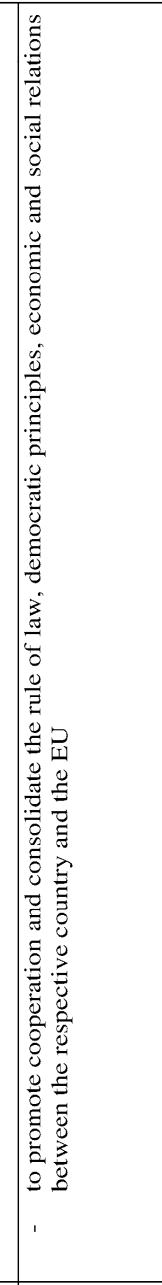 \\
\hline 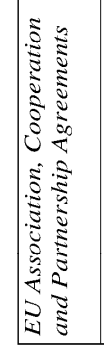 & 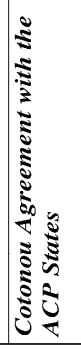 & 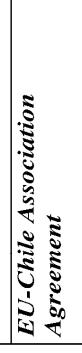 & 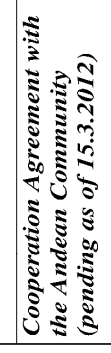 & 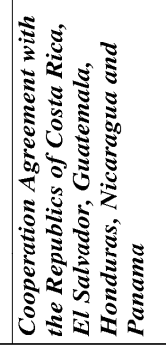 & 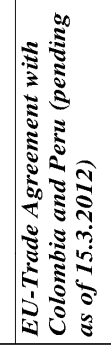 & 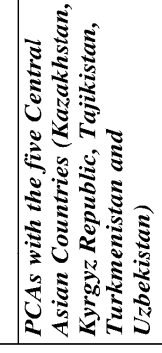 \\
\hline
\end{tabular}




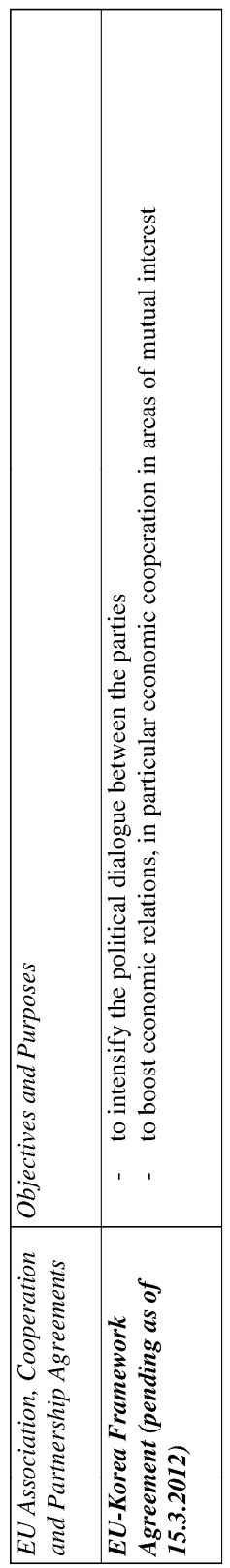




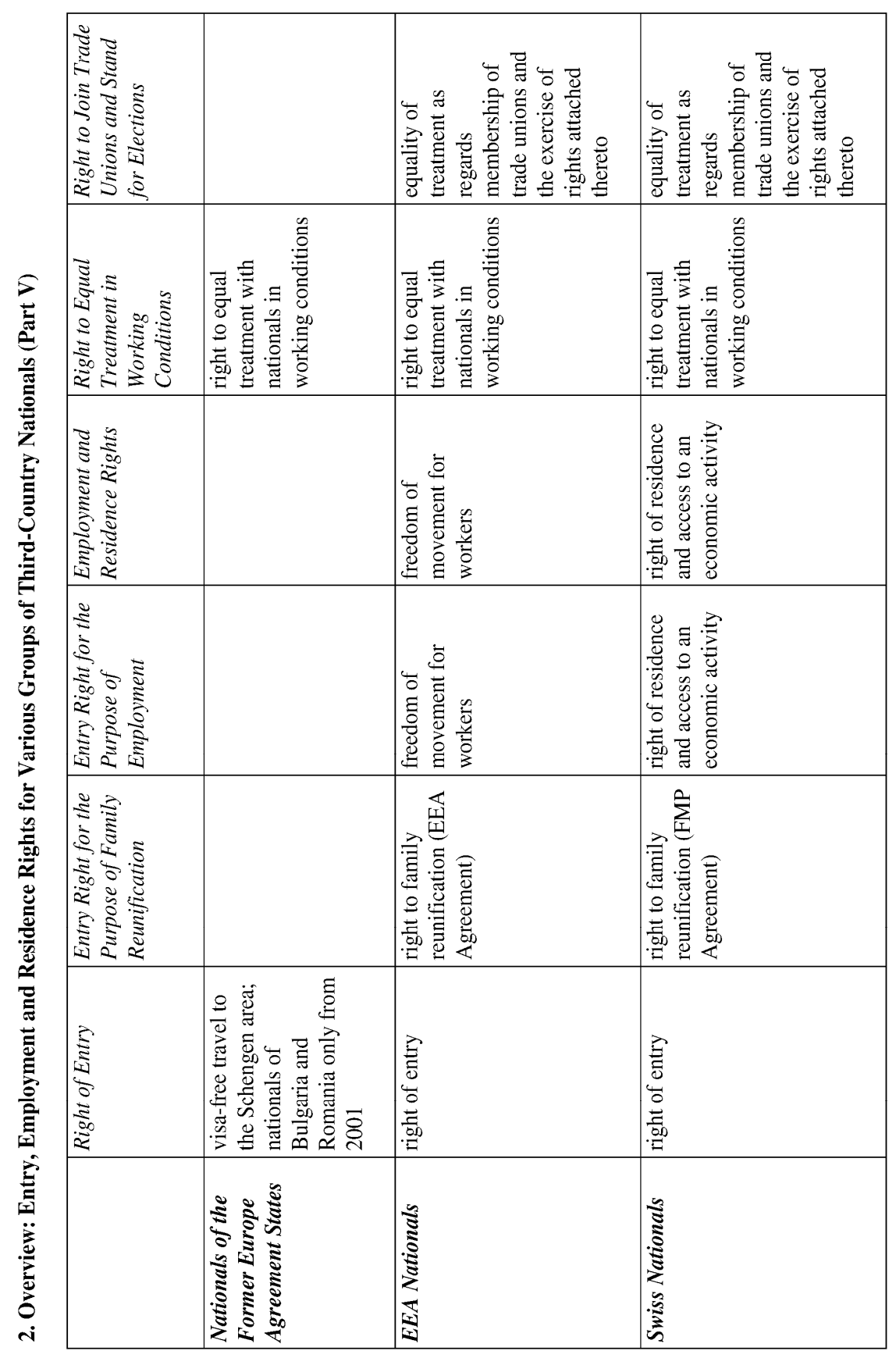




\begin{tabular}{|c|c|c|}
\hline 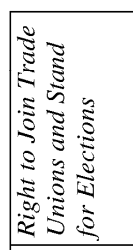 & 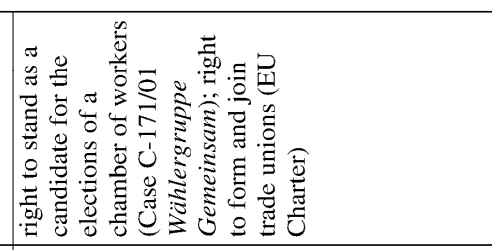 & 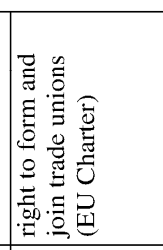 \\
\hline 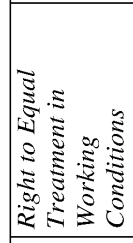 & 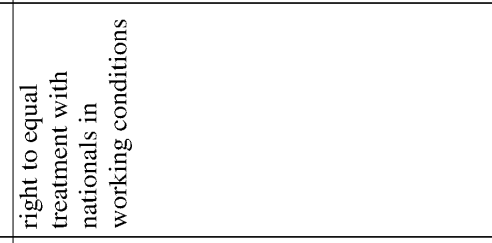 & 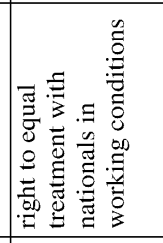 \\
\hline 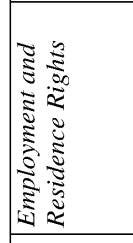 & 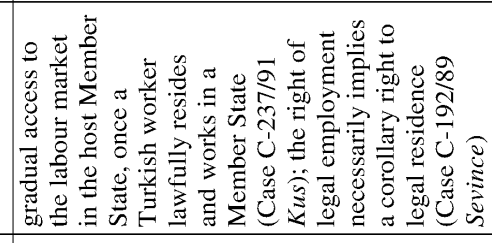 & 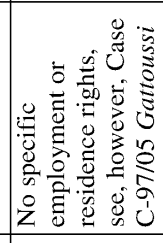 \\
\hline 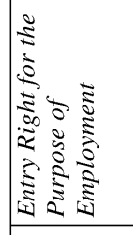 & & \\
\hline 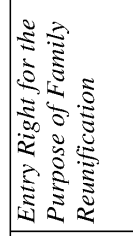 & 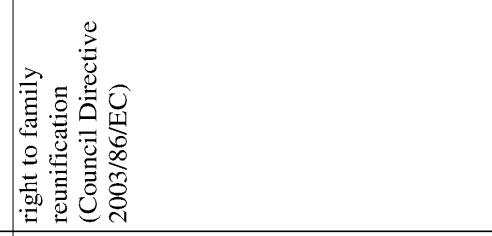 & 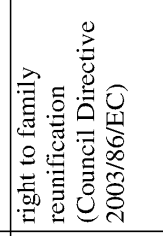 \\
\hline 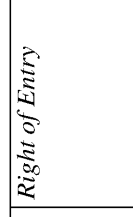 & 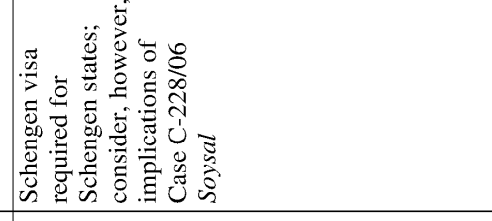 & 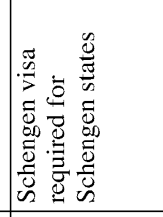 \\
\hline & 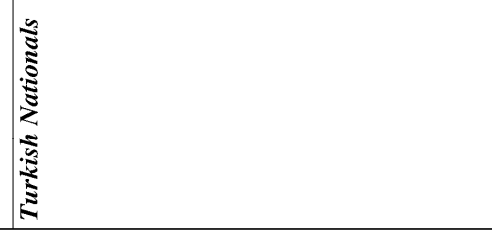 & 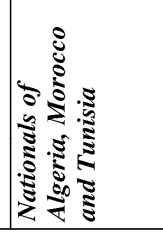 \\
\hline
\end{tabular}




\begin{tabular}{|c|c|c|c|c|}
\hline 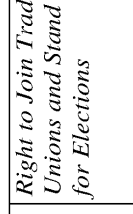 & 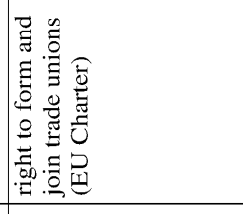 & 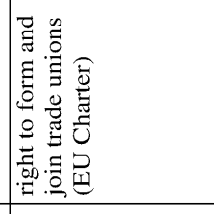 & 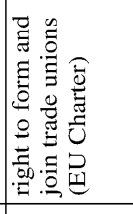 & 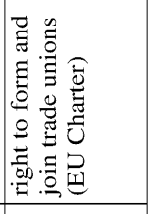 \\
\hline 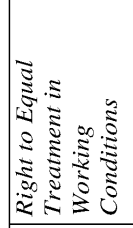 & 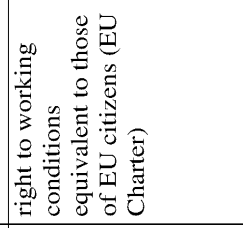 & 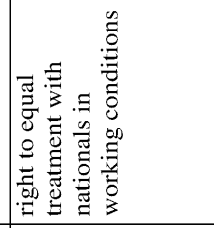 & 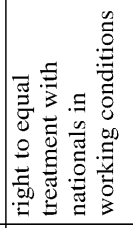 & 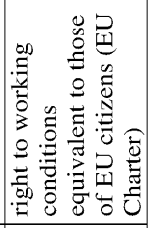 \\
\hline 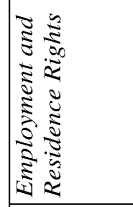 & & & & \\
\hline 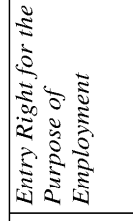 & & & & \\
\hline 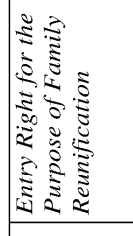 & 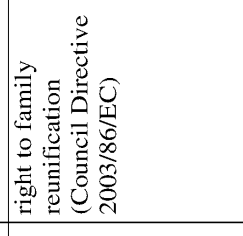 & 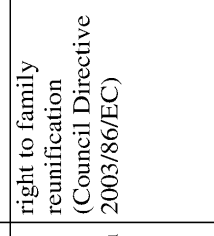 & 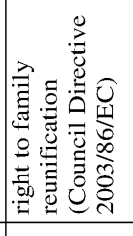 & 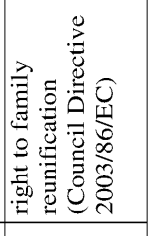 \\
\hline$\overbrace{\bar{\Sigma}}$ & 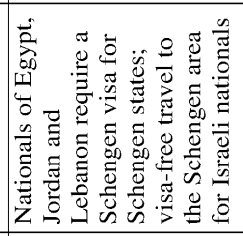 & 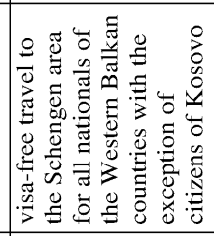 & 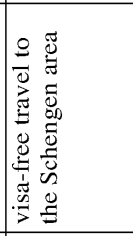 & 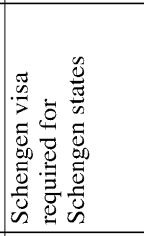 \\
\hline & 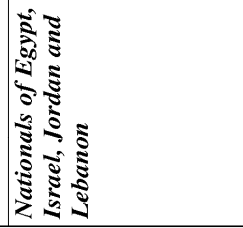 & 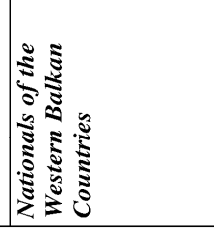 & 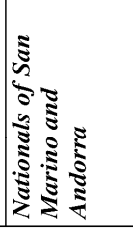 & 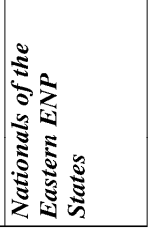 \\
\hline
\end{tabular}




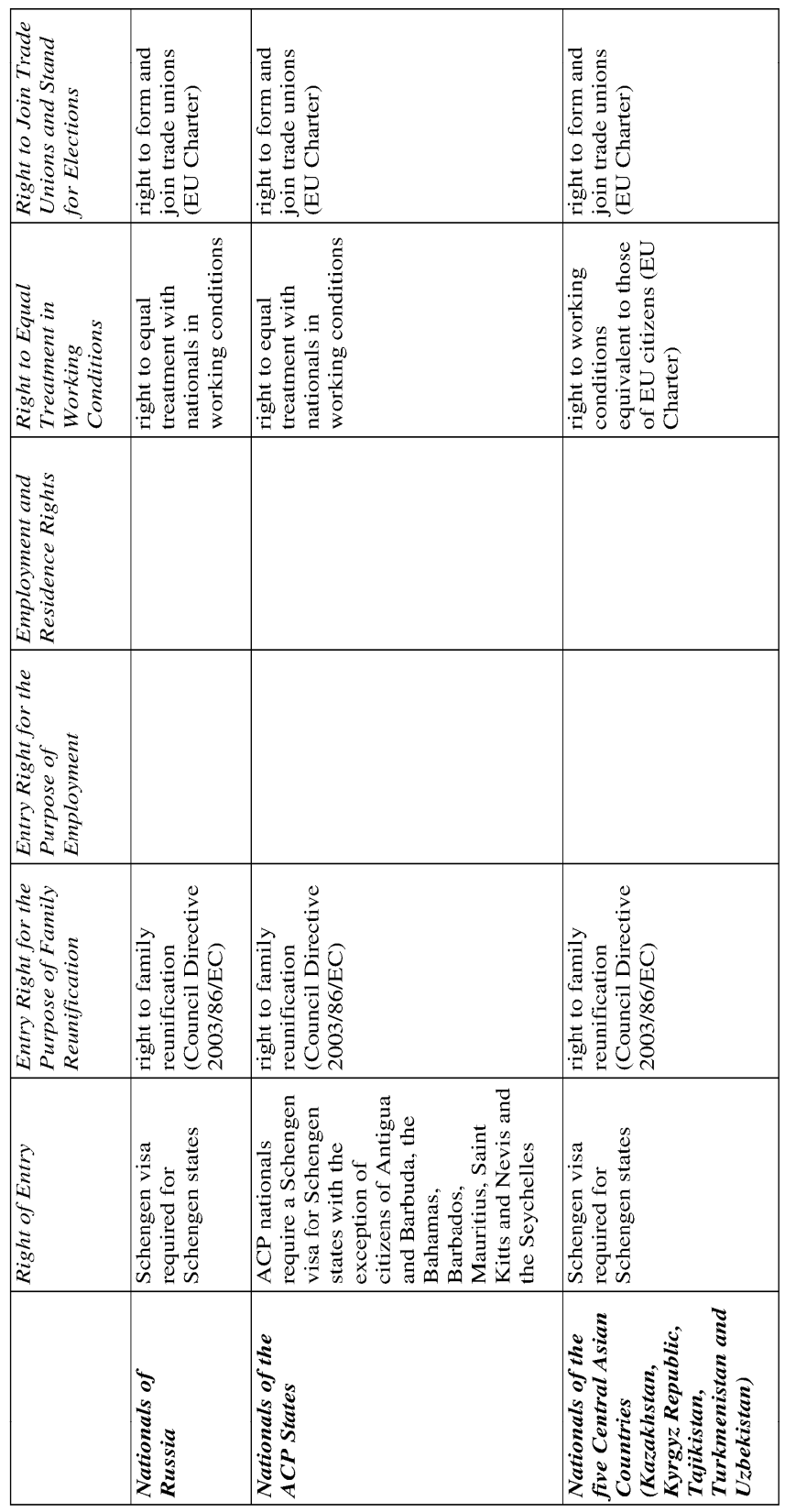




\begin{tabular}{|c|c|}
\hline 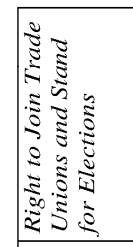 & 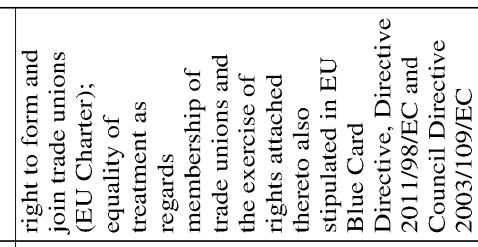 \\
\hline 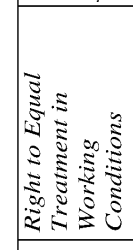 & 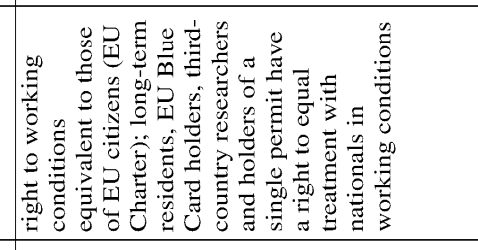 \\
\hline 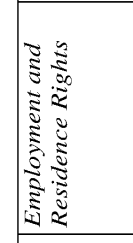 & 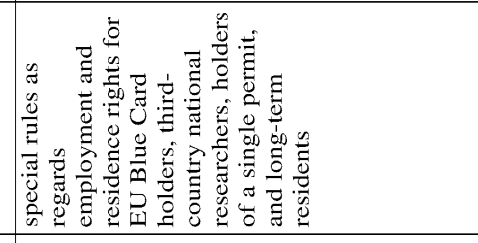 \\
\hline 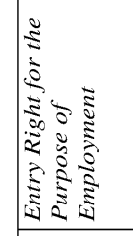 & 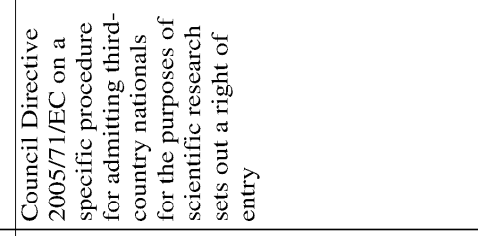 \\
\hline 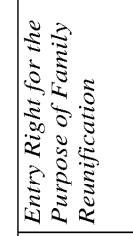 & 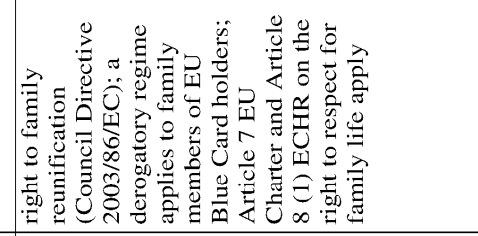 \\
\hline & 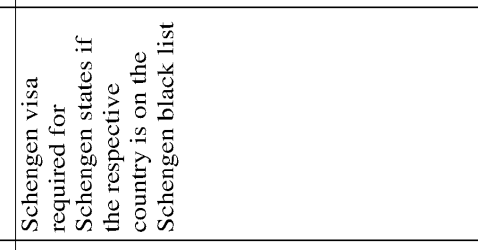 \\
\hline & 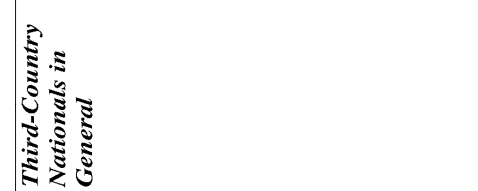 \\
\hline
\end{tabular}




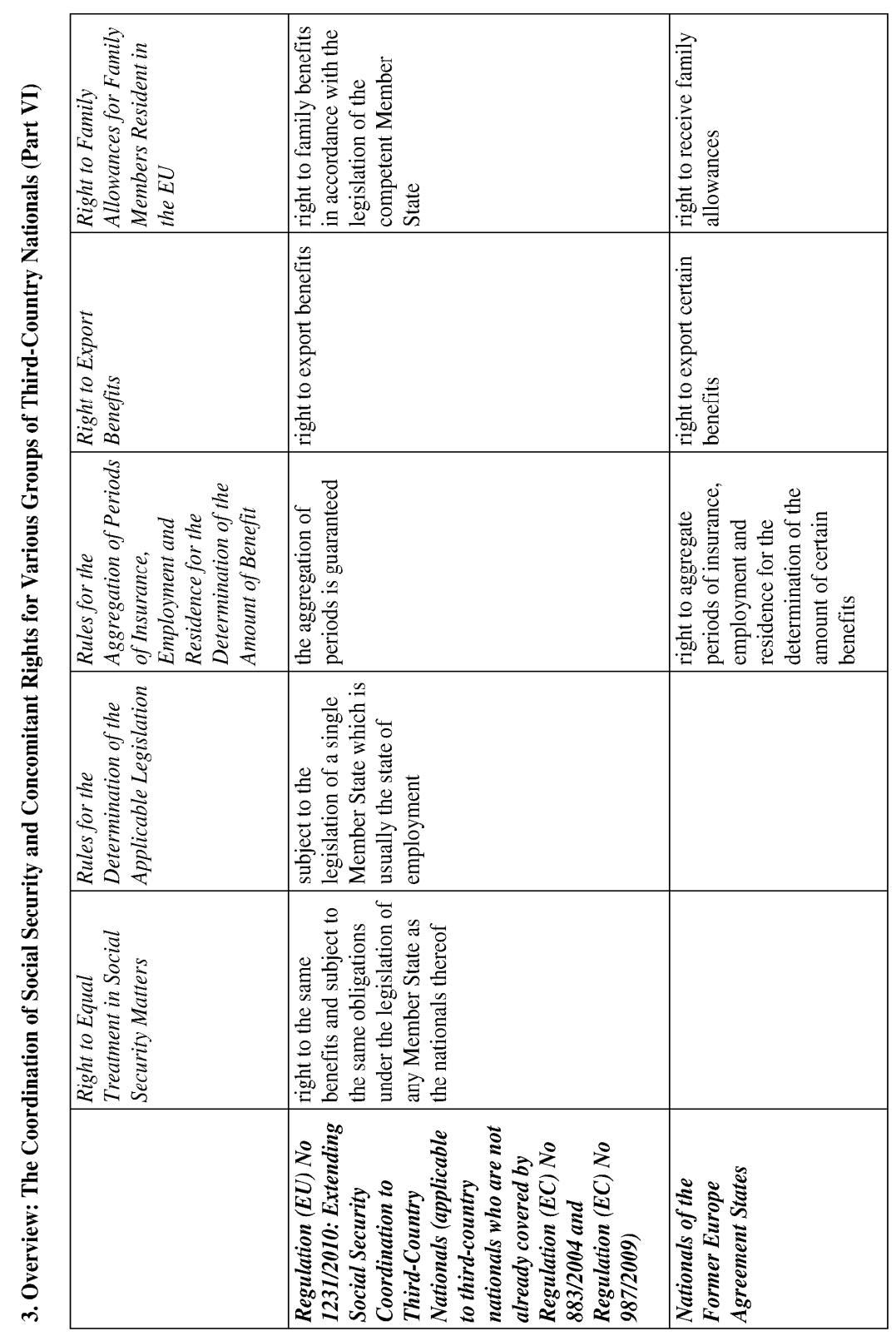




\begin{tabular}{|c|c|c|}
\hline 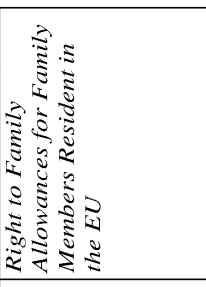 & 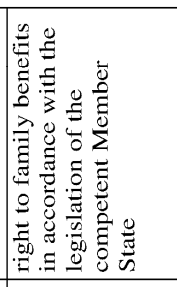 & 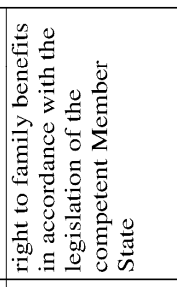 \\
\hline 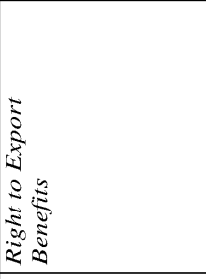 & 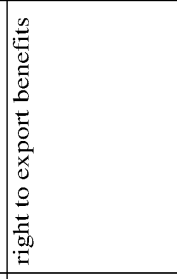 & 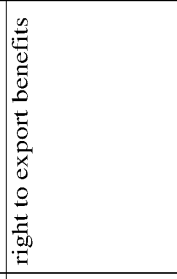 \\
\hline 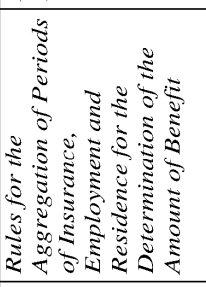 & 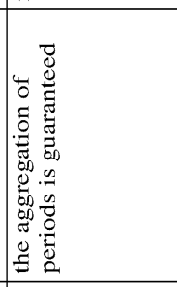 & 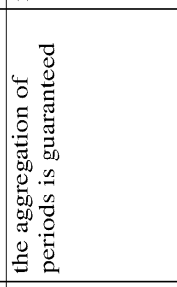 \\
\hline 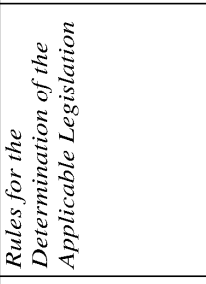 & 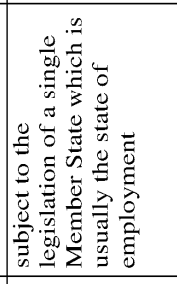 & 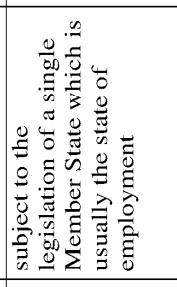 \\
\hline 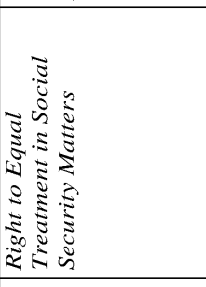 & 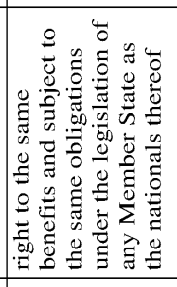 & 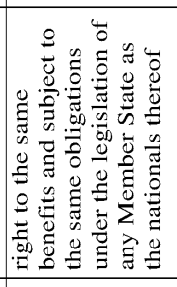 \\
\hline & 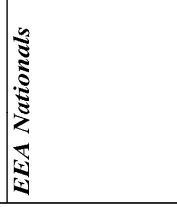 & 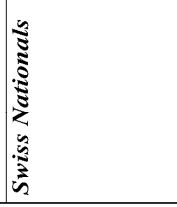 \\
\hline
\end{tabular}




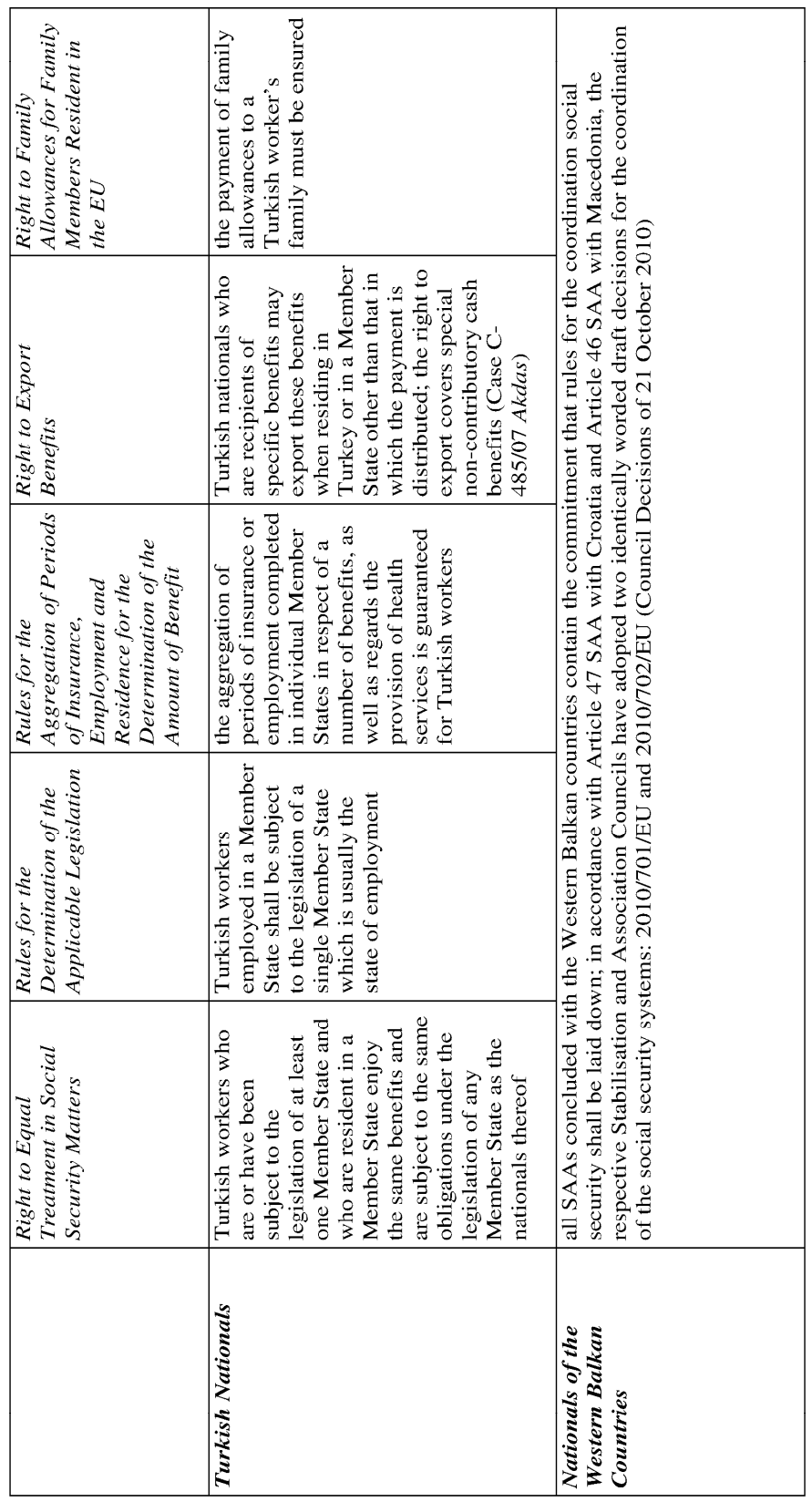




\begin{tabular}{|c|c|}
\hline 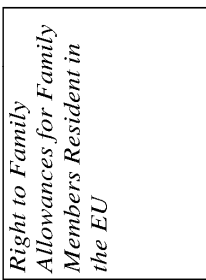 & 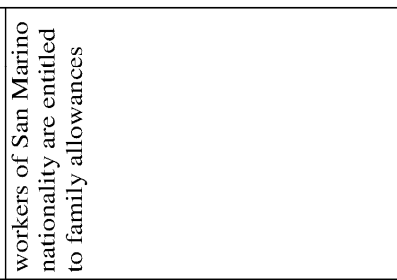 \\
\hline 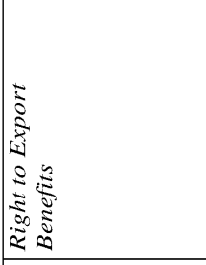 & 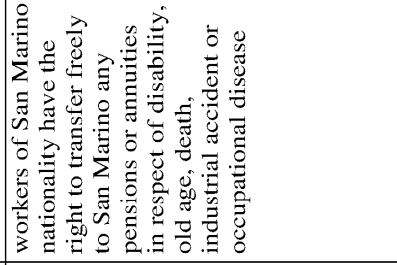 \\
\hline 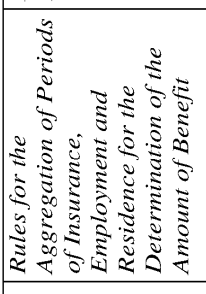 & 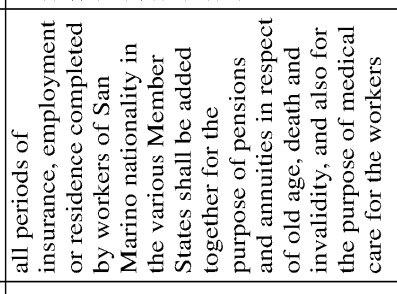 \\
\hline 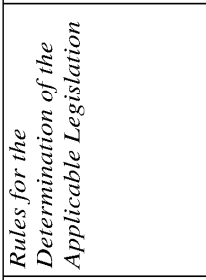 & \\
\hline 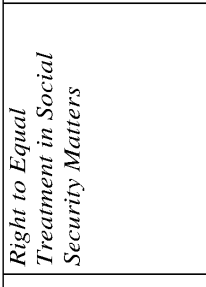 & 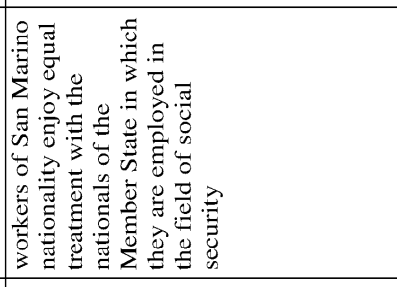 \\
\hline & 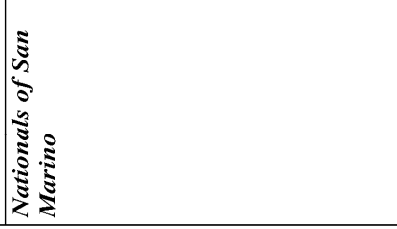 \\
\hline
\end{tabular}




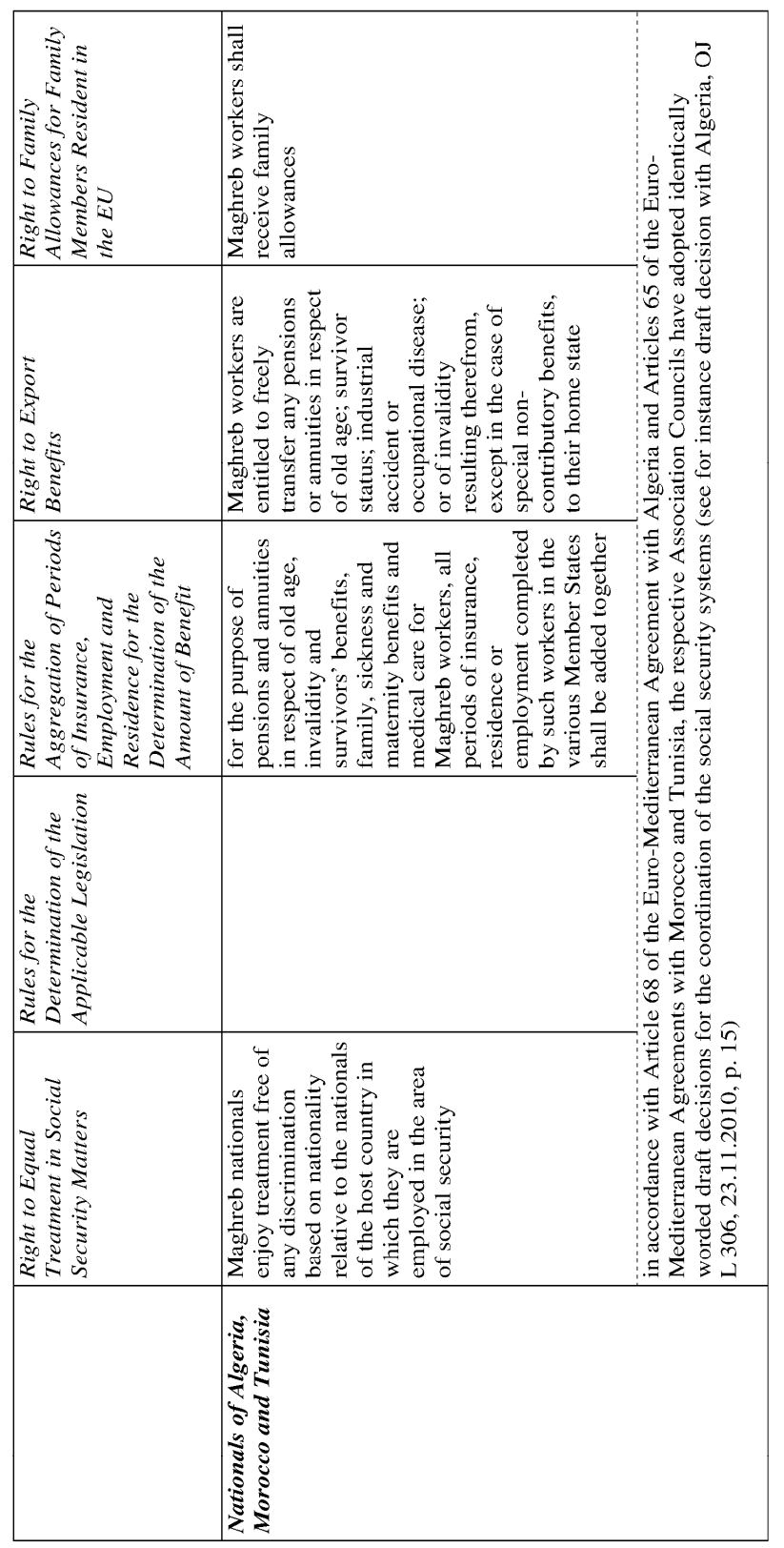




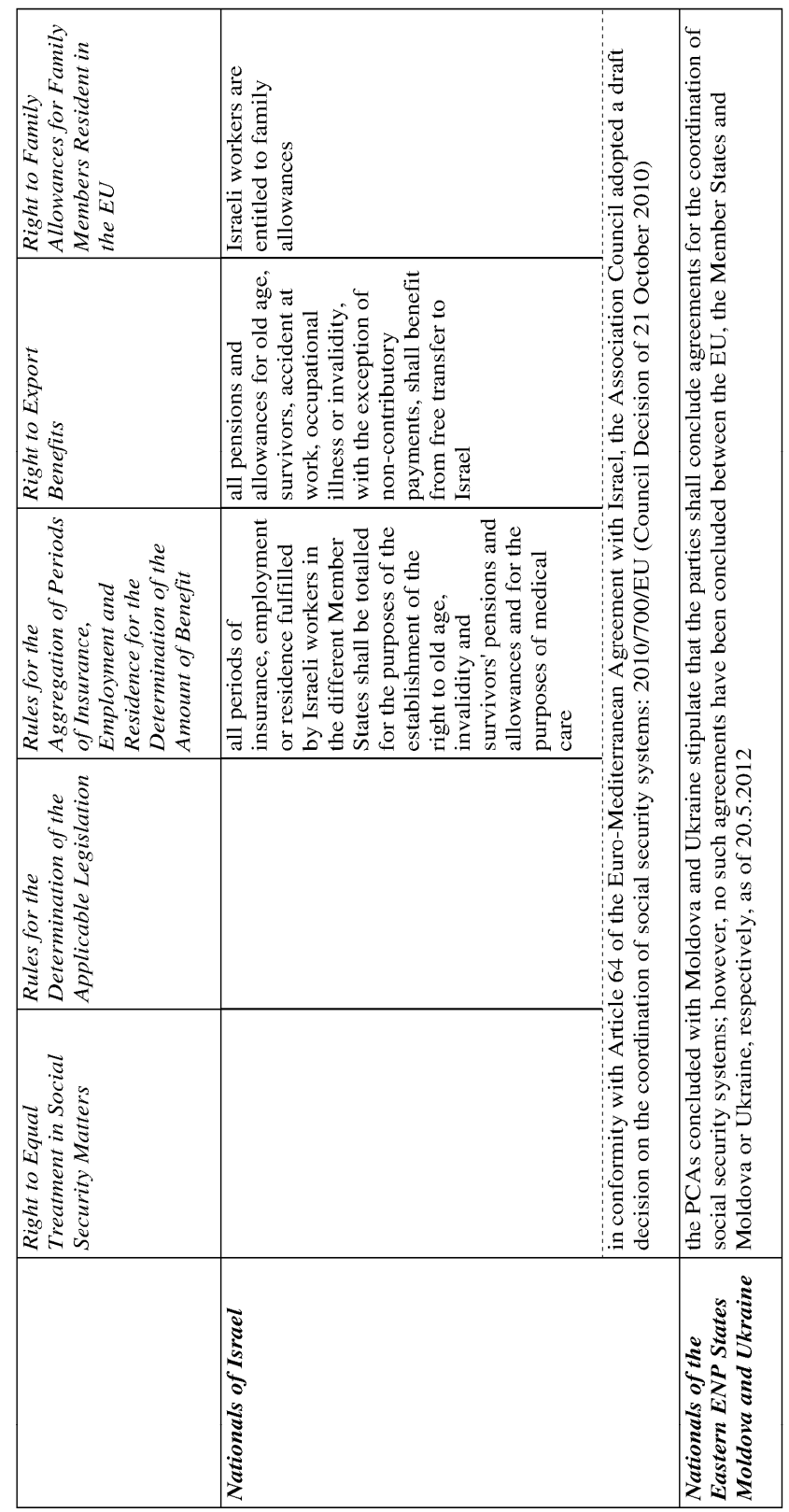


The External Dimension OF THE EU's Migration POLICY

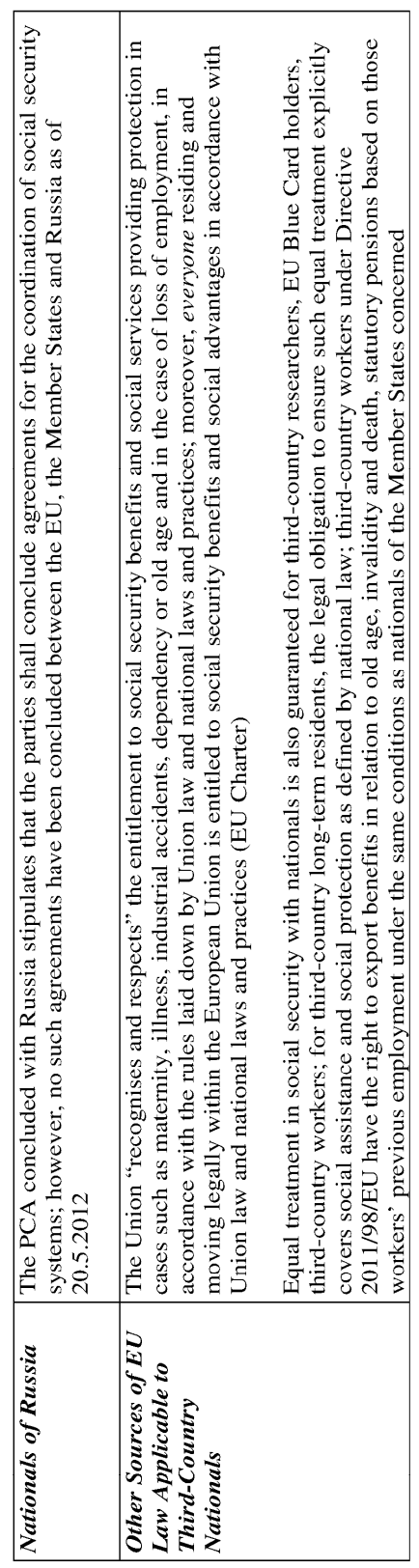




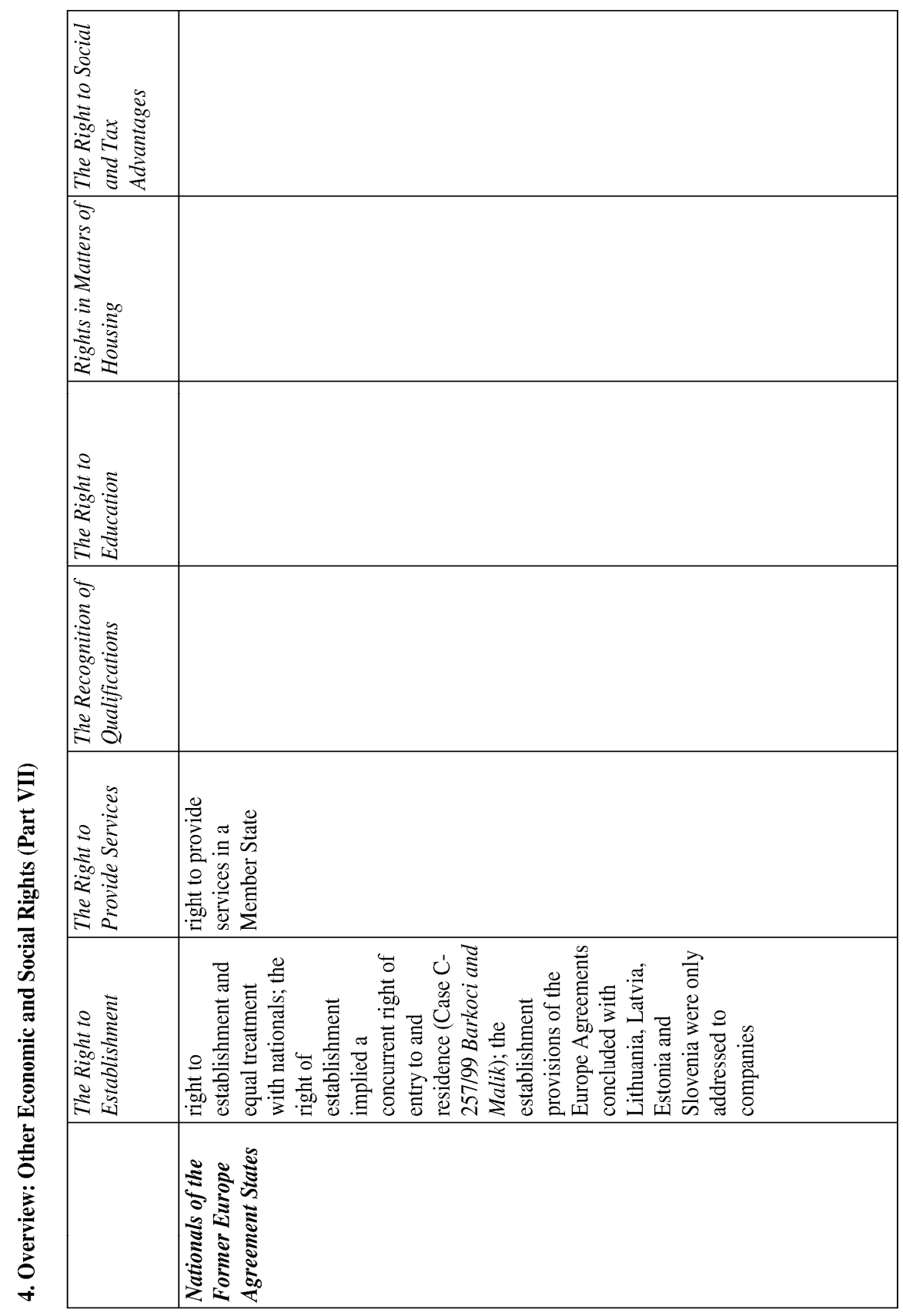




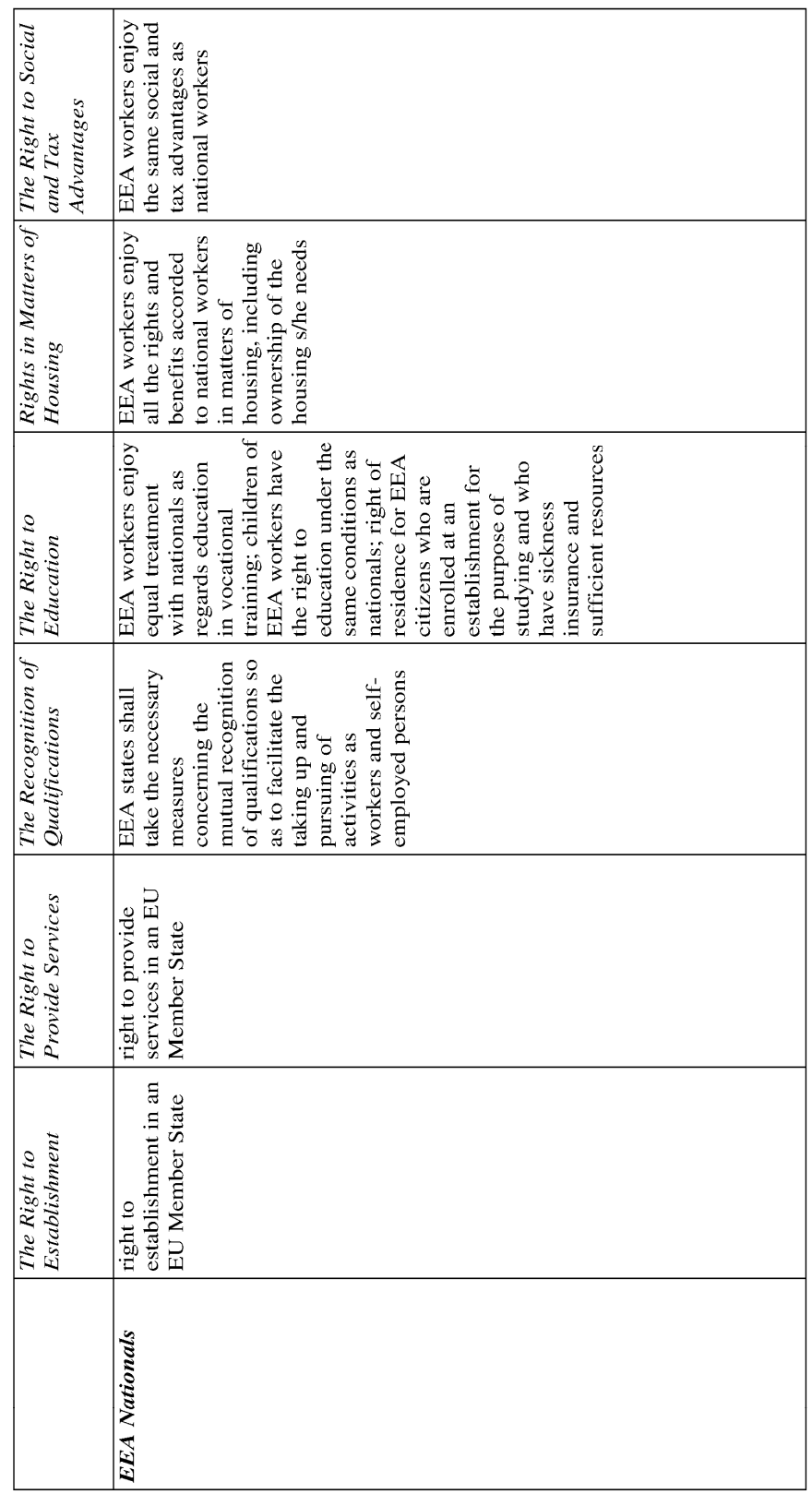




\begin{tabular}{|c|c|}
\hline 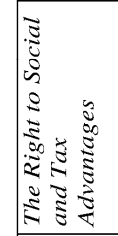 & 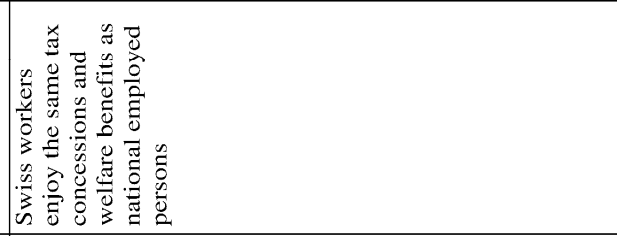 \\
\hline 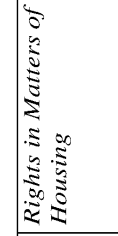 & 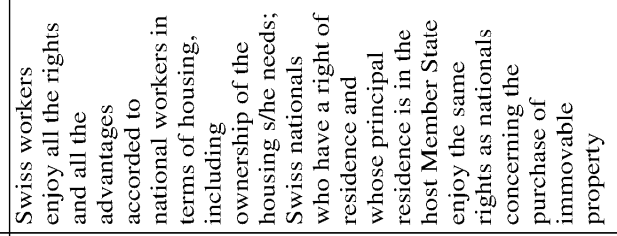 \\
\hline 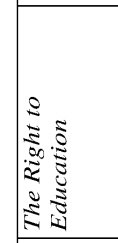 & 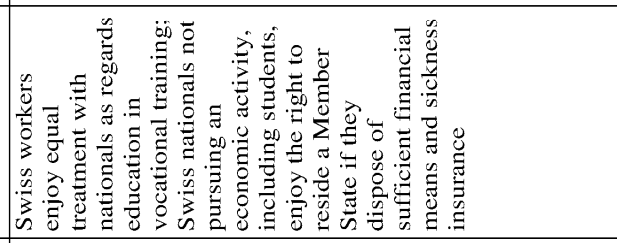 \\
\hline 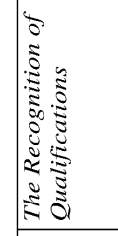 & 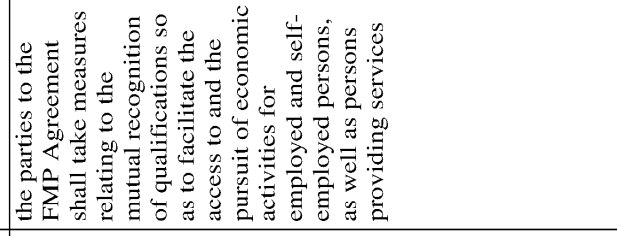 \\
\hline 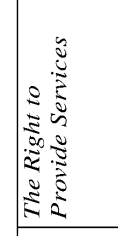 & 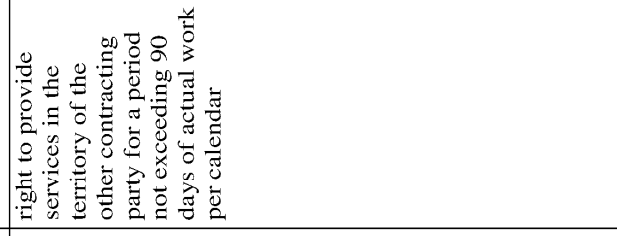 \\
\hline 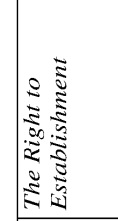 & 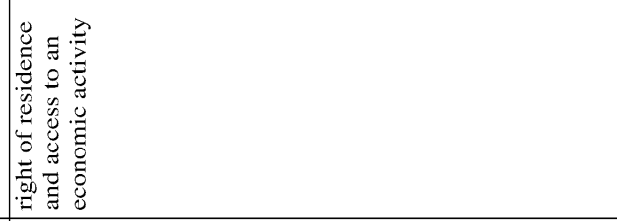 \\
\hline & 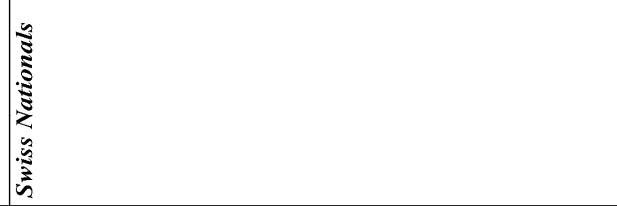 \\
\hline
\end{tabular}




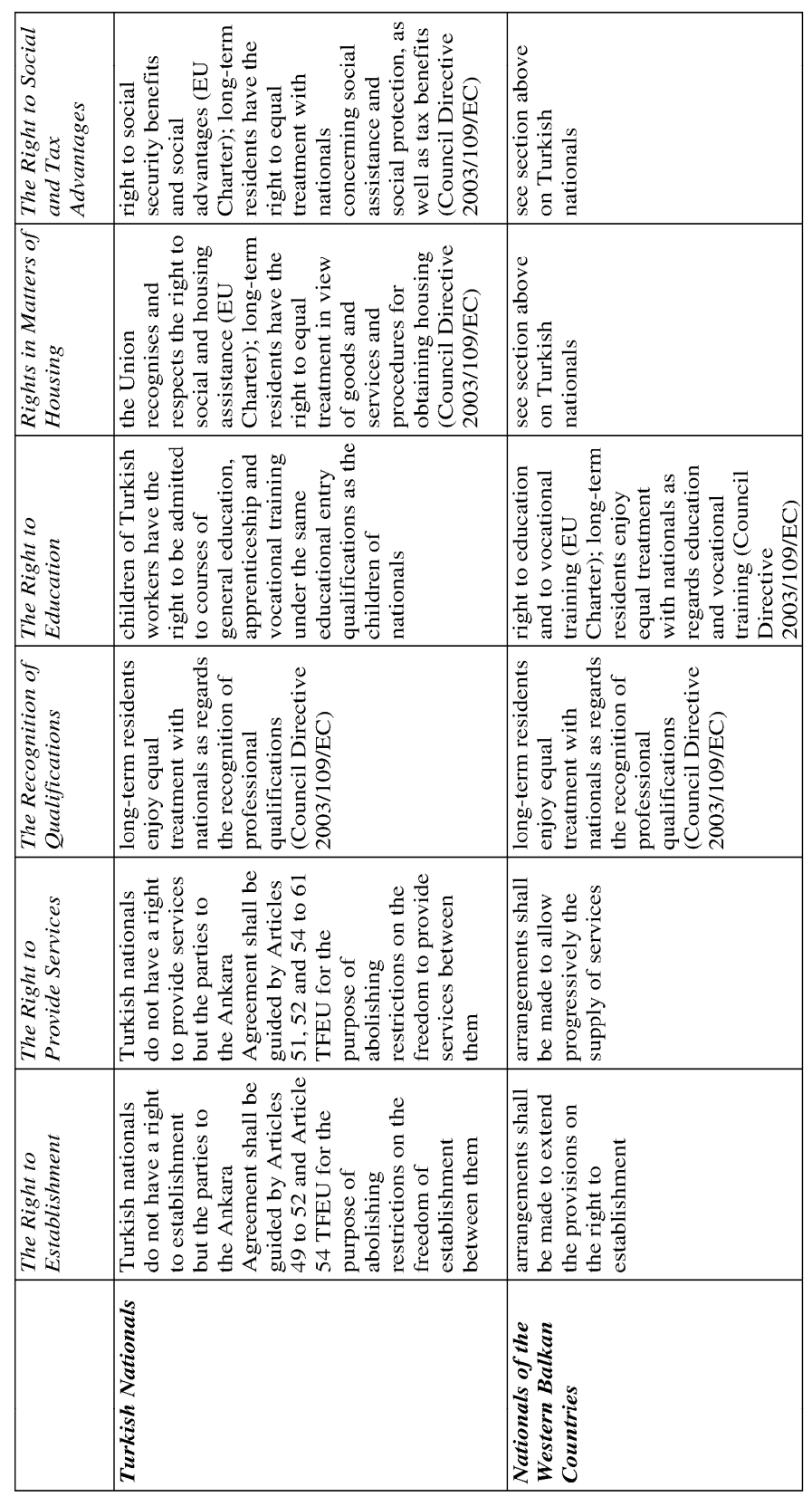




\begin{tabular}{|c|c|c|c|}
\hline 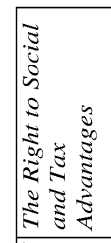 & 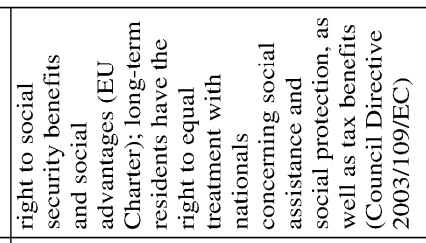 & 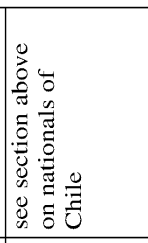 & 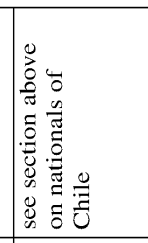 \\
\hline 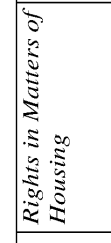 & 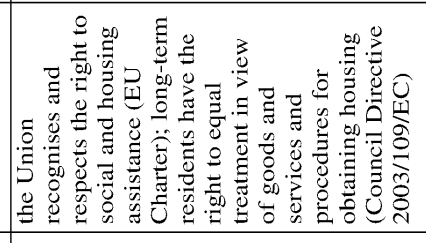 & 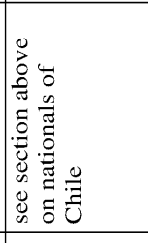 & 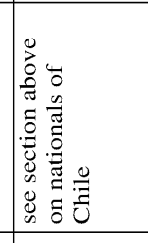 \\
\hline 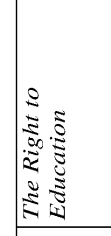 & 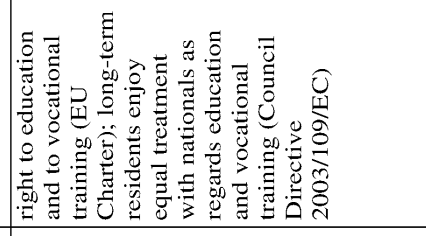 & 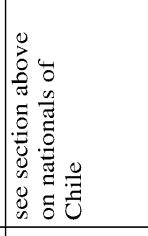 & 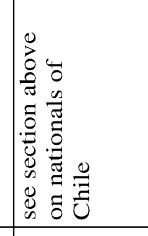 \\
\hline 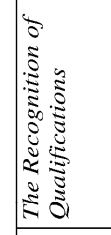 & 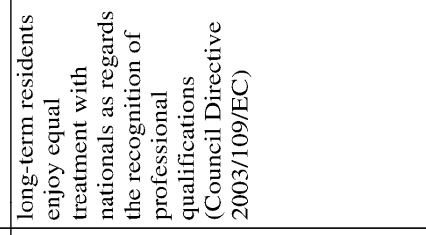 & 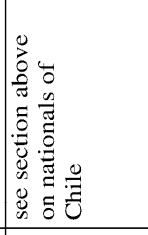 & 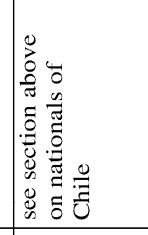 \\
\hline 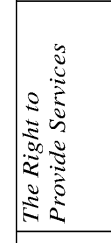 & 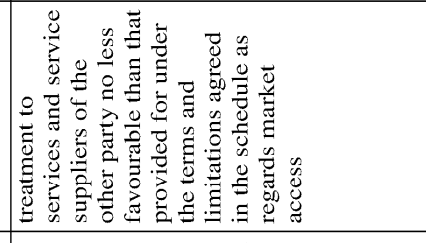 & 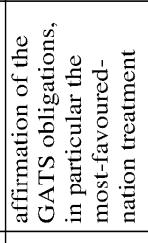 & 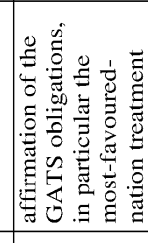 \\
\hline 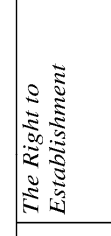 & 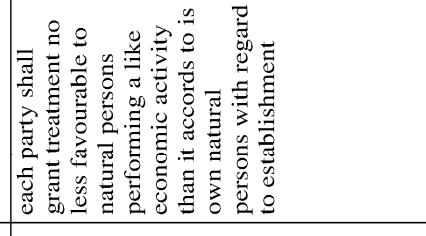 & & \\
\hline & 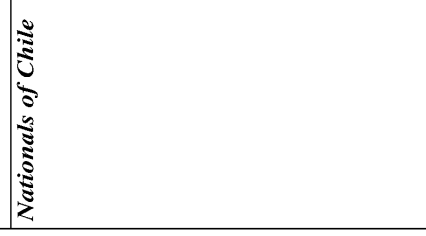 & 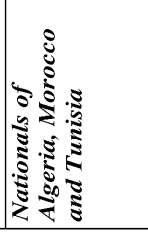 & 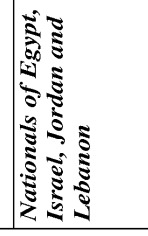 \\
\hline
\end{tabular}




\begin{tabular}{|c|c|c|c|}
\hline 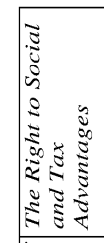 & 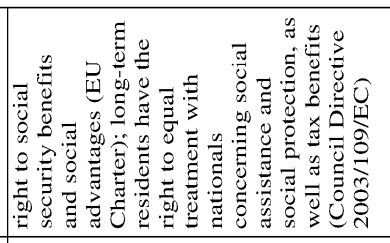 & 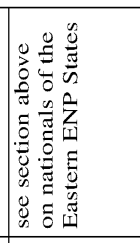 & 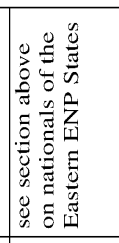 \\
\hline 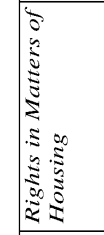 & 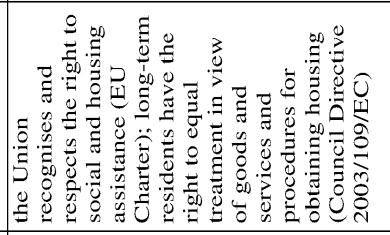 & 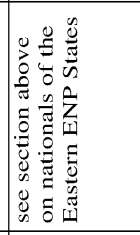 & 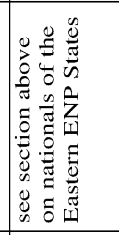 \\
\hline 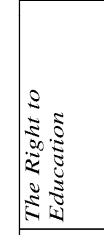 & 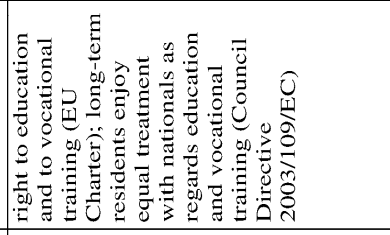 & 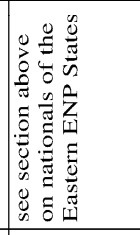 & 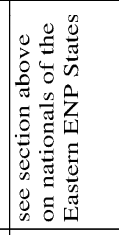 \\
\hline 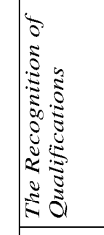 & 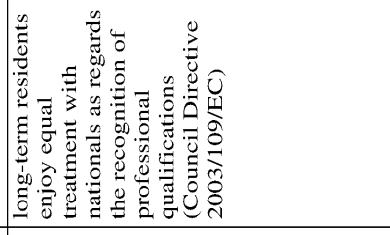 & 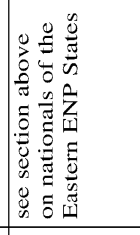 & 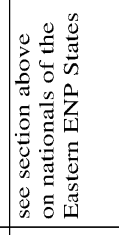 \\
\hline 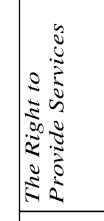 & 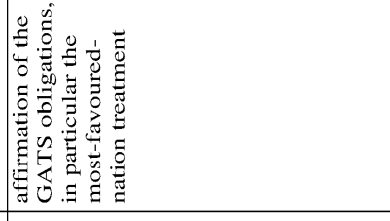 & 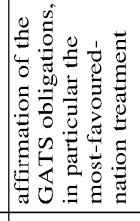 & 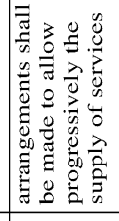 \\
\hline 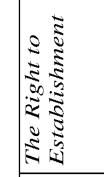 & & & \\
\hline & 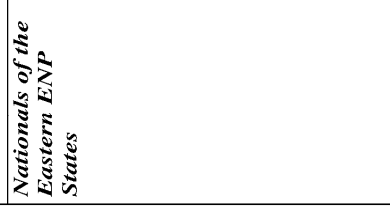 & 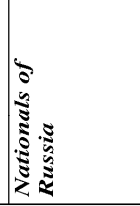 & 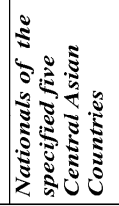 \\
\hline
\end{tabular}




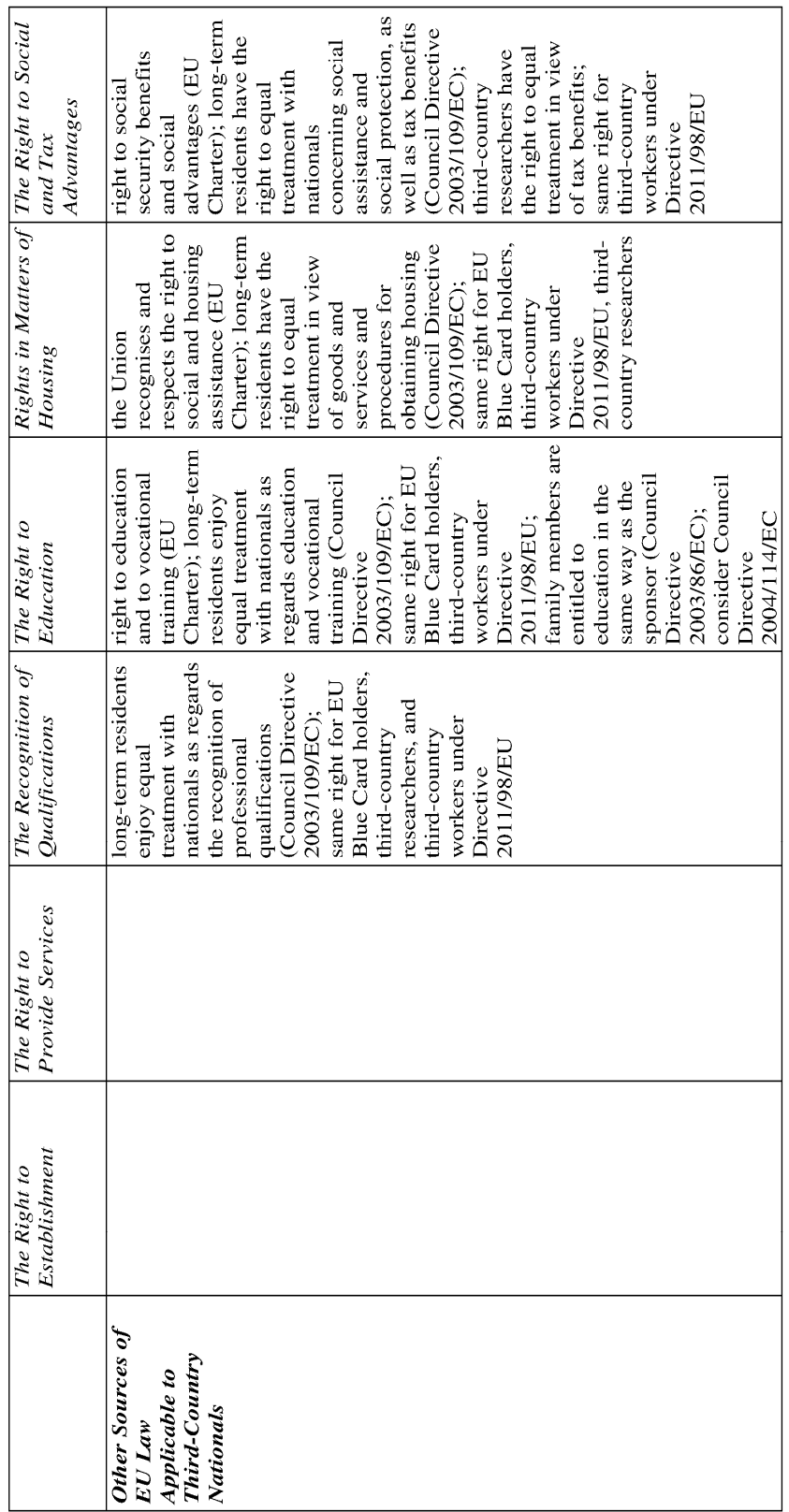





\section{Part X : Samenvatting}

Verschillende migratiestromen hebben Europa en zijn bevolkingsstructuren in zijn geschiedenis zeer beïnvloed en getekend. Tegelijkertijd zijn migratiebeleid en immigratierecht uitdrukking en kern van de soevereiniteit van Staten en zijn tot nu toe een gevoelig thema voor regeringen en de maatschappij. Vanuit traditioneel oogpunt gezien verleent de territoriale soevereiniteit, zoals het internationaal recht bepaalt, discretionaire bevoegdheid an staten de immigratiebepalingen voor buitenlanders vast te leggen. Echter is echter is de discretie beperkt door volkenrechtelijke verplichtingen, die bindend zijn voor Staten. Bovendien zijn lidstaten van de Europese Unie (EU) gebonden aan supranationale wetgeving op de gebieden waarvan zij de bevoegdheid hebben overgedragen aan de EU.

Het EU-recht maakt een verschil tussen migranten, die de nationaliteit van een EUlidstaat hebben en migranten die de nationaliteit van een derde land bezitten. Dit verschil heeft verstrekkende consequenties voor de wettelijke status van migranten die in de EU reizen of al in de EU verblijven. In principe kunnen EU burgers zich vrij binnen het grondgebied van de lidstaten bewegen en verblijven. Het vrije verkeer van personen, een van de vier fundamentele vrijheden van de Europese interne markt, heeft zich oorspronkelijk ontwikkelt op basis van een economische uitgangspunt, met als doelstelling het creëren van een 'gemeenschappelijke markt'. Het vrije verkeer van personen is tot nu toe slechts geldig voor burgers met de nationaliteit van een van de EU-lidstaten. Toen de Europese economische gemeenschap eind jaren vijftig is ontstaan, hebben de regeringen geen aandacht besteed aan onderdanen van derde landen. Langzamerhand hebben niet-EU burgers meer aandacht naar zich toe getrokken op Europees niveau; zo is hun rechtspositie voor het eerst versterkt toen migratierelevante regelingen in EU associatieovereenkomsten geïntegreerd werden alsook de positie van onderdanen van derde landen in hun kwaliteit als familielid van gemeenschapswerknemers werden aangemerkt.

Pas met de inwerkingtreding van het verdrag van Amsterdam in 1999 is het regelgevingkader van de EU veranderd en was de EU voor het eerst bezorgd met bevoegdheden betreffende migratie- en asielbeleid in Titel IV van het verdrag. Vandaag voorziet het verdrag van Lissabon expliciet in de taak van de EU om een gemeenschappelijk migratiebeleid te ontwikkelen, dat erop gericht is in alle stadia te zorgen voor een efficiënt beheer van de migratiestromen, een billijke behandeling van onderdanen van derde landen die legaal op het grondgebied van de lidstaten verblijven, en een preventie en intensievere bestrijding van illegale immigratie en mensenhandel. ${ }^{1}$ Het verdrag van Lissabon heeft mitsdien de Tampere conclusies, die de Europese raad op 15-16 oktober 1999 verkondigd heeft, een juridische basis gegeven. ${ }^{2}$ De Europese raad heeft er toen al op het belang gewezen om de wettelijke status van onderdanen van derde landen meer in overeenstemming te brengen met die van de onderdanen van de lidstaten. In de EU leven op dit moment omtrent 20,1 miljoen onderdanen van derde landen (in 2010) - dat is 4 procent van de bevolking van de EU dat neerkomt op 501 miljoen mensen. De EU wetgeving, die van

Zie art. 79(1) VWEU.

Tampere conclusies van de Europese Raad van 15-16 oktober 1999. 
toepassing is op onderdanen van derde landen, is heden ten dage sterk gefragmenteerd: niet-EU burgers die in een EU lidstaat woonachtig zijn of die zich graag naar een van de lidstaten willen verplaatsen staan tegenover een aantal verschillende rechtsbronnen, die hun respectievelijke rechtspositie bepalen. Er kunnen problemen ontstaan wat betreft transparantie, de coherentie of het kan zelfs de rechtszekerheid bedreigen. Ook ka de vraag worden gesteld of de verschillende rechtsposities van onderdanen van derde landen verenigbaar zijn met het basisprincipe van gelijkheid onder de EU regelgeving.

Tegen deze achtergrond beoogt dit proefschrift de volgende hoofdvragen te beantwoorden: Waarom genieten onderdanen van derde landen met een bepaalde nationaliteit een geprivilegieerde rechtspositie op basis van het EU recht - en op welke manier onderscheidt zich zo'n geprivilegieerde rechtspositie zich van een 'nietgeprivilegieerde' in juridisch opzicht? Met andere woorden doet dit proefschrift onderzoek naar het verschil in behandeling van onderdanen van derde landen met de doelstelling een rechtsvergelijkende analyse te maken van de respectievelijke wettelijke status van niet-EU burgers.

Om de hoofdvragen te beantwoorden behoeft het een verder gaande studie: ten eerste bestudeert dit proefschrift op welke manier de externe betrekkingen van de EU bijgedragen hebben derdelanders met een bepaalde nationaliteit een geprivilegieerde behandeling te verlenen. In deze context wordt de rol van de EU associatie-, coöperatie-, en partnerschapsovereenkomsten, welke belangrijke instrumenten zijn voor de vormgeving van de buitenlandse betrekkingen van EU, onderzocht en de oorzaken voor het aangaan van zulke overeenkomsten met derde landen bestudeerd. Daarnaast wordt geanalyseerd hoe de buitenlandse betrekkingen van de EU het Europees migratierecht en -beleid sinds het ontstaan van de Europese Economische Gemeenschap hebben beïnvloed en, vice versa, hoe het migratiebeleid op de buitenlandse betrekkingen uitwerkt. Deze analyse is tevens verbonden met de vragen wanneer en hoe de 'externe dimensie' van het Europees migratiebeleid zich ontwikkelt heeft. Ten tweede kunnen de hoofdvragen niet worden beantwoord zonder zich op de volgende subvragen te concentreren: op welke rechten kunnen alle derdelanders zich beroepen; hoe waarborgt de EU precies de geprivilegieerde rechtspositie gebaseerd op de associatie, coöperatie, en partnerschapsovereenkomsten - en hoe is dit verschil in behandeling van onderdanen van derde landen compatibel met het principe van gelijkheid; op welke manier divergeren de rechtsposities van derdelanders met betrekking tot toelating, verblijf, dienstverband en sociale verzekering, evenals andere sociale en economische rechten. Met de focus op deze vragen, beoogd het onderzoek deze versnippering te verklaren en de diverse wetsbepalingen, die relevant zijn voor onderdanen van derde landen, te ontvlechten. Tenslotte wordt op basis van de resultaten van dit proefschrift beoordeeld of de ambities van de EU om een gemeenschappelijk migratiebeleid in te voeren, kunnen worden gerealiseerd tegen de achtergrond van het, blijkbaar, extreme selectief immigratiebeleid dat in de EU op dit moment voert.

Het begrip van een gemeenschappelijk Europees migratiebeleid definieer ik in het kader van mijn proefschrift als een migratiebeleid dat voor alle onderdanen van derde landen geldig is - dit in tegenstelling tot een migratiebeleid dat slechts alle lidstaten 'gemeen' hebben. Het blijkt twijfelachtig of het correct is van een hele groep van onderdanen van derde landen te spreken, die de EU burgers als homogene groep 
tegenovergesteld worden, aangezien de omvang van de rechten van onderdanen van derde landen - afhankelijk van hun nationaliteit - heel divergent is.

Om te beginnen is het belangrijk om te benadrukken dat er Europese wetgeving bestaat op het gebied van migratiebeleid die op alle onderdanen van derde landen, ongeacht van nationaliteit, van toepassing is. Deze wetgeving, die onder andere onder het verdrag van Amsterdam in de vorm van richtlijnen was aangenomen betreft het recht op gezinshereniging; de status van langdurig ingezeten onderdanen van derde landen; de voorwaarden voor de toelating van onderdanen van derde landen met het oog op studie, scholierenuitwisseling, onbezoldigde opleiding of vrijwilligerswerk; een specifieke procedure voor de toelating van onderdanen van derde landen met het oog op wetenschappelijk onderzoek; de voorwaarden voor toegang en verblijf van onderdanen van derde landen met het oog op een hooggekwalificeerde baan; een enkele aanvraagprocedure voor een gecombineerde vergunning voor onderdanen van derde landen om te verblijven en te werken op het grondgebied van een lidstaat, alsmede inzake een gemeenschappelijk pakket rechten voor werknemers uit derde landen die legaal in een lidstaat verblijven. ${ }^{3}$

Naast de bepalingen inzake de Europese immigratie- en asielpolitiek, die vandaag in titel $\mathrm{V}$ in het verdrag van Lissabon omtrent de ruimte van vrijheid, veiligheid en recht geregeld is, kunnen zich onderdanen van derde landen ook op primair EU recht beroepen, bijvoorbeeld op het Europees Handvest van grondrechten, waarop een ieder zich kan beroepen. Bovendien worden onderdanen van derde landen ook beschermt door volkenrechtelijke regelgeving die de lidstaten of de EU binden - hier speelt vooral het Europees Verdrag voor de Rechten van de Mens een grote rol, aangezien het feit dat het toepassingsgebied alle onderdanen van derde landen omvat, die zich op het grondgebied van een lidstaat bevinden.

Dit proefschrift doet onderzoek naar het verband tussen de twee beleidsgebieden van migratie en externe betrekkingen sinds het ontstaan van de Europese Economische Gemeenschap en bestudeert in hoeverre dit verband substantieel aan de bevoordeling van bepaalde onderdanen van derde landen heeft bijgedragen. De eerder vermelde associatieovereenkomsten hebben voor het eerst een stevige, contractuele basis voor politieke en economische coöperatie met derde landen geschapen. Terwijl in simpele economische verdragen migratie niet als onderwerp behandeld wordt, waren

3 Zie Richtlijn 2003/86/EG van de Raad van 22 september 2003 inzake het recht op gezinshereniging; Richtlijn 2003/109/EG van de Raad van 25 november 2003 betreffende de status van langdurig ingezeten onderdanen van derde landen; Richtlijn 2004/114/EG van de Raad van 13 december 2004 betreffende de voorwaarden voor de toelating van onderdanen van derde landen met het oog op studie, scholierenuitwisseling, onbezoldigde opleiding of vrijwilligerswerk; Richtlijn 2005/71/EG van de Raad van 12 oktober 2005 betreffende een specifieke procedure voor de toelating van onderdanen van derde landen met het oog op wetenschappelijk onderzoek; Richtlijn 2009/50/EG van de Raad van 25 mei 2009 betreffende de voorwaarden voor toegang en verblijf van onderdanen van derde landen met het oog op een hooggekwalificeerde baan; Richtlijn 2011/98/EU van het Europees Parlement en de Raad van 13 december 2011 betreffende één enkele aanvraagprocedure voor een gecombineerde vergunning voor onderdanen van derde landen om te verblijven en te werken op het grondgebied van een lidstaat, alsmede inzake een gemeenschappelijk pakket rechten voor werknemers uit derde landen die legaal in een lidstaat verblijven. 
regelingen omtrent migratie in associatieovereenkomsten - welke vaak een toetreding van het land aan de EU voorzag - geïntegreerd. Dit gebeurde met de doelstelling de desbetreffende staat eerst op de vrijheid van werknemers en later op de vrijheid van personen binnen de EU voor te bereiden. Hieromtrent is bijvoorbeeld de EUassociatieovereenkomst met Turkije van 1963 te noemen, omdat het nog steeds de basis vormt op grond van welke Turkse werknemers en werkneemsters één geprivilegieerde wettelijke status toekomt. Het sluiten van een dergelijke overeenkomst biedt de EU een belangrijke optie haar externe betrekkingen een regelgevingkader te geven. Associatieovereenkomsten, die in het verleden tot een EU-toetreding hebben geleid, hebben een weggebaand voor de huidige compositie van de EU zoals ze vandaag bestaat als supranationale organisatie met 27 lidstaten.

Het verdrag van Lissabon heeft bovendien de Europese Dienst voor Extern Optreden (EDEO) gecreëerd met de doelstelling de EU met een eigen diplomatische dienst een helder gezicht in de wereld te geven. De Europese Dienst staat de hoge vertegenwoordiger van de EU voor buitenlandse zaken en veiligheidsbeleid bij, die het gemeenschappelijk buitenlands en veiligheidsbeleid, evenals het gemeenschappelijk veiligheids- en defensiebeleid beheert. Het onderwerp migratie was expliciet als wereldwijde uitdaging geïdentificeerd, die de EDEO van plan is te overzien.

Indien mensen grenzen overschrijden teneinde naar een ander land te emigreren, bergt dit proces uit de aard der zaak een internationaal, extern component. In de laatste twee decennia was vooral de "externe" dimensie van het Europees migratiebeleid intensief een onderwerp van discussie op nationaal en Europees niveau. In het begin van de jaren 90 was de focus in de politiek gericht op de vermindering van migratie in verband met stromen van vluchtelingen uit het voormalig Joegoslavië. De Commissie was van de opvatting dat het fenomeen van migratie een Europese dimensie had, die zowel intern als extern gerichte maatregels nodig had. Tegen deze achtergrond heeft zich langzaam de overtuiging doorgezet dat een succesvol management van migratie een politiek eist die ook aan de landen van herkomst en transit geadresseerd is.

Met de 'alomvattende aanpak van migratie' hebben de Europese regeringsleiders in 2005 de overeenkomst gesloten om dialoog en partnerschappen aan te gaan met derde landen betreffende migratie vraagstukken, dat was voornamelijk het politieke antwoord op de tragische gebeurtenissen in Noord-Afrika. De Poging van Afrikaanse migranten om de Spaanse enclaves binnen te dringen eindigde in sommige gevallen met een dodelijk gevolg. De alomvattende aanpak diende het slechte imago van 'het Fort Europa' tegen te gaan. Het is geen geheim dat de discussies inzake migratie nauw verweven zijn met een sterk binnenlands belang van elke staat voor een hoog level van nationale veiligheid. Irreguliere migratie wordt vaak beschouwd als een bedreiging en een probleem voor de binnenlandse veiligheid, die ook wezenlijk van een stabiele situatie buiten de grenzen van een EU-lidstaat afhankelijk is. Daarom heeft zich ook het inzicht verspreid dat immigratie beter in coöperatie met derde landen geregeld dient te worden - dit leidde ertoe dat migratie één van de belangrijkste onderwerpen van het EU buitenlandse beleid is geworden. Volgens de Europese Commissie beoogd de EU een alomvattende aanpak van migratie stromen van migranten effectief te regelen, de alomvattende aanpak is volledig in andere externe beleidsterreinen geïntegreerd en betrekt op een algehele en uitgebalanceerde 
manier alle vragen omtrent migratie en asiel. De alomvattende aanpak houdt zich dus niet alleen met irreguliere migratie bezig, maar ook met legale immigratie tegen de achtergrond van een aanhoudende vergrijzing van de maatschappijen binnen Europa, alsmede het gebrek aan vaklieden wat betreft bepaalde branches. Echter was de alomvattende aanpak ook onderwerp van harde kritiek: wetenschappers hebben het zogenaamde 'evenwicht' afgekeurd, de grensbewaking systematisch af te schuiven, en de verantwoordelijkheid op derde landen, die het vaak aan capaciteit en de nodige knowhow ontbreekt, afgeschoven. De alomvattende aanpak, bekrachtigd door de Europese regeringsleiders in het Stockholm Programma in 2011, werd het 'EU-totaal aanpak van migratie en mobiliteit' genoemd en had als doel de mobiliteit te bevorderen en de individuele migrant en de bescherming van zijn mensenrechten in het middelpunt te stellen.

Dit proefschrift illustreert dat een 'externe dimensie' van migratiebeleid op Europees niveau al in de jaren 60 bestond op basis van migratierechtelijk bepalingen in verschillende EU-associatie- en coöperatieovereenkomsten - alhoewel de EU op die datum nog geen bevoegdheden op het gebied van migratie had.

Er wordt aangetoond op welke manier geprivilegieerde externe betrekkingen invloed hebben op de wettelijke status van onderdanen van derde landen en hoe ze in EU verdragen, afhankelijk van het objectief, het doeleinde, en geaardheid, verankerd worden. Het proefschrift komt tot de conclusie dat EU recht belangrijke verschillen stipuleert wat betreft de behandeling van onderdanen van derde landen op grond van nationaliteit. Dit verschil in behandeling, die in detail wordt analyseert in hoofdstukken V tot VII, geeft zich onder andere in de regelingen van toegang en verblijf, alsmede arbeidsrechtelijke en sociaalverzekeringsrechtelijke bepalingen weer. Derhalve is het moeilijk om over een homogene groep van onderdanen van derde landen te spreken. Het proefschrift stelt ook de strekking van de rechtspraak van het Hof van Justitie van de EU vast van de uitleg van EU-associatie-, coöperatie-, en partnerschapsovereenkomsten en in hoeverre het hoogste gerecht van de EU op basis van zijn rechtspraak de wettelijke status van onderdanen van derde landen essentieel gesterkt heeft. Tenslotte wordt behandeld hoe het principe van gelijke behandeling, die in artikel 18 VWEU neergelegd is, zich op onderdanen van derde landen uitwerkt. Het Hof van Justitie heeft in het arrest Vatsouras beslist, dat het principe van gelijke behandeling geen toepassing vindt op een mogelijke discriminatie tussen onderdanen van EU lidstaten en die van derde landen, indien ze in de werkingssfeer van EU recht valt. Het principe van gelijke behandeling zegt dat overeenkomstige situaties niet verschillend mogen worden behandeld voor zover de differentiatie niet objectief gerechtvaardigd is. Deze houding werd bekritiseerd met name omdat het Hof van Justitie zijn beslissing niet verder had uitgelegd.

Dit proefschrift komt tot de conclusie dat gelijke behandeling van derdelanders op grond van verschillende rechtsbronnen slechts zeer selectief verleend wordt. De oorzaak voor dit lappendeken van rechtsgrondlagen zijn de verschillende rechtsbronnen, wier toepassing van een aantaal van criteria afhangt: de EUassociatieovereenkomsten en coöperatiemechanismen zijn slechts geldig voor onderdanen van derde landen met een bepaalde nationaliteit, en gelijke behandeling wordt slechts voor gedetermineerde en beperkte onderwerpsgebieden goedgekeurd, bijvoorbeeld gelijke behandeling omtrent arbeidsvoorwaarden. Het Europees secundaire recht, dat was aangenomen onder titel VI van het verdrag van 
Amsterdam, voorziet de gelijke behandeling in geselecteerde gebieden voor onderdanen van derde landen, op wie de wet respectievelijk van toepassing is. Bovendien heeft ook het algemeen principe van niet-discriminatie op basis van nationaliteit wat betreft onderdanen van derde landen zijn grenzen. Terwijl de doestelling om de wettelijke status van derdelanders ten opzichte van EU burgers aan te passen in de verre toekomst ligt, moet worden gewaardeerd dat het aangenomen secundaire recht ongetwijfeld de juridische situatie van onderdanen van derde landen, die rechtmatig in een lidstaat leven of legaal in de EU reizen, verbeterd heeft.

De richtlijn betreffende de status van langdurig ingezeten onderdanen van derde landen heeft de wettelijke status verstevigd van onderdanen van derde landen die tenminste vijf jaren rechtmatig in een lidstaat verblijven. En de richtlijn inzake het recht op gezinshereniging maakt de reünie van families in een lidstaat mogelijk. De richtlijnen betreffende de voorwaarden voor toegang en verblijf van onderdanen van derde landen met het oog op een hooggekwalificeerde baan en betreffende een specifieke procedure voor de toelating van onderdanen van derdelanders met het oog op wetenschappelijk onderzoek, hebben een specifiek juridisch systeem voor bepaalde groepen van derdelanders gecreëerd, dat onafhankelijk van nationaliteit van toepassing is. Daarenboven heeft de richtlijn betreffende een enkele aanvraagprocedure voor een gecombineerde vergunning voor onderdanen van derde landen om te verblijven en te werken op het grondgebied van een lidstaat, alsmede inzake een gemeenschappelijk pakket rechten voor werknemers uit derde landen die legaal in een lidstaat verblijven, de voorwaarden voor toegang en verblijf vergemakkelijkt. De aanvaarding van deze richtlijnen, welke niet op grond van nationaliteit discrimineert, is welkom. Echter verbeelden die rechtsinstrumenten slechts 'de grootste gemene deler', en ze doelen in het geheel niet op een aanpassing van de wettelijke status van derdelanders naar die van EU burgers, zoals het geformuleerd was in de Tampere Conclusies van 15-16 oktober 1999.

Op basis van de conclusies van mijn proefschrift zal ik niernavolgend aanbevelingen maken met het oog het Europees migratiebeleid en migratierecht te verbeteren.

\section{De schepping van één Europees migratiebeleid dat een 'inclusieve' EU bevordert}

Mijn proefschrift heeft laten zien dat een gemeenschappelijk Europees migratiebeleid, die gelijkwaardig op alle onderdanen van derde landen van toepassing is, tegenwoordig niet bestaat. Het hoog selectief systeem, dat het acquis migratierecht vormt, zou kunnen worden omgezet in een immigratiebeleid met een verbeterde gelijke behandeling voor alle derdelanders. De EU zou zich 'inclusief gedragen en alle migranten welkom heten. Het berust bij de nationale en supranationale besluitvormers hierop de nodige maatregels te nemen.

\section{Een verbeterde gelijke behandeling voor alle derdelanders}

Gelijke behandeling is van groots belang voor een Europees migratiebeleid dat alle migrantengemeenschappen op gelijke manier als cultureel, economisch en sociaal verrijkende groep van individuen in het gastland beschouwt en een integratie in de ontvangende maatschappij vergemakkelijkt. Het stelt zich de vraag of het voorstelbaar is, gelijke behandeling op een samenhangende manier te verruimen. P. Boeles heeft een immigratiebeleid voorgesteld dat uitzonderingen van gelijke 
behandeling van derdelanders van status van verblijf, niet van nationaliteit afhankelijk makkt. Zijn theorie houdt in dat maatregelen op het gebied van migratierecht, die op derdelanders van toepassing zijn en die niet voor eigen onderdanen kunnen worden genomen, enkel gerechtvaardigd zijn, als ze geschikt en evenredig zijn. Terwijl deze interessante theorie zeker niet in zijn gehele omvang omzetbaar is, zouden toch enkele elementen kunnen worden overgenomen. Op die manier zou bijvoorbeeld de nationaliteit het doorslaggevend criterium voor het recht van toegang zijn voor een kortstondig verblijf (EU witte en zwart visa lijst) alsook verblijven van lange duur (competentie bij de lidstaten). Evenwel zou de duur van het verblijf de cruciale factor moeten zijn voor de omvang van de rechten waarop migranten in het gastland zich kunnen beroepen als ze daar een tijd hebben gewoond. Deze aanpak weerspiegelt zich in de richtlijn 2003/109/EG betreffende de status van langdurig ingezeten onderdanen van derde landen. Dit betekent dat het mogelijk is een wezenlijk gemeenschappelijk migratiesysteem op te bouwen dat gekenmerkt wordt door de duur van verblijf als doorslaggevend criterium vast te stellen in plaats die van nationaliteit.

\section{Een verhoogde transparantie en een versterkte bewustwording}

Een eerste stap om het huidige, gefragmenteerde Europese migratiebeleid aan te pakken is de transparantie van de complexe structuren, welke het Europees migratierecht definiëren, te verbeteren. Het Europees secundaire recht onder Titel V van het verdrag van Lissabon wordt vaak als basis weergegeven voor een gemeenschappelijk Europees migratiebeleid, zonder verder op de verschillenden associatie-, coöperatie en partnerschapverdragen in te gaan. Besluitvormers zouden het bewustzijn van de bevolking voor het tegenwoordige migratierecht dienen te verscherpen, in het bijzonder met het oog op potentiële migranten. Een eerste initiatief is het EU immigratie portal dat actuele en praktische informatie verstrekt voor buitenlanders die van plan zijn om in de EU te reizen, dat online kan worden geraadpleegd.

\section{De introductie van een aangepaste en nitgebreide immigratiecode}

Besluitvormers zouden bovendien een aangepaste en uitgebreide immigratiecode kunnen introduceren, die zich op het acquis communautaire baseert en het bestaande Europees migratierecht consolideert, verbetert en in een document wordt verenigd. In een dergelijke immigratiecode zouden vereenvoudigde eerlijke procedures en duidelijkere regels voor arbeidsmigratie naar de EU kunnen worden verankerd. Maar ook gezinshereniging en de status van langdurig ingezeten onderdanen van derde landen zouden aanmerkelijk kunnen worden geoptimaliseerd.

\section{Het belang van een aanpak, die op rechten gebaseerd is}

Om de doelstellingen van de Raad van Tampere te bereiken, met name betreffende een verbetering van de rechten van derdelanders ten opzichte van de rechten van onderdanen van de lidstaten te bereiken, zou een Europees migratiebeleid een aanpak kunnen volgen die op rechten gebaseerd is en migranten en hun familie leden centraal stelt. De EU-totaal aanpak van migratie en mobiliteit, die de Europese Commissie in 2001 een nieuwe impuls heeft gegeven, integreert en communiceert belangrijke aspecten in deze context: de bescherming van de rechten van migranten 
en de focus op de mens. Een immigratiecode zou hier de mensenrechtendimensie in een juridisch bindend regelgevingkader kunnen vastleggen.

\section{Migratie als positief fenomeen communiceren waarvan maatschappijen profiteren}

Het is de taak van de politiek om migratie en immigratie als positie fenomeen en veelbelovend voor de toekomst naar buiten toe te communiceren. Onkunde en onwetendheid bieden een voedingsbodem voor vooroordelen, wantrouwen en angst tegenover bevolkingslagen met migrantenachtergrond, wat in het ergste geval in racistische en xenofobische houdingen kan culmineren. In economisch barre tijden verscherpen dergelijke ontwikkelingen zich, dat zich weerspiegelt in een groei van rechts-populistische propaganda. Regeringen en parlementen - nationale en Europese besluitvormers - zouden actief moeten worden en het bewustzijn van bevolkingen op basis van feiten sensibiliseren. Maar ook de civiele samenleving, internationale en non-gouvernementele organisaties, evenals de particuliere sector spelen een belangrijke rol in dit verband. Hier is de EU-totaal aanpak van migratie en mobiliteit een juiste stap en de publieke consultatie, die de Europese Commissie tussen april en juni 2012 op geroepen heeft, zeer welkom. De Europa 2020-strategie voorziet, dat migratie en mobiliteit bijdraagt aan een versterkte economische groei, meer vitaliteit en het concurrentievermogen aanzwengelt. Europa is gekenmerkt door vergrijzende maatschappijen door een dalingen van het aantal geboortes; dit eist een responsieve beroepsbevolking die voldoet aan de vraag op de arbeidsmarkt, zoals een immigratiebeleid georiënteerd op de vraag.

\section{De ontwikkeling van een sterker institutioneel kader dat zich coöperatief vragen inzake migratie stelt}

Een intensieve coöperatie op institutioneel niveau vergemakkelijkt regelmatige dialogen en informatie-uitwisseling tussen organisaties en belangenbehartigers betreffende het onderwerp op welke manier grensoverschrijdende migratie beter kan worden beheerd. In dit opzicht bieden de initiatieven zoals het Global Forum on Migration and Development en het UN High-Level Dialogue on International Migration and Development een belangrijk forum op internationaal parket. In juli 2012 is een 'strategisch partnerschap' voor migratievragen geïnaugureerd, die de samenwerking tussen de Internationale Organisatie voor Migratie, de Europese dienst voor extern optreden alsook de Europese Commissie zal verdiepen. Het is te hopen dat dit partnerschap effectief gebruikt zal worden en zo tot succesvolle discussies en praktische resultaten in het beleid zal leiden.

\section{Ratificatie van het VN Verdrag over de bescherming van de rechten van alle migrantenwerkers en bun familieleden}

Het $\mathrm{VN}$ verdrag inzake de bescherming van de rechten van alle migrantenwerkers heeft een uitgebreide internationale regelgeving voor de bescherming van alle migranten en hun familieleden geschapen. Helaas hebben tot op heden maar weinig staten het VN verdrag geratificeerd. Vooral de EU lidstaten zouden verdragspartij kunnen worden om het aantal van ratificaties van industriestaten te verhogen en op die manier substantieel aan een veilige wettelijke status van migranten kunnen bijdragen. 


\section{Part XI : Zusammenfassung}

Diverse Migrationsströme haben Europa und seine Bevölkerungsstrukturen in der geschichtlichen Entwicklung wesentlich beeinflusst und bestimmt. Gleichzeitig sind Einwanderungspolitik und Migrationsrecht Ausdruck sowie Kern staatlicher Souveränität und bis zum heutigen Tag ein sehr heikles Thema für Regierungen und Gesellschaften. Traditionell gesehen, gewährt die territoriale Hoheitsgewalt, wie sie das Völkerrecht vorsieht, Staaten das Ermessen ein, Einwanderungsbestimmungen für Ausländer festzulegen. Dieses Ermessen ist jedoch eingeschränkt durch völkerrechtliche Verpflichtungen, an die Staaten gebunden sind. Darüber hinaus sind die Mitgliedstaaten der Europäischen Union an die supranationale Gesetzgebung der $\mathrm{EU}$ in den Bereichen gebunden, in denen sie Kompetenzen an die Union übertragen haben.

Das Unionsrecht macht einen Unterschied zwischen Migranten, die die Staatsangehörigkeit eines EU-Mitgliedstaates besitzen, und denjenigen, die der Nationalität eines Drittstaates angehören. Diese Unterscheidung hat weitreichende Konsequenzen für die Rechtsposition von Migranten, die in die Union einreisen oder in der Union ihren Wohnsitz haben. Es ist wichtig zu betonen, dass sich EU-Bürger im Prinzip frei im Hoheitsgebiet von Mitgliedstaaten bewegen und aufhalten können. Die Personenfreizügigkeit, eine der vier Grundfreiheiten des europäischen Binnenmarktes, hat sich ursprünglich aus ökonomischen Gesichtspunkten entwickelt einen „Gemeinsamen Markt“ zu schaffen. Die Personenfreizügigkeit gilt bis heute jedoch nur für Bürger, die die Staatsangehörigkeit eines EU-Mitgliedstaates besitzen. Als die europäische Wirtschaftsgemeinschaft Ende der Fünfziger Jahre entstanden ist, waren Drittstaatsangehörigen nicht im Fokus von Regierenden. Nur Schritt für Schritt erlangten Nicht-EU-Bürger mehr Aufmerksamkeit in der europäischen Diskussion und ihre Rechtsposition hat sich erstmals gestärkt, als migrationsrelevante Regelungen in EU-Assoziationsabkommen aufgenommen wurden und Drittstaatsangehörige in ihrer Eigenschaft als Familienangehörige von Gemeinschaftsarbeitnehmern berücksichtigt wurden. Erst mit dem Inkrafttreten des Vertrags vom Amsterdam im Jahr 1999 hat sich das rechtliche Rahmenwerk der EU geändert und der Union wurden erstmals im Titel IV des Vertrags Kompetenzen in den Bereichen Migrations- und Asylpolitik übertragen. Heute sieht der Vertrag von Lissabon ausdrücklich vor, dass der EU die Aufgabe obliegt eine gemeinsame Einwanderungspolitik zu entwickeln, die in allen Phasen eine wirksame Steuerung der Migrationsströme, eine angemessene Behandlung von Drittstaatsangehörigen, die sich rechtmäßig in einem Mitgliedstaat aufhalten, sowie die Verhütung und verstärkte Bekämpfung von irregulärer Einwanderung und Menschenhandel gewährleisten soll. ${ }^{1}$

Der Vertrag von Lissabon hat somit die Tampere-Schlussfolgerungen, die der Europäische Rat am 15.-16. Oktober 1999 verkündete, in einen rechtlichen Rahmen gegossen. ${ }^{2}$ Schon damals hat der Europäische Rat ausdrücklich darauf hingewiesen, die Rechtsstellung von Drittstaatsangehörigen an die Rechtsstellung der Staatsangehörigen der Mitgliedstaaten anzugleichen. In der EU leben derzeit ungefähr 20,1 Millionen Drittstaatsangehörige (Stand: 2010) - ein Anteil, der 4 Prozent der EU-Bevölkerung von insgesamt 501 Millionen Menschen entspricht. Die

Siehe Art. 79(1) AEUV.

Tampere Schlussfolgerungen des Europäischen Rates vom 15.-16. Oktober 1999. 
EU-Gesetzgebung, die auf Drittstaatsangehörige Anwendung findet, ist heute stark fragmentiert: Nicht-EU-Bürger, die ihren Wohnsitz in einem EU-Mitgliedstaat haben oder sich in einem Mitgliedstaat niederlassen wollen, sehen sich einer großen Anzahl von verschiedenen Rechtsquellen gegenüber, die ihre jeweilige Rechtsposition bestimmen. Dies kann zu Problemen führen, was die Transparenz, Klarheit und Kohärenz angeht, oder sogar die Rechtssicherheit gefährden. Es stellt sich auch die Frage, wie die divergierenden Rechtsstellungen von Drittstaatsangehörigen mit dem Gleichheitsgrundsatz, den das EU-Rahmenwerk vorsieht, vereinbar sind.

Vor diesem Hintergrund zielt diese Dissertation darauf ab, folgende Hauptfragen zu beantworten: warum genießen Drittstaatsangehörige mit einer bestimmten Staatsangehörigkeit eine privilegierte Rechtsstellung aufgrund von EU-Recht - und in welchem Hinblick unterscheidet sich eine solche privilegierte Rechtsstellung von einer „nicht-privilegierten“ in rechtlicher Hinsicht? Mit anderen Worten, die vorliegende Forschungsarbeit untersucht die unterschiedliche Behandlung von Drittstaatsangehörigen mit dem Ziel eine rechtsvergleichende Analyse der jeweiligen Rechtspositionen von Nicht-EU-Bürgern zu erstellen.

Um die Hauptfragen zu beantworten, bedarf es weitergehender Studien: erstens untersucht die Arbeit, auf welche Weise die Außenbeziehungen der EU dazu beigetragen haben, Drittstaatsangehörige mit einer bestimmen Staatsangehörigkeit eine privilegierte Behandlung einzuräumen. In diesem Zusammenhang wird die Rolle der EU-Assoziations-, -Kooperations-, und -Partnerschaftsabkommen, die ein wichtiges Instrumentarium für die Gestaltung der EU-Außenbeziehungen darstellen, geprüft und die Gründe für die Schließung dieser Abkommen mit Drittstaaten untersucht. Es wird darüber hinaus analysiert, wie die EU-Außenbeziehungen das europäische Einwanderungsrecht und die Einwanderungspolitik seit der Entstehung der Europäischen Wirtschaftsgemeinschaft beeinflusst hat, und vice versa wie Einwanderungspolitik sich auf die Außenbeziehungen ausgewirkt hat. Diese Analyse ist eng verknüpft mit den Fragen, wann und wie die „externe Dimension“ der europäischen Migrationspolitik sich entwickelt hat. Zweitens können die Hauptfragen nicht beantwortet werden ohne sich auf folgende Nebenfragen zu konzentrieren: auf welche Rechte können sich alle Drittstaatsangehörige berufen; wie garantieren die EU-Assoziations-, -Kooperations-, und -Partnerschaftsabkommen genau eine privilegierte Rechtsstellung - und wie ist die Ungleichbehandlung vereinbar mit dem Gleichheitsgrundsatz; auf welche Weise divergieren die Rechtsstellungen von Drittstaatsangehörigen im Bezug auf Einreise, Beschäftigung, Aufenthalt und Sozialversicherung, sowie anderen sozialen und ökonomischen Rechten. Mit dem Fokus auf diese Fragen, zielt dieses Forschungsvorhaben darauf ab, den fragmentierten Ansatz zu erklären und die verschiedenen Rechtsgrundlagen, die Rechte für Drittstaatsangehörigen festlegen, zu entflechten.

Schließlich wird auf Grundlage von den Ergebnissen dieser Dissertation beurteilt, ob die Bestrebungen der Europäischen Union, eine gemeinsame europäische Migrationspolitik einzuführen, zu verwirklichen sind vor dem Hintergrund des augenscheinlich extrem selektiven Einwanderungssystems, wie es heute in der EU besteht. Das Verständnis einer gemeinsamen europäischen Migrationspolitik definiere ich im Rahmen meiner Dissertation als eine, die für alle Drittstaatsangehörigen gilt - im Gegensatz zu einer Migrationspolitik, die lediglich allen EU-Mitgliedstaaten „gemeinsam“ ist. Es erscheint problematisch von einer 
Gruppe von Drittstaatsangehörigen zu sprechen, die den EU-Bürgern als homogene Gruppe gegenübergestellt werden, wenn man in Betracht zieht, dass der Umfang der Rechte von Drittstaatsangehörigen - abhängig von ihrer Nationalität - sehr divergent ist.

Zunächst ist es wichtig hervorzuheben, dass es europäische Gesetzgebung im Bereich der Einwanderungspolitik gibt, die auf alle Drittstaatsangehörigen, ungeachtet der Staatszugehörigkeit, Anwendung findet. Diese Gesetzgebung, die unter dem Vertrag von Amsterdam inter alia in Form von Richtlinien erlassen wurde, betrifft das Recht auf Familienzusammenführung; die Rechtsstellung von langfristig aufenthaltsberechtigten Drittstaatsangehörigen; die Bedingungen für die Zulassung von Drittstaatsangehörigen zur Absolvierung eines Studiums, zur Teilnahme an einem Schüleraustausch oder einem Freiwilligendienst; das besonderes Zulassungsverfahren für Drittstaatsangehörige zum Zwecke der wissenschaftlichen Forschung; die Bedingungen für die Einreise und den Aufenthalt von Drittstaatsangehörigen zur Ausübung einer hochqualifizierten Beschäftigung; sowie das einheitliches Verfahren zur Beantragung einer kombinierten Erlaubnis für Drittstaatsangehörige, sich im Hoheitsgebiet eines Mitgliedstaats aufzuhalten und zu arbeiten, sowie über ein gemeinsames Bündel von Rechten für Drittstaatsarbeitnehmer, die sich rechtmäßig in einem Mitgliedstaat aufhalten. ${ }^{3}$ Neben den Bestimmungen über die europäische Einwanderungs- und Asylpolitik, die heute im Titel V im Vertrag von Lissabon über den Raum der Freiheit, der Sicherheit und des Rechts festgelegt sind, können sich Drittstaatsangehörige auch auf EUPrimärrecht berufen, zum Beispiel auf die Grundrechtecharta, die größtenteils auf jede Person anwendbar ist. Darüber hinaus werden Drittstaatsangehörige auch geschützt durch völkerrechtliche Regelungen, die die Mitgliedstaaten oder die EU binden, hier spielt insbesondere die Europäische Menschenrechtskonvention eine große Rolle, da ihr Anwendungsbereich alle Drittstaatsangehörigen umfasst, die sich in dem Hoheitsgebiet eines Mitgliedstaates aufhalten.

Die Dissertation untersucht zudem, wie sich die Verbindung zwischen den zwei Politikbereichen von Migration und Außenbeziehungen seit Entstehung der Europäischen Wirtschaftsgemeinschaft entwickelt und wesentlich zur Begünstigung von bestimmten Drittstaatsangehörigen beigetragen hat. Die zuvor erwähnten Assoziationsabkommen der EU haben erstmals eine solide, vertragliche Basis für

Siehe Richtlinie 2003/86/EG vom 22. September 2003 betreffend das Recht auf Familienzusammenführung; Richtlinie 2003/109/EG vom 25. November 2003 betreffend die Rechtsstellung der langfristig aufenthaltsberechtigten Drittstaatsangehörigen; Richtlinie 2004/114/EG vom 13. Dezember 2004 über die Bedingungen für die Zulassung von Drittstaatsangehörigen zur Absolvierung eines Studiums oder zur Teilnahme an einem Schüleraustausch, einer unbezahlten Ausbildungsmaßnahme oder einem Freiwilligendienst; Richtlinie 2005/71/EG vom 12. Oktober 2005 über ein besonderes Zulassungsverfahren für Drittstaatsangehörige zum Zwecke der wissenschaftlichen Forschung; Richtlinie 2009/50/EG vom 25. Mai 2009 über die Bedingungen für die Einreise und den Aufenthalt von Drittstaatsangehörigen zur Ausübung einer hochqualifizierten Beschäftigung; Richtlinie 2011/98/EU vom 13. Dezember 2011 über ein einheitliches Verfahren zur Beantragung einer kombinierten Erlaubnis für Drittstaatsangehörige, sich im Hoheitsgebiet eines Mitgliedstaats aufzuhalten und zu arbeiten, sowie über ein gemeinsames Bündel von Rechten für Drittstaatsarbeitnehmer, die sich rechtmäßig in einem Mitgliedstaat aufhalten. 
politische und wirtschaftliche Zusammenarbeit mit Drittstaaten geschaffen. Während in einfachen Wirtschaftsverträgen Migration nicht als Thema behandelt wurde, wurden Migrationsregelungen in Assoziationsübereinkommen - die oftmals einen zukünftigen EU-Beitritt des betreffenden Drittstaates vorsahen - mitaufgenommen. Dies geschah mit dem Ziel den jeweiligen Staat zunächst auf die Arbeitnehmer-, und später auf die Personenfreizügigkeit innerhalb der EU vorzubereiten. Diesbezüglich ist beispielsweise das EU-Assoziationsabkommen mit der Türkei, das 1963 unterzeichnet wurde, zu nennen, da es noch immer die Grundlage darstellt, aufgrund derer türkische Arbeitnehmer und Arbeitnehmerinnen eine privilegierte Rechtsstellung zukommt. Ein Abkommen abzuschließen, bietet der EU die wichtige Option ihren Außenbeziehungen eine rechtliche Grundlage zu geben. Assoziationsverträge, die in der Vergangenheit zu einem EU-Beitritt geführt haben, haben der EU, wie sie heute als supranationale Organisation mit derzeitig 27 Mitgliedstaaten existiert, den Weg bereitet. Der Vertrag von Lissabon hat zudem den Europäischen Außendienst ins Leben gerufen um der EU durch einen eigenen diplomatischen Dienst ein klares Gesicht in der Weltgemeinschaft zu verschaffen. Der Europäische Außendienst unterstützt den Hohen Vertreter der Union für Außen- und Sicherheitspolitik, der die gemeinsame Außen- und Sicherheitspolitik, sowie die gemeinsame Sicherheits- und Verteidigungspolitik leitet. Das Thema Migration wurde ausdrücklich als eine der globalen Herausforderungen identifiziert, die der Europäischen Außendienst beabsichtigt zu bewältigen.

Wenn Menschen Grenzen überschreiten um in ein anderes Land zu emigrieren, birgt dieser Prozess naturgemäß eine internationale, externe Komponente. In besonderem Maße war vor allem in den letzten zwei Jahrzehnten die „externe Dimension“ der europäischen Migrationspolitik Gegenstand von heißen Debatten, sowohl auf europäischem als auch auf nationalem Parkett. Anfang der 90er Jahre wurde der Fokus in der Politik auf die Drosselung von Migration gelenkt im Zusammenhang mit Flüchtlingsströmen aus dem ehemaligen Jugoslawien. Die Kommission vertrat damals den Standpunkt, dass das Migrationsphänomen eine europäische Dimension hat, die interne sowie außenpolitische Maßnahmen benötigt. Vor diesem Hintergrund hat sich nach und nach die Überzeugung durchgesetzt, dass ein erfolgreiches Migrationsmanagement eine Politik erfordert, die auch an Herkunfts- und Transitländer gerichtet ist.

Mit dem EU-Gesamtansatz für Migration haben die europäischen Regierungschefs 2005 die Übereinkunft getroffen, Migrationsfragen in Partnerschaft und im Dialog mit Drittstaaten anzugehen. Dies war insbesondere auch die politische Antwort auf die tragischen Ereignisse in Nordafrika, wo der Versuch von afrikanischen Migranten, in die spanischen Enklaven einzudringen, in manchen Fällen tödlich endete - es galt dem Image der „Festung Europa“, das in vielen europäischen Ländern in den Medien angeprangert wurde, entgegenzuwirken. Es ist kein Geheimnis, dass die Diskussionen um Einwanderung eng verknüpft sind mit dem starken innenpolitischen Interesse eines jeden Staates nach einer hohen nationalen Sicherheit. Irreguläre Migration wird oftmals als eine Bedrohung und ein Problem für die innere Sicherheit angesehen, die auch wesentlich von einer stabilen Lage außerhalb der Grenzen der EU-Mitgliedstaaten abhängig ist. Auch deshalb hat sich die Einsicht etabliert, dass Einwanderung besser in Kooperation mit Drittstaaten geregelt werden muss - dies hat dazu geführt, dass Migration zu einem wichtigen Thema der EU-Außenpolitik geworden ist. Laut der Europäischen Kommission zielt 
der EU-Gesamtansatz für Migration darauf ab, Migrationsströme effektiv zu steuern, er ist vollständig in andere externe Politikbereiche integriert und bezieht in umfassender und ausgewogener Weise sämtliche Migrations- und Asylfragen ein. Der Gesamtansatz beschäftigt sich demnach nicht nur mit irregulärer Migration, sondern auch mit legaler Einwanderung vor dem Hintergrund der stetig alternden Gesellschaften in Europa sowie einem erheblicher Fachkräftemangel in bestimmen Branchen. Jedoch war der Gesamtansatz auch Gegenstand harter Kritik: Wissenschaftler haben die angebliche „Ausgewogenheit“ moniert, der Grenzschutz werde systematisch externalisiert, und so Verantwortung auf Drittstaaten, denen es oft an Kapazitäten und wichtigem Know-How fehle, abgeschoben. Der Gesamtansatz, bestätigt von den europäischen Regierungschefs im Stockholmer Programm, wurde 2011 in „EU-Gesamtansatz für Migration und Mobilität“ umbenannt, unter anderem um den Mobilitätsaspekt zu fördern und den einzelnen Migranten und den Schutz seiner Menschenrechte in den Mittelpunkt zu stellen.

Die vorliegende Dissertation zeigt, dass es eine „externe Dimension“ von Migrationspolitik auf EU-Ebene bereits in den 60er Jahren aufgrund von migrationsrechtlichen Regelungen in den verschiedenen EU-Assoziations- und Kooperationsabkommen gegeben hat - obwohl die EU zu diesem Zeitpunkt noch keine Kompetenzen in dem Bereich von Migration hatte. Es wird dargelegt, auf welche Weise sich privilegierte Außenbeziehungen auf die Rechtsstellung von Drittstaatsangehörigen ausgewirkt haben und wie sie in EU-Abkommen, abhängig vom Ziel, Zweck und Wesen, verankert wurden. Die Dissertation kommt zu dem Ergebnis, dass das EU Recht wesentliche Unterschiede festlegt, was die Behandlung von Drittstaatsangehörigen untereinander auf Grundlage von Staatsangehörigkeit anbetrifft. Diese Ungleichbehandlung, die im Detail in den Kapiteln V bis VII analysiert wird, spiegelt sich unter anderem in Einreise-, Aufenthaltsregelungen sowie arbeits-, und sozialversicherungsrechtlichen Bestimmungen wider. Daher ist es schwierig von einer homogenen Gruppe von Drittstaatsangehörigen zu sprechen.

Die Arbeit ermittelt zudem die Tragweite, die die Rechtsprechung des Gerichtshofs der Europäischen Union bei der Auslegung von EU Assoziations-, Kooperations-, und Partnerschaftsabkommen hat und auf welche Weise das höchste Gericht in der EU mit seiner Rechtsprechung die Rechtsstellung von Drittstaatsangehörigen wesentlich gestärkt hat. Schließlich wird erörtert, wie der Gleichbehandlungsgrundsatz, der in Artikel 18 AEUV festgelegt ist, sich auf Drittstaatsangehörige auswirkt. Der Gerichtshof der Europäischen Union hat in dem Vatsouras-Urteil entschieden, dass der Gleichbehandlungsgrundsatz keine Anwendung auf eine mögliche Ungleichbehandlung zwischen einem Staatsangehörigen eines Mitgliedstaates und einem Drittstaatsangehörigen findet, wenn sie in den Geltungsbereich des EU-Rechts fällt. Der Gleichbehandlungsgrundsatz besagt, dass ähnliche Situationen nicht unterschiedlich behandelt werden dürfen sofern die Differenzierung nicht objektiv gerechtfertigt ist. Diese Haltung wurde kritisiert, insbesondere auch deshalb, weil der Gerichtshof seine Entscheidung nicht weiter erklärt hat.

Die Dissertation kommt zu dem Ergebnis, dass eine Gleichbehandlung von Drittstaatsangehörigen aufgrund der unterschiedlichen EU-Rechtsquellen nur auf eine mannigfaltige, hoch selektive Art gewährt wird. Der Grund für diesen „Flickenteppich“ von Rechtsgrundlagen sind die verschiedenen Rechtsquellen, deren 
Anwendung von einer Vielzahl von Kriterien abhängt: die EUAssoziationsabkommen und -Kooperationsmechanismen sind nur gültig für Drittstaatsangehörige, die eine bestimmte Nationalität besitzen, und Gleichbehandlung wird größtenteils nur für bestimmte und begrenzte Bereiche gebilligt, zum Beispiel Gleichbehandlung bezüglich der Arbeitsbedingungen. Das europäische Sekundärrecht, das unter dem Titel IV des Vertrags von Amsterdam erlassen wurde, sieht die Gleichbehandlung für einige ausgewählte Bereiche für diejenigen Drittstaatsangehörige vor, auf die das jeweilige Gesetz Anwendung findet. Außerdem hat auch der allgemeine Nichtdiskriminierungsgrundsatz aufgrund von Nationalität im Bezug auf Drittstaatsangehörige seine Grenzen.

Während das Ziel die Rechtsstellung von allen Drittstaatsangehörigen der von EUBürgern anzugleichen in weiter Ferne liegt, muss anerkannt werden, dass das verabschiedete Sekundärrecht zweifellos die rechtliche Situation von allen Drittstaatsangehörigen, die einen rechtmäßigen Aufenthalt in einem EU-Mitgliedstaat haben oder legal in die EU einreisen, verbessert hat. Die Richtlinie betreffend der Rechtsstellung von langfristig aufenthaltsberechtigten Drittstaatsangehörigen hat die Rechtsposition von Drittstaatsangehörigen gestärkt, die sich mindestens fünf Jahre rechtmäßig in einem Mitgliedstaat aufgehalten haben, und die Richtlinie betreffend das Recht auf Familienzusammenführung ermöglicht die Vereinigung von Familien in einem Mitgliedstaat.

Die Richtlinien über die Bedingungen für die Einreise und den Aufenthalt von Drittstaatsangehörigen zur Ausübung einer hochqualifizierten Beschäftigung, sowie über das besonderes Zulassungsverfahren für Drittstaatsangehörige zum Zwecke der wissenschaftlichen Forschung, haben ein rechtliches System für bestimmte Gruppen von Drittstaatsangehörige geschaffen, das unabhängig von der Nationalität anwendbar ist. Darüber hinaus hat die Richtlinie über das einheitliches Verfahren zur Beantragung einer kombinierten Erlaubnis für Drittstaatsangehörige, sich im Hoheitsgebiet eines Mitgliedstaats aufzuhalten und zu arbeiten, sowie über ein gemeinsames Bündel von Rechten für Drittstaatsarbeitnehmer, die sich rechtmäßig in einem Mitgliedstaat aufhalten die Einreise- und Aufenthaltsbedingungen von Drittstaatsangehörigen, die schon in der EU leben und arbeiten oder dies beabsichtigen, vereinfacht. Die Verabschiedung dieser Richtlinien, die nicht aufgrund von Staatsangehörigkeit diskriminiert, ist willkommen. Jedoch stellen diese Rechtsinstrumente lediglich den „kleinsten gemeinsamen Nenner“ dar, und zielen in ihrer Gesamtheit nicht darauf ab, die Rechtsstellung von Drittstaatsangehörigen an die von Staatsangehörigen von Mitgliedstaaten anzugleichen, wie es in den TampereSchlussfolgerungen vom 15. und 16. Oktober 1999 formuliert wurde.

Aufgrund der Ergebnisse meiner Dissertation möchte folgende Empfehlungen abgeben im Hinblick darauf die europäische Migrationspolitik und das europäische Einwanderungsrecht zu verbessern.

\section{Schaffung einer europä̈schen Einwanderungspolitik zur Förderung einer „inklusiven“ Union}

Meine Dissertation hat gezeigt, dass eine gemeinsame europäische Migrationspolitik, die paritätisch auf alle Drittstaatsangehörigen Anwendung findet, derzeitig nicht besteht. Das hoch selektive System, das das Migrationsrecht acquis prägt, könnte umgewandelt werden in eine Einwanderungspolitik mit einer verbesserten 
Gleichbehandlung aller Drittstaatsangehörigen. Die Union sollte sich ,inklusiv“ verhalten und alle Migranten willkommen heißen. Es liegt an den nationalen und supranationalen politischen Entscheidungsträgern die nötigen Maßnahmen hierfür zu treffen.

\section{Eine verbesserte Gleichbehandlung aller Drittstaatsangehörigen}

Gleichbehandlung ist von herausragender Wichtigkeit für eine europäische Migrationspolitik, die alle Einwanderungsgemeinschaften in gleichem Maße als kulturell, wirtschaftlich und sozial bereichernde Gruppe von Individuen im Gastland erachtet und die eine Integration in die empfangende Gesellschaft erleichtert. Die Frage stellt sich, ob es wirklich unvorstellbar ist, Gleichbehandlung auf eine kohärentere Weise auf alle Drittstaatsangehörigen auszuweiten. P. Boeles hat eine Einwanderungspolitik vorgeschlagen, in der Ausnahmen für eine Gleichbehandlung von Drittstaatsangehörigen auf Aufenthaltsstatus, und nicht auf Staatsangehörigkeit basiert. Seine Theorie sieht vor, dass Maßnahmen im Bereich des Migrationsrechts, die Staatsangehörige von Mitgliedstaaten oder Drittstaaten betreffen, und die nicht gegenüber eigenen Staatsangehörigen genommen werden können, nur gerechtfertigt sind, wenn sie geeignet und verhältnismäßig sind. Während diese interessante Theorie sicherlich nicht in ihrem ganzen Umfang in die Realität umsetzbar ist, könnten doch einige Elemente übernommen werden. So könnte zum Beispiel die Staatsangehörigkeit das ausschlaggebende Kriterium für ein Einreiserecht bleiben für Kurzaufenthalte (EU weiße und schwarze Liste) sowie Aufenthalte von längerer Dauer (Zuständigkeit bei den Mitgliedstaaten). Jedoch könnte die Dauer des Aufenthaltes der maßgebende Faktor sein, für den Umfang von Rechten, auf die sich Einwanderer im Gastland berufen können, nach dem sie dort eine gewisse Zeit gelebt haben. Dieser Ansatz spiegelt sich in der Richtlinie 2003/109/EG betreffend der Rechtsstellung von langfristig aufenthaltsberechtigten Drittstaatsangehörigen wider. Folglich ist es möglich ein wahrhaftig gemeinsames Migrationssystem aufzubauen, das dadurch gekennzeichnet ist, dass Aufenthaltsdauer Staatsangehörigkeit als entscheidendes Kriterium ersetzt

\section{Eine erböhte Transparenz und verstärkte Sensibilisierung}

Ein erster Schritt die heutige, fragmentierte europäische Migrationspolitik anzupacken, besteht darin die Transparenz der komplexen Strukturen, die das europäische Migrationsrecht definieren, $\mathrm{zu}$ verbessern. Das europäische Sekundärrecht, das unter Titel V des Vertrags von Lissabon erlassen wurde, wird oftmals als Grundlage für eine gemeinsame europäische Migrationspolitik dargestellt, ohne jedoch näher auf die verschiedenen Assoziations-, Kooperations- und Partnerschaftsabkommen einzugehen. Politische Entscheidungsträger sollten das Bewusstsein in der Zivilbevölkerung für das derzeitige Migrationsrecht schärfen mit besonderem Hinblick auf potenzielle Migranten. Eine erste Initiative ist das EUEinwanderungsportal, das Ausländern, die die Absicht haben in die EU einzureisen, aktuelle und praktische Informationen bereitstellt, die online abgerufen werden können. 


\section{Die Einführung eines angepassten und umfangreichen Migrationskodexes}

Politische Entscheidungsträger sollten zudem einen angepassten und umfangreichen Migrationskodex einführen, der auf dem acquis communautaire basiert, und das bestehende europäische Migrationsrecht konsolidiert, verbessert und in einem Dokument vereint. In einem derartigen Migrationskodex könnten vereinfachte und fairere Verfahrensregelungen und deutlichere Regelungen für Wirtschaftsmigration in die EU verankert werden. Aber auch Familienzusammenführung und der Status von langfristig aufenthaltsberechtigten Drittstaatsangehörigen könnte darin erheblich optimiert werden.

\section{Die Wichtigkeit eines Ansatzes, der auf Rechten basiert}

Um die Ziele des Rates von Tampere, insbesondere eine Angleichung der Rechte von Drittstaatsangehörigen im Vergleich zu den Rechten von Staatsangehörigen von Mitgliedstaaten zu erreichen, sollte die europäische Migrationspolitik einen Ansatz folgen, der auf Rechten basiert und Migranten und deren Familienangehörige in den Mittelpunkt stellt. Der Gesamtansatz für Migration und Mobilität, dem die Europäische Kommission 2011 einen neuen Impetus gegeben hat, integriert und kommuniziert wichtige Aspekt in dieser Hinsicht: der Schutz von Rechten von Migranten und der Fokus auf den Menschen. Ein Migrationskodex könnte hier die Menschenrechtsdimension in ein rechtlich bindendes Gesetzeswerk festlegen.

\section{Migration als ein positives Phänomen kommunizieren von dem Gesellschaften profitieren}

Es ist Aufgabe der Politik Migration und Einwanderung als ein positives und zukunftsträchtiges Phänomen zu kommunizieren. Unwissenheit und Ignoranz bieten Vorurteilen, Misstrauen und Angst gegenüber Bevölkerungsschichten mit Migrationshintergrund Nährboden, was im schlimmsten Fall in rassistischen und fremdenfeindlichen Haltungen kulminieren kann. In wirtschaftlich schwierigen Zeiten verschärfen sich derartige Entwicklungen, die sich im Zuwachs von rechtspopulistischer Propaganda widerspiegelt. Regierungen und Parlamente nationale und europäische Entscheidungsträger - sollten tätig werden und das Bewusstsein der Bevölkerungen hierfür auf Grundlage von Fakten sensibilisieren. Aber auch die Zivilgesellschaft, internationale und regierungsunabhängige Organisationen, sowie der privatwirtschaftliche Sektor spielen eine wichtige Rolle in diesem Unterfangen. In diesem Zusammenhang ist der Gesamtansatz für Migration und Mobilität ein richtiger Schritt und die öffentliche Konsultation, zu der die Europäische Kommission zwischen April und Juni 2012 aufgerufen hat, sehr zu begrüßen. Die Europa-2020-Strategie sieht vor, dass Migration und Mobilität zu einem stärkeren wirtschaftlichen Wachstum und zu mehr Vitalität beitragen und die Wettbewerbsfähigkeit der EU ankurbeln. Europa ist gekennzeichnet durch alternde Gesellschaftsstrukturen und Geburtenrückgänge, die eine anpassungsfähige Erwerbsbevölkerung, die der Nachfrage der Arbeitsmärkte entspricht, sowie eine nachfrageorientierte Einwanderungspolitik erfordern. 
7. Die Entwicklung eines stärkeres institutionellen Rahmenwerks, das sich kooperativ mit Migrationsfragen beschäftigt

Eine intensive Kooperation auf institutioneller Ebene wird regelmäßige Dialoge und den Informationsaustausch zwischen Organisationen und Interessenvertretern darüber, wie grenzüberschreitende Migration besser verwaltet werden kann, erleichtern. In diesem Sinne bieten die Initiativen wie das „Global Forum on Migration and Development“ und der „UN High-Level Dialogue on International Migration and Development" wichtige Foren auf internationalem Parkett. Im Juli 2012 wurde für EU Migrationsfragen eine „strategische Partnerschaft“ ins Leben gerufen, die die Zusammenarbeit zwischen der internationalen Organisation für Migration, dem Europäischen Außendienst sowie der Europäischen Kommission vertiefen soll. Es ist zu hoffen, dass diese Partnerschaft effektiv genutzt wird, und auf diese Weise zu erfolgreichen Diskussionen und praktischen Ergebnissen in der Politik führt.

\section{Ratifizierung der UN-Konvention zum Schutz der Rechte aller W anderarbeitnehmer}

Die UN-Konvention zum Schutz der Rechte aller Wanderarbeitnehmer hat ein umfangreiches, internationales, rechtliches Rahmenwerk für den Schutz von Migranten und deren Familienangehörigen geschaffen. Bedauerlicherweise haben bis zum heutigen Tag nur wenige Staaten die UN-Konvention ratifiziert. Insbesondere die EU-Mitgliedstaaten sollten Vertragsstaaten der UN-Konvention werden um die Anzahl der Ratifikationen von Industriestaaten zu erhöhen und somit wesentlich zu einer sichereren Rechtsstellung von Migranten beitragen. 



\section{Part XII : Bibliography}

D. Acosta Arcarazo, The Long-Term Residence Status as a Subsidiary Form of EU Citizenship: An Analysis of Directive 2003/109 (Martinus Nijhoff Publishers, Leiden 2011).

A. Akgündüz, Labour Migration from Turkey to Western Europe, 1960-1974 (Amsterdam University Press, Amsterdam 2007).

Amnesty International, press release "Amnesty International EU office Reaction to the Return Directive Vote" of 18 June 2008.

K. Annan, UN Secretary-General Report on International Migration and Development, UN/GA A/60/871 of 18 May 2006

Y. Arai-Takahashi, 'Uneven, But in the Direction of Enhanced Effectiveness - A Critical Analysis of "Anticipatory Ill-Treatment" under Article 3 ECHR', 20 Netherlands Quarterly of Human Rights (2002), 5.

F. Attina, 'The Euro-Mediterranean Partnership Assessed: The Realist and Liberal Views', 8 European Foreign Affairs Review (2003), 181.

R. Atzeni, 'L'article 13 de l'Accord de Cotonou et la compétence communautaire en matière de conclusion d'accords de réadmission', 42 Revue trimestrielle de droit européen (2006), 621.

G. Avci, 'Turkey's Slow Candidacy: Insurmountable Hurdles to Membership or Simple Euro-Scepticism', in: A. Çarkoğlu and B. Rubin (eds.), Turkey and the European Union (Frank Cass, London 2003), 149-170.

O. Babarinde and G. Faber, 'From Lomé to Cotonou: Business as Usual?', 9 European Foreign Affairs Review (2004), 27.

K. Bade, Migration in European History (Blackwell Publishing, Oxford 2003).

A. Baldaccini, 'The External Dimension of the EU's Asylum and Immigration Policies: Old Concerns and New Approaches', in: A. Baldaccini, E. Guild and H. Toner (eds.), Whose Freedom, Security and Justice? EU Immigration and Asylum Law and Policy (Hart Publishing, Oxford 2007), 276-298.

R. Baratta, 'Overlaps between European Community Competence and European Union Foreign Policy Activity', in: E. Cannizzaro (ed.), The European Union as an Actor in International Relations (Kluwer Law International, The Hague 2002), 51-76.

C. Barnard, 'Case C-209/03, R (on the application of Danny Bidar) v. London Borough of Ealing, Secretary of State for Education and Skills', 42 Common Market Law Review (2005), 1465. 
P. Barry, The Courier ACP-EC, 'ACP-EEC Convention - Lomé III', No 89 JanuaryFebruary 1985, Special Issue, 7.

J. Bast, Aufenthaltsrecht und Migrationssteuerung (Mohr Siebeck, Tübingen 2011).

M. Bell, 'The New Article 13 EC Treaty: A Sound Basis for European AntiDiscrimination Law? ', 6 Maastricht Journal of European and Comparative Law (1999), 5.

M. Bell, Anti-Discrimination Law and the European Union (Oxford University Press, Oxford 2002).

M. Bell, 'The Principle of Equality: Widening and Deepening', in: P. Craig and G. De Búrca (eds.), The Evolution of EU Law (2nd edn. Oxford University Press, Oxford 2011), 611-640.

S. Berghahn, 'Deutschlands konfrontativer Umgang mit dem Kopftuch der Lehrerin', in: S. Berghahn and P. Rostock (eds.), Der Stoff aus dem Konflikte sind - Debatten um das Kopftuch in Deutschland, Österreich und der Schweiz. (Transcript Verlag, Bielefeld 2009), 3372.

R. Bieber, 'Quelques remarques à l'occasion de l'entrée en vigueur des accords bilateraux suisse-CE', in: R. Bieber (ed.), Mélanges en l'honneur de Bernard Dutoit (Librairie Droz, Genève 2002), 13-20.

I. Boccardi, Europe and Refugees: Towards an EU Asylum Policy (Kluwer Law International, The Hague 2002).

A. Böcker and E. Guild, Implementation of the Europe Agreements in France, Germany, the Netherlands and the UK: Movement of Persons (Platinium, London 2002).

S. Boelaert-Suominen, 'Non-EU Nationals and the Council Directive 2003/109/EC on the Status of Third-Country Nationals who are Long-Term Residents: Five Paces Forward and Possibly Three Paces Back', 42 Common Market Law Review (2005), 1011.

P. Boeles, 'Europese burgers en derdelanders: wat betekent het verbod van discriminatie naar nationaliteit sinds Amsterdam?', 12 Sociaal-Economische Wetgeving (2005), 500 .

P. Boeles and M. Den Heijer, European Migration Law (Intersentia, Leiden 2009).

R. Bohning, 'The ILO and the New UN Convention on Migrant Workers: The Past and Future', International Migration Review (1991), 698.

G. Bono, 'Some Reflections on the CFSP Legal Order', 43 Common Market Law Review (2006), 337.

A. Borghi, La libre circulation des personnes entre la Suisse et PUE (Editions interuniversitaires suisses, Genève 2010). 
L.S. Bosniak, 'Human Rights, State Sovereignty and the Protection of Undocumented Migrants under the International Migrant Workers Convention', 25 International Migration Review (1991), 737.

C. Boswell, "The "External Dimension" of EU Immigration and Asylum Policy', 79 International Affairs (2003), 619.

A. Boudahrain, 'The Insecure Social Protection of Migrant Workers from the Maghreb', 53 International Social Security Review (2000), 47.

B. Brandtner, 'The Drama of the EEA Comments on Opinions 1/91 and 1/92', 3 European Journal of International Law (1992), 300.

S. Breitenmoser, 'Sectoral Agreements between the EC and Switzerland: Contents and Context', 40 Common Market Law Review (2003), 1137.

E. Bribosia and A. Weyembergh, Nouveaux instruments normatifs et nouvelles avancées jurisprudentielles en matière de lutte contre les discriminations sur base de la nationalité après le traité d'Amsterdam', in: E. Bribosia and others (eds.), Union européenne et nationalités: le principe de non-discrimination et ses limites (Bruylant, Bruxelles 1999), 239-248.

M.V. Brombacher Steiner, 'Die soziale Sicherheit im Abkommen über die Freizügigkeit der Personen', in: C. Kaddous and D. Felder (eds.), Accords Bilatéraux Suisse - Union Européenne: Commentaires (Helbing \& Lichtenhahn, Basel 2001), 353-368.

I. Brownlie, Principles of Public International Law (7th edn. Oxford University Press, Oxford 2008).

M. Bulterman, 'Case C-277/94 Taflan-Met and Akol [1996] ECR I-4085', 34 Common Market Law Review (1997), 1497.

J. Bustamante, 'Promotion and Protection of All Human Rights, Civil, Political, Economic, Social and Cultural Rights, including the Right to Development', Report of the Special Rapporteur on the Human Rights of Migrants, 5 March 2008, document number: A/HRC/7/12/Add.2.

P.J. Cardwell, EU External Relations and Systems of Governance: The CFSP, EuroMediterranean Partnership and Migration (Routledge, Abingdon 2009).

S. Carrera, 'What Does Free Movement Mean in Theory and Practice in an Enlarged EU?', 11 European Law Journal (2005), 699.

S. Carrera, In Search of the Perfect Citizen? The Intersection between Integration, Immigration, and Nationality in the EU (Martinus Nijhoff Publishers, Leiden 2009).

S. Carrera and M. Formisano, 'An EU Approach to Labour Migration: What is the Added Value and the Way Ahead?', 232 Centre for European Policy Studies Working Document (2005), 7. 
S. Carrera and R. Hernández i Sagrera, 'The Externalisation of the EU's Labour Immigration - Towards Mobility or Insecurity Partnerships?', Centre for European Policy Studies Working Document (2009).

S. Carrera and M. Merlino, 'Undocumented Immigrants and Rights in the EU addressing the Gap between Social Science Research and Policy-Making in the Stockholm Programme', CEPS Liberty and Security in Europe (2009).

S. Carrera and others, 'The French Presidency's European Pact on Immigration and Asylum: Intergovernmentalism vs. Europeanisation? Security vs. Rights?', CEPS Policy Brief No 170 (2008).

S. Carrera and A. Wiesbrock, Whose Citizenship to Empower in the Area of Freedom, Security and Justice? The Act of Mobility and Litigation in the Enactment of European Citizenship', Centre for European Policy Studies Working Document (2010).

S. Castles and G. Kosack, Immigrant Workers and Class Structure in Western Europe (Oxford University Press, Oxford 1985).

O. Cattaneo and J. Nielsen, Service Providers on the Move: The Economic Impact of Mode 4 (OECD Working Party of Trade Committee, Paris 2003).

D. Chalmers, European Union Public Law (Cambridge University Press, Cambridge 2010).

D. Chalmers and G. Monti, European Union Law: Text and Materials (Cambridge University Press, Cambridge 2006).

R. Chanda, 'Movement of Natural Persons and the GATS', 24 The World Economy (2001), 631.

V. Chetail, 'Paradigm and Paradox of the Migration-Development Nexus: The New Border for North-South Dialogue', 52 German Yearbook of International Law (2008), 183.

I. Cheyne, 'Haegeman, Demirel and their Progeny', in: A. Dashwood and C. Hillion (eds.), The General Law of the EC External Relations (Sweet \& Maxwell, London 2000), $20-41$.

I. Cheyne, 'International Instruments as a Source of Community Law', in: A. Dashwood and C. Hillion (eds.), The General Law of the EC External Relations (Sweet \& Maxwell, London 2000), 254-275.

R. Cholewinski, 'Strasbourg's "Hidden Agenda"?: The Protection of SecondGeneration Migrants from Expulsion under Article 8 of the European Convention on Human Rights', 12 Netherlands Quarterly of Human Rights (1994), 287.

R. Cholewinski, Migrant Workers in International Human Rights Law: Their Protection in Countries of Employment (Clarendon Press, Oxford 1997). 
R. Cholewinski, 'Borders and Discrimination in the European Union', ILPA/Migration Policy Group (London/Brussels 2002).

R. Cholewinski, 'The Rights of Migrant Workers', in: R. Cholewinski, R. Perruchoud and E. MacDonald (eds.), International Migration Law: Developing Paradigms and Key Challenges (T.M.C. Asser Press, The Hague 2007), 255-273.

R. Cholewinski, 'The Human and Labor Rights of Migrants: Visions of Equality', 22 Georgetown Immigration Law Journal (2008), 177.

R. Cholewinski, 'The External Dimension of the EU Immigration Policy', in: M. Maes, M.-C. Foblets and Ph. De Bruycker (eds.), External Dimensions of European Migration and Asylum Law and Policy (Bruylant, Bruxelles 2011), 485-500.

M. Cini, European Union Politics (Oxford University Press, Oxford 2007).

M.A. Clemens, 'Economics and Emigration: Trillion-Dollar Bills on the Sidewalk?', 25 The Journal of Economic Perspectives (2011), 83.

E. Collett, 'The “Global Approach to Migration”: Rhetoric or Reality?', European Policy Centre (2007).

E. Collett, 'The EU Immigration Pact - from Hague to Stockholm, via Paris', EPC Policy Brief (2008).

M. Comelli, 'The Challenges of the European Neighbourhood Policy', 39 The International Spectator (2004), 97.

M. Condinanzi, A. Lang and B. Nascimbene, Citizenship of the Union and Free Movement of Persons (Martinus Nijhoff Publishers, Leiden 2008).

R. Cornelissen, 'The European Co-ordination of Social Security and Third Country Nationals', in: D. Pieters and P. Schoukens (eds.), The Social Security Co-ordination Between the EU and Non-EU Countries (Intersentia, Antwerp 2009), 1-17.

P. Craig and G. De Búrca, EU Law: Text, Cases, and Materials (4th edn. Oxford University Press, Oxford 2008).

M.C.R. Craven, The International Covenant on Economic, Social, and Cultural Rights: A Perspective on its Development (Clarendon Press, Oxford 1995).

M. Cremona, 'The Doctrine of Exclusivity and the Position of Mixed Agreements in the External Relations of the European Community', 2 Oxford Journal of Legal Studies (1982), 393.

M. Cremona, "The "Dynamic and Homogeneous" EEA: Byzantine Structures and Variable Geometry', 19 European Law Review (1994), 508. 
M. Cremona, 'Citizens of Third Countries: Movement and Employment of Migrant Workers within the European Union', 2 Legal Issues of European Integration (1995), 87.

M. Cremona, 'External Relations and External Competence: The Emergence of an Integrated Policy', in: P. Craig and G. de Búrca (eds.), The Evolution of EU Law (Oxford University Press, Oxford 1999), 137-175.

M. Cremona, 'External Relations of the EU and the Member States: Competence, Mixed Agreements, International Responsibility, and Effects of International Law', EUI Working Papers LAW (2006).

M. Cremona, 'Defining Competence in EU External Relations: Lessons from the Treaty Reform Process', in: A. Dashwood and M. Maresceau (eds.), Law and Practice of EU External Relations: Salient Features of a Changing Landscape (Cambridge University Press, Cambridge 2008), 34-69.

K.A. Dahlberg, 'The EEC Commission and the Politics of the Free Movement of Labour', 6 Journal of Common Market Studies (1968), 310.

A. Dashwood, 'The Paper Tiger that is No Threat to Britain's Fundamental Rights', Parliamentary Brief, 10 March 2008.

A. Dashwood and J. Heliskoski, 'The Classic Authorities Revisited', in: A. Dashwood and C. Hillion (eds.), The General Law of EC External Relations (Sweet \& Maxwell, London 2000), 3-19.

G. De Baere, 'The Framework of EU External Competences for Developing the External Dimension of the EU Asylum and Migration Policy', 50 Leuven Centre for Global Governance Studies Working Paper (2010).

P. De Bruycker, 'Vers un statut des ressortissants des pays-tiers dans le traité d'Amsterdam: libre circulation ou discrimination?', in: E. Bribosia and others (eds.), Union européenne et nationalités: le principe de non-discrimination et ses limites (Bruylant, Bruxelles 1999), 227-238.

P. De Bruycker, 'L'émergence d'une politique européenne d'immigration', in: P. De Bruycker (ed.), L'émergence d'une politique européenne d'immigration (Bruylant, Bruxelles 2003), 1-95.

G. De Búrca, 'The Drafting of the EU Charter of Fundamental Rights', 26 European Law Review (2001), 126.

E. De Vos, 'The Cotonou Agreement: A Case of Forced Regional Integration?', in: G. Kreijen (ed.), State, Sovereignty, and International Governance (Oxford University Press, Oxford 2002), 497-518.

E. Decaux, 'Le Processus de Décision de la PESC: Vers une Politique Etrangère Européenne?’, in: E. Cannizzaro (ed.), The European Union as an Actor in International Relations (Kluwer Law International, The Hague 2002), 17-49. 
A. Deighton, 'The European Security and Defence Policy', 40 Journal of Common Market Studies (2002), 719.

C. Decker, 'Case Note on Leyla Şahin v. Turkey', 6 European Human Rights Law Review (2004), 672.

J. Delbrück and C. Tietje, 'Die Frage der unmittelbaren Anwendbarkeit des Assoziationsbeschlusses EWG/Türkei Nr. 3/80', 1 Zeitschrift für Ausländerrecht und Ausländerpolitik (1995), 29.

M.B. Dembour, 'Human Rights Law and National Sovereignty in Collusion: The Plight of Quasi-Nationals in Strasbourg', 21 Netherlands Quarterly of Human Rights (2003), 63.

E. Denza, The Intergovernmental Pillars of the European Union (Oxford University Press, Oxford 2002).

P. Devisscher, 'Legal Migration in the Relationship between the European Union and ACP Countries: The Absence of a True Global Approach Continues', 13 European Journal of Migration and Law (2011), 53.

A. Drzemczewski, 'The Position of Aliens in Relation to the European Convention of Human Rights: A General Survey', in: Council of Europe (ed.), Human Rights of Aliens in Europe (Martinus Nijhoff Publishers, Dordrecht 1985), 351-399.

S. Duke, 'The Treaty of Lisbon and External Relations', EIPASCOPE (2008), 13.

S. Duke, 'Providing for European-Level Diplomacy after Lisbon: The Case of the European External Action Service', 4 The Hague Journal of Diplomacy (2009), 211.

ECDPM, 'The EU-Africa Partnership in Historical Perspective', Issue Paper I (2006).

P.W. Edge, 'The European Court of Human Rights and Religious Rights', 47 International and Comparative Law Quarterly (1998), 680.

P. Eeckhout, EU External Relations Law (2nd edn. Oxford University Press, Oxford 2011).

K. Eisele, 'Case C-484/07 Pehlivan', 18 Mastricht Journal of European and Comparative Law (2011), 573.

K. Eisele, 'The Movement Regime of Turkish Citizens based on the Ankara Association - An Ever-Growing Mosaic of Rights?', in: H. Kabaalioğlu, A. Ott and A. Tatham (eds.), EU and Turkey: Bridging the Differences (Economic Development Foundation İstanbul 2011), 31-66.

K. Eisele, 'Reinforcing Migrants' Rights? The EU's Migration and Development Policy under Review', 5 Global Justice Network Journal: Special Issue on Global Justice and Migration (2012), 31. 
K. Eisele and A.P. van der Mei, 'Portability of Social Benefits and Reverse Discrimination of EU Citizens vis-à-vis Turkish Nationals: Comment on Akdas', 37 European Law Review (2012), 204.

K. Eisele and A. Wiesbrock, 'Enhancing Mobility in the European Neighborhood Policy? The Cases of Moldova and Georgia', 36 Review of Central and East European Law (2011), 127.

A. Epiney, 'Die schweizerische Rechtsprechung zum Personenfreizügigkeitsabkommen - ein Überblick', Annuaire du droit de la migration 2004/2005 (2005), 141.

A. Epiney, 'Zur Bedeutung der Rechtsprechung des EuGH für die Anwendung und Auslegung des Personenfreizügigkeitsabkommen', 141 Zeitscbrift des Bernischen Juristenvereins (2005), 1.

EU Agency for Fundamental Rights, European Court of Human Rights and Council of Europe, Handbook on European Non-Discrimination Law (Vienna/Strasbourg 2011).

Europa, press release "Wider Europe Neighbourhood: proposed new framework for relations with the EU's Eastern and Southern Neighbours", IP/03/358 of 11 March 2003.

Europa, press release "EEAS Decision - main elements", MEMO/10/311, of 8 July 2010.

Europa, press release "A new step in the setting-up of the EEAS: Transfer of staff on 1 January 2011”, IP/10/1769, 21 December 2010.

Europa, press release "Moving to the EU? Good advice is now just a few clicks away", IP/11/1370, 18 November 2011.

A. Farahat, 'Is there a Human Right to Equal Social Security? EU Migration Law and the Requirements of Art. 9 ICESCR', in: M. Maes, M.-C. Foblets and Ph. De Bruycker (eds.), External Dimensions of European Migration and Asylum Law and Policy (Bruylant, Bruxelles 2011), 529-548.

D. Feldman, 'The Developing Scope of Article 8 of the European Convention on Human Rights', 3 European Human Rights Law Review (1997), 265.

N. Fennelly, 'Pillar Talk: Fundamental Rights Protection in the European Union', Judicial Studies Institute Journal (2008), 95.

F. Filliez, 'Schengen/Dublin: The Association Agreements with Iceland, Norway and Switzerland', in: B. Martenczuk and S. Van Thiel (eds.), Justice, Liberty, Security: New Challenges for EU External Relations (VUBPRESS, Brussels 2008), 145-183.

J. Fitzpatrick, 'Revitalizing the 1951 Refugee Convention', 9 Harvard Human Rights Journal (1996), 229. 
J. Fitzpatrick, 'The Human Rights of Migrants', in: T.A. Aleinikoff and V. Chetail (eds.), Migration and International Legal Norms (T.M.C. Asser Press, The Hague 2003) 169-184.

C. Flaesch-Mougin, Les accords externes de la Communauté économique européenne: essai done typologie (Editions de L'Université de Bruxelles, Bruxelles 1979).

C. Flaesch-Mougin and J. Lebullenger, 'Les relations contractuelles de l'Union européenne avec les pays et groupement latino-américains', in: European Communities (ed.), The European Union in a Changing World (European Commission, Bruxelles 1996), 581-628.

C. Forder, 'Family Rights and Immigration Law: A European Perspective', in: H. Schneider (ed.), Migration, Integration and Citizenship (Forum Maastricht, Maastricht 2005), 71-108.

J. Forman, 'The EEA Agreement Five Years On: Dynamic Homogeneity in Practice and its Implementation by the two EEA Courts', 36 Common Market Law Review (1999), 751.

M. Garbagnati Ketvel, 'The Jurisdiction of the European Court of Justice in Respect of the Common Foreign and Security Policy', 55 International and Comparative Law Quarterly (2006), 77.

S. Garben, 'The Bologna Process: From a European Law Perspective', 16 European Law Journal (2010), 186.

J.C. Gautron, 'De Lomé à Cotonou: rupture et continuité conventionelles', in: A. De Walsche and G. Vandersanden (eds.), Mélanges en hommage à Jean-Victor Louis (Université Libre de Bruxelles, Bruxelles 2003), 79-93.

W. Gerven, 'The Genesis of EEA Law and the Principles of Primacy and Direct Effect', 16 Fordham International Law Journal (1992), 955.

M.A. Glendon, 'Knowing the Universal Declaration of Human Rights', 73 Notre Dame Law Review (1997), 1153.

Global Commission on International Migration, Migration in a Interconnected World: New Directions for Action (SRO-Kundig, Switzerland 2005).

S. Goedings, Labor Migration in an Integrating Europe: National Migration Policies and the Free Movement of Workers, 1950-1968 (Sdu Uitgevers, The Hague 2005).

M. Gondek, 'Extraterritorial Application of The European Convention on Human Rights: Territorial Focus in the Age of Globalization?', 52 Netherlands International Law Review (2005), 3.

G. Gori, Towards an EU Right to Education (Kluwer Law International, The Hague 2001). 
S. Grant, 'International Migration and Human Rights', Global Commission on International Migration (2005).

K. Groenendijk, 'Are Third-Country Nationals Protected by the Union Law Prohibition of Discrimination on Grounds of Nationality?', in: K. Barwig and R. Dobbelstein (eds.), Den Fremden akezeptieren - Festschrift für Gisbert Brinkmann (Nomos, Baden-Baden 2012), 131-141.

K. Groenendijk, 'Citizens and Third-Country Nationals: Differential Treatment or Discrimination', in: J.-Y. Carlier and E. Guild (eds.), L'avenir de la libre circulation des personnes dans l'UE (Bruylant, Bruxelles 2006), 79-101.

K. Groenendijk and E. Guild, 'Visa Policy of Member States and the EU towards Turkish Nationals after Soysal', 249 Economic Development Foundation Publications, Second revised and updated version (Istanbul 2011).

E. Guild, 'The European Convention on the Legal Status of the Migrant Workers (1977): An Analysis of its Scope and Benefits' (Council of Europe, Strasbourg 1999), document number: mig \tmg \docs $\backslash 99 \backslash$ cdmg (99) $11 \mathrm{e}$.

E. Guild, Immigration Law in the European Community (Kluwer Law International, The Hague 2001).

E. Guild, The Legal Elements of European Identity: EU Citizenship and Migration Law (Kluwer Law International, The Hague 2004).

E. Guild and A. Baldaccini, Terrorism and the Foreigner: A Decade of Tension Around the Rule of Law in Europe (Martinus Nijhoff Publishers, 2007).

E. Guild and D. Bigo, 'La mise à l'écarts des étrangers - La logique du Visa Schengen', 49 Cultures \& Conflits (2003), 85-95.

E. Guild, S. Carrera and A. Atger, 'Challenges and Prospects for the EU's Area of Freedom, Security and Justice: Recommendations to the European Commission for the Stockholm Programme', CEPS Working Document No 313 (2009).

E. Guild and others, A Guide to the Right of Establishment under the Europe Agreements (Baileys Shaw \& Gillett in association with the Immigration Law Practitioners' Association, London 1996).

E. Guild and S. Peers, 'Out of the Ghetto? The Personal Scope of EU Law', in: S. Peers and N. Rogers (eds.), EU Immigration and Asylum Law (Martinus Nijhoff, Leiden 2006), 81-114.

K. Hailbronner, 'Visafreiheit für türkische Staatsangehörige? Zum Soysal-Urteil des EuGH', 12 Neue Zeitschrift für Verwaltungsrecht (2009), 760.

F.S. Hakura, 'The External EU Immigration Policy: The Need to Move Beyond the Orthodoxy', 3 European Foreign Affairs Review (1998), 115. 
T. Hammarberg, 'It is Wrong to Criminalize Migration', 11 European Journal of Migration and Law (2009), 383.

D. Harris, 'A Fresh Impetus for the European Social Charter', 41 International and Comparative Law Quarterly (1992), 659.

T. Hartley, 'International Agreements and the Community Legal System', 8 European Law Review (1983), 383.

M. Hasenau, 'ILO Standards on Migrant Workers: The Fundamentals of the UN Convention and their Genesis', 25 International Migration Review (1991), 687.

T.J. Hatton, 'Should We Have a WTO for International Migration?', 22 Economic Policy (2007), 339.

M. Hedemann-Robinson, 'An Overview of Recent Legal Developments at Community Level in Relation to Third Country Nationals Resident within the European Union, with particular Reference to the Case Law of the European Court of Justice', 38 Common Market Law Review (2001), 525.

F. Hendrickx, 'The European Non-EU Player and the Kolpak-Case', International Sports Law Journal (2003), 12.

B. Hepple, 'European Social Charter', 17 Industrial Law Journal (1988), 124.

S. Hix, The Political System of the European Union (2nd edn. Palgrave Macmillan, Basingstoke 2005).

B. Hoekman and Ç. Özden, 'The Euro-Mediterranean Partnership: Trade in Services as an Alternative to Migration?', 48 Journal of Common Market Studies (2010), 835.

F. Hoffmeister, 'The Contribution of EU Practice to International Law', in: M. Cremona (ed.), Developments in EU External Relations Law (Oxford University Press, Oxford 2008), 37-127.

House of the Lords - The Select Committee on the European Union, Inquiry on EU's Global Approach on Migration and Mobility, Evidence Session No. 5, 18 July 2012.

V. Hreblay and G. Vandersanden, Les accords de Schengen: origine, fonctionnement, avenir (Bruylant, Brussels 1998).

C. Hublet, 'The Scope of Article 12 of the Treaty of the European Communities visà-vis Third-Country Nationals: Evolution at Last?', 15 European Law Journal (2009), 757.

ILO, 'The European Social Charter and International Labour Standards', 84 International Labour Review (1961), 354. 
ILO, Multilateral Framework on Labour Migration: Non-Binding Principles and Guidelines for a Rights-Based Approach to Labour Migration (International Labour Office, Geneva 2006).

E. Imhof, 'Das Freizügigkeitsabkommen EG-Schweiz und seine Auslegungsmethode', 5-6 Zeitschrift für europäisches Sozial- und Arbeitsrecht (2007), 217.

K. Inglis, 'Treading the Tightrope between Flexibility and Legal Certainty', in: D. Hanf and R. Muñoz (eds.), La libre circulation des personnes - États des lieux et perspectives (Cahiers du Collège d'Europe, Bruxelles 2007).

IOM, The Human Rights of Migrants - IOM Policy and Activity (IOM, Geneva 2009), document number: MC/INF/298 of 12 November 2009.

IOM, World Migration Report 2011 - Communicating Effectively about Migration (IOM, Geneva 2011).

IOM Press Briefing Note, "IOM, European Commission and European External Action Service Strengthen Partnership" of 16 July 2012.

F.G. Jacobs, 'Direct effect and interpretation of international agreements in the recent case law of the European Court of Justice', in: A. Dashwood and M. Maresceau (eds.), Law and Practice of EU External Relations: Salient Features of a Changing Landscape (Cambridge University Press, Cambridge 2008), 13-33.

M.-F. Jarret and F.-R. Mahieu, 'Éthique et Développement dans le Système de Lomé, in: M.-F. Labouz (ed.), Le Partenariat de l'Union Européenne avec les pays tiers (Bruylant, Bruxelles 2000), 59-72.

C. Kaddous, 'Role and Position of the High Representative of the Union for Foreign Affairs and Security Policy under the Treaty of Lisbon', in: S. Griller and J. Ziller (eds.), The Treaty of Lisbon: EU Constitutionalism without a Constitutional Treaty? (Springer Verlag, Wien 2008), 205-221.

C. Kaddous, 'The Relations between the EU and Switzerland', in: A. Dashwood and M. Maresceau (eds.), Law and Practice of EU External Relations: Salient Features of a Changing Landscape (Cambridge University Press, Cambridge 2008), 227-269.

C. Kaddous and M. Jametti Greiner, Accords Bilatéraux II Suisse - Union Européenne et Autres Accords Récents (Helbing \& Lichtenhahn, Basel 2006).

K. Kapuy, 'European and International Law in Relation to the Social Security of Irregular Migrant Workers', in: D. Pieters and P. Schoukens (eds.), The Social Security Co-ordination Between the EU and Non-EU Countries (Intersentia, Antwerp 2009), 115155.

N. Kassenova, 'EU-Central Asian Bilateral Cooperation', in: A. Warkotsch (ed.), The European Union and Central Asia (Routledge, Abingdon 2011), 48-62. 
J. Klabbers, 'International Law in Community Law: The Law and Politics of Direct Effect', 21 Yearbook of European Law (2002), 263.

J. Klabbers, An Introduction to International Institutional Law (3rd edn. Cambridge University Press, Cambridge 2005).

E. Koeb and H. Hohmeister, 'The Revision of Article 13 on Migration of the Cotonou Partnership Agreement: What's at Stake for the ACP? ', ECDPM Briefing Note (Maastricht 2010).

P. Koutrakos, EU International Relations Law (Hart Publishing, Oxford 2006).

P.J. Kuijper, Of 'Mixity' and 'Double-hatting': EU External Relations Law Explained (Vossiuspers UvA, Amsterdam 2008).

H. Lambert, 'The European Court of Human Rights and the Right of Refugees and Other Persons in Need of Protection to Family Reunion', 11 International Journal of Refugee Law (1999), 427.

A. Lazowski, 'EEA Countries (Iceland, Liechtenstein and Norway)', in: S. Blockmans and A. Lazowski (eds.), The European Union and Its Neighbours: A Legal Appraisal of the EU's Policies of Stabilisation, Partnership and Integration (T.M.C. Asser Press, The Hague 2006), 95-146.

A. Lazowski, 'Switzerland', in: S. Blockmans and A. Lazowski (eds.), The European Union and Its Neighbours: A Legal Appraisal of the EU's Policies of Stabilisation, Partnership and Integration (T.M.C. Asser Press, The Hague 2006), 147-184.

K. Lenaerts, 'L'égalité de traitement en droit communautaire - un principe aux apparences multiples', 27 Cabiers de droit européen (1991), 3.

K. Lenaerts and E. De Smijter, 'The European Community's Treaty-Making Competence', 16 Yearbook of European Law (1996), 1.

K. Lewin, 'The Free Movement of Workers', 2 Common Market Law Review (1964), 300.

R.B. Lillich, The Human Rights of Aliens in Contemporary International Law (Manchester University Press, Manchester 1984).

T. Lindholm, 'The Strasbourg Court Dealing with Turkey and the Human Right to Freedom of Religion and Belief: A Critical Assessment in the Light of Recent Case Law (Leyla Sahin v. Turkey, 29 June 2004) ', Strasbourg Consortium (Strasbourg 2005).

S. Laçiner, M. Özcan and I. Bal, European Union with Turkey: The Possible Impact of Turkey's Membership on the European Union (USAK, Ankara 2005). 
J. Lonnroth, 'The International Convention on the Rights of All Migrant Workers and Members of their Families in the Context of International Migration Policies: An Analysis of Ten Years of Negotiation', International Migration Review (1991), 710.

D. Lyon and D. Spini, 'Unveiling the Headscarf Debate', 12 Feminist Legal Studies (2004), 333.

D. MacGoldrick, International Relations Law of the European Union (Longman, London 1997).

I. MacLeod, I.D. Hendry and S. Hyett, The External Relations of the European Communities (Oxford University Press, Oxford 1996).

M. Maresceau and E. Montaguti, 'The Relations between the European Union and Central and Eastern Europe: A Legal Appraisal', 32 Common Market Law Review (1995), 1327.

D. Martin, 'The Privileged Treatment of Turkish Nationals', in: E. Guild and P. Minderhoud (eds.), The First Decade of EU Migration and Asylum Law (Martinus Nijhoff Publishers, Leiden 2012), 75-91.

D.A. Martin, 'The Authority and Responsibility of States', in: T.A. Aleinikoff and V. Chetail (eds.), Migration and International Legal Norms (T.M.C. Asser Press, The Hague 2003), 31-45.

D. Martin and E. Guild, Free Movement of Persons in the European Union (Butterworths, London 1996).

R. Marx, 'Sprachnachweis und Ehegattennachzug', Zeitschrift für Ausländerrecht und Ausländerpolitik (2011), 15.

R. Matsas, 'The Global Forum on Migration and Development: A New Path for Global Governance', The Brussels Journal of International Relations, EGMONT Institute (Brussels 2008).

A. Mattoo and A.G. Carzaniga, Moving People to Deliver Services (World Bank Washington, D.C. 2003).

A.P. van der Mei, Free Movement of Persons Within the European Community - Cross-Border Access to Public Benefits (Hart Publishing, Oxford 2003).

A.P. van der Mei, 'Freedom of Movement for Students: In Search of a More Satisfactory Balance between the Goal to Promote Student Mobility and the Need to Protect Education Systems', in: H. Schneider (ed.), Migration, Integration and Citizenship (Forum Maastricht, Maastricht 2005), 167-186.

A.P. van der Mei, 'The Bozkurt-Interpretation Rule and the Legal Status of Family Members of Turkish Workers under Decision 1/80 of the EEC-Turkey Association Council', 11 European Journal of Migration and Law (2009), 367. 
B. Melis, Negotiating Europe's Immigration Frontiers (Kluwer Law International, The Hague 2001).

A.J. Menéndez, 'Chartering Europe: Legal Status and Policy Implications of the Charter of Fundamental Rights of the European Union', 40 Journal of Common Market Studies (2002), 471.

P.E. Minderhoud, 'Noot Akdas', 9 Jurisprudentie V reemdelingenrecht (2011/276), 1204.

M. de Mol, 'Kücükdeveci: Mangold Revisited - Horizontal Direct Effect of a General Principle of EU Law', 6 European Constitutional Law Review (2010), 293.

G. Moon, 'The Draft Discrimination Protocol to the European Convention on Human Rights: A Progress Report', European Human Rights Law Review (2000), 49.

J.L. Murray, 'Fundamental Rights in the European Community Legal Order', 32 Fordham International Law Journal (2008), 531.

W.A. McKean, Equality and Discrimination under International Law (Clarendon Press, Oxford 1983).

J. Morsink, The Universal Declaration of Human Rights: Origins, Drafting, and Intent (University of Pennsylvania Press, Philadelphia 1999).

E. Muir, 'Enhancing the Effects of Community Law on National Employment Policies: The Mangold Case', European Law Review (2006), 879.

E. Muir, 'Enhancing the Protection of Third-Country Nationals Against Discrimination: Putting EU Anti-Discrimination Law to the Test', 18 Maastricht Journal of European and Comparative Law (2011), 136.

E. Neframi, 'International Responsibility of the European Community and of the Member States under Mixed Agreements', in: E. Cannizzaro (ed.), The European Union as an Actor in International Relations (Kluwer Law International, The Hague 2002), 193 206.

J. Nickless, European Code of Social Security: A Short Guide (Council of Europe Publishing, Strasbourg 2003).

J. Niessen, 'Association Agreements - Part of the Developing Immigration Policy of the European Union', in: E. Antalovsky and others (eds.), Assoziierungsabkommen der EU mit Drittstaaten (Manz Verlag, Wien 1998), 21-28.

J. Niessen, 'International Migration on the EU Foreign Policy Agenda', 1 European Journal of Migration and Law (1999), 483.

J. Niessen, 'Negotiating the Liberalization of Migration: Is GATS a Vehicle or a Model for Global Migration Governance?', European Policy Centre Issue Paper No. 6 (Brussels 2003). 
S. Norberg and others, The European Economic Area: EEA law: A Commentary on the EEA Agreement (Fritzes, Stockholm 1993).

R. O'Connell and R.R. Marin, 'The European Convention and the Relative Rights of Resident Aliens', 5 European Law Journal (1999), 4.

D. O'Keeffe, 'The Schengen Convention: A Suitable Model for European Integration?', 11 Yearbook of European Law (1991), 185.

D. O'Keeffe, 'Exclusive, Concurrent and Shared Competence', in: A. Dashwood and C. Hillion (eds.), The General Law of the EC External Relations (Sweet \& Maxwell, London 2000), 179-199.

D. O'Keeffe and others, Legal Issues of the Maastricht Treaty (Wiley Chancery Law, London 1994).

OECD, GATS: The Case for Open Services Markets (OECD, Paris 2002).

R. van Ooik, 'Cross-Pillar Litigation before the ECJ: Demarcation of Community and Union Competences’, 4 European Constitutional Law Review (2008), 399.

A. Ott, 'Grundfreiheiten', in: F. Merli and S. Huster (eds.), Die Verträge zur EUOsterweiterung - Kommentar mit systematischen Erläuterungen (Berliner Wissenschaftsverlag, Berlin 2008), 129-178.

A. Ott and R. Wessel, 'The EU's External Relations Regime: Multilevel Complexity in an Expanding Union', in: S. Blockmans and A. Lazowski (eds.), The European Union and its Neighbours (T.M.C. Asser Press, The Hague 2006), 19-60.

C. Ovey and R.A.W. White, The European Convention on Human Rights (4th edn. Oxford University Press, Oxford 2006).

K. Pärli, 'Arbeitsrechtliches Diskriminierungsverbot europäischer Wanderarbeitnehmer nach Gemeinschaftsrecht und nach dem Personenfreizügig-keitsrecht mit der Schweiz', Zeitschrift für europäisches Sozial- und Arbeitsrecht (2007), 21.

G. Papagianni, Institutional and Policy Dynamics of EU Migration Law (Martinus Nijhoff Publishers, Leiden 2006).

S. Peers, 'Towards Equality: Actual and Potential Rights of Third-Country Nationals in the European Union', 33 Common Market Law Review (1996), 7.

S. Peers, 'Equality, Free Movement and Social Security', 22 European Law Review (1997), 342.

S. Peers, 'Social Security Equality for Turkish Nationals', 24 European Law Review (1999), 627. 
S. Peers, 'The EC-Switzerland Agreement on Free Movement of Persons: Overview and Analysis', 2 European Journal of Migration and Law (2000), 127.

S. Peers, 'EC Frameworks of International Relations: Cooperation, Partnership and Association', in: A. Dashwood and C. Hillion (eds.), The General Law of the EC External Relations (Sweet \& Maxwell, London 2000), 160-175.

S. Peers, 'Fragmentation or Evasion in the Community's Development Policy? The Impact of Portugal v. Council', in: A. Dashwood and C. Hillion (eds.), The General Law of the EC External Relations (Sweet \& Maxwell, London 2000), 100-114.

S. Peers, 'Irregular Immigration and EU External Relations', in: B. Bogusz and others (eds.), Irregular Migration and Human Rights: Theoretical, European and International Perspectives (Nijhoff, Leiden 2004), 193-219.

S. Peers, 'Transforming Decision-Making on EC Immigration and Asylum Law', 30 European Law Review (2005), 283.

S. Peers, 'Human Rights, Asylum and European Community Law', 24 Refugee Survey Quarterly (2005), 24.

S. Peers, 'The Jurisdiction of the Court of Justice Over EC Immigration and Asylum Law: Time For a Change? ', in: A. Baldaccini, E. Guild and H. Toner (eds.), Whose Freedom, Security and Justice? EU Immigration and Asylum Law and Policy (Hart Publishing, Oxford 2007), 85-108.

S. Peers, 'EU Migration Law and Association Agreements', in: B. Martenczuk and S. Van Thiel (eds.), Justice, Liberty, Security: New Challenges for EU External Relations (VUBPRESS, Brussels 2008), 53-88.

S. Peers, 'EC Immigration Law and EC Association Agreements: Fragmentation or Integration?', 34 European Law Review (2009), 628.

S. Peers, EU Justice and Home Affairs Law (3rd edn. Oxford University Press, Oxford 2011).

S. Peers, 'An EU Immigration Code: Towards a Common Immigration Policy', 14 European Journal of Migration and Law (2012), 33-61.

F. Pennings, European Social Security Law (5th edn. Intersentia, Antwerp 2010).

E. Philippart, 'The Euro-Mediterranean Partnership: A Critical Evaluation of an Ambitious Scheme', 8 European Foreign Affairs Review (2003), 201.

S. Pizarro, 'The Agreements on Social Security between the Community and Third States: Legal Basis and Analysis', Records of the Seminar Social Security in Europe: Social Security in Europe: Equality between Nationals and Non-Nationals, Oporto, 1012 November 1994 (1995). 
R. Plender, International Migration Law (Kluwer Academic Publishers, Dordrecht 1988).

R. Plender, 'Competence, European Community Law and Nationals of Non-Member States', 39 International and Comparative Law Quarterly (1990), 599.

Population Division UN Department of Economic and Social Affairs, World Population Prospects: The 2010 Revision' (2010).

R. Prodi, "A Wider Europe - A Proximity Policy as the Key to Stability", Speech delivered on 5 December 2002 at the Sixth ECSA World Conference on Peace, Stability and Security, Brussels.

J. Raitio, 'The General Principle of Legal Certainty as a General Principle of EU Law', in: U. Bernitz, J. Nergelius and C. Cardner (eds.), General Principles of EC Law in a Process of Development (Kluwer Law International, Alphen aan den Rijn 2008), 47-73.

N. Reslow, 'Deciding on EU External Migration Policy: The Member States and the Mobility Partnerships', Journal of European Integration (2011), 1.

N. Reslow, 'The Role of Third Countries in EU Migration Policy: The Mobility Partnerships', 14 European Journal of Migration and Law (2012), 393.

C. Reymond, 'Institutions, Decision-Making Procedure and Settlement of Disputes in the European Economic Area', 30 Common Market Law Review (1993), 449.

J.J. Rijpma and M. Cremona, 'The Extra-Territorialisation of EU Migration Policies and the Rule of Law', EUI Working Papers LAW (2007).

N. Rogers, 'Immigration and the European Convention on Human Rights: Are New Principles Emerging?', European Human Rights Law Review (2003), 53.

N. Rogers and R. Scannell, Free Movement of Persons in the Enlarged European Union (Sweet \& Maxwell, London 2005).

A. Rosas, 'The European Union and Mixed Agreements', in: A. Dashwood and C. Hillion (eds.), The General Law of EC External Relations (Sweet \& Maxwell, London 2000), 200-220.

J. Rupnik, 'L'Europe et ses Périphéries', in: J. Rupnik (ed.), Les Banlieues de l'EuropeLes Politiques de Voisinage de l'Union Européenne (Presses de Sciences Po, Paris 2007), 940.

G. Scappucci, 'EU-ACP Relations in the 1990s', in: C. Cosgrove-Sacks and G. Scappucci (eds.), The European Union and Developing Countries: The Challenge of Globalization (Palgrave Macmillan, Basingstoke 1999), 109-126. 
M. Schieffer, 'Readmission and Repatriation of Illegal Residents', in: B. Martenczuk and S. Van Thiel (eds.), Justice, Liberty, Security: New Challenges for EU External Relations (VUBPRESS, Brussels 2008), 89-110.

D. Schiek, 'A New Framework on Equal Treatment of Persons in EC Law?', 8 European Law Journal (2002), 290.

D. Schiek, 'The ECJ Decision in Mangold: A Further Twist on Effects of Directives and Constitutional Relevance of Community Equality Legislation', 35 Industrial Law Journal (2006), 329.

D. Schiek and V. Chege, European Union Non-Discrimination Law: Comparative Perspectives on Multidimensional Equality Law (Routledge-Cavendish, Abingdon 2009).

A. Schmitz, 'The Central Asia Strategy: An Exercise in the EU Foreign Policy', in: A. Warkotsch (ed.), The European Union and Central Asia (Routledge, Abingdon 2011), 11 21.

H. Schneider, Die Anerkennung von Diplomen in der Europäischen Gemeinschaft (METRO, Maastricht 1995).

H. Schneider, 'Towards a European Migration Policy: From Maastricht to Amsterdam, from Tampere to The Hague', in: H. Schneider (ed.), Migration, Integration and Citizenship (Forum Maastricht, Maastricht 2005), 7-33.

H. Schneider and S. Claessens, 'The Recognition of Diplomas and the Free Movement of Professionals in the European Union', in: H. Schneider (ed.), Migration, Integration and Citizenship (Forum Maastricht, Maastricht 2005), 123-166.

J. van Selm, 'Immigration and Asylum or Foreign Policy: The EU's Approach to Migrants and Their Countries of Origin', in: S. Lavenex and E. Uçarer (eds.), Migration and the Externalities of European Integration (Lexington Books, Lanham 2002), 143-160.

J.M. Sera, 'The Case For Accession of the European Union to the European Convention For the Protection of Human Rights', 14 Boston University International Law Journal (1996), 151.

L. Sevon and M. Johansson, 'The Protection of the Rights of Individuals under the EEA Agreement', 24 European Law Review (1999), 373.

M. Siegel, Money and Mobility: Migration and Remittances (Doctoral Dissertation, Boekenplan, Maastricht 2010).

W.R. Simpson, 'The ILO and Tripartism: Some Reflections', 117 Monthly Labor Review (1994), 40.

J. Somavia, Statement of the Director-General of the International Labour Office, 2006 ECOSOC High-Level Segment, Geneva, 5 July 2006. 
H. Staples, The Legal Status of Third Country Nationals Resident in the European Union (Kluwer Law International, The Hague 1999).

Steering Committee for Human Rights, Report to the Committee of Ministers on the elaboration of legal instruments for the accession of the European Union to the European Convention on Human Rights of 14 October 2011, document number: $\mathrm{CDDH}(2011) 009$.

S. Sterkx, The Comprehensive Approach Off Balance: Externalisation of EU Asylum and Migration Policy (Universiteit Antwerpen, Antwerp 2004).

H. Storey, 'The Right to Family Life and Immigration Case Law at Strasbourg', 39 International and Comparative Law Quarterly (1990), 328.

P.A. Taran, 'Human Rights of Migrants: Challenges of the New Decade', 38 International Migration (2001), 7.

P.A. Taran, 'The Need For a Rights-Based Approach to Migration in the Age of Globalization', in: R. Cholewinski (ed.), Migration and Human Rights (Cambridge University Press, Cambridge 2009), 150-168.

J.E. Taylor, 'International Migration and Economic Development', Report for the International Symposium on International Migration and Development, 26 June 2006, document number: UN/POP/MIG/SYMP/2006/09.

N. Tezcan-Idriz, 'Free Movement of Persons Between Turkey and the EU: To Move Or Not To Move? The Response of the Judiciary', 45 Common Market Law Review (2009), 1621.

T. Theele, 'Rights of Turkish Workers on the Basis of the EEC/ Turkey Association Agreement', in: H. Schneider (ed.), Migration, Integration and Citizenship - A Challenge for Europe's Future, Volume II (Forum Maastricht, Maastricht 2005), 139-165.

D. Thym, 'Respect for Private and Family Life Under Article 8 ECHR in Immigration Cases: A Human Right to Regularize Illegal Stay?', 57 International and Comparative Law Quarterly (2008), 87.

C. Tiburcio, The Human Rights of Aliens under International and Comparative Law (Martinus Nijhoff Publishers, Leiden 2001).

N. Tocci, 'Does the ENP respond to the EU's Post-Enlargement Challenges?', 40 The International Spectator (2005), 21.

C. Tomuschat, 'Liability for Mixed Agreements', in: D. O'Keeffe and H.G. Schermers (eds.), Mixed Agreements (Kluwer Law and Taxation, Leiden 1983), 125132.

C. Tomuschat, 'The International Responsibility of the European Union', in: E. Cannizzaro (ed.), The European Union as an Actor in International Relations (Kluwer Law International, The Hague 2002), 177-191. 
F. Trauner and I. Kruse, 'EC Visa Facilitation and Readmission Agreements: A New Standard EU Foreign Policy Tool?', 10 European Journal of Migration and Law (2008), 411.

T. Tridimas, 'The Court of Justice and Judicial Activism', 21 European Law Review (1996), 199.

T. Tridimas, The General Principles of EU Law (2nd edn. Oxford University Press, Oxford 2006).

T. Tridimas and P. Eeckhout, 'The External Competence of the Community and the Case-Law of the Court of Justice: Principle versus Pragmatism', 14 Yearbook of European Law (1994), 143.

C. Tsardanidis, 'The EC Cyprus Association Agreement: Ten Years of a Troubled Relationship, 1973-1983', 22 Journal of Common Market Studies (1984), 351.

V. Tywuschik and A. Sherriff, 'Beyond Structures? Reflections on the Implementation of the Joint Africa-EU Strategy’, ECDPM Discussion Paper 87 (2009).

UNHCR, press release "UNHCR Position on the Proposal for a Directive on Common Standards and Procedures in Member States for Returning Illegally Staying Third-Country Nationals" of 16 June 2008.

S. Urdze, 'The Tool Kit of the EU-Central Asia Cooperation', in: A. Warkotsch (ed.), The European Union and Central Asia (Routledge, Abingdon 2011), 22-32.

A. Vakulenko, “Islamic Headscarves"and the European Convention On Human Rights: An Intersectional Perspective', 16 Social \& Legal Studies (2007), 183.

D. Valentine, 'Agreement of Association between Greece and the European Common Market', 10 International and Comparative Law Quarterly (1961), 903.

S. Vanhoonacker and N. Reslow, 'The European External Action Service: Living Forwards by Understanding Backwards', 15 European Foreign Affairs Review (2010), 1.

P. Van den Bempt and G. Theelen, From Europe Agreements to Accession (European Interuniversity Press, Bruxelles 1996).

S. Van den Bogaert, 'Free Movement of Workers and the Nationality Requirements', in: H. Schneider (ed.), Migration, Integration and Citizenship (Forum Maastricht, Maastricht 2005), 55-72.

C. Van den Wyngaert, 'Applying the European Convention on Human Rights to Extradition: Opening Pandora's Box?', 39 International and Comparative Law Quarterly (1990), 757. 
H. Verschueren, 'Na het arrest Taflan-Met: is er leven na de dood? Besluit 3/80 (sociale zekerheid) van de Associatie EEG-Turkije bestudeerd', 2 Migrantenrecht (1997), 29.

H. Verschueren, 'EC Social Security Coordination Excluding Third-Country nationals: Still in Line with Fundamental Rights after the Gaygusuz Judgment?', 34 Common Market Law Review (1997), 991.

H. Verschueren, 'The Sürül Judgment: Equal Treatment for Turkish Workers in Matters of Social Security', 1 European Journal of Migration and Law (1999), 371.

H. Verschueren, 'De socialzekerheidspositie van niet-EG-onderdanen in het Europese gemeenschapsrecht', in: D. Cuypers, B. Hubeau and M.C. Foblets (eds.), Migratie-en migrantenrecht: recente ontwikkelingen (die Keure, Brugge 2000), 73-101.

H. Verschueren, 'Social Security Co-ordination in the Agreements between the EU and Mediterranean Countries, in particular Turkey and the Maghreb Countries', in: D. Pieters and P. Schoukens (eds.), The Social Security Co-ordination Between the EU and NonEU Countries (Intersentia, Antwerp 2009), 19-55.

A. Von Bogdandy, 'The European Union as a Human Rights Organization? Human Rights and the Core of the European Union', 37 Common Market Law Review (2000), 1307.

G. Vonk and S. van Walsum, 'Access Denied. Towards a New Approach to Social Protection for Formally Excluded Migrants', in: G. Vonk (ed.), Cross-Border Welfare State (Intersentia, Antwerp 2012), 3-60.

L. Waddington, 'Testing the Limits of the EC Treaty Article on Non-Discrimination', 28 Industrial Law Journal (1999), 133.

M. Waelbroeck, 'The Emergent Doctrine of Community Pre-emption - Consent and Re-delegation', in: T. Sandalow and E. Stein (eds.), Courts and Free Markets: Perspectives from the United States and Europe (Clarendon Press, Oxford 1982), 548-580.

C. Warbrick, 'The Structure of Article 8', European Human Rights Law Review (1998), 32

A. Ward, 'Community Development Aid and the Evolution of the Inter-institutional Law of the European Union', in: A. Dashwood and C. Hillion (eds.), The General Law of the EC External Relations (Sweet \& Maxwell, London 2000), 42-47.

M. Wathelet, 'The Case Law of the European Court of Justice and Nationals of NonEuropean Community Member States', 20 Fordham International Law Journal (1996), 603.

J. Weiler, 'The External Legal Relations of Non-Unitary Actors: Mixity and the Federal Principle', in: D. O'Keeffe and H.G. Schermers (eds.), Mixed Agreements (Kluwer, Dordrecht 1983), 35-83. 
A. Weinar, 'EU Cooperation Challenges in External Migration Policy', Research Report European University Institute and Migration Policy Institute (2011).

F. Weiss and F. Wooldridge, Free Movement of Persons Within the European Community (Kluwer Law International, The Hague 2002).

D. Weissbrodt, 'The Protection of Non-Citizens in International Human Rights Law', in: R. Cholewinski, R. Perruchoud and E. MacDonald (eds.), International Migration Law: Developing Paradigms and Key Challenges (T.M.C. Asser Press., The Hague 2007), 221-235.

R.A. Wessel, The European Union's Foreign and Security Policy: A Legal Institutional Perspective (Kluwer Law International, The Hague 1999).

E. Whitaker, 'The Schengen Agreement and Its Portent for the Freedom of Personal Movement in Europe', 6 Georgetown Immigration Law Journal (1992), 191.

A. Wiesbrock, Legal Migration to the European Union (Martinus Nijhoff Publishers, Leiden 2010).

A. Wiesbrock, 'Court of Justice of the European Union: The Right to Family Reunification of Third-Country Nationals under EU Law; Decision of 4 March 2010, Case C-578/08 Rhimou Chakroun v. Minister van Buitenlandse Zaken', 6 European Constitutional Law Review (2010), 462.

M. Wild, 'Die Anerkennung von Diplomen im Rahmen des Abkommens über die Freizügigkeit der Personen', in: C. Kaddous and D. Felder (eds.), Accords Bilatéraux Suisse - Union Européenne: Commentaires (Helbing \& Lichtenhahn, Basel 2001), 383-403.

A. Willis, 'EU Signs Trade Deals with EU and Colombia', EU Observer, 14 April 2011.

L.A. Winters and others, 'Liberalising Temporary Movement of Natural Persons: An Agenda for the Development Round', 26 The World Economy (2003), 1137.

B. De Witte, 'Nationals, EU Citizens and Foreigners: Discrimination on Grounds of Nationality in EU Law', EUI (2010).

WorldBank, 'Labor Mobility and the WTO: Liberalizing Temporary Movement', Global Economic Prospects 2004 - Realizing the Development Promise of the Doba Agenda (World Bank, Washington, D.C. 2003).

J. Wouters, D. Coppens and B. De Meester, 'The European Union's External Relations after the Treaty of Lisbon', in: S. Griller and J. Ziller (eds.), The Treaty of Lisbon: EU Constitutionalism without a Constitutional Treaty? (Springer Verlag, Wien 2008), 142-203.

WTO, Annual Report 2011 (WTO, Geneva 2011). 
A. Yollu-Tok, '50 Jahre Anwerbeabkommen mit der Türkei - Zur Lage der Türkeistämmigen auf dem sich wandelnden Arbeitsmarkt', 61 Aus Politik und Zeitgeschichte (2011), 22. 


\section{Part XIII : EU Official Documents, Table of Cases, and List of Interviewees}

1 EU OFFICIAL DOCUMENTS

1.1 List of Association, Cooperation, Partnership and Trade Agreements (referred to in this dissertation)

\section{ACP States:}

- Convention d'association entre la Communauté économique européenne et les États africains et malgache associés à cette Communauté, JO 93 du 11 juin 1964, p. 1431 (Yaoundé I)

- Convention d'association entre la Communauté économique européenne et les États africains et malgache associés à cette Communauté, JO L 282 du 28 décembre 1970, p. 2 (Yaoundé II)

- ACP-EEC Convention of Lomé, OJ L 25, 30 January 1976, p. 2 (Lomé I)

- Second ACP-EEC Convention, OJ L 347, 22 December 1980, p. 2 (Lomé II)

- Third ACP-EEC Convention, OJ L 86, 31 March 1986, p. 3 (Lomé III)

- Fourth ACP-EEC Convention, OJ L 229, 17 August 1991, p. 3 (Lomé IV)

- Agreement amending the fourth ACP-EC Convention of Lomé, OJ L 156, 29 May 1998, p. 3 (Lomé IV bis)

- Partnership agreement between the members of the African, Caribbean and Pacific Group of States of the one part, and the European Community and its Member States, of the other part, OJ L 317, 15 December 2000, p. 3 (Cotonou Agreement I)

- Agreement amending the Partnership Agreement between the members of the African, Caribbean and Pacific Group of States, of the one part, and the European Community and its Member States, of the other part, OJ L 209, 11 August 2005, p. 27 (Cotonou Agreement II)

- Agreement amending for the second time the Partnership Agreement between the members of the African, Caribbean and Pacific Group of States, of the one part, and the European Community and its Member States, of the other part, OJ L 287, 4 November 2010, p. 3 (Cotonou Agreement III)

Albania:

- Agreement between the European Economic Community and the Republic of Albania, on trade and commercial and economic cooperation, OJ L 343, 25 November 1992, p. 2

- Stabilisation and Association Agreement between the European Communities and their Member States, of the one part, and the Republic of Albania, of the other part, OJ L 107, 28 April 2009, p. 166 
Algeria:

- Cooperation Agreement between the European Economic Community and the People's Democratic Republic of Algeria, OJ No L 263, 27 September 1978, p. 2

- Euro-Mediterranean Agreement establishing an Association between the European Community and its Member States, of the one part, and the People's Democratic Republic of Algeria, of the other part, OJ L 265, 10 October 2005, p. 2

Andean Community:

- Framework Agreement on Cooperation between the European Economic Community and the Cartagena Agreement and its member countries, namely the Republic of Bolivia, the Republic of Colombia, the Republic of Ecuador, the Republic of Peru and the Republic of Venezuela, OJ L 127, 29 April 1998, p. 11

- Political Dialogue and Cooperation Agreement between the European Community and its Member States, of the one part, and the Andean Community and its Member Countries (Bolivia, Colombia, Ecuador, Peru and Venezuela), of the other part, signed on 15 December 2003, ratification pending as of 23 November 2011

Arab States and the Gulf:

- Cooperation Agreement between the European Economic Community, of the one part, and the countries parties to the Charter of the Cooperation Council for the Arab States of the Gulf (the State of the United Arab Emirates, the State of Bahrain, the Kingdom of Saudi Arabia, the Sultanate of Oman, the State of Qatar and the State of Kuwait) of the other part, OJ L 54, 25 February 1989, p. 3

Argentina:

- Accord commercial entre la Communauté économique européenne et la République argentine, JO L 249 du 10 novembre 1971, p. 19

Armenia:

- Partnership and Cooperation Agreement between the European Communities and their Member States, of the one part, and the Republic of Armenia, of the other part, OJ L 239, 9 September 1999, p. 3

Austria:

- Agreement between the European Economic Community and the Republic of Austria, OJ L 300, 31 December 1972, p. 2 


\section{Azerbaijan:}

- Partnership and Cooperation Agreement between the European Communities and their Member States, of the one part, and the Republic of Azerbaijan, of the other part, OJ L 246, 17 September 1999, p. 3

Bangladesh:

- Commercial Cooperation Agreement between the European Economic Community and the People's Republic of Bangladesh, OJ L 319, 19 November 1976, p. 2

- Cooperation Agreement between the European Community and the People's Republic of Bangladesh on partnership and development, OJ L 118, 27 April 2001, p. 48

Bosnia and Herzegovina:

- Stabilisation and Association Agreement between the European Communities and their Member States, of the one part, and Bosnia and Herzegovina, of the other part, signed on 16 June 2008

Brazil:

- Trade Agreement between the European Economic Community and the Federal Republic of Brazil, OJ L 102, 11 April 1974, p. 24

\section{CARIFORUM States:}

- Economic Partnership Agreement between the CARIFORUM States, of the one part, and the European Community and its Member States, of the other part, OJ L 289, 30 October 2008, p. 3

Chile:

- Agreement establishing an Association between the European Community and its Member States, of the one part, and the Republic of Chile, of the other part, OJ L 352, 30 December 2002, p. 3

\section{Colombia:}

- Trade Agreement between the European Union and its Member States and Colombia and Peru, signed on 13 April 2010 
Costa Rica:

- Framework Cooperation Agreement between the European Economic Community and the Republics of Costa Rica, El Salvador, Guatemala, Honduras, Nicaragua and Panama, OJ L 63, 12 March 1999, p. 39

- Political Dialogue and Cooperation Agreement between the European Community and its Member States, of the one part, and the Republics of Costa Rica, El Salvador, Guatemala, Honduras, Nicaragua and Panama, signed on 15 December 2003

Croatia:

- Stabilisation and Association Agreement between the European Communities and their Member States, of the one part, and the Republic of Croatia, of the other part, OJ L 26, 28 January 2005, p. 3

Cyprus:

- Agreement establishing an Association between the European Economic Community and the Republic of Cyprus, OJ L 133, 21 May 1973, p. 2

El Salvador:

- Framework Cooperation Agreement between the European Economic Community and the Republics of Costa Rica, El Salvador, Guatemala, Honduras, Nicaragua and Panama, OJ L 63, 12 March 1999, p. 39

- Political Dialogue and Cooperation Agreement between the European Community and its Member States, of the one part, and the Republics of Costa Rica, El Salvador, Guatemala, Honduras, Nicaragua and Panama, signed on 15 December 2003

Egypt:

- Cooperation Agreement between the European Economic Community and the Arab Republic of Egypt, OJ L 266, 27 September 1978, p. 2

- Euro-Mediterranean Agreement establishing an Association between the European Communities and their Member States, of the one part, and the Arab Republic of Egypt, of the other part, OJ L 304, 30 September 2004, p. 39

European Economic Area (EEA):

- Agreement on the European Economic Area, OJ L 1, 3 January 1994, p. 3

Europe Agreements:

- $\quad$ Europe Agreement, OJ L 347, 31 December 1993, p. 2 (Hungary)

- Europe Agreement, OJ L 348, 31 December 1993, p. 2 (Poland) 
- Europe Agreement, OJ L 360, 31 December 1994, p. 2 (Czech Republic)

- Europe Agreement, OJ L 359, 31 December 1994, p. 2 (Slovak Republic)

- Europe Agreement, OJ L 357, 31 December 1994, p. 2 (Romania)

- Europe Agreement, OJ L 358, 31 December 1994, p. 3 (Bulgaria)

- Europe Agreement, OJ L 26, 2 February 1998, p. 3 (Republic of Latvia)

- Europe Agreement, OJ L 51, 20 February 1998, p. 3 (Republic of Lithuania)

- Europe Agreement, OJ L 68, 9 March 1998, p. 3 (Republic of Estonia)

- Europe Agreement, OJ L 51, 26 February 1999, p. 3 (Republic of Slovenia)

Finland:

- Agreement between the European Economic Community and the Republic of Finland, OJ L 328, 28 November 1973, p. 2

Georgia:

- Partnership and Cooperation Agreement between the European Communities and their Member States, of the one part, and Georgia, of the other part, OJ L 205, 4 August 1999, p. 3

Greece:

- Agreement establishing an Association between the European Economic Community and Greece, OJ 26, 18 February 1963, p. 294

Guatemala:

- Framework Cooperation Agreement between the European Economic Community and the Republics of Costa Rica, El Salvador, Guatemala, Honduras, Nicaragua and Panama, OJ L 63, 12 March 1999, p. 39

- Political Dialogue and Cooperation Agreement between the European Community and its Member States, of the one part, and the Republics of Costa Rica, El Salvador, Guatemala, Honduras, Nicaragua and Panama, signed on 15 December 2003

Honduras:

- Framework Cooperation Agreement between the European Economic Community and the Republics of Costa Rica, El Salvador, Guatemala, Honduras, Nicaragua and Panama, OJ L 63, 12 March 1999, p. 39

- Political Dialogue and Cooperation Agreement between the European Community and its Member States, of the one part, and the Republics of Costa Rica, El Salvador, Guatemala, Honduras, Nicaragua and Panama, signed on 15 December 2003 
Iceland:

- Agreement between the European Economic Community and the Republic of Iceland, OJ L 301, 31 December 1972, p. 2

India:

- Commercial Cooperation Agreement between the European Economic Community and the Republic of India, OJ L 82, 27 March 1974, p. 2

- Cooperation Agreement between the European Community and the Republic of India on partnership and development, OJ L 223, 27 August 1994, p. 24

Indonesia:

- Cooperation Agreement between the European Economic Community and Indonesia, Malaysia, the Philippines, Singapore and Thailand, OJ L 144, 10 June 1980, p. 2

Israel:

- Accord commercial entre la Communauté économique européenne et l'état d'Israël, JO 95 du 13 juin 1964, p. 1518 (Israel I)

- Accord entre la Communauté économique européenne et l'état d'Israël, JO L 183 du 17 août 1970, p. 2 (Israel II)

- Agreement between the European Economic Community and the State of Israel, OJ L 136, 28 May 1975, p. 3 (Israel III)

- Euro-Mediterranean Agreement establishing an Association between the European Communities and their Member States, of the one part, and the State of Israel, of the other part, OJ L 147, 21 June 2000, p. 3

Jordan:

- Cooperation Agreement between the European Economic Community and the Hashemite Kingdom of Jordan, OJ L 268, 27 September 1978, p. 2

- Euro-Mediterranean Agreement establishing an Association between the European Communities and their Member States, of the one part, and the Hashemite Kingdom of Jordan, of the other part, OJ L 129, 15 May 2002, p. 3

Kazakhstan:

- Partnership and Cooperation Agreement between the European Communities and their Member States and the Republic of Kazakhstan, OJ L 196, 28 July 1999, p. 3 
Korea:

- Framework Agreement between the European Union and its Member States, on the one part, and the Republic of Korea, on the other part, signed on 10 May 2010

Kyrgyz Republic:

- Partnership and Cooperation Agreement establishing a partnership between the European Communities and their Member States, of the one part, and the Kyrgyz Republic, of the other part, OJ L 196, 28 July 1999, p. 48

Lebanon:

- Agreement in the form of an exchange of letters renewing the Agreement on trade and technical cooperation between the European Economic Community and the Member States, of the one part, and the Lebanese Republic, of the other part, OJ L 278, 29 October 1975, p. 22 (Lebanon I)

- Euro-Mediterranean Agreement establishing an Association between the European Community and its Member States, of the one part, and the Republic of Lebanon, of the other part, OJ L 143, 30 May 2006, p. 2

Macedonia:

- Cooperation Agreement between the European Community and the former Yugoslav Republic of Macedonia, OJ L 348, 18 December 1997, p. 2

- Stabilisation and Association Agreement between the European Communities and their Member States, of the one part, and the former Yugoslav Republic of Macedonia, of the other part, OJ L 84, 20 March 2004, p. 13

Malaysia:

- Cooperation Agreement between the European Economic Community and Indonesia, Malaysia, the Philippines, Singapore and Thailand, OJ L 144, 10 June 1980 , p. 2

Malta:

- Agreement establishing an Association between the European Economic Community and Malta, OJ L 61, 14 March 1971, p. 2

Mexico:

- Agreement between the European Economic Community and the United Mexican States, OJ L 247, 23 September 1975, p. 11 
Moldova:

- Partnership and Cooperation Agreement between the European Communities and their Member States, of the one part, and the Republic of Moldova, of the other part, OJ L 181, 24 June 1998, p. 3

Montenegro:

- Stabilisation and Association Agreement between the European Communities and their Member States of the one part, and the Republic of Montenegro, of the other part, OJ L 108, 29 April 2010, p. 3

Morocco:

- Accord créant une association entre la Communauté économique européenne et le Royaume du Maroc, JO L 197 du 8 août 1969, p. 3

- Cooperation Agreement between the European Economic Community and the Kingdom of Morocco, OJ L 264, 27 September 1978, p. 2

- Euro-Mediterranean Agreement establishing an Association between the European Communities and their Member States, of the one part, and the Kingdom of Morocco, of the other part, OJ L 70, 18 March 2000, p. 2

Nicaragua:

- Framework Cooperation Agreement between the European Economic Community and the Republics of Costa Rica, El Salvador, Guatemala, Honduras, Nicaragua and Panama, OJ L 63, 12 March 1999, p. 39

- Political Dialogue and Cooperation Agreement between the European Community and its Member States, of the one part, and the Republics of Costa Rica, El Salvador, Guatemala, Honduras, Nicaragua and Panama, signed on 15 December 2003

Norway:

- Agreement between the European Economic Community and the Kingdom of Norway, OJ L 171, 27 June 1973, p. 2

Pakistan:

- Commercial Cooperation Agreement between the European Economic Community and the Islamic Republic of Pakistan, OJ L 168, 28 June 1976, p. 1

- Cooperation agreement between the European Community and the Islamic Republic of Pakistan, relating to the partnership and to development, OJ L 378, 23 December 2004, p. 23 
Panama:

- Framework Cooperation Agreement between the European Economic Community and the Republics of Costa Rica, El Salvador, Guatemala, Honduras, Nicaragua and Panama, OJ L 63, 12 March 1999, p. 39

- Political Dialogue and Cooperation Agreement between the European Community and its Member States, of the one part, and the Republics of Costa Rica, El Salvador, Guatemala, Honduras, Nicaragua and Panama, signed on 15 December 2003

Peru:

- Trade Agreement between the European Union and its Member States and Colombia and Peru, signed on 13 April 2010

The Philippines:

- Cooperation Agreement between the European Economic Community and Indonesia, Malaysia, the Philippines, Singapore and Thailand, OJ L 144, 10 June 1980 , p. 2

Portugal:

- Agreement between the European Economic Community and the Portuguese Republic, OJ L 301, 31 December 1972, p. 165

Russia:

- Agreement on partnership and cooperation establishing a partnership between the European Communities and their Member States, of one part, and the Russian Federation, of the other part, OJ L 327, 28 November 1997, p. 3

Serbia:

- Stabilisation and Association Agreement between the European Communities and their Member States, of the one part, and the Republic of Serbia of the other part, signed on 29 April 2008

\section{Singapore:}

- Cooperation Agreement between the European Economic Community and Indonesia, Malaysia, the Philippines, Singapore and Thailand, OJ L 144, 10 June 1980 , p. 2 
Spain:

- Agreement between the European Economic Community and Spain, OJ L 182, 16 August 1970, p. 2.

Sri Lanka:

- Agreement on commercial cooperation between the European Economic Community and the Republic of Sri Lanka, OJ L 247, 23 September 1975, p. 2

- Cooperation Agreement between the European Community and the Democratic Socialist Republic of Sri Lanka on partnership and development, OJ L 85, 19 April 1995, p. 33

Sweden:

- Agreement between the European Economic Community and the Kingdom of Sweden, OJ L 300, 31 December 1972, p. 97

Switzerland:

- Agreement between the European Economic Community and the Swiss Confederation, OJ L 300, 31 December 1972, p. 189

- Agreement between the European Community and its Member States, of the one part, and the Swiss Confederation, of the other, on the free movement of persons, OJ L 114, 30 April2002, p. 6

Syria:

- Cooperation Agreement between the European Economic Community and the Syrian Arab Republic, OJ L 269, 27 September 1978, p. 2

Tajikistan:

- Partnership and Cooperation Agreement establishing a partnership between the European Communities and their Member States, of the one part, and the Republic of Tajikistan, of the other part, OJ L 350, 29 December 2009, p. 3

Thailand:

- Cooperation Agreement between the European Economic Community and Indonesia, Malaysia, the Philippines, Singapore and Thailand, OJ L 144, 10 June 1980, p. 2 
Tunesia:

- Accord créant une association entre la Communauté économique européenne et la République tunisienne, JO L 198 du 8 août 1969, p. 3

- Cooperation Agreement between the European Economic Community and the Republic of Tunisia, OJ L 265, 27 September 1978, p. 2

- Euro-Mediterranean Agreement establishing an Association between the European Communities and their Member States, of the one part, and the Republic of Tunisia, of the other part, OJ L 97, 30 March 1998, p. 2.

Turkey:

- Agreement establishing an Association between the European Economic Community and Turkey (Ankara Agreement), OJ L 361, 31 December 1977, p. 1

- Additional Protocol and Financial Protocol signed at Brussels on 23 November 1970, annexed to the Agreement establishing the Association between the European Economic Community and Turkey and on measures to be taken for their entry into force, OJ L 293, 29 December 1972, p. 4

Turkmenistan:

- Partnership and Cooperation Agreement establishing a partnership between the European Communities and their Member States, of the one part, and the Republic of Turkmenistan, of the other part, signed on 25.5.1998 (see European Commission Communication, $\operatorname{COM}(97)$ 693, 6 February 1998)

- Interim Agreement between the European Community, the European Coal and Steel Community and the European Atomic Energy Community, of the one part, and Turkmenistan, of the other part, on trade and trade-related matters, OJ L 80, 26 March 2011, p. 21

\section{Ukraine:}

- Partnership and Cooperation Agreement between the European Communities and their Member States, and Ukraine, OJ L 49, 19 February 1998, p. 3

Uruguay:

- Trade Agreement between the European Economic Community and the Eastern Republic of Uruguay, OJ L 333, 4 December 1973, p. 2

Uzbekistan:

- Partnership and Cooperation Agreement establishing a partnership between the European Communities and their Member States, of the one part, and the Republic of Uzbekistan, of the other part, OJ L 229, 31 August 1999, p. 1 
Yemen:

- Cooperation Agreement between the European Community and the Republic of Yemen, OJ L 72, 11 March 1998, p. 18

\subsection{Directives, Regulations, Decisions and Joint Actions}

Council Directive 64/221/EEC of 25 February 1964 on the co-ordination of special measures concerning the movement and residence of foreign nationals which are justified on grounds of public policy, public security or public health

Council Directive 73/148/EEC of 21 May 1973 on the abolition of restrictions on movement and residence within the Community for nationals of Member States with regard to establishment and the provision of services

Council Directive 77/486/EC of 25 July 1977 on the education of the children of migrant workers

Council Directive 89/48/EEC of 21 December 1988 on a general system for the recognition of higher-education diplomas awarded on the completion of professional education and training of at least three years' duration

Amended Council Directive 92/51/EEC of 18 June 1992 on a second general system for the recognition of professional education and training to supplement Directive 89/48/EEC

Council Directive 2000/43/EC of 29 June 2000 implementing the principle of equal treatment between persons irrespective of racial or ethnic origin

Council Directive 2000/78/EC of 27 November 2000 establishing a general framework for equal treatment in employment and occupation

Council Directive 2003/86/EC of 22 September 2003 on the right to family reunification

Council Directive 2003/109/EC of 25 November 2003 concerning the status of third-country nationals who are long-term residents

Directive 2004/38/EC of the European Parliament and the Council of 29 April 2004 on the right of citizens of the Union and their family members to move and reside freely within the territory of the Member States

Council Directive 2004/114/EC of 13 December 2004 on the conditions of admission of third-country nationals for the purposes of studies, pupil exchange, unremunerated training or voluntary service

Directive 2005/36/EC of the European Parliament and of the Council of 7 September 2005 on the recognition of professional qualifications

Council Directive 2005/71/EC of 12 October 2005 on a specific procedure for admitting third-country nationals for the purposes of scientific research

Council Directive 2008/115/EC of 16 December 2008 on common standards and procedures in the Member States for returning illegally staying third-country nationals

Council Directive 2009/50/EC of 25 May 2009 on the conditions of entry and residence of third-country nationals for the purposes of highly qualified employment

Council Directive 2009/52/EC of 18 June 2009 providing for minimum standards on sanctions and measures against employers of illegally staying third-country nationals 
Directive 2011/98/EU of the European Parliament and of the Council of 13 December 2011 on a single application procedure for a single permit for thirdcountry nationals to reside and work in the territory of a Member State and on a common set of rights for third-country workers legally residing in a Member State

Règlement $\mathrm{n}^{\circ} 15$ relatif aux premières mesures pour la réalisation de la libre circulation des travailleurs à l'intérieur de la Communauté

Regulation No 38/64/EEC of the Council of 25 March 1964 concerning the free movement of workers within the Community

Council Regulation (EEC) No 1408/71 of 14 June 1971 on the application of social security schemes to employed persons, self-employed persons, and to members of their families moving within the Community

Council Regulation (EEC) No 574/72 of 21 March 1972 laying down the procedure of implementing Council Regulation (EEC) No 1408/71 of 14 June 1971 on the application of social security schemes to employed persons, self-employed persons, and to members of their families moving within the Community

Council Regulation (EEC) No 2210/78, Council Regulation (EEC) No 2211/78, and Council Regulation (EEC) No 2212/78 of 26 September 1978

Council Regulation (EEC) No 1612/68 of 15 October 1968 on the freedom of movement for workers within the Community on the workers' families

Council Regulation (EEC) No 1247/92 of 30 April 1992 amending Regulation (EEC) No 21408/71 on the application of social security schemes to employed persons, to self-employed persons and to members of their families moving within the Community

Council Regulation (EC) No 1683/95 of 29 May 1995 laying down a uniform format for visas

Council Regulation (EC) No 2317/95 of 25 September 1995 determining the third countries whose nationals must be in possession of visas when crossing the external borders of the Member States

Council Regulation (EC) No 574/1999 of 12 March 1999 determining the Non-EU Member Countries whose nationals must be in possession of visas when crossing the external borders of the Member States

Council Regulation (EC) No 539/2001 of 15 March 2001 listing the third countries whose nationals must be in possession of visas when crossing the external borders and those whose nationals are exempt from that requirement

Council Regulation (EC) No 453/2003 of 6 March 2003 amending Regulation (EC) No 539/2001 listing the third countries whose nationals must be in possession of visas when crossing the external borders and those whose nationals are exempt from that requirement

Council Regulation (EC) No 859/2003 of 14 May 2003 extending the provisions of Regulation (EEC) No 1408/71 and Regulation (EEC) No 574/72 to nationals of third countries who are not already covered by those provisions solely on the ground of their nationality

Council Regulation (EC) No 377/2004 of 19 February 2004 on the creation of an immigration liaison officers' network

Regulation (EC) No 883/2004 of the European Parliament and of the Council of 29 April 2004 on the coordination of social security systems

Council Regulation (EC) No 2007/2004 of 26 October 2004 establishing a European Agency for the Management of Operational Cooperation at the External Borders of the Member States of the European Union 
Council Regulation (EC) No 1932/2006 of 21 December 2006 amending Regulation (EC) No 539/2001 listing the third countries whose nationals must be in possession of visas when crossing the external borders and those whose nationals are exempt from that requirement

Council Regulation (EC) No 1244/2009 of 30 November 2009 amending Regulation (EC) No 539/2001 listing the third countries whose nationals must be in possession of visas when crossing the external borders and those whose nationals are exempt from that requirement

Regulation (EC) No 767/2008 of the European Parliament and of the Council of 9 July 2008 concerning the Visa Information System (VIS) and the exchange of data between Member States on short-stay visas

Regulation (EC) No 810/2009 of the European Parliament and of the Council of 13 July 2008 establishing a Community Code on Visas

Regulation (EU) No 265/2010 of the European Parliament and of the Council of 25 March 2010 amending the Covention Implementing the Schengen Agreement and Regulation (EC) No 562/2006 as regards movement of persons with a longstay visa

Regulation (EU) No 1231/2010 of the European Parliament and of the Council of 24 November 2010 extending Regulation (EC) No 883/2004 and Regulation (EC) No $987 / 2009$ to nationals of third countries who are not already covered by these Regulations solely on the ground of their nationality

Commission Regulation (EU) No 1244/2010 of 9 December 2010 amending Regulation (EC) No 883/2004 of the European Parliament and of the Council on the coordination of social security systems and Regulation (EC) No 987/2009 of the European Parliament and of the Council laying down the procedure for implementing Regulation (EC) No 883/2004

Regulation (EU) No 492/2011 of the European Parliament and of the Council of 5 April 2011 on freedom of movement for workers within the Union

Regulation (EU) No 465/2012 of the European Parliament and of the Council of 22 May 2012 amending Regulation (EC) No 883/2004 on the coordination of social security systems and Regulation (EC) No 987/2009 laying down the procedure for implementing Regulation (EC) No 883/2004

Council Decision 93/614/CFSP of 22 November 1993 on the Common Position defined on the basis of Article J.2 of the TEU with regard to the reduction of economic relations with Libya

Council Decision 93/678/CFSP of 6 December 1993 on a joint action adopted by the Council on the basis of J.3 of the TEU concerning support for the transition towards a democratic and multi-racial South Africa

Council Decision 93/729/CFSP of 20 December 1993 supplementing the joint action on support for the convoying of humanitarian aid in Bosnia-Herzegovina

Council Decision 94/165/CFSP of 15 March 1994 on the Common Position defined on the basis of Article J.2 of the TEU concerning the imposition of an embargo on arms, munitions and military equipment on Sudan

Council Decision 94/276/CFSP of 19 April 1994 on a joint action adopted by the Council on the basis of J.3 of the TEU in support of the Middle East peace process

Council Decision 94/672/CFSP of 10 October 1994 on the Common Position defined on the basis of Article J.2 of the TEU and concerning the reduction of economic and financial relations with those parts of the territory of the Republic of Bosnia-Herzegovina under the control of the Bosnian Serb forces 
Council Decision 94/697/CFSP of 24 October 1994 concerning the Common Position adopted by the Council on the basis of Article J.2 of the TEU on the objectives and priorities of the European Union vis-à-vis Rwanda

Council Decision 95/11/CFSP of 23 January 1995 concerning the Common Position, defined on the basis of Article J.2 of the TEU, and regarding the extension of the suspension of certain restrictions on trade with the Federal Republic of Yugoslavia (Serbia and Montenegro)

Council Decision 94/509/CFSP of 25 July 1994 concerning the joint action adopted by the Council on the basis of J.3 of the TEU regarding the preparation for the 1995 Conference of the States parties to the Treaty on the Non-Proliferation of Nuclear Weapons

Joint Action 2002/589/CFSP of 12 July 2002 with a view to a European Union contribution to the destruction of ammunition for small arms and light weapons in Albania

Council Decision of 22 December 2004 providing for certain areas covered by Title IV of Part Three of the Treaty establishing the European Community to be governed by the procedure laid down in Article 251 of that Treaty

Council Decision 2010/427 of 26 July 2010 establishing the organisation and functioning of the European External Action Service

Council Decision of 9 June 2011 on the application of the provisions of the Schengen acquis relating to the Schengen Information System in the Principality of Liechtenstein

Council Decision of 16 December 2011 on the position to be taken by the European Union in the Joint Committee established under the Agreement between the European Community and its Member States, of the one part, and the Swiss Confederation, of the other, on the free movement of persons as regards the replacement of Annex II to that Agreement on the co-ordination of social security schemes $(2011 / 863 / \mathrm{EU})$

\subsection{Decisions of the EU-Turkey Association Council}

Decision No 2/76 of the EC-Turkey Association Council of 20 December 1976 on the implementation of Article 12 of the Ankara Agreement

Decision No 1/80 of the EC-Turkey Association Council of 19 September 1980 on the development of the Association

Decision No 3/80 of the EC-Turkey Association Council of 19 September 1980 on the application of the social security schemes of the Member States to Turkish workers and members of their families

Decision No 1/95 of the EC-Turkey Association Council of 22 December 1995 on implementing the final phase of the Customs Union (96/142/EC)

Decision No 1/98 of the EC-Turkey Association Council of 25 February 1998 on the trade regime for agricultural products $(98 / 223 / \mathrm{EC})$

\subsection{European Commission}

European Commission, COM(74) 2250, 14 December 1974, Action Programme in favour of migrant workers and their families (transmitted by the Commission to the Council on 18 December 1974)

European Commission, COM(85) 48, 7 March 1985 
European Commission, Commission Decision 85/381/EEC of 8 July 1985 setting up a prior communication and consultation procedure on migration policies in relation to non-member countries

European Commission, COM(1985) 310, 14 June 1985

European Commission, Commission Decision 88/384/EEC of 8 June 1988 setting up a prior communication and consultation procedure on migration policies in relation to non-member countries

European Commission Communication, SEC(91) 1855, 23 October 1991

European Commission Communication, COM(94) 23, 23 February 1994

European Commission, proposal for a Directive of the European Parliament and the Council on the posting of workers who are third-country nationals for the provision of cross border services and proposal for a Council Directive extending the freedom to provide cross-border services to third-country nationals established within the Community, COM(1999) 3, 27 January 1999/26 February 1999

European Commission, amended proposal for a Council Directive extending the freedom to provide cross-border services to third-country nationals established within the Community, $\operatorname{COM}(2000) 271,31$ October 2000

European Commission, proposal for a Council Directive on the conditions of entry and residence of third-country nationals for the purpose of paid employment and self-employed economic activities, $\operatorname{COM}(2001)$ 386, 11 July 2001

European Commission Communication, $\operatorname{COM}(2001)$ 672, 15 November 2001

European Commission Communication, COM(2002) 564, 14 October 2002

European Commission Communication, COM(2002) 703, 3 December 2002

European Commission Communication, COM(2003) 104, 11 March 2003

European Commission Communication, $\operatorname{COM}(2004)$ 373, 12 May 2004

European Commission Communication, COM(2004) 542, 10 March 2005

European Commission Communication, COM(2005) 390, 1 September 2005

European Commission Communication, COM(2005) 489, 12 October 2005

European Commission, SEC(2005) 1426, 9 November 2005

European Commission Communication, COM(2005) 621, 30 November 2005

European Commission Communication, COM(2005) 636, 8 December 2005

European Commission Communication, COM(2005) 669, 21 December 2005

European Commission Communication, COM(2006) 402, 19 July 2006

European Commission Communication, COM(2006) 571, 12 October 2006

European Commission Communication, COM(2006) 726, 4 December 2006

European Commission Communication, COM(2006) 735, 30 November 2006

European Commission Communication, COM(2007) 160, 11 April 2007

European Commission Communication, $\operatorname{COM}(2007)$ 247, 16 May 2007

European Commission Communication, $\operatorname{COM}(2007)$ 248, 16 May 2007

European Commission Recommendation, COM(2007) 353, 26 June 2007

European Commission, proposal for a Council Directive on a single permit for thirdcountry nationals to reside and work in the territory of a Member State and on a common set of rights for third-country workers legally residing in a Member State, $\operatorname{COM}(2007)$ 638, 30 October 2007

European Commission Communication, $\operatorname{COM}(2007)$ 512, 11 September 2007

European Commission Communication, COM(2007) 774, 5 December 2007

European Commission Communication, COM(2007) 780, 5 December 2007

European Commission Communication, COM(2008) 164, 3 April 2008

European Commission Communication, COM(2008) 319, 20 May 2008 
European Commission Communication, $\operatorname{COM}(2008)$ 359, 17 June 2008

European Commission Communication, COM(2008) 391, 19 June 2008

European Commission, DG for Economic and Financial Affairs, "European Neighbourhood Policy: Economic Review of EU Neighbour Countries", Occasional Papers No 40, August 2008

European Commission Communication, $\operatorname{COM}(2008)$ 611, 8 October 2008

European Commission Communication, COM(2008) 823, 3 December 2008

European Commission Communication, COM(2009) 188/3, 23 April 2009

European Commission Communication, COM(2009) 262, 10 June 2009

European Commission Communication, COM(2009) 266, 10 June 2009

European Commission Staff Working Document, SEC(2009) 1240, 18 September 2009

European Commission Communication, COM(2010) 171, 20 April 2010

European Commission Communication, COM(2010) 207, 12 May 2010

European Commission, proposal for a directive of the European Parliament and of the Council on conditions of entry and residence of third-country nationals in the framework of an intra-corporate transfer, $\operatorname{COM}(2010)$ 378, 13 July 2010

European Commission, proposal for a directive of the European Parliament and of the Council on the conditions of entry and residence of third-country nationals for the purposes of seasonal employment, $\operatorname{COM}(2010)$ 379, 13 July 2010

European Commission Communication, COM(2010) 638, 5 November 2010

European Commission/High Representative of the European Union for Foreign Affairs and Security, Joint Communication, COM(2011) 200, 8 March 2011.

European Commission Communication, $\operatorname{COM}(2011)$ 248, 4 May 2011

European Commission Communication, COM(2011) 291, 24 May 2011

European Commission Communication, COM(2011) 292, 24 May 2011

European Commission/High Representative of the European Union for Foreign Affairs and Security Policy, Joint Staff Working Paper, SEC(2011) 645, 25 May 2011

European Commission Communication, COM(2011) 455, 20 July 2011

European Commission Communication, COM(2011) 564, 26 September 2011

European Commission Communication, COM(2011) 585, 28 September 2011

European Commission Communication, COM(2011) 587, 28 September 2011

European Commission Communication, COM(2011) 735, 15 November 2011

European Commission Communication, COM(2011) 743, 18 November 2011

European Commission Communication, COM(2012) 250, 30 May 2012

\subsection{European Council}

Edinburgh Presidency Conclusions of 11 and 12 December 1992

Copenhagen Presidency Conclusions of 21 and 22 June 1993

Madrid Presidency Conclusions of 15 and 16 December 1995

Tampere Presidency Conclusions of 15 and 16 October 1999

Helsinki Presidency Conclusions of 10 and 11 December 1999

Santa Maria da Feira Presidency Conclusions of 19 and 20 June 2000

Laeken Presidency Conclusions of 15 and 16 December 2001

Seville Presidency Conclusions of 21 and 22 June 2002

Thessaloniki Presidency Conclusions of 19 and 20 June 2003

Brussels Presidency Conclusions of 16 and 17 December 2004 
Brussels Presidency Conclusions of 15 and 16 December 2005

The Stockholm Programme - An Open and Secure Europe Serving and Protecting Citizens, OJ C 115, 4 May 2010, p. 1

\subsection{Council of the European Union}

Council of the European Union, Council Resolution of 21 January 1974 concerning a social action programme

Joint Declaration by the European Parliament, the Council and the Commission "Concerning the Protection of Fundamental Rights and the European Convention for the Protection of Human Rights and Fundamental Freedoms, OJ C 103, 27 April 1977, p. 1

Council of the European Union, Council Resolution of 16 July 1985 on guidelines for a Community policy on migration

Council of the European Union, Strategy Paper on Immigration and Asylum to the K4 Committee, Austrian Presidency 1998, 9809/98, July 1998

Council of the European Union, Council Resolution of 20 June 1994 on limitation on admission of third-country nationals to the territory of the Member States for employment

Resolution on the influx of migrants from Iraq and the neighbouring region: EU action plan adopted by the Council on 26 January 1998, document number 5573/98 - C4-0124/98

Action Plan of the Council and the Commission on how best to implement the provisions of the Treaty of Amsterdam on an area of freedom, security and justice, Text adopted by the Justice and Home Affairs Council of 3 December 1998, 1999/C 10/01

Press Release of General Affairs Council of 6 December 1998, document number $13677 / 98$

Final Report of the High Level Working Group on Asylum and Migration of 29 September 1999, document number 11450/99 JAI 79 AG 27

Council of the European Union, Introductory Note: Adoption of the Action Plan for Albania and the Region and the Implementation of the Action Plans for Afghanistan and the Region, Iraq, Somalia and Sri Lanka, Brussels 2000, document number 8939/00

Council of the European Union, "A" Item Note from COREPER to the General Affairs Council/ European Council, document number: 7653/00 LIMITE JAI 35 on "European Union priorities and policy objectives for external relations in the field of justice and home affairs" of 6 June 2000; previous draft, document number 7512/00 LIMITE JAI 33 of 24 May 2000

Council of the European Union, EU-Presidency and Commission Joint Press Release on the opening of the negotiations with Iran of 12 December 2002

Council of the European Union, "A Secure Europe In A Better World - The European Security Strategy", 12 December 2003

Council of the European Union, Meeting between the European Union and the Latin American and Caribbean countries on Migration - Quito, 4-5 March 2004, document number: 7267/04 of 11 March 2004

Council of the European Union: "The Hague Programme: strengthening freedom, security and justice in the European Union", document number 16054/04 JAI 559 of 13 December 2004 
Council of the European Union: "Council Conclusions on Migration and External Relations", document number: 14769/05 of 21 November 2005

Council of the European Union, Council Conclusions on an EU Strategy for Africa, document number: 14831/05 of 22 November 2005

Council of the European Union, Press Release, 2696th Council Meeting, Justice and Home Affairs, Brussels, 1-2 December 2005

Joint Statement by the Council and the representatives of the governments of the Member States meeting within the Council, the European Parliament and the Commission on the European Union Development Policy: 'The European Consensus' (2006/C 46/01), published in the OJ on 24 February 2006

Council of the European Union, "The EU and Central Asia: Strategy for a New Partnership", document number: 10113/07 of 31 May 2007

Council of the European Union, "Strengthening the European Neighbourhood Policy - Council Conclusions" of 19 June 2007, document number: 11016/07

Council of the European Union, The Africa-EU Strategic Partnership - A Joint Africa EU Strategy, document number: 16344/07 (Presse 291) of 9 December 2007

Council of the European Union, "Protocol between the European Union, the European Community, the Swiss Confederation and the Principality of Liechtenstein on the accession of the Principality of Liechtenstein to the Agreement between the European Union, the European Community and the Swiss Confederation on the Swiss Confederation's association with the implementation, application and development of the Schengen acquis" of 13 February 2008, document number: 16462/06

Council of the European Union, Third Experts Meeting on Migration between the European Union and the Countries of Latin America and the Caribbean (Brussels, 10-11 March 2008), document number: 7640/08 of 14 March 2008

Council of the European Union: "Adoption of the Council Conclusions on enhancing the Global Approach to Migration", document number: 9604/08 of 20 May 2008

Council of the European Union, Joint Declaration on a Mobility Partnership between the European Union and the Republic of Moldova, document number: 9460/08 of 21 May 2008

Council of the European Union, "European Pact on Immigration and Asylum", document number 13440/08 of 24 September 2008

Council of the European Union, "Joint Declaration of the Prague Eastern Partnership Summit" of 7 May 2009

Council of the European Union, "Multiannual Programme for an Area of Freedom, Security and Justice serving the Citizen (The Stockholm Programme) ", document number: $14449 / 09$ of 16 October 2009

Council of the European Union, Joint Declaration on a Mobility Partnership between the European Union Georgia, document number: 16396/09 of 20 November 2009

Council of the European Union, Joint Communiqué - EU-Cape Verde political dialogue meeting at ministerial level, document number: 5796/10 of 27 January 2010

Council of the European Union, Visa liberalisation of Albania and Bosnia and Herzegovina, document number: $15957 / 10$ of 8 November 2010

Council of the European Union, EU-LAC SUMMIT, Madrid, 18 May 2010 "Towards a new stage in the bi-regional partnership: innovation and technology 
for sustainable development and social inclusion" Madrid Action Plan 2010-012, document number: 10449/1/10 REV 1, 15 November 2010

Council of the European Union, Council Conclusions on EU-Turkey Readmission Agreement and Related Issues, 3071st Justice and Home Affairs Council meeting, 24 and 25 February 2011

Council of the European Union, "EU reinforces restrictive measures concerning Belarus" of 10 October 2011, document number: 15310/11

Council of the European Union, "Libya - Council Conclusions" of 14 November 2011, document number: 16871/11

Council of the European Union, "Syria - Draft Council Conclusions, Foreign Affairs Council" of 23 May 2011, document number: 10557/11

Council of the European Union, "Accession of the Union to the European Convention for the Protection of Human Rights and Fundamental Freedoms State of Play", of 6 December 2011, document number: 18117/11

Council of the European Union, "Schengen enlargement: Liechtenstein to become 26th member state" of 13 December 2011, document number: 18446/11

Council of the European Union, "Council Conclusions on the Global Approach to Migration and Mobility", document number: 9417/12 of 3 May 2012

Council of the European Union, EU-Ukraine Cooperation Council 15th Meeting, document number: 9993/12 (Presse 206) of 15 May 2012

\subsection{European Parliament}

European Parliament Recommendation of 15 March 2007 to the Council on the negotiating mandate for an association agreement between the European Union and its Member States, of the one part, and the Andean Community and its member countries, of the other part (2006/2221(INI)), OJ C 301E, 13 December 2007, p. 238

European Parliament, "Multi-annual Programme 2010-2014 regarding the area of freedom, security and justice (Stockholm Programme)", document number: P7_TA-PROV(2009)0090

EP resolutions of 18 April 2012 containing the EP's recommendations to the Council, the Commission and the European External Action Service on the negotiations of the EU-Azerbaijan Association Agreement (2011/2316(INI)) and on the negotiations of the EU-Armenia Association Agreement (2011/2315(INI))

\subsection{Cases of the Court of Justice of the European Union}

Case 26/62 Van Gend en Loos [1963] ECR 13

Case 75/63 Hoekstra [1963] ECR 177

Case 6/64 Costa v. ENEL [1964] ECR 585

Case 40/64 Sgarlata and Others [1965] ECR 215

Case 29/69 Stauder [1969] ECR 419

Case 11/70 Internationale Handelsgesellschaft [1970] ECR 1125

Case 22/70 Commission v. Council (ERTA) [1971] ECR 263

Joined Cases 21-24/72 International Fruit Company [1972] ECR 1219 
Case 152/73 Sotgiu [1974] ECR 153

Case 4/73 Nold [1974] ECR 491

Case 167/73 Commission v. French Republic [1974] ECR 359

Case 187/73 Callemeyn [1974] ECR 553

Case C-181/73 Haegeman [1974] ECR 449

Case 33/74 V an Binsbergen [1974] ECR 1299

Case 41/74 Van Duyn v. Home Office [1974] ECR I-01337

Case 36/74 W alrave and Koch [1974] ECR 1405

Case 9/74 Casagrande [1974] ECR 773

Case 67/74 Bonsignore [1975] ECR 297

Case 2/74 Reyners [1974] ECR 631

Case 36/75 Rutili [1975] ECR 1219

Case 32/75 Cristini [1975] ECR 1085

Case 48/75 Royer [1976] ECR 497

Opinion 1/75 Understanding on a Local Cost Standard [1975] ECR 1355

Joined Cases 3, 4 and 6/76 Kramer [1976] ECR 1279

Opinion 1/76 European Laying-up Fund for Inland Waterway Vessels [1977] ECR 741

Case 40/76 Kermaschek [1976] ECR 1669

Case 41/76 Donckerwolcke [1976] ECR 1921

Case 117/76 and Case 16/77 Ruckedeschel [1977] ECR 1753

Case 65/77 Razanatsimba [1977] ECR I-2229

Case 30/77 Boucherau [1977] ECR 1999

Case 199/77 Defrenne [1978] ECR 1365

Opinion 1/78 Natural Rubber [1979] ECR 2871

Ruling 1/78 Euratom [1978] ECR 2151

Case 115/78 Knoors [1979] ECR 399

Case 175/78 R. v. Saunders [1979] ECR 1129

Case 44/79 Hauer [1979] ECR 3727

Case C-804/79 Commission v. UK [1981] ECR 1045

Case 270/80 Polydor [1982] ECR 329

Joined Cases 212-217/80 Salumi [1981] ECR 2735

Case C-104/81 Kupferberg [1982] ECR 3641

Case 65/81 Reina [1982] ECR 33

Case C-115 and 116/81 Adoui [1982] ECR 1665

Case C-53/81 Levin [1982] ECR 1035

Case 286/82 and 26/83 Luisi and Carbone [1984] ECR 377

Case C-228/83 Meade [1987] ECR I-2631

Case 249/83 Hoeckx [1985] ECR 973

Case 107/83 Klopp [1984] ECR 2971

Case C-293/83 Gravier [1985] ECR 593

Case 261/83 Castelli [1984] ECR 3199

Case 222/84 Johnston [1986] ECR 1651

Case 137/84 Mutsch [1985] ECR 2681

Case 66/85 Lawrie Blum [1986] ECR 2121

Case 352/85 Bond van Adverteerders [1988] ECR 2085

Case 225/85 Commission v. Italy [1987] ECR 2625

Joined Cases 281, 283, 284, 285 and 287/85 Germany and Others v. Commission [1987] ECR I-3202

Case 45/86 Commission v. Council [1987] ECR 2871

Case 197/86 Brown [1988] ECR 3205 
Case 63/86 Commission v. Italian Republic [1988] ECR 29

Case 39/86 Lair [1988] ECR 3161

Case C-12/86 Demirel [1987] ECR I-3719

Case 263/86 Humbel [1988] ECR 5365

Case 344/87 Bettray [1989] ECR 1621

Case C-374/87 Orkem [1989] ECR 3283

Case C-379/87 Groener [1989] ECR 3967

Joined Cases 389 and 390/87 Eternach and Moritz [1989] ECR I-7091

Case 186/87 Cowan [1989] ECR 195

Case 9/88 Lopes da Veiga [1989] ECR 2989

Case C-192/89 Sevince [1990] ECR I-3461

Case C-357/89 Raulin [1992] ECR I-1027

Case C-308/89 Di Leo [1990] ECR I-4185

Case C-292/89 Antonissen [1991] ECR I-745

Case C-18/90 Kziber [1991] ECR I-199

Case C-369/90 Micheletti [1992] ECR I-4239

Case C-213/90 ASTI [1991] ECR I-3507

Case C-111/91 Commission v. Luxembourg [1993] ECR I-817

Case C-237/91 Kus [1992] ECR I-6781

Case C-316/91 Parliament v. Council [1994] ECR I-625

Case C-181/91 Parliament v. Commission and Council [1993] ECR I-3685

Case C-312/91 Metalsa [1993] ECR 3751

Case C-310/91 Schmid [1993] ECR I-3011

Opinion 2/91 ILO Convention No 170 [1993] ECR I-1061

Opinion 1/91 EEA Agreement [1991] ECR 6079

Opinion 1/92 EEA Agreement II [1992] ECR I-2821

Case C-272/92 Spotti [1993] ECR I-5185

Case C-19/92 Kraus [1993] ECR I-1663

Case C-109/92 Wirth [1993] ECR I-6447

Case C-12/93 Drake [1994] ECR I-4337

Case C-43/93 V an der Elst [1994] ECR I-3803

Case C-355/93 Eroglu [1994] ECR I-5113

Case C-469/93 Chiquita [1995] ECR I-4533

Case C-434/93 Boqkurt [1994] ECR I-1475

Case C-58/93 Yousfi [1994] ECR I-199

Case C-415/93 Bosman [1995] ECR I-4921

Opinion 2/94 Accession to the ECHR [1996] ECR I-1759

Case C-55/94 Gebhard [1995] ECR I-4165

Case C-107/94 Asscher [1996] ECR I-3089

Case C-61/94 Commission v. Germany [1996] ECR I-3989

Opinion 1/94 WTO Agreements [1994] ECR I-5267

Case C-268/94 Portugal v. Council [1996] ECR I-6177

Case C-277/94 Taflan-Met [1996] ECR I-4085

Case C-103/94 Krid [1995] ECR I-719

Case C-126/95 Hallouri-Choho [1996] ECR I-4807

Case C-299/95 Kremrow [1997] ECR I-2629

Case C-351/95 Kadiman [1997] ECR I-2133

Case C-285/95 Kol [1997] ECR-3069

Case C-386/95 Eker [1997] ECR I-329

Case C-171/95 Tetik [1997] ECR I-329 
Case C-98/96 Ertanir [1997] ECR I-5179

Case C-36/96 Günaydin [1997] ECR I-5143

Case C-249/96 Grant [1998] ECR I-621

Case C-162/96 Racke [1998] ECR I-3655

Case C-149/96 Portugal v. Council [1999] ECR I-8395

Case C-85/96 Martínez Sala [1998] ECR I-2691

Case C-170/96 Commission v. Council (Airport Transit Visas) [1998] ECR I-2763

Case C-416/96 El-Yassini [1999] ECR I-1209

Case C-262/96 Sürül [1999] ECR I-2685

Case C-348/96 Calfa [1999] ECR I-11

Case 158/96 Kobll [1998] ECR I-1931

Case C-1/97 Birden [1998] ECR I-7747

Case C-230/97 Awoyemi [1998] ECR I-6781

Case C-340/97 Naqli [2000] ECR I-957

Case C-329/97 Ergat [2000] ECR I-1487

Case C-210/97 Akman [1998] ECR I-7519

Case C-113/97 Babahenini [1998] ECR I-183

Case C-179/98 Mesbah [1999] ECR I-7955

Case C-113/98 Rush Portuguesa [1990] ECR I-1417

Case C-468/98 Commission v. Sweden [2002] ECR I-9575

Joined Cases C-102/98 \& 211/98 Kocak and Örs [2000] ECR I-1287

Case C-37/98 Savas [2000] ECR I-2927

Case C-268/99 Jany [2001] ECR I-8615

Case C-157/99 Geraets-Smits/Peerbooms [2001] ECR I-5473

Case C-212/99 Commission v. Italy [2001] ECR I-4923

Case C-257/99 Barkoci and Malik [2001] ECR I-6557

Case C-33/99 Fahmi [2001] ECR I-2415

Case C-184/99 Grzelcrylk [2001] ECR I-6193

Case C-235/99 Kondova [2001] ECR I-6427

Case C-413/99 Baumbast [2002] ECR I-07091

Case C-459/99 MRAX [2002] ECR I-6591

Case C-63/99 Gloszrzuk [2001] ECR I-6369

Joined Cases C-95/99 to C-98/95 Khalil and Others and C-180/99 Addou [2001] ECR I-7413

Opinion 2/00 Cartagena Protocol [2001] ECR I-9713

Case C-162/00 Pokrzeptowicz-Meyer [2002] ECR I-1049

Case C-188/00 Kur₹ [2000] ECR I-10691

Case C-60/00 Carpenter [2002] ECR I-6279

Case C-13/00 Commission v. Ireland [2002] ECR I-2943

Case C-438/00 Deutscher Handballbund [2003] ECR I-4135

Case C-28/00 Kauer [2002] ECR I-1343

Case C-109/01 Akrich [2004] ECR I-9607

Case C-56/01 Inizan [2003] ECR I-12403

Case C-413/01 Ninni-Orasche [2003] ECR I-1387

Case C-369/01 Abatay and Others [2003] ECR I-12301

Case C-493/01 Orfanopoulos and Oliveri [2004] ECR I-5257

Case C-313/01 Morgenbesser [2003] ECR I-13467

Case C-171/01 Wäblergruppe Gemeinsam [2003] ECR I-4301

Case C-465/01 Commission v. Austria [2004] ECR I-8291

Case C-23/02 Alami [2003] ECR I-1399 
Case C-456/02 Trojani [2002] ECR I-7573

Case C-358/02 Haddad [2004] ECR I-1562

Case C-327/02 Panayotova [2004] ECR I-11055

Case C-476/02 Cetinkaya [2004] ECR I-10895

Case C-275/02 Ayaz [2004] ECR I-8765

Case C-92/02 Kristiansen [2003] ECR I-14597

Case C-373/02 Öqtürk [2004] ECR I-3605

Case C-105/03 Pupino [2005] ECR I-5285

Case C-230/03 Sedef [2006] ECR I-157

Case C-209/03 Bidar [2005] ECR I-2119

Case C-373/03 Aydinli [2005] ECR I-6181

Case C-383/03 Doğan [2005] ECR I-6237

Case C-176/03 Commission v. Council (Environmental Criminal Law) [2005] ECRI-7879

Case C-239/03 Commission v. France [2004] ECR I-9325

Opinion 1/03 Lugano Convention [2006] ECR I-1145

Case C-540/03 EP v. Council [2006] I-5769

Case C-374/03 Gürol [2005] ECR I-6199

Case C-265/03 Simutenkov [2005] ECR I-2579

Case C-144/04 Mangold [2005] ECR I-9981

Case C-522/04 Commission v. Belgium [2007] ECR I-5701

Case C-502/04 Torun [2006] ECR I-1563

Case C-258/04 Ioannidis [2005] ECR I-8275

Case C-372/04 Watts [2006] ECR I-4325

Case C-4/05 Güzeli [2006] ECR I-10279

Case C-325/05 Derin [2007] ECR I-6495

Case C-438/05 Viking [2007] ECR I-10779

Case C-91/05 Small Arms and Light Weapons (ECOW AS) [2008] ECR I-3651

Case C-336/05 Echouikh [2006] ECR I-5223

Case C-97/05 Gattoussi [2006] ECR I-11917

Case C-213/05 Geven [2007] ECR I-6347

Case C-440/05 Commission v. Council (Ship-Source Pollution) [2007] ECR I-9097

Case C-16/05 Tüm and Darn [2007] ECR I-7415

Case C-228/06 Soysal [2009] ECR I-1031

Case C-450/06 V arec [2008] ECR I-581

Joined Cases C-11/06 and C-12/06 Morgan and Bucher [2007] ECR I-9161

Case C-294/06 Payir and Others [2008] ECR I-203

Case C-276/06 El Youssfi [2006] ECR I-2851

Case C-540/06 Parliament v. Council [2006] ECR I-7569

Case C-540/07 Commission v. Italy [2009] ECR I-10983

Case C-484/07 Pehlivan [2011] Judgment of 16 June 2011, not yet reported

Case C-92/07 Commission v. The Netherlands [2010] ECR I-06383

Case C-5/07 Commission v. Portugal [2007] ECR I-120

Case C-158/07 Förster [2008] ECR I-8507

Case C-59/07 Commission v. Spain [2007] ECR I-161

Case C-34/07 Commission v. Luxembourg [2007] ECR I-175

Case C-555/07 Kücükedeveci [2010] ECR I-00365

Case C-269/07 Commission v. Germany [2009] ECR I-7811

Case C-571/07 Blanco Pérez. [2010] ECR I-04629

Case C-485/07 Akdas [2011] Judgment of 26 May 2011, not yet reported

Joined Cases C-22 and C-23/08 V atsouras [2009] ECR I-4585 
Case C-127/08 Metock and Others [2008] ECR I-6241

Case C-153/08 Commission v. Spain [2009] ECR I-9735

Case C- 578/08 Chakroun [2010] ECR I-01839

Case C-73/08 Bressol [2010] ECR I-2735

Case C-351/08 Grimme [2009] ECR I-10777

Case C-13/08 Stamm and Hauser [2008] ECR I-11087

Case C-541/08 Fokus Invest [2010] ECR I-01025

Case C-105/08 Commission v. Portuguese Republic [2010] ECR I-05331

Case C-371/08 Ziebell [2011] Judgment of 8 December 2011, not yet reported

Joined Cases C-483/09 and C-1/10 Gueye and Salmerón Sánchez. [2011] Judgment of 15 September 2011, not yet reported

Case C-14/09 Hava Genc [2010] ECR I-00931

Case C-34/09 Zambrano [2010] Judgment of 8 March 2011, not yet reported

Case C-16/09 Schwemmer [2010] ECR I-09717

Case C-70/09 Hengartner and Gasser [2010] ECR I-07223

Case C-72/09 Rimband [2010] ECR I-10659

Case C-434/09 McCarthy [2011] Judgment of 5 May 2011, not yet reported

Case C-247/09 Xbymshiti [2010] Judgment of 18 November 2010, not yet reported

Case C-400/10 PPU McB [2010] ECR I-08965

Case C-303/08 Bozkurt [2010] Judgment of 22 December 2010, not yet reported

Case C-506/10 Graf and Engel [2011] Judgment of 6 October 2011, not yet reported

Case C-101/10 Pavlov [2011] Judgment of 7 July 2011, not yet reported

Case C-257/10 Bergström [2011] Judgment of 15 December 2011, not yet reported

Joined Cases C-7/10 and C-9/10 Kahveci and Inan [2012] Judgment of 29 March 2012, not yet reported

Case C-265/11 Dereci and Others [2011] Judgment of 15 November 2011, not yet reported

Case C-451/11 Dülger [2012] Judgment of 19 July 2012, not yet reported

2.2 Case C-221/11 Demirkan, reference for a preliminary ruling lodged on 11 May 2011 (2011/C 232/25) Cases of the General Court

Case T-115/94 Opel Austria [1997] ECR II-39

Case T-54/99 max.mobil Telecommunikation [2002] ECR II-313

Case T-315/01 Kadi [2005] ECR II-3649

Case T-77/01 Territorio Histórico de Álava [2002] ECR II-81

\subsection{Cases of the EFTA Court}

Case E-1/94 Restamark, decided on 16 December 1994

Case E-9/97 Sveinbjoernsdóttir, decided on 10 December 1998

\subsection{Cases of the European Court of Human Rights}

Belgian Linguistic Case (No. 2) (Application Nos. 1474/62; 1677/62; 1691/62; 1769/63; 1994/63; 2126/64) Judgment of 23 July 1968, 1 EHRR 252 
East African Asians v. The United Kingdom (Application Nos. 4403-19/70 ; 4422/70; $4423 / 70 ; 4434 / 70 ; 4443 / 70 ; 4476-8 / 70 ; 4486 / 70 ; 4501 / 70 ; 4526-30 / 70)$ Commission Decision of 14 December 1973, 3 EHRR 76

Marckx v. Belgium (Application No. 6833/74) Judgment of 13 June 1979, 2 EHRR 330

Rasmussen v. Denmark (Application No. 8777/79) Judgment of 28 November 1984, 7 EHRR 371

Berrehab v. The Netherlands (Application No. 10730/84) Judgment of 21 June 1988, 11 EHRR 322

Abdulaziz, Cabales and Balkandali v. The United Kingdom (Application Nos. 9214/80; 9473/81; 9474/81) Judgment of 28 May 1985, 7 EHRR 471

Moustaquim v. Belgium (Application No. 12313/86) Judgment of 18 February 1991, 13 EHRR 802

Beldjoudi v. France (Application No. 12083/86) Judgment of 26 March 1992, 14 EHRR 801

Soering v. United Kingdom (Application No. 14038/88) Judgment of 7 July 1989, 11 EHRR 439

Gaygusuz v. Austria (Application No. 17371/90) Judgment of 16 September 1996, 23 EHRR 364

Nasri v. France (Application No. 19465/92) Judgment of 13 July 1995, 21 EHRR 458

$V$ an Raalte $v$. The Netherlands (Application No. 20060/92) Judgment of 2 February 1997, 24 EHRR 503

C. v. Belgium (Application No. 21794/93) Judgment of 7 August 1996

Boughanemi v. France (Application No. 22070/93) Judgment of 24 April 1996, 22 EHRR 228

Boughanemi v. France (Application No. 22070/93) Judgment of 24 April 1996, 22 EHRR 228

Ahmut v. The Netherlands (Application No. 21702/93) Judgment of 28 November 1996, 24EHRR 62

Chassagnou and Others v. France (Application Nos. 25088/94; 28331/95; 28443/95) Judgment of 29 April 1999, 29 EHRR 615

Boujlifa v. France (Application No. 25404/94) Judgment of 21 October 1994, 30 EHRR 419

Gül v. Switzerland (Application No. 23218/94) Judgment of 19 February 1996, 22 EHRR 93

Sen v. The Netherlands (Application No. 31465/96) Judgment of 21 December 2001, 36 EHRR 81

Leyla Şabin v. Turkey (Application No. 44774/98) Judgment of 10 November 2005, 41 EHRR 8

Kona Poirrez v. France (Application No. 40892/98) Judgment of 30 December 2003, 40 EHRR 34

Üner v. The Netherlands (Application No. 46410/99) Judgment of 18 October 2006

Rodrigues da Silva and Hoogkamer v. The Netherlands (Application No. 50435/99) Judgment of 31 January 2006, 44 EHRR 729

Okpiszv. Germany (Application No. 59140/00) Judgment of 25 February 2006

Boultif v. Switzerland (Application No. 54273/00) Judgment of 2 August 2001, 33 EHRR 50

Amrollahi v. Denmark (Application No. 56811/00) Judgment of 11 July 2002, 22 EHRR 585

Andrejeva v. Lativa (Application No. 55707/00) Judgment of 18 February 2009

Bashir and Others v. Bulgaria (Application No. 65028/01) Judgment of 14 June 2007 
Kervanci v. France (Application No. 31645/04) Judgment of 4 March 2009

Liu v. Russia (Application No. 42086/05) Judgment of 6 December 2007

Arvelo Aponte v. The Netherlands (Application No. 28770/05) Judgment of 3 November 2011

Mutlag v. Germany (Application No. 40601/05) Judgment of 25 March 2010

Dogru v. France (Application No. 27058/05) Judgment of 4 March 2009

Nunez v. Norway (Application No. 55597/09) Judgment of 28 June 2011

\subsection{Cases of the International Court of Justice}

Reparation for Injuries Suffered in the Service of the United Nations, Advisory Opinion [1949] ICJ Reports 174

\subsection{Cases of National Courts}

Federal Administrative Court of Germany (Bundesverwaltungsgericht): BVerwG 1 C 8.09 (VG 35 V 47.08)

Federal Supreme Court of Switzerland (Bundesgericht):

BGE 130 II 493

BGE 129 II 249

BGE 131 V 209

BGE 131 II 339

\section{LIST OF INTERVIEWEES}

Wolfgang Hammer - Permanent Representation of the Federal Republic of Germany to the European Union, Brussels, interview held on 24 January 2011

Rob Cornelissen - European Commission, Brussels, interview held on 3 February 2011

Vivien Vadasi - Permanent Representation of Hungary to the European Union, Brussels, interview held on 3 February 2011

Franziska Keller - Member of the European Parliament, Brussels, interview held on 3 February 2011

Susanne Mooij - Everaert Advocaten, Amsterdam, interview held on 4 February 2011

Martino Paolo Cossu - General Secretariat of the Council of the European Union, Brussels, interview held on 16 February 2011

Zoltán Lékó - Permanent Representation of Hungary to the European Union, Brussels, interview held on 16 February 2011

Nils Coleman - Permanent Representation of the Netherlands to the European Union, Brussels, interview held on 21 February 2011

Pawel Busiakiewicz - European Commission, Brussels, interview held on 21 February 2011

Rob Rozenburg - European Commission, Brussels, interview held on 21 February 2011

Sevil Karadag - Karadag Advocatuur, telephone interview held on 24 February 2011

Agata Sobiech - European Commission, Brussels, interview held on 31 March 2011 



\section{Curriculum Vitae}

Katharina Eisele was born on 12 October 1983 in Heidelberg, Germany. As a PhD candidate at the Faculty of Law, Maastricht University, Katharina drafted this doctoral dissertation between March 2009 and August 2012 under the supervision of Prof. Dr. Hildegard Schneider and Dr. Anja Wiesbrock. Katharina studied comparative and European law at the Universities of Bremen, Oldenburg and Groningen (Hanse Law School) in Germany and the Netherlands. After studying for one year in Aix-en-Provence, France, she graduated from Maastricht University in 2009 with an LL.M. in European and international law. Katharina has been a visiting researcher at Bilgi University in İstanbul, Turkey, and she worked from March to July 2012 as a trainee for the European Commission's Legal Service in Brussels, Belgium. Katharina is currently a researcher at the justice and home affairs section of the Centre for European Policy Studies (CEPS) and she is author of a number of articles, policy briefs and book contributions. 